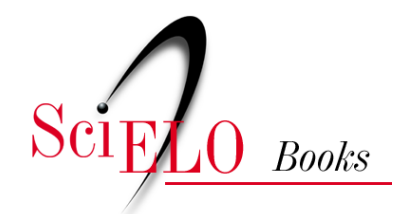

EDUFU

\title{
A oeste das minas \\ escravos, índios e homens livres numa fronteira oitocentista Triângulo Mineiro (1750-1861)
}

\author{
Luís Augusto Bustamante Lourenço
}

\section{SciELO Books / SciELO Livros / SciELO Libros}

LOURENÇO, L.A.B. A oeste das minas: escravos, índios e homens livres numa fronteira oitocentista Triângulo Mineiro (1750-1861) [online]. Uberlândia: EDUFU, 2005, 353 p. ISBN 978-85-7078-5169. https://doi.org/10.7476/9788570785169.

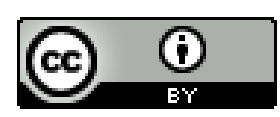

All the contents of this work, except where otherwise noted, is licensed under a Creative Commons Attribution 4.0 International license.

Todo o conteúdo deste trabalho, exceto quando houver ressalva, é publicado sob a licença Creative Commons Atribição $\underline{4.0}$.

Todo el contenido de esta obra, excepto donde se indique lo contrario, está bajo licencia de la licencia $\underline{\text { Creative Commons }}$ Reconocimento 4.0. 
A Oeste das Minas 


\section{Luís Augusto Bustamante Lourenço}
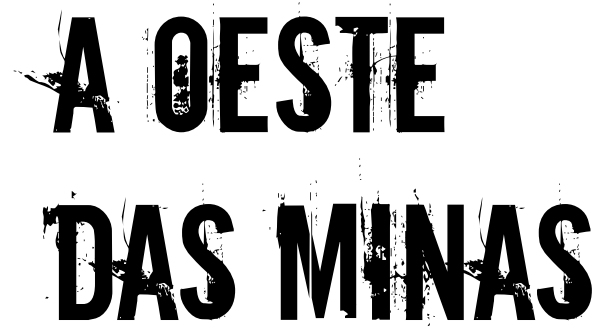

Escravos, índios e homens livres

numa fronteira oitocentista

Triângulo Mineiro (1750-1861)

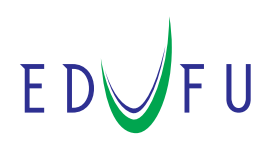

2005 
REITOR

Alfredo Júlio Fernandes Neto

VICE-REITOR

Darizon Alves de Andrade

DireçÃo Edufu

Humberto Guido

Conselho Editorial

Adão de Siqueira Ferreira

Daurea Abadia de Souza

Décio Gatti Júnior

Gina Maria Barbosa de Oliveira

João Carlos Gabrielli Biffi

Técnica Administrativa

Maria Amália Rocha

Luiz Carlos de Laurentiz

Manuel Gonzalo Hernández Terrones

Paulo Roberto de Lima Bueno

Roberto Rosa

Capa, Projeto Gráfico e Editoração

Arlen Costa de Paula

REVISÃo

Tiragem

Luciane Chedid Melo Borges

300 exemplares

FICHA CATALOGRÁFICA

Elaborada pelo Sistema de Bibliotecas da UFU / Setor de Catalogação e Classificação / mg 04/05

L892o Lourenço, Luís Augusto Bustamante.

A oeste das minas: escravos, índios e homens livres numa fronteira oitocentista, Triângulo Mineiro (1750 - 1861) / Luís Agusto

Bustamante Lourenço. - Uberlândia: EDUFU, 2005.

358p. : il.

Inclui bibliografia.

ISBN 85-7078-080-X

1.Minas Gerais - Geografia histórica. 2. Cidades e vilas - Minas

Gerais - Séc. XIX. 3. Triângulo Mineiro - Colonização.

I. Título.

Direitos Autorais (C) 2005 Edufu

EDUFU - EDITORA DA UNIVERSIDADE FEDERAL DE UBERLÂNDIA

Av. João Naves de Ávila, 2121 - Bloco 1S - Térreo

Cep 38400-902 - Uberlândia - Minas Gerais

Telefax: (34) 3239-4293

www.edufu.ufu.br / e-mail: livraria@ufu.br 
Ao geralista Augusto Lourenço de Lima, meu avô. Das histórias que me contou, nasceu este trabalho. 


\section{Agradecimentos}

Este livro é uma versão modificada da dissertação de mestrado por mim defendida em setembro de 2002, no Instituto de Geografia da Universidade Federal de Uberlândia.

Agradeço, em primeiro lugar, à minha orientadora e amiga, professora Beatriz Ribeiro Soares, pelo carinho e paciência com que acompanhou este trabalho por dois anos. Sua leitura atenta e, sobretudo, sua capacidade de dar liberdade ao livre pensar - ao mesmo tempo em que corrigia os meus excessos e trazia-me ao chão do rigor do método — fazem dela co-responsável pelos méritos que, porventura, este livro tenha.

Ao professor Maurício de Almeida Abreu, membro da banca julgadora, agradeço as sugestões e o prefácio deste livro. À professora Vera Lúcia Salazar Pessoa, também membro da banca, pelas orientações metodológicas e por algumas indicações de leituras, fundamentais a este trabalho. Devo a ela meu primeiro contato com a obra de Alexander Chayanov. Aos professores Júlio César de Lima Ramires, João Kleps Júnior e Rossevelt José dos Santos, pela leitura paciente e cuidadosa de trechos destes escritos, e pelas sugestões, todas acatadas.

O Sr. Hélio Rodrigues da Cunha, de Miraporanga, e Dona Guiomar Maria da Silva são co-autores e personagens da história aqui contada. Seus depoimentos deram vida àquilo que eu, analfabeto em assuntos do sertão, ia encontrando em minhas pesquisas.

A Cida, do Arquivo Público de Araguari, e a sensacional equipe do Arquivo Público de Uberaba, em especial dona Neuza, abriram-me os caminhos de acesso à documentação que foi essencial a este trabalho. Com essas pessoas, aprendi a amar essas duas cidades maravilhosas.

À Sra. Ione Mercedes Miranda Vieira, agradeço pela cuidadosa revisão

ortográfica e gramatical. À Glaucione, minha cunhada, pela digitação da lista de referências bibliográficas, num momento em que eu já não estava agüentando mais olhar para a tela do computador. Isa, Diniz, Soraia, Tatiana, Andréia, Isis, Raquel, Rocio, Maurício, Rodrigo e Saulo, meus colegas de 
trabalho, "seguraram as pontas" no Pronto Socorro, enquanto eu terminava o "parto" da dissertação.

Minha mãe ajudou-me na tabulação dos registros de sesmarias, na compilação das entrevistas gravadas, nos trabalhos de campo e nas visitas ao Arquivo Público de Uberaba, onde passamos incontáveis tardes no difícil, mas prazeroso, trabalho de decifrar escritos antigos. Valeu a pena, mãe, copiamos todos!

Meu pai legou-me um precioso documento, com as recordações de sua infância, nos sertões de São Pedro da Ponte Firme. Agradeço também por iniciar-me nos mistérios do sertão, traduzindo-me termos como cambão, cangalha, carros de milho, roça de toco... Esse trabalho é uma forma de manifestar meu orgulho em ser filho de um sertanejo.

À Simone, agradeço pela ajuda na correção dos originais e, principalmente, pela compreensão do que é fazer uma dissertação de mestrado em casa. Nesse tempo, ela também escreveu a dela, e ficamos os dois na biblioteca, por um ano e meio, soterrados de papéis. Queria que ela soubesse que, por detrás das montanhas de livros, seu sorriso lindo era o que me animava a seguir adiante... 


\section{Lista de Ilustrações}

\section{Capitulo 2: Os índios da Farinba Podre}

43 Figura 1: O sistema biogeográfico do Cerrado e a área de estudo

45 Figura 2: Áreas de cultivos indígenas preferenciais e área cultural caiapó meridional antes da conquista européia

51 Figura 3: Rugendas: aldeia de Tapuias

53 Figura 4: Estrada do Anhanguera ou dos Goiases (1736)

57 Figura 5: Aldeamentos na Estrada dos Goiases (1748-1816)

58 Figura 6: Administração dos aldeamentos goianos até 1758

63 Figura 7: Áreas povoadas no centro-sul brasileiro em meados do século XVIII

67 Figura 8: Mapa do Oeste da capitania de Minas Gerais, em fins do século XVIII

77 Figua 9: Mameluca com bócio (Spix e Martius, 1981)

80 Figura 10: Sítio provável do aldeamento de Santana do Rio das Velhas

83 Figura 11: Igreja Matriz N. Senhora de Santana, construída no aldeamento de Santana do Rio das Velhas em 1844

84 Figura 12: Aldeamento de São José de Mossâmedes

85 Figura 13: Missão de Santo Inácio Mini

86 Figura 14: Planta do aldeamento de Maria I

89 Figura 15: Distribuição da população indígena em terras aldeanas do Sertão da Farinha Podre em 1821

91 Figura 16: Mesorregião do Triângulo Mineiro: solos

Capitulo 3: Triângulo Mineiro, uma fronteira na Colônia e no Império 97 Figura 1: Vila Rica

103 Figura 2: Migração geralista entre 1760 e 1890

110 Figura 3: Área dos quilombos e seus principais núcleos no oeste mineiro em 1748

112 Figura 4: Quilombo do Ambrósio 
112 Figura 5: Sítio do Quilombo do Ambrósio (Ibiá, MG)

114 Figura 6: Povoados surgidos no oeste mineiro entre 1750 e 1800, e principais picadas e caminhos

118 Figura 7: Área de utilização dos bebedouros de Araxá e Patrocínio (1800-1820)

122 Figura 8: Sertão da Farinha Podre: núcleos surgidos até 1820 e limites dos julgados de Araxá e Desemboque

129 Figura 9: Termo de Uberaba (1822-1831): solos e localização das fazendas inventariadas no Juizado de Órfãos da Vila de Uberaba

135 Figura 10: Naturalidade dos testadores da freguesia de Uberaba (1822-1861)

153 Figura 11: Termos das vilas e julgados correspondentes às principais áreas de fronteira da capitania de Minas Gerais (1818-1822)

157 Figura12: Sede da fazenda de João Pereira da Rocha, um dos geralistas que se apossaram de terras expropriadas aos aldeamentos indígenas

159 Figura 13: Expropriação de terras indígenas no Triângulo Mineiro (1819-1821)

164 Figura 14: Aldeamentos do Triângulo Mineiro no mapa de Gerber (1862)

\section{Capitulo 4: As formas do viver no sertão}

182 Figura 1: Taunay: mata reduzida a carvão

192 Figura 2: Nova Ponte (MG): casa de fazenda e curral contíguo

193 Figura 3: Sistemas de pecuária na província de Minas Gerais (18001850)

196 Figura 4: Áreas preferenciais de cultivo do milho e da mandioca para alimentação humana (1819)

200 Figura 5: pilão (Nova Ponte - MG).

201 Figuras 6 e 7: Monjolo (Nova Ponte, MG)

204 Figura 8: Descaroçador de algodão de Cuiabá (século XVIII)

207 Figura 9: Tear Horizontal (Goiás Velho)

214 Figura 10: Fazenda de gado (Pirenópolis, GO)

215 Figura 11: Rego d'água e pinguela (Nova Ponte, MG)

219 Figura 12: Habitação de negros

222 Figura 13: Moradia rural coberta de sapé (Piraquê, TO) 
223 Figura 14: Pau-a-pique (Goiás Velho, GO)

224 Figura 15: Adobe (Pirenópolis, GO)

\section{Capítulo 5: Riqueza, pobreza e escravidão}

263 Figura 1: Comboio de negros

\section{Capitulo 6: Os primeiros tempos do viver urbano}

292 Figura 1: Família de roceiros indo à igreja

294 Figura 2: Praça matriz de Uberaba com comércio realizado no adro da igreja no início do século XX

299 Figura 3: Igreja Nossa Senhora do Rosário (Araguari 1909)

300 Figura 4: Adro e matriz de Nossa Senhora do Carmo no início do século XX (Uberlândia)

300 Figura 5: Matriz de Santo Antônio vista do vale do Ribeirão da Laje, Uberaba 1890

301 Figura 6: Planta de São Pedro do Uberabinha (final do século XIX), com destaque para córregos e rego d'água

302 Figura 7: Cemitério e matriz do Desemboque

303 Figura 8: Procissão em frente ao adro da Matriz de Bom Jesus da Cana Verde (Araguari) em 1909.

304 Figura 9: Funcionário do governo a passeio com a família

307 Figura 10: Planta do centro de Uberaba em 1880. A Rua Direita aparece cruzando o largo da matriz perpendicularmente, na parte inferior da planta

310 Figura 11: Planta de Uberaba de 1855, com destaque para a Rua Direita e as saídas para Cuiabá e São Paulo

311 Figura 12: São Pedro do Uberabinha (1880): arruamento e chácaras

317 Figura 13: Rede mercantil mineira (1815-1825). Fontes: Saint Hilaire (1975 a, 1975 b, 2000), Eschwege (1996), Cunha Matos (1981), Pohl (1976)

318 Figura 14: Porto da Estrela.

321 Figura 15: Rede dendrítica do oeste mineiro em 1816

321 Figura 16: Alcance espacial dos arraiais e bocas de sertão segundo o modelo de Christaller

325 Figura 17: Arraiais surgidos no Triângulo Mineiro entre 1820 e 1850 
327 Figura 18: Miraporanga: resquícios da antiga Estrada Real, aberta por Antônio Eustáquio Silva e Oliveira em 1824

328 Figura 19: Trajeto das forças brasileiras na Guerra do Paraguai pela Estrada Real (1865-1870)

329 Figura 20: Rotas salineiras e navegação fluvial na região de Uberaba (1827-1859)

331 Figura 21: Pouso de tropas

336 Figura 22: Local de moradia da clientela do comerciante Francisco José da Silva, estabelecido em Uberaba em 1837

338 Figura 23: Área de influência e principais estradas uberabenses (18321880)

340 Figura 24: Intercessão das redes dendríticas do noroeste paulista e do oeste mineiro nos anos 1840 


\section{Sumário}

\section{Prefácio \\ 17 Introdução}

27 Geografia Histórica: considerações teórico-metodológicas

27 O lugar da Geografia e da História

34 Os métodos da Geografia Histórica

41 Os índios da Farinha Podre

41 O ambiente do cerrado e sua primeira ocupação

47 Sertanismo e caboclização

48 Legislação, aldeamentos e a escravidão indígena na Capitania de São Paulo

51 A estrada dos Goiases e os aldeamentos do Sertão da Farinha Podre

58 Índios soldados e índios escravos

62 A geopolítica dos aldeamentos

73 Economia e organização social dos aldeamentos

78 O Sítio e o traçado dos aldeamentos

85 Demografia e mobilidade espacial

95 Triângulo Mineiro: uma fronteira na Colônia e no Império

95 A diáspora mineira

103 O Mito da decadência mineira e a montagem de uma economia Agropastoril

108 A guerra contra os quilombos

112 As picadas do Oeste e a colonização do Desemboque

116 A colonização geralista do Sertão dos Araxás

121 A colonização geralista do Sertão da Farinha Podre

130 Fatores demográficos de repulsão e atração migracional

141 Fatores geopolíticos na Migração Geralista 
153 Geralistas contra índios: o primeiro conflito de terras do Triângulo Mineiro

171 As formas do viver no Sertão

171 A dimensão da técnica na Geografia Histórica

173 Terras de cultura e campos de criar

183 Currais, boiadas e sal

193 O milho e a mandioca

203 Fios e panos

214 Casas de morada, cozinha e quintal

225 Riqueza, pobreza e escravidão

225 A produção historiográfica sobre a Colônia e o Império

233 Chayanov revisitado: a economia política do campesinato

235 A divisão social do trabalho no Triângulo Mineiro oitocentista

239 Formas de riqueza

251 Propriedade e posse da terra

262 O tráfico negreiro

266 Trabalho familiar e trabalho escravo

279 A sociedade escravista do Triângulo Mineiro

281 Os primeiros tempos do viver urbano

281 Os arraiais sertanejos

286 Viver num arraial sertanejo

290 Os moradores temporários dos arraiais

298 Espaço de vender, casar, batizar, rezar e morrer

303 Espaço de morar

312 A rede mercantil sanjoanense

322 A rede mercantil uberabense

337 Uberaba como centro regional do Império

341 Considerações finais

345 Referências

353 Fontes primárias 


\section{Prefácio}

A geografia histórica brasileira vem passando por um momento bastante promissor. Depois de um longo período em que o passado foi somente tratado como cronologia, como sucessão, ou então incorporado à análise geográfica apenas como dimensão explicativa de formas morfológicas do presente, eis que vemos surgir trabalhos que conseguem se libertar dessas limitações e/ou amarras nefastas e que mergulham o olhar geográfico em tempos idos sem a obrigação de conduzi-los até o momento atual. Ao concentrarem atenção em períodos definidos, isto é, ao realizarem cortes sincrônicos, esses estudos aprofundam nosso conhecimento do passado, atestam quão grande é o manancial de temas que a geografia deixou até agora inexplorado, e, finalmente, reafirmam a disciplina como produtora de conhecimentos sobre a sociedade brasileira, qualquer que seja a duração do tempo em que ela esteja inserida. A excelente dissertação de mestrado elaborada por Luís Augusto Bustamante Lourenço, que agora chega ao grande público sob a forma de livro, preenche, de forma admirável, todos esses requisitos.

Trata-se, com efeito, de uma obra que se destaca no cenário intelectual pela sua qualidade. Embora seu objetivo maior — plenamente alcançado — tenha sido o de analisar os primeiros momentos da produção do espaço regional conhecido hoje como Triângulo Mineiro, identificando os agentes que nela intervieram, as formas que produziram e os conflitos que geraram, a verdade é que o autor nos brinda com um estudo que ultrapassa, em muito, a recuperação de um processo histórico regional. Trabalhando muito bem com as diversas tradições geográficas, Luís Augusto consegue, em primeiro lugar, associar as preocupações clássicas da morfologia da paisagem com os referenciais teóricos da geografia crítica, não abrindo mão, por outro lado, de fazer uso eficiente e adequado dos instrumentos metodológicos que o neopositivismo nos proporcionou. Em segundo lugar, revela a rara capacidade de trafegar bem pelas escalas de análise da geografia e da história, integrando com bastante propriedade o universal, o particular e o singular; em outras palavras, consegue não apenas relacionar formação social com região 
e lugar, mas também os tempos longos com as conjunturas e os eventos. Em terceiro, faz dialogar o empírico com a teoria por todo o trabalho, demonstrando, ademais, sólida sustentação em fontes primárias e secundárias. Em quarto, utiliza essas fontes de maneira exemplar, encapsulando-as em mapas, gráficos, pirâmides populacionais e esquemas variados, em tudo revelando domínio das técnicas que permitem ao geógrafo relacionar ações com materialidades. Finalmente, oferecenos um texto que está ancorado nos ditames da seriedade acadêmica, mas que é, ao mesmo tempo, leve e de agradável leitura, qualidade rara nos dias de hoje.

Por todas essas qualidades, este livro torna-se, desde já, leitura obrigatória não apenas para os que se interessam pela história do Triângulo Mineiro, que terão nele uma obra de referência, mas também para os que procuram um modelo de geografia histórica bem feita. Esperemos todos que seu efeito demonstração se difunda pelo país, pois sem ocupar o lugar que lhe cabe na análise do passado, isto é, sem produzir geografias do passado, a geografia brasileira jamais poderá atingir seu objetivo de contribuir plenamente para o entendimento do processo de produção do território nacional. Sendo a geografia uma forma de abordagem do real, o que a distingue das outras ciências sociais não é a duração do tempo que ela estuda, mas as questões que coloca para o entendimento da sociedade. E essas questões não podem ser apenas as do presente. Passado, presente e futuro são categorias eminentemente sociais, e não categorias determinadoras da geografia ou de qualquer outra ciência social. Todas trabalham com as três. São as conexões que tentam fazer que dão peculiaridade a cada uma. Com o estudo feito por Luís Augusto Bustamante Lourenço, temos um bom exemplo de quais são essas questões geográficas e de como as conexões que a disciplina realiza contribuem para um maior conhecimento da sociedade brasileira.

\author{
Maurício de Almeida Abreu \\ Departamento de Geografia da UFRJ
}




\section{Introdução}

O caminho de automóvel mais curto de Brasília a São Paulo é feito pela rodovia BR-050, que atravessa a região mais ocidental do estado de Minas Gerais, conhecida como Triângulo Mineiro. Um viajante que por ela estiver saindo de Goiás e entrando em Minas, ao cruzar a ponte sobre o rio Paranaíba, encontrará um vale fluvial de relevo dissecado, onde a estrada se mostra sinuosa por aproximadamente 40 quilômetros. Após subir por um longo trecho, terá, à sua direita, a cidade de Araguari, a 900 metros de altitude. A estrada começa novamente a descer e, em pouco tempo, ele verá diante de si o profundo vale do rio Araguari, anunciado pelas escarpas onde terminam as chapadas.

Esse rio será cruzado a uma altitude de 600 metros e, 15 quilômetros à frente, o viajante se verá novamente no topo de um vasto tabuleiro, a mais de 800 metros de altitude. Estará então às portas da cidade de Uberlândia. Daí em diante, ele percorrerá um impressionante planalto liso, de aproximadamente 60 quilômetros de extensão, tendo dos dois lados imensidões de campos artificiais de soja. A monotonia dessa paisagem sequer é quebrada pela presença de povoações, ausentes por 100 quilômetros.

Repentinamente, o chapadão termina, em escarpas quase verticais. Ao fundo, o rio Tejuco, que nesse trecho é pouco mais que um córrego. A partir daí, uma série de colinas se sucedem até Uberaba, a 100 quilômetros de Uberlândia, situada num declive que se prolonga mais além, até a fronteira com o estado de São Paulo, sobre o rio Grande. Nesse momento, o viajante terá a impressão de que acabou de cruzar uma região quase desabitada: são 210 quilômetros onde se vêem apenas três povoações.

Essa impressão se tornará ainda mais viva quando o viajante continuar sua jornada pelo estado de São Paulo. Igarapava, Guará, Ituverava, São Joaquim da Barra, Orlândia, Jardinópolis, Ribeirão Preto: são sete cidades atravessadas pela Rodovia Anhanguera num trecho de apenas 150 quilômetros. De Limeira em diante, estende-se uma linha de conurbações quase contínuas, até a cidade de São Paulo. 
Essa imagem pode ser reforçada ao se examinar um mapa rodoviário. No estado de São Paulo, diversas cidades, muito próximas umas das outras, pontuam o espaço, cruzadas por uma densa rede de rodovias, traçadas em todas as direções. A intervalos médios de 100 quilômetros, sucedem-se cidades médias, em torno das quais gravitam várias cidades menores, num padrão que lembra muito o proposto pela Teoria das Localidades Centrais de Walter Christaller.

Esse padrão, contudo, é subitamente interrompido pela linha da fronteira com o Triângulo Mineiro. Ali, o que se vê são poucas cidades, algumas de porte médio, bastante isoladas umas das outras. Cidades com cem mil, duzentos mil, até quinhentos mil habitantes, mas com imensos vazios em torno de si, num raio de 50 a 100 quilômetros.

Pode-se tentar imputar essas diferenças geográficas ao determinismo econômico: o estado de São Paulo é mais rico, teve maior desenvolvimento urbano e, por isso, conta com maiores densidades demográficas. Mas esse tipo de argumento não resiste a uma análise mais cuidadosa. Os indicadores econômicos e sociais de cidades como Araguari, Uberlândia e Uberaba não são muito diferentes dos do norte de São Paulo. Por outro lado, regiões mineiras bem mais povoadas, como a Zona da Mata ou o Alto Jequitinhonha, com um número maior de núcleos urbanos, são muito mais pobres do que o Triângulo Mineiro.

Tampouco tem cabimento qualquer tipo de reducionismo cronológico: a ocupação do Triângulo Mineiro não é "recente". Remonta a 200 anos, sendo anterior à ocupação da Zona da Mata Mineira, e muito mais antiga que a do Noroeste Paulista. E talvez não seja necessário dizer que também não competem explicações calcadas no determinismo geográfico.

As conformações espaciais das redes urbanas têm diferenças que não podem ser explicadas por nenhum tipo de reducionismo determinista. Suas raízes estão na história, isto é, na forma como se fizeram a gênese dos lugares e a ocupação das regiões. Apesar de o mundo contemporâneo ser cada vez mais homogêneo no que diz respeito aos lugares e aos fluxos, com tendência a dissolver as diferenças, produzir não-lugares e fluxos virtuais, acreditamos na força das permanências (e, portanto, na historicidade) como o fator que reproduz as diferenças regionais. Noutras palavras, o espaço que as sociedades humanas produziram no passado é uma herança continuamente reproduzida no espaço contemporâneo. 
A força das permanências pode ser testada, comparando-se essa viagem feita por um automóvel no século XXI — com aquelas realizadas na mesma região, há quase 200 anos, pelos naturalistas, geólogos e geógrafos trazidos pela Corte portuguesa, instalada no Rio de Janeiro em 1808. Wilhelm Ludwig von Eschwege, Luiz D'Allincourt e Auguste de Saint Hilaire fizeram o trajeto do nosso viajante entre 1816 e 1819. Naquele tempo, a estrada, chamada dos Goiases ou do Anbanguera, situava-se um pouco mais a leste da atual $\mathrm{BR}-050$. A primitiva estrada cruzava três povoações, no seu trecho mineiro: os aldeamentos de Rio das Pedras ${ }^{1}$ e Santana do Rio das Velhas, ${ }^{2}$ e o arraial de Uberaba. E como nos dias de hoje, Eschwege não encontrou nenhum povoado entre o rio Uberaba Verdadeira ${ }^{3}$ e o rio Tejuco: "percorremos nove léguas sem encontrar vivalma" (1996, p. 124).

Agora, os campos de soja substituem os campos sujos e campos limpos do início do século XIX, mas os viajantes de hoje ainda se impressionam, tanto quanto os de então, com a imensa planura entre os dois rios.

O padre Aires de Casal, em 1817, assim descreveu os espigões situados entre os rios Uberaba Falsa ${ }^{4}$ e Uberaba Legítima: “o terreno médio entre os dois Uberabas é uma planície de dez léguas de largura, sem a menor elevação acima do horizonte, e absolutamente destituída de mato, onde andam veados e emas" (1976, p. 160). Saint Hilaire, entre o Uberaba Legítima e o Tejuco, assim se referiu à paisagem: "[...] num trecho de cinco léguas, atravessamos a planície mais regular que eu já havia visto desde que chegara ao Brasil. A terra era um pouco arenosa e em quase toda a sua extensão coberta por um capim mirrado" (1975 A, p. 149). Eschwege, em 1816, ao passar pelo chapadão situado entre o rio Paranaíba e o rio das Velhas, anotou em seu diário: "atravessamos, por muito tempo, as planícies mais bonitas, de extensão significativa, que nenhuma arte poderia ter criado tão planas (1996, p. 124)". O engenheiro português Luiz D'Allincourt, dois anos depois de Eschwege, descreveu o trecho da Estrada dos Goiases entre o Tejuco e o Uberaba Legítima:

[...] depois entra-se numa vasta planície, que se estende a perder de vista, sem encontrar-se água: quase a tocar o horizonte, para a direita, oferece-se

\footnotetext{
Hoje Cascalho Rico

Hoje Indianópolis

Hoje rio Uberabinha

Hoje rio Uberaba
} 
um interessante quadro, que representa a figura do mar sereno, e algumas árvores ao longe, dispostas em longos intervalos, formam a mais agradável ilusão de ótica, figurando navios [...]. Em várias partes, a superfície deste plano mostra o terreno levantado como formando pequenas ilhas, divididas por estreitos canais, que são cheios d'água na época das chuvas, e dão tantas voltas que dão bem a conhecer o quanto esta grande campina é horizontal (1975, p. 76-77).

Os viajantes contemporâneos, como os joaninos, até hoje têm a região como uma área de passagem. Como naquele tempo, saem de uma cidade planejada, construída pelo Estado no centro do país (como Vila Boa de Goiás, então, e como Brasília hoje) para se dirigirem à capital do estado (então capitania) de São Paulo.

As coincidências encerram-se por aí, todavia. Não encontramos mais arraiais ou aldeamentos, mas cidades com mais de uma centena de milhar de habitantes. Uma rodovia pavimentada substitui a antiga picada, por onde trafegam caminhões e não mais tropas de burros. Mas não deixa de ser curioso notar que, daquele tempo para cá, pouco aumentou o número de localidades. Como se pode observar no gráfico 1 e no quadro 1, quase todas as cidades do Triângulo Mineiro surgiram de arraiais fundados até 1850. Dito de outra forma, a geografia das localidades urbanas da região teve o seu arcabouço montado na primeira metade do século XIX, ao tempo do povoamento pioneiro.

É muito diferente o que se vê além da fronteira mineira, no estado de São Paulo. O povoamento pioneiro do norte da capitania de São Paulo resultou, como o do Extremo Oeste Mineiro, da migração de roceiros vindos do centro-sul de Minas Gerais, do final do século XVIII em diante. Ali os geralistas construíram uma paisagem agrária e proto-urbana em tudo semelhante à mineira, fundando fazendas, sítios e arraiais ao longo da Estrada dos Goiases (Monbeig, 1998).

A partir de 1860, a província de São Paulo, particularmente o seu Oeste, sofreu uma profunda transformação em seu espaço, com a expansão da cafeicultura e das ferrovias. Ao mesmo tempo, vieram novas formas de exploração dos solos, os imigrantes estrangeiros e o colonato, e as cidades fundadas sobre os espigões, nos cruzamentos do tronco principal das ferrovias com os ramais "cata-café" (Monbeig, 1998). 


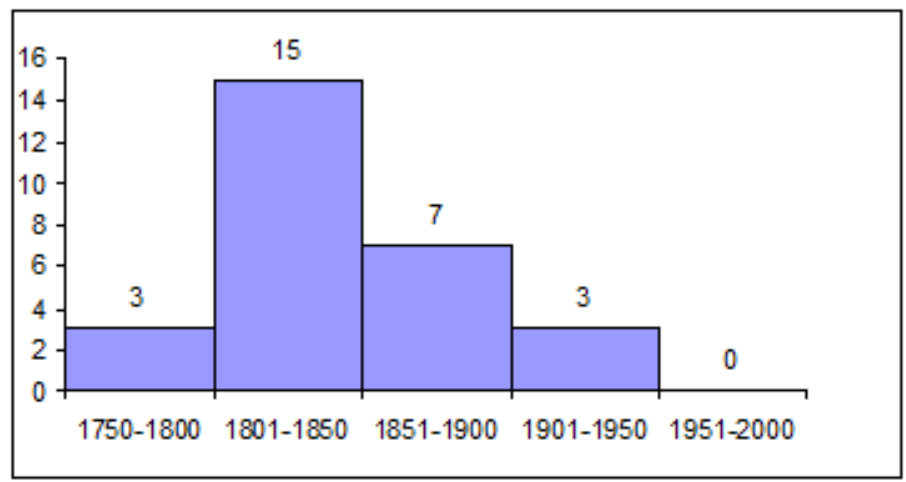

Gráfico 1. Triângulo Mineiro e Alto Paranaíba: número de arraiais (fundação de capelas), por período cronológico.

Fonte: Barbosa (1995).

\begin{tabular}{c|c|c|c|c|c}
\hline Cascalho Rico & 1750 & Delta & 1827 & Miraporanga & 1860 \\
\hline Indianópolis & 1750 & Frutal & 1830 & Monjolinho & 1869 \\
\hline Desemboque & 1760 & Campina Verde & 1830 & Nova Ponte & 1872 \\
\hline Araxá & 1804 & $\begin{array}{c}\text { São Francisco } \\
\text { de Sales }\end{array}$ & 1835 & $\begin{array}{c}\text { Conceição das } \\
\text { Alagoas }\end{array}$ & 1878 \\
\hline Prata & 1811 & Tupaciguara & 1841 & Veríssimo & 1891 \\
\hline Campo Florido & 1812 & Araguari & 1842 & Conquista & 1895 \\
\hline Sacramento & 1819 & $\begin{array}{c}\text { Monte Alegre } \\
\text { de Minas }\end{array}$ & 1843 & Tapuirama & 1932 \\
\hline Ituiutaba & 1820 & Uberlândia & 1846 & Canápolis & 1938 \\
\hline
\end{tabular}

Data de fundação dos arraiais no Triângulo Mineiro e Alto Paranaíba Fonte: Barbosa (1995).

Essa nova paisagem, criada pela cafeicultura associada ao capital financeiro e ferroviário, é a antecessora da atual, no Oeste Paulista. Obviamente, hoje não são as ferrovias, mas suas sucessoras - as autovias - que funcionam como o suporte material dos fluxos na região. Contudo, os lugares produzidos por 
aquelas ainda são os mesmos. Uma olhada no mapa basta para perceber que a rede urbana paulista contemporânea é a mesma que foi delineada pelos troncos das grandes ferrovias, sobre os interflúvios dos rios paulistas.

No Triângulo Mineiro, diferentemente, a paisagem atual é sucessora direta daquela produzida há 150 anos pela grande imigração de roceiros e criadores, vindos do centro e do sul da província. Talvez esteja aí a resposta a uma pergunta que, por certo, intriga a todos os visitantes da região: por que as cidades do Triângulo, apesar de seu porte considerável, são tão distantes umas das outras?

As implicações dessa questão interessam a todos nós, pesquisadores da Geografia. As cidades médias triangulinas, apesar de terem o mesmo porte das do interior de São Paulo, contam com entornos muito mais despovoados, o que se reflete, por exemplo, na escala e na diversidade dos serviços oferecidos por elas. Acreditamos que a resposta só poderá ser encontrada se entendermos o processo do povoamento pioneiro da região.

As motivações que nos levaram a este trabalho não se encerram nessa pergunta, contudo. Os pesquisadores que já tenham necessitado de estudos relativos ao Triângulo Mineiro dos séculos XVIII e XIX, provavelmente perceberam que eles simplesmente não existem. Acreditamos que o mutismo relativo a essa região, naquele período histórico, deve-se, por um lado, a contingências da sua própria formação histórica, e por outro, a algumas preferências da produção acadêmica.

O Triângulo ${ }^{5}$ nasceu paulista, em 1725 , quando então era, para aquela província, apenas uma área de passagem rumo às minas goianas. Tornou-se parte da então recém-criada capitania de Goiás, em 1736, permanecendo como corredor para o tráfego de tropas para São Paulo por quase um século, quando finalmente se integrou a Minas Gerais, ${ }^{6}$ em 1816. Para historiadores paulistas e goianos, trata-se de uma simples área de passagem, sem importância estrutural em seus objetos de estudo. Para historiadores mineiros, representa área periférica em um período - o século XIX — que, em si, também é periférico em seus interesses, já que a maioria deles tem na Idade de Ouro do século XVIII seu principal foco de investigações.

5 Usaremos os termos Triângulo ou Triângulo Mineiro, em referência à região situada entre os rios Paranaíba e Grande, hoje parte do estado de Minas Gerais.

6 Usaremos os termos Minas Gerais, ou Minas, em referência tanto à capitania real dos tempos coloniais quanto à província e estado de mesmo nome. 
A importância em estudar o Triângulo Mineiro dos Setecentos e Oitocentos está na oportunidade de acompanhar uma fronteira ${ }^{7}$ em plena expansão, naquele período histórico. Pretendemos abordar em nosso estudo o contato entre as culturas indígena e colonial, a apropriação do espaço précolonial, a formação do espaço agrícola e dos primeiros núcleos urbanos, e suas ligações com o restante da sociedade colonial ou nacional.

Este estudo se fez na perspectiva da Geografia Histórica. Por isso, privilegiaremos o estudo da gênese e difusão de técnicas, dos fluxos migratórios, e, a todo momento, estaremos atentos às interações entre as sociedades e á natureza. Contudo, este trabalho é também historiográfico, uma vez que, para atingir esses objetivos, é necessária a compreensão do evolver de uma sociedade no passado.

Antes de partirmos para o estudo de nosso objeto propriamente dito a colonização do Triângulo Mineiro desde a segunda metade do século XVIII —, iniciaremos, no primeiro capítulo, uma discussão sobre a importância de se estudar a gênese das configurações espaciais, isto é, a pertinência de se considerar a historicidade nos estudos geográficos. Na introdução teórico-metodológica apresentada a seguir, sopesaremos a legitimidade de uma abordagem genética num estudo de Geografia, proposta deste trabalho. Faremos um balanço dos métodos e abordagens da Geografia Histórica, com base, principalmente, na sistematização ensaiada pelo geógrafo norteamericano Carl Ortwin Sauer.

No segundo capítulo, reconstituiremos o espaço dos povos indígenas anteriores à colonização luso-brasileira no Triângulo Mineiro. A ocupação do Triângulo Mineiro, pelos povos ameríndios, consistiu de duas experiências radicalmente distintas. A primeira correspondeu às sociedades de língua jê, conhecidas no período colonial como caiapós, cuja presença na região remonta

Usaremos o termo fronteira no sentido que lhe vem sendo dado desde Frederick Jackson Turner: "the frontier is the outer edge of the wave, the meeting point between savagery and civilization" (Turner, 2002, p. 3). Não entendemos por "selvagem" o espaço que antecedeu às sociedades ocidentais no processo de expansão destas. Por isso, talvez um conceito melhor que o de Turner seja o de José de Souza Martins (Martins, 1997, p. 11): "a fronteira [é] a frente de expansão da sociedade nacional sobre povos indígenas". De uma perspectiva geográfica, entenderemos fronteira como uma linha de contato dinâmico entre diferentes espacialidades (isto é, formas específicas de apropriação da natureza e produção de ambientes por sociedades historicamente constituídas). 
a pelo menos 1.000 anos. A segunda correspondeu aos aldeamentos indígenas, povoados por índios bororos, parecis, chacriabás e acroás, fundados pelo governo da capitania de Goiás desde 1748, e que sobreviveram até a segunda metade do século XIX.

Fugiria ao escopo deste trabalho uma reconstituição paleoantropológica das sociedades caiapós anteriores a 1748. A partir de uma revisão sobre fontes secundárias, recuperaremos apenas três aspectos relativos a elas, que nos interessam diretamente: as formas de apropriação do ambiente de cerrado desenvolvidas por esses povos, com ênfase nas técnicas; suas tendências demográficas; e, por fim, o impacto ambiental produzido por essas sociedades sobre o ambiente de cerrado.

A experiência dos aldeamentos, ao contrário, interessa-nos de forma mais direta, pois tratou-se da primeira ocupação da sociedade colonial sobre a região, apesar de as populações ameríndias terem sido os seus agentes. Dela resultaram o primeiro traçado viário e as primeiras localizações dos povoados, que influíram decisivamente nos eventos futuros. Utilizando fontes secundárias dispersas, de alguns documentos de época (cartas e corografias) e, principalmente, dos relatos dos viajantes oitocentistas, reconstituiremos a paisagem, a economia, aspectos demográficos e ambientais desses povoados triangulinos primitivos.

No terceiro capítulo, abordaremos um dos mais formidáveis (e menos estudados) movimentos migratórios internos da população do Brasil Colônia e Império: a migração centrífuga de roceiros e criadores vindos da região centro-sul da capitania de Minas Gerais, do final do século XVIII em diante. Usando como fontes os relatos dos viajantes joaninos e o catálogo de sesmarias do Arquivo Público Mineiro, estudaremos os fatores de repulsão migracional, as formas de migração, a posição social dos migrantes, e as direções seguidas pelo fluxo migratório, no interior e para fora da capitania. Analisaremos, em particular, os migrantes que se dirigiram para o Triângulo Mineiro, cuja origem rastreamos pela naturalidade declarada em testamentos pesquisados no Arquivo Público de Uberaba.

Ainda no capítulo 3, realizaremos uma análise das principais tendências demográficas da população da região em estudo, no início do século XIX. As estimativas de fecundidade, mortalidade, natalidade e as pirâmides etárias foram feitas com base nos títulos de herdeiros e descrições dos plantéis de 
escravos, contidos nos inventários pesquisados, por amostragem seletiva cômoda (MArcílio, 1977). As estimativas da população regional foram feitas tendo por base os mapas de população de Eschwege (1996) e Cunha Matos (1981), e alguns mapas eleitorais do Império, reproduzidos na Revista do Arquivo Público Mineiro.

No quarto capítulo, estudaremos a formação e a evolução da paisagem do Triângulo Mineiro ao longo da primeira metade do século XIX. Para isso, apresentaremos o funcionamento dos principais complexos técnicos utilizados pelos pioneiros geralistas, ou seja, estudaremos como, cotidianamente, era feita a reprodução material de suas vidas. Utilizaremos como fontes os inventários pesquisados no Arquivo Público de Uberaba, os relatos dos viajantes joaninos e, ainda, entrevistas e depoimentos de antigos moradores da região sobre técnicas e costumes tradicionais.

No quinto capítulo, faremos um painel da economia de então, considerando o trabalho escravo, o trabalho livre e as principais formas de riqueza. Serão avaliadas as relações de trabalho predominantes e a distribuição da riqueza. Como fontes, usaremos, principalmente, os inventários post mortem de Uberaba, entre 1822 e 1861.

No sexto capítulo, conheceremos o papel dos arraiais na vida dos pioneiros geralistas. Reconstituiremos sua localização, sítios preferidos e traçados, tendo como fontes as descrições dos viajantes; fotografias, pinturas e plantas antigas; bem como o traçado atual das cidades que se originaram desses arraiais. Estudaremos, também, qual era a inserção econômica, religiosa e cultural desses núcleos no cotidiano desses primeiros moradores, e reconstituiremos a estratificação social no espaço dos povoados, usando as descrições dos imóveis contidas nos inventários post mortem. Nesse mesmo capítulo, abordaremos a natureza do comércio local e as principais vias usadas nos circuitos mercantis da região, tanto no âmbito local como nas trocas com outras regiões. 


\title{
1 | Geografia Histórica: considerações teórico-metodológicas
}

\author{
O lugar da Geografia e da História
}

Os últimos vinte anos têm sido muito férteis em estudos regionais, nos campos da Geografia, História e Ciências Sociais. Resultado da saudável proliferação de trabalhos de mestrado e doutoramento. Por meio deles, o Brasil torna-se cada vez mais conhecido de si mesmo. São necessários, porém, avanços teóricos e metodológicos que contribuam para um diálogo frutífero entre essas áreas do conhecimento, particularmente entre a História e a Geografia.

É lamentável que ainda seja comum a crença de que geógrafos e historiadores lidem com objetos diferentes. Esse divórcio entre os dois saberes, motivado mais pelas divisões burocráticas entre departamentos e institutos universitários do que por uma real diferença entre seus objetos, acaba por limitar as questões propostas e diminuir o alcance de reflexões que, de outra forma, seriam muito mais fecundas.

A História muito tem a ganhar quando considera a natureza e as técnicas na perspectiva da Geografia. Na verdade, há muito vem fazendo isso, pois entende que seu objeto é o todo da experiência humana (NovaIs, 2002). Coube aos historiadores recuperar a dimensão da técnica, da cultura e do ambiente como fatores importantes nos rumos e nas formas das sociedades humanas. Por exemplo, a obra de Sérgio Buarque de Holanda (1995), no Brasil, mantém um permanente sabor de atualidade, por tratar da gênese e difusão das técnicas, da influência do meio e das diferenciações de áreas culturais, numa perspectiva geográfica.

Por meio dos métodos da Geografia, alguns historiadores estrangeiros têm abordado, mais recentemente, antigas questões que não encontravam resposta satisfatória pelo instrumental teórico-metodológico da investigação 
histórica convencional. Por exemplo, quais são as razões da diversidade cultural humana? Por que algumas sociedades criaram aparatos tecnológicos extremamente complexos e outras não? Por que as sociedades mais sofisticadas do ponto de vista tecnológico também possuem superioridade bacteriológica? Até que ponto fatores como mudanças climáticas, salinização de solos, presença de espécies animais e vegetais domesticáveis influíram na história humana? Desses questionamentos, surgiram trabalhos como o de Crosby (1993), Ponting (2000) e Diamond (2001).

A percepção de que abordagens monolíticas e unidirecionais - fundamentadas na ortodoxia marxista ou na estruturalista - estão por se esgotar tem levado os historiadores a buscar novas referências, a partir da idéia da multicausalidade do processo histórico. Um novo paradigma teórico, o Paradigma da Complexidade, influenciado pela Teoria do Caos, ${ }^{1}$ vem sendo aplicado cada vez mais aos diversos campos do conhecimento. Com ele, os cientistas sociais têm sido levados a compreender que não existem leis mecânicas na História. $\mathrm{Na}$ verdade, um número infinito de variáveis que se influenciam mutuamente é o que conduz a história humana: climas, espécies vegetais disponíveis, correntes oceânicas, conflitos sociais, demografia, solos, eficácia das técnicas de beneficiamento de alimentos, geleiras, devastação de áreas naturais, religiões, famílias, mentalidades, lideranças carismáticas.

A percepção da dimensão complexa da realidade não exclui os grandes modelos explicativos, mas aponta a necessidade de se atentar para a grande diversidade das experiências humanas. Daí a necessidade de estudos regionais em busca das especificidades ao mesmo tempo em que não se deve prescindir dos grandes ensaios. Reconhecer o Paradigma da Complexidade não significa abandonar qualquer esperança de conhecimento racional da realidade. Significa, antes, reconhecer a multiplicidade dos fatores concorrentes para que a realidade exista, o que, no mínimo, imuniza o estudioso contra os dogmatismos.

Até pouco tempo, e infelizmente, a posição dos geógrafos havia sido de recuo teórico frente a muitas dessas temáticas, ao contrário da de outros campos do conhecimento. Pelo menos desde os anos 1940, essa posição

1 Ver, por exemplo, Gleick (1988), para uma explanação geral sobre os fundamentos da Teoria do Caos e sua crescente influência sobre vários campos do conhecimento; Gleiser (2002), sobre o Paradigma da Complexidade no pensamento econômico. Sobre o Paradigma da Complexidade e a Teoria do Caos aplicados à Geografia, ver Souza (1997). 
defensiva dos geógrafos vinha sendo denunciada por um deles: Carl Ortwin Sauer, que, naquela data, produziu um importante ensaio no qual diagnostica o que chamou de O Grande Recuo da Geografia norte-americana (SAUER, 2002). Segundo o autor, duas atitudes marcavam a tradição geográfica de seu país: a falta de interesse nos processos históricos e na sua seqüência, e a tentativa de jogar para outras disciplinas o campo da Geografia Física.

No começo do século XX, com o nascimento da geologia como uma disciplina acadêmica independente nos Estados Unidos, os geógrafos passaram a procurar interesses que os geólogos não podiam reivindicar: renunciaram então à Geografia Física como objeto de investigação. Tentaram, a partir daí, criar uma ciência natural do ambiente humano, e dificuldades metodológicas levaram-nos a auto-restrições cada vez maiores. A Geografia teorético-quantitativa, deslumbrada pela miragem do algarismo e das formas, tentou fazer uma descrição não-genética do conteúdo humano do espaço. O pressuposto dessa atitude era o de que os geógrafos são demasiado fracos para dar conta de tudo o que tem sido proposto como objeto da Geografia, e daí a tendência de limitar cada vez mais o seu campo, de forma a dominá-lo. A conseqüência dessa posição defensiva foi a grande questão que atormentou os geógrafos do século XX: a incapacidade de encontrar um campo inconteste, um objeto (SAUER, 2002).

Um diagnóstico semelhante foi feito por Maurício de Almeida Abreu (2000) ao reconstituir o recuo da Geografia francesa do início do século XX frente aos temas históricos. Como Sauer, ele também viu na necessidade de definir um estatuto disciplinar autônomo — na França, frente à História — o recuo dos geógrafos diante dos estudos do passado. Assim, para Brunhes, em 1912, a Geografia definiase como uma ciência do presente, sendo o método geográfico "um método que privilegia o estudo exato, preciso, do que existe hoje”" (ABREU, 2000).

Os sociólogos, por seu turno, avançaram sobre a ecologia humana Odum (1988) e a escola da Carolina do Norte, por exemplo — , explorando com sucesso as conotações de região e regionalismo. A Geografia Econômica passou a ser abordada por economistas como Zimmerman e Mc Carty (SAUER, 2002). Ao final, a Geografia, sentindo-se acuada, presa aos tormentos de limitações auto-impostas, passou a ser dominada por um pedantismo que mal escondia a irrelevância de sua produção.

Sauer é particularmente ácido nas suas críticas à Geografia do Meio- 
Oeste americano, expoente da vertente teorético-quantitativa. Essa região dos EUA, onde as diferenças culturais rapidamente esvaeceram-se com o surgimento de uma civilização comercial, fortemente baseada em grandes recursos naturais, tornou-se campo fértil para um pensamento geográfico que acreditava na existência de uma forma precisa e ótima de utilização econômica de cada ambiente. Por exemplo, formulações do tipo milho = praire, ou Chicago $=$ (praire + milho $)+$ porto sul do Lago Michigan...O resultado foi uma geografia ingênua, com conclusões medíocres, relacionando meio natural, distância de mercado, planos sobre o "melhor" uso da terra e a "melhor" distribuição da população (SAUER, 2002).

Sauer não propõe uma saída para a crise, pois entende que ela foi criada pelos próprios geógrafos: não existe uma crise epistemológica da Geografia. O que esse autor propõe é simplesmente um retorno à tradição mais antiga da Geografia, que poderia começar pela releitura da completude dos trabalhos de grandes geógrafos clássicos, como Ritter e Humboldt, e não da crítica feita a eles (sempre datada). No pensamento saueriano, somente uma análise genética das paisagens tornará convincentes e relevantes os estudos geográficos. Defende, também, que os geógrafos desenvolvam a sua competência na Geografia Física, para que se possa entender a interação entre as culturas humanas e o meio no qual estas se reproduzem.

O que esse autor propõe, principalmente, é o retorno a uma ciência saudável, engajada na descoberta, verificação, comparação e generalização. Propõe que se abandone o questionamento (comum em algumas academias) sobre a admissibilidade dos trabalhos e temas abordados, a obsessiva preocupação sobre o que é ou não é objeto da Geografia, e que se passe a questionar a competência, a originalidade e a significância da produção geográfica:

Uma ciência saudável está engajada na descoberta, verificação, comparação e generalização. Seu objeto é determinado por sua competência na descoberta e organização. Apenas quando chegar o dia em que avançarmos na noite, comparando nossos achados e discutindo todos os seus significados é que nos recuperaremos da anemia perniciosa do 'será isto geografia?'. (SAUER, 2002, p. 3).

Acreditamos, como esse autor, que a Geografia Humana e a História lidam com o mesmo objeto, sob diferentes abordagens. Essa é, aliás, a mesma conclusão de Milton Santos: 
Os mesmos objetos podem dialogar com as mais diversas disciplinas. [...] De um ponto de vista epistemológico, as mesmas coisas seriam, de um lado, objetos sociais e, do outro, objetos geográficos. [...] Não cremos, pois, que seja indispensável continuar buscando a definição de um objeto com existência separada, isto é, uma existência geográfica, um objeto geográfico em si. A partir do entendimento que tivemos do que deve ser o objeto da disciplina geográfica, ficamos em condição de tratar, geograficamente, os objetos encontrados. (SANTOS, 1996, p. 62-63).

A perspectiva geográfica é capaz de iluminar, de forma inusitada, questões que os historiadores tendem a secundarizar. $\mathrm{O}$ conhecimento histórico também tem muito a perder, no dizer de Maurício de Abreu (2000), com a "ditadura do presente" dos geógrafos. Segundo o autor,

Teve início uma "ditadura do presente", que empobreceu bastante nosso conhecimento sobre o passado. Com efeito, como a história não abordava os tempos idos a partir de questões geográficas, acabamos deixando uma lacuna aberta que cabia a nós preencher. (ABREu, 2000, p. 15).

O espaço geográfico, como todas as demais dimensões da realidade, é dotado de historicidade. Negá-la equivale a negar o seu próprio estatuto de coisa real: o espaço é real porque histórico. Essa perspectiva faz dos estudos retrospectivos uma etapa essencial ao conhecimento geográfico. Nas palavras de Santos:

Ao nosso ver, a questão a colocar é a da própria natureza do espaço, formado, de um lado, pelo resultado material acumulado das ações humanas através do tempo, e, de outro lado, animado pelas ações atuais que hoje lhe atribuem um dinamismo e uma funcionalidade. [...] O seu caráter de palimpsesto, memória viva de um passado já morto, transforma a paisagem em um precioso instrumento de trabalho, pois essa imagem imobilizada de uma vez por todas permite rever as etapas do passado numa perspectiva de conjunto. $\mathrm{O}$ autor dessas palavras, o historiador Marc Bloch, é, por assim dizer, um dos criadores dessa Geografia retrospectiva da qual Fernand Braudel nos dá um modelo definitivo em seu livro La Mediterranée. (SANTOS, 1996, p. 85-86). 
Qual seria então esse objeto, comum à Geografia e à História? Segundo Fernando Novais, "o objeto da História é o acontecer humano em qualquer tempo e em todo o espaço, só o futuro não é seu objeto" (NovaIs, 2002, p. 123). A diferença entre o saber geográfico e o saber histórico está na abordagem, que faz conhecer as suas diferentes dimensões. Enquanto a História se preocupa em entender o evolver das sociedades humanas no tempo, a Geografia procura saber como tais sociedades, ao fazê-lo, criam seus lugares e produzem suas paisagens.

A História é um saber, não uma ciência. Isto é, não possui uma metodologia própria e, por isso, utiliza-se das ciências auxiliares, como a Sociologia, a Economia, a Demografia, a Ecologia, para produzir seu conhecimento (NovaIs, 2002). Da mesma forma, a Geografia também é um saber erudito, que não possui urna metodologia, mas metodologias. Usa os métodos daquelas ciências para estudar o mesmo objeto, porém de uma perspectiva sincrônica. Interessa à Geografia mapear os eventos e, fundamentada em noções como circulação, difusão, interação, distância, proximidade, fluxo, entender como o espaço é produzido à medida que as sociedades humanas se reproduzem.

A compreensão dos fenômenos, a partir de sua espacialização, estaria, portanto, na essência do método geográfico. Nas palavras de Sauer:

A espacialização dos fenômenos sobre a Terra expressa o problema geográfico geral da distribuição, que leva-nos a questionar o significado da presença ou ausência, aumento ou diminuição de qualquer coisa ou grupo de coisas variáveis sobre uma extensão de área. Nesse sentido mais inclusivo, o método geográfico ocupa-se de examinar a localização de qualquer fenômeno sobre a Terra (SAuer, 2002, p. 5).

Duas conclusões se impõem a estas reflexões:

1. Se o objeto da Geografia é o espaço, ou seja, a natureza valorizada pelas sociedades humanas e suas técnicas no seu evolver histórico, portanto, tanto os espaços produzidos no passado quanto o espaço contemporâneo são objetos igualmente legítimos da investigação geográfica. Assim, toda Geografia é, nesse sentido, Geografia Histórica, e a única diferença entre estudar o passado ou o presente é que, neste caso, conta-se com mais dados para análise do que naquele. 


\section{Como escreveu Sauer:}

Uma discordância deve ser aqui registrada em relação à visão que considera geografia como exclusivamente ou peculiarmente envolvida com economias ou culturas do presente. [...] Alguém não será menos geógrafo se estiver engajado em conhecer a ascensão e passagem de uma cultura que repouse nos passado histórico, do que se estivesse envolvido em conhecer o crescimento da Chicago industrial. Há coisas tão importantes a aprender sobre geografia humana na arqueologia do Delta do Mississipi quanto em campos de cana de açúcar. Qualquer tópico nas ciências sociais é importante, não por causa de seus dados, mas pela luz que lança na natureza das origens da cultura e suas mudanças. [...] Se isto estiver correto, todo o tempo da humanidade está envolvido no campo da geografia, e a predileção em considerar o presente como intrinsecamente mais importante faz perder o objetivo expresso da geografia enquanto ciência genética. (2002, p. 10).

2. Não se pode falar em um método, mas em métodos na investigação e análise geográficas. Em grande parte, são tomados de empréstimo às ciências auxiliares (como a Antropologia, a Sociologia, a Ecologia, a Geomorfologia, a Economia, a Demografia etc.) para a construção do saber geográfico. Mas, além desses, a Geografia conta com um método próprio, que advém da perspectiva que lhe é inerente: a análise sincrônica e espacializada dos fenômenos.

Se existe um ofício que se assemelha ao do geógrafo, este é o do arqueólogo. Como este, o geógrafo busca reconstituir as paisagens do passado. Mas, se os arqueólogos se atêm às evidências materiais das atividades humanas, fossilizadas no espaço, os geógrafos historiadores contam com inúmeras outras fontes para buscar seus objetivos. O uso de arquivos para obtenção de fontes documentais e a análise de mapas antigos e contemporâneos juntam-se ao trabalho de campo, como estratégias das quais o geógrafo lança mão para obter dados em seu trabalho de reconstrução das paisagens antigas.

Assim, além das evidências materiais de antigas formas e técnicas, fossilizadas no espaço ou reutilizadas, e ressignificadas pela sociedade contemporânea (o traçado de uma cidade recapitulando o traçado do antigo arraial, 
uma voçoroca aberta por um garimpo há centenas de anos, formas ancestrais de transporte ainda utilizadas), o geógrafo ainda pode recorrer às técnicas da Paleografia, da Demografia, da Econometria, da Antropologia para atingir seus objetivos. Como diz Milton Santos:

Onde, talvez, a noção e a realidade do objeto melhor se aproxima da geografia é na arqueologia. Para ambas, o objeto é, primeiro, um dado, cujo exame permite, depois, a construção intelectual de sua realidade. O arqueólogo busca identificar uma cultura e uma época, a partir das amostras encontradas. O geógrafo se interessa pelo conjunto de condições características de várias épocas, mas a partir do presente, indo, freqüentemente, deste para o passado. Como para o arqueólogo, os objetos, seu modo de fabricação e sua função também são um terreno estável para o geógrafo. [...] Arqueólogos e geógrafos partem de objetos concretos, mas os geógrafos trabalham também com os objetos do presente. (1996, p. 60).

\section{Os métodos da Geografia Histórica}

De todas as ciências auxiliares da Geografia, Sauer tem uma clara preferência pelos métodos da Antropologia. Em seus trabalhos, utiliza principalmente os conceitos de difusão cultural (propagação territorial de traços culturais) e de área cultural (território que compartilha traços culturais), extraídos daquela ciência. A partir deles, seria possível elaborar um quadro da distribuição geográfica das culturas e dos traços culturais. Os traços culturais, uma vez mapeados, teriam determinada ocorrência, sofreriam descontinuidades e perdas, teriam locais de origem. (SAUER, 2002).

Segundo esse autor, tudo o que tenha distribuição desigual sobre a Terra, a qualquer época, pode ser expresso num mapa, que representa o padrão de unidades em ocorrência espacial. Uma vez mapeada a distribuição de um traço ou fenômeno, leva-se a inquirir sobre sua presença ou ausência: essa seria a expressão mais abstrata e geral da tarefa do geógrafo. O mapa seria, então, a descrição geográfica formal ideal, e produzi-los seria etapa essencial a qualquer estudo nessa área do conhecimento. O mapeamento estaria na essência do método geográfico, pois lidaria com as noções de distância e 
proximidade, que tornariam possível a identificação de padrões localizados ou diferenciações de área.

$\mathrm{O}$ autor identifica dois métodos possíveis de abordagem geográfica histórica e cultural: um seria o estudo da extensão espacial de traços culturais particulares (por exemplo, uma técnica de plantio ou beneficiamento), e o outro a determinação de complexos culturais e suas respectivas áreas (por exemplo, um determinado tipo de organização de povoados rurais que, ao mesmo tempo, compartilhasse uma determinada técnica de cultivo e beneficiamento). Tais complexos culturais seriam o equivalente saueriano ao que os geógrafos franceses chamam genre de vie.

Os complexos culturais conformariam a paisagem cultural. Segundo o autor:

Paisagem cultural [...] é a versão geográfica da economia de grupo, enquanto capaz de prover a si mesma de alimentos, abrigos, mobílias, ferramentas e transportes. A expressão geográfica específica corresponde às pastagens, madeiras e minas; de um lado as terras produtivas, e de outro as moradias, oficinas e armazéns, para usar os termos genéricos. (SAUER, 2002, p. 6).

Sauer também considera essencial em sua metodologia a influência do meio ambiente na história humana, mas rejeita a possibilidade do determinismo ambiental. O conceito-chave saueriano, nessa abordagem, é o de resposta ambiental (environmental response). Consiste no comportamento de um determinado grupo sob um determinado ambiente. Esse comportamento não depende de estímulos físicos, tampouco de necessidades lógicas, mas de hábitos adquiridos, os quais constituem a cultura. Dito de outra forma, os grupos humanos são os responsáveis por produzir sua cultura e história, mas fazem-no num dado ambiente, que condiciona a gama de opções das quais dispõe. Tais opções surgem no horizonte de possibilidades do grupo a partir de sua história, isto é, de atitudes e habilidades aprendidas: "An environmental response is nothing more than a specific cultural option with regard to the habitat at a particular time". (SAUER, 2002, p. 6).

A bistoricidade é um outro aspecto fundamental à metodologia de Sauer. Considera que todo grupo humano constitui seu modo de vida da forma mais adequada possível. Mas a compreensão da racionalidade que levou o grupo a determinadas escolhas só é possível mediante a compreensão de sua história, isto é, da gênese do complexo de técnicas e seu significado para o grupo. A 
geografia cairia na esterilidade descritiva se se limitasse a tratar da localização de técnicas, sem inquirir sobre sua gênese. Nesse sentido, toda geografia seria histórica, pois todo momento é um ponto numa linha, parte de um continuum.

A tarefa do geógrafo historiador seria, então, a de reconstituir paisagens passadas. Esse trabalho seria realizado em três etapas:

- conhecimento do funcionamento da cultura na sua totalidade;

- conhecimento das evidências contemporâneas à cultura em questão;

- conhecimento do terreno, isto é, do meio físico que a cultura ocupou.

Dada a envergadura de tal empreitada, o geógrafo historiador deve ser necessariamente um especialista regional, pois deve conhecer não só a região como ela se apresenta hoje, mas também reconhecer nela traços do passado. Sauer duvida da possibilidade de um geógrafo historiador tornar-se uma autoridade continental, tamanho o cabedal de conhecimentos e investigações que isso exigiria. Condena a posição do geógrafo "turista", isto é, do conhecedor superficial de inúmeras realidades regionais.

O autor propõe um outro conceito-chave para a geografia histórica e cultural: a área cultural (cultural area). Trata-se da área em que domina um modo de vida funcional e coerente. À maneira dos antropólogos, o conceito é construído pelo encontro suficiente de traços comuns que delimitem a área, e pelo domínio de um complexo econômico único. As áreas culturais não existiriam num único plano: Sauer fala de áreas culturais de ordem superior, que seriam definidas pela interdependência de um grupo de economias de área. Os limites das áreas culturais não são rígidos. Podem se transformar, mudar centros, ganhar ou perder territórios, ou, ainda, mudar completamente sua localização.

Como já foi dito, o interesse de Sauer pela cultura é fundamentalmente genético: interessa-lhe mapear não só a distribuição dos traços, num dado momento, ou as áreas culturais, mas também entender a gênese dos sistemas culturais. Nesses estudos genéticos, a difusão ocupa um lugar central: a maioria dos traços culturais é adquirida pelo contato com outras culturas, e espalha-se sobre uma determinada área, até encontrar resistências. Assim, deve-se buscar entender como uma certa cultura (com particular forma e taxa de avanço) ocupa determinada área. Em seguida, deve-se buscar entender as formas de 
estabilização de uma área cultural em relação à outra. E, finalmente, devem-se abordar os problemas do declínio ou colapso e sucessão de culturas.

A concepção saueriana é semelhante à ecológica: haveria uma sucessão de culturas semelhante, no padrão geral, à sucessão ecológica. Essa visão é compartilhada pela clássica tese do historiador norte-americano Frederick J. Turner (2002) sobre a ocupação de fronteira: o povoamento de um território far-se-ia em estágios cultural-tecnológicos sucessivos. Mas Sauer é melhor que Turner, uma vez que, diferentemente deste, não vê a sucessão cultural como uma evolução unidirecional rumo ao progresso, e sim como histórias particulares de ganhos e perdas para cada cultura. Não haveria uma ordem teleológica de sucessão rumo à maior complexidade, mas uma sucessão imprevisível, dependente de inúmeras variáveis. Essa concepção, ao que nos parece, é próxima da idéia de contingência, fundamental ao Paradigma da Complexidade.

O instrumental teórico desenvolvido por Carl Sauer, por tudo isso, conta com grande atualidade. Seria o mais adequado para a abordagem do nosso objeto de estudo: a ocupação pioneira do Triângulo Mineiro nos séculos XVIII e XIX. Identificamos três grandes sistemas culturais que se superpuseram ao longo do período em questão: as culturas ameríndias horticultoras, caçadoras e coletoras, representadas na região pelos caiapós meridionais; a cultura dos aldeamentos indígenas, muito diferente da cultura dos ameríndios caiapós e mais próxima à dos camponeses que lhes sucederam; e a cultura geralista, herdeira de técnicas e representações luso-brasileiras, mas repleta também de traços culturais africanos e ameríndios.

Do primeiro complexo cultural, dos ameríndios caiapós, pouco iremos tratar, por nos faltar conhecimento etnográfico e arqueológico suficientes. Mas acreditamos ser possível usar o método saueriano na abordagem dos outros dois — os aldeamentos e os núcleos geralistas — e obter resultados satisfatórios. Didaticamente, Sauer recomenda três passos na reconstrução dos estágios passados de uma determinada área cultural:

1. Uso de arquivos. Domínio de documentos escritos, mapas contemporâneos, documentos sobre concessões de terras, e relatos feitos pelos colonizadores e viajantes coevos sobre a região em estudo. Grande parte de nosso trabalho baseou- se em estudos, textos e depoimentos 
produzidos sobre a história da região, e que hoje se encontram dispersos e ainda sem uma leitura sistematizada e acadêmica.

Os trabalhos dos historiadores regionais, não-acadêmicos, são inestimáveis, pois não só coligem fontes às quais nunca teremos acesso, como também são o testemunho de personagens da época e da região que iremos estudar. Assim, em nosso estudo, trabalhos como os de Antônio Borges Sampaio (2001), Hildebrando Pontes (1978), Pedro Pezzuti (1922), Tito Teixeira (1970), Edelweiss Teixeira (2001), Pedro dos Reis Coutinho (s.d.) e Jorge Alberto Nabut (1986) foram fundamentais, dentre outros motivos, pela riqueza factual que apresentam. A leitura e o cotejo da contribuição desses historiadores, cada qual relativa à sua cidade de origem, permitiu-nos visualizar o desenvolvimento histórico e espacial de toda a região.

Tivemos a fortuna de poder contar com os diários de viagem e relatos dos viajantes do período joanino e do Primeiro Império, dos quais cinco estiveram no Triângulo Mineiro: Luiz D’Allincourt (1975), Wilhelm Ludwig von Eschwege (1996), Johann Emmanuel Pohl (1976), Auguste de Saint Hilaire (1975 a, 1975 b, 1976, 2000) e Francis Castelneau (2000). Conseguimos acesso a três corografias produzidas sobre a região no período: as de Cunha Matos (1981), Aires de Casal (1976) e do Vigário Silva (1970).

$\mathrm{Na}$ reconstituição dos complexos técnicos, da economia e da demografia da região e época em estudo, contamos, principalmente, com pesquisas feitas sobre 167 inventários postmortem e 21 testamentos do termo da freguesia (depois vila) de Uberaba, do período de 1822 a 1861, que se encontram no Arquivo Público de Uberaba.

Utilizamos alguns mapas antigos da região, produzidos no período em estudo (em 1788, 1794, 1862 e 1868), que nos revelam as conformações territoriais do período, bem como o nível de informação que a sociedade coeva dispunha sobre a região. Usamos também cartas topográficas contemporâneas, que foram cotejadas com os relatos dos viajantes e com as descrições contidas nos inventários post mortem, na reconstituição do traçado das estradas primitivas.

2. Trabalho de campo. Sauer considera o trabalho de campo fundamental ao geógrafo historiador. Dentre seus objetivos, estaria a comparação de 
uma área descrita no passado com o presente. Seriam avaliadas linhas de comunicação, locais de habitação, no intuito de se ter uma idéia do queaconteceu com a paisagem anterior (SAUER, 2002).

O primeiro objetivo do trabalho de campo seria o de valorizar o habitat primitivo e relocalizar o padrão passado de atividade, de acordo com o indicado na documentação anteriormente examinada. Nessa investigação, a atenção seria dada à procura de fósseis culturais (objetos utilizados no passado e hoje abandonados) e relíquias culturais.

Relíquias culturais (cultural relicts), na terminologia saueriana, significa sobrevivências culturais, isto é, instituições sobre viventes que recordam formas antigamente dominantes. Por exemplo, estruturas de beneficiamento agrícola ou arquitetônica, plano dos povoados, padrões de cultivo sobreviventes, que podem ser úteis, principalmente, quando há silêncio das fontes escritas. Sauer apresenta um roteiro sistemático de pesquisa de relíquias culturais. E, como nos utilizamos deste roteiro em nosso trabalho, expomo-lo a seguir:

a. Plano dos povoados.

b. Padrões de cultivo agrícola.

c. Distribuição de variedades de cultivos nativos como indicador de difusões culturais.

d. Estudos de formas antigas de animais e plantas domésticas.

e. Formas antigas de derrubar troncos e se entalhar madeira.

f. Técnicas de moagem, tração animal e força hidráulica.

g. Sobrevivência de velhas formas de transporte.

h. Investigação de formas fósseis: alterações de solos antigamente cultivados, antigas plantas domésticas que se tornaram selvagens, ruínas, sulcos antigos etc.

i. Trabalho com memória e relatos: toponímia, folclore, diferenças dialetais, memória dos mais velhos.

Na verdade, trata-se do que Milton Santos chamou depois de rugosidades: "anomalias técnicas ou organizacionais que resultam da elaboração desigual ou da evolução desigual de um conjunto e de tal maneira que, quando uma parcela progride, uma outra se atrasa” (SANTOS, 1986). 
Nosso trabalho de campo consistiu no levantamento dessas relíquias culturais ou rugosidades, que revelam traços de elementos dominantes no passado: plantas das partes mais antigas das cidades e povoados; arrolamento e descrição de técnicas antigas, como, por exemplo, o uso da taipa na construção de moradias, fiação e tecelagem, criação de bovinos etc.; e, principalmente, a coleta de depoimentos de antigos moradores da região em estudo. Nas entrevistas com os moradores, procuramos recuperar os complexos materiais e suas respectivas relações funcionais. Fizemos três entrevistas com antigos moradores de localidades da região em estudo.

3. Mapeamento. Após o levantamento nos arquivos e no trabalho de campo, na tentativa de sistematizar e reconhecer padrões no processo de povoamento e de difusão cultural, mapeamos os nossos resultados em cartogramas que mostraremos no decorrer deste trabalho.

Dessa forma, nosso principal objetivo é reconstituir as paisagens culturais e as configuraçôes territoriais do Triângulo Mineiro, ao tempo de sua ocupação pela sociedade colonial, em fins do século XVIII e princípios do século XIX, na perspectiva da Geografia Histórica, tendo por base a metodologia desenvolvida por Carl Ortwin Sauer. Para tanto, tivemos que avançar no estudo da fração da sociedade luso-brasileira — e de sua economia escravista e camponesa que aqui se formou no processo, dada a insuficiência de trabalhos acadêmicos nesse campo. 


\section{2 | Os índios da Farinha Podre}

\section{O ambiente do Cerrado e sua primeira ocupação}

Conceber a história e o espaço como dimensões formadas por cadeias de eventos complexos significa, antes de tudo, rejeitar qualquer interpretação determinista dos fatos históricos e geográficos: o determinismo geográfico, que desistoriciza a realidade, e o determinismo histórico, que vê a história dos homens como a única possível, e o homem como o seu demiurgo. Existe uma história do ambiente, de tempos longos, da qual o homem não é o único partícipe e, muitas vezes, sequer o principal.

Nesse sentido, a compreensão da história humana passa pelo conhecimento do ambiente sobre o qual ela se desenrola. Ambiente que não pode ser visto como um palco inerte, que apenas cria o cenário para a trama dos homens. Formado pelas heranças da natureza e das ações humanas do passado, ele é parte ativa dessa trama.

Assim, neste trabalho, tornou-se fundamental conhecer as possibilidades oferecidas às sociedades do passado pelo ambiente do Cerrado. Como já foi dito linhas atrás, estudaremos a transição — radical e violenta — ocorrida entre duas espacialidades, nos séculos XVIII e XIX: o Cerrado indígena, que consistia num espaço milenar, ocupado por uma economia horticultora e aldeã, complementada por atividades de caça e coleta; e o Cerrado geralista, espaço de uma sociedade que se fundamentava numa economia agrícola e pecuarista, que, apesar de ter incorporado um grande número de técnicas indígenas, organizava o trabalho humano e utilizava os recursos do Cerrado de forma inteiramente diferente da sociedade anterior e que, por isso, a destruiu.

Esse, sabemos nós, é apenas um capítulo de uma história maior que ainda não se encerrou: a expansão econômica, cultural, demográfica, tecnológica, biológica e microbiológica da Europa sobre as sociedades e ambientes précolombianos. Esse confronto teve desfechos distintos, por ter-se tratado não 
de um, mas de vários confrontos diferentes, já que muitas eram as sociedades do Novo Mundo que enfrentaram os europeus. Em todos eles, sem dúvida, o resultado não foi outro senão o genocídio e a destruição dos povos americanos. Porém, diferenças importantes existiram, por exemplo, entre a América Andina e a Mesoamérica de um lado, e entre o Brasil e os Estados Unidos de outro.

No primeiro caso, como no México asteca ou nos Andes incaicos, os conquistadores espanhóis encontraram sociedades estratificadas e sedentárias, organizadas sobre uma base camponesa, com elites urbanas vivendo do excedente extraído de seu trabalho. Na conquista, essas classes dominantes nativas foram eliminadas, e o aparato de dominação espanhol tomou o seu lugar, preservando as populações camponesas e adaptando, mas não eliminando, as velhas relações de produção pré-colombianas. Sobreviveram as sociedades camponesas no sul do México, Guatemala, Honduras, Peru, Equador e Bolívia, inclusive com suas línguas e relações de parentesco.

A existência de um campesinato pré-colombiano, que praticava agricultura com terraceamento, sistemas de irrigação, e que contava com densidades demográficas significativas, explica por que os conquistadores preferiram o domínio ao extermínio. Forjou-se, nesse caso, uma sociedade colonial singular, na qual, para Cardoso e Brignoli:

As comunidades indígenas constituíam o eixo principal do sistema de trabalho que estiveram em ação entre 1550 e o fim do período colonial. Sua origem está claramente estabelecida: trata-se das congregações e reduções ordenadas pela Coroa na Segunda metade do século XVI. O sistema associou, porém, a um plano urbano e administrativo tipicamente espanhol, centrado na Igreja e no cabildo, concepções de propriedade e organização do trabalho coletivo de origem pré-hispânica (carpulli, aylu, minca, aymi) e de ascendência hispânica (ejidos, terras de légua, próprios de aldeia etc.). O resultado foi uma rede de comunidades fortemente integradas entre si e que proporcionaram um importante fluxo tributário para a Coroa, e prestações de trabalho para os proprietários de minas e para os fazendeiros. (1984, p. 86-87).

A partir dessas constatações, relativas à América Espanhola, podemos formular a seguinte pergunta: por que, no Brasil, o contato entre europeus e índios resultou no extermínio destes? Na verdade, não houve extermínio físico 
total dos índios: grande parte da população indígena brasileira miscigenou-se com os brancos e africanos. As sociedades indígenas é que desapareceram, e por uma razão: tratava-se de sociedades comunais, que viviam em pequenos bandos dispersos, esporadicamente se reuniam em grupos maiores e proviam suas existências pela horticultura, caça e coleta. Tais formas econômicas e sociais eram incompatíveis com os interesses coloniais.

Os caiapós meridionais, nome que designava grupos do Tronco MacroJê lingüisticamente aparentados, habitavam o Triângulo Mineiro e mais uma vasta área correspondente aos atuais estados de Minas Gerais, Goiás, São Paulo, Mato Grosso do Sul e Mato Grosso, à época da chegada dos primeiros colonizadores luso-brasileiros (Turner, 1992). Esta região é parte da área do Sistema Biogeográfico do Cerrado, que domina grande parte do Brasil Central, e áreas menores, em alguns países vizinhos (figura 1).

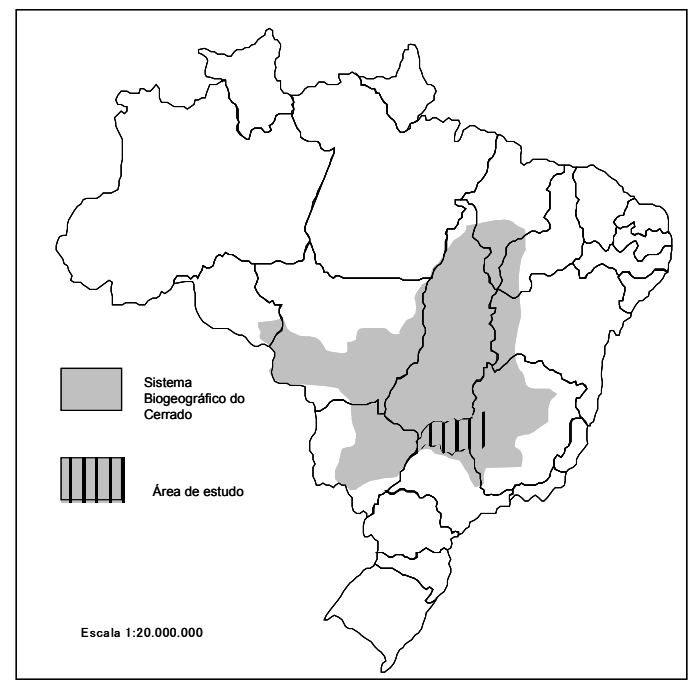

Figura 1: O Sistema Biogeográfico do Cerrado e a área de estudo Fonte: Ferreira (1998)

A presença desses povos na região em estudo já era muito antiga quando da chegada dos colonizadores: os indícios arqueológicos dos primeiros povos horticultores e ceramistas remontam a 1.000 anos, aproximadamente, conhecidos como Tradição Aratu-Sapucaí (Barbosa; Shmiz, 1998). Esses 
agricultores construíam aldeias nas matas-galeria, na margem dos cursos d'água, praticavam agricultura fundamentada no milho, e desconheciam a mandioca.

A área de distribuição da Tradição Aratu-Sapucaí (Oeste Mineiro e Sul Goiano) correspondia quase exatamente à região dos caiapós meridionais. Inúmeras outras coincidências entre os achados arqueológicos e os registros históricos sobre os caiapós levam os especialistas à suposição de que existe uma continuidade cultural entre aquela tradição e esse povo indígena do período colonial (BARBOSA; SHMIZ, 1998). Não foram, contudo, os primeiros povoadores da região, pois uma outra cultura ainda mais antiga, a Tradição Itaparica, formada por caçadores e coletores exclusivos, antecedeu a Aratu-Sapucaí, e remontava ao final do Pleistoceno (Dillehay, 2000). Nossa região em estudo, desse modo, vem sendo habitada há pelo menos 12.000 anos.

Os caiapós meridionais, hoje extintos, alternavam as atividades de horticultura com a caça e a coleta. Quase todos os povos pré-cabralianos cultivavam uma lista de espécies vegetais, que consistia basicamente no milho, na mandioca brava, no aipim ou mandioca mansa, em duas espécies de feijão, na abóbora e na batata-doce (GALVÃo, 1979). Havia, contudo, algumas espécies preferencialmente cultivadas em algumas áreas culturais, como o milho na região em estudo e em toda a área dos caiapós. O antropólogo Roberto Galvão (1979) dividiu o espaço pré-colonial brasileiro em uma imensa área milheira e outra mandioqueira. Tal divisão tem importância para o entendimento das técnicas de cultivo e beneficiamento incorporadas pelos colonizadores, quando do contato com os povos nativos (figura 2).

A abertura das roças caiapós em nada diferia do usual, dentre as populações indígenas. Começava pela derrubada de um trecho de mata, utilizando como instrumento o machado de basalto, granito ou diabásio. Em seguida, ocorria a queimada e o plantio nas primeiras chuvas de inverno, usando como instrumento o pau de cavar (GALVÃo, 1979) ou chuço (HolANDA, 1994), bastão de um metro e meio de comprimento, com ponta endurecida a fogo. Os cultivos repetiam-se no mesmo lugar, por dois ou três anos, após o quê a área era abandonada e novo trecho da mata era utilizado.

Eram essas as práticas dos caiapós meridionais em nossa área de estudo, à época da chegada dos primeiros colonos luso-brasileiros. O primeiro vigário da freguesia de Uberaba, Antônio José da Silva, ao narrar a entrada pioneira de geralistas na região, em 1810, relatou que os sertanistas evitavam o encontro 
com os caiapós, "cuja existência se conhecia, ou pelas queimadas, que fazia, de campos, ou pelos seus ranchos encontrados aqui e ali” (1970, p. 07).

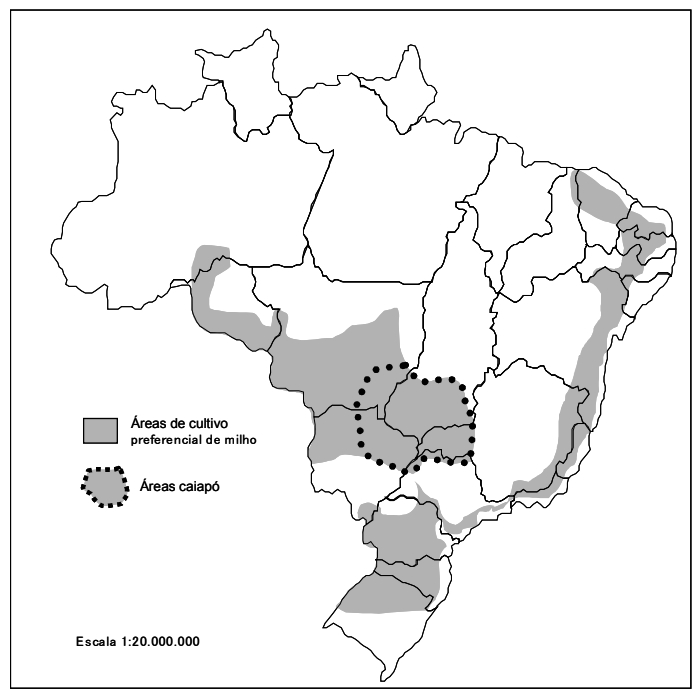

Figura 2: áreas de cultivos indígenas preferenciais e área cultural caiapó meridional antes da conquista européia.

Fonte: Galvão (1979).

À medida que as áreas de cultivo iam-se distanciando da aldeia, surgiam os centros, para onde as famílias se transferiam e transportavam o instrumental de beneficiamento. Com o passar do tempo, tais centros podiam transformarse em novas aldeias (GALVÃo, 1979). Desse modo, o sistema itinerante da agricultura indígena impunha um caráter seminômade às aldeias. Ao mesmo tempo, era exatamente essa forma de vida que garantia a sustentabilidade da economia indígena no ambiente do Cerrado.

Boserup (1987) criou um esquema de classificação dos sistemas agrícolas tradicionais, baseado na intensidade do uso da terra. Os cultivos de pousioflorestal consistem em clareiras abertas na floresta virgem, nas quais a terra é cultivada por dois anos. Após esse período de cultivo, é deixada em repouso por 20 a 25 anos, tempo necessário à recolonização completa da cobertura vegetal original e à reconstituição do solo de floresta. Segundo o modelo da autora, aumentos da densidade demográfica obrigam o encurtamento do pousio 
e a utilização de sistemas cada vez mais intensivos.

No caso da horticultura indígena da região em estudo, parece claro que se tratava de um cultivo de pousio florestal típico, compatível com as baixas densidades demográficas dos povos ameríndios na região do Cerrado. Tal sistema de agricultura itinerante em ambientes tropicais pode sustentar-se indefinidamente, sem grandes impactos ambientais. Usando a terminologia de Odum (1988), o clímax ecológico regional não se alteraria com as práticas dessas sociedades, já que a relação produção/respiração total do ecossistema regional se manteria inalterada, embora pudessem alterar, ainda que transitoriamente, essa relação em ecossistemas locais.

É provável, inclusive, que algumas fisionomias vegetais, encontradas nas matas e nos cerrados pelos colonizadores luso-brasileiros e tidas como "naturais", sejam estágios de desenvolvimento (ou comunidades transitórias, no dizer de Odum) de sucessões ecológicas iniciadas sobre campos de cultivo indígenas abandonados. Pierre Monbeig (1998) refere-se, por exemplo, à "quiçaça”, ou campo cerrado, encontrada no Oeste Paulista por botânicos do início do século XX, em áreas povoadas por índios. $\mathrm{Na}$ verdade, tal formação corresponderia ao primeiro estágio na sucessão ecológica sobre solos por eles cultivados, do Bauru Superior, evoluindo, em algumas dezenas de anos, para o cerrado strictu sensu.

Os caiapós meridionais abriam suas roças de milho e, uma vez plantadas, dispersavam-se em pequenos bandos para as atividades de caça e coleta, voltando a concentrar-se na época da colheita. O plantio era feito pelas mulheres, em sistema de mutirão, quando algumas abriam as covas e outras jogavam nelas três ou quatro grãos. Uma vez maduras as espigas, as mulheres percorriam novamente a roça para quebrá-las, para proteger a colheita das chuvas. As espigas eram recolhidas aos poucos nos paióis - pequenas construções de duas águas, cobertas de sapé e elevadas do chão. Após a colheita, a área era normalmente usada para o plantio do feijão, utilizando-se a haste do milho como proteção e suporte para as ramas (GALVÃo, 1979). Como veremos no capítulo 4, tais técnicas de preparo da terra, plantio e beneficiamento de alimentos foram quase integralmente adotadas pelos colonizadores luso-brasileiros, em nossa região de estudo, com poucas modificações.

Os sistemas de propriedade, organização e divisão social do trabalho dos ameríndios brasileiros, diversamente do que acontecia na América Espanhola, eram incompatíveis com as formas de produção da sociedade colonial. Daí, 
conforme vimos, o desaparecimento daquelas sociedades. Suas técnicas, contudo, resultado de um milenar processo de aperfeiçoamento frente às características ecológicas de ambientes tropicais, sobreviveram, incorporadas pelo colonizador.

\section{Sertanismo e caboclização}

A sociedade colonial prescindia das sociedades horticultoras, caçadoras e coletoras indígenas, e por isso foram destruídas. Entretanto, não prescindia da força de trabalho indígena, daí sua escravização. A escravidão indígena teve grande importância em todo o período colonial, principalmente na Amazônia, até o século XIX, e em São Paulo, até o início do século XVIII (GORENDER, 1988).

Quando o objetivo dos grupos coloniais era destruir as sociedades indígenas, para que o espaço por elas ocupado pudesse ser colonizado, recorria-se ao sertanismo de extermínio, isto é, expedições armadas destinadas a aniquilar fisicamente os núcleos indígenas. Elas se fizeram presentes em toda a história da ocupação do território brasileiro, e ainda existem nos dias atuais, consistindo no primeiro passo na ocupação de uma região de fronteira. No Oeste Paulista, no período compreendido entre 1890 e 1900 , por exemplo, ocorriam as dadas — expedições de extermínio contra os caingangues organizadas pelos bugreiros, sertanistas mercenários especializados no extermínio indígena — que alugavam seus serviços em zonas pioneiras desde o Sul do Brasil (MonBEIG, 1998). No final dos anos 1980, expedições de caça e extermínio de índios Uruéu-wau-wau e Arara foram realizadas em Rondônia e no Pará, respectivamente (MARTINs, 1998).

No período colonial, no entanto, eram freqüentes as expedições destinadas não só a aniquilar os núcleos nativos, mas também a escravizar os índios. Chamaremos essa prática de sertanismo de apresamento. As expedições sertanistas foram, na maioria dos casos, o primeiro contato que os povos indígenas tiveram com a sociedade colonial.

Outro desfecho, que se pode seguir ao contato entre a sociedade nacional e os povos indígenas, é o da aculturação, que resulta de uma acomodação entre indígenas e roceiros. Nesse caso, estabelece-se uma coexistência, na qual o indígena, aos poucos, abre mão das práticas de caça e coleta e da agricultura tradicional, e se sedentariza, absorvendo de forma crescente elementos culturais dos caboclos, 
até que seu modo de vida se torne indistinguível destes. A língua e a religião são esquecidas e a identidade indígena desaparece, diluída na sociedade sertaneja circundante. Chamaremos caboclização esse processo de aculturação. Galvão cita o exemplo dos Tenetehara, do rio Pindaré (MA), onde o contato com grupos caboclos que vivem da coleta comercial do babaçu permitiu relações econômicas cada vez mais intensas entre índios e a economia local. Segundo o autor:

Embora o grupo mantenha sua unidade tribal e possa ser distinguido da população cabocla por uma configuração cultural diferente, são evidentes os sinais de desgaste da cultura tradicional e os de substituição de valores tribais por outros, brasileiros, resultantes do impacto de trezentos anos de convívio geralmente pacífico com nossa sociedade rural. Concluímos que não demoraria talvez mais do que uma ou duas gerações para que os Tenetehara se transformassem em caboclos (GALVÃo, 1979, p. 130-131).

No Triângulo Mineiro, houve tanto o extermínio das populações caiapós, quanto sua caboclização. A região em estudo passou, todavia, por uma experiência histórica pouco comum. Aqui, foram assentadas populações indígenas vindas de outras regiões, como de Goiás (acroás, chacriabás e tapirapés) e do Mato Grosso (bororos e parecis), em aldeamentos criados pelo colonizador. Estes consistiram, na verdade, na primeira forma de ocupação colonial da região, que começou em 1730, quando a região em estudo, e de resto todos os atuais territórios dos estados de Goiás, Tocantins, Mato Grosso e Mato Grosso do Sul ainda eram parte da capitania de São Paulo. Para que possamos entender o papel dos aldeamentos na ocupação colonial do Triângulo Mineiro, é necessário recapitular como essa forma paulista de exploração da força de trabalho indígena irradiou-se até lá.

\section{Legislação, aldeamentos e a escravidão indígena na capitania de São Paulo}

No Triângulo Mineiro, a primeira forma de ocupação colonial consistiu, paradoxalmente, em núcleos de população indígena instituídos pelo colonizador: os aldeamentos. Estes foram uma criação colonial que teve sua primeira aparição no Planalto do Piratininga, de 1553 em diante. Os jesuítas, liderados pelo padre José de Anchieta, foram criadores do sistema em sua versão luso-brasileira. 
Nestes núcleos, a população ameríndia nativa era sedentarizada, de forma compulsória ou cooptada pela catequese, e a partir de então era tutelada pelo colonizador. Para tanto, a Companhia de Jesus recebeu da Coroa concessões de terra em torno da vila de São Paulo, onde instalou capelas, povoados e fazendas, dando forma aos aldeamentos.

Houve árdua disputa entre colonos e jesuítas pelo controle dos indígenas nos primeiros anos da colonização de São Paulo (1553-1640). Os fazendeiros paulistas, sem contar com gêneros tropicais que pudessem ter valor na exportação transatlântica — e por isso sem recursos para utilizar o tráfico negreiro como fonte de força de trabalho --, recorreram de início à escravidão dos índios do próprio Planalto. Com o escasseamento destes, passaram a organizar expedições de apresamento em zonas cada vez mais remotas, no interior do continente. Parte dos índios descidos do sertão era mantida na escravaria particular do sertanista apresador, e parte era entregue aos jesuítas, que os reduzia nas missões. Nelas, os colonos podiam também usar sua força de trabalho, desde que pagassem seu jornal aos padres da Companhia (Monteiro, 1994).

Em 1611, a Ley sobre a Liberdade do Gentio da Terra, e a Guerra que se lhe Pode Faz̧er estabeleceu as bases que, desde então, passaram a justificar as expedições de apresamento. Embora declarasse livres todos os índios do Brasil, aceitava a escravidão daqueles capturados em guerras justas. As pressões exercidas pelos jesuítas sobre os colonos e a ambigüidade da legislação conformaram, no século XVII, a peculiar escravidão indígena paulista, que negava a si própria nos inventários e noutros documentos da capitania de São Paulo, mas, na prática, reproduzia-se da mesma forma que a escravidão de africanos em outras regiões do Brasil (Monteiro, 1994).

Nos aldeamentos criados pelos jesuítas em torno da vila de São Paulo (Pinheiros, Guarulhos e São Miguel em 1560, Carapicuíba, Escada, Barueri, Itapecerica e Itaquaquecetuba no início do século XVII) também existia trabalho compulsório, de cujo excedente os padres se apropriavam, sendo o produto restante dividido entre os indígenas.

As Cartas Régias de 26 de janeiro e 19 de fevereiro de 1696 passaram a disciplinar uma prática que, desde o início daquele século, já ocorria em São Paulo: a administração (Petrone, 1995). Consistia no uso da força de trabalho dos indígenas dos aldeamentos, pelos fazendeiros ou sob ordens da Coroa, 
mediante pagamento, na verdade, irrisório, entregue aos seus diretores. Muitas vezes, esse pagamento não ocorria, e os índios de um determinado aldeamento poderiam manter-se como escravos de um proprietário até sua morte. Também era comum que sertanistas solicitassem aos jesuítas ou à Câmara de São Paulo, no caso das aldeias do Padroado Real, um certo número de índios para organizar uma armação (expedição sertanista). Jacob Gorender (1988) chama esse conjunto de práticas de escravidão incompleta, e Pasquale Petrone (1995), de escravidão disfarçada. Ambos perceberam sua semelhança com o sistema de encomiendas usado nas colônias espanholas da América.

Tanto nas encomiendas espanholas quanto na administração luso-brasileira, as reduções funcionavam como reservas de força de trabalho para a coletividade de colonos, os quais solicitavam índios ao encomiendero ou administrador, geralmente, um funcionário ou uma ordem religiosa. A estes estavam subordinados os caciques ou principais — indígenas na posição de chefe — , cuja tarefa era selecionar os índios que seriam cedidos pelo aldeamento (Petrone, 1995).

A diferença essencial entre as duas instituições decorria da própria natureza dos sistemas coloniais português e espanhol, como visto linhas atrás. Enquanto no Brasil houve a completa destruição das sociedades précabralianas e do seu modo de produção coletivista, na América Espanhola as comunidades camponesas pré-colombianas foram mantidas, inclusive com parte de suas instituições políticas, como o cacicato. Assim, nos aldeamentos hispano-americanos, houve uma superposição do aparato colonial sobre as comunidades camponesas indígenas. $\mathrm{Na}$ América luso-brasileira, no entanto, os aldeamentos foram criações novas, comunidades rurais que surgiam pelas mãos do colonizador, com a redução dos índios apresados em núcleos sedentários. As sociedades indígenas tradicionais eram destruídas no processo, e a cultura e as relações de trabalho da sociedade colonial eram impostas aos índios (figura 3).

Em 1727, o governador da capitania de São Paulo criou um regimento para o sistema de administração, no qual os aldeamentos ficariam sob as ordens de um Protetor dos Índios (um jesuíta) e de um procurador secular, subordinado ao primeiro (PETRONE, 1995). Nesse período, os paulistas criaram novos núcleos coloniais em torno de jazidas auríferas recém-descobertas, como Minas Gerais (1690), Cuiabá (1718) e Goiás (1725), onde repetiriam a experiência dos aldeamentos já praticada no Planalto do Piratininga. 


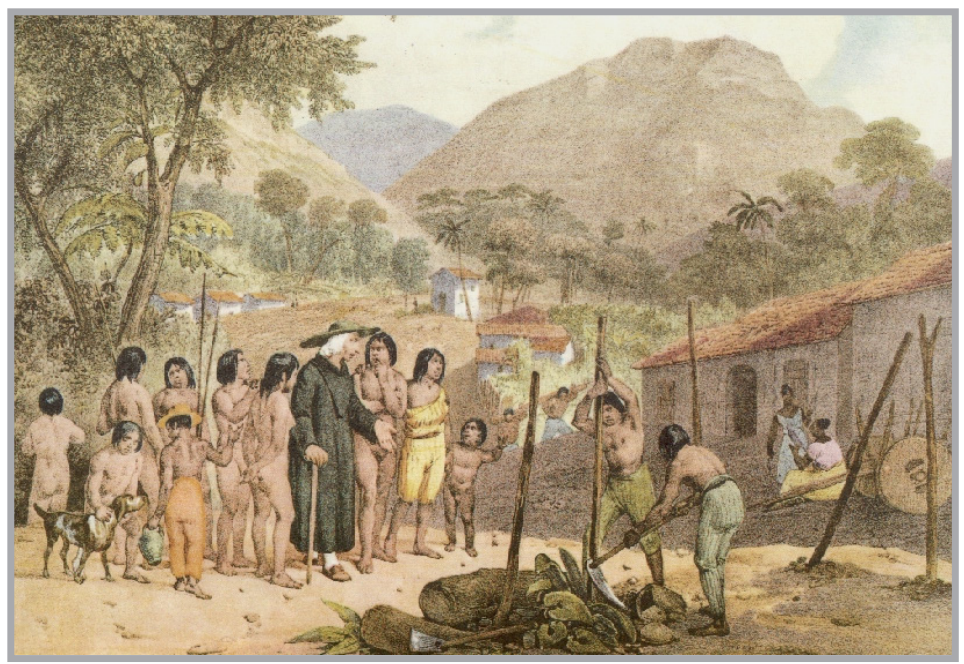

Figura 3: Rugendas: Aldeia de Tapuias Fonte: Rugendas (1998)

Os aldeamentos goianos interessam-nos mais de perto, pois o Triângulo Mineiro foi parte do território de Goiás até 1816. Durante os mais de sessenta anos que essa região pertenceu àquela capitania, os aldeamentos foram praticamente a única experiência colonizadora ali empreendida pelo governo goiano. É dela que trataremos a seguir.

\section{A Estrada dos Goiases e os aldeamentos do Sertão da Farinha Podre}

Entre 1722 e 1725, sertanistas paulistas, liderados por Bartolomeu Bueno da Silva (o Anhanguera) e João Leite da Silva Ortiz, descobriram as Minas dos Goiases, nas cabeceiras do rio Vermelho, afluente da bacia do Araguaia. Em pouco tempo, paulistas afluíram para lá, criando arraiais em torno das lavras, tais como Santa Cruz, Santa Luzia, ${ }^{1}$ Meia Ponte ${ }^{2}$ e Jaraguá, e uma vila planejada, Vila Boa ${ }^{3}$ (Palacin; Moraes, 1994).

\footnotetext{
Hoje Luziânia

Hoje Pirenópolis

3 Hoje Cidade de Goiás
} 
Entre o território das minas goianas e São Paulo, foi aberto um caminho régio, em 1730, que correspondia aproximadamente ao trajeto do Anhanguera (Palacin; Garcia; Amado, 1995), cujos descendentes, até o início do século XIX, mantiveram o usufruto do pedágio (SAint Hilaire, 1975). Uma Carta Régia, datada de 1730, estabelecia aquele como o único caminho para as minas de Goiás, e previa penas para quem usasse desvios (Palacin; Garcia; Amado, 1995).

Esse caminho, disposto aproximadamente na direção sul-sudeste nor-noroeste, atravessava uma área de chapadões, cortados por vales fluviais, cujos cursos d'água são orientados no sentido sudeste-noroeste. Foi possível reconstituir, com certa aproximação, o traçado do caminho, graças aos relatos de viagem de Saint Hilaire (1975 a; 1976), Eschwege (1996) e Luís D’Alincourt (1975), cotejados com cartas topográficas (figura 4).

O trecho que chegava até Mogi-Guaçu já era bastante conhecido e transitado pelos sertanistas, desde o século XVII (Palacin; Garcia; Amado, 1995). Desse ponto em diante, percebe-se, pelo traçado, a intenção de cruzar-se os rios "mais próximos às suas nascentes (...), [seguindo] próximo às primeiras elevações da banda ocidental da Serra da Mantiqueira, evitando as regiões mais alagadiças, de difícil travessia e sujeitas às febres palustres" (BACELAR; BRIOSCHI, 1999, p. 46).

No trecho paulista, a estrada estava disposta no sentido nor-noroeste. Após a travessia do rio Grande, já em Goiás, no território que hoje corresponde ao Triângulo Mineiro, seguia pelo sentido norte, num notável alinhamento com o meridiano $47^{\circ} 58^{\prime} \mathrm{O}$, para novamente assumir o sentido nor-noroeste após a travessia do rio Paranaíba.

No trecho triangulino, a estrada passava pela crista dos chapadões, por ser esse o espaço mais transitável na mesopotâmia entre os rios Grande e Paranaíba. Estendia-se por $195 \mathrm{~km}$ de grande regularidade topográfica, sobre planuras cobertas por campo sujo e campo cerrado, cujas altitudes variavam de 915 a $950 \mathrm{~m}$, exceto nos vales fluviais. Nestes, apenas três cursos d'água eram de difícil travessia: o rio Grande, cujo profundo vale, então recoberto por densa floresta, chega a $550 \mathrm{~m}$ de altitude; o rio das Velhas ${ }^{4}$ e o rio Paranaíba. Os rios Uberaba Falsa, ${ }^{5}$ Tejuco e Uberaba Legítima ${ }^{6}$ eram

\footnotetext{
Hoje rio Araguari

Hoje rio Uberaba

6 Hoje rio Uberabinha
} 


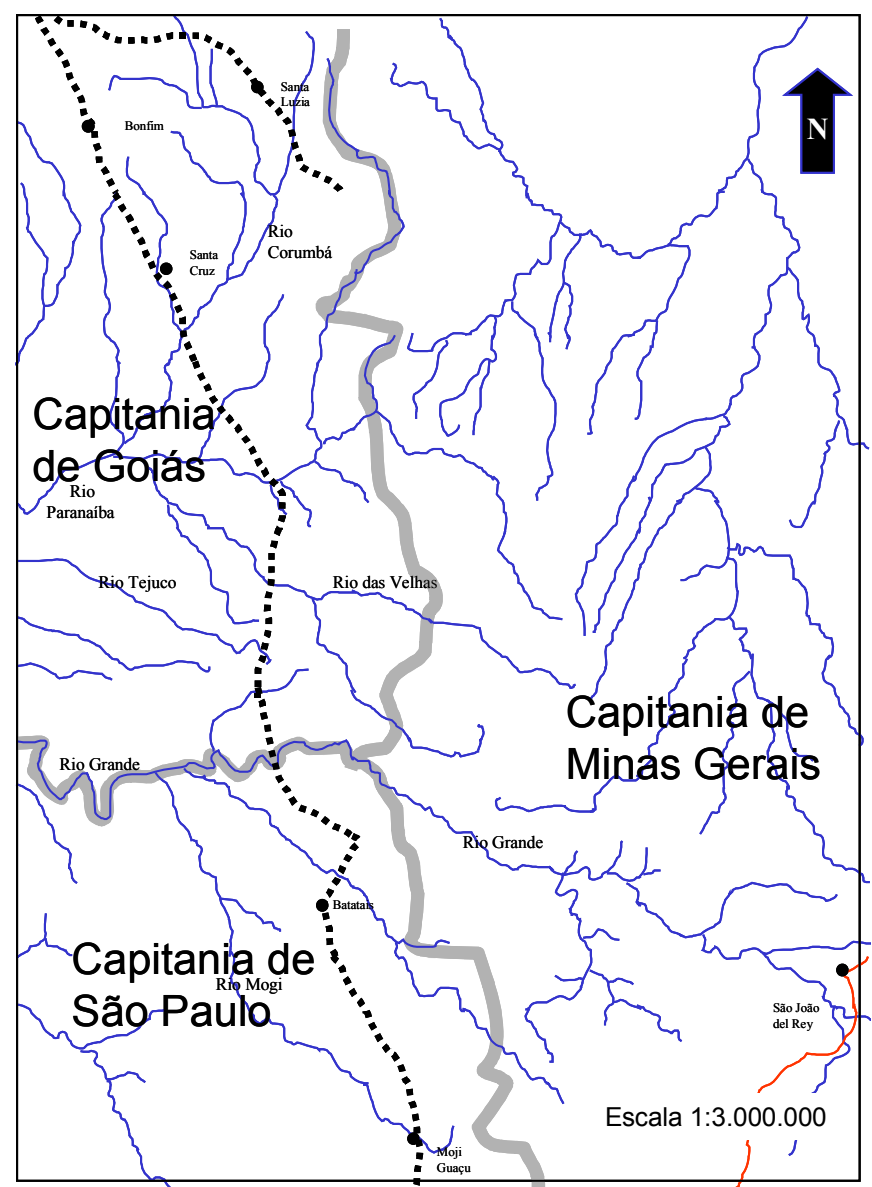

Figura 4: estrada do Anhanguera ou dos Goiases (1736).

Fonte: D’Alincourt (1975); Saint Hilaire (1975); Eschwege (1996) ; IBGE (1972).

cruzados próximos de suas cabeceiras, em pontos facilmente vadeáveis durante a seca (SAint Hilaire, 1975).

No início da colonização de Goiás, incursões caiapós ameaçaram a estabilidade dos arraiais do ouro e, principalmente, o tráfego pela estrada do Anhanguera. A resistência caiapó já era conhecida dos paulistas desde as primeiras bandeiras em Goiás. É provável que os revezes dos colonizadores tenham sido o fator responsável pela absoluta ausência de povoados e fazendas 
em toda a faixa de terras compreendida na bacia do baixo Paranaíba e baixo rio Grande (atual sul de Goiás, noroeste de São Paulo, pontal do Triângulo Mineiro e leste do Mato Grosso do Sul), até a época em que Aires de Casal (1976) escreveu sua Corografia Brasílica, em 1817:

É a menos conhecida [região da província de Goiás], não havendo nela estabelecimento algum de cristãos. Os caiapós, que a dominam (repartidos ainda, segundo dizem, em várias tribos), têm sido fatais por vezes aos comboios cuiabanos, e invadido a parte setentrional da província de São Paulo, onde causaram a deserção de muitos estabelecimentos. (CASAL, 1976, p. 151).

Casal apropriadamente chamou essa região de Caiapônia, pois tratava-se de uma parte do interior da Colônia, onde a resistência indígena impediu, por muito tempo, que se instaurassem os poderes do Estado Colonial. Até o início do século XVIII, correspondia ao território do julgado goiano de Santa Cruz. O arraial de Santa Cruz, sede daquele território, situava-se ao longo do trajeto da Estrada dos Goiases. Saint Hilaire refere-se a ele como tendo

[...] 40 léguas aproximadamente, de norte ao sul, indo desde o Rio Jurubatuba até o Paranaíba, na fronteira da província [de Goiás]. Ainda não tem limites fixos a oeste, onde existe uma imensa região desabitada e desconhecida. A paróquia inteira de Santa Cruz não conta com mais de 3.000 fiéis. (1975 a, p. 118).

De fato, a colonização do Sudoeste Goiano por mineiros geralistas só começou depois de 1830, após o aldeamento e o extermínio dos caiapós, e com a abertura de uma Estrada Real pelo engenheiro militar Cunha Matos, nos anos 1820 (FERREIRA, 1958).

Em Carta Régia de 1749, destinada a D. Marcos Mendonça, governador da capitania de Goiás, a Coroa portuguesa decidiu pela guerra aos caiapós, "que não cessa de infestar com as mais cruéis hostilidades o caminho de São Paulo para os Goiás, e até as povoações daquelas Minas" (PALACIN; Garcia; AmADo, 1995, p. 69). Um ano antes, em 1748, os caiapós haviam dizimado os garimpeiros de um núcleo aurífero, nas cabeceiras do rio das Abelhas, ${ }^{7}$ no

\footnotetext{
Hoje rio Araguari
} 
mesmo lugar onde, alguns anos depois, surgiria o arraial do Desemboque (VASCONCELOS, 1999). Impunha-se uma solução militar contra os caiapós da região dos rios Paranaíba e Grande, para resguardar a segurança do tráfego na Estrada dos Goiases. Para isso, o governo da capitania de Goiás contratou os serviços do sertanista paulista Antônio Pires de Campos, o moço.

Ainda no século XVIII, parecia ser comum a contratação de paulistas pelo Estado Colonial, para a prática do sertanismo de extermínio, com o intuito de desinfestar de índios e quilombolas as áreas de fronteira. Fórmula semelhante já havia sido usada, por exemplo, nas expedições contratadas pelo governador de Pernambuco e comandadas por Domingos Jorge Velho contra o Quilombo de Palmares, em 1694 (LARA, 1996).

Em Minas, tal prática também era freqüente: uma Ordem Régia, de 1745, dirigida ao governador Gomes Freire de Andrade, propunha a vinda de duzentos casais de índios paulistas para que se estabelecesse uma rede de aldeamentos nas comarcas do Oeste Mineiro, de onde partiriam expedições de extermínio aos quilombos do alto São Francisco (VAsconcelos, 1999). Nas primeiras campanhas da guerra contra os quilombos do Oeste Mineiro, de 1745 a 1749, o paulista Antônio João de Oliveira liderou 400 índios bororos, contratados pelo governador interino de Minas, José Antônio Freire de Andrade (Mello E Souza, 1999).

Essa foi também a solução adotada pela câmara de Vila Boa de Goiás para acabar com os ataques dos caiapós na estrada para São Paulo. De acordo com carta de D. Marcos de Noronha, Conde dos Arcos, datada de 1749, depois de repetidas solicitações feitas pelo governador de São Paulo, a autorização para o início de ações contra os caiapós foi finalmente concedida em 1746 (Palacin; Garcia; Amado, 1995). A câmara de Vila Boa contratou, às expensas dos fazendeiros e mineradores goianos, o paulista (estabelecido no Cuiabá) Antônio Pires de Campos, o moço, filho do legendário Antônio Pires de Campos, o velho, pioneiro da navegação monçoneira e descobridor das lavras cuiabanas (Holanda, 1995). Tinha a seu serviço índios bororos e parecis, contactados durante a colonização cuiabana e aldeados nos arredores da vila do Cuiabá.

Pires de Campos partiu daquela vila acompanhado de 500 índios, iniciando uma campanha de extermínio e apresamento dos caiapós, que duraria até 1750. Com grande violência, repeliu os caiapós em todo o trecho da estrada entre os rios Paranaíba e Grande, na região que, do final do século XVIII em diante, 
passaria a ser conhecida por Sertão da Farinha Podre. Em seguida, obedecendo ainda à determinação do governador paulista, fundou alguns aldeamentos ao longo do trecho, onde distribuiu seus índios bororos, que doravante se tornariam responsáveis pela defesa do trânsito na estrada (PALACIN; GARCIA; AmAdo, 1995).

O número exato desses aldeamentos originais é controverso, mas o padre Luiz Antônio Silva e Souza, em 1812, recolheu da tradição oral o número de três, situados próximos às passagens dos rios mais caudalosos: as aldeias do Rio das Pedras, ${ }^{8}$ Santana ${ }^{9}$ e Lanhoso ${ }^{10}$ (Palacin; Garcia; Amado, 1995). Já Aires de Casal (1976) escreveu que a aldeia de Lanhoso surgiu depois, em 1775, quando os índios bororos da aldeia de Santana foram transferidos para as proximidades do rio Grande, para dar lugar aos chacriabás trazidos pelo governo goiano. Eschwege (1996) visitou nove aldeamentos no trajeto da estrada, em 1816. A maioria deles, como sugeriremos adiante, deve ter nascido de divisões da população dos três originais. Saint Hilaire relatou que Pires de Campos fundara somente Rio das Pedras e Santana. As aldeias de Estiva, Piçarrão e Boa Vista surgiram, segundo o cronista, de desmembramentos da população do Rio das Pedras.

Pela descrição que aqueles viajantes deram desses núcleos, só Rio das Pedras, Santana e Piçarrão mereceriam o nome de aldeamentos, pois eram os únicos que contavam com capelas. A presença do templo religioso era sinal da oficialidade de sua fundação, de que o núcleo havia sido reconhecido pelas autoridades religiosas. Os demais povoados eram destacamentos dos núcleos originais, resultado de um processo de dispersão centrífuga da população aldeada, cujas causas analisaremos adiante.

Pires de Campos recebeu do governador de Goiás uma faixa de terra de uma légua e meia de cada lado da estrada, do rio Paranaíba até o rio Grande, onde foram erguidos os aldeamentos (SAint Hilaire, 1975). Anos depois, como veremos no capítulo 3, essas terras seriam objeto de intensas disputas entre os índios e os colonos geralistas.

Tomando como base os relatos de Saint Hilaire, D’Alincourt e Eschwege, cotejados com a toponímia dos rios e córregos, e com o auxílio de cartas topográficas, estabelecemos a posição aproximada dos aldeamentos do Sertão da Farinha Podre no início do século XIX (figura 5).

\footnotetext{
Hoje Cascalho Rico

Hoje Indianópolis

10 Hoje desaparecido
} 
Os aldeamentos da Farinha Podre provavelmente se organizavam da forma estabelecida pelo Regulamento paulista de 1727, que propunha

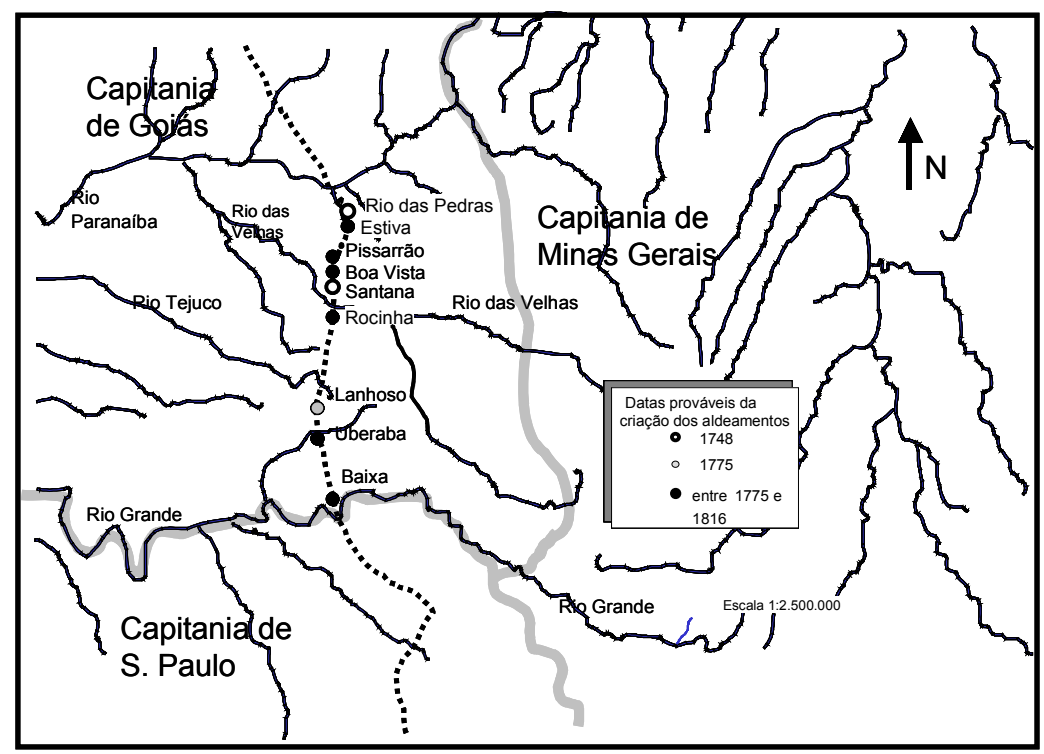

Figura 5: aldeamentos na Estrada dos Goiases (1748-1816)

Fonte: Eschwege, (1996), Sainte Hilaire (1975 a), Aires de Casal (1976).

a direção de um padre jesuíta, nomeado Protetor dos Índios, um Administrador e um Governador dos Índios, estes últimos seculares (CHAIM, 1983). O padre jesuíta José de Castilhos foi nomeado protetor dos índios dos aldeamentos triangulinos em 1749, e foi o responsável pela ereção da capela (e provavelmente pelo plano do aldeamento) da aldeia de Santana do Rio das Velhas, na beira daquele rio, um ano depois (Palacin, Garcia, Amado, 1995). Em pelo menos mais dois aldeamentos, existiam capelas Rio das Pedras e Piçarrão - , mas a capela de Santana era a única curada (Saint Hilaire, 1975). Ali foi erguida a matriz da freguesia em 1761, já depois da expulsão dos jesuítas (BARBosa, 1995). Como nos aldeamentos da região das minas goianas, os da Farinha Podre dispunham de um único administrador para todos os núcleos. 


\section{Índios soldados e índios escravos}

A historiadora goiana Marivone Matos Chaim reconstituiu o organograma administrativo dos aldeamentos goianos anteriores ao Diretório pombalino, de 1758 (figura 6), dentre os quais se incluíam os da Farinha Podre. Como se vê, a administração dos aldeamentos era feita conjuntamente por jesuítas e diretores seculares, aos quais estava subordinada uma guarda de pedestres. Como nos aldeamentos paulistas, a gestão conjunta dos inacianos e dos administradores não-religiosos era fonte de conflitos freqüentes, quase sempre versando sobre a primazia do uso da força de trabalho indígena.

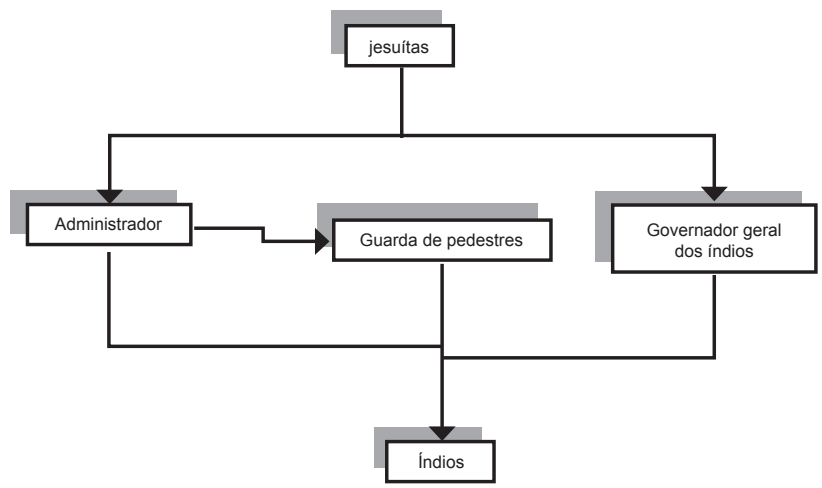

Figura 6: administração dos aldeamentos goianos até 1758

Fonte: Chaim (1983, p. 130).

Na Farinha Podre, Saint Hilaire (1975) relatou que, desde o início, os padres se indispuseram contra o primeiro administrador dos índios, o sertanista Pires de Campos. Este acabou por estabelecer-se no Rio das Pedras, enquanto os jesuítas mantiveram-se em Santana, após acordo de divisão de índios entre os dois aldeamentos. Outro exemplo de conflito entre o poder secular e o poder religioso pode ser visto numa carta de 1757, do padre jesuíta Estevão de Souza, da Aldeia de Santana, dirigida ao governador Conde de São Miguel, que falava do sucessor de Pires de Campos, guarda-mor João de Godoy. Nela, o padre pedia

pelos missionários moradores e viandantes deste sertão, se digne por serviço de Deus e Sua Majestade, livrar-nos do cruel jugo do guarda-mor João de Godoy, 
que tendo a seu cuidado a conquista do gentio caiapó, experimentamos nele um caiapó disfarçado (Palacin, Garcia, Amado, 1995, p. 72-73).

A presença de um regimento de guardas pedestres nos aldeamentos, prevista no regulamento, é significativa das duas funções que eles desempenhavam: a de defesa e de reserva de força de trabalho. Os soldados, a serviço do administrador, comandavam os indígenas em ações de defesa e ataque contra tribos hostis e, ao mesmo tempo, eram elementos de dissuasão contra a resistência deles à exploração escravista.

A disciplina nos aldeamentos, imposta pelo governo da capitania de Goiás, tinha caráter militar, que lembra a disciplina de caserna. É o que se pode perceber no Regimento emitido por D. Marcos Noronha, em 1754, e que passou a substituir o Regimento paulista de 1727:

Cap. I - os soldados darão inteira obediência àquela pessoa a cujo cargo estiver o governo da aldeia e na falta desta à que por ela ficar nomeada para fazer as suas vezes, e havendo algum soldado que desobedeça às suas ordens será logo castigado como o detido o merecer.

Cap. II - o tambor tocará alvorada ao romper da aurora, e a recolher às 8 horas da noite, e fora destas duas ocasiões não poderá tornar a tocar senão a rebate, se for preciso, e se tiver ordem para isso; a este toque se acharão logo prontos com os seus armamentos, não só os soldados, mas todos os índios, mais pessoas que assistirem na aldeia, para se lhes determinar os lugares que devem ocupar e havendo algum soldado ou índio, ou qualquer outra pessoa, que não satisfaça prontamente esta obrigação, serão logo presos, para se lhe impor os mais castigos, que o delito merecer.

Cap. III - todas as pessoas assistentes nas mesmas aldeias guardarão aos missionários todo o respeito e acatamento devido ao seu grande caráter, para que, vendo a grande estimação que se faz deles, com este bom exemplo não só façam os índios o mesmo, mas abracem com mais fervor e eficácia a nossa Santa Fé (Palacin, Garcia, Amado, 1995, p. 71).

Nos aldeamentos da Farinha Podre, o destacamento militar, comandado por um alferes, tinha quartel no Porto do Registro, no rio das Velhas, onde estava estabelecido um posto fiscal de alfândega para o trânsito entre São 
Paulo e Goiás, sob as ordens do fiel (funcionário de alfândega). Havia também destacamentos avançados na beira do rio Paranaíba e do rio Grande. O comandante do destacamento tinha a seu serviço índios da Aldeia de Santana, sob regime de administração (Saint Hilaire, 1975).

O papel defensivo e militar exercido pelos aldeamentos da capitania de Goiás era evidente, não só na Farinha Podre, onde foram criados explicitamente com esse objetivo, mas também em outros núcleos, fundados em torno da zona mineradora goiana, de 1749 em diante. O aldeamento de Nova Beira, por exemplo, na Ilha do Bananal, foi criado em 1775, junto ao Presídio (quartel) de São Pedro do Sul. Contava com índios carajás e javaés que ali haviam sido reduzidos, nativos da própria região do rio Araguaia. O governo goiano explorava então a rivalidade entre eles e grupos não aldeados, instando-os contra os caiapós setentrionais e os xavantes, que ameaçavam a navegação fluvial do rio Araguaia (Снагм, 1983).

O uso dos índios aldeados como linha militar de frente não foi uma invenção goiana. Resultava de uma longa tradição iniciada pelos paulistas nos aldeamentos do Piratininga (Petrone, 1995). Não faziam só a defesa passiva, mas também eram usados na prática do sertanismo. Monteiro (1994) confirma que o sertanismo era o principal destino dos índios do sexo masculino em São Paulo, no século XVII, sendo o trabalho na agricultura tarefa para as índias. Petrone (1995) chega à conclusão semelhante, mostrando que, com o passar do tempo, a utilização intensiva da população aldeada nas incursões pelo sertão foi um dos fatores que levou à decadência demográfica dos aldeamentos.

Nesse sentido, em Goiás, a própria expedição bororo de Pires de Campos, inaugurando na Farinha Podre o ciclo dos aldeamentos goianos, foi significativa do uso de índios no sertanismo. Posteriormente, índios do aldeamento do Rio das Pedras foram transferidos para Nova Beira, para fazer frente aos xavantes (Saint Hilaire, 1975).

Porém, o aldeamento de São José de Mossâmedes ${ }^{11}$ foi o que provavelmente mais exerceu o papel de reserva de braços para o sertanismo. Fundado em 1775, nas vizinhanças de Vila Boa, com a transferência dos índios acroás rebelados em Duro, no Leste Goiano, recebeu vários reforços demográficos posteriores, por meio de transferências compulsórias de índios de outras partes da capitania.

11 Hoje Mossâmedes 
Em 1780, recebeu os carajás e javaés de Nova Beira e, em 1813, os caiapós aldeados na Aldeia de D. Maria I, no Oeste Goiano. Esses índios foram usados nas grandes campanhas contra os xavantes, em 1788 (СНAIM, 1983).

Em Goiás, outra função importante dos aldeamentos foi a de reserva de força de trabalho escrava, explorada tanto pelos administradores quanto pelos padres e colonos. A intensiva utilização dos índios na escravidão deveu-se, principalmente, à pobreza da capitania, incapaz de importar negros da Guiné, em número suficiente para suprir as demandas locais por força de trabalho.

Em relação aos aldeamentos da Farinha Podre, há indícios que sugerem a existência de escravidão indígena no início do século XIX. No aldeamento do Rio das Pedras, por exemplo, um índio era escolhido como capitão, numa posição equivalente à do cacique nas encomiendas espanholas. Tinha como trabalho recrutar mensalmente os índios, que serviriam ao destacamento militar próximo, além de "fiscalizar as plantações e punir os preguiçosos" (SAINT HiLAire, 1975, p. 131).

Como até o início do século XIX o povoamento da região do atual Triângulo Mineiro por colonos luso-brasileiros havia sido pouco significativo, é provável que a exploração da escravidão indígena não fosse muito intensa. De fato, Saint Hilaire, referindo-se aos índios de Rio das Pedras, relatou em 1819:

Jamais vi índios tão felizes quanto aqueles. Raros eram os portugueses que se tinham estabelecido entre eles. Ninguém os incomodava, ninguém perturbava o seu repouso, e eles nem mesmo pagavam o dízimo. Tinham poucas necessidades e poucas tentações. Suas terras eram excelentes e com pouco trabalho produziam o suficiente para o seu sustento (Saint Hilaire, 1975, p. 136).

Outro papel desempenhado pelos aldeamentos da Farinha Podre, por causa de sua localização, era o de local para pousos de tropas. Os pousos eram ranchos, geralmente cobertos de sapé, abertos dos lados, onde tropas e viajantes descarregavam, dormiam e se alimentavam (SAINT HiLAIRE, 1975 a, 2000; Eschwege, 1996). Dispunham do apoio logístico da população vizinha, que preparava os víveres vendidos aos viajantes. Havia pousos em Rio das Pedras, Estiva, Piçarrão, Boa Vista, Santana e Lanhoso, onde os índios vendiam alimentos aos que lá faziam paradas (SAint Hilaire, 1975 a). 


\section{A geopolítica dos aldeamentos}

Os aldeamentos do Sertão da Farinha Podre foram criações do Estado Colonial, por meio do governo da capitania de Goiás. Sua localização resultou numa configuração territorial que refletia suas concepções sobre o uso estratégico do espaço.

Merece atenção o fato de que, ao criar aqueles aldeamentos, não parecia haver, por parte do governo goiano, a intenção de povoar. A própria disposição geográfica dos núcleos - ao longo da Estrada, no sentido sul-norte — mostrava seu caráter muito mais defensivo que propriamente de ocupação territorial. Os aldeamentos alinhavam-se como num corredor, para dar proteção e apoio logístico às tropas que transitavam de São Paulo aos arraiais goianos. Em torno destes, até o final do século XVIII, havia uma imensa área onde praticamente inexistiam povoações sedentárias coloniais. Essa configuração territorial - aglomerações regionais de povoados, isolados por zonas intermediárias não colonizadas e ligadas entre si por caminhos de trânsito obrigatório - era a que vigia em todo o centrosul brasileiro até aquele tempo, como se vê no mapa da figura 7 .

Nesse sentido, devemos nos perguntar quais seriam as razões desse peculiar arranjo geográfico. Acreditamos que a permanência de imensos espaços não colonizados — como a Caiapônia e a Bororônia de Casal, e mais o Oeste Paulista - entre os núcleos auríferos goianos e cuiabanos e o litoral, cortados por estradas de trânsito obrigatório, devia-se a fatores que iam além da presença dos "gentios selvagens".

O mito do caiapó selvagem e hostil sobreviveu até a primeira metade do século XIX. Em 1819, Saint Hilaire (1975) relatava que:

Os coiapós atacavam de surpresa as tropas de burros que vinham de São Paulo, tendo forçado os portugueses a abandonarem vários postos estabelecidos por eles na parte setentrional da província do mesmo nome (Saint Hilaire, 1975 a, p. 63).

O padre Luiz Antônio Silva e Souza, em 1812, descrevia os caiapós como uma "nação bravíssima e muito numerosa que, com os seus ataques, obstou em princípio ao aumento da capitania [de Goiás]" (Palacin, Garcia, Amado, 1995, p. 14). Eschwege, referindo-se ao Triângulo Mineiro de 1816, descreveu-o como "distritos ou julgados [que] abrangem uma área igual à de Portugal, pelo menos, 


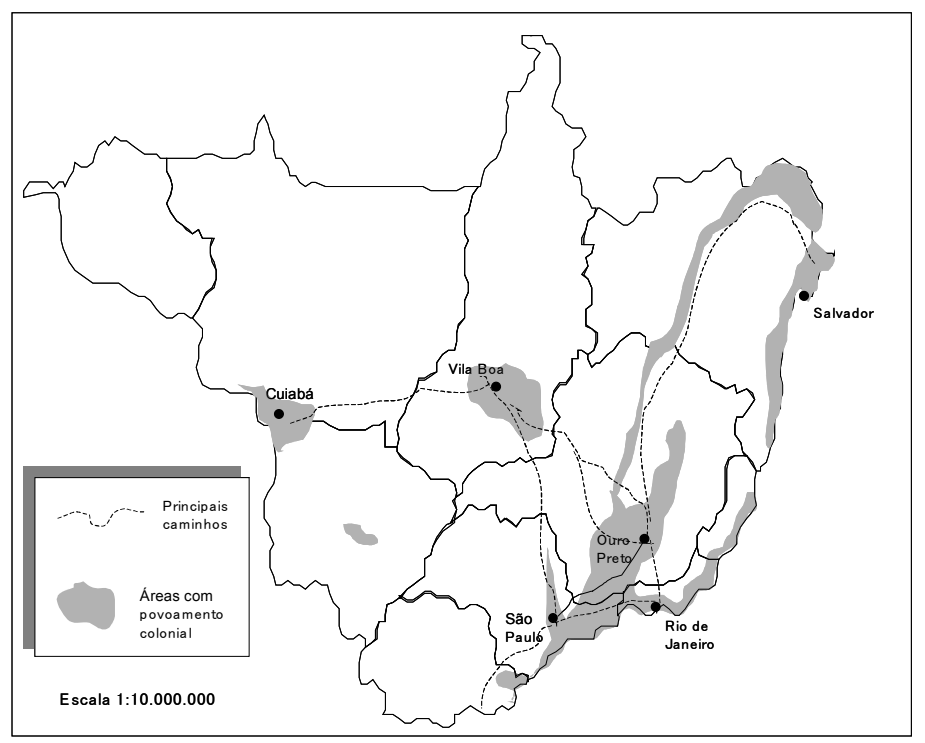

Figura 7: áreas povoadas no centro-sul brasileiro em meados do século XVIII Fonte: Holanda (1989, p. 293)

estendendo-se entre o rio Grande e o rio Paranaíba, até a sua confluência, zona até agora desconhecida por causa dos selvagens caiapós” (1996, p. 104).

É provável que as autoridades régias se interessassem em manter esse mito, por mais que a bravura caiapó tivesse fundamento na realidade. Até o período pombalino (1755-1777), não havia, da parte do Estado português, o desígnio de ocupar o interior da Colônia como um fim em si mesmo, já que o papel desta, na sua concepção mercantilista, era gerar riquezas, sobretudo auríferas. A geopolítica do Império Português relativa à Colônia resumia-se então à intenção de criar vários territórios restritos, destinados à produção de formas específicas de riqueza, ligados entre si por vias únicas e de acesso vigiado. Daí o cuidado dispensado às fronteiras entre as capitanias, e a instalação de postos militares e registros nas ligações interprovinciais. A essência das preocupações do Estado estava em extrair ouro e pedras preciosas e em evitar seu contrabando.

Nesse sentido, espaços "vazios" povoados por índios, tais como a 
Caiapônia, funcionavam como grandes barreiras naturais aos fluxos clandestinos, um desestímulo ao contrabando. A favor dessa hipótese, há o fato de que, quando se deu a abertura da Estrada dos Goiases, em 1730, foi expedida uma Carta Régia proibindo o uso de outros caminhos entre Goiás e São Paulo:

Por atalhar os grandes danos e prejuízos, que podiam seguir a Real Fazenda de Sua Majestade nos descaminhos de seus Reais Quintos, Entradas e Passagens dos Rios, e ainda dos moradores desta capitania, que não haja mais de um caminho para as Minas dos Goyazes, e se dever só conservar o que vai desta cidade à Vila de Jundiaí e continua de Mogi do Campo e dali até as ditas Minas, para cuja observância se lançou nesta cidade um Bando de 10 de janeiro de 1730, cominando-se nele as penas em que deviam incorrer os que o encontrassem (Palacin, Garcia, Amado, 1995, p. 123-124).

O mesmo cuidado existiu em relação ao isolamento das minas do Cuiabá. Pelas Ordens de 25/03/1725 e 29/04/1727, o acesso a elas deveria ser feito, obrigatoriamente, pela navegação fluvial monçoneira ou pela Estrada dos Goiases. O alvará de 27/10/1733, de forma mais abrangente e explícita, proibiu a abertura de novas estradas ou picadas para todas as zonas mineradoras (isto é, Minas Gerais, Goiás e o Cuiabá) em que houvesse arrecadação regular da Fazenda Real (Cunha Matos, 1981).

Um desses espaços "vazios" era o Leste de Minas. Nessa grande zona fronteiriça às capitanias do Espírito Santo e Rio de Janeiro, a Mata Atlântica, povoada por índios botocudos, funcionava como obstáculo natural ao extravio do ouro mineiro. Tal área, que só seria efetivamente colonizada nos séculos XIX e XX, era conhecida como Área Proibida, conforme escrito de 1784, do Capitão General Luís da Cunha Menezes: "Sertão para a parte de Leste denominado Áreas Proibidas, na hipótese de servirem os ditos sertões de uma barreira natural a esta capitania para a segurança de sua fraude" (Vasconcelos, 1999, p. 226). De fato, Cunha Matos (1981) cita o caso de um morador de Aiuruoca, punido em 1745 por abrir uma estrada clandestina de Minas ao Rio de Janeiro.

Saint Hilaire (1975) e Eschwege (1996), nos seus relatos de viagem, deixam perceber que a configuração territorial de Minas do início do século XIX ainda lembrava essa estratégia setecentista. A Estrada Real era a única 
ligação legal entre o arquipélago de arraiais do ouro mineiros e a cidade do Rio de Janeiro até 1810, quando foi autorizada a abertura de um segundo caminho, o do Rio Preto, um pouco mais ao sul (Saint Hilaire, 1975 a).

A Estrada Real, apesar de datar de 1710, não teve seus arredores povoados até o princípio do século XIX. Quando da visita dos cronistas europeus, atravessava um território ermo, coberto pela mata, onde os únicos sinais de atividade humana eram os Registros e os postos militares:

[...] enquanto que a setenta ou oitenta léguas do mar [em Minas] se encontram cidades bastante consideráveis, grande número de povoações, imensa extensão de terrenos despojados de matas, não existe, pelo contrário, a pequena distância da capital senão uma povoação nascentes; as florestas virgens se mostram aí ainda com toda a pompa nativa, e os índios erram em liberdade (SAINT HiLAIRE, 2000, p. 39).

Imagine-se uma trilha de 50 léguas, aproximadamente, aberta pelo pisoteio de mulas de carga, sombreada pela espessa mata virgem, e tendo à frente, à retaguarda e dos lados altos morros ou profundas grotas e desfiladeiros, que devemos galgar ou descer [...]. Imaginem-se as enfadonhas travessias do Paraíba e do Paraibuna, onde guardas vigilantes, fardados, como se tratasse de uma fronteira estrangeira, exigissem dos viajantes passaporte, ao mesmo tempo que exibem olhares inquisidores sobre eles (EsCHWEGE, 1996, p. 60-61).

Dessa maneira, a ocupação territorial setecentista da Colônia não mais se restringia a uma franja litorânea, como no século anterior. Desde o início do século XVIII, avançara para o binterland, com os núcleos auríferos e diamantíferos mineiros, goianos e cuiabanos, além dos portos da rede fluvial amazônica. Contudo, a configuração territorial que ia sendo gerada nesse processo não se desenhava por ocupações contíguas, com redes de núcleos interligando áreas econômicas vizinhas que penetrassem rumo ao interior, tal como o padrão descrito por Turner (2002) para o Oeste dos EUA, ou o modelo das redes dendríticas de Johnson e Kelley (CORREA, 1997). O que existia, ao contrário, era uma ocupação fragmentada, em mosaico, com territórios isolados e cercados por áreas de ocupação proibida.

A região em estudo, situada entre os rios Paranaíba e Grande, parecia ser uma das áreas cujo povoamento foi restringido pelo Estado. Até o século 
XVIII, formava, juntamente com os atuais Sul Goiano, Oeste Paulista e Mato Grosso do Sul, um imenso interstício (a Caiapônia) entre as minas goianas, mineiras e cuiabanas, onde o povoamento colonial era desestimulado.

Nessa fase, quando a geopolítica do Estado Imperial visava principalmente a proteger as regiões auríferas, o papel dos quartéis e presídios militares era muito diferente daquele que teriam no período joanino. As unidades e destacamentos militares estavam dispostos de forma a cercar as regiões auríferas, para controlar o contrabando e fiscalizar os registros e passagens.

O mapa do Oeste de Minas de fins do século XVIII, reproduzido na figura 8 , mostra as principais estradas ocidentais da capitania (em tracejado) e os postos militares (círculos com bandeirinhas triangulares). A linha vermelha representa as divisas entre as capitanias de Minas e Goiás. Percebe-se que os dois principais caminhos que as ligavam, as picadas entre Pium-i e Desemboque (que aparece como Julgado do Rio das Velhas, na parte inferior esquerda do documento) e as Picadas Velha (parte superior direita do documento) e Nova de Goiás (acompanhando grosseiramente a divisa) estavam pontuados por guardas e quartéis.

Dessa forma, o Estado Imperial Português concebia o território colonial, até meados do século XVIII, como um arquipélago de unidades regionais geradoras de riquezas, rigidamente protegidas, e isoladas umas das outras por interstícios vazios, onde os índios não-contactados e a vegetação funcionavam como muralhas naturais. Tal parecia ser o caso da região do Triângulo Mineiro, que, junto com os atuais Sul Goiano e o Oeste Paulista, isolava as minas goianas e cuiabanas, ligadas aos centros do Leste apenas pelas estradas oficiais.

No entanto, as concepções geopolíticas do Reino de Portugal, relativas ao território de sua colônia americana, mudaram muito na segunda metade do século XVIII, com a emergência do ministro Sebastião José de Carvalho e Melo, Marquês de Pombal, elevado à condição de principal figura do Estado português entre 1750 e 1777.

Pombal empreendeu, nesse período, uma ampla reforma do Estado, inspirada em concepções iluministas. O que as motivou foi a constatação da posição de inferioridade de Portugal frente às outras potências européias, principalmente a Inglaterra. Acuado pela Espanha, nas guerras e na diplomacia colonial, o país se via na contingência de manter uma aliança militar com os britânicos que, em troca, exigiam o cumprimento de um tratado comercial (o Tratado de Methuen), desfavorável aos portugueses. O déficit no comércio 


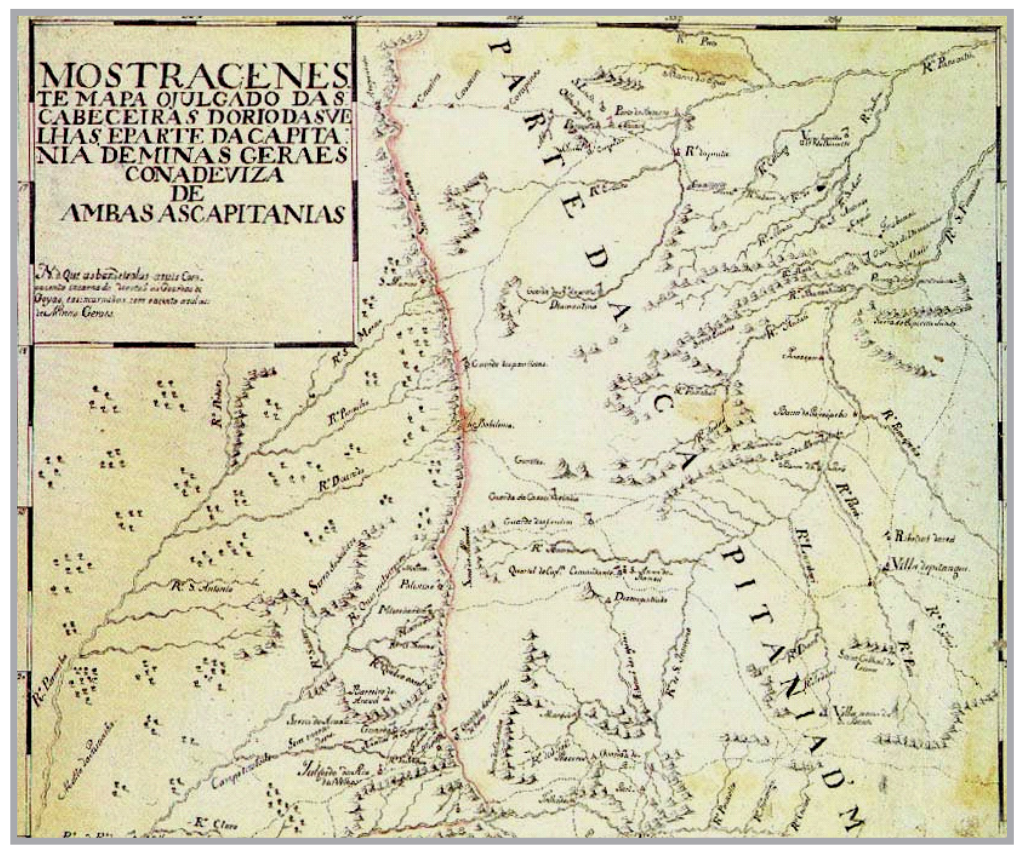

Figura 8: mapa do Oeste da capitania de Minas Gerais, em fins do século XVIII Fonte: site www.asminasgerais.com.br

com a Inglaterra era financiado pelo ouro das Minas Gerais e, por esse motivo, o monopólio sobre o comércio colonial era vital para a sobrevivência da metrópole (MAXWELL, 1996).

Pombal iniciou uma obra de engenharia política e econômica, a partir de 1755, que tinha por projeto redefinir a aliança luso-britânica em termos mais simétricos. A estratégia do ministro foi, de um lado, modernizar as instituições do Estado absolutista português, para torná-lo menos anacrônico em relação às potências do norte da Europa, e de outro, reduzir a influência britânica sobre o comércio colonial. O primeiro objetivo, para ser cumprido, necessitaria da eliminação das resistências conservadoras mais arraigadas, representadas principalmente por algumas famílias da nobreza e pela Companhia de Jesus, onipresente em algumas instituições na colônia americana, como as missões e os aldeamentos (MAXwel, 1996). 
O choque com os inacianos foi o resultado das ações de Pombal, no sentido de laicizar as instituições estatais, substituindo a elite religiosa jesuíta, que gozava de grande prestígio, por aristocratas, comerciantes e funcionários seculares a ele ligados. A tentativa de assassinato de D. José I, em 1758, forneceu o pretexto que faltava para o ministro eliminar seus inimigos. Jesuítas foram acusados de conspiração, presos, alguns executados, e em 1759, foram expulsos de Portugal e suas propriedades, confiscadas (MAXWELL, 1996).

A percepção da importância vital da colônia americana para a sobrevivência de Portugal levou o ministro a criar uma formulação geopolítica clara para o Brasil. Pombal herdara, do reinado de D. João V, o Tratado de Madri entre Portugal e Espanha que, em 1750, reconhecia a obsolescência dos termos de Tordesilhas, e estabelecia novas fronteiras na América do Sul. Tais fronteiras resultaram, em grande parte, da colonização paulista do Cuiabá e Guaporé, ao centro, e da expansão militar e jesuítica pela bacia amazônica, ao norte (MAXWell, 1996). O ministro iniciou o processo de demarcação e ocupação das divisas do extremo ocidente brasileiro, inclusive com a construção de vilas planejadas, a exemplo de Vila Bela, na beira do rio Guaporé, e Cáceres (SANTOS, 2001).

Além da demarcação de fronteiras, Pombal via como essencial o povoamento do território, como forma preservá-lo das ambições espanholas e estrangeiras em geral. Estimulou a imigração de ilhéus da Madeira e Açores para o Brasil e, principalmente, influenciado pelo intelectual iluminista duque de Silva-Tarouca, passou a ver no índio um povoador em potencial. Em 1752, o duque escrevia a Pombal:

Os reis de Portugal podem vir a ter no Brasil um império como a China. Mouros, brancos, negros, mulatos ou mestiços, todos servirão, todos são homens e são bons, se bem governados. A população é tudo, muitos milhares de léguas de desertos são inúteis (MAXwell, 1996, p. 54).

Escrevendo em 1751 a Gomes Freire de Andrade, então responsável por demarcar as fronteiras do sul do Brasil, Pombal recomendava abolir todas as diferenças entre índios e portugueses e libertá-los da tutela religiosa, para que se mestiçassem e se integrassem à massa de colonos (MAxwell, 1996). Pombal e seus colaboradores entendiam que o poder de um Estado era também poder 
demográfico, isto é, só uma grande população poderia garantir a base econômica e militar de uma grande nação. Tinha também, nas palavras de Maxwell, o "reconhecimento estratégico do interior", a consciência da identidade territorial que o Tratado de Madri criara (1996, p. 71-72).

Essa postura representou uma guinada em relação à clássica orientação do Estado português relativa ao território da Colônia, analisada linhas atrás. Até então, como vimos, o território era apenas a fonte da riqueza mercantil, e não um valor em si. Questões como a ocupação produtiva e demográfica do território colonial eram secundárias, e inclusive indesejáveis, frente à necessidade da extração de ouro ou da exportação dos gêneros da plantation. No entanto, após 1755, Pombal e seus intelectuais, bafejados pelas Luzes e deslumbrados pelo sucesso do industrialismo inglês, passaram a conceber Território e Povo como elementos centrais às estratégias imperiais.

Para implementar seu projeto geopolítico e econômico no Brasil, Pombal escalou homens de sua confiança em postos-chave da administração colonial, como D. Luís Antônio de Souza, morgado de Mateus, nomeado governador de São Paulo, e o seu próprio irmão Francisco Xavier de Mendonça Furtado, nomeado governador do Grão-Pará e Maranhão. O morgado de Mateus resumiu as instruções que recebera do ministro da seguinte forma:

O espírito [...] pode ser reduzido a três pontos principais: primeiro, defender as fronteiras; segundo, povoá-las para que possam defender-se por si mesmas, e terceiro, tornar lucrativo o uso das minas e dos benefícios que venham a ser descobertos nesse vasto continente (MAXWELL, 1996, p. 127).

No intuito de transformar o indígena num povoador, Mendonça Furtado pretendia acabar com a escravidão indígena e instituir paróquias nos aldeamentos, para que, posteriormente, pudessem se tornar vilas. Em 1754, esse homem de Pombal libertou os índios da tutela jesuíta com a publicação do Diretório que se deve observar nas Povoações dos Índios do Pará e Maranhão. Contudo, não acreditava na capacidade de autogestão indígena:

$\mathrm{Na}$ qualidade de alguém que lidou com eles [a população indígena] no dia-adia e que viveu em seus povoados durante dois anos, [que] as mais piedosas intenções de Sua Majestade serão frustradas se a esses rústicos ignorantes e 
miseráveis for dado o completo controle de seus próprios negócios [...] e como não é possível passar de um extremo ao outro sem buscar algum meio pelo qual seja possível alcançar o objetivo [da legislação], não vejo medida mais apropriada do que nomear para cada povoado um homem com o título de Diretor (MAXwell, p. 59).

Assim, substituiu a tutela religiosa sobre os índios pela tutela laica, sem, na verdade, acabar com o status de casta excluída e sujeita a escravização em que se encontravam os índios.

O Diretório foi estendido às demais regiões do Brasil em 1758, acabando de vez com o poder da Companhia de Jesus sobre os índios e transferindo todos os aldeamentos para o controle secular (MAXwELL, 1996). No ano seguinte, os jesuítas seriam definitivamente expulsos do Brasil. Nos aldeamentos, o Diretório previa a criação de escolas públicas para as crianças indígenas e proibia o uso da língua geral, tornando o português a única língua permitida. Os diretores dos aldeamentos deveriam também incentivar o estabelecimento de brancos em terras indígenas e a miscigenação (CHAIM, 1983). Tinha uma nítida intenção civilizadora, isto é, buscava erradicar as influências culturais indígenas, tidas como inferiores, e homogeneizar cultural e racialmente a colônia pela europeização e miscigenação.

Em Goiás, a aplicação das medidas do Diretório não fizeram amenizar, mas sim piorar a situação dos índios dos aldeamentos. Os homens nomeados como diretores, em sua maioria goianos, ligados aos interesses das oligarquias locais e não às intenções da Coroa, agora sem o controle e a ação moderadora dos jesuítas, viam-se desimpedidos para a prática sistemática da escravidão indígena (Karash, 1998). A permissão de que brancos se estabelecessem em terras indígenas incentivou a violência e a expulsão de índios em áreas sob jurisdição dos aldeamentos. As rebeliões indígenas ocorridas no período da vigência do Diretório atestam o nível de maus-tratos a que as populações estavam sendo submetidas. É desse período a rebelião acroá-chacriabá nos aldeamentos do Duro e Formiga, ocorrida em 1775 (CHAIM, 1983).

O governador goiano José de Almeida Vasconcelos, barão de Mossâmedes, tentou estabelecer as diretrizes pombalinas para os aldeamentos, como demonstra este trecho escrito por ele em 1771: 
[...] sem população não se podia esperar utilidade alguma da capitania de Goiás. [considerava] a impraticabilidade de se povoar a dita capitania [...] senão com os nacionais da mesma América; e que, achando-se todo o sertão daquele vasto continente coberto de índios, estes deveriam ser os que principalmente povoassem os lugares, as vilas e as cidades [...] na esperança de que, sem eles, nem poderia haver cultura, nem comércio, nem opulência, nem segurança que não fosse precária no Brasil (KARASH, 1998, p. 399).

Provavelmente, o governador teve que ceder, em vários momentos, às pressões dos fazendeiros em favor da escravização indígena, pois a decadência do ouro goiano empobrecia a capitania e tornava cada vez mais difícil a continuidade da importação de escravos africanos.

Nos aldeamentos da Farinha Podre, a ausência, ainda, de um processo efetivo de povoamento luso-brasileiro parece ter refreado, até o princípio do século XIX, a exploração escravista dos índios. Transferências forçadas ocorreram, porém, no período do Diretório pombalino, com o intuito de povoar com vários núcleos o trecho da Estrada dos Goiases situado entre o rio Paranaíba e o rio Grande. Índios bororos da Aldeia de Santana do Rio das Velhas foram transferidos para um novo núcleo, Lanhoso, nas proximidades do rio Grande, para dar lugar aos chacriabás reduzidos no Duro, no Leste Goiano (CASAL, 1976).

Santana foi transformada em paróquia em 1761, após a expulsão dos jesuítas (BARBOSA, 1995), com freguesia estabelecida sobre toda a área dos aldeamentos entre o Paranaíba e o das Velhas, seguindo a orientação do Diretório de transformar os núcleos indígenas em povoados e vilas.

No período mariano-joanino (1778-1822), moldou-se uma nova política indigenista, pela qual a exploração do trabalho indígena deixaria de ser central, sendo substituída pela questão das terras indígenas (CuNHA, 1998). Essa mudança resultou, em primeiro lugar, do aprofundamento da concepção estratégica do povoamento interior, o que decorria de um entendimento cada vez mais "moderno" de questões como Estado, Território e Soberania, principalmente com a transferência da Corte para o Rio de Janeiro, em 1808. Em segundo lugar, resultou da crescente valorização mercantil da terra em várias regiões do país, com o avanço do povoamento. As áreas vazias e "barreiras naturais" do século XVIII deixavam de ter esse papel, com a decadência da 
mineração aurífera e diamantífera, e começavam a ser ocupadas.

Com a Carta Régia de 25 de julho de 1798, D. Maria I acabou com a tutela dos diretores, prescrita pelo Diretório pombalino e, em seu lugar, instituiu a guarda particular dos índios, cedendo-os a quem pudesse educá-los, instruílos e pagá-los. Sob essa legislação, autoridades locais passaram a ser nomeadas administradores dos índios, particularmente juízes de órfãos (CunHA, 1998). Essa medida, ao retirar a tutela indígena das autoridades centrais e passá-la às autoridades locais, expôs ainda mais os índios à escravidão e às arbitrariedades.

Em Goiás, além disso, o empobrecimento da capitania levou as autoridades reinóis a perderem o interesse por ela. Cada vez mais, o governo goiano foi sendo ocupado por potentados locais, com interesses muito mais imediatistas. Com isso, na virada do século XVIII para o XIX, os índios, mais ainda do que antes, foram entregues à sanha das oligarquias goianas (KARASH, 1992).

De maneira coerente com essa nova orientação, o governador da capitania de Minas Gerais, Pedro Maria Xavier de Ataíde e Melo, recebeu, em 13 de maio de 1808, uma Carta Régia de D. João VI ordenando o início da colonização da região dos rios Doce e Mucuri, e a guerra aos índios botocudos que a povoavam:

[...] até reduzi-los aos termos de sujeição e ao estado de vida agricultora ou sedentária; que formasse um corpo de soldados pedestres para serem empregados no serviço contra os bárbaros; que se distribuísse em seis distritos o terreno infestado pelos botocudos e que, em cada um desses distritos houvesse um comandante encarregado de fazer guerra aos selvagens; que os botocudos aprisionados de armas na mão ficassem obrigados a servir ao respectivo comandante por tempo de 10 anos, ou enquanto mais durasse a sua ferocidade [...] que se promovesse o melhoramento da navegação, agricultura e comércio do Rio Doce, concedendo favores àquelas pessoas que ali se fossem estabelecer ou negociar (CunHa Matos, 1981, p. 61).

Em outra Carta Régia do mesmo ano (02 de dezembro de 1808), o governador recebeu outra ordem, complementado a anterior, de distribuir as terras resgatadas nas incursões contra os botocudos, e que os índios capturados fossem entregues aos fazendeiros da região (Cunha Matos, 1981). Alguns anos depois, uma lei de 05 de dezembro de 1812 passou a permitir, em toda 
a Colônia, o arrendamento e o aforamento de terras indígenas por colonos luso-brasileiros (CunHA, 1992).

Em Goiás, no contexto dessa nova política indigenista, a curadoria dos índios da Farinha Podre foi entregue a uma autoridade local pelo Marquês de Palma, então governador da capitania. Em 27 de outubro de 1809, o sargentomor Antônio Eustáquio Silva Oliveira, estabelecido no arraial do Desemboque, foi nomeado Comandante Regente dos Sertões da Farinha Podre e curador dos índios (SILVA, 1970). Esse ato selou o destino deles: suas terras foram espoliadas nos anos seguintes e, na segunda metade do século XIX, desapareceram completamente os registros sobre os índios da Farinha Podre. Do embate entre os colonos e os índios trataremos no capítulo 3.

\section{Economia e organização social dos aldeamentos}

Os aldeamentos indígenas tinham uma natureza diferente de outro tipo de aglomerado que existiu em seu tempo: os arraiais luso-brasileiros. Estes podiam ser considerados como povoados proto-urbanos, não só por reunirem atividades de serviço como o comércio, mas também porque havia, entre seus fundadores, a intenção explícita de um dia transformá-los em vilas, com pelourinho, vereança, casa de câmara e cadeia. Os aldeamentos eram, ao contrário, espaços impostos a seus ocupantes, criados para abrigar indivíduos tidos pela sociedade inclusa como uma casta que pairava num limbo: não eram escravos, e tampouco homens livres.

Eram escravos incompletos (GORENDER, 1988), que podiam ser explorados pelo administrador do aldeamento ou pela coletividade dos vizinhos lusobrasileiros. Mas, no seu cotidiano, viviam como camponeses, dispondo de campos de cultivo, nos quais praticavam uma agricultura de tipo familiar, com todos os elementos que caracterizavam o campesinato luso-brasileiro da mesma época: base familiar de produção, trabalho fundamentado na cooperação com reciprocidade, organização sócio-espacial baseada nos laços de parentela. Dizendo de outra forma, era como se a brecha camponesa — termo criado por Ciro Flamarion Cardoso (1987) para denominar a economia de autoconsumo própria do escravo - fosse maior nos aldeamentos que nas fazendas de plantagem, onde vigia a escravidão negra. 
Nos aldeamentos, as autoridades coloniais impunham a aculturação aos índios. A incorporação de práticas luso-brasileiras ao cotidiano da produção indígena nos aldeamentos se dava de forma gradual, começando pela negação das práticas tradicionais (embora um ou outro elemento delas pudesse permanecer) e passando pela disciplinação do trabalho, voltado para a produção de excedentes.

O que se percebe, pela descrição dos cronistas, é um painel com núcleos indígenas em diferentes fases de caboclização. Ao se comparar o tempo de aldeamento de cada população indígena, quando da passagem dos viajantes, com as observações por eles deixadas sobre seus costumes, percebe-se um grau crescente de aculturação, com abandono das técnicas ameríndias e incorporação do sistema técnico luso-brasileiro.

Um exemplo de aldeamento com uma população recentemente reduzida era São José de Mossâmedes, nas proximidades da capital goiana, visitado por Saint Hilaire (1975) e Pohl (1976) entre 1817 e 1819. Com a morte e fuga dos javaés e carajás, esse núcleo havia se despovoado, e por isso recebera, alguns anos antes da passagem dos cronistas, um grande contingente de índios caiapós meridionais, retirados da Aldeia de Maria I, onde haviam sido reduzidos em 1781 (Saint Hilaire, 1975). A redução dos caiapós no núcleo continuou nos anos seguintes, com a atividade da sertanista Damiana da Cunha, que fazia freqüentes incursões pelo Cerrado do Sul Goiano, trazendo índios ainda não aculturados e capturando os fugitivos (KARAsh, 1998). Passara-se, portanto, muito pouco tempo desde a redução dos índios no núcleo, quando da visita dos viajantes europeus.

O quadro descrito pelos cronistas em Mossâmedes mostrava índios que ainda resistiam à aculturação. Pohl encontrou homens e mulheres "quase inteiramente nus, tendo apenas os quadris envoltos em trapos” (1976, p. 151). Haviam abandonado os alojamentos construídos pelas autoridades em torno da praça maior do aldeamento, para se instalarem próximo aos seus cultivos "em cabanas construídas por eles próprios, de palmeiras, e cobertas de ervas" (1976, p. 152). Segundo Saint Hilaire, preferiam habitar tais choças porque "acharam muito frias as casas de teto alto e cobertas de telhas que lhe foram reservadas" (1975, p. 64). A divisão sexual do trabalho ainda era a da sociedade indígena tradicional, pois o botânico francês viu "várias mulheres colhendo espigas de milho, sob supervisão de dois ou três pedestres" (1975, p. 66). 
A permanência de práticas e mentalidades das sociedades horticultoras, caçadoras e coletoras foi atestada pelos comentários dos cronistas acerca da "imprevidência" e da "preguiça" dos caiapós de Mossâmedes. A ausência de práticas de estoque de colheitas, o uso do milho ainda verde, típico das sociedades pré-cabralianas (e não o milho maduro como cereal, como nas sociedades coloniais), a presença de jogos de caça e a ausência de elementos ideológicos ligados à acumulação material foram assim vistos por eles:

Esses índios são como todos os outros, volúveis e totalmente imprevidentes. Ao fazerem a colheita, em suas plantações particulares, raramente esperam que os frutos ou grãos estejam perfeitamente maduros. Nunca pensam no dia de amanhã, não guardam nada, vivendo apenas a hora presente [...] (SAINT Hilaire, 1975, p. 69).

As suas ocupações favoritas são caçar, perambular pela mata e pescar, mas nisso não se esforçam muito. Quando caçam um animal, o que não é trabalhoso, dada a abundância deles na mata virgem, descansam o dia inteiro, deitam-se e entregam-se à ociosidade (PoHL, 1976, p. 154).

A aculturação e a submissão dos índios aos interesses coloniais, mediante sua escravização, era uma das funções a que se destinavam os aldeamentos. Assim, em Mossâmedes, eram submetidos a uma rígida disciplina de trabalho, supervisionados pelos soldados pedestres ali aquartelados. Trabalhavam cinco dias por semana nas roças do aldeamento, folgando aos domingos e segundas feiras, quando cuidavam de suas roças particulares. As índias dispunham de um descaroçador de algodão e mais vinte e quatro rodas de fiar, e eram instruídas por uma mulher, paga pelo diretor do aldeamento, para que aprendessem as técnicas luso-brasileiras (Saint Hilaire, 1975).

Já nos aldeamentos da Farinha Podre, onde a população indígena se encontrava reduzida há muito mais tempo que em Mossâmedes (desde meados do século XVIII), os cronistas encontraram um processo de aculturação bem mais avançado. Neles, a agricultura de subsistência era a principal atividade econômica dos índios, embora a caça e a coleta ainda compusessem uma parte de sua dieta (Saint Hilaire, 1975). As famílias viviam juntas no núcleo, e diariamente os homens se deslocavam para os campos de cultivo, enquanto 
as mulheres permaneciam em suas casas, envolvidas no trabalho do artesanato e no beneficiamento dos produtos agrícolas, numa divisão sexual do trabalho já tipicamente luso-brasileira. Eschwege (1996), visitando a região em 1816, encontrou apenas mulheres em Santana, numa segunda feira, pois os homens achavam-se todos nas lavouras. Saint Hilaire (1975) pôde encontrar todos os moradores da Aldeia da Estiva à noite, quando os homens voltavam de seu trabalho. Mais adiante, ao passar por Santana, fez a mesma observação que Eschwege: "Quando cheguei só encontrei mulheres; os homens se achavam todos na lavoura" (1975, p. 143).

Também a cooperação e a reciprocidade, dos quais o melhor exemplo é o mutirão, existiam nos aldeamentos triangulinos. O naturalista francês assim relatou sua chegada à Aldeia de Boa Vista:

Quando cheguei era dia de festa. Um de seus moradores tinha acabado de derrubar um trecho da mata, o qual, depois de queimado, iria servir para fazer uma roça. Todos os lavradores pedem a ajuda dos vizinhos para este tipo de serviço e em seguida lhes oferece um repasto, com muita cachaça, o qual termina sempre com danças e batuques (Saint Hilaire, 1975, p. 135).

O trecho mostra não só a prática da reciprocidade, mas também a comemoração oferecida pelo beneficiado, o que, na verdade, é característico do campesinato luso-brasileiro. D’Alincourt (1975), contemporâneo de Saint Hilaire, descrevera a mesma prática entre moradores da beira do rio Capivari, próximo a Jundiaí, e Antônio Cândido (2001), entre os caipiras paulistas nos anos 1950. Como veremos no capítulo 4, essa prática recebia no Triângulo Mineiro o nome de treição.

A produção agrícola destinava-se quase inteiramente ao autoconsumo, mas havia um pequeno excedente que era trocado por gêneros como o sal e ferramentas, por meio das tropas vindas pela estrada do Anhanguera (SAINT Hilaire, 1975). O algodão e o milho eram os principais gêneros cultivados, mas não havia entre eles a pecuária bovina, sendo essa atividade exclusiva dos colonos brancos (Eschwege, 1996). Eschwege relatou a presença de um monjolo no centro do largo principal de Santana, destinado ao uso coletivo. Como veremos, a pilagem de grãos com o uso do monjolo é uma técnica ibérica, incorporada ao complexo produtivo colonial.

A atividade artesanal feminina, sobretudo tecelagem e cerâmica, tinha 
grande importância na formação do excedente comercializável. As trocas eram feitas não só com os tropeiros da estrada, mas também com os fazendeiros luso-brasileiros vizinhos, que lhes forneciam, no escambo, carne, cachaça e rapadura (SAINT HiLAIRE, 1975). Alguns índios, inclusive, acabaram se tornando fazendeiros, como o chefe Leopoldo de Rio das Pedras, dono de um engenho de açúcar e fábrica de aguardente (EsCHwEGE, 1996).

A presença da tecelagem e da cerâmica sugere a permanência de algumas técnicas pré-cabralianas entre os índios da Farinha Podre. Pasquale Petrone (1995) relata o mesmo tipo de atividade entre os índios dos aldeamentos paulistas até meados do século XIX, destacando ainda que o comércio do artesanato e a atividade dos jornaleiros tornaram-se, com a perda das terras ou seu esgotamento, as únicas alternativas de sobrevivência para os índios de Itaquaquecetuba, Barueri, São Miguel e Pinheiros ainda em 1845. Sobre essas técnicas, não dispomos de informações que nos permitam maiores detalhes, por exemplo, se usavam o tear vertical indígena ou o horizontal português.

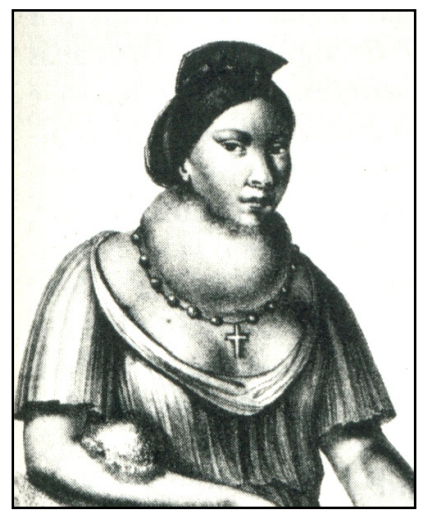

Figura 9: Mameluca com bócio (Spix e Martius, 1981)

Uma prova indireta da aculturação sofrida pelos índios da Farinha Podre pode ser fornecida pela epidemiologia do bócio endêmico entre os índios, rastreada pelos relatos dos cronistas. Essa doença, uma hipertrofia da glândula tireóide provocada pela carência de iodo na dieta (MAZZAFERRI, 1988), é evidenciada por um grande papo, visto na porção anterior do pescoço (figura 9). Hoje pouco freqüente, devido à obrigatoriedade de iodação do sal de cozinha e pela melhora 
do padrão nutricional da população, o bócio era, todavia, de alta prevalência no Brasil Colonial, como se pode perceber pelos relatos dos naturalistas do período joanino. Isso se devia à ausência do sal iodado, que não era compensada pela dieta colonial, rica em carboidratos, mas pouco diversificada e carente em proteínas de origem animal. ${ }^{12}$

Os povos indígenas, no entanto, eram pouco suscetíveis à doença, por terem uma dieta mais diversificada que a população luso-brasileira, graças a maiores opções nutricionais oferecidas pela caça e coleta. Falando dos caiapós de Mossâmedes, Pohl relata que "é notável que esses índios sejam imunes ao bócio, de que se acham acometidos quase todos os europeus e negros residentes na aldeia" (1976, p. 155). Isso demonstra que, naquele momento, ainda não havia ocorrido uma completa assimilação, por eles, da dieta luso-brasileira.

$\mathrm{Na}$ Farinha Podre, contudo, Saint Hilaire encontrou uma situação epidemiológica muito mais próxima da realidade colonial, o que certamente refletia a aculturação dietética. Em Rio das Pedras, observou que os índios bororos "têm o peito largo, o pescoço curto e grosso, quase sempre acrescido de um enorme bócio" (1975, p. 129).

Os núcleos dos aldeamentos não dispunham de estabelecimentos comerciais sedentários, tampouco oficinas de ofícios (SAint Hilaire, 1975), sendo o artesanato uma atividade eminentemente doméstica. A explicação, provavelmente, é que não havia escala suficiente de comercialização e demanda por serviços, devido à baixa margem de produção de excedentes na economia indígena, não induzindo, portanto, à formação de uma classe de artesãos e comerciantes exclusivos. O comércio era feito diretamente pelos índios com os tropeiros, para os quais existiam ranchos de pouso, e com os fazendeiros, que levavam seus gêneros aos aldeamentos (Saint Hilaire, 1975).

\section{O sítio e o traçado dos aldeamentos}

Em seu opúsculo Vilas e Cidades no Brasil Colonial, Aroldo de Azevedo (1957) mostra como houve intencionalidade na escolha de sitios em acrópole -

12 Para uma análise da dieta colonial e suas relações com doenças endêmicas, ver Castro (sd). Uma discussão sobre as condições nutricionais da região central do Brasil e a epidemiologia do bócio endêmico se encontra nas páginas 240 a 244. 
sítios sobre pontos elevados com domínio visual da paisagem circunvizinha — no processo de criação dos primeiros aglomerados urbanos no Brasil. Rio de Janeiro, erguida sobre o Morro do Castelo, a Cidade Alta de Salvador, e São Paulo, erguida no espigão entre o rio Tamanduateí e o córrego do Anhangabaú, foram exemplos de como a preocupação com a defesa foi fundamental ao urbanismo colonial.

Também como parte dessas preocupações, a necessidade do amuralhamento fazia desses primeiros núcleos vilas e cidades fortificadas, que lembravam bastidas medievais, como os castros portugueses. No caso do Rio de Janeiro, Cidade Filipéia, ${ }^{13}$ Salvador, Natal, Fortaleza e Belém, todas nascidas já cercadas de muralhas e baluartes, havia a preocupação óbvia com a defesa marítima. Mas em São Paulo, cidade interior e boca de sertão desde o final do século XVI, também foram erguidos muros de taipa batida cercando todo o sítio urbano, de forma a resguardar a vila contra os ataques dos indígenas: até o início do século XVII, ainda havia a ameaça de grupos hostis vizinhos, como os guaianases e os guarulhos.

Petrone (1995) demonstrou, de forma convincente, que o sítio em acrópole predominou também no planejamento dos aldeamentos circunvizinhos à vila de São Paulo. Embora a preocupação com a defesa estivesse presente em tempos tão instáveis, havia também a necessidade de se ter acesso às aguadas. Daí a escolha de pontos que, embora estivessem a cavaleiro dos rios, também fossem situados a jusante dos seus cursos. A escolha, portanto, quase sempre recaía sobre os terraços fluviais, locais próximos aos rios, mas abrigados de suas cheias. Foi o caso, num dos estudos do autor, do sítio de Pinheiros, na margem direita do rio do mesmo nome, aproximadamente 10 metros mais alto do que a várzea vizinha.

Quanto aos aldeamentos da Farinha Podre, não temos informações precisas, mas aproximadas, dos sítios da Estiva, Piçarrão, Boa Vista e Lanhoso. Não sabemos se o sítio de Rocinha correspondia exatamente ao atual povoado de Tapuirama, pois este teve seu patrimônio delimitado e sua capela construída recentemente, em 1933. Temos a localização aproximada do sítio da Aldeia de Uberaba, pois até 1860 ainda eram vistos os restos do seu cemitério (PONTES, 1978). Os sítios dos aldeamentos de Rio das Pedras e Santana do Rio das Velhas correspondem,

13 Hoje João Pessoa 
respectivamente, às atuais cidades de Cascalho Rico e Indianópolis.

O sítio do aldeamento de Rio das Pedras encontrava-se numa elevação entre o córrego da Grota, um outro córrego menor e a cavaleiro do rio das Pedras (BArbosa, 1998). A posição dominante sobre uma colina era também a de Santana do Rio das Velhas, situada sobre o espigão entre os córregos Manoel Velho e Lava Pés, aproximadamente a 35 metros acima do vale escavado por este último (figura 10).

Em todos eles, percebe-se a intenção do sítio em acrópole, e ao mesmo tempo a jusante de cursos d'água, seguindo o mesmo padrão dos núcleos paulistas. Não poderia ser de outra forma, pois, como já visto, os aldeamentos triangulinos foram criados com a explícita intenção de funcionar como postos de defesa ao longo da Estrada do Anhanguera.

Outra diferença entre os aldeamentos e os arraiais era quanto ao traçado. Autores, separadamente, estudaram um e outro tipo de aglomerado, mas não tivemos acesso a nenhuma síntese mostrando diferenças e semelhanças entre ambos. Murilo Marx (1991) escreve que, diferente da América Espanhola, o Brasil não contou com algo parecido com as Leyes das Índias, a rígida legislação pela qual a Coroa espanhola impunha um modelo urbanístico uniforme às cidades das suas colônias. Demonstra que isso não significou, diferente do que diz Paulo Santos (2001), que a cidade colonial brasileira fosse um exemplo de "cidade informal", irregular no traçado e espontânea no crescimento.

Havia uma regulamentação, não secular, mas religiosa, que os próprios colonos faziam questão de aplicar, para que suas capelas fossem reconhecidas pelas autoridades eclesiais e se transformassem em paróquias (MURILO MARX, 1991). Tal regulamentação estava codificada nas Constituições Primeiras do Arcebispado da Bahia, que governava todo o clero brasileiro, e que estabelecia as posturas que deveriam ser seguidas pela Igreja no Brasil.

Assim, a constituição 687 determinava que:

Conforme direito canônico, as Igrejas se devem fundar, e executar em lugares decentes, e acomodados, pelo que mandamos, que havendo-se de edificar de novo alguma Igreja paroquial em nosso Arcebispado, se edifique em sítio alto, e em lugar decente, livre de umidade, e desviado, quanto for possível, de lugares imundos e sórdidos (Murilo Marx, 1991, p. 22). 
Mais adiante, a mesma constituição estabelecia que as igrejas paroquiais estivessem livres de "casas particulares, e de outras paredes, em distância que possam andar as procissões ao redor delas" (Murilo Marx, 1991, p. 22-23). Essas disposições definiam uma posição dominante do templo, com sua porta voltada para a parte mais baixa, e seus arredores livres de outras edificações, definindo o espaço do adro. A partir deste, num ordenamento ortogonal, se traçavam as ruas e travessas do povoado.

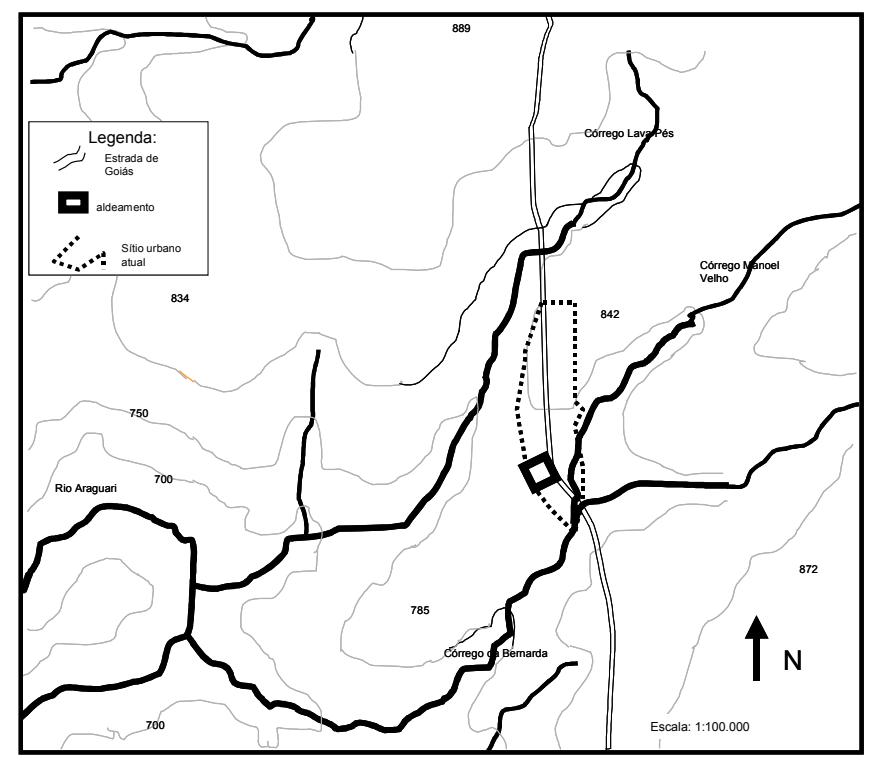

Figura 10: Sítio provável do aldeamento de Santana do Rio das Velhas Fonte: Saint Hilaire (1975), D’Alincourt (1975), IBGE (1972).

Os aldeamentos indígenas no Brasil obedeciam a um traçado diferente dos arraiais. Planejados pelos jesuítas, não estavam sob influência direta do Arcebispado da Bahia, mas tiveram como modelo, segundo Petrone (1995), as missões criadas na América Espanhola, regulamentadas pelas Leyes das Índias. Estabeleciam a obrigatoriedade de um adro em formato retangular, com o templo e casas unidos lado a lado e voltados para o centro do largo, "para que sirvam de defesa e força contra os que a quiserem estorvar ou infestar" (Petrone, 1995, p. 230, 232). Ainda, os lados da praça maior deveriam estar orientados no sentido norte-sul, para receber os ventos dessas direções. Isso 
fez os aldeamentos brasileiros mais parecidos com as missões guarani-jesuíticas do Sul ou com as cidades da América Espanhola do que com os arraiais lusobrasileiros.

Os aldeamentos da Farinha Podre também tinham essa disposição, pelo menos o de Santana. A descrição que Saint Hilaire fez desse núcleo é clara:

A aldeia foi construída numa região descampada e no alto de uma colina, ao pé da qual passa um córrego cujas águas vão se juntar ao Rio das Velhas. É composta de umas trinta casas muito pequenas, quase quadradas e cobertas de palha. Algumas ficam espalhadas pela colina, sem nenhuma ordem, enquanto outras se enfileiram ao redor de uma praça de formato quadrangular, com um dos lados ocupado pela igreja, que é muito pequena (SaINT HiLAIRE, 1975, p. 143).

Seu testemunho é reforçado pelo de seu contemporâneo Luiz D'Alincourt, que por lá passara um ano antes: "[A Aldeia de Santana] tem uma ermida, e em frente a ela um largo retangular, ornado de casas pequenas cobertas de palha, e algumas de telha. Fora do largo há mais algumas casas dispostas avulsamente" (1975, p. 78). Como nos aldeamentos paulistas, a única regularidade era a imposta pela praça maior, não havendo arruamento definido ao redor dele (PETRONE, 1995).

Dispomos do testemunho material da matriz de Nossa Senhora de Santana, em Indianópolis, erigida em 1844 no mesmo sítio da antiga capela do aldeamento (PMI, s/d). O atual traçado da cidade não corresponde ao da primitiva aldeia, pois foi totalmente modificado pelo prefeito Nelson Soares de Oliveira, em 1939, quando da fundação do município. Por isso, a igreja de Santana tem sua fachada desalinhada em relação à rua atual (figura 11). A fachada está voltada para o rumo oeste, de forma que os lados do adro primitivo, possivelmente, dispunham-se na direção norte-sul, paralelos à Estrada do Anhanguera.

As imagens que nos chegam de outros aldeamentos criados pela capitania de Goiás revelam a mesma disposição. A finalidade era provavelmente defensiva, pois as casas, cerradas junto da igreja, funcionavam como uma muralha tosca, uma primeira linha de defesa contra agressores. É o caso do aldeamento de Mossâmedes, criado alguns anos depois de Santana, que lembra muito um presídio militar setecentista (figura 12).

A prova definitiva da influência jesuítico-espanhola no plano dos aldeamentos paulistas e goianos está na comparação de plantas das missões do 


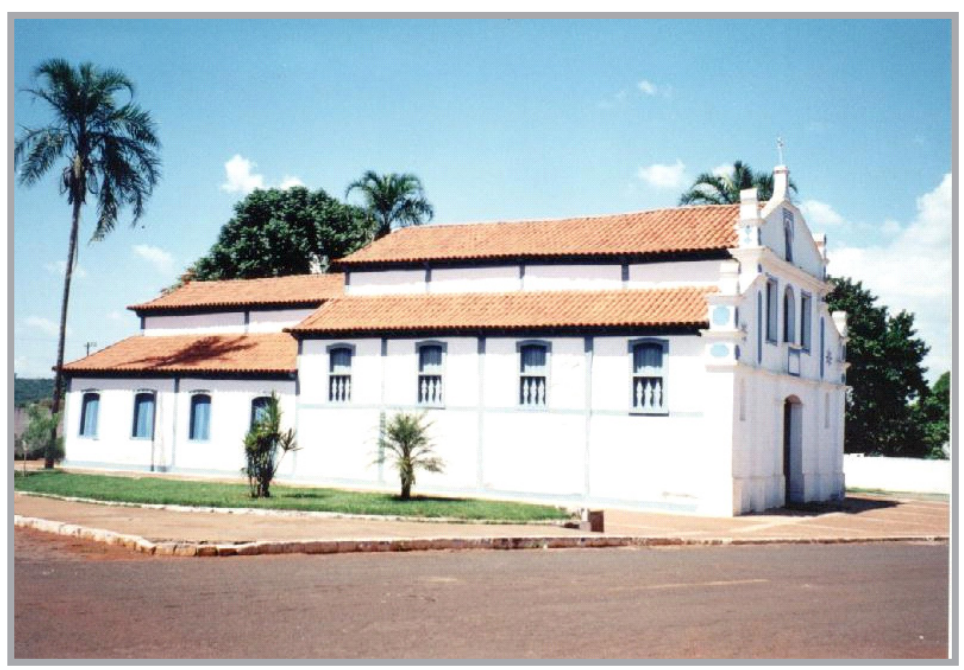

Figura 11: Igreja Matriz N. Senhora de Santana, construída no aldeamento de Santana dos Rio das Velhas em 1844

Fonte: foto Lourenço, L. A. B. (2001).

Guaíra e Tape com a destes últimos. Mesmo separadas por mais de um século, é admirável a semelhança, por exemplo, entre a planta da missão de Santo Inácio Mini, construída no final do século XVII nas margens do rio Paraná, em território hoje argentino ${ }^{14}$ (figura 13), e o plano para um aldeamento goiano de índios caiapós, de 1782 (figura 14).

Em ambos, o adro quadrangular tem o templo disposto em posição mediana de um dos lados, e voltado para o largo. Nos lados, estão os alojamentos dos índios e as vias, que partem do largo em disposição ortogonal. Atrás da igreja, um campo para cultivos coletivos. É interessante notar que a planta da aldeia caiapó data de 1782, vinte e três anos depois da expulsão dos jesuítas, e num momento em que os aldeamentos já se encontravam subordinados a autoridades seculares, e não mais à Companhia de Jesus.

Criara-se um modelo que passou a se repetir em todo aldeamento, subordinado ou não às autoridades inacianas. E, provavelmente, isso ocorria porque era eficaz, não só como um sistema de defesa, que imitava um

14 Seus vestígios arqueológicos foram estudados em 1901 (LugON, 1977). 


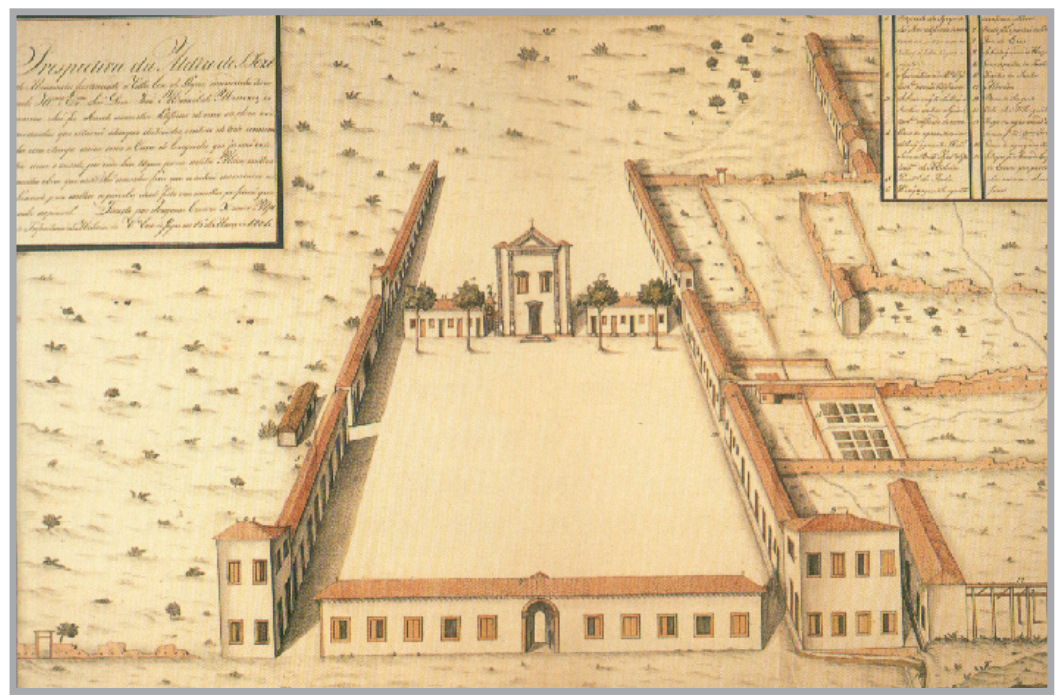

Figura 12: aldeamento de São José de Mossâmedes Fonte: Goulart Reis (2001).

amuralhamento, mas também porque facilitava a vigilância sobre todos os índios, expostos ao olho das autoridades eclesiais e seculares em torno do adro, num panóptico muito parecido com o benthaniano. A rígida disciplina militar dos aldeamentos goianos; a presença obrigatória de destacamentos militares exercendo controle e comando; as rebeliões que, como vimos, mostravam o caráter compulsório da moradia indígena no aldeamento, tudo isso tornava funcional (do ponto de vista das autoridades) o modelo criado a partir das Leyes. Dessa forma, parece claro o caráter de instituição disciplinar dos aldeamentos, um lugar onde o poder colonial impunhase aos índios. Para usar uma palavra daqueles tempos, era o lugar onde recebiam a civilização.

\section{Demografia e mobilidade espacial}

Os aldeamentos indígenas criados pelo Estado Colonial não se assemelhavam a núcleos pré-urbanos, mas a aldeias, tal como conceituadas 


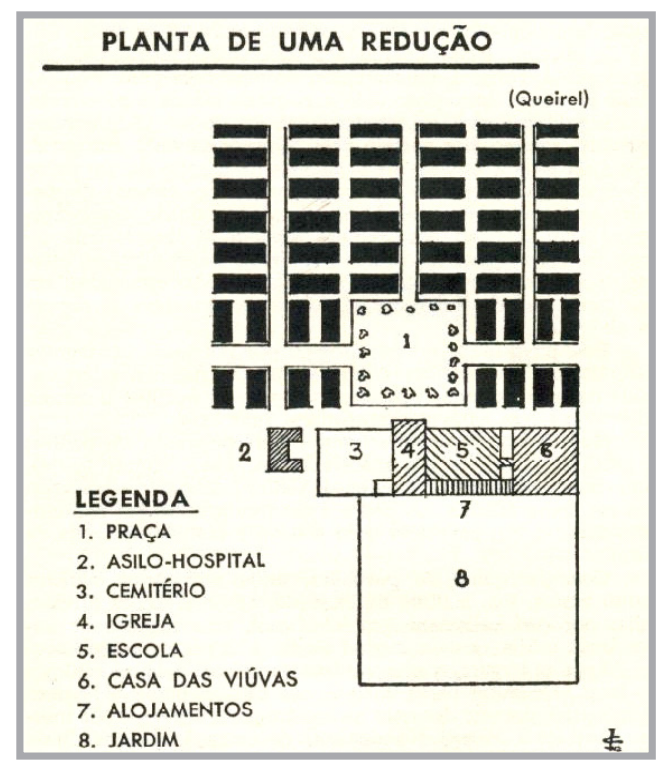

Figura 13 : missão de Santo Inácio Mini Fonte: Lugon (1977).

por Petrone (1995): uma forma de habitat rural concentrado. O termo aldeia era usado em Portugal para designar aglomerados camponeses, equivalente ao villagio italiano ou à village francesa. No Brasil, os colonizadores passaram a designar de aldeias, indistintamente, tanto as tabas indígenas, isto é, os aglomerados de origem pré-cabraliana, quanto os aldeamentos, núcleos de reclusão indígena compulsória. Continua o autor, o rótulo de aldeia seria uma forma de caracterizar a inferioridade do aglomerado indígena, associando-o ao rural e, portanto, inferior aos arraiais e vilas: estes teriam caráter urbano, mesmo se tratando de aglomerações extremamente modestas.

Mais do que um simples jogo de palavras, as denominações aldeamento e arraial revelam diferenças fundamentais entre os dois tipos de aglomerado, na lógica e na mentalidade coloniais, mesmo quando aparentemente não houvesse nenhuma diferença na economia, estrutura ou demografia entre um e outro. Os arraiais, desde o momento da ereção da capela e delimitação do patrimônio, já mostravam a intenção de uma coletividade de colonos de 


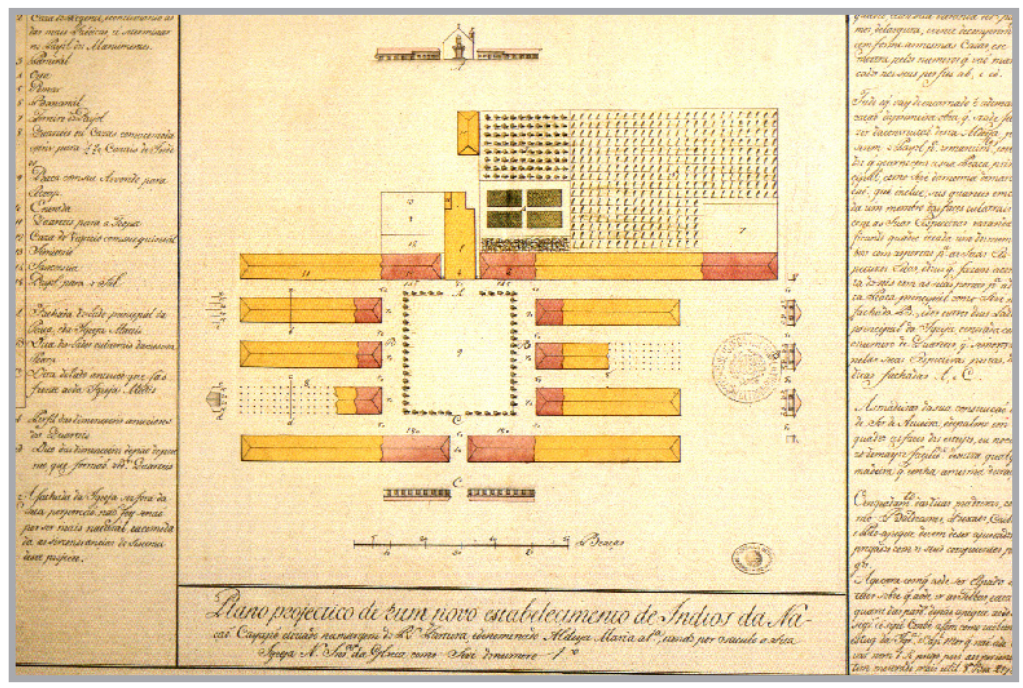

Figura 14: planta do aldeamento de Maria I.

Fonte: Goulart Reis (2001)

constituir um núcleo que, ao mesmo tempo que funcionasse como elo com a sociedade inclusa, seria a forma espacial de sua identidade e territorialidade. Essa identidade se expressava na devoção coletiva a um santo, em cuja honra era erigida a capela, e em laços de parentesco e vizinhança, que gradualmente iam se estreitando. O próximo passo era a constituição da paróquia e freguesia e, mais tarde, com a casa de câmara e cadeia e o pelourinho, o reconhecimento da vila e da municipalidade.

Desse modo, a comunidade de vizinhança aspirava ser reconhecida pelas autoridades eclesiais e estatais, esse reconhecimento sendo um elemento de reforço da sua própria identidade. Daí a necessidade, desde o início, da identificação do arraial com o urbano, mesmo quando não passasse de uma modesta capela rodeada por taperas. E daí insistirmos no termo proto-urbano aplicado a ele, sem que isso signifique qualquer distorção teleológica. Disso derivava o caráter centrípeto dos arraiais, isto é, a sua tendência a atrair moradores, comércio e ofícios, e sua tendência, via de regra, ao crescimento. Elemento de identidade de uma comunidade, à medida que ela crescia tendia a concentrar no povoado suas demandas de toda espécie, o que contribuía para fixar-lhe uma população sedentária. 
Os aldeamentos, nesse sentido, não eram povoados proto-urbanos. A aglomeração era imposta aos índios pelo poder coercitivo da Igreja ou do Estado, para finalidades de defesa, escravização ou catequese. Não havia qualquer aspiração autônoma ao reconhecimento dos núcleos como urbanos, já que sobre eles pesava o estigma de aldeia (isto é, de não-urbano) e habitat indígena (de não-livres e não-brancos), o que implicava uma total heteronomia.

Mesmo as mudanças que a política pombalina tentou implementar por meio do Diretório, como a transformação dos aldeamentos em freguesias, acabaram se frustrando por causa do ranço que pairava sobre os índios: os colonos e as autoridades locais faziam letra morta das determinações legais, mantendo a escravização, a espoliação de terras e negando o status de urbano às paróquias dos aldeamentos. O que nos leva à hipótese de que, na verdade, os índios aldeados compunham uma casta, no sentido empregado por Florestan Fernandes e Roger Bastide (1975), isto é, um estamento que não compartilhava do mesmo ordenamento jurídico dos homens livres.

A tendência centrífuga dos aldeamentos, ou seja, sua tendência ao despovoamento, já havia sido detectada por Petrone (1995) no caso paulista. Nos aldeamentos do Piratininga, à medida que havia esgotamento de terras, a tendência dos índios era de se mudar dos núcleos para junto de suas roças, numa dispersão que as autoridades tentavam reverter pela força.

Outro fator de dispersão era a espoliação de terras indígenas promovida por proprietários brancos, que ia reduzindo as áreas cultiváveis dos aldeamentos, até obrigar os índios a abandoná-los. O expediente de aforar terras indígenas e depois expropriá-las ilegalmente parece ter sido muito usado pelos colonos luso-brasileiros, tanto que, entre os núcleos piratininganos, o da Escada foi o que manteve por mais tempo as terras cultiváveis, porque os padres haviam proibido de aforá-las aos brancos (Petrone, 1995).

Nos aldeamentos da Farinha Podre, a tendência demográfica centrífuga também foi dominante. Saint Hilaire (1975), ao passar pela Aldeia do Piçarrão, em 1819, relatou que muitos habitantes do núcleo haviam abandonado o local e se fixado nas redondezas. Na Aldeia do Lanhoso, encontrara somente duas choupanas miseráveis, e seus moradores disseram que parentes seus estavam estabelecidos pelas vizinhanças. Três anos antes, Eschwege (1996) encontrara índios vivendo de forma dispersa, bem distantes dos núcleos dos aldeamentos, ao longo do trecho da Estrada dos Goiases entre o aldeamento de Rio das Pedras e o rio Paranaíba. 
Na verdade, os núcleos de Estiva, Boa Vista, Rocinha, Lanhoso, Uberaba e Baixa não eram aldeamentos strictu sensu, mas sítios indígenas, ${ }^{15}$ resultado da dispersão espontânea da população, ao longo da faixa de terras aldeanas, a partir dos aldeamentos verdadeiros - Rio das Pedras, Piçarrão e Santana. D'Alincourt referiu-se a Boa Vista como pouso e depois como sitio, onde vivia uma única grande família indígena:

Os moradores desse sítio [da Boa Vista] são índios, divididos em várias famílias, que todas trazem na origem um velho de mais de cem anos, que ainda governa o lugar e que já tem netos de seus netos: as casas dessa gente são cobertas de palha (D’Alincourt, 1975, p. 78).

Saint Hilaire relatou que a Aldeia do Piçarrão havia sido fundada pelas autoridades goianas, com o desmembramento da população de Rio das Pedras, para formar um outro pouso que pudesse servir às tropas, 21 quilômetros mais ao sul. Os índios, contudo, por causa do esgotamento dos solos em torno do Piçarrão, formaram mais outras duas localidades — as já citadas Estiva e Boa Vista - , respectivamente, a 10 quilômetros ao norte e 12 quilômetros ao sul daquela paragem. O naturalista francês destacou que sempre, todavia, se estabeleciam às margens da Estrada, onde se beneficiavam do acesso à passagem das tropas, mediante a venda de seus excedentes (1975 a). Vigário Silva (1970), primeiro pároco da freguesia de Uberaba e contemporâneo de Saint Hilaire, descreveu o mesmo padrão de ocupação:

[Até 1807] era apenas conhecida a estrada, que a atravessa de S. Paulo para Goiás, onde residião alguns índios, que tinham saído da Aldeia de Santa Ana, os quais nunca tiveram ânimo de alongar-se para algum dos lados da mesma estrada, nem ao menos meia légua, como depois se conheceu pelas suas culturas sempre vizinhas de suas habitações (1970, p. 07).

Desse modo, nos aldeamentos triangulinos a tendência migratória também era de dispersão, talvez causada pelo esgotamento dos solos, cultivados com pousios curtos. Havia, contudo, uma tendência de os índios se estabelecerem

15 Chamavam-se sitios ou situações as unidades de produção agropastoris no período colonial. 


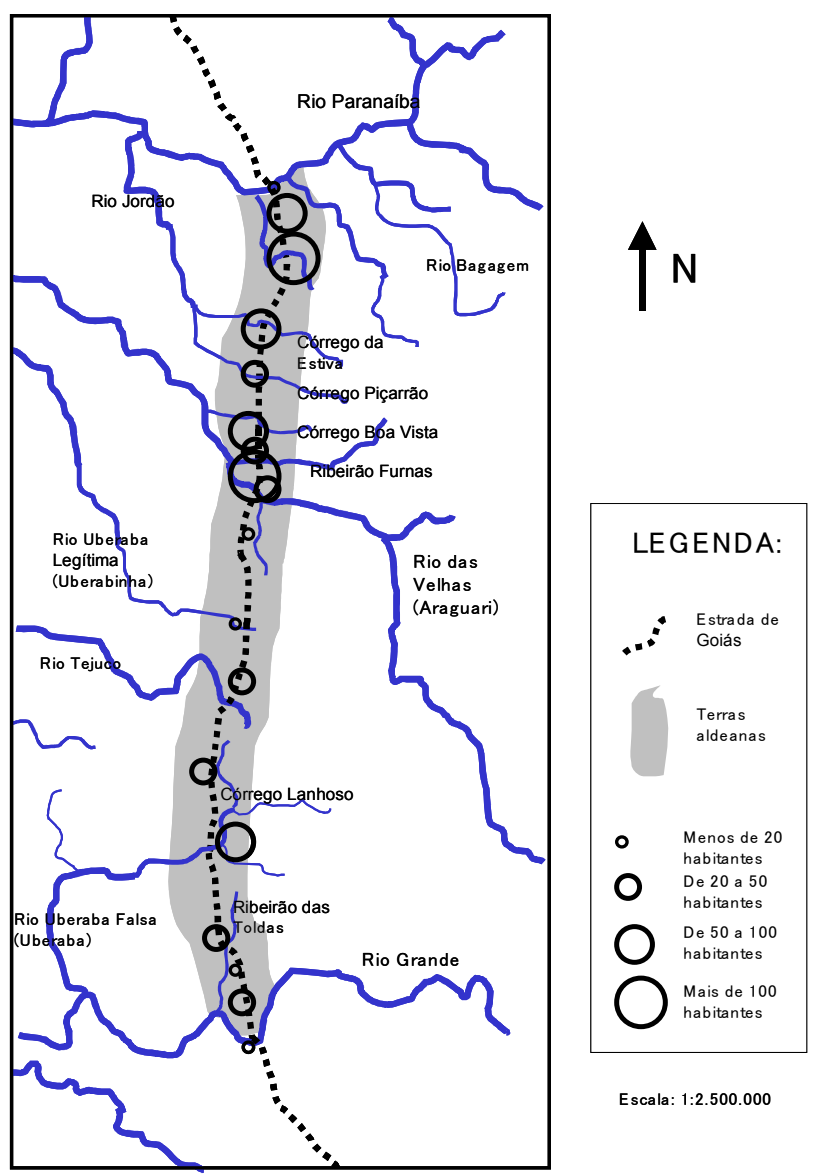

Figura 15: distribuição da população indígena em terras aldeanas do Sertão da Farinha Podre em 1821

Fonte: Eschwege (1996), IBGE (1972).

sempre dentro das terras aldeanas, já que estas consistiam numa área bastante grande, de aproximadamente 3.460 quilômetros quadrados. Eschwege (1996) reproduziu um mapa demográfico, feito pelos representantes dos índios da Farinha Podre em 1821, constando do número e do nome das paragens em que então se encontravam as famílias indígenas. Cotejamos essas informações com as cartas topográficas do IBGE (1972), para produzirmos o mapa da figura 15, 
com a localização aproximada dos núcleos de famílias indígenas em 1821.

Como se pode observar, os núcleos espalhavam-se ao longo de todo o traçado da Estrada, mas havia uma tendência a confluírem em dois trechos: do rio Paranaíba ao rio das Velhas, e do rio Tejuco ao rio Grande. Comparando-se essa distribuição com uma carta de solos do Triângulo Mineiro (figura 16), nota-se um claro liame entre os núcleos indígenas e as áreas de latossolo roxo (em cor negra), adequados para cultivos. Percebe-se, igualmente, uma menor densidade demográfica na área sobre o chapadão que se estende entre o rio das Velhas e o rio Tejuco, formada por latossolos álicos (em hachura), pouco férteis.

Assim, parece claro que, para uma população indígena sedentarizada e dependente de cultivos, o acesso a solos férteis era fundamental à localização dos seus sítios. Porém, a utilização de um sistema de cultivo de pousio arbustivo (Marcílio, 2000) levava as famílias a freqüentemente mudar a localização de seus sítios, de preferência em direção às áreas de mata virgem. Como os aldeamentos não cumpriam funções urbanas, sendo apenas habitats rurais concentrados, sua tendência, à proporção que as roças iam se distanciando deles, era de se despovoarem.

Um outro fator importante, que tendia a despovoar os aldeamentos, era a grande suscetibilidade das populações indígenas aos vírus e bactérias trazidos pelos colonizadores. Em São José de Mossâmedes, por exemplo, foram reduzidos os índios acroás, que tinham se rebelado no aldeamento do Duro, próximo a Natividade, em 1774 (CHAIm, 1983). Todos esses índios haviam morrido ou se dispersado até 1781, quando foram substituídos por javaés e carajás, que também se extinguiram até o início do século XIX. Finalmente, nos primeiros anos daquele século, Mossâmedes recebeu os caiapós trazidos da Aldeia Maria I. Estes, pouco antes da visita de Saint Hilaire, em 1819, haviam sofrido uma devastadora epidemia de sarampo, que exterminou mais de 80 índios (SAint Hilaire, 1975).

Nos aldeamentos da Farinha Podre, as epidemias também provocaram grande mortandade, principalmente nos seus primeiros tempos. Eschwege (1996) relatou que, em Santana, 50 anos antes de sua visita (portanto em 1766), havia ocorrido uma epidemia que vitimara um grande número de índios. Por causa disso, foram trazidos índios tapirapés, do rio Araguaia, para reforçar demograficamente a população do aldeamento. 

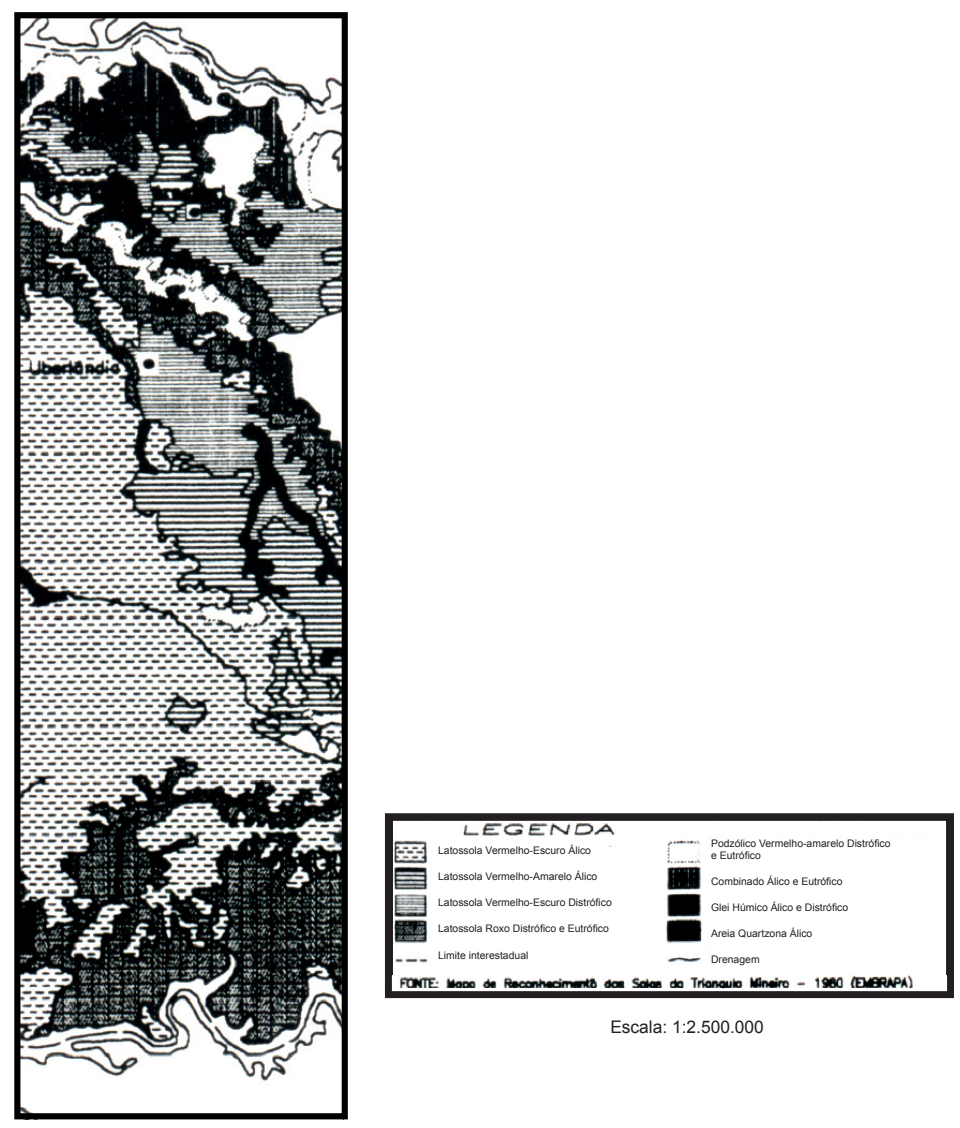

Escala: $1: 2.500 .000$

Figura 16: Mesorregião do Triângulo Mineiro: solos

Fonte: Siqueira e Rosa (1998).

Os deslocamentos forçados da população indígena foram um outro fator que alterou profundamente a demografia dos aldeamentos da região. Em 1775, uma leva de índios chacriabás foi trazida para Santana, vindos do Duro, após a já citada rebelião. Para que estes pudessem ser reduzidos, os índios que ocupavam anteriormente o aldeamento foram deslocados para o Lanhoso (CASAL, 1976). Em 1809, homens em idade militar foram transferidos em massa do Rio das Pedras para Nova Beira (Ilha do Bananal), para uma guerra contra os xavantes (Saint Hilaire, 1975, Chaim, 1983). A maioria 
deles morreu em combate, e ainda em 1816, Eschwege observara, em sua passagem por Rio das Pedras:

Estranhei a ausência de jovens de 14 a 20 anos. Indagando o motivo, foi-me dito que, 20 anos atrás, a maioria dos homens havia sido enviada contra os índios do Araguaia, tendo retornado apenas um pequeno número deles (EsCHWEGE, 1996, p. 118).

Pudemos reconstituir uma pequena série de dados demográficos de alguns núcleos indígenas, entre 1816 e 1823, graças aos dados coligidos por Saint Hilaire (1975, p. 154), Eschwege (1996, p. 126-127) e do tenente Francisco Inocêncio de Miranda (BARBosA, 1995, p. 39, 51, 128, 185, 251), que mostramos na tabela 1. Dela, excluímos os aldeamentos de Rio das Pedras, Santana e Uberaba, pois já nessa época recebiam intensa imigração lusobrasileira. Podemos perceber um aumento das populações de Estiva, Piçarrão e Boa Vista, enquanto houve decréscimo de Lanhoso e estagnação de Baixa. Baixa e Lanhoso, com tendência à estagnação e decréscimo populacional,

\begin{tabular}{l|c|c|c}
\hline \multicolumn{1}{c|}{ Aldeamento } & 1816 & 1821 & 1823 \\
\hline Estiva & 47 & 74 & 84 \\
\hline Pissarrão & 30 & 42 & 44 \\
\hline Boa Vista & 15 & 55 & 66 \\
\hline Lanhoso & 27 & 30 & 21 \\
\hline Baixa & 14 & - & 20 \\
\hline
\end{tabular}

Tabela 1 : população dos aldeamentos do Sertão da Farinha Podre de 1816 a 1823 Fonte: Eschwege (1996), Saint Hilaire (1975), Barbosa (1995).

situavam-se ao sul do rio das Velhas, no trecho de terras aldeanas entre esse rio e o Grande. Os demais, que mostravam um pequeno crescimento, situavam-se entre o rio das Velhas e o Paranaíba. O mapa da figura 16, que vimos anteriormente, expõe uma diferença significativa de densidade demográfica indígena, entre o norte e o sul do rio das Velhas, em 1821: ao norte, habitavam 637 índios, ou 0,51 por quilômetro quadrado de terras aldeanas; ao sul, estavam 234 índios, ou 0,10 por quilômetro quadrado (EsCHWEGE, 1996). 
Menores densidades de população indígena, tendência de decréscimo populacional: esses números refletem um processo que já havia se iniciado então, que era a espoliação de terras indígenas por colonos ao sul do rio das Velhas, no termo da freguesia de Uberaba. Liderados pelo sargento-mor Antônio Eustáquio Silva Oliveira, os colonos geralistas, que emigravam em massa vindos da região central da província de Minas Gerais, em poucos anos, exterminaram e expulsaram os índios da faixa aldeana. Anos depois, o mesmo aconteceria na faixa ao norte do rio das Velhas, no termo da vila de Araxá. Veremos esse processo com mais detalhes no capítulo que se segue. 


\section{3 | Triângulo Mineiro: uma fronteira na Colônia e no Império}

\section{A diáspora mineira}

Depois de percorrer, maravilhado, o exuberante trecho de Mata Atlântica que se estendia do litoral carioca à vila de Barbacena, em Minas Gerais, o naturalista Auguste de Saint Hilaire (2000) passou a descrever, de Queluz ${ }^{1}$ em diante, um cenário de devastação e abandono que mais lembrava uma paisagem lunar. Entre Ouro Branco e Vila Rica ${ }^{2}$

A paisagem toma um ar de tristeza que conserva quase sempre até Vila Rica. Não se descobrem de todos os lados senão campos desertos, sem cultura e sem rebanhos. Se se avistam algumas casas, ordinariamente estão em ruínas; os contornos das montanhas são ásperos e irregulares; continuamente se avistam escavações para a lavagem de ouro; a terra vegetal foi eliminada, com ela desapareceu a vegetação, e nada mais ficou senão montes de cascalho (SAint Hilaire, 2000, p. 68).

Ao passar por Antônio Pereira, povoado ao norte de Vila Rica, "não se percebe no campo o menor sinal de cultura; não se vê um único rebanho em meio às vastas pastagens que cobrem os morros" (Saint Hilaire, 2000, p. 75). Em Mariana; “os morros nos arredores [...] são estéreis e incultos” (p. 80). Ao passar por Camargos, ao norte de Mariana, viu uma paisagem "rodeada de morros desolados, esburacados pelos mineradores de ouro" (p. 87). Chegando a Catas Altas,

todo o dia se passou sem que lobrigássemos a menor lavoura; [...] sem a presença de uma ovelha ou cabeça de gado sequer; e o que mais freqüentemente chamava

Hoje Conselheiro Lafaiete

2 Hoje Ouro Preto. 
a nossa atenção eram os morros áridos, sulcados em todos os sentidos pelas mãos dos mineradores (SAint Hilaire, 2000, p. 88).

Em Santa Bárbara, a caminho da comarca do Serro do Frio, " "não se observa em seus arredores o menor sinal de cultura; por todos os lados, a terra foi escavada e revolvida pelos faiscadores" (SAINT Hilaire, 2000, p. 98).

Esse espetáculo de devastação ambiental não foi notado só pelo olhar cuidadoso e ilustrado do cientista francês. Os desenhos feitos por Rugendas, retratando as vilas do ouro, na década de 1820, mostram cenários de solos arruinados por voçorocas, ausência de cultivos ou pastagens, morros sem qualquer vestígio de matas (figura 1). Em Santana do Sapucaí, os alemães Spix e Martius observaram:

[...] encontramos lavras de ouro já de considerável extensão. De longe parecem trincheiras cavadas. Nas encostas, formando terraços, estavam abertos fossos de alguns pés de profundidade e de largura, pelos quais era levada a água da chuva pelos flancos abertos do barro vermelho. [...] Tudo dá um aspecto triste de destruição selvagem; as próprias estradas estão danificadas, e essa paisagem entristece o viajante, penosamente (Spix; Martius, 1981, p. 182).

Contemporâneos deles, como o engenheiro alemão Wilhelm von Eschwege (1996) e o general português Raimundo Cunha Matos (1981), tiveram a mesma impressão, e foram unânimes em apontar as causas de um quadro tão desolador: a lavagem dos solos pela mineração, e o sistema agrícola predatório usado pelos mineiros.

O sistema de mineração de ouro e diamantes, usado desde os primeiros anos do século XVIII na região central de Minas Gerais, só agora começa a ter o seu impacto ambiental avaliado pelos estudiosos. De início extraído pela lavagem do cascalho retirado nos aluviões dos córregos, logo o esgotamento desse ouro de aluvião levou os mineiros a iniciarem a exploração do ouro nas encostas dos morros. As florestas eram queimadas e, em seguida, os rios e córregos eram desviados, às vezes, usando-se sistemas de aquedutos com quilômetros de extensão, para que a água erodisse os morros onde se localizavam as jazidas (LunA; Costa, 1982). Os riachos, às vezes, eram voltados diretamente

3 Hoje norte de Minas e Vale do Jequitinhonha. 


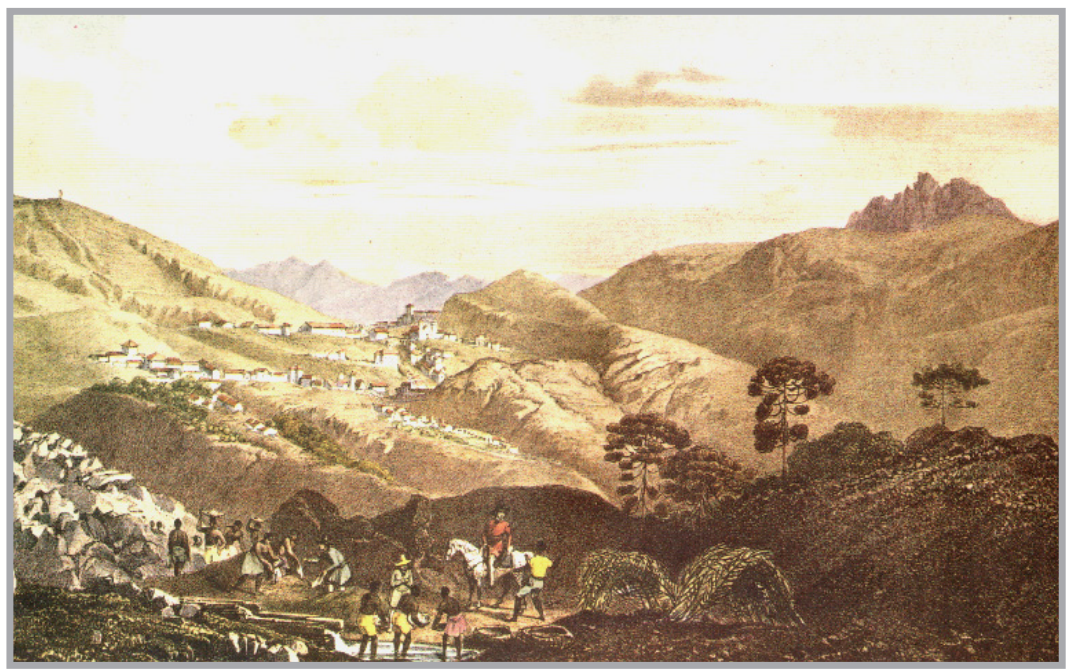

Figura 1: Vila Rica.

Fonte: Rugendas (1998)

contra as encostas, para provocar o desabamento de uma formação rochosa promissora, técnica conhecida como carregar uma montanha em talho aberto. Em outras situações, as encostas eram drenadas a seco, abrindo-se crateras de até 2 metros de profundidade em média (DEAN, 1996). Em poucos meses, os solos eram removidos por um processo erosivo antrópico, praticado sobre grandes superfícies, que eram abandonadas assim que novas lavras eram localizadas.

Tais técnicas exigiam grande vazão de água dos cursos fluviais locais. Daí a face leste da Serra do Espinhaço ter sido a mais atingida por esse tipo de exploração: cobertas pela Mata Atlântica e a barlavento das massas de ar oceânicas, seu regime pluvial permitia que o trabalho de extração aurífera não tivesse que ser interrompido na estação seca (DEAN, 1996).

Estudos atuais tentam estimar a área devastada pela prospecção de ouro e diamantes. Dean (1996) calcula que, se os mineiros obtinham um grama de ouro em um metro cúbico de ganga, em média, é provável que, durante o século XVIII, tenham sido revirados $4.000 \mathrm{~km}^{2}$ de solos de Mata Atlântica. Esse historiador estima a destruição de uma faixa de $450 \mathrm{~km}$ de extensão por 45 km de largura, em média, ao longo da Serra do Espinhaço, estendendo-se de Lavras a Diamantina. 
Solos arrancados pela febre do ouro, deixando imensas voçorocas abertas, cobertas apenas por tufos de mata-pastos. Esta não seria a única causa da catástrofe ambiental que destruiu, apenas no século XVIII, $30.000 \mathrm{~km}^{2}$ de Mata Atlântica, a maior parte em Minas Gerais (DEAN, 1996). Um outro fator também não escapou aos olhos dos observadores estrangeiros de então: o sistema agrícola usado pelos habitantes de Minas Gerais.

A extração aurífera exigiu que, em pouco tempo, já nos primeiros anos do século XVIII, se criasse uma agricultura voltada para o consumo local, na região em torno das lavras. A própria oferta de meio circulante, na forma do ouro em pó, estimulou não só a vinda de comerciantes para a região, mas o surgimento de uma diversificada agricultura e artesanato locais. A agricultura do milho dos primeiros tempos, trazida pelos pioneiros paulistas, foi logo complementada por uma variedade muito maior, com cultivos de feijão, algodão, fumo, cana de açúcar, e criação de porcos e gado (HolAndA, 1985). As fazendas, geralmente, combinavam as lavras auríferas com engenhos de cana, farinha e pecuária (Silveira, 1997).

A febre do ouro atraiu um número muito grande de migrantes para a região, e aqueceu, a níveis nunca vistos, o tráfico negreiro transatlântico. Aproximadamente, 500 mil portugueses emigraram no século XVIII, a maioria para Minas (DeAn, 1996), despovoando regiões inteiras de Portugal, como o Minho (LunA; Costa, 1982). Dez mil moradores do Rio de Janeiro emigraram para as Minas, e os núcleos paulistas e baianos tiveram redução populacional. Em 1763, quando se tornou manifesta a exaustão das lavras, a população da capitania já somava meio milhão de pessoas (HoLANDA, 1985). Esse aumento demográfico causou forte incremento na demanda por produtos da agricultura de subsistência nos níveis local, regional e extra-regional.

Esse quadro criou uma situação demográfica e ecológica que pode ser assim resumida: uma grande população (para os padrões da época) que dependia de uma agricultura de técnicas rudimentares, praticada em solos de mata. Esta agricultura tinha que competir pelos solos com as lavras e, por isso, as áreas cultivadas eram sobrecarregadas, exigindo intervalos de pousio cada vez mais curtos.

O modo como o crescimento demográfico — como nesse caso — impõe as formas de agricultura foi estudado por Marcílio (2000), a partir de uma revisão de autores como Boserup, Clark e Kayser. A autora, ao fazer o estudo 
de caso da capitania de São Paulo do século XVIII, concluiu que o crescimento da população levou à passagem de um sistema agrícola de pousio florestal (20 a 25 anos de pousio das áreas cultivadas, com reconstituição da mata original) para um sistema de pousio arbustivo (6 a 10 anos de pousio, com reconstituição de uma vegetação secundária do tipo herbáceo-arbustivo ou capoeira). Tais sistemas são compatíveis com níveis técnicos bastante rudimentares e sistema itinerante (MARCílIo, 2000).

Uma das conseqüências do uso de sistemas de pousio longo, com baixo nível técnico, é que eram necessárias áreas muito grandes para manter um número relativamente pequeno de famílias. O governador paulista Pimentel, por exemplo, afirmou em resposta a uma consulta do Conselho Ultramarino, que meia légua em quadra (aproximadamente 1.089 hectares) era muito pouco para uma única família de roceiros:

Por que como na mesma terra ou roça que semeiam este ano, o não fazem para o seguinte, mas derrubam e queimam novo mato, e quando se vem chegar ao fim de meia légua, não tem passado o curso, dos anos necessários para que no princípio de meia légua, e primeira roça, tenham crescido novas árvores e lenhas para se tornarem a roçar e queimar, e por esta causa deixam os lavradores as tais terras, a que chama capoeiras e procuram outras ou por sesmarias, ou por compra em que possam continuar as suas granjerias e plantas (MARCílio, 2000, p. 168).

Um crescimento demográfico ainda maior poderia gerar três situações distintas entre as populações agricultoras: aumentos na produtividade com redução ainda maior do tempo de pousio, na condição de se contar com técnicas mais avançadas; fome e tensões sociais; ou emigração para regiões de fronteira. Esta terceira situação foi a mais comum, no caso estudado pela autora.

Marcílio afirma que, a partir de meados do século XVIII, houve a passagem, em várias regiões do território paulista, do pousio florestal para o arbustivo. Isto se deu por causa do aumento da população paulista, de 15.000 habitantes no final do século XVII, para $169.544 \mathrm{em} \mathrm{1800.} \mathrm{A} \mathrm{partir} \mathrm{daquele}$ período, novos aumentos demográficos estimularam a emigração, em busca de novas terras, para o Vale do Paraíba, o Oeste Velho (região de Campinas e Mogi-Guaçu), e para os campos do Paraná e Santa Catarina. 
Ainda não existem estudos semelhantes para o caso mineiro, mas podemos inferir que, na agricultura praticada em Minas Gerais, se deu a mesma seqüência de eventos que em São Paulo, numa escala muito maior. Antonil (1997) estimava em 30.000 o número de mineiros no início do século XVIII. O levantamento demográfico da capitania feito pelo desembargador Teixeira Coelho, em 1776, somava 319.769 habitantes (Cunha Matos, 1981). Trinta e cinco anos depois, o mapa demográfico feito por Eschwege (1996) totalizava 514.107 habitantes. Dito de outra forma, Minas Gerais iniciou o século XVIII com uma população que já era o dobro da de São Paulo, e o terminou com uma população cinco vezes maior que a daquela capitania. É provável, por isso, que as pressões exercidas pela demanda por alimentos sobre os cultivos em solos de mata fossem ainda maiores do que naquele caso.

Os relatos deixados pelos viajantes joaninos permitem concluir que o sistema agrícola utilizado na região central de Minas era semelhante ao analisado por Marcílio para o caso paulista. Saint Hilaire (2000) assim o descreve:

Quando já se fizeram duas colheitas em um solo outrora coberto de matas virgens, deixa-se o terreno repousar um pouco; brotam aí árvores muito mais delgadas que as primeiras. [...] deixam-se estas crescer durante cinco, seis ou sete anos, segundo as regiões; cortam-se, novamente, queimam-se em seguida, e faz-se a plantação nas cinzas. [...] quando, nessa parte do Brasil, um terreno já foi cultivado umas poucas vezes, vê-se nascer uma samambaia imensa [...] [e] uma gramínea viscosa, pardacenta, chamada capim-gordura [...]. O agricultor, não mais podendo esperar ver nascer árvores sobre o seu terreno, diz que este está definitivamente perdido (é terra acabada); após fazer sete ou oito colheitas em um campo, ele o abandona, e queima outras matas, que em breve têm a mesma sorte das precedentes (Saint Hilaire, 2000, p. 90-91).

No caso mineiro, contudo, pressões demográficas maiores sobre uma superfície agricultável relativamente menor, por causa das superfícies que tiveram os solos removidos pelas lavagens da mineração, levaram a uma superutilização das áreas de cultivo, refletindo-se num encurtamento do período de pousio. O Barão de Eschwege resumiu, numa de suas anotações, o que ocorria com os solos mineiros, ao falar dos arredores de Vila Rica: 
Cada solo exige longo período de descanso, conforme o grau de fertilidade que possui, antes que se possa replantar. Esse prazo é indicado pelo crescimento da capoeira, que se desenvolve depressa e alcança boa altura. Assim, o replantio, nesse caso, pode ser feito após oito anos. Em outras regiões, esse prazo pode estender-se até a doze, quinze e vinte anos. O agricultor que não respeitou esses limites e plantou, por exemplo, 20 alqueires em área suscetível de apenas 10 , acaba por transformar sua terra fértil em árida estepe, onde brotam apenas samambaia e caniço, como é o caso da maioria dessas regiões (EsCHWEGE, 1996, p. 64).

Noutras palavras, as grandes demandas, impostas pela população urbana dos arraiais e vilas do ouro, pressionavam pelo encurtamento do pousio e superutilização dos solos, mantendo-se, contudo, as técnicas rústicas do sistema itinerante. O resultado era um nível de esgotamento tal que impedia até mesmo a reconstituição da capoeira. Segundo Dean:

A maior densidade de população incentivava a redução do intervalo entre queimadas nas fazendas das vizinhanças de minas e vilas maiores. [...] o crescimento da floresta secundária nessas áreas, em conseqüência, fica em uma fase bastante imatura, e reforçava a tendência de que ela não mais voltasse a crescer. [...] a degradação de grande parte dos solos das áreas derrubadas estava acontecendo a tal ponto que a vegetação que renascia carecia de muitas das espécies que teriam reconstituído, na ausência de interferência humana, a floresta original (1996, p. 116).

Com o esgotamento dos solos nas proximidades das vilas do ouro, ocorreu um progressivo afastamento entre as áreas produtoras de alimentos e as áreas mineradoras. Em 1816, Vila Rica era abastecida por áreas produtoras situadas no vale do rio Paraopeba, a $100 \mathrm{~km}$ de distância, pois, próximo àquele núcleo, já não existiam mais terras cultiváveis (Eschwege, 1996). Saint Hilaire, em 1819, escreveu que "os morros dos arredores de Mariana são estéreis e incultos, e os gêneros que se consomem na cidade vêm de grande distância” (2000, p. 80).

Da mesma forma que no caso paulista, estudado por Marcílio, também aqui o aumento das tensões demográficas impôs aos agricultores a emigração para áreas de fronteira, diante da inexistência da opção pela intensificação dos 
cultivos com o avanço técnico. Tal imigração, contudo, deu-se em proporções mineiras e não paulistas, isto é, contando com uma população migrante muito maior. Um grande (e pouco estudado) movimento centrífugo de população, talvez o maior até então visto, tendo como área de repulsão a região mineradora da capitania de Minas Gerais, iniciou-se, a partir da década de 1760, em direção a todas as regiões circunvizinhas. As demais comarcas de Minas Gerais e as capitanias (depois províncias) de São Paulo, Rio de Janeiro, Mato Grosso e Goiás receberam grandes levas desses migrantes, em sua maioria, roceiros em busca de terras para cultivo e pastagens.

Tais migrantes, como aparece nos documentos de época, eram chamados geralistas pelas populações locais. O mapa mostrado na figura 2, produzido com base na revisão de estudos realizados por outros autores, que abordaram frações desse fluxo migratório em casos regionais, resume a área abrangida por essa dispersão populacional. Esse movimento centrífugo teve longa duração: iniciado em 1760, só se interrompeu nas primeiras décadas do século XX (PRADO JR., 1986).

O esgotamento das jazidas superficiais de ouro e diamantes, a partir de 1750, causou decréscimo populacional em alguns arraiais e vilas da região central de Minas, principalmente naquelas cujas atividades de comércio e serviços eram alimentadas exclusivamente pelo ouro das lavras. Saint Hilaire, ao passar por Queluz, observou que "o mato aí cresce por todos os lados; casas bastante lindas nos pareciam estar abandonadas, e quase todas estavam mal conservadas a ponto de cair em ruínas" (Saint Hilaire, 2000, p. 65). Em Santa Bárbara, "é fácil perceber que teve outrora grande importância; mas esse vilarejo está de tal forma abandonado, que um proprietário que aí possui várias casas garantiume que ninguém queria habitá-las, mesmo de graça” (Saint Hilaire, 2000, p. 98). Em Conceição do Mato Dentro, “o mato que cresce nas ruas esconde quase completamente as pedras do calçamento; grande número de casas já foi abandonado, e as outras caem em ruínas" (Saint Hilaire, 2000, p. 135).

O abandono de alguns núcleos, com o esgotamento das lavras e dos aluviões auríferos, e o abandono das fazendas cujos solos haviam se esgotado, ou sido destruídos pelos métodos hidráulicos de mineração, levaram a comarca de Ouro Preto a um decréscimo demográfico pela emigração, ao longo da segunda metade do século XVIII e início do século XIX. Isso pode ser comprovado pelas estimativas demográficas compiladas por Cunha Matos (1981), que mostram uma perda de população absoluta de 5.573 habitantes, entre 1776 e 1829 . 


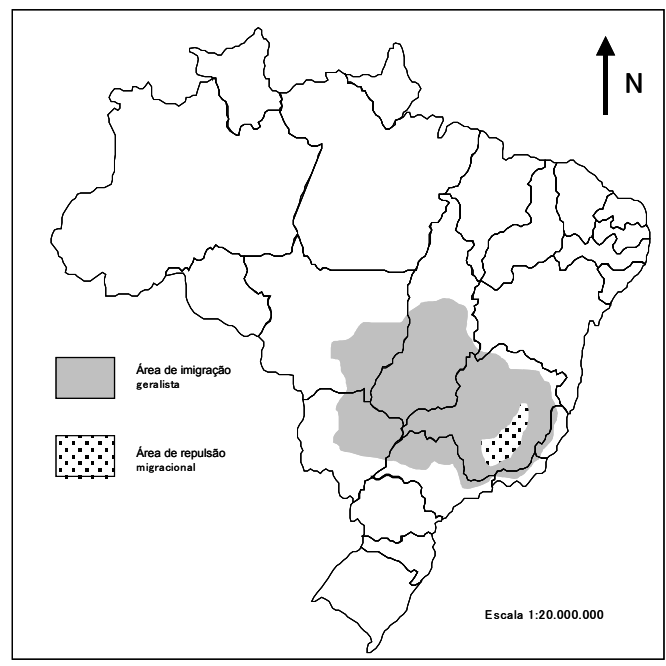

Figura 2: migração geralista entre 1760 e 1890

Fontes: Prado jr. (1986), Palacin e Moraes (1994), Monbeig (1998), Sodré (1941).

No entanto, isso não significou a "decadência" da economia mineira, como interpretaram alguns autores. Enquanto a atividade mineradora perdia fôlego e os solos da zona aurífera se exauriam, outras regiões, como a comarca de Paracatu, do Serro Frio e principalmente a do Rio das Mortes, viram prosperar uma importante economia agropastoril e manufatureira. É o que veremos a seguir.

\section{O mito da decadência mineira e a montagem de uma economia agropastoril}

Delineado esse quadro, que entendemos estar por trás dos fatores que levaram à emigração de geralistas para as zonas de fronteira, duas ressalvas devem ser feitas. Em primeiro lugar, nem todos os núcleos urbanos da região mineradora se despovoaram com a emigração. Aqueles que conservaram a condição de capital administrativa ou religiosa e, principalmente, os que estavam estrategicamente situados de forma a tornarem-se núcleos comerciais, 
não decresceram - e até mesmo prosperaram — no período em questão. No primeiro caso, encontra-se Vila Rica e Mariana, respectivamente, as capitais administrativa e religiosa da capitania (depois província) de Minas Gerais. Vila Rica, por exemplo, na década de 1820, contava com aproximadamente 8.000 habitantes, dos quais $92 \%$ se ocupavam em atividades urbanas de artesanato e serviços, e destes, 23\% eram funcionários da administração civil, eclesiástica e militares (LunA; Costa, 1982).

O melhor exemplo de dissociação entre um entorno rural $/$ minerador decadente e uma próspera paisagem urbana, no início do século XIX, era São João Del Rei. Antigo núcleo aurífero, capital da comarca do Rio das Mortes, tornara-se, juntamente com a vila de Barbacena, uma das cidades mais importantes da província de Minas Gerais, na primeira metade do século XIX. O viajante inglês Alexander Caldcleugh, entre Santa Rita ${ }^{4}$ e São João Del Rei, comentava que, por quinze quilômetros, percorrera "uma região escalvada e deserta, cujo terreno está todo minado pelas escavações do ouro" (DEAN, 1996, p. 114). As pastagens em torno de São João ${ }^{5}$ eram tão impraticáveis que Saint Hilaire teve que parar sua tropa no Rancho do Marçal, a alguns quilômetros de distância. Mas, ao chegar àquela vila, surpreendeu-se com seu aspecto de prosperidade e abastança:

As ruas de São João são geralmente calçadas e muito largas. Segundo o uso da região, as casas são baixas; mas são em geral bonitas, bem cuidadas, e um grande número entre elas possui um andar além do térreo. [...] Vêem-se, em São João, principalmente na Rua Direita, um grande número de lojas, geralmente muito bem sortidas. Não somente esta vila não tem esse ar de tristeza e abandono, peculiar a quase todas as desta província; não somente não se vêem, a cada passo, casas abandonadas caindo em ruínas, mas ainda tudo aí parece vivo e animado (1974, p. 111).

As impressões de Pohl foram igualmente positivas: "esta cidade figura entre as mais limpas e alegres que já encontrei no Brasil” (1976, p. 86). Spix e Martius assim a descreveram:

\footnotetext{
4 Hoje Ritápolis.

5 Usaremos às vezes, como faziam os viajantes joaninos e como faz hoje a população sanjoanense, apenas o termo São João para nos referirmos a São João Del Rei.
} 
Ruas calçadas, belas igrejas guarnecidas com pinturas de artistas nacionais, lojas fornecidas de todos os artigos de luxo e do comércio europeu, muitas oficinas, indicam a riqueza do lugar que, por suas transações com o sertão, é considerado entre os mais animados do Brasil (SpIX; MarTius, 1981, p. 194).

Assim, nesse caso (e como veremos adiante, também no de Oliveira), a prosperidade do núcleo urbano não se ligava ao entorno rural, aliás, devastado como de resto toda a região aurífera, e sim ao fato de deter a primazia do comércio sobre uma ampla rede de arraiais, que se irradiava pelo sertão a oeste. Analisaremos mais detidamente o comércio sanjoanense do século XIX, e suas relações com o sertão do Triângulo Mineiro, no capítulo 6.

Outra ressalva importante é que não compartilhamos da idéia da "decadência", que teria se seguido ao esgotamento da mineração aurífera e diamantífera em Minas Gerais. A idéia da decadência mineira é, na realidade, muito antiga, e já estava presente no discurso ilustrado das elites mineiras do final do século XVIII, que contrapunham a decadência de seus dias a um passado glorioso, dos tempos de apogeu econômico e cultural, que supostamente teria se dado até meados do século (SiLveIrA, 1997).

A idéia da decadência acabou sendo incorporada por autores como Celso Furtado, pois coadunava com a Teoria dos Ciclos e com a concepção de Sistema Colonial:

Não se havendo criado nas regiões mineiras formas permanentes de atividades econômicas — à exceção de alguma agricultura de subsistência - era natural que, com o declínio da produção do ouro, viesse uma rápida e geral decadência. [...] Ao contrário do que ocorria no caso da economia açucareira [...] na mineração a rentabilidade tendia a zero e a desagregação das empresas produtivas era total. Muitos dos antigos empresários transformaram-se em simples faiscadores e com o tempo revertiam à simples economia de subsistência. Uns poucos decênios foi suficiente para que se desarticulasse toda a economia da mineração, decaindo os núcleos urbanos e dispersando-se grande parte de seus elementos numa economia de subsistência, espalhados por uma vasta região em que eram difíceis as comunidades e isolando-se os pequenos grupos uns dos outros (FURTADO, 1987, p. 84-86). 
Tal idéia foi, contudo, refutada por Sérgio Buarque de Holanda (1985). O historiador paulista afirmou que, ao contrário, durante o meio século de exploração aurífera desenvolveram-se paralelamente atividades agropecuárias de grande importância, estimuladas pela própria presença do ouro como meio circulante, e voltadas para o mercado interno. Kenneth Maxwell, na mesma vertente, escreveu:

A economia regional, com suas propriedades rurais horizontalmente integradas, era particularmente capaz de absorver o choque das transformações que vieram após a exaustão do ouro aluvial. Tanto tinha capacidade para corresponder ao estímulo recebido da economia interna quanto do amplo comércio exterior que fluía pela estrada do Rio de Janeiro e que minguou na proporção direta do declínio da produção aurífera (Maxwell, 1978, p. 112).

Libby (1988), na mesma linha, mostra que Minas manteve o maior plantel de escravos de todas as províncias do Império ao longo do século XIX, e que o crescimento demográfico fora constante no período. Em seu trabalho, demonstra que houve, na verdade, uma substituição das atividades mineradoras pelas agropastoris e artesanais. Segundo esse autor, a economia mineira do século XIX sustentava-se por uma agricultura mercantil de subsistência, voltada em parte para o autoconsumo, e em parte para o mercado interno. Além dessa agricultura mercantil, havia um setor formado por atividades de transformação: fios e panos, oficinas artesanais, pequenas e médias manufaturas, voltadas sobretudo para o mercado do Rio de Janeiro.

Em resumo, não houve colapso econômico com o esgotamento da mineração porque já se encontrava em funcionamento, há muito tempo, uma estrutura produtiva bastante diversificada, e que obtinha a maior parte de sua renda em atividades agropastoris e manufatureiras. Silveira (1997), examinando os documentos das devassas civis do Museu da Inconfidência, concluiu que, em Vila Rica e freguesias próximas, ao final dos Setecentos, 65\% das ocupações estavam voltadas para a economia com vistas ao mercado local, contra $15 \%$ para a mineração. $\mathrm{O}$ autor mostra o quadro de uma economia mineira diversificada, onde as fazendas combinavam a lavra do ouro com engenho de cana, ou com a pecuária. A exploração aurífera era uma das atividades das quais os fazendeiros mineiros lançavam mão, e isto desde meados do século XVIII. Nas palavras 
de Gorender, "há muito tempo, Minas Gerais não era somente mineração de ouro e de diamantes" (1988, p. 465).

A exploração aurífera, atividade pioneira que impulsionou a colonização das Minas, realmente se esgotou, mas esse esgotamento não interrompeu o processo de transformação da capitania num dos principais produtores de gêneros destinados ao abastecimento do litoral, especialmente do Rio de Janeiro. Meio século de extração aurífera foi capaz de criar uma economia regional diversificada e integrada a outras regiões da colônia, capaz de resistir ao esgotamento dos filões. A exaustão das minas e dos solos agricultáveis da comarca de Ouro Preto apenas fez deslocar geograficamente o centro gravitacional da economia mineira para a florescente comarca do Rio das Mortes. ${ }^{6}$

As áreas de fronteira daquela comarca — o Sul Mineiro e a área fronteiriça à capitania do Rio de Janeiro - foram povoadas pelos geralistas, emigrados da zona aurífera, já na segunda metade do século XVIII. Nessa época, afrouxavase o controle dos interstícios em torno das minas, onde a colonização era, até então, proibida (VASCONCELOS, 1999). Ali, tornaram-se criadores de gado, e já em 1765, desciam boiadas para o Rio de Janeiro (GORENDER, 1988).

De início, como já foi visto, a expansão sobre essas regiões fora o resultado da itinerância da agricultura de abastecimento interno da capitania, que já não mais podia contar com os solos dos arredores das vilas do ouro. Como o despovoamento dos núcleos mineradores coincidiu com a ascensão do Rio de Janeiro à condição de principal porto e cidade do Brasil, principalmente após a transferência da Corte portuguesa em 1808, para lá passaram a ser drenados os excedentes produzidos pela comarca. Estes tomavam a forma não só das boiadas, mas também das porcadas, dos carregamentos de toicinho e de couros, e dos panos de algodão, produzidos pelo artesanato doméstico (FraGoso, 1998).

Nessa mesma época, a migração geralista também tomava o rumo oeste, ultrapassando a barreira das montanhas, o vale do rio São Francisco, e avançando sobre o domínio biogeográfico do Cerrado. Levavam consigo as práticas e técnicas de pecuária e agricultura desenvolvidas, por quase um século, no planalto mineiro, e que iriam sofrer um rápido processo adaptativo ao novo ambiente.

Havia ali, contudo, um poderoso empecilho à corrente migratória ocidental dos geralistas: uma importante rede de quilombos, formados pelos

Hoje Sul de Minas e Zona da Mata Mineira. 
escravos, que, durante um século, haviam fugido dos arraiais e vilas do ouro. Do enfrentamento entre esses quilombos e o poder colonial, falaremos em seguida.

\section{A guerra contra os quilombos}

Em 1736, no apogeu da Idade de Ouro de Minas, o governador da capitania, Gomes Freire de Andrade, seguindo ordem régia, iniciou a abertura de um caminho ligando as minas goianas a São João Del Rei e Vila Rica, passando pelas recém descobertas minas do Paracatu (VAsconcelos, 1999). Esse caminho ficaria conhecido como a Picada de Goiás, e deveria tirar o ouro goiano da influência de São Paulo e dos contrabandistas, pondo-o diretamente sob controle da fiscalização instalada em Minas e drenando-o para o Rio de Janeiro. Logo depois, em 1737, Gomes Freire concedeu várias sesmarias ao longo da picada aos homens que se haviam consorciado ao governo da capitania na sua abertura (VAsconcelos, 1999). ${ }^{7}$ Com a Picada, a Estrada do Anhanguera entraria em decadência relativa, pois o tráfego goiano passou a se fazer quase todo pela estrada mineira, e o tráfego cuiabano vivia o auge da navegação das monções (BACELAR; BRIOSCHI, 1999).

O povoamento ao longo da estrada não se daria ainda desta vez. A partir da década de 1740, apesar de as pressões demográficas já se fazerem sentir na zona mineradora de Minas, e o esgotamento do ouro obrigar os mineiros à busca de novos veios, havia um fator que impedia o início da ocupação colonial do Oeste Mineiro: toda a faixa de terras do alto São Francisco e médio rio Grande encontrava-se povoada por quilombos. Pelas informações do padre Diogo de Vasconcelos, foi possível mapear a localização aproximada desses quilombos (figura 3). Formavam um crescente sobre as serras da Marcela, da Saudade, o Campo Grande e a Serra da Canastra, que marcam o início dos

Em nosso trabalho de reconstituição do traçado dos antigos caminhos coloniais, encontramos pelo menos três estradas que recebiam o nome de Picada de Goiás. A mais antiga delas, provavelmente o caminho aberto por Gomes Freire em 1736, passava pelo Registro de Sete Lagoas e pelo Porto do Espírito Santo, no Rio São Francisco e, portanto, ficava mais ao norte do que o traçado reconstituído por Vasconcelos (BARBOSA, 1998). O traçado de Vasconcelos realmente existiu, como mostra o mapa de 1788 da capitania de Minas, e a Picada Nova de Goiás tinha um traçado bem conhecido, pois foi percorrida por todos os viajantes joaninos. Os três traçados já eram mostrados no mapa de 1788. 
chapadões que se estendem até o atual Triângulo Mineiro. Provavelmente a escolha desses sítios pelos quilombolas deveu-se à dificuldade de acesso para quem vem do leste.

Descobertas de jazidas auríferas a oeste colocavam cada vez mais os mineiros em choque com os quilombolas. A sudoeste, lavras foram sendo sucessivamente descobertas nas vertentes das serras da Mantiqueira e da Canastra. Campanha (1737), Ourofino (1746) e Jacuí (1755) atraíam para suas datas os mineiros da região central e, na mesma medida, tornavam-se cada vez mais freqüentes as escaramuças entre mineradores e quilombolas na região do rio Sapucaí e no Campo Grande (BARBOSA, 1998). Em 1748, garimpeiros vindos de Paracatu, em busca de novas jazidas, foram massacrados por negros do quilombo do Queimado, no alto São Francisco. No ano seguinte, o padre Marcos Freire de Carvalho, estando à procura de ouro no Campo Grande, teve 49 membros de sua comitiva mortos num ataque quilombola. O tráfego pela Picada de Goiás também se tornara difícil para os colonos pelo mesmo motivo (VAsconcelos, 1999). A resistência dos quilombos era tão eficaz que nenhum povoado luso-brasileiro havia se estabelecido na área do sertão do Pium-i, Serra da Canastra e rio das Abelhas até 1752 (Pontes, 1978).

A guerra contra os quilombos tornou-se uma das prioridades do governo da capitania de Minas Gerais de 1746 em diante. O governador José Antônio Freire de Andrade, substituindo interinamente seu irmão Gomes Freire, organizou nessa data a entrada do capitão Antônio João de Oliveira contra o quilombo do Ambrósio, derrotando-o. Em 1757, o capitão-mor Bartolomeu Bueno do Prado enfrentou os quilombos do Indaiá, do Zundu e novamente o do Ambrósio, que ressurgira. ${ }^{8}$ Em 1758, seria a vez de Diogo Bueno da Fonseca alimpar os sertões do Pium-i, e de Antônio Francisco França a região do rio Sapucaí (VAsConcelos, 1999). A campanha assumira tal importância que o governador mudou provisoriamente a capital para São João Del Rei, de forma a ficar mais próximo do campo de operações (MeLo E SouZA, 1999).

8 Nessa expedição, surgiu a lenda, popularizada por Pedro Taques na Nobiliarquia, dos "três mil e novecentos pares de orelhas enfileiradas", que Bueno do Prado teria arrancado dos quilombolas como troféu de guerra. Diogo de Vasconcelos cita carta do governador em que o mesmo refere que o capitão-mor, após quatro meses de campanha, havia "matado 25 , prendido 20 no quilombo do Indaiá, e também prendido 49” (1999, p. 155). As patranhas eram comuns nos relatos de campanha da época.... 


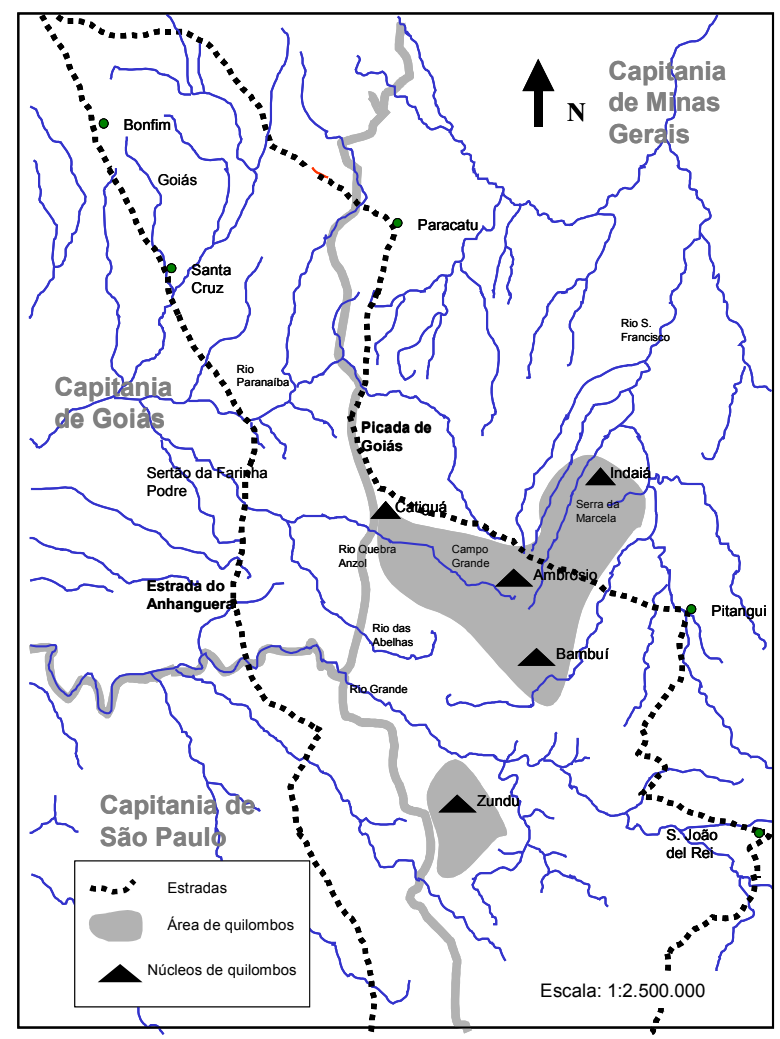

Figura 3: área dos quilombos e seus principais núcleos no oeste mineiro em 1748.

Fonte: Vasconcelos (1999).

O golpe definitivo sobre os quilombos seria dado pelo governador Luís Diogo Lobo da Silva. Nomeado capitão-general da capitania em 1763, decidiu fazer uma longa viagem pela fronteira sudoeste da capitania, para avaliar as novas descobertas auríferas e tomar informações sobre o sertão ocidental. Nessa viagem de 365 léguas, foi acompanhado pelo futuro inconfidente Cláudio Manoel da Costa (VAsconcelos, 1999).

Vivia-se então o apogeu das reformas pombalinas, dentre as quais despontava, como já visto, o projeto geopolítico de ocupação do interior da Colônia, como forma de resguardá-la dos interesses estrangeiros. A 
velha concepção de isolamento territorial das zonas mineradoras ia sendo abandonada. Mello e Souza (1999) aponta esse como um dos motivos centrais da guerra anti-quilombos. Ao mesmo tempo, já se faziam sentir os fatores de tensão demográfica na região aurífera da capitania, já analisado anteriormente.

Tendo de um lado os interesses de Estado, e de outro tendo que lidar com a tensão social, a ocupação da fronteira oeste tornara-se vital para o governo de Luís Diogo. Em 1767, o capitão-general assinou 20 cartas de sesmaria em terras além da Marcela, na Picada de Goiás (VAsCOnCelos, 1999). Entre 1764 e 1768, concedeu um total de 362 sesmarias, o que corresponde à média anual de 90,5, num evidente esforço de povoamento (Melo E SouZA, 1999).

Nesse último ano, o governador organizou aquela que seria a derradeira campanha contra os quilombolas: a expedição de Ignácio Corrêa Pamplona. Este fazendeiro, estabelecido em Pitangui e nomeado regente dos sertões do Pium-i, Bambuí, Campo Grande e Picada de Goiás, partiu em 1769 em expedição contra os quilombos, tendo também a missão de obter terras a serem distribuídas em sesmarias e fundar povoados (Melo E SouzA, 1999). O sertanista exterminou quilombos no Pium-i, Bambuí e Campo Grande, onde se encontrava o maior deles, o do Ambrósio, pela terceira vez ressurgido. Em incursões posteriores, fundou alguns povoados, erigindo capelas, entre eles Bambuí, próximo ao sítio do quilombo extinto homônimo (VASCONCELOS, 1999).

A entrada de Pamplona conta com detalhada documentação, uma Notícia Diária e Individual escrita por um de seus membros (Melo e SouzA, 1999). Nela, encontram-se inclusive mapas, mostrando o sítio e o traçado dos núcleos quilombolas. Num deles, o do Ambrósio, podemos ver (figura 4) que se situava na confluência de dois córregos. Era cercado por um valo, e depois dele havia uma linha de paliçadas e estrepes, sugerindo um amuralhamento. No núcleo, as taperas estavam dispostas de forma desalinhada em torno de um paço central. O valo ainda hoje pode ser visto (figura 5).

A partir das campanhas contra os quilombos, iniciou-se uma verdadeira vaga migratória de geralistas em direção aos sertões do oeste, da década de 1750 em diante. Esses migrantes, alguns já detentores de posses, em geral modestas, e alguns escravos, mas majoritariamente formados por roceiros pobres e negros libertos, em breve, ocupariam, com seus sítios e fazendas, as terras liberadas dos quilombos do Oeste Mineiro, apagando a maior parte dos traços de sua existência anterior. 


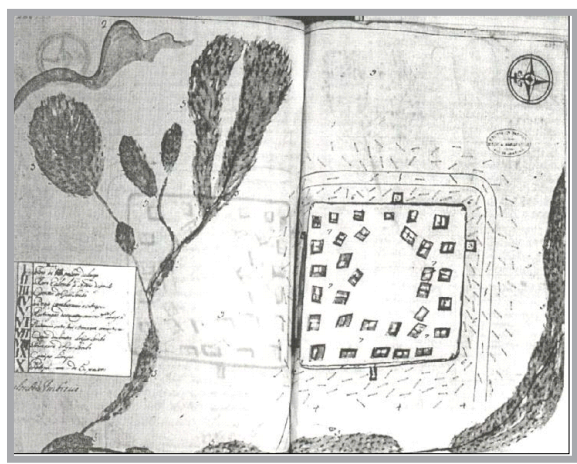

Figura 4: Quilombo do Ambrósio Fonte: Melo e Souza (1999)

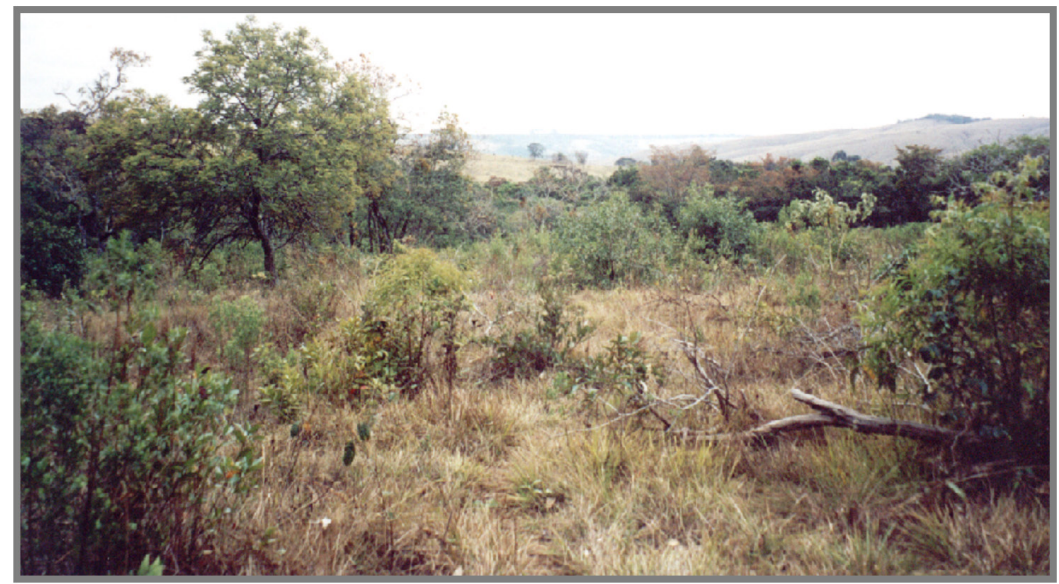

Figura 5: Sítio do Quilombo do Ambrósio (Ibiá, MG)

Fonte: foto de Lourenço, L. A. B. (2001)

\section{As picadas do Oeste e a colonização do Desemboque}

Os primeiros povoados surgidos no oeste mineiro foram ainda orientados pelas descobertas auríferas. Na mesma época em que se erradicavam os quilombos, surgiam os arraiais de Ourofino e São Pedro de Alcântara do Jacuí, na Mantiqueira, a sudoeste do atual estado de Minas, até 1755. Algum tempo depois, em 1760, formou-se o arraial de Nossa Senhora do Desterro do 
Desemboque, em torno das jazidas da cabeceira do rio das Velhas (BARBOsA, 1998). Mais ao norte, o surgimento dos povoados parece ter se dado em função da ocupação circunvizinha de pastagens para a pecuária, orientados pelas picadas Velha e Nova de Goiás (figura 6).

Existem diferenças geográficas entre o tipo de povoamento que se origina da mineração e o que surge da pecuária, apontadas por Prado Júnior (1986). As áreas mineradoras geralmente se desenvolvem sem contigüidade com outras já povoadas, pois fatores geológicos determinam a localização dos novos núcleos. As áreas de pecuária, ao contrário, vão-se espraiando por contigüidade a partir dos núcleos irradiadores, como uma atividade econômica complementar, mantendo continuidade geográfica com eles.

O caso do Oeste Mineiro, nas últimas décadas do século XVIII, é exemplar de ambos os casos. Como se pode acompanhar pela seqüência de datas na figura 6 , enquanto os arraiais ligados à pecuária lentamente se irradiavam das picadas Velha e Nova de Goiás, a extração do ouro já implantara, em paragens bem mais remotas a ocidente, dois arraiais que experimentavam intenso crescimento: Jacuí e Desemboque.

Há outra diferença, no padrão espacial de ocupação, que pudemos perceber no caso do Oeste Mineiro. A localização dos núcleos mineradores é que conformou o traçado das vias, e não o contrário. Parece lógico que, à medida que se faziam as descobertas auríferas, e que em torno delas se desenvolviam os arraiais do ouro, o intenso fluxo de mercadorias e pessoas fazia surgir os caminhos, ligando-os aos núcleos primazes ou de exportação.

No caso da ocupação pela pecuária, era o inverso que ocorria. Os caminhos funcionavam como vetores, a partir dos quais os fazendeiros iam-se instalando às margens, criando caminhos colaterais, fundando povoados. Não poderia ser diferente, pois os criadores dependiam, antes de tudo, do acesso a mercados para realizar seu excedente, na forma das boiadas comercializadas nos núcleos urbanos do leste.

Desse modo, a descoberta das jazidas do Desemboque por faiscadores vindos de Pitangui e Tamanduá, em 1760, levou ao surgimento de uma picada de Jacuí ao novo arraial, que já acusava intenso movimento em 1764 (BARBOSA, 1998). O formidável crescimento do Desemboque, entretanto, que em 1765 já contava com 195 casas, ou aproximadamente 1.300 habitantes, parece ter sido influenciado por outros fatores que não a mineração, como veremos adiante. 


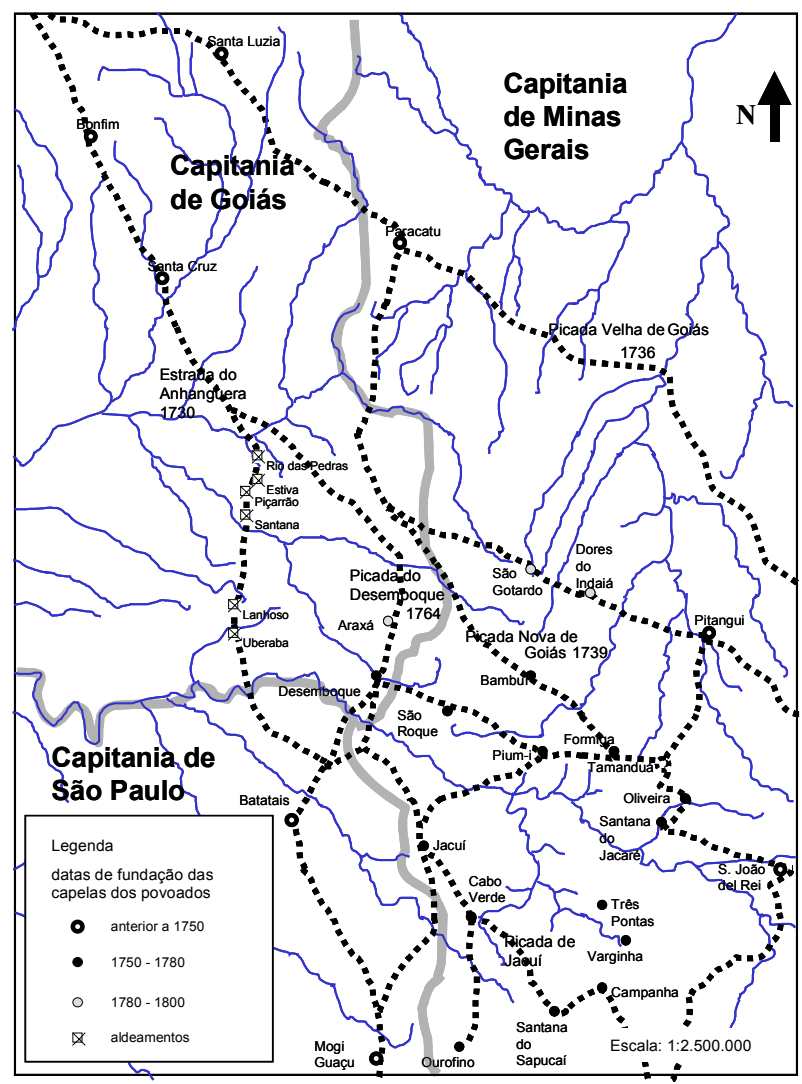

Figura 6: povoados surgidos no oeste mineiro entre 1750 e 1800, e principais picadas e caminhos. Fonte: Saint Hilaire (1975 b), Barbosa (1998) Bacelar e Brioschi (1999), Vasconcelos (1999), e Mapa da capitania de Minas Gerais (www.asminasgerais.com.br).

O padre Marcos Freire de Carvalho, do Desemboque, contrariando ordens régias, abriu uma picada partindo desse arraial até Santa Cruz, na capitania de Goiás. O bispo de Goiás reconheceu então a paróquia do Desemboque como sendo de sua jurisdição e provisionou o padre Félix José Soares, ligado a Marcos Freire, seu vigário em 1765. O fato de o novo povoado colocar-se sob autoridade goiana fez o bispo de Mariana indispor-se contra os padres do Desemboque. O 
vigário foi preso pelas autoridades eclesiais mineiras por duas ocasiões, mas o julgado do Desemboque, que passou a incluir todo o território das bacias dos rios Paranaíba, das Velhas e da margem direita do Grande, acabou se incorporando à capitania de Goiás (VAsConcelos, 1999). Devido ao litígio, ocorreram nos anos seguintes tensões — e até mesmo choques de fronteira — entre os governos das duas capitanias envolvidas (BARBOSA, 1998).

As peripécias do padre Marcos Freire e do seu vigário, padre Félix, notórios contrabandistas de ouro, foram expressivas da vontade de uma parte da população do arraial de fugir do controle do governo de Minas. A razão parece clara: quando em 1765 o governador Luís Diogo publicou uma derrama de treze arrobas, houve uma verdadeira corrida de mineiros rumo ao Desemboque para escapar dela, principalmente vindos do Tamanduá9 (VAsConcelos, 1999).

Assim, é muito provável que a rápida prosperidade do povoado tenha sido conseqüência de ele ter se transformado num centro de contrabando do ouro mineiro para fora dos limites da capitania, nas fugas do imposto do quinto e das derramas. Das 100 arrobas de ouro que, segundo Borges Sampaio (2001), saíram do Desemboque, é muito difícil saber o que realmente foi extraído ali.

A picada de Marcos Freire emendava-se à Picada do Desemboque, que seguia ao sul até Jacuí e de lá até Mogi-Guaçu, formando um desvio da Estrada do Anhanguera. Ao norte, a picada continuava pelo sítio do futuro arraial do Araxá, atravessava o rio Paranaíba e unia-se de novo à Estrada do Anhanguera em Catalão, Goiás (figura 6). Esse trajeto passou a ser usado por contrabandistas de mercadorias vindos de São Paulo. Por ele, fugiam da fiscalização do registro do rio das Velhas, na Estrada do Anhanguera, forjavam guias falsas no Desemboque e seguiam adiante (BARBOSA, 1998).

O contrabando assumiu proporções significativas, pois, em 1778, o governo de Minas interditou as passagens por sudoeste para a capitania de São Paulo, de forma a impedir que o ouro de Cabo Verde e Jacuí fosse contrabandeado, pelo desvio de Franca, para o Desemboque (BACELAR; BRIOSCHI, 1999). Em 1781, o governo de Minas instalou um posto de fronteira no alto rio das Velhas, para coibir o extravio de ouro e diamantes, mas a população e as autoridades do Desemboque destruíram-no, liderados pelo próprio comandante do regimento goiano (Pontes, 1978). Em 1789, foi a vez

$9 \quad$ Hoje Itapecerica. 
de São Paulo proibir a utilização da picada para o povoado (BARBOSA, 1998).

Desemboque contava com outros caminhos clandestinos. Havia um que o ligava a Franca, e outro que ia de Franca ao Aterrado, ${ }^{10}$ e dali ao arraial (BACELAR; BRIOSCHI, 1999). Estava ligado aos principais centros da comarca do Rio das Mortes, São João Del Rei e Tamanduá, não só pela picada de Jacuí, mas também pelo caminho mais curto do sertão do Pium-i, passando pelo arraial de mesmo nome, Formiga e Oliveira (figura 6). Situado além fronteira de Minas, mas ligado aos seus principais centros e a São Paulo e Goiás, confluência de caminhos vindos das três capitanias, o povoado beneficiou-se de uma posição privilegiada pela eqüidistância geográfica em relação a elas. Desse modo, acolhia as fugas das derramas mineiras, e ao mesmo tempo era rota de contrabando de mercadorias e ouro que trafegavam entre Goiás, Minas e São Paulo.

A hipótese de que a prosperidade do Desemboque deveu-se muito mais ao contrabando que à mineração já havia sido aventada pelo historiador uberabense Ronaldo Cunha Campos, que ainda lembrou outra evidência: o fim das derramas, no início do século XIX, coincidiu com o princípio da decadência do povoado (NABut, 1986). Nessa época, desenvolvia-se um outro núcleo vizinho, mas com uma dinâmica geográfica e econômica completamente distinta do Desemboque: a cinqüenta quilômetros ao norte, sobre a picada clandestina que levava a Santa Cruz, nascia o arraial de São Domingos do Araxá.

\section{A colonização geralista do Sertão dos Araxás}

Ao longo da Picada do Desemboque, usada pelos contrabandistas, sesmarias foram sendo concedidas desde a derrota dos quilombos do Campo Grande por Pamplona, em 1769 (BARBOSA, 1998). Esses primeiros moradores descobriram, nos chapadões situados entre as nascentes do rio Quebra-Anzol e do rio das Velhas, fontes de águas salitrosas, que passaram a usar como bebedouros para o gado.

A notícia de que, nas terras além do Campo Grande, em território goiano, havia fontes naturais de água salgada, provocou grande afluxo de colonos geralistas para a região, a partir de 1770 (VASCONCELOS, 1999). Criadores de gado, roceiros

$10 \quad$ Hoje Ibiraci. 
sem terra ou que haviam abandonado terras esgotadas, e até mesmo muitos devedores insolventes e foragidos da justiça, acorreram à região, há pouco tempo desobrigada dos quilombos (SAint Hilaire, 1975 b). Próxima ao bebedouro, foi erguida a capela de São Domingos do Araxá, ainda naquela década, transformada em paróquia em 1804 (EsCHWEGE, 1996). O arraial surgia como um núcleo que, graças aos bebedouros salitrosos, passou a polarizar a atividade de pecuária extensiva, que então avançava rapidamente pelo Oeste Mineiro.

As fazendas organizaram-se inicialmente, nas proximidades dos bebedouros. Eschwege (1996) relatou que andara quatro léguas e meia (aproximadamente $30 \mathrm{~km}$ ) do Quartel dos Ferreiros até São Pedro de Alcântara sem encontrar uma única fazenda. A partir desse arraial, as fazendas tornavamse cada vez mais comuns: três fazendas em sete léguas, até Araxá, e dali a Patrocínio, quatro fazendas em quatro léguas e meia.

Os fazendeiros araxaenses organizaram um sistema de utilização do bebedouro do Barreiro, transformado em bem público. O gado era trazido das fazendas situadas num raio de 8 a 12 léguas, uma vez por mês (figura 7). Ao chegar, a boiada era confinada nas imediações das fontes salitrosas, cercadas por um muro de pedra onde cabiam 1.500 cabeças, durante a metade do dia (Eschwege, 1996). Em 1816, havia 60 fazendeiros que se utilizavam do Barreiro, às vezes, tendo de conduzir as boiadas por vários dias desde o seu local de origem (SAINT HiLAiRe, 1975 b).

Outros bebedouros foram sendo descobertos nas proximidades. Nos pés da Serra do Salitre, os bebedouros do Salitre, Serra Negra e Marrecas deram origem, da mesma forma que em Araxá, a um arraial: Patrocínio. Na vizinhança, ao longo da Picada de Goiás, surgiram arraiais como São Pedro de Alcântara e Pouso Alegre do Carabadela, cujos criadores de gado se utilizavam dos bebedouros de Araxá e Patrocínio (SAint Hilaire, 1975 b; Eschwege, 1996).

Dessa forma, houve uma grande expansão da pecuária de corte sobre os chapadões do Alto Paranaíba e Alto Rio das Velhas, entre 1800 e 1820, orientada de um lado pela presença das fontes de água salgada e, de outro, pelas picadas, a de Goiás e a do Desemboque, que tornavam possível o acesso ao mercado do Rio de Janeiro. O aumento do fluxo de mercadorias por esses caminhos transformou os núcleos situados a jusante deles em verdadeiras bocas de sertão: Formiga e Oliveira tornaram-se importantes centros de pouso de tropeiros e boiadas, passagem obrigatória do oeste para o leste. 


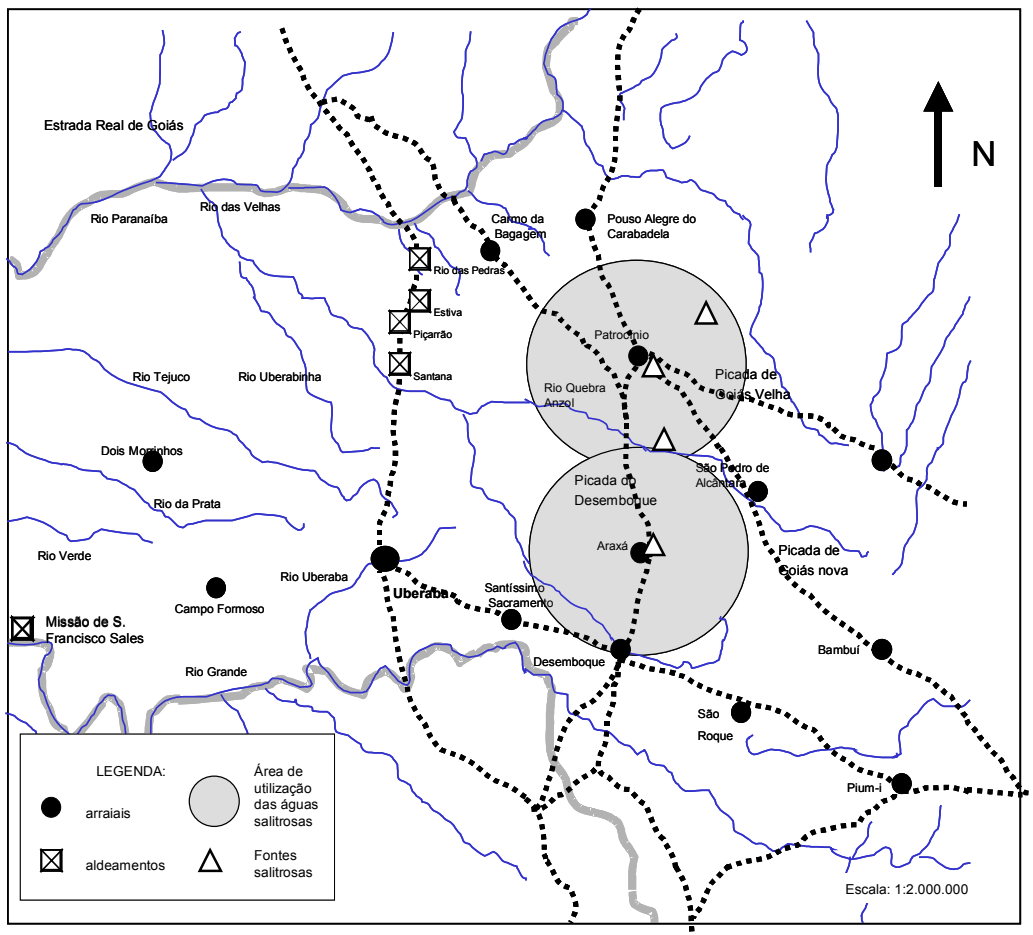

Figura 7: área de utilização dos bebedouros de Araxá e Patrocínio (1800-1820) Fonte: Saint Hilaire (1975 b), Eschwege (1996).

Os fazendeiros locais criavam os bezerros, vendidos com um ano de idade para fazendas de recria e engorda vizinhas. Quando atingiam a idade de quatro anos, eram então revendidos por estas aos compradores de São João Del Rei, que, periodicamente, percorriam a região (EsChwEGE, 1996). Esses fazendeiros araxaenses especializados na invernada tornaram-se, com o tempo, importantes compradores de gado em Goiás, principalmente das fazendas do Sul Goiano (termos de Santa Cruz e Bonfim ${ }^{11}$ ), de onde os rebanhos eram trazidos a Araxá, mantidos até a idade de abate nas fazendas próximas aos bebedouros, e então vendidos aos compradores sanjoanenses. Saint Hilaire encontrou, num pouso, pouco antes de chegar a Bonfim, mercadores araxaenses:

11 Hoje Silvânia. 
Eles percorriam as fazendas levando cobertores, chumbo para caça e outros artigos, que trocavam por bois. $\mathrm{O}$ gado assim adquirido era posto a engordar nas excelentes pastagens de sua terra e depois vendido aos mercadores da comarca de São João Del Rei, os quais [...] vão todos os anos comprar bois no distrito de Araxá (1975 a, p. 102).

Outros gêneros de menor valor, sobretudo o algodão, também tinham alguma saída para os mercados do leste, só que o ônus do transporte era dos próprios fazendeiros locais, que levavam a mercadoria em carros de boi até Barbacena. Alguns produtos agrícolas também eram comercializados em Paracatu (SAINT Hilaire, 1975 b).

Brandão (1989) refere-se à hipótese, que já havia sido levantada por Caixeta Silva (APU, 1987), de que os interesses mercantis dos criadores araxaenses foram o fator que os levou a reivindicar a separação dos julgados ${ }^{12}$ de Araxá e Desemboque e sua anexação a Minas. Parece, sem dúvida, que a condição de pecuaristas e principais intermediários na compra e revenda do gado goiano — mas contando como principal mercado São João Del Rei, em Minas — colocava-os em desvantagem. No trânsito de uma capitania a outra, incidiam dois impostos: as taxas pagas nos registros e as entradas (FURTADO, 1999). Dessa forma, as boiadas araxaenses deveriam ser vendidas a preços muito baixos aos intermediários sanjoanenses, se quisessem concorrer no mercado carioca. Pouco antes de o julgado de Araxá ser incorporado a Minas, cada rês era negociada a 7\$000 no Rio de Janeiro, e o invernista araxaense recebia apenas $4 \$ 800$ pela venda (ESCHWEGE, 1996).

Mas outros fatores também pesaram de forma decisiva. $\mathrm{Na}$ Carta Régia assinada por D. João VI, a justificativa para a transferência era a imensa distância entre Araxá e Vila Boa, o que dificultava o acesso à comarca goiana e o desembaraço de processos nos quais era necessária a ouvidoria (BARBOSA, 1998).

Graças à petição feita pelos fazendeiros araxaenses e patrocinenses, o grande território formado pelos termos dos julgados do Desemboque e de São Domingos do Araxá, que hoje corresponde ao Triângulo Mineiro, foi anexado a Minas por Carta Régia em 1816 (Eschwege, 1996). O Barão de Eschwege,

12 Um julgado era uma unidade territorial abrangida pela jurisdição de um juiz, lotado numa localidade que era a sede do julgado. O juiz poderia ser ordinário (isto é, eleito pelos moradores de posses) ou de fora (nomeado pela Ouvidoria, geralmente um jurista de carreira). Para maiores informações sobre o sistema judiciário colonial, ver Holanda (1985). 
nomeado pelo governador da capitania de Minas para determinar os limites dos novos domínios, registrou em seu diário a satisfação dos pecuaristas de Araxá e Patrocínio pela decisão régia. Na fazenda do Bom Jardim, em Patrocínio, o cronista soube que os fazendeiros haviam inclusive mobilizado representantes para que intercedessem em seu favor na Corte:

[...] pertence a um homem abastado, que estava sobremaneira empenhado em se livrar do domínio da província de Goiás e, por isso, entregou ao meu companheiro, Antônio da Costa [pecuarista araxaense], uma grande contribuição, para pagamento no Rio de Janeiro que, de acordo com o costume local, não representava apenas uma avaliação de suas despesas [do pecuarista Antônio Costa], mas também do prejuízo, com mora e juros sobre o capital que perdera [na sua estada no Rio] (EsCHWEGE, 1996, p. 114-115).

Um motivo provável para a decisão régia, favorável aos interesses araxaenses, talvez tenha sido a maior capacidade de Minas de promover a colonização do Extremo Oeste mineiro, se comparada com Goiás. Em Minas, havia um grande excedente demográfico na região central que já há mais de sessenta anos iniciara um movimento migratório para áreas de fronteira. Realmente, após a anexação dos novos territórios a Minas, foram concedidas dez sesmarias no julgado do Araxá, das quais sete apenas em 1817, no ano seguinte ao da anexação (APM, 1988). O total de sesmeiros não permite uma estimativa do total de novos fazendeiros, pois era muito comum que criadores se estabelecessem nas terras de outros como foreiros ou agregados. Segundo informação de Barbosa (1998), 50 novas famílias fixaram-se em Araxá só em 1819.

No termo da freguesia de Araxá, nesse período, foram surgindo novos arraiais, fundados pelos fazendeiros que iam se instalando na região: Carmo do Monte Carmelo ${ }^{13}$ (1816) e Santana do Pouso Alegre da Carabadela (1819). A intensidade do povoamento, nos anos seguintes à anexação, mostra que Araxá tornara-se o núcleo a partir do qual se organizava o processo de colonização do "sertão inculto" entre o rio das Velhas e o Paranaíba. Simultaneamente, mais ao sul, outro núcleo — Uberaba — exercia papel semelhante em relação

13 Hoje Monte Carmelo. 
ao sertão situado entre o rio das Velhas e o rio Grande, chamado de Sertão da Farinha Podre.

\section{A colonização geralista do Sertão da Farinha Podre}

No Desemboque, como seria de se esperar, a decisão da Coroa de anexar o julgado à capitania de Minas Gerais representou mais um revés para sua economia que, em grande parte, fundamentava-se no contrabando. O arraial perderia sua posição privilegiada de principal entreposto da tríplice fronteira, onde o tráfico clandestino de gêneros ocorria não só a partir de Minas como também de São Paulo. De 1816 em diante, entrou numa decadência irreversível.

Grande parte da população do Desemboque, a partir de então, passou a emigrar para outras regiões. A migração centrífuga transformou o arraial em cabeça de ponte para a colonização das terras mais a oeste (figura 8), antes mesmo da anexação da Farinha Podre a Minas. Dali se organizaram as entradas de colonos que, após conhecer as novas paragens, obtinham as sesmarias do governo goiano. As entradas não só levavam os colonos a conhecer as potencialidades de ocupação das áreas incultas, como, muitas vezes, eles já estabeleciam as bases da futura ocupação, ao formarem roças e ao delimitarem os terrenos para a ereção de futuras capelas.

Em 1807, uma incursão formada por seis sertanistas e seus dependentes avançou a oeste do Desemboque, retornando com boas notícias sobre a presença de terras de cultura (SILva, 1970). No mesmo ano, José Francisco de Azevedo, natural de Bambuí e estabelecido no Desemboque, tomou posse de uma sesmaria nas cabeceiras do Ribeirão Lajeado e iniciou a fundação de um arraial, com capela dedicada a Santo Antônio e São Sebastião, que passou a ser conhecido como Arraial da Capelinha ${ }^{14}$ (PONTES, 1978). Nos anos seguintes, nos arredores de Capelinha, muitos geralistas criadores de gado foram-se estabelecendo, por causa das fontes minerais salitrosas (EschwEGE, 1996). O paulista João Batista de Siqueira e o padre Cláudio José da Cunha, em 1808, penetraram até as vertentes do rio Verde, afluente do Grande, onde se apossaram de várias sesmarias (Pontes, 1978; BARBosA, 1995). Numa segunda incursão, em 1811, Siqueira chegou às férteis terras, então cobertas por matas densas, situadas entre os rios São Francisco e Piracanjuba, cerca de $170 \mathrm{~km}$ a oeste do Desemboque.

\footnotetext{
14 Hoje extinto.
} 


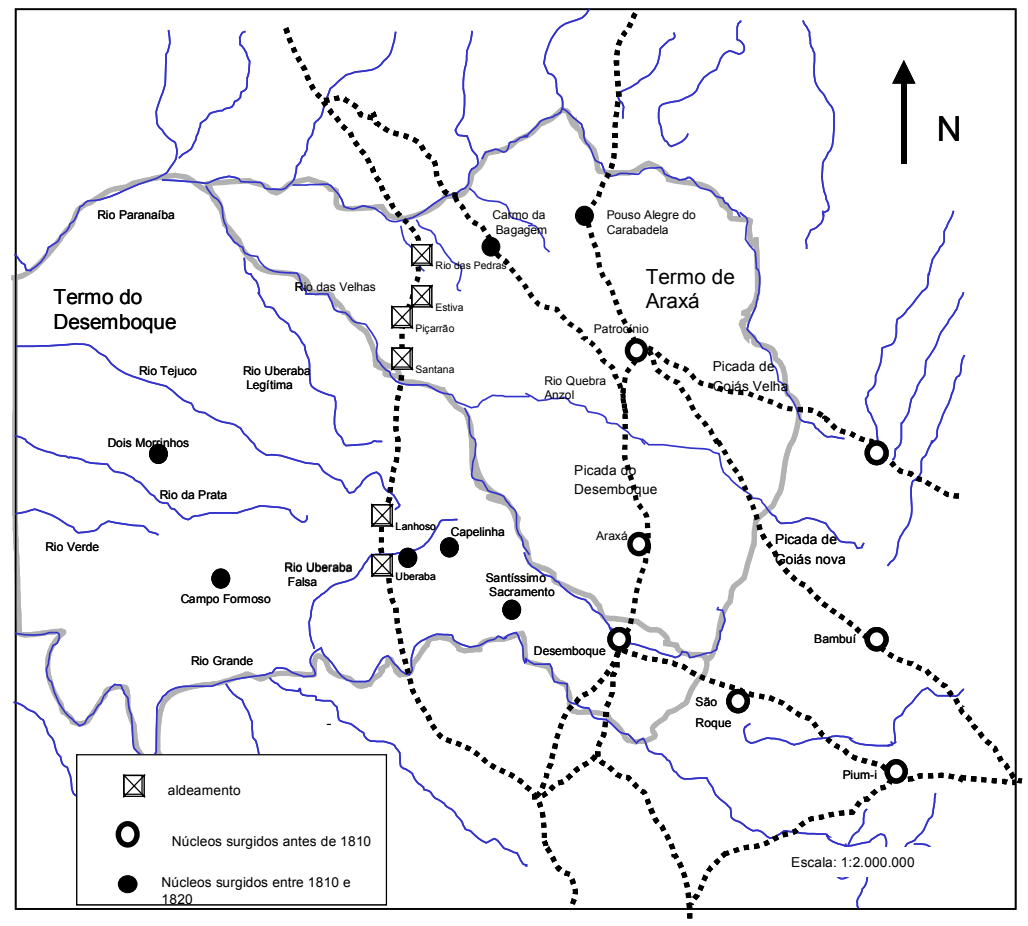

Figura 8: Sertão da Farinha Podre: núcleos surgidos até 1820 e limites dos julgados de Araxá e Desemboque.

Fonte: Barbosa (1995), Nabut (1986).

Ali demarcaram o patrimônio onde, no ano seguinte, surgiria o arraial de Nossa Senhora das Dores do Campo Formoso ${ }^{15}$ (Ferreira, 1958).

Dois anos depois, o sargento-mor Antônio Eustáquio da Silva Oliveira, natural de Casa Branca ${ }^{16}$ (arraial próximo a Vila Rica) e morador do Desemboque, organizou uma entrada com 30 sertanistas, que ultrapassou a faixa de terras dos índios em torno da Estrada do Anhanguera, e avançou até o rio Paranaíba. Na metade do percurso, próximo ao rio da Prata, escolheu o sítio para o patrimônio do futuro arraial de Nossa Senhora do Carmo dos Dois Morrinhos ${ }^{17}$ (Barbosa, 1995; Pontes, 1978).

\footnotetext{
15 Hoje Campo Florido.

16 Hoje Glaura.

17 Hoje Prata.
} 
A ocupação da fronteira pelos geralistas se fazia estruturada em parentelas. Os laços de parentesco eram importantes em todas as fases do processo, desde a organização das expedições sertanistas até o assentamento das fazendas e arraiais. Normalmente, após um pioneiro tomar posse das novas terras, voltava ao núcleo de origem para trazer sua família - esposa, filhos, dependentes e escravos, se os tivesse - para iniciar a estruturação do sítio ou fazenda. Após algum tempo, uma vez constituída a unidade produtiva, o pioneiro poderia retornar várias vezes à região de origem para buscar parentes (consangǘneos ou rituais), para que se estabelecessem nas vizinhanças. No caso em estudo, existem alguns exemplos, relativamente bem documentados, de como se estruturava uma rede de parentesco, num processo de migração e povoamento.

Em 1788, José Manoel Oliveira e Silva, geralista vindo de Vila Rica, recebeu do governo goiano a patente de Coronel Comandante do regimento de cavalaria do Desemboque e foi nomeado juiz do julgado (TeixeIra, 2001). Anos mais tarde, trouxe o irmão Joaquim, que se estabeleceu em sesmaria nos sertões recentemente desbravados a oeste (APM, 1988). Em 1807, veio de Vila Rica o terceiro irmão, Antônio Eustáquio, que, por sua influência, foi nomeado Regente dos Sertões da Farinha Podre e diretor dos índios aldeados na faixa de terras em torno da Estrada dos Goiases. Algum tempo depois, chegaria o primo, padre Hermógenes Casimiro de Araújo, que seria nomeado vigário da paróquia do Desemboque (TEIXEIRA, 2001). Essa parentela foi a fundadora de alguns dos primeiros arraiais a oeste do Desemboque, como o Santíssimo Sacramento $^{18}$ e São João Batista, ${ }^{19}$ pelo padre Hermógenes, e Dois Morrinhos ${ }^{20}$ e Farinha Podre, ${ }^{21}$ pelo sargento-mor Antônio Eustáquio (BARBOSA, 1995).

Antônio Eustáquio, o segundo irmão, organizou, em 1810, uma incursão à região que se estendia à oeste do Desemboque. Contou com 30 homens nessa expedição, quando avançou 30 léguas $(198 \mathrm{~km})$ até o rio da Prata. Ali foram "lançadas algumas posses ou sinais pelo sertão na decorrência de dois meses e feitas algumas pequenas roças" (SILVA, 1970, p. 8) Retornou ao Desemboque para "cuidar de meios para transportar-se" (p. 8), isto é, instalar-se nas novas posses, o que também fizeram os outros sertanistas que o acompanharam. Em

\footnotetext{
18 Hoje Sacramento.

19 Hoje Serra da Canastra.

20 Hoje Prata.

21 Hoje Uberaba.
} 
1812, construiu sua chácara em terras indígenas, à beira do córrego da Lage, na vizinhança da Aldeia de Uberaba, um dos aldeamentos bororos criados no século XVIII e que agora estavam sob sua direção (PONTES, 1978).

Antônio Eustáquio fez outra incursão pelos sertões do oeste em 1812, desta vez, acompanhado de seu primo, o padre Hermógenes (Silva, 1970), e de volta dela, retornou a Vila Rica, para convidar parentes a se instalarem nas novas terras (TeIXeIra, 2001). Hermógenes e os irmãos de Antônio Eustáquio, Joaquim e Domingos, afazendaram-se em sesmarias a eles concedidas nas proximidades. Só Joaquim, por exemplo, formou três fazendas: Ponte Alta, Bebedouro e Santo Inácio (Pontes, 1978).

As terras férteis em torno do arraial continuaram atraindo familias de povoadores. Os Alves Gondim, vindos de Tamanduá e Formiga; os Prata, de Tamanduá, que se apossaram das fazendas Buriti, Correias, Água Comprida, Quatis, Nunes e Alagoas, adquiridas do pioneiro João Batista de Siqueira; e entre os rios Uberaba Falsa e Tejuco, instalaram-se as parentelas dos Rodrigues da Cunha, Marquês e Pereira dos Santos (Pontes, 1978). Em 1821, João Pereira da Rocha, vindo de Paraopeba, apossou-se de uma sesmaria a ele concedida entre o rio das Velhas e o rio Uberaba Legítimo. Acompanhado de alguns camaradas, montou benfeitorias e plantou roças, voltando, em seguida, a Paraopeba para buscar a familia, escravos e protegidos. Seus treze filhos legítimos e mais dois naturais se estabeleceram em suas terras e, além disso, cedeu posses em seus domínios a outros dependentes. Algum tempo depois, José Alves de Resende, conhecido de João Pereira da Rocha e vindo também de Paraopeba, afazendou-se em terras vizinhas (Pezzuti, 1922). Pereira da Rocha vendeu parte de suas terras aos irmãos Carrejo, de quem logo se aparentou casando-se com uma prima deles.

Esses fazendeiros, muitas vezes, já traziam alguma escravaria, recebida de herança, mas a regra era que geralmente não tinham muitas posses. Por isso, desde o início, dada a dificuldade inicial de se comprar escravos, esses homens se preocupavam em ocupar suas fazendas com posseiros pobres (agregados), transformados, assim, num campesinato dependente. Grande número de pequenos e médios proprietários de terras também se estabeleceram na região, como veremos no capítulo 5 . As impressões deixadas pelos viajantes reforçam o comentário feito pelo historiador uberabense Hildebrando Pontes de que a primeira corrente migratória para os sertões da Farinha Podre "era representada por famílias pouco abastadas" (1978, p. 89). 
Ainda em 1812, um vizinho de Antônio Eustáquio, posseiro de terras indígenas, doou parte delas a outro patrimônio dedicado a Santo Antônio e São Sebastião, e iniciou nos anos seguintes a ereção da capela, nas vizinhanças da casa de Antônio Eustáquio. Esta foi autorizada por alvará de 1818, sob faculdade do padre Hermógenes, que a abençoou no mesmo ano (SAMPAIo, 2001). Surgiu então, dentro das terras aldeanas, o arraial da Farinha Podre, que, em 1820, adotaria o nome de Uberaba (Pontes, 1978).

De modo repentino, o arraial da Capelinha, o primeiro a ser fundado a oeste do Desemboque, entrou em rápida decadência e desapareceu, entre 1816 e 1817. Eschwege (1996) passou por Capelinha em 1816 e anotou que haviam sido construídas 26 casas, o que permite deduzir uma população aproximada no arraial de 156 habitantes. No ano seguinte, seus moradores se mudaram todos para a Farinha Podre, situada a uma légua mais ao sul, por razões que permanecem controversas. D'Alincourt esteve, em 1817, na Farinha Podre, e encontrou um povoado recém-construído: "a Farinha Podre é lugar de 500 pessoas de confissão [...] o principal negócio desta gente consiste de gado, e capados; e planta legumes, milho e algodão" (1975, p. 75). Borges Sampaio (2001), que viveu em Uberaba na segunda metade do século XIX e conheceu alguns dos antigos moradores da Capelinha, cita a abundância de água e as terras mais férteis como as razões da opção dos moradores e fazendeiros pela Farinha Podre. Hildebrando Pontes aponta como principal razão da transferência o "prestígio do sargento-mor Antônio Eustáquio" (1978, p. 80), que vivia nas proximidades. Edelweiss Teixeira (2001) cita o depoimento de uma neta de um morador da Capelinha, no qual relata que o povoado foi abandonado depois de um ataque dos índios caiapós, onde morreu o padre capelão. A mudança se teria dado então pela segurança oferecida pelos índios bororos da Aldeia de Uberaba, dirigidos por Antônio Eustáquio.

É muito provável que todos esses fatores tenham contribuído para que o arraial mudasse de lugar, pois a superioridade do sítio de Farinha Podre era realmente indiscutível. Situava-se ao longo da Estrada do Anhanguera, ao mesmo tempo tendo acesso a São João Del Rei e à Corte, por um caminho de 30 léguas $(198 \mathrm{~km})$, que o ligava ao Desemboque e dali a Pium-i (SAINT Hilaire, 1975 a). Além disso, contava com a presença dos quase 100 índios, que viviam nos aldeamentos de Lanhoso, Uberaba e Baixa, que, com grande probabilidade, deviam ser explorados como escravos e usados no sertanismo. 
Como no caso do Desemboque, o arraial se beneficiaria da eqüidistância de três regiões econômicas, só que agora não no contexto da economia do ouro, mas num outro, no qual o que interessava eram os fluxos e a produção de gêneros alimentícios, para um mercado interno colonial que se tornava cada vez mais importante.

O que se pode perceber é que, nos vinte primeiros anos do século XIX, ocorreu uma transferência da condição de principal núcleo do Sertão da Farinha Podre do Desemboque para Uberaba. Embora a migração a partir do Desemboque tenha seguido também a direção do julgado de Araxá, parece claro que houve interesse da elite desemboquense em criar novos núcleos e transferir-se para uma área mais promissora. $\mathrm{O}$ fundador de Uberaba e líder do processo de colonização dos sertões ocidentais fora o próprio irmão do juiz do Desemboque, e o vigário do antigo arraial fora quem conseguira o alvará de criação da freguesia de Uberaba, em 1818. Essa freguesia acabou herdando quase todo o termo do antigo julgado do Desemboque, isto é, toda a faixa de terras limitada pelos rios das Velhas, baixo Paranaíba e Grande.

Talvez o fator que, de modo mais determinante, influiu na escolha do sítio do arraial da Farinha Podre tenha sido mesmo a fertilidade dos solos da porção sudeste do Triângulo Mineiro. Trata-se de uma área onde afloramentos basálticos originaram latossolos roxos, de grande fertilidade, primitivamente cobertos por mata decídua e cerradão (ReAtTo; Correia; Spera, 1998). Ao passar por Farinha Podre, em 1819, Saint Hilaire assinalou:

As pastagens nas cercanias de Farinha Podre são tão boas que, apesar da prolongada seca que ainda se fazia sentir quando passei por lá, os campos queimados estavam cobertos por um espesso tapete verde e viçoso. Os colonos dessa região souberam tirar proveito dessa enorme vantagem. [...] tudo leva a crer que a fertilidade das terras de Farinha Podre the assegure no futuro uma grande prosperidade (1975 a, p. 151).

Eschwege também comentou da fertilidade dos solos na área do aldeamento da Baixa, ${ }^{22}$ relatando inclusive que, por causa disso, em quatro anos (isto é, de 1812 a 1816), estabeleceram-se 80 fazendas na região do sul do Sertão da

22 Hoje Baixa, distrito do município de Uberaba. 
Farinha Podre. A área de colonização, à época da passagem do engenheiro alemão, "a despeito dos assaltos, ainda a recear, dos caiapós bravios" (1996, p. 125), já avançara 20 léguas a oeste do mais meridional aldeamento de defesa da Estrada dos Goiases, tendo por limite mais extremo as margens do rio São Francisco. ${ }^{23}$ As suas informações permitem deduzir que, nessa época, a colonização já estava avançando pela região polarizada pelo arraial de Dores do Campo Formoso.

A riqueza dos solos do sul do Triângulo Mineiro (chamado então de Sertão do Novo Sul da Farinha Podre) foi também celebrizada por uma carta escrita pelo padre Leandro Rabelo Peixoto e Castro, que lá esteve em 1827, com o objetivo de fundar o colégio e seminário de Campo Belo, ${ }^{24}$ endereçada a José Teixeira de Vasconcelos, presidente da província de Minas Gerais:

Não posso deixar de dizer que na minha viagem ao sertão do Novo Sul da Farinha Podre vi talvez o mais fértil terreno da América; um campo com mais de 90 léguas povoado por geralistas e das melhores famílias, que não compreende gente ociosa ou de pouco porte, pois quase todos são fazendeiros; a produção ordinária de mais de 250 por um chega a 300 ou mais; um país o mais saudável, o mais abundante de águas, o mais próprio para criações por causa dos singulares capins sempre verdes e pelos bebedouros salitrosos [...] Em uma palavra a abundância de todos os frutos que ali produz me faz crer o que acima disse (PONTES, 1978, p. 90).

Há correlação entre a ocorrência de latossolo roxo, não só com os sítios dos primitivos arraiais que surgiram na área em questão até 1820 (Uberaba, Carmo dos Dois Morrinhos, Capelinha, Santíssimo Sacramento ${ }^{25}$ e Dores do Campo Formoso), mas também com a localização das fazendas da época. Usando inventários post mortem feitos entre 1822 e 1831 pelo Juizado de Órfãos de Uberaba, ${ }^{26}$ cujas descrições e toponímia das fazendas inventariadas foram cotejadas com cartas topográficas e uma carta de solos (SiQueIRA; Rosa, 1998), produzimos o mapa da figura 9, que mostra como as fazendas se concentravam em torno dos arraiais recém-criados, em áreas de latossolo roxo.

\footnotetext{
23. Afluente da margem direita do Rio Grande.

24 Hoje Campina Verde.

25 Hoje Sacramento.

26 Arquivo Público de Uberaba, inventários post mortem (1822 a 1831).
} 
O único arraial que, até 1830, aparecia fora dessa área de concentração, estando localizado um pouco mais ao norte, era o de Carmo dos Dois Morrinhos, paradoxalmente o primeiro a ter seu patrimônio demarcado, já na primeira incursão sertanista de Antônio Eustáquio, em 1810. Mas, apesar de o sargento-mor, desde 1811, já ter provisão da Mesa de Consciência e Ordem para a ereção da capela, não se interessou por fazê-lo até 1826, segundo o Vigário Silva, "porque a povoação do lugar, onde querem erigir a referida capela, ainda hoje é mui pouco considerável” (1970, p. 8).

Essa observação mostra que, só depois de relativamente povoada por sitiantes e fazendeiros, é que estes tomavam a iniciativa de fundar um arraial. Eles se tornavam necessários como núcleos de referência social, religiosa-cultural e mercantil da população rural. $\mathrm{O}$ arraial, que surgia com a ereção de uma capela, marcava a territorialização de um bairro rural, como veremos no capítulo 6.

Deste modo, à exceção de Dois Morrinhos, as fazendas e os arraiais concentravam-se, dos primeiros anos da colonização geralista até 1830, a sudeste do termo do julgado do Desemboque, grosso modo em um quadrilátero limitado pelos paralelos $19^{\circ} 27^{\prime}$ e $20^{\circ} \mathrm{S}$ e os meridianos $48^{\circ} 52^{\prime}$ e $47^{\circ} 7^{\prime} \mathrm{O}$, em área de matas e cerradões e de ocorrência de latossolos roxos eutróficos.

Percebe-se, contudo, que, apesar de as fazendas se concentrarem nessa área, estavam praticamente ausentes no vale do rio Grande. Realmente, dos 167 inventários do Juizado de Órfãos de Uberaba produzidos entre 1822 e 1861, por nós revisados, apenas um deles cita o rio Grande como divisa de fazenda. ${ }^{27}$ A explicação dessa ausência é, possivelmente, epidemiológica. A endemicidade da malária, ${ }^{28}$ nas matas daquele vale, foi aludida por Saint Hilaire (1975 a) e Eschwege (1996) como a razão da transferência do Registro da Fazenda Real das margens do rio Grande, divisa entre as capitanias de Minas e São Paulo, para o rio das Velhas. D’Alincourt (1975) descreveu a área de inundação do rio como "sazonática" ${ }^{29}$ e, seguindo no sentido sul-norte após cruzá-lo, só foi encontrar o primeiro morador nas proximidades do Registro da Posse, próximo ao Quartel das Toldas, destacamento militar a pouca distância do arraial da Farinha Podre. Saint

27 Arquivo Público de Uberaba, inventário de Antônio Leal Alemão, 04/09/1832, maço N6.

28 Doença trazida da África pelo tráfico negreiro e que rapidadamente se alastrou pelas regiões tropicais e subtropicais da América.

29 Causadora das sazões ou malária. 


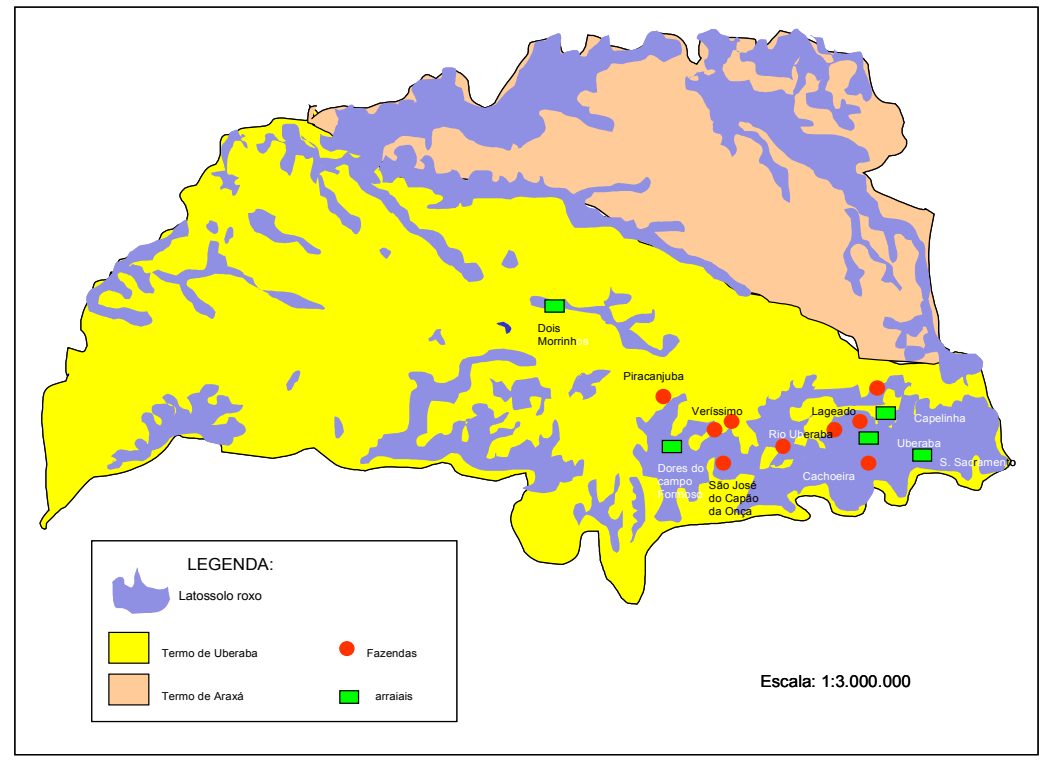

Figura 9: Termo de Uberaba (1822-1831): solos e localização das fazendas inventariadas no Juizado de Órfãos da Vila de Uberaba.

Fonte: APU, inventários post mortem (1822 a 1831), Siqueira e Rosa (1998).

Hilaire, depois de passar pelo Quartel das Toldas em direção ao rio Grande, seguindo no sentido contrário ao de D'Alincourt, dois anos depois dele, não encontrou sitiantes, a não ser um casebre onde morava uma família que recebia o pedágio da travessia. Desconhecendo, obviamente, que o mosquito anofelino era o vetor da doença, escreveu:

Já me referi à insalubridade do Rio Grande. As terras pantanosas que o margeiam ficam inteiramente recobertas pelas águas na estação das chuvas. Depois o terreno vai secando paulatinamente. E nos meses de abril, maio e junho começa a exalar vapores pestilenciais que causam febres malignas e febres intermitentes. O homem que recebia o pedágio em nome da família Anhanguera e morava num casebre na margem esquerda do rio disse-me que se estabelecera ali havia quinze anos e ficara doente dez vezes. Naquele ano, particularmente, todas as pessoas da casa tinham adoecido (1975 a, p. 154). 
Com o desmatamento das margens do rio, ao longo do século XIX, e a extinção da fauna que funcionava como reservatório natural do Plasmodium sp., a endemia foi sendo aos poucos erradicada, permitindo o povoamento mais efetivo do vale. No tempo de Borges Sampaio (2001), no final daquele século, ocorriam ainda casos esporádicos de malária.

O crescimento da população nas terras recém-conquistadas foi muito rápido para os padrões da época. Eschwege (1996), em 1816, estimou a população do julgado do Desemboque (que incluía então todo o Sertão da Farinha Podre) em 3.945 habitantes. A totalização do recenseamento de Silva Pinto, de 1821, somava, no termo do julgado, 7.655 habitantes (Cunha Matos, 1981), número que se aproxima do que calculamos com base no Mappa Estatístico da Secretaria de Estado dos Negócios da Justiça, de 1825, que somava 856 fogos nos arraiais e 290 fogos rurais, permitindo estimar algo em torno de 6.876 habitantes (RAPM, 1897). De qualquer forma, apesar da inexatidão das estatísticas oitocentistas, particularmente em regiões de fronteira, esses números mostram um crescimento demográfico não menor que $60 \%$ em nove anos.

Contudo, ainda não analisamos de perto essa intensa migração de geralistas, ocorrida na primeira metade do século XIX, e que foi o grande motor da transformação de uma região indígena numa região de unidades rurais agropastoris, integrada ao mercado interno da Colônia e do Império. Resta considerar dois aspectos: os fatores de repulsão e atração migracional dos roceiros e criadores geralistas; e o confronto entre estes e os outros grupos humanos que já se encontravam na região. Estes consistiam dos últimos remanescentes dos índios caiapós, na confluência dos rios Paranaíba e Grande, e dos índios bororos, parecis e chacriabás, aldeados pelo governo goiano ao longo da Estrada do Anhanguera.

\section{Fatores demográficos de repulsão e atração migracional}

Em 1816, o Barão de Eschwege fez uma viagem aos julgados do Araxá e do Desemboque, designado pelo governo mineiro para iniciar a demarcação, e fazer uma estimativa demográfica e econômica das potencialidades daqueles territórios, então incorporados à capitania de Minas Gerais. A caminho daquela região, entre os arraiais de Formiga e Bambuí, encontrou uma grande 
caravana de emigrantes "que se dirigiam para as regiões incultas do Araxá e Desemboque" (1996, p. 86).

O engenheiro alemão fez uma viva descrição desses migrantes, flagrados em pleno trânsito para o vale do rio Paranaíba, onde iriam se estabelecer:

Em dois carros de bois, transportavam algumas caixas e panelas e muitas crianças, pretas, brancas e mulatas. Dez mulas transportavam os mantimentos e outros objetos. Escravos de ambos os sexos tocavam diversos animais, inclusive vacas e cabras. Os membros do grupo, a cavalo, acompanhavam a tropa, seguidos dos cães de caça e perdigueiros (1996, p. 87).

O cronista perguntou ao chefe da família as razões do abandono da terra natal, Congonhas do Campo, na região aurífera. Este lhe respondeu que havia abandonado suas propriedades "sem mesmo tentar vendê-las" (p. 87), pois as terras estavam cansadas, tendo perdido metade de sua fertilidade em um ano de cultivo.

Essa preciosa cena, legada por Eschwege, ajuda a esclarecer alguns elementos do movimento migratório geralista que povoou o Triângulo Mineiro, nas primeiras décadas do século XIX. Por ela, sabemos que parte desses migrantes chegou à região já com algumas posses, na forma de escravos e rebanhos, as principais formas de riqueza de então. Sabemos também que se tratava de uma migração familiar, isto é, núcleos familiares deslocavam-se por inteiro para as regiões de fronteira, com o objetivo de reproduzir unidades agropastoris sustentadas pelo trabalho de todos os seus membros, muitas vezes, complementado pelo trabalho escravo.

O caráter familiar diferenciava-a de outras migrações, tipicamente masculinas, como a imigração portuguesa para os núcleos mercantis mineiros, na época em estudo. Esse fluxo foi estudado por Júnia Ferreira Furtado (1999), usando inventários post mortem de Vila Rica e do Serro do Frio, na segunda metade do século XVIII. A autora assim caracterizou o perfil do comerciante que se estabelecia naqueles núcleos:

Em geral, provinham do Norte português, especialmente Minho e Douro. Eram, em sua maioria, solteiros, sem grandes vínculos familiares e deixavam numerosa prole bastarda, geralmente com negras, muitas delas alforriadas em testamento (1999, p. 275). 
As migrações coloniais para as regiões de fronteira agrária tinham um perfil muito distinto. Castro Faria (1998), estudando a região de Campos dos Goitacases dos séculos XVIII e XIX, concluiu que a mobilidade espacial era muito grande, em todas as camadas da sociedade. Normalmente, os libertos somente emigravam após constituir família, pois, segundo a autora:

Em zonas agrárias, a presença da família, pelo menos a constituída pelo casal, era condição básica para o estabelecimento de unidades domésticas de produção, em particular para os mais pobres. A necessidade de uma maior estabilidade levava ao casamento legal. Em 147 inventários post mortem de proprietários rurais, do século XVIII, dos Campos dos Goitacases, pôde-se verificar que $96 \%$ eram casados (1998, p. 155).

Em seguida, a autora aponta a razão de uma taxa de casamentos tão alta, em regiões rurais:

A recorrência das taxas torna clara a necessidade de constituir e manter família em áreas rurais, tanto para os ricos quanto para os pobres, em contraste com as áreas urbanas onde as atividades econômicas não pressupunham, a princípio, a família como base de produção (1998, p. 155).

Esse parece ser o caso da população do Sertão da Farinha Podre nos primeiros anos do século XIX. Em nossa região de estudo, nos 167 inventários post mortem analisados, produzidos entre 1822 e 1861, no termo da freguesia (depois Vila) de Uberaba, encontramos 21 testamentos, nos quais se revela a origem do testador. Verificou-se que, em cem por cento dos casos, eles haviam nascido fora do termo, revelando o caráter adventício da população. Dos inventariados, 165 eram casados e apenas dois solteiros, o que corresponde a uma taxa de nupcialidade de 98\%, próxima à encontrada por Castro Faria em Campos.

Usando os títulos de herdeiros dos inventários, ${ }^{30}$ que trazem sempre o nome dos herdeiros, sua condição — casado, solteiro ou viúvo — e geralmente sua idade, procuramos deduzir a taxa e a idade média de nupcialidade da população

30 Para uma revisão dos métodos de construção de fichas de família em Demografia Histórica, ver Marcílio (1977). 
do termo de Uberaba, entre 1822 e 1861. Construímos, para isso, o gráfico 1. Percebe-se que apenas duas, de cada dez mulheres, permanecia solteira após os 25 anos. Entre os homens, a taxa de nupcialidade era ainda maior: depois dos 35 anos, menos de um homem, de cada dez, permanecia solteiro. As mulheres se casavam entre os 15 e os 20 anos, e a partir dessa idade diminuíam muito as suas chances de matrimônio, mantendo-se constantes as taxas de celibato feminino após os 20 anos. Os homens, por sua vez, casavam-se em idades que variavam dos 20 aos 35 anos. Esse perfil diferia bastante dos imigrantes portugueses do sexo masculino nos núcleos urbanos, os quais mantinham taxas de celibato, quando de suas mortes, de até 76\% (FurTAdo, 1999).

A taxa de nupcialidade relativamente maior dos homens reflete um fenômeno típico de populações do tipo pré-malthusiano, presente na maioria

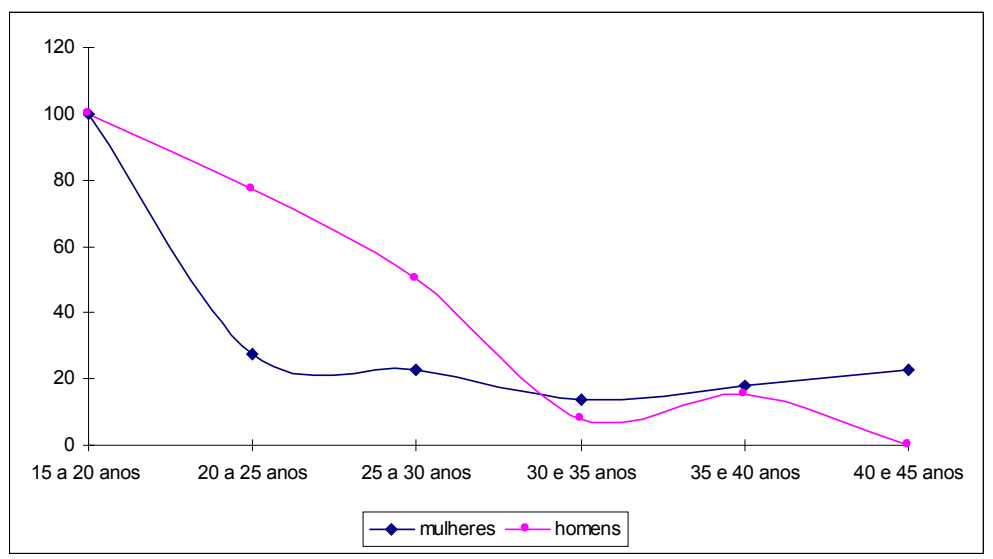

Gráfico 1: mulheres e homens solteiros em relação aos casados, em função da idade (15 a 20 anos $=100)$, no termo de Uberaba (1822-1861)

Fonte: APU, série de 167 inventários do Juizado de Órfãos de Uberaba (1822-1861).

dos estudos relativos a populações rurais coloniais: ${ }^{31}$ a maior mortalidade masculina, reduzindo a razão de gênero — número de homens para cada 100 mulheres - a números menores que 100. Usando os dados censitários

31 Ver, por exemplo, Marcílio (2000). 
coligidos por Luiz Maria Pinto em 1821 (Cunha Matos, 1981), referentes ao Desemboque (que incluía o termo da freguesia de Uberaba), verifica-se que, naquela data, havia 3.176 homens e 3.282 mulheres livres no julgado, o que perfazia uma razão de gênero igual a 96,77, valor próximo ao encontrado por Marcílio (2000) — 91,55 — para a província de São Paulo em 1828. ${ }^{32}$ Tais números, é importante ressalvar, referem-se à população livre. Entre a população escrava, as razões de gênero eram sempre maiores que 100, refletindo o efeito do tráfico, como veremos no capítulo 5.

A vaga geralista no Triângulo Mineiro teve, portanto, o caráter de uma migração familiar: só após constituir família é que roceiros e criadores decidiam deslocar-se para essa região de fronteira. Que fatores — resta saber - levavam essas pessoas a tomarem tal decisão? Já abordamos em parte esta questão páginas atrás, ao discutirmos os efeitos produzidos pela mineração aurífera e pelo crescimento demográfico sobre as terras de cultura, na região central de Minas Gerais. Vimos que esses fatores levaram ao esgotamento da fertilidade natural dos solos, o que empurrou parte da população das comarcas de Ouro Preto, Mariana e Sabará para as comarcas do Rio das Mortes, Serro do Frio e Paracatu, da qual faziam parte os julgados do Desemboque e Araxá.

A cena descrita por Eschwege ilustrou, de forma lapidar, que também a região em estudo recebeu famílias que migraram por causa desses fatores. Com efeito, em nossa série de 21 testamentos do Juizado de Órfãos de Uberaba, escritos entre 1822 e 1861, mapeamos a origem declarada dos testadores (figura 10). Observa-se que a maioria vinha de um polígono formado por Vila Rica, Conceição de Mato Dentro, Prados e Tamanduá, regiões mineradoras ocupadas no século XVIII, comprovando que parte da diáspora da zona aurífera também se dirigiu para o Triângulo Mineiro, nos primeiros anos do século XIX. Porém, o mesmo mapa mostra que uma fração dos migrantes também veio de zonas agropastoris prósperas, como Formiga, Baependi e Curral Del Rei. ${ }^{33}$ Seria um erro, portanto, imputar a uma suposta "decadência" da zona

\footnotetext{
32 Acreditamos que não só a aritmética da demografia, mas também fatores culturais, estão por trás das taxas relativamente maiores de celibato feminino. Saint Hilaire (1975 b) e Eschwege (1996) referiram-se ao costume de as famílias imporem o celibato a algumas filhas, para que cuidassem da velhice dos pais.

33 Hoje o sítio da capital planejada de Minas, Belo Horizonte.
} 
aurífera o único fator de repulsão migracional dos geralistas que chegaram ao Triângulo Mineiro e outras regiões.

Nossa hipótese é que a migração geralista foi o resultado natural de pressões demográficas exercidas sobre regiões agropastoris, onde a agricultura e a pecuária eram praticadas sob determinadas condições técnicas, que

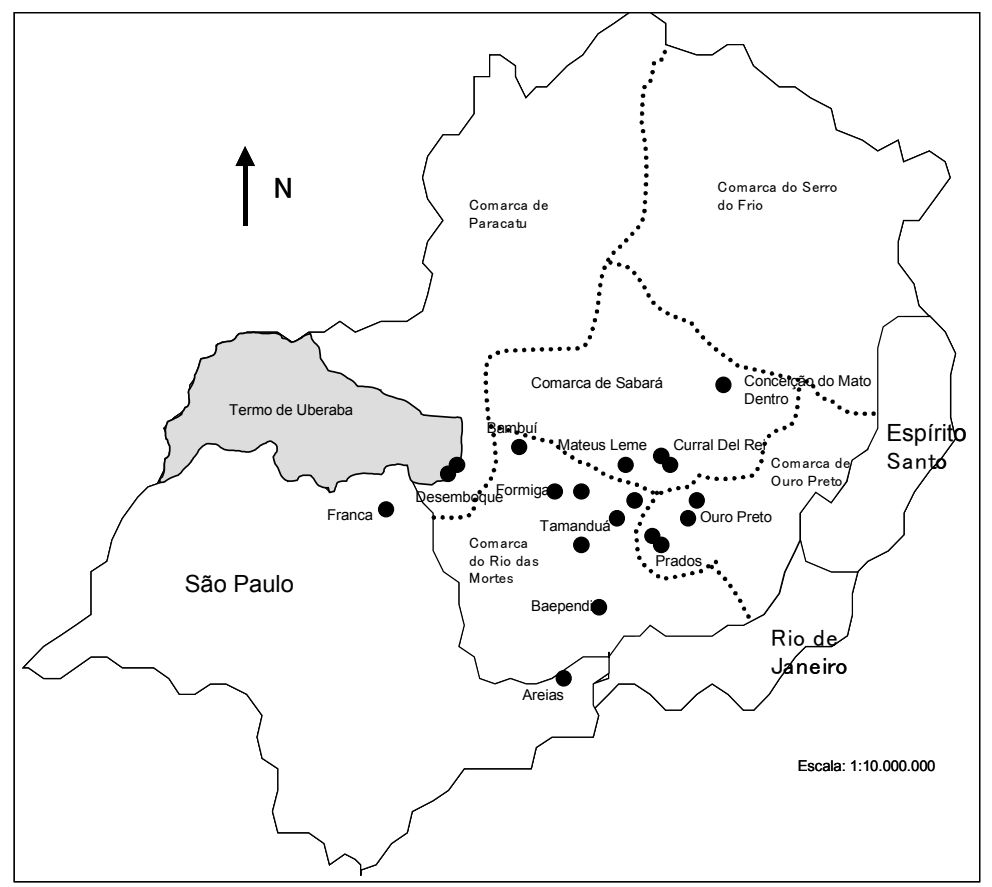

Figura 10: naturalidade dos testadores da freguesia de Uberaba (1822-1861)

Fonte: Arquivo Público de Uberaba, série de 21 testamentos do Juizado de Órfãos de Uberaba (1822-1861).

impunham limites à densidade demográfica, e obrigavam à mobilidade horizontal. Essa hipótese não é inteiramente nova, embora o seja para o caso mineiro. Marcílio (2000) e seus orientandos (BACELAR, 2001) há muito já vêm demonstrando a importância da dimensão demográfica e ambiental no estudo das migrações coloniais, especialmente aquelas ocorridas na capitania de São Paulo, entre os séculos XVIII e XIX. 
Contando com um singular corpo documental — as listas anuais e nominativas de todos os habitantes de cada uma das vilas da capitania de São Paulo do século XVIII — que, lamentavelmente, não foi produzido, na mesma época, em outras regiões do Brasil, os autores vêm estudando as relações entre população, recursos e ambiente em São Paulo colonial. Marcílio, ao estudar a estrutura familiar e a mobilidade espacial no meio rural setecentista de São Paulo, concluiu, pela existência de relações entre o padrão de família nuclear — formada por pai, mãe e filhos solteiros — o sistema de pousio florestal ou arbustivo e a mobilidade espacial:

A economia era de autoconsumo com escasso excedente para troca; a família do roceiro, base econômica, social e cultural do sistema de agricultura de repouso florestal, era, no entanto, predominantemente pequena, resumindo-se na célula conjugal e nos poucos filhos solteiros sobreviventes. $\mathrm{O}$ patrimônio quase nulo desses grupos domésticos rústicos — reduzidos quase que apenas a enxada e machado, alguma arma de fogo e um tosco rancho de sapé — estava associado justamente aos contínuos deslocamentos do grupo para novas parcelas desbravadas mais adiante na mata virgem (2000, p. 161).

O sistema de pousio florestal — vinte anos, em média, de descanso após o plantio, com reconstituição da mata secundária — exigia uma larga área útil para grupos familiares relativamente pequenos, o que restringia as densidades demográficas. Aumentos de população podem levar à adoção do pousio arbustivo - pousios mais curtos, de cinco a sete anos, com reconstituição de vegetação secundária do tipo herbáceo-arbustivo ou capoeira — - que leva a uma redução da produtividade por unidade de área. Aumentos ainda maiores de população, mantendo-se as mesmas técnicas rústicas de cultivo, poderiam levar a reduções ainda maiores na produtividade, rompendo o equilibrio entre população e produção de alimentos e gerando fomes. Contudo, dispondo-se de áreas de fronteira com solos de mata virgem, as migrações impediriam aquela situação limite, como foi o caso em quase todo o período colonial.

A mobilidade espacial, nesse caso, seria decorrência estrutural do crescimento demográfico, numa população vivendo sob um sistema rústico de agricultura, e que contava com áreas de fronteira. O crescimento da população, por sua vez, seria decorrência do próprio caráter familiar da unidade rural. 
Usando uma lógica que lembra a do equilíbrio trabalho-consumo, de Chayanov (1986), a autora comenta:

Qualquer aumento do grupo doméstico, por inclusão de mais pessoas, embora significasse aumento de mão-de-obra, representava, sobretudo, necessidade de extensão da área cultivada para atender as novas bocas. O equilíbrio entre população e produção para o consumo se mantinha quando a família se resumia no casal e nos filhos, e ele só era quebrado quando a família se tornava incompleta, ou no caso de algum de seus membros ativos ficar incapacitado para o trabalho (MArcílio, 2000, p. 161).

Dito de outra forma, tratava-se de um ciclo de retro-alimentação positiva, no qual a prole numerosa, importante para constituir o núcleo familiar de trabalho por garantir ganhos marginais, impunha, por sua vez, uma intensificação dos cultivos e/ou um aumento da área cultivada. Quando os filhos se casavam, constituíam então eles próprios novos núcleos familiares, destacando-se do núcleo paterno e assentando-se nos arredores ou em áreas distantes, reiniciando o ciclo noutra área.

A autora explica, dessa maneira, a tendência a se constituírem núcleos familiares pouco numerosos, contrariando a idéia, até algum tempo consensual entre historiadores, da família extensa - três ou mais gerações vivendo sob o mesmo teto - como o padrão no período colonial. Na verdade, a necessidade da mobilidade, tornada imperativa pelo próprio sistema tradicional de cultivo, impunha o desmembramento de novos grupos familiares, assim que os filhos se casassem.

Uma dinâmica semelhante ocorria nas comarcas mineiras de colonização mais antiga, como a de Ouro Preto, de Sabará e do Rio das Mortes. Na região do rio Paraopeba, Eschwege (1996) referiu-se ao sistema de pousio arbustivo como o então adotado pelos agricultores locais. Saint Hilaire também descreve o mesmo sistema, afirmando que era adotado principalmente nas regiões próximas a Vila Rica:

Nos pontos da província de Minas que se avizinham de sua capital as capoeiras que substituíram as florestas virgens são geralmente cortadas ao cabo de cinco, seis ou sete anos. Depois de se desenvolverem livremente durante vinte anos 
essas matas, então chamadas de capoeirões, adquirem o mesmo vigor das florestas primitivas (SAint Hilaire, 1975 b, p. 136).

Nos arredores de Itambé, o esgotamento dos solos como resultado do encurtamento do pousio foi relatado ao cronista por um fazendeiro. De início, as terras eram "grandemente produtivas". Ao final de alguns anos, contudo, “o milho não rende mais [...] do que 100 por 1" (SAINT Hilaire, 1974, p. 56).

Na região do Oeste Mineiro, porém, os roceiros preferiam as áreas de mata virgem para plantio, devido à abundância destas. Em Pium-i, os agricultores "derrubam as matas dos arredores que se prestam a todo tipo de cultura" (SAINT Hilaire, 1975 b, p. 96). Em Araxá, "como em todos os lugares, só se planta nos capões, ficando os campos reservados exclusivamente aos rebanhos” (p. 130).

O esgotamento das terras das regiões de origem foi a razão alegada aos viajantes joaninos por todos os geralistas que haviam se estabelecido no Triângulo Mineiro. Em Araxá, Saint Hilaire encontrou imigrantes vindos de Sabará (1975 b), e em Farinha Podre, vindos de Formiga e Oliveira (1975 a). Eschwege deparou-se, nas proximidades do rio Grande, com um geralista de Congonhas do Campo, "onde deixara casa e uma grande fazenda, já inteiramente desprovida de matas” (1996, p. 131).

Pelo relato desses cronistas, percebe-se que os sitiantes se estabeleciam quase sempre em unidades familiares simples, isto é, formadas pelo casal e seus filhos. À beira do rio Tejuco, no Sertão da Farinha Podre, Eschwege (1996) encontrou uma fazenda habitada apenas por um casal com um filho pequeno. Nas proximidades do arraial da Capelinha, encontrou dois jovens recémcasados, ainda sem filhos. Saint Hilaire, na Serra da Canastra, perguntou a um homem que lá havia se estabelecido "como podia ele viver em lugar tão solitário. Respondeu-me que gostava do sossego e além do mais não vivia sozinho, pois tinha mulher e filhos" (1975 b, p. 102).

Famílias simples, conjugais, foi o que encontramos também no estudo dos inventários oitocentistas de Uberaba. Os títulos de herdeiros, presentes nos inventários, constam sempre o nome dos filhos, condição (casado, solteiro ou viúvo), idade e local de moradia, se com o inventariante ou noutro lugar. Por meio deles, portanto, foi possível reconstituir a estrutura da maioria das famílias dos inventariados. Percebemos que raramente os filhos casados permaneciam morando com os pais, porém freqüentemente se assentavam nas imediações. Por 
exemplo, no inventário de Lauriana Teresa dos Santos, ${ }^{34}$ seus filhos Deodoro, José, João e Jerônimo, respectivamente com 20, 18, 16 e 15 anos, todos solteiros, moravam "em companhia de seu pai”, o viúvo Manuel Antônio da Silveira. Já os filhos casados Maria, Luciana e Custódio residiam na mesma fazenda, mas em outros sítios. Os filhos Francisco e Pedro, solteiros, mas um pouco mais velhos — respectivamente com 25 e 30 anos — residiam também em habitações separadas: um na mesma fazenda, e o outro em Dores do Campo Formoso.

Quantificando-se os dados dos títulos de herdeiros, pudemos ter uma idéia diacrônica da dinâmica demográfica familiar. O gráfico 2 foi construído calculando-se o número médio de membros, em função da idade da família. ${ }^{35}$ Nele se pode perceber que as famílias de 20 a 30 anos alcançavam o número máximo de membros, em média dez pessoas, que decaía logo depois, com o casamento dos filhos, a uma média de cinco pessoas. Trata-se do que Marcílio (2000) chamou de ciclo vital das famílias do meio rural tradicional brasileiro, do período colonial: uma história de vida que consistia na constituição de uma família conjugal num novo fogo, o nascimento de filhos, sua adolescência quando a família atingia 20 anos de idade e vivia o seu apogeu produtivo - e o casamento dos filhos, com o desmembramento da família em novas unidades conjugais e a permanência apenas dos pais idosos, com um ou outro filho celibatário, quando a família atingia a idade superior a 30 anos.

Esse padrão — novas famílias desmembradas das parentais, mas fixandose nas cercanias destas — também foi observado por Castro Faria (1998) em seu estudo dos inventários post mortem da região de Campos dos Goitacases, do século XVIII. Os casais novos se estabeleciam, segundo a autora, em novos sítios em terras dos pais ou sogros. Saint Hilaire também observou o mesmo, em sua viagem pela região em estudo, em 1819. Em Serra da Canastra, "os escassos habitantes dos arredores [...] parecem todos aparentados uns com os outros" (1975 b, p. 105). No sítio do Pari, próximo a Bonfim de Goiás, "os numerosos moradores [...] [são] todos parentes uns dos outros" (1975 a, p. 109).

Acreditamos, portanto, que os fatores que levavam à migração e dispersão da população rural, analisados por Marcílio (2000) — tensão demográfica crescente sobre solos com diminuição do tempo de pousio,

\footnotetext{
34 APU, inventário de Lauriana Teresa dos Santos (14/08/1838), maço N7.

35 Estimamos a idade da família adicionando-se um ano à idade do filho mais velho.
} 


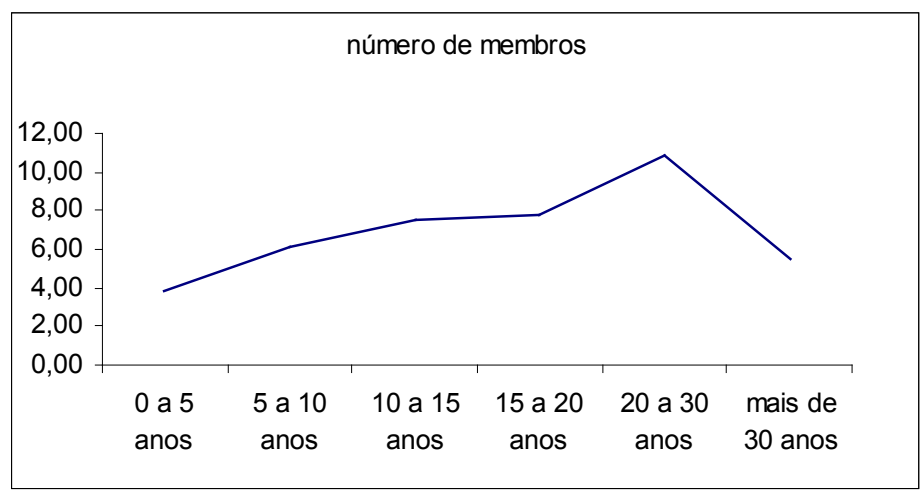

Gráfico 2: número de membros em função da idade das famílias, no termo de Uberaba , entre 1822 e 1861.

Fonte: 174 inventários do Juizado de Órfãos de Uberaba (1822-1861).

demanda por novas áreas cultiváveis — também estavam presentes em Minas Gerais, tanto na emigração a partir das áreas de colonização setecentista (região aurífera e comarca do Rio das Mortes) para o Sertão da Farinha Podre, quanto nos deslocamentos ocorridos no interior desta última região. Em decorrência disso, o padrão era de uma permanente mobilidade espacial da população.

Contudo, tal processo migratório não se fazia a esmo, mas estruturado em parentelas, isto é, grupos de famílias nucleares unidas entre si por laços de parentesco consangüíneo ou ritual, e vivendo em habitações próximas (LEWIN, 1987). As pessoas procuravam instalar-se em áreas onde pudessem contar com redes de solidariedade vicinal, fundamentais à dinâmica da economia e da sociedade camponesas. Tais redes eram mais confiáveis - e se estruturavam mais rapidamente — quando formadas por parentes.

Outro aspecto importante a ser notado no gráfico 2 é a média de filhos das famílias do julgado de Uberaba, na primeira metade do século XIX. Como se verá no capítulo seguinte, um grande número de filhos era desejável pela familia rural, como forma de ampliar a força de trabalho familiar. No apogeu de seu ciclo vital, as famílias contavam em média com oito filhos sobreviventes, decaindo, em seguida, com o casamento deles. A fecundidade dos casais devia ser muito maior, pois tratava-se de uma sociedade em que as mulheres se 
casavam jovens e não havia nenhum tipo de controle de natalidade. Porém, a elevada taxa de mortalidade — principalmente infantil — impedia que as proles fossem ainda mais numerosas.

Pudemos estimar as taxas de mortalidade infantil e juvenil calculando o lapso médio entre um filho e outro, em função da idade destes. A taxa de fecundidade era muita elevada, pois o intervalo médio entre os filhos mais jovens era de apenas um ano. $\grave{A}$ medida que aumentava a idade dos filhos, aumentava proporcionalmente o intervalo entre eles (gráfico 3). Percebe-se que há uma forte inclinação da curva de zero até cinco anos de idade, quando o intervalo médio entre filhos saltava de 1 para 2,3 anos, o que se devia à elevada mortalidade infantil. Dos cinco até os vinte anos, a curva se mantinha quase horizontalizada, para novamente sofrer inclinação ascendente após essa idade, por causa da mortalidade juvenil. Esta provavelmente estava ligada a fatores ambientais, como o trabalho ou a violência. Tratava-se, portanto, de uma população de tipo pré-malthusiano, isto é, sem nenhum controle sobre a natalidade ou a mortalidade (MARcílio, 2000), mas que, por causa da alta natalidade, tinha crescimento vegetativo positivo.

É necessário lembrar que, ao usar esse tipo de fonte, podemos apenas fazer inferências qualitativas sobre as tendências demográficas na região em estudo. Tais inferências, para serem confirmadas, necessitariam de estudos usando fontes mais adequadas, como, por exemplo, os registros paroquiais.

\section{Fatores geopolíticos na migração geralista}

Vimos, no segundo capítulo, que, do período pombalino em diante, a Coroa portuguesa mudara suas estratégias relativas ao território colonial. As antigas regiões "proibidas", que rodeavam as zonas auríferas e diamantíferas, onde era vedada a colonização e a abertura de estradas, desapareceriam em nome de uma nova orientação geopolítica. No entendimento do Marquês de Pombal e de seu círculo de intelectuais iluministas, o território e a população da colônia americana passaram a ter um novo significado. Importava, assim, criar um mercado que pudesse estimular as manufaturas portuguesas e, em especial, criar uma economia complementarà da metrópole, inclusive com algumas unidades industriais, como as forjas siderúrgicas de São Paulo e Minas (NovAIs, 


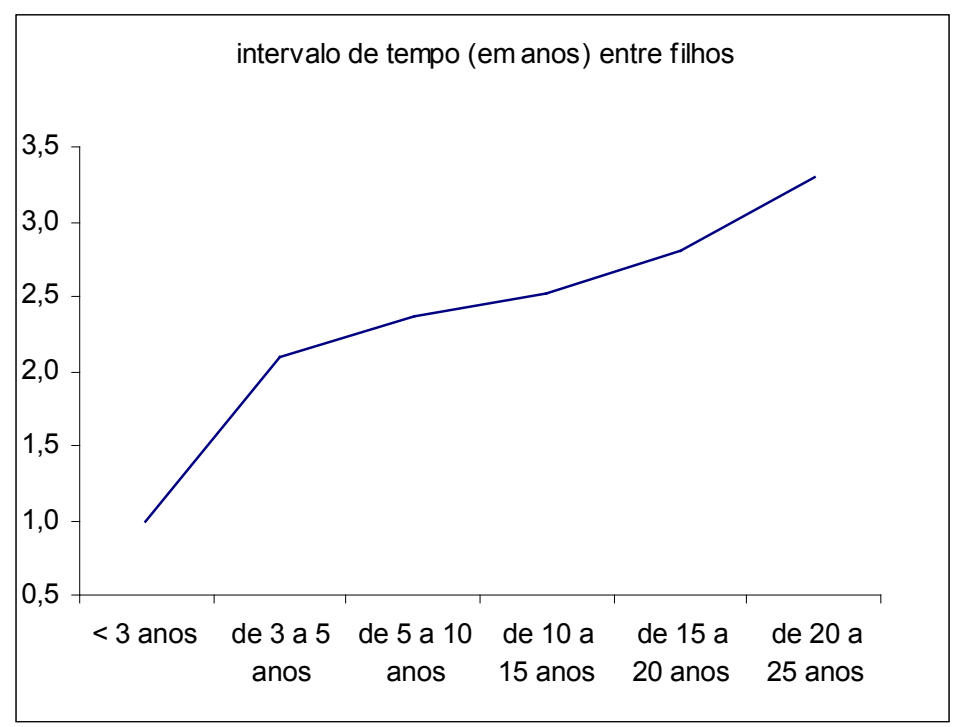

Gráfico 3: intervalo (em anos) entre os filhos, em função da idade dos filhos, nas famílias livres, no termo de Uberaba (1822-1861)

Fonte: APU, 174 inventários do Juizado de Órfãos de Uberaba (1822-1861).

1986). Importava também estimular o crescimento populacional, de forma a ocupar as regiões de fronteira e, assim, impedir que o inimigo espanhol as reivindicasse (MARCílIo, 2000).

Os governos das capitanias reais, contando com colaboradores de Pombal à sua frente, seguiram fielmente a cartilha dos novos tempos. No período de 1750 a 1771, o governador de São Paulo, D. Luís Antônio de Souza, morgado de Mateus, criou catorze novas vilas e povoados naquela capitania, como parte da política de povoamento interior (MArcílio, 2000). Em Minas, na mesma época, o governador Gomes Freire iniciou a guerra contra os quilombos do Oeste Mineiro, para alimpar aquela região, com vistas à colonização.

Com o fim do período pombalino, pela a morte de D. José I, em 1777, a ascensão ao trono português de $\mathrm{D}$. Maria I aprofundou a mudança de rumos na geopolítica colonial. Em 1792, com a loucura de sua mãe, o príncipe regente D. João continuou com a política de valorização estratégica do interior. Estimulou a vinda de famílias do arquipélago de Açores, que foram assentadas em glebas no 
Sul do Brasil; e, em Minas, declarou guerra aos índios botocudos do vale do rio Doce, para que aquela região pudesse ser liberada para a colonização.

No período joanino, restavam ainda, no território da capitania de Minas Gerais, vastas regiões esparsamente povoadas no Leste (Zona da Mata e vales dos rios Doce e Mucuri), no Noroeste (termo da Vila de Paracatu) e no Extremo Oeste (Triângulo Mineiro). O governo de Minas usou então de dois instrumentos poderosos para promover a ocupação dessas regiões: as isenções fiscais e as concessões de sesmarias. Quando da chegada da Corte ao Rio de Janeiro, em 1808, o Conde de Linhares promulgou lei isentando do dízimo, por dez anos, os colonos que se estabelecessem nas regiões ermas de Minas (Saint Hilaire, 2000). Nessa mesma época, começou um verdadeiro boom de concessões de sesmarias pelo governo mineiro, que durou até 1822, tendo por objetivo dirigir o povoamento para as regiões de fronteira.

A instituição sesmeira vigeu por todo o período colonial brasileiro, tendo sido extinta em 1822. As sesmarias eram concessões estatais, mas não dependiam somente das diretrizes colonizadoras do Estado. É falsa a idéia, difundida por Alberto Passos Guimarães (1977), de que apenas fidalgos portugueses e brasileiros enobrecidos recebiam sesmarias no Brasil. A maioria dos sesmeiros não era de origem nobre, e a própria legislação portuguesa, como atesta o foral de Duarte Coelho, de 1534, prescrevia as doações a "a quaisquer pessoas de qualquer qualidade e condição que sejam, contanto que sejam cristãos" (ABreu, 1997, p. 205). Particularmente de meados do século XVIII em diante, não interessava à coroa povoar com nobres, mas simplesmente povoar (GORENDER, 1988).

O principal critério usado nas concessões, e que a própria lei estabelecia, era a possibilidade de cultivo pelos pretendentes. Com o tempo, a posse de escravos tornou-se critério seletivo na aquisição de sesmarias, o que foi colocado textualmente no alvará de 1795, obrigando inclusive a venda ou a alienação daquelas cujos cessionários não tivessem "possibilidades e escravatura" para cultivá-las (GORENDER, 1988, p. 394). Desse modo, colonos que já tivessem acumulado ou herdado alguma riqueza eram preferidos pelos governos das capitanias para obter sesmarias. Em nossa região de estudo, é muito provável que assim tenha ocorrido, pois como pode ser visto nos quadros 1 e 2 , que mostram as sesmarias concedidas entre 1816 e 1822 no Triângulo Mineiro, era grande o número de sesmeiros com cargos eclesiásticos ou detentores de 
postos militares das Companhias de Ordenanças, o que era considerado sinal de distinção pessoal, e, portanto, de certa fortuna (Fragoso, 1998).

A decisão sobre que terras conceder não dependia só do governo colonial. Muitas vezes, o colono inicialmente se apossava das terras, para depois reivindicar a carta de sesmaria a elas correspondente. Assim, os capitãesgenerais apenas ordenavam legalmente ocupações que freqüentemente já haviam ocorrido de fato. Em 1818, por exemplo, o alferes João Pereira da Rocha apossou-se de uma larga extensão de terras entre os rios Uberaba Legítimo e das Velhas (Pezzuti, 1922). Afazendou-se próximo às margens desse último, mas sua carta de sesmaria só foi concedida posteriormente, em 1821, conforme se vê no Inventário de Cartas de Sesmarias do Arquivo Público Mineiro (RAPM, 1988, vol. 2, p. 128).

O gráfico 4, produzido a partir de um levantamento das cartas registradas no Inventário, mostra a distribuição de sesmarias entre 1800 e 1822, em Minas Gerais. Percebem-se dois períodos de intensificação nas concessões: de 1800 a 1802 , e de 1816 a 1821.

É provável que o primeiro pico reflita o êxodo da região auríferometalúrgica de Minas - como vimos, motivado pela pressão demográfica e pelo esgotamento dos solos agricultáveis — gerando uma intensa migração para a comarca do Rio das Mortes. O segundo pico, cujo ápice se deu em 1818, chegando naquele ano a mais de 350 cartas expedidas, possivelmente reflete a política joanina de colonização das fronteiras mineiras.

\begin{tabular}{l|l|l|l}
\hline SESMEIRO & PARAGEM & DATA & OBSERVAÇÃO \\
\hline Antônio de Paiva Lima & Campo Belo & 1818 & alferes \\
\hline Bento de Magalhães Portilho & Mocotó & 1818 & - \\
\hline Brígida Antunes dos & Campo Belo, \\
Santos & $\begin{array}{l}\text { entre os rios } \\
\text { Paranaíba e } \\
\end{array}$ & Tejuco & \\
\hline Fortunato José de Miranda & Ribeirão da & 1818 & - \\
& Bagagem & & \\
\hline Francisco Alvarez & Rio Tejuco & 1818 & padre \\
\hline Manoel Dias da Rocha & Ribeirão da Bagagem & 1818 & - \\
\hline
\end{tabular}




\begin{tabular}{|c|c|c|c|}
\hline \multirow[t]{2}{*}{ Manoel Ferreira Ribeiro } & \multicolumn{3}{|l|}{ Bocaina, no Rio } \\
\hline & da Prata & 1818 & alferes \\
\hline Matheus Cardoso Parreira & Rio da Prata & 1818 & tenente \\
\hline Alexandre Roiz Gondim & Formiga & 1819 & - \\
\hline Hermógenes Casimiro & Sertão & & \\
\hline \multirow[t]{3}{*}{ de Araújo } & da Prata & 1819 & padre \\
\hline & Ribeirão dos & & \\
\hline & Santos Fortes & & \\
\hline João do Vale & e Ribeirão de & & \\
\hline Pereira & São Jerônimo & 1819 & capitão \\
\hline Joaquim Silva e Oliveira & Rio Tejuco & 1819 & tenente \\
\hline José da & Sertão do & & \\
\hline Silva & Rio da Prata & 1819 & - \\
\hline Maximiano José de Andrade & Boa Vista & 1819 & - \\
\hline Miguel Eugênio de Araújo & Lagoa dos patos & 1819 & - \\
\hline Floriano José Marques & Rio Uberaba & 1820 & - \\
\hline Francisca Angélica da & Aldeia Velha, margem & & \\
\hline Silva & do Rio da Prata & 1820 & - \\
\hline Francisco de & Bebedouro & & \\
\hline Paula Teixeira & do Burité & 1820 & alferes \\
\hline Francisco Nogueira Mendes & Douradinho & 1820 & - \\
\hline Ignácio Gonçalves da Silva & - & 1820 & - \\
\hline Januário Luiz da Silva & Ribeirão São Félix & 1820 & - \\
\hline Joaquim Patrício & Rio & & \\
\hline Maxado Roiz & Uberaba & 1820 & - \\
\hline Joaquim Silvério & Ribeirão & & \\
\hline Teixeira de Melo & do Cabaçal & 1820 & - \\
\hline \multirow[t]{2}{*}{ José Francisco de Azevedo } & Rio Piracanjuba e & & \\
\hline & Rio do Peixe & 1820 & - \\
\hline José Joaquim Carneiro & Rio Uberaba & 1820 & capitão \\
\hline
\end{tabular}




\begin{tabular}{llll}
\hline José Luciano & Barra do Douradinho e & \\
Teixeira & Rio da Prata & 1820 & - \\
\hline José Teixeira Alvares & Capão Debaixo & 1820 & - \\
\hline Vicente Nogueira Mendes & Douradinho & 1820 & - \\
\hline Francisco Ferreira da & Ribeirão & & padre \\
Rocha & de São Mateus & 1821 & - \\
\hline Francisco Roiz Rebello & Rio Claro & 1821 & alferes \\
\hline João Pereira da Rocha & Rio Uberaba Legítima & 1821 & - \\
\hline José Alves de Resende & Monjolinho & 1821 & - \\
\hline José Manoel & entre os rios Seco & & alferes \\
da Silva & e da Prata & 1821 & - \\
\hline Manoel Caetano de Menezes & Turvo & 1821 & - \\
\hline Thomé Pinto de Almeida & Santo Antônio e Almas & 1821 & - \\
\hline Demétrio José de Andrade & Rio Uberaba & 1822 & 1822 \\
\hline Joaquim Pereira da Rocha & Morro da Boa Vista & - & - \\
\hline
\end{tabular}

Quadro 1: relação de sesmeiros do Sertão da Farinha Podre (1816-1822). Fonte: RAPM (1988).

\begin{tabular}{|c|c|c|c|}
\hline SESMEIRO & PARAGEM & DATA & OBSERVAÇÃo \\
\hline Maria Pelágia do Carmo & Margem do Paranaíba & 1816 & - \\
\hline José de Resende & $\begin{array}{l}\text { Margens do Paranaíba, } \\
\text { no lugar do Piçarrão }\end{array}$ & & \\
\hline Costa & e da Estiva & 1817 & - \\
\hline Confraria de São & Margens do Rio & & \\
\hline Francisco e & Paranaíba, Ribeirão & & \\
\hline \multirow[t]{2}{*}{ Santo Antônio } & Bom Sucesso & 1819 & - \\
\hline & Margens do & & \\
\hline Antônio José & Paranaíba, pântano das & & \\
\hline de Melo & Araras & 1817 & padre \\
\hline
\end{tabular}




\begin{tabular}{llll}
\hline ssabel Damiana Monteira & Margens do Paranaíba & 1817 & - \\
\hline Lourenço Antônio Monteiro & Margens do Paranaíba & 1816 & - \\
\hline Francelina & Margens do Rio & & \\
Carneira de & Paranaíba, paragem & & \\
Resende & de Piçarrão e Estiva & 1817 & - \\
\hline João Francisco & Distrito da ermida de & & \\
Rodovalho & Santana & 1817 & - \\
\hline $\begin{array}{l}\text { Manoel Francisco } \\
\text { Rodovalho }\end{array}$ & $\begin{array}{l}\text { Distrito da ermida de } \\
\text { Santana }\end{array}$ & \\
\hline José Pereira & Salto do Piçarrão, & & - \\
da Silva & vertente do Rio & & \\
& das Velhas & 1817 & - \\
\hline José Bento & Margens do Paranaíba, & & \\
Soares & no Serrote & 1817 & sargento-mor \\
\hline
\end{tabular}

Quadro 2: relação de sesmeiros do Sertão dos Araxás (1816-1822). Fonte: RAPM (1988).

Se agruparmos as sesmarias por comarcas, como fizemos no gráfico 5 , poderemos visualizar como se deu, por região da capitania, o processo de apropriação pioneira do território. No boom de concessões do início do século, as comarcas que mais tiveram terras distribuídas foram as de Rio das Mortes, Ouro Preto e Sabará, onde se situavam algumas das regiões de fronteira. Nessa época, o Triângulo Mineiro (julgados do Araxá e Desemboque) ainda pertencia à capitania de Goiás. No período posterior, de 1815 em diante, quando se verifica nova onda de concessões, Rio das Mortes tornou-se, indubitavelmente, a região que passou a ser mais intensamente colonizada em Minas. Em segundo lugar, vinha a comarca de Ouro Preto e em terceiro a de Paracatu.

Se analisarmos a distribuição das sesmarias no interior dessas comarcas, agrupadas por termo, veremos que algumas vilas concentravam o processo colonizador, o que torna mais fácil localizá-lo no espaço. Em Rio das Mortes (gráfico 6), na primeira onda de concessões (1800-1803), a maioria delas 


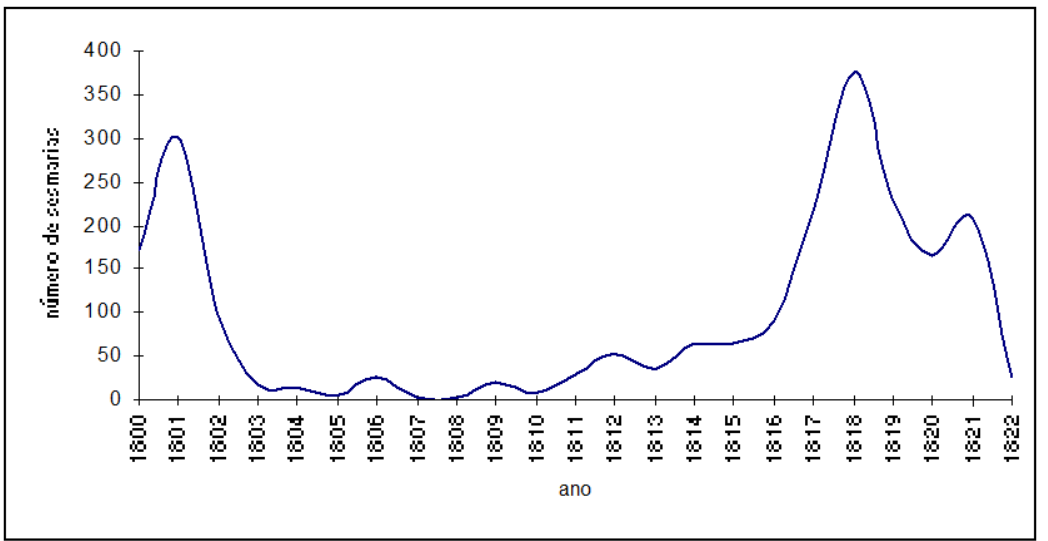

Gráfico 4: distribuição de sesmarias na capitania de Minas Gerais (1800-1822) Fonte: RAPM (1988).

ocorreu no termo da vila do Tamanduá, que incluía a maior parte das terras situadas nas cabeceiras do Rio São Francisco, até a Serra da Canastra, isto é, a região alimpada dos quilombos pelas expedições da segunda metade do século XVIII, e que então vivia os últimos momentos do surto colonizador que se seguiu ao extermínio dos quilombolas. Formava-se ali, dessa forma, uma região agropastoril produtora de alimentos que, como veremos, drenava seus excedentes para o mercado do Rio de Janeiro pela Picada Nova de Goiás e pela Estrada Real.

O segundo pico na curva da distribuição das concessões sesmariais foi praticamente monopolizado, nessa comarca, pelo termo da vila de Barbacena. O vasto território desta vila incluía grande parte do que hoje é chamado Zona da Mata Mineira, e que por essa época sofria intensa ocupação. A pioneira economia agropastoril produtora de mantimentos, responsável pela ocupação daquela área, seria sucedida, a partir dos anos 1840, pela cafeicultura em regime de plantation, tornando-se, com isso, uma das regiões econômicas mais importantes da província, durante o Império.

O gráfico 7 mostra a distribuição das sesmarias na comarca de Ouro Preto. No termo da então capital mineira, praticamente nenhuma carta foi concedida no período em questão, pela óbvia razão de que o território de Vila 
Triângulo Mineiro: uma fronteira na Colônia e no Império

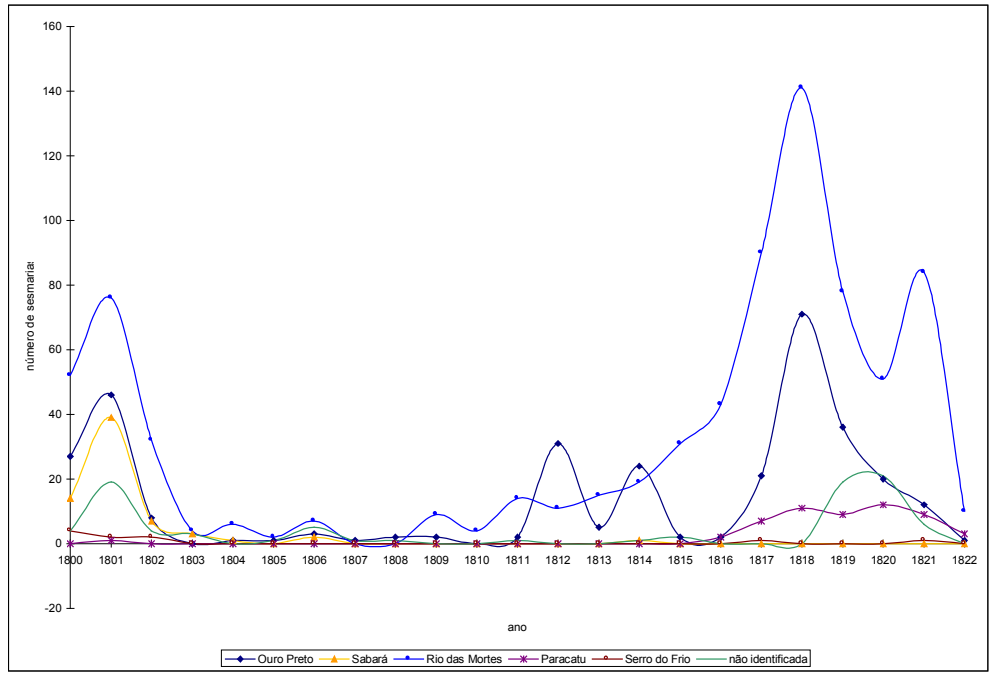

Gráfico 5: distribuição de sesmarias, por comarca, na capitania de Minas Gerais (1800-1822) Fonte: RAPM (1988).

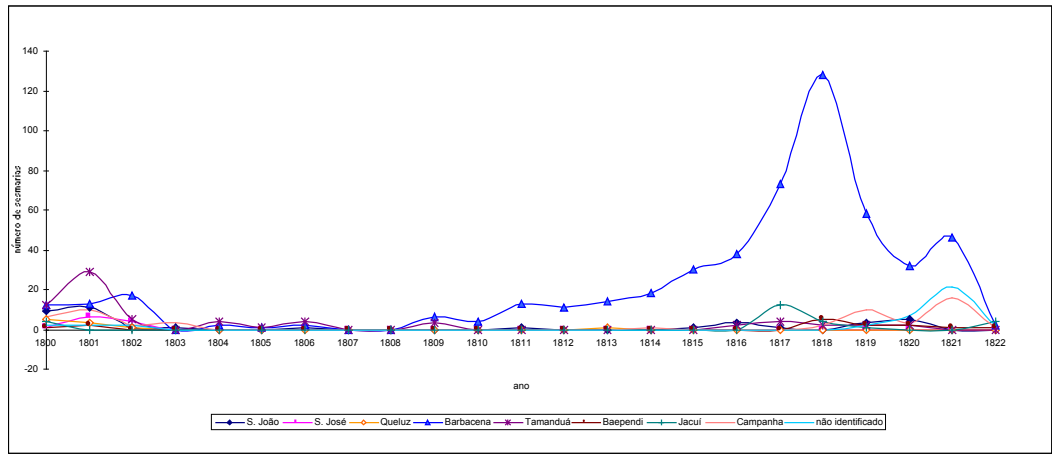

Gráfico 6: distribuição de sesmarias, por termo, na comarca do Rio das Mortes (1800-1822). Fonte: RAPM (1988). 
Rica, intensamente ocupado desde o século XVIII, já não dispunha mais de terras devolutas. A cidade de Mariana, porém, tinha seu termo estendendo-se por quase toda a margem direita do rio Doce, até as divisas com as capitanias do Espírito Santo e Rio de Janeiro, tendo havido ali grande número de concessões.

Desde o final do século XVIII, o vale do rio Doce - parte do termo da cidade de Mariana - deixou de ser considerado "área proibida" pelo governo colonial. O marco dessa nova orientação foi a Portaria de 1784, do governador Luís da Cunha Menezes, dando início à exploração dos sertões do Leste. A partir de então, aquele território tornou-se alvo de intensa colonização, precedida por uma campanha de aldeamento, escravização e extermínio dos índios coroados e coropós (VAsconcelos, 1999). A campanha oficial de colonização continuou nos anos seguintes, no médio rio Doce, com a guerra contra os índios botocudos, promovida, desde 1808, pelo Príncipe Regente (Cunha Matos, 1981). Isso explica porque, durante quase todo o período em questão, mas principalmente após 1810, houve intensa concessão de terras naquele município.

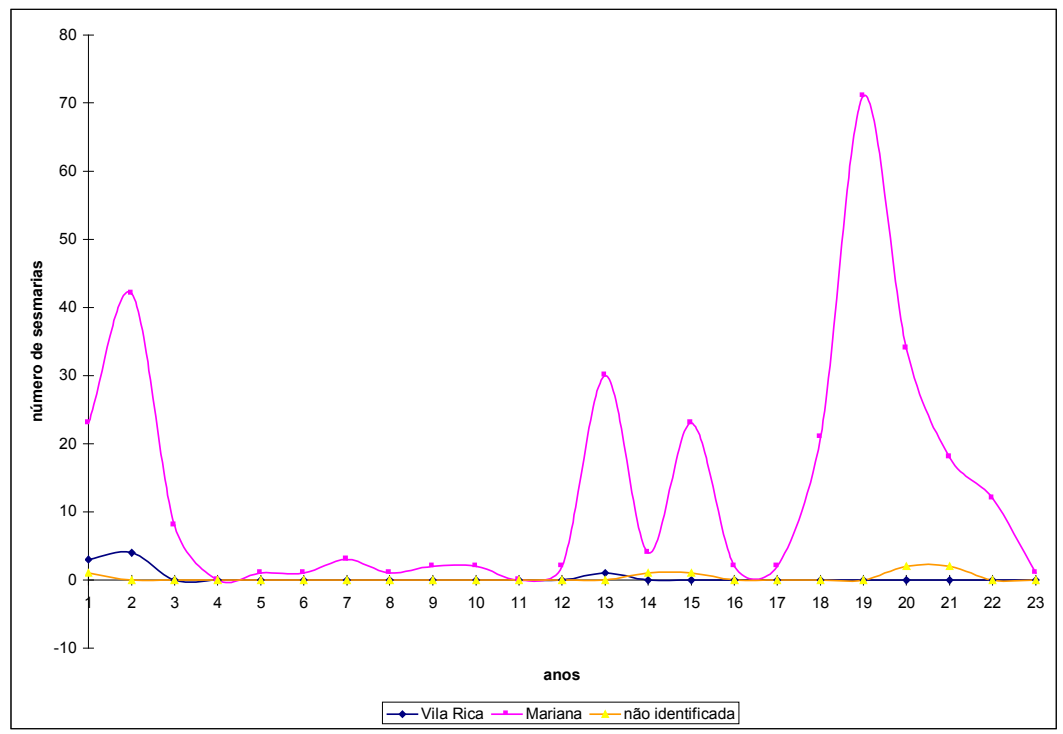

Gráfico 7: sesmarias concedidas, por termo, na comarca de Ouro Preto (1800-1822). Fonte: RAPM (1988). 
A região que estamos estudando, então formada pelos termos dos julgados de Araxá e Desemboque, anexada ao território mineiro em 1816, também foi alvo de uma política colonizadora do governo da capitania, como vimos pelo gráfico 5 (curva da comarca de Paracatu). Na verdade, a comarca de Paracatu, formada pelos termos da vila homônima e pelos julgados de São Romão, Salgado, ${ }^{36}$ Araxá e Desemboque, praticamente só teve terras concedidas nestes dois últimos, sugerindo que a colonização do Noroeste Mineiro (termos de Paracatu, São Romão e Salgado) ainda era muito incipiente (gráfico 8).

O gráfico 8 mostra uma dissociação, tanto no tempo quanto na intensidade, entre as curvas das sesmarias concedidas no Araxá e no Desemboque. Isso não reflete um povoamento supostamente mais tímido dos arredores do rio Paranaíba, mas o fato de a colonização da região araxaense ter se dado, em grande parte, no período da soberania goiana. Nota-se que, no ano de 1817 — ano seguinte à anexação do julgado - , sete sesmarias foram concedidas, o que mostra um processo de colonização em pleno curso. De fato, Saint Hilaire, chegando a Araxá em 1819, três anos após a anexação, relatou que "embora os primeiros habitantes tivessem vindo de Minas Gerais, a autonomia que eles reconheciam era do governo de Goiás. [...] os agricultores podiam obter sesmarias de 3 léguas, que são as concedidas pela província de Goiás" (1975 b, p. 128).

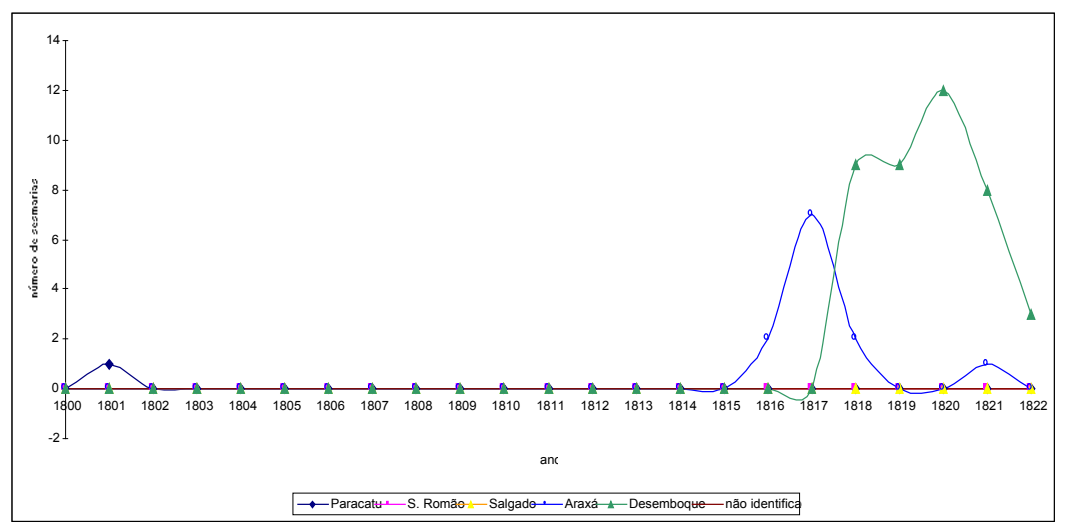

Gráfico 8: distribuição de sesmarias, por termo, na comarca de Paracatu (1800-1822). Fonte: RAPM (1988).

36 Hoje Januária. 
O mesmo gráfico mostra que a colonização do termo do Desemboque (o Sertão da Farinha Podre) começou apenas em 1818, um pouco depois do Araxá. A julgar pelo traçado da curva, é provável que a colonização oficial dessa área tenha sido um empreendimento posterior à sua anexação por Minas, não tendo havido interesse das autoridades goianas em fazê-lo antes. Borges Sampaio (2001) relatou que a primeira sesmaria na região somente foi concedida pelo governo goiano em 1803. Outras concessões certamente foram feitas entre essa data e 1816, pois Eschwege (1996), como vimos, encontrou a região já com oitenta fazendeiros assentados em 1816. ${ }^{37}$ Contudo, elas não parecem ter sido muito numerosas. Não tivemos acesso aos registros das sesmarias goianas para confirmar essa impressão.

As concessões de sesmarias apenas indicam, em linhas gerais, as orientações espaciais do processo de apropriação fundiária, mas não é possível reconstituí-lo apenas pela localização, no território, das extensões concedidas. Maurício de Abreu (1997) mostrou as inúmeras "brechas" do sistema sesmarial, como os posseiros, que ocupavam porções não aproveitadas de sesmarias, e os "restos de sesmarias", áreas devolutas que permaneciam entre os limites das concessões legais e que eram apossadas pelos agricultores. O autor também demonstra que as sesmarias eram freqüentemente subdivididas, por herança ou por venda, havendo um ativo mercado de terras nas regiões mais densamente povoadas. Além disso, muitos sitiantes estabeleciam-se, como veremos, como agregados em terras alheias. Dessa forma, a apropriação fundiária não se limitava apenas às concessões de sesmarias, tendo existido muitas outras formas que escapam às fontes que estudamos.

Pudemos, dessa maneira, avançar na compreensão da geografia da colonização do território de Minas Gerais, nas primeiras décadas do século XIX. O mapa da figura 11 mostra os termos das vilas de Barbacena e Campanha, da cidade de Mariana e do julgado do Desemboque, territórios onde se encontravam, respectivamente, 45\%, 5\%, 23\% e 7\% das 595 sesmarias concedidas entre 1818 e 1822 , perfazendo $80 \%$ do total de cartas. Pela distribuição espacial e cronológica das áreas concedidas em sesmarias,

37 O que significa um número bem menor de sesmeiros, pois, vale lembrar, os fazendeiros sesmeiros eram minoritários, predominando os fazendeiros posseiros e agregados. 
foi possível verificar que o Leste e o Extremo Oeste (hoje Triângulo Mineiro) correspondiam às fronteiras da capitania, naquele período.

Vimos que a instituição sesmarial era um importante instrumento do Estado para promover a colonização de regiões de fronteira, mas era também o reflexo das migrações que para elas se dirigiam, motivadas por fatores outros que não a política oficial. No caso em estudo, esses fatores estavam ligados às tensões demográficas nas regiões de emigração, geradas pelo crescimento de uma população que tinha por base uma economia agropastoril, de nível técnico rudimentar. Resta avaliar, na região em estudo, como se deu a apropriação fundiária sobre terras antes ocupadas por povos indígenas, e os conflitos gerados nesse processo.

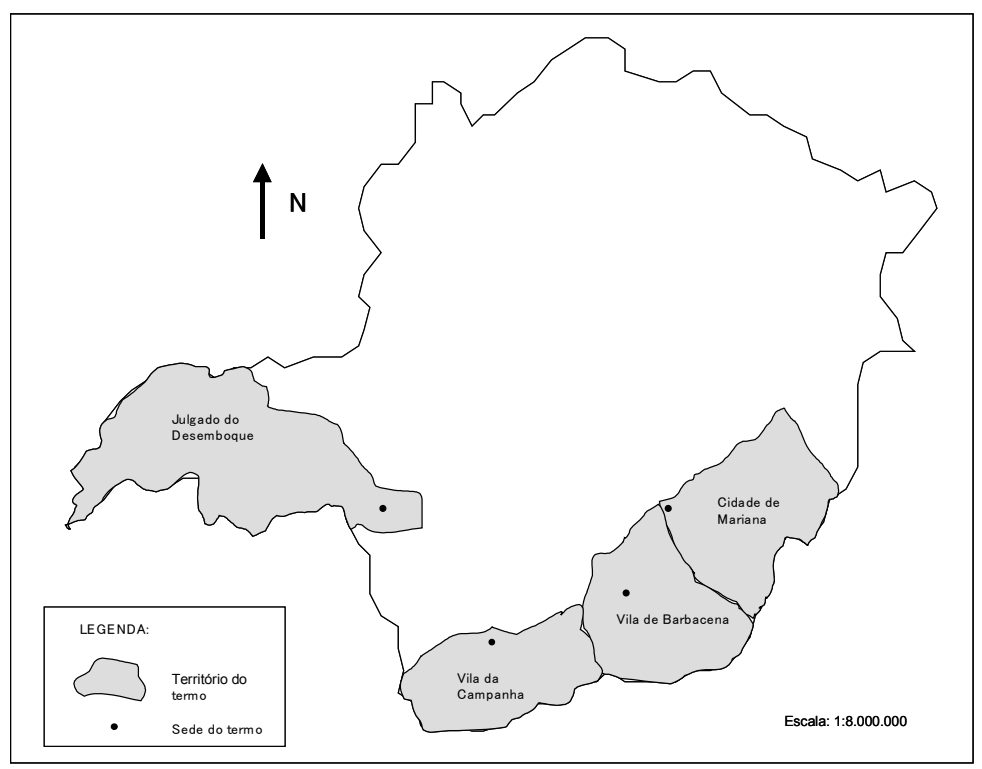

Figura 11: Termos das vilas e julgados correspondentes às principais áreas de fronteira da capitania de Minas Gerais (1818-1822).

Fontes: RAPM (1988), Mendes (2000), Barbosa (1995). 


\section{Geralistas contra índios: o primeiro conflito de terras do Triângulo Mineiro}

Em 1809, o Marquês de Palma, governador da capitania de Goiás, nomeou o sargento-mor Antônio Eustáquio Silva e Oliveira diretor dos índios do Sertão da Farinha Podre (SILVA, 1970). A partir de então, esse fazendeiro empenhou-se, de forma obstinada, em expulsar os índios da faixa de terras de três léguas em torno da Estrada do Anhanguera, para torná-las livres para o assentamento de colonos.

Parte dessas terras já havia sido espoliada, em 1812, ao se propagar, entre os colonos, a versão de que as terras aldeanas estendiam-se por meia légua, e não légua e meia, de cada lado da Estrada. ${ }^{38} \mathrm{O}$ geralista Tristão de Castro, por exemplo, já havia se afazendado, antes de 1812, em terras localizadas dentro da faixa aldeana. Ali, junto com sua esposa, suas duas filhas e mais sete escravos, construiu um sítio com um engenho de cana e uma casa coberta de capim. ${ }^{39}$ A propriedade dessas terras já tinha sido reconhecida nessa data, pois doou parte delas a um patrimônio para ereção da capela de Santo Antônio e São Sebastião, onde seria fundado, quatro anos depois, em terras indígenas, o arraial da Farinha Podre (SAmpaIO, 2001).

Antes de o potentado uberabense Antônio Eustáquio dar o golpe final sobre os direitos fundiários indígenas, em 1821, os viajantes joaninos, que por lá passaram entre 1816 e 1819, encontraram vários fazendeiros já instalados em terras aldeanas, a maioria na condição de foreiros ou agregados. Eschwege (1996), que em 1816 fez o trajeto norte-sul pela Estrada dos Goiases, encontrou, no ribeirão das Furnas, um colono casado com uma índia e instalado na faixa de terras indígenas. Na beira do rio Tejuco, ao longo da Estrada, vivia outro colono, também casado com uma índia e com um filho pequeno (EsCHWEGE, 1996).

A seqüência cronológica dos relatos de Eschwege (1986), D’Alincourt (1975) e Saint Hilaire (1975 a) sobre o sítio da Rocinha ${ }^{40}$ dá-nos uma idéia diacrônica do processo de espoliação dos índios. Na Rocinha, o aristocrata alemão, em 1816, registrou existir uma aldeia com duas famílias indígenas — na verdade, um sítio

38 Essa imprecisão provocou inclusive uma pendência judicial em 1909 entre a câmara de Uberaba e a fábrica da Matriz, pois esta alegava o direito ao patrimônio doado por Tristão de Castro, enquanto a câmara lembrava que as terras dos índios, transformadas em terras devolutas, correspondiam a légua e meia de cada lado da estrada e, portanto, incluíam todo o patrimônio da matriz de Uberaba. (PONTES, 1978)

39 APU, inventário de Tristão de Castro (25/08/1825), maço N21, caixa 459.

40 Hoje Tapuirama, distrito de Uberlândia. 
indígena — que eram "invejadas pelos portugueses da vizinhança" (p. 124), pois dispunham de fontes de água salitrosa para o gado. No ano seguinte, D'Alincourt (1975) não encontrou mais as famílias indígenas, mas a Fazenda da Rocinha, a mesma visitada por Saint Hilaire dois anos depois. Ali, o naturalista francês encontrou um homem que havia chegado há pouco tempo do arraial goiano de Bonfim:

Esse homem [...] viera morar no meio dos índios por razões desconhecidas. Ele me disse, é bem verdade, que achava mais vantajoso viver nessa região, onde os produtos tinham escoamento mais fácil que em Bonfim, o sal era menos caro e as pastagens excelentes (Saint Hilaire, 1975 a, p. 147).

O cronista afirmou, contudo, que o número de brancos nas terras dos índios ainda era pequeno em 1819, pois, nas vizinhanças, ainda existiam terras abundantes (Saint Hilaire, 1975 a). A partir dessa data, com o aumento da imigração dos geralistas, aumentou a demanda fundiária, fazendo crescer, como decorrência disso, a pressão pela espoliação das terras aldeanas.

Eschwege (1996), ao fazer a viagem para a demarcação dos limites da capitania de Minas, em 1816, encontrou-se em Rio das Pedras com o principal $^{\text {11 }}$ daquele aldeamento, um índio chamado Leopoldo. Este lhe disse que os índios de sua aldeia tinham ouvido falar que perderiam seus direitos e suas terras e seriam escravizados. Ao passar por Farinha Podre, encontrou-se com o sargento-mor Antônio Eustáquio, e o apontou como o algoz dos índios da região:

Nas regiões afastadas das capitais e, particularmente nos sertões, encontram-se quase sempre indivíduos que, por meio da inteligência ou de sua riqueza, são superiores aos vizinhos e, de certo modo, conseguem sujeitá-los, embora poucas vezes em benefício da própria comunidade. Também nessa região, um desses tais instituíra-se em soba, cujas ordens valiam, em geral, mais que as do governador, e cujo chicote se exercia mais e mais sobre os pobres índios. Ele comunicou-me que o projeto que tinha em mente, de tomar pouco a pouco a seus índios o seu distrito, para distribuí-lo entre os portugueses, sob o pretexto de que o Rei deles não auferia lucro. (1996, p. 126).

41 Liderança indígena dos aldeamentos. 
Saint Hilaire (1975 a) também não teve boa impressão do potentado uberabense: chamou-o de "pequeno déspota", ao se referir às suas ações antiindígenas.

Um documento assinado por trinta e cinco fazendeiros da Farinha Podre, de 1818, outorgava ao sargento-mor Antônio Eustáquio o poder de comandar a colonização dos sertões sob sua regência, e pedia ao ouvidor da comarca de Paracatu sua nomeação como juiz de sesmarias, o que se deu em 1819 (TeIXEIRA, 2001). A partir de então, ele teria o poder de estabelecer os limites das sesmarias e posses, o que foi usado em favor dos fazendeiros - e em prejuízo dos índios.

Em 1821, os índios apresentaram uma queixa contra os invasores de suas terras, à frente dos quais Antônio Eustáquio, que estavam expulsando a maioria das famílias indígenas que viviam no trecho de terras aldeanas entre o rio Grande e o rio das Velhas (Eschwege, 1996). De fato, algumas sesmarias concedidas nesse período já se situavam dentro de terras indígenas. É o caso da sesmaria de José Alves de Resende, com carta datada de 1821, que se limitava “[...] pelo nascente pela estrada que vai para Goiases, pelo norte com o Rio das Velhas, e pelo sul com o Rio Uberava [Legítimo][...]” (APU, 1987, p. 37). Na mesma data, João Pereira da Rocha, que já havia se instalado numa fazenda vizinha ao rio das Velhas, tomou posse de mais uma porção de terras que se estendiam até o Ribeirão Rocinha, também em área de terras aldeanas (figura 12).

Seria um erro, contudo, acreditar que a expropriação fundiária dos indígenas foi obra apenas de grandes sesmeiros e fazendeiros. Há provas de que também pequenos sitiantes apossaram-se de terras indígenas. À beira do rio Uberaba Legítima, ao longo da Estrada dos Goiases, por exemplo, Saint Hilaire encontrou um velho agricultor, vivendo sozinho e pobremente: "em sua casa viam-se apenas algumas cabaças que lhe serviam de vasilhas, umas poucas panelas e uma pequena provisão de milho destinada a ser vendida aos viajantes" (1975 a, p. 149). O inventário post mortem de Ana Joaquina de Jesus, mulher de João Manuel Garcia, descreve seu sítio como localizado "no Taquaral, em terras da Estrada" ${ }^{42}$ — portanto, na faixa indígena — em 1829. Esse casal de modestos sitiantes não possuía escravos, sendo seu patrimônio formado apenas por dois bois carreiros, um cavalo e uma égua.

Em 1827, os sesmeiros da região do rio das Velhas fizeram uma denúncia

42 APU, inventário de Ana Joaquina de Jesus (16/10/1829), maço N44. 
contra o Fiel do Registro de Santana, que estaria afastando os marcos de sesmaria de dentro da faixa de uma légua e meia ao longo da Estrada de São Paulo, alegando que tais terras pertenciam aos índios. O presidente da província consultou Antônio Eustáquio sobre a questão, e este respondeu tomando o partido dos fazendeiros: “[...] inicialmente as terras próximas à estrada permaneceram desocupadas por se ouvir dizer que pertenciam aos índios da Aldeia de Santana" (Brasileiro, sd, p. 15). Procurou então por Ordem Régia, ou do Governador da antiga capitania de Minas, que concedesse aos índios

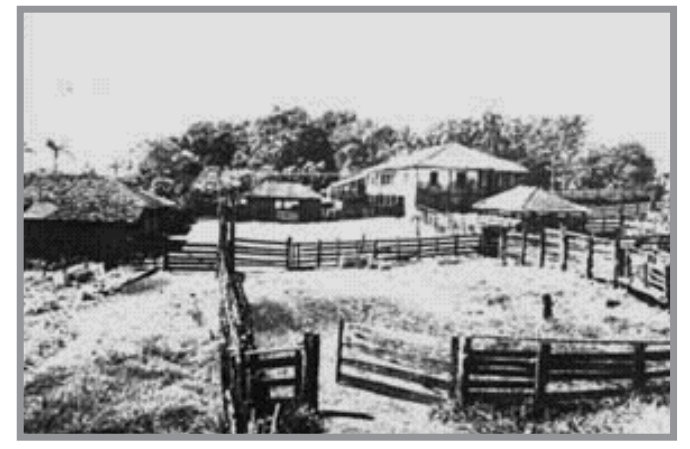

Figura 12: sede da fazenda de João Pereira da Rocha, um dos geralistas que se apossaram de terras expropriadas aos aldeamentos indígenas

Fonte: http://www.uberlandia.mg.gov.br

uma légua e meia de cada lado da Estrada, entre o rio Grande e Paranaíba. Continuou o sargento-mor:

[...] e como não as encontrasse ainda mesmo consultando o Diretório que servisse aos índios, tomei o expediente de franquear todo o terreno às pessoas já mencionadas [os entrantes] para lançar suas posses, reservando todavia meia légua de cada lado da referida estrada para a residência de alguns poucos índios que se achavam dispersos da Aldeia [...] A meia légua reservada também se foi pouco a pouco ocupando até que hoje, porque o povo custa a conter-se, acha-se com mais de mil pessoas o contudo em nada prejudicou, nem prejudica a esses poucos índios já referidos, da Aldeia de Santana os quais tem todo o terreno que se lhes demarcou desde o Rio das Velhas até o Paranaíba em distância de 14 léguas de comprimento com 3 de largura (BrasiLeIro, sd, p. 15). 
O raciocínio usado pelo chefe político uberabense era típico das concepções que informavam a política indigenista do Império, na primeira metade do século XIX: os governos provinciais curvavam-se às pressões exercidas pelos poderes locais, e iniciava-se um processo que Carneiro da Cunha (1998) chamou de politica de concentração dos grupos indígenas. Esta consistia na deportação de índios das reservas para núcleos de adensamento, de forma a liberar as terras indígenas para a colonização.

No caso da Farinha Podre, as ações dos colonos liderados por Antônio Eustáquio - posteriormente referendadas pelo governo provincial — reduziram as terras indígenas de $1.072 \mathrm{~km}^{2}$ (do rio Paranaíba ao rio Grande) para apenas $40 \%$ disso, ou $412 \mathrm{~km}^{2}$ (faixa entre o rio das Velhas e o rio Paranaíba). De acordo com o documento reproduzido por Eschwege (1996), 871 índios foram desalojados da faixa situada no termo de Uberaba e deportados para a faixa do norte, no termo do Araxá, onde se juntaram aos 637 índios que já viviam ali. Com isso, aproximadamente $660 \mathrm{~km}^{2}$ entre o rio Grande e o rio das Velhas foram liberados para a colonização (figura 13). Em 1823, o tenente Inocêncio de Miranda recenseou apenas 67 índios ainda vivendo ao sul do rio das Velhas (BARBOSA, 1995).

Um outro documento, redigido em 1829 e que se encontrava em poder do padre Hermógenes Casimiro de Araújo, vigário do Desemboque e primo de Antônio Eustáquio, deixou claro qual fora a intenção, quando da expulsão dos índios da Farinha Podre. Esse texto resumiu os eventos que se desenrolaram entre 1816 e 1827:

Como essas hordas de índios se fossem diminuindo em número, e o sargento-mor Antônio Eustáquio Silva e Oliveira fosse encarregado por P. do Exmo. Marquês de Palma então Governador da província de Goiás de explorar e acomodar os novos colonos que para os sertões do Tijuco e Rio da Prata e suas anexas mudassem os seus estabelecimentos propôs o dito S. M. ao Governo de Minas [...] que algumas dessas hordas de índios que ainda existiam entre o Rio das Velhas e o Rio Grande, território do Julgado do Desemboque, fossem mudadas para o território do Araxá que fica entre o Rio das Velhas e o Rio Paranaíba (Sampaio, 2001, p. 148).

Adiante, o documento esclarece que toda essa ação de expropriação contou com a chancela das autoridades provinciais, que, em seguida, liberaram o território para a colonização: 
Anexo a esta representação o Governo de Minas, sendo então o Governador da província D. Manuel de Portugal e Castro e por seu despacho mandou que a Reg. dos mesmos índios fizesse mudar essas hordas de índios para o indicado território, como de fato se mudaram. Exaqui como ficando recolhido ao Patrimônio nacional aquele território evacuado das ditas hordas de índios também ficou sendo livre de concessão e aquisição e por isso muitos proprietários nele existentes lançaram posses e levantaram nele seus estabelecimentos que estão possuindo (SAMPaio, 2001, p. 148).

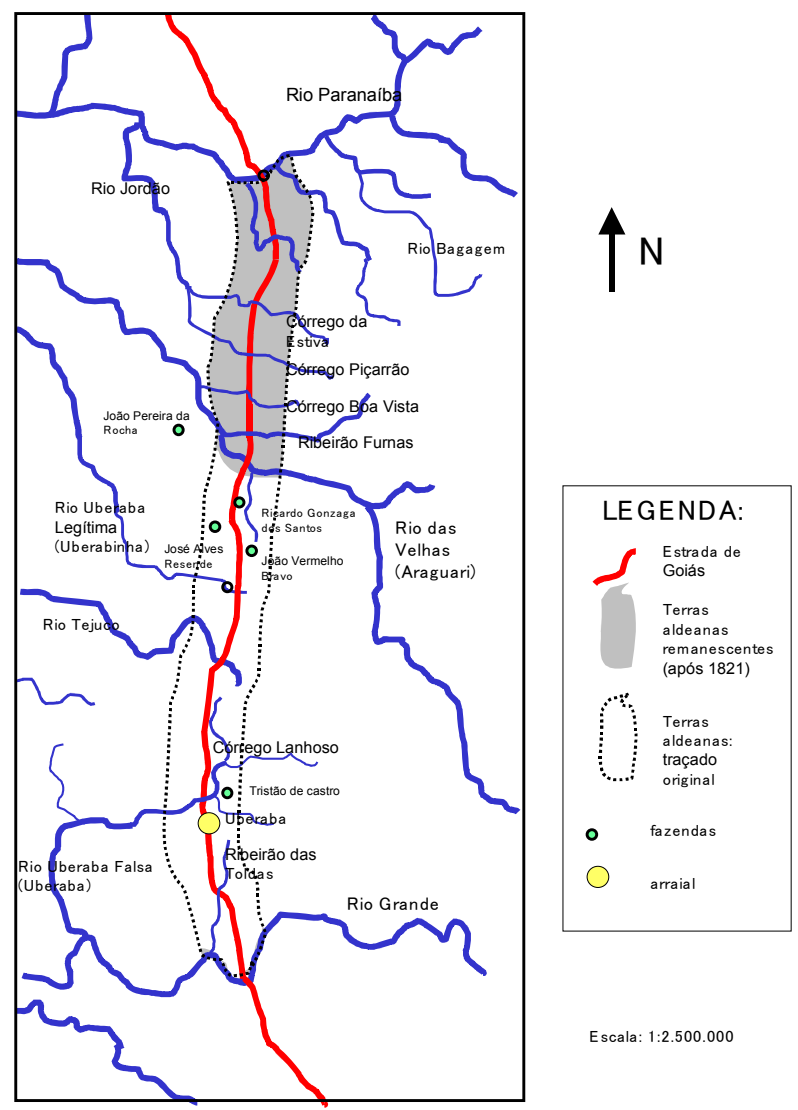

Figura 13: expropriação de terras indígenas no Triângulo Mineiro (1819-1821). Fonte: Eschwege (1996), Sampaio (2001), Teixeira (1970), APU (1987). 
Nossas fontes revelam que alguma resistência foi esboçada pelos índios, durante processo de espoliação a que foram submetidos. As duas queixas, redigidas pelos representantes dos índios aldeados, vistas anteriormente, são um exemplo. Uma outra forma de resistência deve ter sido o uso da violência contra os invasores: D'Alincourt encontrou, próximo ao aldeamento do Lanhoso, uma familia de posseiros brancos "a quem dois índios ali estabelecidos queimaram tudo quanto possuía, e ainda quando passei estava arranchado debaixo de uma coposa árvore" (1975, p. 76).

A espoliação das terras indígenas no termo de Uberaba não era um caso isolado no Brasil do período joanino. Era parte de um processo mais geral, que ocorria em todo o país, particularmente nas regiões de fronteira. A política indigenista pombalina, que estimulava o aldeamento, a aculturação, a mestiçagem e a transformação do índio num povoador, fora definitivamente abandonada com a extinção do Diretório, em 1798. No século que se iniciava, a nova política indigenista seria francamente pior do que a do século XVIII. O índio não interessava mais como força de trabalho, como no século XVII, nem como povoador, como no período pombalino. Suas terras, no entanto, com o crescimento demográfico e a expansão econômica, passaram a ser alvo dos interesses do Estado e da sociedade luso-brasileira. Nas palavras de Carneiro da Cunha:

Porque é fundamentalmente um problema de terras e porque os índios são cada vez menos essenciais como mão-de-obra, a questão indígena passa a ser discutida em termos que, embora não sejam inéditos, nunca haviam no entanto sido colocados como uma política geral a ser adotada. Debate-se a partir do fim do século XVIII e até meados do século XIX, se se devem exterminar os índios "bravos", "desinfestando" os sertões, — solução em geral propícia aos colonos — ou se cumpre civilizá-los e incluí-los na sociedade política — solução em geral propugnada por estadistas [...] (1998, p. 134).

O século XIX, segundo a autora, questionou a humanidade dos índios, muito influenciado pelo pensamento cientificista da época. A guerra justa contra os índios, típica dos séculos XVI e XVII, foi ressuscitada por D. João VI, no combate e extermínio dos botocudos do rio Doce. Na verdade, esses discursos apenas racionalizavam o projeto maior de civilização do espaço, o que, na prática, 
significava o alargamento dos espaços apropriáveis no território. A crescente demanda por terras, em parte resultado da expansão de cultivos de exportação para o interior do país, em parte conseqüência do crescimento demográfico e da expansão do mercado interno, junto com o discurso de desumanização dos índios foram os elementos que levaram às práticas que culminaram no desaparecimento de vários grupos étnicos no Brasil, dentre eles, os bororos, chacriabás e caiapós do Triângulo Mineiro.

Com a transferência da Corte para o Rio de Janeiro, em 1808, o poder imperial passou a ser mais diretamente pressionado por interesses localistas. A questão indígena, por isso, passava cada vez mais da esfera do governo central para as Câmaras Municipais: "são em geral as Câmaras Municipais, cobiçosas de terras, que pressionam no sentido da concentração de índios em poucas aldeias" (CunHA, 1998. p. 144). Como vimos, os interesses da proto-oligarquia uberabense foram o fator que motivou a expropriação das terras aldeanas no Triângulo, de 1816 a 1827. Também aqui, o governo provincial legitimou todas as ações antiindígenas do poder local.

Ao norte do rio das Velhas, na faixa de terras indígenas situada entre este rio e o Paranaíba, os aldeamentos ainda sobreviveriam à pressão dos colonos até a segunda metade do século XIX. Mas também ali, em terras situadas no termo da Vila de Araxá e onde estavam os dois aldeamentos mais populosos - Santana e Rio das Pedras — os conflitos com os colonos brancos já se fizeram sentir nos anos 1830.

Naquele ano, em Santana do Rio das Velhas, o regente do distrito dos índios Manuel José de Almeida dirigiu-se ao Presidente da província denunciando invasores, inclusive o juiz de paz Joaquim Rodrigues de Resende. Segundo o regente, mais de 50 fazendeiros violavam os domínios dos índios. Nos anos seguintes, uma denúncia revelava que dois índios tiveram suas choças incendiadas por capangas a serviço do fazendeiro Antônio do Vale Pereira. Em 1836, a Câmara de Araxá propôs ao governo provincial a dispersão dos índios (BArbosa, 1995).

A população do aldeamento de Santana pouco cresceu nesse período. Em 1838, o núcleo perdeu a prerrogativa de paróquia, após 77 anos (TEIXeIRA, 2001). Em 1843, a paróquia foi restabelecida, e nesse mesmo ano foi visitada pelo mineralogista francês Francis Castelneau, que observou já predominarem os luso-brasileiros na população do arraial: 
a aldeia de indígena só tem o nome, pois hoje é habitada apenas por brasileiros. [...] dispersando-se depois [de fundada] a colônia, que de índia que era, passou pouco a pouco a tornar-se quase portuguesa, com exceção dos poucos descendentes mestiços que ainda se vêm (2000, p. 124).

Três anos mais tarde, um relatório de Uberaba informava que na aldeia ainda viviam 424 índios, mas que as melhores terras de cultura já haviam sido tomadas pelos brancos (BARBOSA, 1995). Tito Teixeira (1970) relatou que, ao tempo da Guerra do Paraguai (1865-1870), índios de Santana ainda eram vistos cultivando algumas roças na margem direita do rio das Velhas. As referências aos índios dessa região desaparecem das fontes a que tivemos acesso, a partir dessa data.

$\mathrm{Na}$ verdade, as terras indígenas, submetidas a grilagens desde 1821, permaneceram devolutas até bem recentemente. Existe uma esclarecedora carta do técnico agrícola José Carlos Pedro Grande, destinada ao historiador araguarino Calil Porto, que indica a forma como provavelmente se dava a expropriação indígena. ${ }^{43}$ José Carlos havia sido assistente do $7^{\circ}$ Distrito de Terras e Colonização, sediado em Uberaba, em 1914, e fora chamado para regular a situação das terras ditas aldeanas, próximas ao distrito de paz de Santana do Rio das Velhas, já então no município de Araguari. Identificou-as como se estendendo "do Porto do Registro [no rio das Velhas] até o Porto Mão de Pau [no Rio Paranaíba], légua e meia para cada lado da estrada [do Anhanguera]".

Inúmeras invasões teriam ocorrido na tal faixa após o fim do regime de sesmarias, em 1822. Com a Lei de Terras, em 1854, as paróquias passaram a poder registrar no livro das freguesias "as terras ocupadas pacificamente". Diversos desses registros haviam sido examinados pelo técnico, mas, em 1910, a paróquia de Santana os queimou, pois o Bispado de Uberaba estava envolvido numa questão de terras. O agrimensor lembrava-se, contudo, de que as posses haviam se limitado às terras de cultura, e campos e chapadões permaneciam, ao tempo do seu trabalho, devolutas.

Assim permaneceram até bem recentemente, como mostra um artigo publicado num jornal de Uberlândia em 30 de Janeiro de 1939, escrito pelo agrimensor e então prefeito de Indianópolis, Nelson Soares de Oliveira,

43 José Carlos Pedro Grande, carta a Calil Porto, 1962, originais de Calil Porto, vol. 3, p. 8, Arquivo Público de Araguari. 
envolvido numa disputa de divisas com o município de Araguari.

De forma alguma a estrada do Anhanguera passa na cabeceira do Santo Antônio, estando desta cabeceira afastada 10.000 metros aproximadamente. Esta estrada ninguém a conhece como eu: levantei-a toda, pelos seus marcos de pedra de 1 metro de altura, existentes há mais de 70 anos, para subdivisão das terras devolutas que circundam a mesma. Isto é, todas as terras situadas a légua e meia portuguesa da mesma são devolutadas. O limite da légua e meia do lado de quem sobe de Indianópolis para o Paranaíba ainda está a mais de 900 metros da cabeceira do Córrego Santo Antônio. A prova real disto é que deixei a fazenda do Santo Antônio como legítima por estar a mais de légua e meia da estrada do Anhanguera (Oliveira, 1939).

A posse livre de terras, que perdurou entre o fim das sesmarias e a Lei de Terras de 1850, foi talvez a brecha da qual muitos colonos se aproveitaram para expropriar terras aos índios, na faixa aldeana ao norte do rio das Velhas. O fato de a maioria dessas terras serem de cultura torna pouco provável que a posse tenha sido pacífica.

Sobre a Aldeia do Rio das Pedras, temos poucas informações entre o último registro de Saint Hilaire, em 1819, e a criação do distrito de paz em 1890. Um Decreto Imperial de 1854, vigente até 1856, reconhecia, no distrito de Rio das Pedras (então município da vila da Bagagem ${ }^{44}$ ) uma demarcação de uma faixa de terras de cinco por três léguas como reserva dos índios (FERREIRA, 1959), com certeza, o trecho em torno da Estrada do Anhanguera. Uma Carta de Minas Gerais, produzida pelo engenheiro Henrique Gerber a pedido do presidente da província, em 1862, mostra Rio das Pedras e ainda os aldeamentos de Boa Vista, São Domingos e Lanhoso (figura 14). Os demais já haviam desaparecido

$\mathrm{O}$ que parece certo é que os aldeamentos não evoluíam diretamente para arraiais. A pobreza indígena, o fato de serem habitats rurais concentrados e não aglomerados pré-urbanos, a expropriação de terras e a exploração em regime de semi-escravidão, o estigma de índios, tudo isso contribuiu para a forte tendência centrífuga dos aldeamentos, fazendo com que nunca passassem de um aglomerado de casebres e uma capela freqüentemente em ruínas.

$\overline{44 \quad \text { Hoje Estrela do Sul. }}$ 
Alguns aldeamentos desapareceram sem deixar vestígios, como Estiva, Piçarrão, Boa Vista e Lanhoso. Outros tiveram seus sítios ocupados por povoados ou cidades, mas sem nenhum tipo de continuidade com o espaço e a sociedade criados pelos índios, como Rocinha e a Aldeia de Uberaba. Outros só começaram a evoluir para arraiais no momento em que deixaram de ser considerados aldeias, fazendo com que pouco a pouco se diluísse o

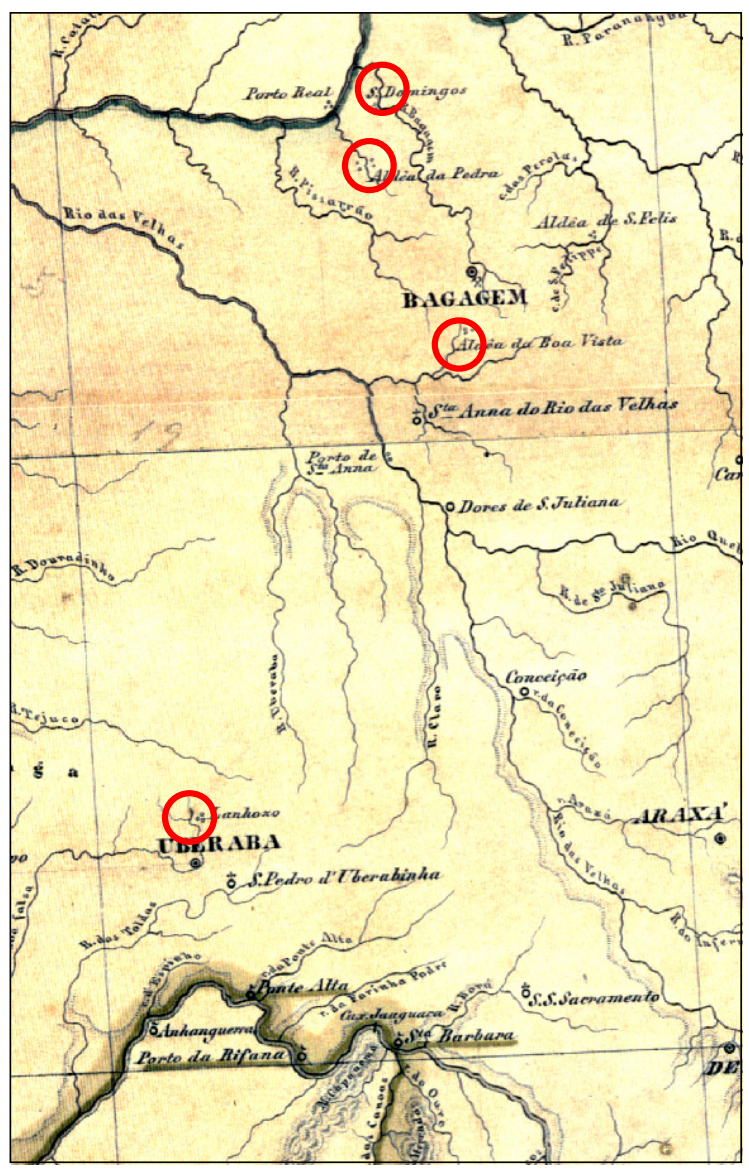

Figura 14: Aldeamentos do Triângulo Mineiro no mapa de Gerber (1862) Fonte: Gerber (1862) 
estigma de indios. A partir daí, estes foram sendo substituídos ou fundiramse com os invasores brancos, como no Rio das Pedras e em Santana. Nossa conclusão, ao se estudar todos esses casos, é a mesma de Petrone:

[...] na realidade o papel dos aldeamentos para o povoamento em última análise foi diminuto, dado que, a não ser poucas exceções, durante séculos não deram margem ao surgimento de núcleos urbanos. [...] considerada a natureza de suas funções, os aldeamentos dificilmente poderiam evoluir dentro dos padrões comuns aos povoados frutos das iniciativas dos moradores europeus. A natureza de aldeamento distinguia-os dos povoados de moradores brancos, estes podendo evoluir para condições rururbanas desde que tivessem possibilidades para isso, aqueles permanecendo com suas características originais. A prova está no fato de que, somente quando a tutela dos indígenas deixou de existir, com a abolição da condição de aldeado, é que os núcleos puderam evoluir dentro de padrões comuns aos restantes (1995, p. 341).

Ao mesmo tempo em que as oligarquias uberabenses se esforçaram em colonizar o Sertão da Farinha Podre, à custa da expropriação dos índios aldeados em torno da Estrada do Anhanguera, houve a iniciativa de aldear os últimos remanescentes de índios caiapós que ainda viviam no baixo rio Grande. Não há paradoxo nisso: aldear os últimos caiapós significava dar continuidade à política de concentração dos grupos indígenas, de forma a liberar seus territórios à colonização.

Eschwege (1996) relatou que esses índios ainda atacavam colonos em 1816, e em 1826 Antônio Eustáquio enviou notícias sobre uns mil caiapós que povoavam as margens do rio Grande (CÉSAR, 1975). Mas, em 1827, o padre Leandro Rabelo Peixoto e Castro só encontrou índios dóceis e fragilizados (PONTES, 1978). Nessa data, o padre fora enviado pela Congregação da Missão São Vicente de Paulo, com sede no Caraça, para fundar um colégio no patrimônio doado pelo fazendeiro João Batista de Siqueira na região do Campo Belo, ${ }^{45}$ entre os rios São Domingos e Verde, afluentes do Grande. O padre Leandro contatou os índios caiapós, e em carta ao presidente da província, relatou sua experiência:

45 Hoje Campina Verde. 
Tive fala com os índios caiapós, e apesar de só por intérprete lhes falava, achei neles as melhores disposições, batizei quatro meninos com consentimento de seus pais aos quais não batizei por não terem instrução, mas os convidei e consegui que viessem morar junto da nossa habitação, lhes fiz arranjamentos, os vesti e dei as providências para que com eles mesmos se fizesse roça e plantasse mandioca para o seu sustento, enfim eu os vi chorar quando deles me apartei [...]. O padre David é quem ficou à testa desse aldeamento que dista 32 léguas de Santo Antônio de Uberaba e 5 léguas do Rio Grande quase junto ao Parnaíba (Pontes, 1978, p. 89-91).

Naquele local, o padre vicentino fundou um aldeamento, onde foram reduzidos os últimos caiapós do Triângulo Mineiro. Vigário Silva, em sua História Topográfica, referiu-se a 1.000 índios caiapós aldeados a 30 léguas de distância do arraial de Uberaba. Tratava-se certamente do aldeamento vicentino e, por suas informações, sabemos que Antônio Eustáquio também dirigia aquele núcleo:

Estes índios caiapós passeiam de tempos em tempos por toda a freguesia, mas não cometem a menor hostilidade, o que se deve sem dúvida ao jeito e ao amor com que têm sido tratados pelo sargento-mor Antônio Eustáquio da Silva, que os visita todos os anos, prodigalizando-lhes roupa e ferramentas, ora a sua custa, ora a custa da Fazenda Pública (SiLva, 1970, p. 9).

Com a redução dos últimos caiapós, o sertão dos baixos cursos dos rios Grande e Paranaíba, região hoje conhecida como Pontal do Triângulo Mineiro, estava livre para a colonização. Povoações novas foram surgindo, como Campo Belo, e do outro lado do rio Paranaíba, na província de Goiás, o arraial de Santana do Paranaíba, ${ }^{46}$ núcleos que tornaram possível a abertura da estratégica estrada do Piquiri, ligando Uberaba ao Campo Grande da Vacaria. ${ }^{47}$

A tendência demográfica do núcleo caiapó, como os demais, também foi de despovoamento. Em 1846, padre Jerônimo Gonçalves de Macedo batizou o aldeamento caiapó com o nome de Missão de São Francisco de

46 Hoje Paranaíba, no estado do Mato Grosso do Sul.

47 Hoje Campo Grande (MS). 
Sales, ${ }^{48}$ que em seu tempo contava com apenas 200 índios (BArBosa, 1995). Em pouco tempo, também na Missão os índios desapareceriam: o mapa de Gerber, de 1862, já não menciona mais S. Francisco de Sales como aldeia, e sim como arraial, o que torna provável que, naquele momento, os índios já fossem minoritários frente aos colonos no núcleo.

Parte desses índios foram deslocados para a Aldeia da Baixa, um dos aldeamentos bororos recenseados por Eschwege, a três léguas ao sul de Uberaba. Um documento de autoria anônima, datado de 1866, citado por César, referia-se aos caiapós da Baixa:

Sendo em outro tempo agressores e cometendo não pequenas hostilidades, hoje se conservam na maior quietação depois que os reduzi à amizade, dando-lhes roupas, ferramentas e algumas quinquilharias (1975, p. 308). ${ }^{49}$

E adiante, outro trecho sugere que a aculturação (ou civilização) era a intento ao se reduzir índios tão próximo a Uberaba, um argumento coerente com o discurso ilustrado da época, que propunha a miscigenação dos índios e sua assimilação pela sociedade brasileira:

Dê-se uma légua de terra a uma grande família de índios; dê-se uma légua vizinha a um brasileiro de grande família; assim se vão entrelaçando e civilizando sem maior despesa da Nação que deve, contudo, dar um pároco que sirva para os índios e para os brasileiros (CÉSAR, 1975, p. 308).

Na Corografia Histórica de Cunha Matos, de 1837, lê-se que caiapós ainda atravessavam com certa freqüência o Paranaíba, próximo da foz desse rio no Grande, e que "há poucos anos fizeram grandes depredações nessa comarca e na do rio das Velhas, mas agora raríssimas vezes penetram no rio Paranaíba" (1979, p. 55-56).

$\mathrm{O}$ último registro sobre os caiapós na região data do século $\mathrm{XX}$, feito pelo etnólogo Curt Nimuendaju: “em 1910 [a tribo] estava reduzida a umas trinta e tantas pessoas, em ambas as margens do rio Grande, abaixo

48 Hoje São Francisco de Sales.

49 José Vicente César, Índios de Minas Gerais por ocasião da Independência, Revista do Instituto Histórico de Minas Gerais, vol. XVI, 1975, p 308 
do Salto Vermelho, a $19^{\circ} 50^{\prime} \mathrm{S}$ e 50 30' O” (1982, p. 219), a $50 \mathrm{~km}$ a oeste da Missão de São Francisco de Sales, nas proximidades da atual cidade de Iturama.

Mas afinal, para onde foram os índios? É muito provável que tenham tido o mesmo destino dos índios dos aldeamentos paulistas, a respeito do qual Petrone (1995) e Monteiro (1994) concordam: a caboclização, isto é, a fusão com o campesinato pobre da região. Ao emigrar dos aldeamentos, fugiam da pobreza, do esgotamento de terras, da violência e do estigma de casta de indios. É provável que tenham se incorporado à massa de agregados pobres e posseiros que gravitavam em torno das grandes fazendas na região, e tenham se tornado, com o tempo, indistinguíveis deles. Tivemos a oportunidade, em outro trabalho, de reproduzir o relato de um antigo morador do meio rural de Uberlândia, Sr. Oscar Jacinto de Souza, nascido em 1894, que afirmava ser neto de uma índia da Aldeia de Santana (Lourenço, 1986). Na verdade, quantos de nós, no Triângulo Mineiro, não temos na família uma história de descendência de uma índia "pega no laço"?

Neste capítulo, procuramos entender o movimento migratório de roceiros e criadores que, vindos da região aurífera de Minas, povoaram a região em estudo, nos últimos anos do século XVIII e primeiros anos do século XIX. Vimos que os fatores de natureza demográfica e ambiental estavam na base das motivações daquela migração. O Estado teve participação central nas diferentes fases do processo de colonização, das áreas de fronteira do território mineiro, como o Sertão da Farinha Podre: nas campanhas contra os quilombos, no século XVIII; na concessão de sesmarias; na política indigenista; na abertura de picadas e estradas. A migração tomava a forma de deslocamentos de núcleos familiares, às vezes organizados em parentelas, fundamentais ao estabelecimento de redes de solidariedade, na região de chegada. A chegada dos migrantes geralistas no Triângulo Mineiro, porém, provocou a expulsão dos índios que ali viviam, e a destruição dos seus aldeamentos.

Analisamos, enfim, a gênese da configuração territorial do Triângulo Mineiro oitocentista. Resta estudar a espacialidade produzida por essa sociedade, isto é, a forma como ela, no ambiente do Cerrado do Triângulo Mineiro, de posse de um dado complexo de técnicas, dispondo de determinados 
Triângulo Mineiro: uma fronteira na Colônia e no Império

referenciais culturais, e inserida numa certa estrutura econômica territorial e mundial, produzia formas espaciais específicas. Abordaremos, no capítulo que se segue, o meio técnico no Triângulo Mineiro do século XIX. 


\section{As formas do viver no sertão}

\section{A dimensão da técnica na Geografia Histórica}

No primeiro capítulo de A Natureza do Espaço, obra em que faz a sistematização de seu pensamento, Milton Santos (1996) discute a importância da técnica para a apreensão do conceito de espaço. Segundo o autor, a técnica é a forma como as sociedades operam no espaço. Mas ela não é só isso: a técnica é, ela própria, um meio, isto é, as sociedades, ao utilizarem-na, criam um novo meio natural. As técnicas são os objetos que compõem o espaço, mas objetos prenhes de conteúdo, isto é, só fazem sentido à medida que são usados pelos atores sociais.

Santos fala então em formas-conteúdo: os objetos (formas) só são técnicos por terem uma lógica que os aciona, arranjados num todo coerente (conteúdo). O espaço, na concepção miltoniana, seria composto por essas formas-conteúdo. Os objetos técnicos propagam-se no espaço na forma de sistemas técnicos, isto é, conjuntos de elementos técnicos historicamente datados. Toda técnica, nesse sentido, ao difundirse ou surgir num determinado lugar, o faz segundo as condições históricas que ali operam: a técnica é a síntese da história no espaço. Nas palavras de Santos:

Toda situação é uma construção real que admite uma construção lógica, cujo entendimento passa pela história da sua produção. O recurso à técnica deve permitir identificar e classificar os elementos que constroem tais situações. Esses elementos são os dados históricos e toda técnica inclui história. $\mathrm{Na}$ realidade, toda técnica é história embutida. Através dos objetos, a técnica é história no momento da sua criação e no de sua instalação e revela o encontro, em cada lugar, das condições históricas (econômicas, sócio-culturais, políticas, geográficas) que permitiram a chegada desses objetos e presidiram à sua operação. A técnica é tempo congelado e revela uma história (1996, p. 40).

O autor afirma que o tempo dos sistemas técnicos não é único, e nem estes se impõem homogeneamente no espaço: num mesmo território, podem coexistir 
diferentes sistemas técnicos, com ritmos temporais diferentes. Às vezes, um sistema técnico de tempos rápidos torna-se dominante, mas sistemas de tempos lentos podem resistir nos interstícios (SANTOS, 1996). A essas sobrevivências de sistemas técnicos antigos, de tempos lentos, Santos chama rugosidades, conceito que lembra as cultural relicts de Sauer (2002). Como vimos na introdução teórica deste trabalho, mapear e entender a dinâmica de tais rugosidades — um trabalho que Santos compara ao do arqueólogo — pode ser um passo metodológico eficaz na compreensão de sistemas técnicos dominantes em outras épocas.

A abordagem que propomos para o nosso objeto de estudo - a região do Triângulo Mineiro entre os séculos XVIII e XIX, período em que foi ocupada pela sociedade luso-brasileira colonial, e em que se extinguiram as sociedades ameríndias que a antecederam - passa, como vimos afirmando desde o início deste texto, pela categoria da espacialidade - a forma particular, historicamente produzida, com que cada sociedade produz espaço. Entender essas espacialidades consiste, principalmente, em entender a lógica do conjunto de objetos técnicos que essas sociedades produziram. Como Santos, acreditamos que tais objetos técnicos — que em conjunto formam os sistemas técnicos — são a cristalização da História. Por isso, entender sua gênese, difusão e lógica é etapa essencial ao estudo da formação histórica da região.

Neste capítulo, propomo-nos a compreender a gênese e a dinâmica de algumas das técnicas usadas pelos colonos do Triângulo Mineiro, na primeira metade do século XIX, principalmente aquelas ligadas à reprodução cotidiana de suas existências. Usamos três fontes nessa reconstituição: os relatos dos viajantes joaninos, as descrições dos objetos técnicos constantes nos inventários post mortem da vila de Uberaba entre 1822 e 1861, e depoimentos de antigos moradores da região. Esses depoimentos foram coletados num esforço de mapear as rugosidades — isto é, sobrevivências, até tempos recentes, de complexos técnicos antigos — que pudessem nos revelar a lógica do sistema técnico produzido pelos geralistas no século XIX, no Triângulo Mineiro.

Os imigrantes geralistas colonizaram a região do Triângulo dispondo de um sistema técnico engendrado na região central de Minas, ao longo do século XVIII. Teve, contudo, de sofrer adaptações ao ambiente do Cerrado, algo distinto das montanhas mineiras onde surgiu.

A região aurífero-metalúrgica de Minas Gerais, descoberta e colonizada em seus primórdios por paulistas de São Paulo e Taubaté, recebeu 
posteriormente um intenso afluxo de imigrantes baianos, pernambucanos, cariocas, portugueses e açorianos. Simultaneamente, centenas de milhares de escravos africanos foram traficados para a região e, além deles, um grande número de índios foi aldeado e escravizado, desde os tempos dos paulistas.

Esse melting pot de influências gerou uma cultura que herdou técnicas de todos esses grupos. Estes, ao oferecerem uma gama variada de opções, advindas de culturas distintas, deram ampla flexibilidade às formas de exploração daquele ambiente de floresta e campos sobre montanhas. Esse "pacote" de técnicas, assim geradas, foi usado posteriormente na instalação de uma economia agropastoril na comarca do Rio das Mortes, na segunda metade do século XVIII, e no início do século XIX, no Alto Paranaíba e Triângulo Mineiro.

Nessas duas últimas regiões, porém, os mineiros tiveram que adaptar essas técnicas ao ambiente do Cerrado. Nele, a presença de pastagens naturais favoreceu uma pecuária de corte de produtividade expressiva para os padrões da época, mas cujo excedente era difícil de ser escoado. Falaremos a seguir dos complexos técnicos da pecuária bovina e dos principais cultivos — com os respectivos processamentos — desenvolvidos no Triângulo Mineiro, na primeira metade do século XIX.

\section{Terras de cultura e campos de criar}

Ao trazerem a descrição das fazendas, os inventários post mortem do termo de Uberaba, escritos entre 1822 e 1861, sempre se referiam às terras ou matas de cultura e aos campos de criar. Da extensão total de cada fazenda arrolada, aquelas sempre correspondiam a áreas muito menores do que estes, e eram avaliadas por preços bem mais altos. Por exemplo, no inventário de Francisca Cândida de Jesus, sua Fazenda da Saudade foi descrita como

uma parte de terras de cultura e campos de criar que foram vistas e avaliadas por cinquenta e cinco alqueires de plantas de cultura e os matos avaliados a dezessete mil réis cada alqueire de planta, e os campos em duzentos e cinquenta alqueires de planta, avaliados a mil e quinhentos réis o alqueire. ${ }^{1}$

\footnotetext{
${ }^{1}$ APU, inventário de Francisca Cândida de Jesus (25/05/1831), maço N73.
} 
Esses termos designavam, genericamente, fitofisionomias do domínio do Cerrado —- naturais ou secundárias à intervenção antrópica — , vistas segundo seu potencial de aproveitamento pelos roceiros e fazendeiros.

As terras de cultura eram assim chamadas por serem as mais apropriadas aos cultivos de subsistência, por causa da sua fertilidade natural. Correspondiam aos solos de matas, e a presença nelas de algumas espécies vegetais arbóreas revelava sua qualidade. Saint Hilaire referiu-se a essa forma de reconhecimento dos solos: "a experiência ensinou aos brasileiros quais as espécies de árvores comuns nas matas que, preparadas para as culturas, dão colheitas mais lucrativas" (2000). Averiguamos, por meio de depoimentos de antigos moradores da região em estudo, quais eram as espécies de árvores que, uma vez encontradas, mostravam a presença de terras de cultura: “jatobá de cultura (diferente do jatobá de cerrado), ipê amarelo, ipê roxo, bálsamo e peroba rosa”, disse-nos Hélio Rodrigues da Cunha, morador da zona rural de Santa Maria desde os anos $1910 .^{2}$

Tais árvores são encontradas em matas mesofíticas e em matas ciliares, duas fitofisionomias do Cerrado freqüentemente associadas a solos de alta e média fertilidade (RIBEIRO; WALTER, 1998). Portanto, as terras de cultura correspondiam, geralmente, a solos desenvolvidos sobre rochas básicas, como a terra roxa, cambissolos, e latossolos roxo e vermelho-escuro (RIBEIRO; WALTER, 1998).

Nos inventários pesquisados, as terras de cultura usualmente eram referidas pelas fitofisionomias que as cobria, como matas de cultura, capões de mato ou matas virgens, ou - caso se tratassem de matas secundárias - como capoeiras. Por exemplo, José Luís Pereira possuía, em 1841, "quinze alqueires de cultura em capoeira e poucas matas, cercados de valos, e sete e meio alqueires de cultura com capoeiras na margem do córrego denominado Simões". 3 O capitão Mário Bernardes Ferreira tinha "trinta e oito alqueires de Goiás de mato tapado". 4

As terras de cultura com capoeiras, por já terem perdido parte da fertilidade original, eram menos valorizadas que os solos de matas. Por exemplo, no inventário de José Luís Pereira de Sá, já citado, seus sete e meio alqueires de cultura com capoeiras valiam 45 mil réis (ou seis mil réis o alqueire) em 1841.

\footnotetext{
Hélio Rodrigues da Cunha, depoimento gravado, (15/01/2002).

APU, inventário de José Luís Pereira de Sá (21/06/1841), maço N10.

APU, inventário de capitão Mário Bernardes Ferreira (08/11/1845), maço M94.
} 
Já no inventário de Custódio Gonçalves Beirigo, ${ }^{5}$ do mesmo ano, "noventa e sete alqueires de matas" foram avaliados "à razão de dez mil réis o alqueire".

Os campos de criar, referidos nos inventários, correspondiam às áreas usadas - como o nome indica — para o pastejo do rebanho bovino, cavalar e ovino. Nesse caso, tratava-se, na maioria das vezes, de áreas de campos sujo ou limpo, campo cerrado ou mesmo o cerrado strictu sensu mais ralo, onde predominavam latossolos distróficos e álicos, pouco férteis (RiBEIRO; WALTER, 1998). Na região em estudo, tais fisionomias distinguiam-se sobre os chapadões areníticos (REATTO, CORREA; SPERA, 1998), principalmente naqueles localizados entre o rio Uberaba e o rio das Velhas (Feltran, 1997). Quando de sua morte, em 1842, o fazendeiro Manuel Pereira da Silva, por exemplo, possuía "uma sorte de campos no chapadão"; "Francisco Alves Carrejo possuía "duzentos e noventa e sete alqueires de campos no chapadão, à margem do rio das Velhas". 7

Também era comum formarem-se campos secundários, que resultavam, ao cabo de alguns anos, da prática de cultivos de pousio arbustivo sobre terras de cultura. Nos inventários, esses campos eram referidos junto às terras de cultura, já que se desenvolviam a partir destas. Por exemplo, no inventário de Albano Pereira Valle (1846), suas terras foram descritas como "doze alqueires de culturas com campos na fazenda Felicidade" (grifo nosso). ${ }^{8}$

Tais campos secundários originavam-se da deterioração de solos férteis. Os cultivos com pousio arbustivo — de quatro a cinco anos — , quando repetidos várias vezes sobre os mesmos solos, impediam a reconstituição da mata secundária (capoeira ou capoeirão), e a área terminava sendo invadida por ervas alienígenas, como o capim meloso e o capim Jaraguá. Saint Hilaire assim descreveu a formação desses campos secundários:

Quando já se fizeram duas colheitas em um solo outrora coberto de matas virgens, deixa-se o terreno repousar um pouco; brotam aí árvores muito mais delgadas que as primeiras [...]. Deixam-se estas crescer durante cinco, seis ou sete anos, segundo as regiões; cortam-se, novamente, queimam-se em seguida, e faz-se a plantação nas cinzas [...] Quando [na província de Minas Gerais]

\footnotetext{
5 APU, inventário de Custódio Gonçalves Beirigo (03/07/1841), maço N28, caixa 463. APU, inventário de Manuel Pereira da Silva (08/11/1842), maço N 156.

APU, inventário de Ana Joaquina de Jesus (12/06/1844), maço N8.

8 APU, inventário de Albano Pereira Vale (12/04/1846), maço N1.
} 
um terreno já foi cultivado umas poucas vezes, vê-se nascer uma samambaia imensa do gênero Pteris. Uma gramínea viscosa, pardacenta e fétida, denominada capim-gordura, sucede em breve a essa criptógama, ou se desenvolve ao mesmo tempo que ela. Então, quase todas as outras plantas desaparecem com rapidez. Se algum arbusto nasce de permeio ao capim gordura, é logo comido pelo gado e a ambiciosa gramínea fica senhora do terreno (2000, p. 90-91).

Os depoimentos que recolhemos confirmam que, na região em estudo, tais práticas - cultivos em sistema de pousio arbustivo, culminando com a formação de campos antrópicos, onde predominavam gramíneas alienígenas - sobreviveram até tempos recentes. Um morador da zona rural de Patos de Minas (Alto Paranaíba), nos anos 1940, relata que

as pastagens eram naturais, formadas, nas regiões baixas e de terras de cultura, pelo capim Jaraguá, conhecido também por capim provisório, devido à sua efemeridade. Brotava em setembro, no início das chuvas, e mantinha-se verdejante até o final do outono, quando apareciam os primeiros sinais do sol e frio [...]. Nas encostas, predominava o capim meloso ou gordura. ${ }^{9}$

Em Santa Maria (região do médio rio Tejuco), o depoimento de outro morador confirma que, nos anos 1920, as formações de campos antrópicos sobre terras desgastadas de mata eram usadas como pastagens:

A terra agüentava plantar quatro a cinco anos. Depois o povo largava porque tinha mais mata e valia mais a pena, e plantava mais [...]. Nas [terras de] cultura que eram invernadas, onde eram os matos que a gente fazia as roças, a gente semeava as sementes de Jaraguá. Jaraguá e [capim] gordura. Eram só esses dois capins que tinha naquela época para a cultura. Para plantar a gente semeava. ${ }^{10}$

Warren Dean (1996), em sua história ecológica das matas brasileiras, afirma que a prática do pastejo bovino sobre áreas deterioradas de mata surgiu nos séculos XVIII e XIX, no Rio de Janeiro, Minas Gerais e São Paulo. Os capins africanos Jaraguá e meloso (capim gordura), que freqüentemente

9 Geraldo Lourenço Castro, depoimento escrito (02/05/2002).

10 Hélio Rodrigues da Cunha, depoimento gravado (15/01/2002). 
invadiam essas áreas, apareceram, pela primeira vez, nas invernadas próximas ao Rio de Janeiro, em alguma data incerta do século XVIII. Provavelmente trazidos pelos tumbeiros, onde eram usados como cama de palha para os escravos traficados, esses capins se espalharam rapidamente pela capitania de Minas Gerais (DEAn, 1996). Ao tempo de Saint Hilaire, que viajou pela região em estudo em 1819, o capim gordura já havia chegado às nascentes do rio São Francisco, mas ainda não ao Alto Paranaíba:

O capim-gordura, infelizmente tão comum a leste da Serra do Espinhaço, quase nunca ultrapassa a vertente ocidental dessa cadeia, mas aparece com abundância a leste da outra cadeia que limita a bacia do São Francisco, e finalmente deixa de ser visto a oeste da parte meridional desta última cadeia (SAINT HILAIRE, 1975 b, p. 121).

Esses capins foram disseminados pelo próprio gado, segundo Dean (1996). Os criadores reconheciam que essas espécies tinham baixo valor nutricional para as criações. Saint Hilaire comentou que o capim gordura "se por um lado engorda os animais cargueiros e o gado, diminui-lhes sensivelmente as forças" (2000, p. 91). Esse juízo era o mesmo dos moradores que tivemos a oportunidade de entrevistar, e Dean (1996) confirma que ele era verdadeiro: os capins africanos — particularmente o gordura — reduziam a biodiversidade representada pelas diversas espécies de capins nativos, e assim impediam um regime balanceado de aminoácidos e micronutrientes para os rebanhos. $\mathrm{O}$ Jaraguá era tido como um capim mais nutritivo, mas só crescia em terras de cultura e secava logo depois do fim da estação das chuvas. ${ }^{11}$

Os capins nativos eram melhores que os invasores, mas só podiam ser consumidos logo após as queimadas, quando os brotos novos eram mais palatáveis ao gado (DEAN, 1996). Cresciam normalmente sobre os chapadões, compondo a flora nativa dos campos cerrados, campos limpos e campos sujos, como as espécies capim mimoso, capim branco e capim flecha (BACELAR; Brioschi, 1999). Saint Hilaire (1975 a, 1975 b) citou o capim flecha como o preferido pelos criadores de seu tempo, na região em estudo.

A técnica de queimada dos campos do Cerrado, para o manejo de pastagens, foi descrita por Saint Hilaire, nos arredores de Paracatu:

11 Geraldo Lourenço Castro, depoimento escrito (02/05/2002). 
Os pastos nos arredores de Paracatu só são queimados nos meses de julho e agosto, isto é, durante a estação da seca, pois o fogo não se alastra neles quando ateado antes dessa época. Entretanto, quando os fazendeiros desejam ter pastos de capim novo mais cedo, para suas vacas leiteiras, eles reservam uma certa extensão deles, deixando de atear fogo durante um ano inteiro, para no ano seguinte poderem queimá-los nos meses de abril ou maio (1975 b, p. 152).

O pastejo sem pousio sobre os campos, nos chapadões, também levava à deterioração dos solos e da flora nativa, num processo análogo ao das matas. A necessidade de realizar queimadas todos os anos era o principal fator responsável pelo impacto ambiental dessa prática. Dean resumiu os efeitos ecológicos das técnicas de pastejo, correntes nos século XVIII e XIX, na região do Cerrado:

A queimada danifica de modo sutil os solos e o capim. Destrói plantas que se disseminam horizontalmente formando esteiras, em favor das que formam touceiras, expondo o solo e provocando erosão. $O$ fogo reduz a permeabilidade do solo, favorecendo plantas de raízes superficiais, menos eficientes na reciclagem de minerais lixiviados e mais rapidamente ressequidos e não comestíveis na estação seca. A saúva invade quando esses solos secam, promovendo a ingrata tarefa de revolver sua matéria orgânica. A queimada, além do mais, elimina nitrogênio e as bactérias que participam de sua fixação no solo, essencial à nutrição animal. O pasto degradado então se enche de filicíneas, como o capim sapé [...] e com o barba-de-bode, outra gramínea sem valor nutritivo [...] (1996, p. 129).

Nos depoimentos que colhemos, pudemos notar que diferentes situações ambientais levaram a diferentes níveis de valorização dos campos naturais do Cerrado. Áreas possivelmente degradadas, cobertas por barba-de-bode, eram usadas só como último recurso na alimentação do gado. ${ }^{12}$ Já nas regiões onde ainda se encontravam capins nativos mais nutritivos, as pastagens naturais eram mais valorizadas:

12 Geraldo Lourenço Castro, depoimento escrito (02/05/2002). 
Do cerrado o melhor era o capim branco. Ele era meio peludinho. $\mathrm{O}$ cerrado dava mais pasto era no tempo de queimada, na seca o pasto secava muito, aí punha fogo, aí vinham aqueles brotos novos. O gado engordava, ficava bonito, comendo o broto novo. ${ }^{13}$

Para entender a forma como ocorreu a valorização dos campos de criação e das terras de cultura na região e no período em estudo, separamos 34 inventários post mortem, que continham dados mais completos sobre as extensões - medidas em alqueires mineiros ${ }^{14}$ — e preços relativos de ambos, nas fazendas inventariadas no termo da vila de Uberaba, entre 1822 e $1841 . .^{15}$

Os campos correspondiam, em média, a extensões 7,75 vezes maiores que as terras de cultura, em cada fazenda. Isso demonstra que a fazenda típica era formada por extensões relativamente vastas de campos, com algumas áreas de matas ou solos de matas, usados nos cultivos de subsistência.

Havia diferenças, contudo, entre as propriedades maiores e menores que 500 alqueires. As menores tinham uma proporção relativamente maior de terras de cultura: em média, os campos superavam-nas em 5 vezes a sua área. Já as propriedades maiores do que 500 alqueires eram-no principalmente por causa dos campos (de cultura ou de chapadão): nelas, a extensão das pastagens superava, em média, 17 vezes as terras de cultura. Isso demonstra que as terras de cultura, essenciais à agricultura de autoconsumo, eram as mais procuradas pelos pequenos proprietários, para quem os rebanhos, pouco numerosos, podiam ser mantidos em pastagens pequenas. Para quem possuía rebanhos maiores, criando-os para venda ou invernados, as áreas de pastagens tinham que ser muito extensas, por causa do caráter superextensivo da pecuária.

Em função da grande importância dos solos de mata na produção de alimentos em sistema familiar (ou familiar com escravos), à medida que aumentava a densidade demográfica, ao longo da primeira metade do século XIX, subia o preço do alqueire das terras de cultura, no termo de Uberaba. Mas o preço do alqueire de campos aumentou num ritmo muito mais lento no mesmo período, como se vê no gráfico 1. Isso pode ser explicado pela baixíssima densidade de rebanhos sobre os imensos chapadões cobertos por campos naturais, usados como pastagens. O crescimento do rebanho bovino

13 Hélio Rodrigues da Cunha, depoimento gravado (15/01/2002).

14 Um alqueire mineiro ou goiano corresponde a $48.400 \mathrm{~m} 2$, ou 4,8 hectares.

15 APU, inventários post mortem (1822-1861). 
regional e do aproveitamento dos chapadões, até 1861, não foi suficiente para pressionar o preço das terras de campos, o mesmo não acontecendo com as terras de cultura. Estas tiveram seu preço aquecido pelo aumento da demanda por elas, tanto dos pequenos quanto dos grandes agricultores.

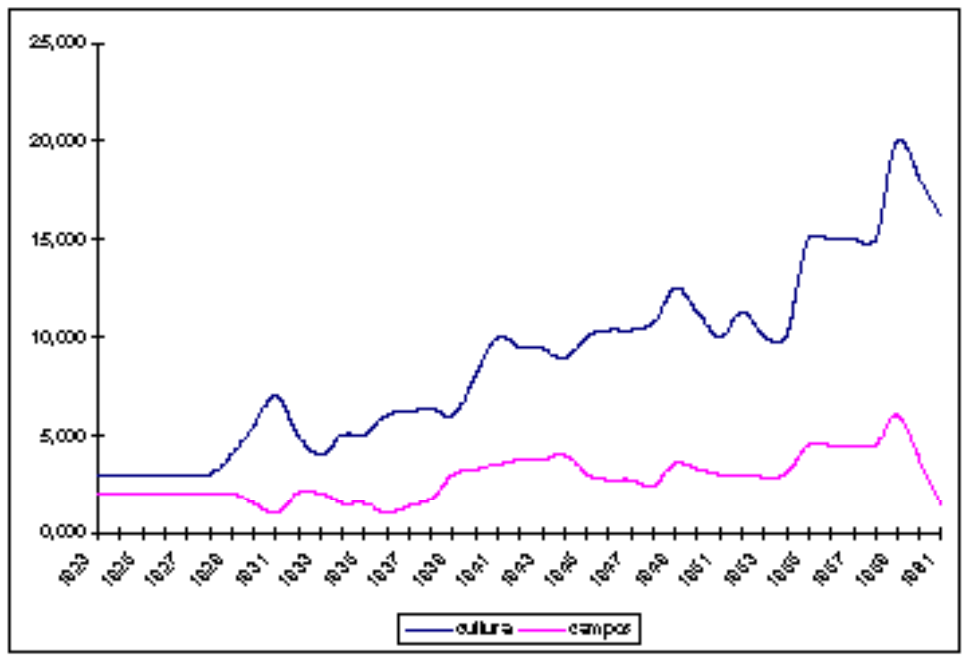

Gráfico 1: preço do alqueire da terra de cultura e dos campos no termo de Uberaba entre 1822 e 1861 (em réis).

Fonte: 174 inventários do Juizado de Órfãos de Uberaba (1822-1861).

Os viajantes joaninos já se impressionavam com o modo extensivo da pecuária dos sertões do Oeste Mineiro. Em 1816, Eschwege comentou, no Araxá, que "a criação de gado, embora em estado semi-selvagem, já rende lucro, sem muito trabalho. O gado é apascentado em campos abertos, em plena liberdade” (1996, p. 107). Dois anos depois dele, Saint Hilaire descreveu a pecuária extensiva araxaense:

Como em todos os lugares, ali só se planta nos capões, ficando os campos reservados exclusivamente aos rebanhos [...]. As fazendas são geralmente de grande extensão, e não é raro encontrar algumas com 9 a 10 léguas de comprimento. Todavia [...] raros são os que contam com rebanhos de mil cabeças, e os que possuem oito ou dez escravos já são considerados ricos (1975 b, p. 130-131). 
Podemos estimar o nível de utilização média das pastagens dividindose a extensão total de campos pela soma de cabeças dos rebanhos, naquela amostra de 34 inventários que destacamos anteriormente. Chegamos ao número de uma cabeça para cada 20 alqueires, ou 97 hectares. Esse número é muito mais baixo que o estimado por Saint Hilaire (1975 b) para a pecuária do Alto Rio Grande, na comarca do Rio das Mortes (uma cabeça por 1,4 hectare), ou do estimado por Dean (1996) para a média da pecuária dos sertões brasileiros (uma cabeça por 5 hectares).

Esse caráter superextensivo da pecuária, mesmo se comparado com outras regiões mineiras da mesma época, como a comarca do Rio das Mortes, devia-se a dois fatores:

- A especificidade da fronteira. O caráter disperso e rarefeito da ocupação fazia com que as fazendas fossem muito grandes, devido ao baixo valor da terra e à existência de extensões devolutas. Com efeito, no mapa demográfico de Luís Maria Pinto, de 1821, a densidade demográfica da comarca do Rio das Mortes era de 64,7 habitantes por légua quadrada $\left(1,4 \mathrm{hab} / \mathrm{km}^{2}\right)$, enquanto que, na de Paracatu, era de 7,3 habitantes por légua quadrada $\left(0,16 \mathrm{hab} / \mathrm{km}^{2}\right)$ (Cunha Matos, 1981).

- O aproveitamento das pastagens naturais. Pelo fato de as espécies herbáceas aproveitáveis no apascentamento se acharem dispersas no terreno, eram necessárias grandes extensões para se obter uma área útil de pastagens relativamente pequena.

A baixa densidade dos rebanhos nas fazendas de gado pôde ser avaliada qualitativamente pela leitura dos inventários post mortem: Antônio da Silveira, ${ }^{16}$ que em 1829 era dono da Fazenda Veríssimo, com extensão de uma légua de comprido por meia légua de largo, com 200 alqueires de campos, possuía apenas 38 cabeças de gado, 6 cavalos e 6 carneiros, o que equivale a cinco alqueires por cabeça, ou uma cabeça para cada 24 hectares.

Os solos de matas eram preparados para o cultivo da mesma forma que nas demais regiões da capitania de Minas Gerais. A derrubada da mata era feita com machado, pouco depois da estação das chuvas. Após alguns dias,

16 APU, inventário de Maria Rodrigues de Jesus (04/04/1829), maço N48, caixa 459. 
com a secagem da rama, ateava-se fogo antes da próxima estação de chuvas (figura 1). No meio da madeira carbonizada, os roceiros abriam covas dispostas irregularmente, usando a enxada, onde então eram lançadas as sementes (SAINT Hilaire, 2000). Nos inventários post mortem pesquisados, os únicos instrumentos agrícolas arrolados em todos os inventários eram enxadas, machados, foices e facões — sendo notável a absoluta ausência de arados — confirmando que esse era realmente o sistema, até 1861, na região em estudo.

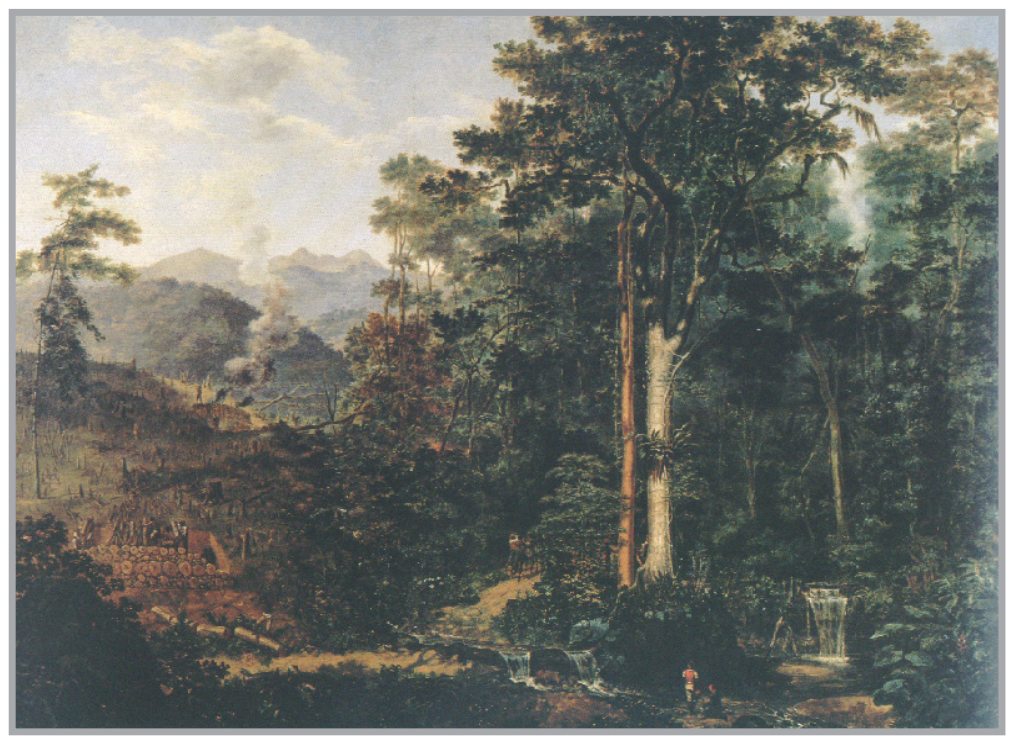

Figura 1: Taunay: mata reduzida a carvão.

Fonte: Beluzzo (1999).

Essa técnica foi chamada, nos depoimentos que coletamos, de roça de toco. Tratava-se, na verdade, da técnica indígena de preparo da terra e cultivo, um pouco modificada, como vimos no segundo capítulo deste trabalho. Essas modificações consistiram, basicamente, no uso do machado de ferro e da foice na derrubada (aumentado a extensão da área abatida, em comparação com a técnica indígena), no uso da enxada na abertura das covas, em vez do chuço, e no encurtamento do tempo de pousio, substituindo o sistema florestal indígena (20 anos) pelo sistema arbustivo sertanejo (5 a 6 anos).

Não foi só nesse caso que as técnicas indígenas foram incorporadas 
ao sistema sertanejo luso-brasileiro, ao longo da colonização. Como veremos, além do sistema de preparo da terra, também no caso das técnicas de cultivo, armazenamento de colheitas e beneficiamento, houve absorção — com adaptações - dos complexos técnicos nativos. Na maioria das vezes, isto se fez porque estes eram vantajosos, mais bem adaptados ao ambiente tropical do que os equivalentes ibéricos. Diante das escolhas postas aos colonos, estes foram adotando as técnicas que sabiam funcionar, observando os indígenas ou aprendendo com os escravos índios e, muitas vezes, depois de testar e abandonar, por inadequadas, aquelas trazidas da metrópole.

No caso que estamos analisando, a tentativa de introdução do arado em terras paulistas é exemplar. Em 1766, o governador de São Paulo morgado de Mateus, escreveu ao vice-rei do Brasil justificando o abandono do uso do arado em favor da cavadeira de pau ou chuço naquela província. Em sua carta, diz que "a terra é fria e não dá sustância senão na superfície, que se não pode usar arado, que alguns já usaram dele, que tudo se lhes perdeu”. O remédio adequado, segundo o governador, seria "um arado que só risque a superfície" (Holanda, 1995, p. 205).

Nos casos que selecionamos a seguir, veremos como os complexos técnicos da pecuária, cultivos e beneficiamento agrícola foram sendo criados historicamente, e adaptaram-se ao ambiente do Cerrado - particularmente no Triângulo Mineiro — nos primeiros anos do século XIX.

\section{Currais, boiadas e sal}

As fazendas de gado foram a principal forma pela qual os colonos geralistas se estabeleceram no Triângulo Mineiro, nos primeiros anos do século XIX. A denominação mais apropriada para essas unidades rurais pioneiras talvez fosse fazendas agropecuárias, já que eram bastante diversificadas. Porém, enquanto cultivos como feijão e milho se destinavam principalmente ao autoconsumo, a pecuária era a principal forma assumida pelo trabalho excedente (mas não a única, conforme se verá), tendo seu valor realizado pela venda de rebanhos em Formiga e São João Del Rey, destinados ao abastecimento do Rio de Janeiro.

No Extremo Oeste Mineiro, Saint Hilaire (1975 a, 1975 b) referiu-se freqüentemente à rusticidade dos criadores de gado, que, não obstante, muitas vezes, 
eram proprietários de imensas extensões fundiárias. De fato, é notável a simplicidade das instalações e dos equipamentos técnicos, nos inventários post mortem da época. Ao morrer, em maio de 1850, Antônio Francisco de Assis possuía um rebanho de 83 cabeças de gado, formado sobretudo por vacas paridas e solteiras, em uma pequena fazenda próxima ao córrego do Lajeado, nos arredores de Uberaba. Era provavelmente jovem, pois tinha apenas duas filhas pequenas — Severiana, de dois anos, e Maria, de três anos — e sua esposa Jesuína estava grávida de um terceiro filho. Contava com um escravo de dez anos, Domingos, e seis cavalos adultos para ajudá-lo no trabalho diário. Vivia em uma casa de taipa coberta de capim, em cujas proximidades funcionava um monjolo. Sua esposa, com o auxílio da escravinha Eva, descaroçava, cardava e fiava algodão, usando um par de cardas e duas rodas de fiar. Também tecia, provavelmente para uso da família, com um tear de madeira. O equipamento técnico com que contavam Antônio e Domingos era formado apenas por um carro com três cangas arreadas (para o qual dispunha de quatro bois carreiros), duas foices, um serrote, uma enxó, um formão, três enxadas, dois machados e uma cavadeira. ${ }^{17}$

O mundo de Antônio é representativo da ampla maioria das unidades rurais do Triângulo Mineiro de então: produção dependente de forma quase integral da força de trabalho humana e da tração animal, baixo investimento na aquisição de bens de capital e subordinação total das atividades agrícolas e de pastoreio à disponibilidade de recursos naturais. No caso da pecuária, o equipamento técnico permanente resumia-se aos currais de aroeira, aos cochos de sal e aos animais de montaria. A simplicidade dessa prática foi registrada pelos viajantes, como o Barão de Eschwege. Referindo-se à região de Araxá e Patrocínio, o mineralogista alemão relatou que "a criação de gado, embora em estado semi-selvagem, já rende lucro [...]. O serviço de dois a três homens, nessas condições, é o bastante para o manejo e a condução do rebanho aos bebedouros" (1986, p. 107).

O investimento em bens de capital, por isso, era muito baixo ou praticamente inexistente. Gorender (1988) acredita que o baixo nível técnico da economia colonial devia-se à rigidez do sistema escravista, incapaz de gerar ou absorver inovações. No caso em estudo, além disso, a baixa receptividade a inovações explicava-se também pela facilidade com que os recursos naturais

17 APU, Inventário de Antônio Francisco de Assis (04/05/1850), maço N14, caixa 470. 
eram obtidos e manipulados, em fronteira aberta, o que desestimulava sua otimização e os aumentos de produtividade. Gorender chamou a atenção para o baixo custo da implantação de uma fazenda de gado mineira, devido ao fácil acesso à terra (principalmente em regiões de fronteira) e à existência de pastagens naturais:

Sob o prisma econômico, chama logo a atenção a pequenez do fundo inicial exigido pela pecuária em comparação com o engenho de açúcar. A rigor, o fundo inicial se resumia em certo número de cabeças de gado para a criação e de cavalos, que servirão de animais de trabalho. Uma fazenda pequena, informa um observador de começos do século XIX, principia com 200 ou 300 reses, bastando-lhe 25 a 30 cavalos. [...] As instalações, por sua vez, são extremamente sumárias: residências sumárias e currais que se constroem sem muita dificuldade. As pastagens naturais dispensam preparação, quando muito precisam ser periodicamente queimadas a fim de revigorarem. [...] A mão de obra na fazenda é reduzida: grandes fazendas não carecem mais que 15 ou 20 homens de trabalho (GORENDER, 1988, p. 426).

A pecuária do Extremo Oeste Mineiro da primeira metade do século XIX baseava-se em práticas algo diferentes das de duas outras regiões de Minas, na mesma época: o Sertão ou Deserto do rio São Francisco, ${ }^{18}$ e a comarca do Rio das Mortes. Não tão extensiva como a primeira, porém menos intensiva que a última, parece ter sido o resultado da adaptação das técnicas desenvolvidas na região aurífera e no Sul de Minas, ao longo do século XVIII, ao ambiente do Cerrado do Triângulo Mineiro.

Por certo, tratava-se de uma pecuária completamente diferente daquela desenvolvida na mesma época no Sertão ou Deserto do São Francisco. Ali, as práticas da pecuária sertaneja, descritas por Saint Hilaire, filiavam-se à tradição do Sertão Nordestino. O naturalista francês relatou que, na região de Formiga do Sertão ${ }^{19}$ — em área de transição do Cerrado para o domínio da Caatinga —, as pastagens eram muito extensas, e o gado era criado nelas "passando todo o ano nos campos; não é recolhido a currais, e colonos existem que, só possuindo dois

\footnotetext{
18 Hoje Norte e Noroeste do Estado de Minas Gerais.

19 Hoje Montes Claros.
} 
escravos, têm, no entanto, vários milhares de cabeças de gado" (2000, p. 313).

O uso do trabalho escravo naquelas fazendas era pouco comum: "os vaqueiros são muito comumente os próprios filhos do proprietário, ou então homens livres a quem se dá o terço do produto do rebanho" (p. 314). As imensidões das pastagens faziam com que "muito freqüentemente os currais [estivessem] situados a certa distância das fazendas. Na época em que as vacas e éguas têm crias, os vaqueiros vão estabelecer-se próximo a esses recintos, em uma cabana a que chamam retiro [...]" (p. 314).

Esse sistema era o mesmo adotado na região dos Pastos Bons, entre o Piauí e o Maranhão, no Sertão Nordestino. A única diferença era que, na relação de trabalho entre o fazendeiro e o trabalhador livre, no lugar da terça parte dos novilhos que nasciam, o vaqueiro nordestino obtinha do dono da boiada a quarta parte, ou quarta, com o que ia formando seu próprio rebanho (GORENDER, 1988).

Uma vantagem natural com que contava a pecuária de toda a região do São Francisco, Nordeste e Norte de Minas era a presença das minas de salitre, que supriam as necessidades de sal do rebanho sem que os criadores tivessem que recorrer ao sal marinho importado. No Norte Mineiro, o salitre era extraído em Coração de Jesus e Formiga do Sertão, de onde era vendido a negociantes nos portos fluviais de Salgado ${ }^{20}$ e São Romão, e dali distribuído aos fazendeiros do Sertão e a Paracatu, chegando por essa vila aos criadores goianos (SAint Hilaire, 2000).

O sistema de pecuária que era então praticado na comarca do Rio das Mortes, particularmente no Alto Rio Grande, tinha características bastante diferentes do sistema superextensivo do Sertão do São Francisco. Saint Hilaire esteve, em 1819, na região da vertente ocidental da Serra da Mantiqueira, que corresponde ao atual Sul de Minas. Ali percebeu que, diferentemente do Sertão, "o cuidado dos animais é normalmente confiado a escravos" (1975 b, p. 50). As pastagens eram divididas e aproveitadas de forma mais racional e intensiva, num sistema de rotação:

Na região do Rio Grande, os grandes proprietários costumam dividir em quatro porções as pastagens destinadas às vacas de leite, e de três em três meses põem

20 Hoje Januária. 
fogo numa delas, para renovar o capim. [...] depois de divididas as pastagens em diferentes verdes [...] não se pode alimentar mais do que 600 ou 700 cabeças de gado em cada duas léguas de terra (p. 51).

Outro aspecto peculiar dessa pecuária era a sua maior produtividade em leite, para os padrões da época: em média, quatro litros por vaca por dia, o que corresponde ao dobro do que se produzia no Sertão do São Francisco. A maior parte desse leite era transformada em queijos, que, embarcados em tropas, eram vendidos no Rio de Janeiro (SAINT HiLAIRE, 1975 b).

Os fazendeiros do Alto Rio Grande desciam para a Corte um grande número de boiadas e porcadas (FRAGOSO, 1998). Por causa da maior proximidade geográfica, se comparada com os sertões ocidentais, esse comércio contava com um número menor de intermediários. Por causa disso, é possível que uma maior fração do excedente, gerado nas atividades de criação e fabricação de queijos, fosse retida pelos fazendeiros locais. Com efeito, Saint Hilaire comentou que

é de supor que as fazendas da região do Rio Grande dêem um certo rendimento aos seus proprietários, ao contrário das que, encravadas nos sertões de Goiás ou mesmo em algumas partes mais afastadas da província de Minas, quase nenhum lucro dão aos fazendeiros. A vizinhança com o Rio de Janeiro coloca a região e toda a comarca do Rio das Mortes numa situação bastante favorável.

Essa maior acumulação se refletia na aquisição de escravos e gado. Saint Hilaire refere-se a fazendeiros do Alto Rio Grande com até 5.000 cabeças, sendo que, nos inventários analisados em nossa região de estudo, o proprietário do maior rebanho era o tenente Joaquim da Silva e Oliveira, ${ }^{21}$ com 2.351 cabeças, em 1839.

A pecuária trazida pelos geralistas que imigraram para o Triângulo Mineiro na primeira metade do século XIX, vindos da região aurífera e da comarca do Rio das Mortes, originou-se decerto dessas práticas. Contudo, dois fatores geográficos obrigaram os criadores triangulinos a modificarem algumas delas.

Em primeiro lugar, a maior distância em relação ao Rio de Janeiro condicionava a existência de uma rede de comerciantes de gado, intermediária

21 APU, inventário de tenente Joaquim da Silva e Oliveira (06/03/1839), maço N7, caixa 461. 
entre os criadores e aquele mercado. Os relatos de Eschwege (1996) e Saint Hilaire (1975 a; 1975 b) revelam que, entre os criadores triangulinos e o mercado da Corte, interpunham-se os compradores de gado de São João Del Rei ou Formiga, e os condutores de boiadas de Barbacena ou da própria Corte, que as compravam daqueles. Na prática, isso significava uma maior fração do excedente retido nas mãos de intermediários, o que reduzia o montante acumulado pelos fazendeiros triangulinos. Ao mesmo tempo, escravos e artigos como sal e ferragens, comprados do litoral, chegavam muito mais caros ali do que nas regiões mais próximas do litoral.

O acesso ao sal era uma dificuldade a mais para os criadores da região, e talvez um fator limitante na expansão dos rebanhos. No termo de Uberaba, uma saca de sal de $20 \mathrm{~kg}$ custava $5 \$ 120 \mathrm{em} 1837,{ }^{22}$ enquanto um garrote de quatro anos — e, portanto, em ponto de venda - era avaliado a $8 \$ 000 .{ }^{23}$ De acordo com as informações que colhemos em nossos depoimentos, ${ }^{24} \mathrm{um}$ boi consumia em média $100 \mathrm{~g}$ de sal por mês, ou 1,2 kg por ano. Assim sendo, para manter um rebanho de 100 cabeças, um criador teria que comprar $120 \mathrm{~kg}$, despendendo $30 \$ 720$ por ano. Saint Hilaire informou que uma boiada de 100 cabeças rendia até 10 garrotes por ano: "um fazendeiro não poderia, sem reduzir o seu capital, vender todo ano mais do que um décimo do seu gado" (1975 b, p. 49-50), e assim, em 1837, obteria $80 \$ 000$ de receita bruta, dos quais teria que reservar $30 \$ 700$, ou $37 \%$ do total, na aquisição de sal. Dessa maneira, entende-se a razão do caráter superextensivo da prática da pecuária: a atividade só seria lucrativa se os outros fatores de produção (pastagens, força de trabalho) tivessem custo reduzido.

O custo do sal, em alguns casos, era mitigado pela presença dos bebedouros: fontes naturais de águas salitrosas, usadas pelos fazendeiros para dar de beber ao gado. Vimos que a abundância dessas fontes na região do Araxá e Patrocínio fora o fator que tornara esses núcleos — principalmente Araxá — os principais centros de pecuária do Oeste Mineiro, nos primeiros anos do século XIX.

Se bem que menos abundantes que o Barreiro araxaense, tais bebedouros eram encontrados em outras partes do Triângulo Mineiro, e também nelas sua presença estimulou a ocupação pelas fazendas de gado. Esses bebedouros foram referidos, por exemplo, na região da Rocinha, nas vizinhanças do rio das

22 APU, innçalves Firme (01/02/1837), maço N5.

23 APU, inventário de Antônio da Silveira (19/08/1837), maço N37.

24 Geraldo Lourenço Castro, depoimento escrito (02/05/2002). 
Velhas (Eschwege, 1996; Saint Hilaire, 1975 a); nas paragens de Sobradinho e Bebedouro, entre o rio das Velhas e o Uberaba Legítima (TeixeIRA, 1970); e principalmente nos arredores de Uberaba, devendo ser destacado como um dos fatores que estimulou o crescimento do arraial. De fato, Vigário Silva, referindo-se àquela freguesia, escreveu em 1829:

[...] se vê sempre gordo o gado, que não depende de sal, cuja falta se supre com as águas dos bebedouros, que bá em quase todas as faz̃endas. São estas águas nascidas em olhos à margem dos córregos; no paladar não apresentam diferença das outras, mas esfregando-se nelas as mãos sente-se escorregarem; a cana do mato e mesmo o gado acostumado aos bebedouros as procuram sempre na lua nova, passando por outras muitas águas puras, que desprezam apesar da sede [grifo nosso] (SILVA, 1970, p. 11).

Distâncias tão grandes em relação ao mercado da Corte obviamente impediam que o queijo pudesse ser comercializado pelos criadores do Triângulo Mineiro e Alto Paranaíba. Por isso, não havia interesse em produzi-lo. Eschwege observou que:

De manhã e à tarde, as vacas deixam espontaneamente o pasto pra alimentarem os bezerros e é nessas ocasiões que são ordenhadas. [...] Logo que as crias atingem alguns meses de vida e o fazendeiro não tem maior necessidade de leite — na maioria das fazendas não se fabricam queijos nem manteiga, atividade considerada cansativa -, tanto as vacas quanto as crias são enxotadas para o pasto (1996, p. 107-108).

Desse modo, distintamente dos criadores de gado do Alto Rio Grande, a pecuária do Extremo Oeste realizava excedentes exclusivamente na forma do gado de corte.

Outro fator importante era a diferença geomorfológica entre o ambiente da Serra da Mantiqueira e o das chapadas do Oeste. É muito provável que as desvantagens, devidas à distância em relação aos mercados litorâneos, fossem parcialmente compensadas pela possibilidade de explorar pastagens muito mais extensas do que na comarca do Rio das Mortes. Não só porque o Extremo Oeste Mineiro era menos povoado, mas também porque o relevo de chapadas impunha 
menor desgaste físico ao gado em deslocamentos de longa distância, se comparado aos morros do Sul de Minas. Só assim se explica, por exemplo, a funcionalidade do Barreiro do Araxá, para onde os fazendeiros, todos os meses, num raio de 12 léguas $(79 \mathrm{~km})$, levavam seus rebanhos a fim de se servirem das águas salitrosas.

Era possível aos pecuaristas triangulinos, portanto, explorar extensas áreas de pastagens com rebanhos relativamente pequenos. Se, por um lado, isso acarretava uma densidade menor de cabeças por unidade de área, por outro, reduzia o trabalho necessário ao manejo das pastagens. Saint Hilaire relatou que, no Araxá, “a mão-de-obra é bastante cara [...]. Os criadores vêem-se impossibilitados de cercar seus pastos e dividi-los, conforme a prática adotada no Rio Grande" (1975 b, p. 131).

Assim, os pecuaristas do Triângulo Mineiro e Alto Paranaíba conseguiam compensar, em parte, as desvantagens da distância em relação ao grande mercado consumidor da época - a Corte do Rio de Janeiro e a cafeicultura em expansão no vale do Paraíba do Sul — , reduzindo os custos de implantação e manejo da atividade a níveis elementares. Isto só poderia se dar numa situação em que se pudesse contar com recursos naturais abundantes e facilmente exploráveis, e numa forma de produção não-capitalista, na qual a reprodução da força de trabalho não se fazia pela sua prévia realização no mercado. Discutiremos esse aspecto no capítulo 5.

As distâncias e as extensões das pastagens naturais não eram, contudo, tão grandes como no Sertão do São Francisco. No Triângulo Mineiro, todo o manejo do gado era feito nos currais contíguos à casa de morada, não havendo, como lá, o sistema dos retiros. No Norte Mineiro, como vimos, os vaqueiros deslocavam-se para os pastos mais longínquos na época de parição das vacas. Já na região em estudo, segundo Eschwege,

durante o período que vai de agosto a janeiro, porém, requer-se mais trabalho humano, pois é tempo de parição. Ao darem cria, as vacas são levadas para as proximidades da sede da fazenda, onde ficam encerradas no curral, durante a noite. De manhã e à tarde, as vacas deixam espontaneamente o pasto pra alimentarem os bezerros e é nessas ocasiões que são ordenhadas (1996, p. 107-108)

A necessidade de acompanhar as vacas na parição e mantê-las nos currais, segundo um depoimento que colhemos de um antigo morador da região de 
Patos de Minas, devia-se a

dois motivos: o primeiro porque, se deixasse ela parir no pasto, sozinha, poderia ser vítima de alguma complicação [...], e o segundo, porque se não tivesse ninguém por perto ou se não estivesse fechada no curral, era evidente que ela amoitaria o bezerro que, se não o achassem, não saia do local onde foi posto. ${ }^{25}$

O curral era também o lugar onde era realizada a ordenha da vaca. Ao tempo de Eschwege, a técnica de ordenha era a mesma que se manteve na região até bem recentemente:

De manhã e à tarde, as vacas deixam espontaneamente o pasto para alimentarem os bezerros e é nessas ocasiões que são ordenhadas. Para tanto, espera-se que a cria mame um pouco, para, logo em seguida, ser afastada à força e atada às pernas dianteiras da mãe com corda curta, a fim de que ambas se mantenham quietas. É o momento em que se inicia a ordenha. Sem tais precauções, dizem, a vaca não solta o leite (1996, p. 107).

Esse conjunto de técnicas, tão diferentes daquelas do Sertão do Norte Mineiro, são, todavia, as mesmas descritas por Saint Hilaire (1975 b) para a pecuária do Alto Rio Grande. Os currais, anexos à morada do fazendeiro ou sitiante e construídos em madeira aroeira ou pedra, eram o local onde se fazia o manejo do gado. Essa disposição ainda hoje pode ser vista em antigas fazendas da região (figura 2).

Uma outra característica da pecuária do Rio das Mortes que se manteve no Triângulo Mineiro foi o uso do trabalho familiar, estendido pelo trabalho escravo, como forma predominante de organização do trabalho, conforme teremos oportunidade de demonstrar no próximo capítulo. Isso diferenciava a pecuária triangulina da do Sertão do São Francisco, onde, como vimos, predominava o trabalho livre não-assalariado.

Dessa forma, a pecuária triangulina do século XIX era herdeira das técnicas desenvolvidas na região central e sul da capitania de Minas Gerais, ao longo da segunda metade do século XVIII. No entanto, adaptou-se ao ambiente

25 Geraldo Lourenço Castro, depoimento escrito (02/05/2002). 
de Cerrado e chapadas, e às grandes distâncias em relação ao mercado litorâneo, modificando as técnicas de apascentamento de forma a reduzir ao mínimo os custos de produção, pela máxima exploração dos recursos naturais.

A partir do que expusemos, foi possível mapear as principais formas de pecuária desenvolvidas na província de Minas Gerais, na primeira metade do século XIX, conforme se nota na figura 3. Vimos serem três os tipos de pecuária mineira: a pecuária superextensiva do Sertão do Rio São Francisco, ligada às tradições do Nordeste brasileiro; a pecuária da comarca do Rio das Mortes, semi-intensiva (para os padrões oitocentistas) e leiteira; e a pecuária dos sertões do Oeste Mineiro (destacando-se a região em estudo), mais extensiva que esta última e voltada para a venda exclusiva de rebanhos de corte, mas com práticas herdadas das regiões central e sul de Minas.

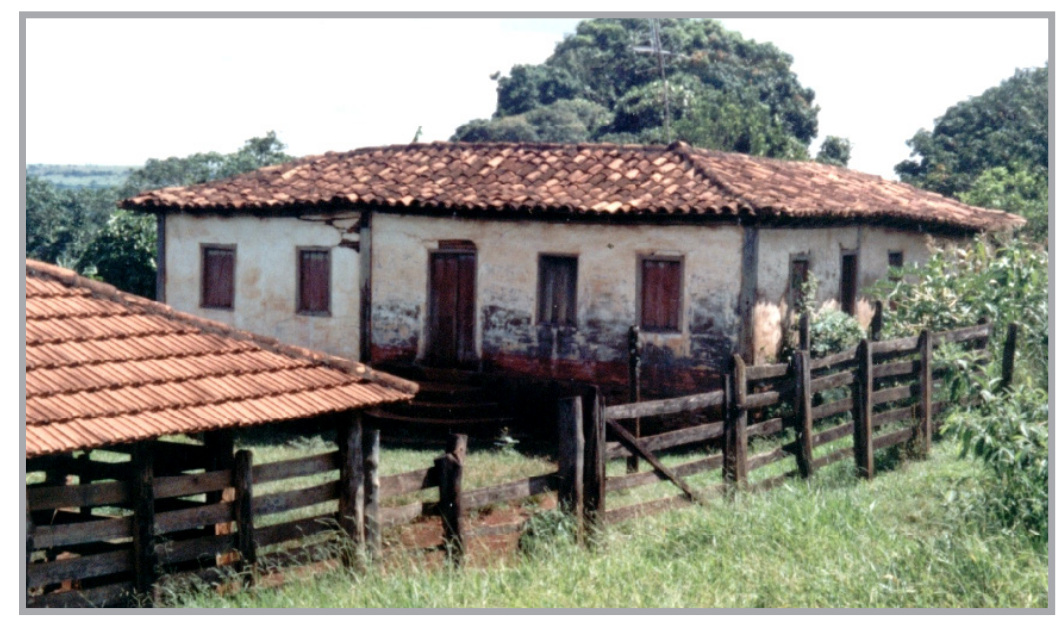

Figura 2: Nova Ponte (MG): casa de fazenda e curral contíguo.

Fonte: foto de Lourenço, L. A. B. (2002).

\section{O milho e a mandioca.}

Sérgio Buarque de Holanda (1995) analisou a difusão do que chamou de civilização do milho, isto é, o conjunto de tradições responsáveis por tornar o milho a principal forma de alimento consumido pelos colonos do Planalto Paulista, no século XVII. Era consumido na forma de farinha pilada — usada para 


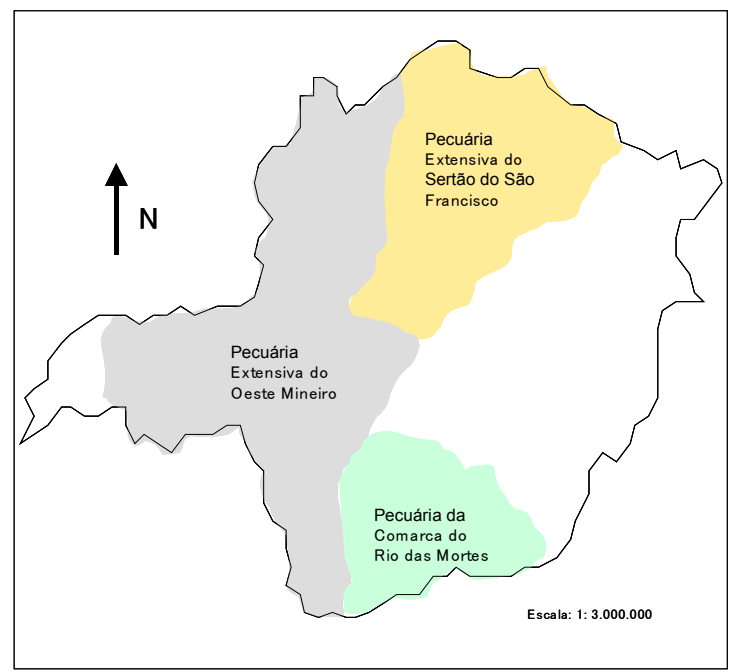

Figura 3: sistemas de pecuária na província de Minas Gerais (1800-1850).

fazer o "pão da terra" —; verde, à moda indígena (cozido ou assado); moído, na forma do fubá, usado para fazer o angu dos escravos; e, seco e debulhado, na alimentação de porcos e galinhas. As técnicas de cultivo e beneficiamento desse grão indígena foram apropriadas quase integralmente dos povos nativos, com exceção da moagem. Esta só surgiu no espaço paulista no século XVIII, com a escravidão negra (HoLANDA, 1995).

O historiador revela que os paulistas, colonos pioneiros das Minas na virada do século XVII para o XVIII, foram os introdutores nessa capitania do complexo do milho. $\mathrm{O}$ uso do milho como principal alimento calórico diferenciava a área sob influência paulista daquela sob influência nordestina, onde a mandioca tomava o lugar do cereal (Holanda, 1995). De fato, Antonil (1982) descreveu em 1711, na vertente ocidental da Serra da Mantiqueira, uma paisagem agrícola tipicamente paulista, onde se nota a presença do milho e a ausência da mandioca:

Aqui há roças de milho, abóboras e feijão, que são as lavouras feitas pelos descobridores das minas e por outros, que por aqui querem voltar. E só disto constam aquelas e outras roças nos caminhos e paragens das minas, e quando muito, têm de mais algumas batatas (ANTONIL, 1982, p. 182-183). 
Um século depois, Saint Hilaire registrou a presença do milho e a falta da mandioca, nos arredores de Vila Rica. Falando do Sertão do São Francisco, relatou que "um vegetal que cultivam muito, e que não se vê nos arredores de Vila Rica, é a mandioca" (2000, p. 311). Nas vizinhanças da capital mineira, por outro lado, "todos os agricultores plantam milho" (p. 106).

O cronista assinalou, inclusive, quando da sua passagem pela região em estudo, uma linha divisória aproximada separando a preferência pelo milho e pela mandioca: "ao norte do Paranaíba começam as plantações de mandioca” (Saint Hilaire, 1975 b, p. 120). Embora não tenha feito uma localização precisa das áreas do grão e do tubérculo, Pohl (1976) só veio descrever os sistemas de cultivo e beneficiamento da mandioca nas proximidades da Serra dos Cristais, ${ }^{26}$ em Goiás, sendo provável que não os tenha visto na sua passagem por Araxá.

Apesar de a carta de frei Leandro, de 1827, referir-se em Uberaba a "mandiocas de cinco a seis meses que tinha maiores raízes que as de seis anos nas Gerais" (PonTes, 1978, p. 91), e Vigário Silva (1970), dois anos depois, citar a mandioca entre os cultivos uberabenses, é possível que o tubérculo não estivesse entre as preferências alimentares da região. Nos inventários pesquisados, produzidos no termo de Uberaba, que corresponde a todo o atual centro-sul do Triângulo Mineiro, é notável a ausência da mandioca e dos equipamentos técnicos usados em seu beneficiamento, entre 1822 e 1861.

Alguns desses documentos traziam a descrição dos estoques de mantimentos em poder do inventariado, quando de sua morte. Dessa forma, pela discriminação e quantificação dos estoques, podemos ter idéia do que se produzia nas fazendas e sítios. Conforme pode ser visto na tabela 1, não houve uma única ocorrência de estoques de mandioca ou farinha de mandioca. Tampouco encontramos, nos arrolamentos dos inventários, qualquer referência ao instrumental usado no beneficiamento da mandioca: raladores, tapiches ou espremedores. É muito provável, portanto, que a porção central e sul da região em estudo - pelo menos até 1861, período a que se referem nossas fontes primárias — não usasse habitualmente a farinha de mandioca.

26 Hoje Cristalina. 


\begin{tabular}{l|cccc}
\hline & \multicolumn{5}{|c}{ NÚMERO DE OCORRÊNCIAS POR PERIODO } \\
\hline GÊNERO & $1822 / 1831$ & $1832 / 1841$ & $1842 / 1851$ & $1852 / 1861$ \\
\hline MILHO & 3 & 3 & 2 & 5 \\
\hline FEIJÃO & 2 & 1 & 1 & 2 \\
\hline ARROZ & - & - & - & 1 \\
\hline ALGOdÃO & - & - & 2 & 1 \\
\hline CANA/AÇÚCAR/ & 1 & 2 & 2 & 3 \\
RAPADURA & - & - & - & 1 \\
\hline FUMO & - & - & - & - \\
\hline MAMONA & - & - & & 1 \\
\hline MANDIOCA & & &
\end{tabular}

Tabela 1: número de ocorrência de estoques de mantimentos nos inventários post mortem no termo de Uberaba, por período (1022-1861).

Fonte: APU, inventários post mortem (1822-1861).

Se dermos crédito à geografização proposta por Saint Hilaire, as áreas de cultivo preferencial do milho e da mandioca, em Minas Gerais, distribuíam-se da forma mostrada no mapa da figura 4 . O botânico francês tentou explicar essa distribuição por fatores de ordem natural. Segundo ele, a presença da mandioca ao norte do Rio Paranaíba "parece provar que a região ali é mais quente e mais elevada, pois essa planta, muito comum na parte do sertão que percorri em 1817, não é encontrada em regiões elevadas e de clima temperado" (1975 b, p. 120).

Holanda, de outro modo, parece julgar que a geografia dos cultivos coloniais se deve muito mais a fatores culturais do que propriamente climáticos ou pedológicos. A mandioca, muito comum na Baixada Santista desde o início da colonização, esteve ausente dos cultivos praticados na vila de São Paulo até 1800. Ali, era o milho que ocupava o lugar de principal fonte de carboidratos para a população do Planalto do Piratininga. A razão, segundo o autor, é que as ramas de mandioca eram muito difíceis de serem transportadas, pois morriam alguns dias depois de arrancadas e ocupavam muito espaço nas bagagens. Assim, como as viagens serra-acima 


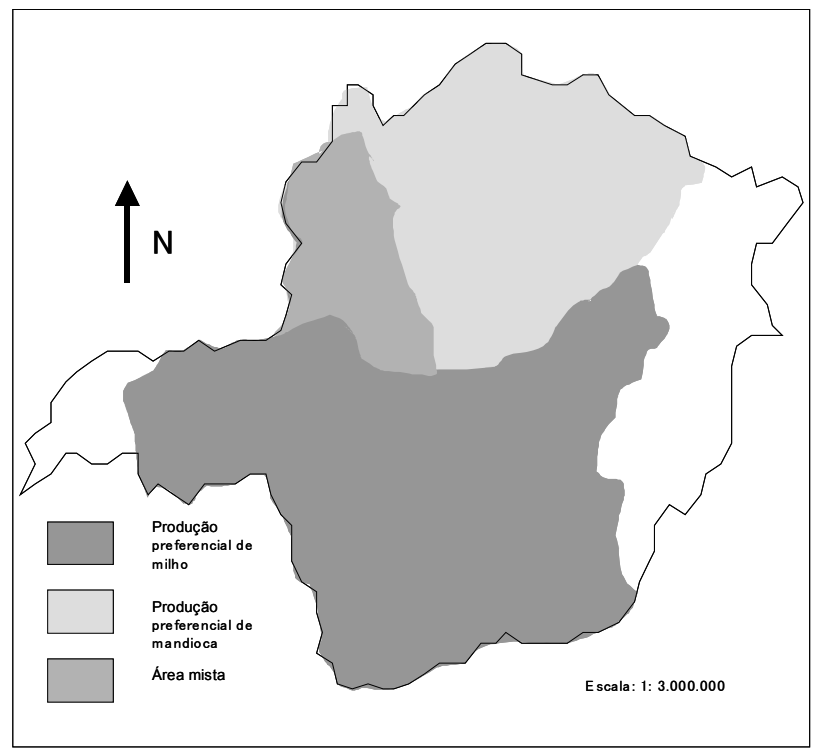

Figura 4: áreas preferenciais de cultivo do milho e da mandioca para alimentação humana (1819). Fonte: Saint Hilaire (2000).

eram relativamente longas, o milho — levado em sementes - é que se transformou no principal alimento. Os colonos só adotavam a mandioca quando, nas áreas a serem colonizadas, já existissem grupos indígenas mandioqueiros (Holanda, 1995).

Outros elementos de ordem cultural também influíram nas preferências regionais pelo tubérculo ou pelo grão. Holanda (1995) escreveu que os paulistas antigos tinham aversão à farinha de mandioca, considerada pouco nutritiva. Já entre os nordestinos e os nortistas, segundo o mesmo autor, o juízo negativo era dirigido contra a farinha de milho. No norte de Minas Gerais, Saint Hilaire destacou o uso da mandioca como alimento preferencial em todo o Sertão ou Deserto do Rio São Francisco. O milho, embora cultivado, era tido como alimento de animais e escravos:

Os sertanejos preferem a raiz da mandioca, porque têm, em geral, a crença de que [...] o milho produz neles moléstias de pele tais como a sarna, a lepra 
e a elefantíase, e aqueles mesmos que o têm em abundância o não empregam senão para a alimentação dos burros, dos porcos e das galinhas (2000, p. 311).

O quadro geográfico que parece se desenhar para o território mineiro oitocentista, em relação ao binômio milho/mandioca, é o da delimitação de duas áreas culturais distintas, uma com o predomínio do complexo da mandioca, e outra com o predomínio do complexo do milho. E é interessante notar que os limites entre tais áreas coincidem aproximadamente com os dos dois sistemas de pecuária de corte, que estudamos linhas atrás. Desse modo, o domínio do complexo da mandioca coincide aproximadamente com o espaço da pecuária superextensiva de tradição nordestina, e a área do milho, com a pecuária escravista que se originou no centro e no sul de Minas. A conclusão que se impõe é que a região em estudo se filiava a uma tradição cultural mineira strictu sensu, enquanto no Médio São Francisco parece clara a influência do Sertão Nordestino.

No entanto, tais preferências rapidamente se interpenetraram na cultura sertaneja triangulina. Pohl (1976) descreveu, em Goiás, bem próximo ao Triângulo Mineiro, a presença tanto de produtos do milho quanto da mandioca, em 1817. No termo de Uberaba, pelo menos até 1861, a mandioca tinha pouco significado na vida sertaneja, mas, em algum momento entre essa data e o final do século XIX, a prática de seu cultivo se intensificou na região. Em depoimento, o agricultor Hélio Rodrigues da Cunha, que vive na região do Médio Rio Tejuco desde a década de 1910, descreveu o preparo da farinha de mandioca quando de sua infância. ${ }^{27}$

Preparamos o quadro 1 para mostrar, por etapas, o cultivo do milho, comparando a técnica indígena descrita por Galvão (1979) usada pelos Kaiuá e os povos do cerrado; a técnica descrita por Saint Hilaire (2000), dos roceiros de Minas em 1819; e aquela empregada pelos moradores da região rural de Patos de Minas em 1945. ${ }^{28}$

Pode-se verificar, no quadro comparativo, que as etapas no cultivo e no preparo do milho são as mesmas, nos três casos. Isso faz supor que o manejo indígena do milho foi incorporado pelos roceiros luso-brasileiros, mantendose praticamente inalterado desde os tempos coloniais até muito recentemente.

27 Hélio Rodrigues da Cunha, depoimento gravado (15/01/2002).

28 Geraldo Lourenço Castro, depoimento escrito (02/05/2002). 
Holanda (1995) já tinha chamado a atenção para esse fato, referindo-se ao complexo do milho no Planalto Paulista:

Tomadas, quase que sem alteração, aos antigos naturais da terra, essas técnicas acomodavam-se mais facilmente à vida andeja e simples de parte notável da população do planalto. Tratando-se, além disso, de gênero cuja produção visava, não ao lucro comercial, mas à subsistência familiar, faltou um estimulo técnico poderoso para o desenvolvimento de recursos técnicos favoráveis à produção em maior escala (1995, p. 188).

O quadro 1 também mostra grande semelhança entre o sistema usado na província de Minas Gerais, descrito por Saint Hilaire, em 1819, e o que ainda era comum entre os sertanejos de Patos de Minas, na década de 1940. Essa semelhança aparece até mesmo em detalhes, como distância entre as covas e época de capina. Comparando-se o sistema sertanejo com o indígena, percebe-se que foi na etapa do beneficiamento, principalmente, que técnicas luso-brasileiras foram incorporadas.

Assim, a associação do plantio do milho ao do feijão, de forma que os talos do primeiro servissem às ramas do segundo - técnica milenar entre os povos ameríndios —, manteve-se como prática na região em estudo. Nos inventários do termo de Uberaba, de 1822 a 1861, encontramos estoques de milho arrolados em treze documentos. Em seis deles, o estoque de milho é descrito junto com o estoque de feijão e, em outros sete, o milho é arrolado isoladamente. Mas não encontramos nenhum registro de estoques isolados de feijão. Isso demonstra que o feijão era sempre colhido — quando plantado — junto com o milho, havendo então a associação entre os cultivos.

O pilão indígena foi mantido, para produzir, do milho seco, a canjica ou farinha de milho (figura 5). Mas a máquina rústica que mais freqüentemente está associada ao complexo do milho é o monjolo (figuras 6 e 7), trazida pelos portugueses e incorporada ao complexo do milho.

Esse maquinário rústico, trazido da Ásia Oriental pelos portugueses, e usado em Portugal no beneficiamento do milhete, foi introduzido na Baixada Santista ainda no século XVI, associado originalmente ao beneficiamento do arroz. Até o século XVIII, não parece ter sido muito utilizado no Planalto Paulista, preferindo-se até então o pilão indígena. Dessa época em diante, porém, o monjolo de pé — que não usa água e sim a força humana — passou a ser 


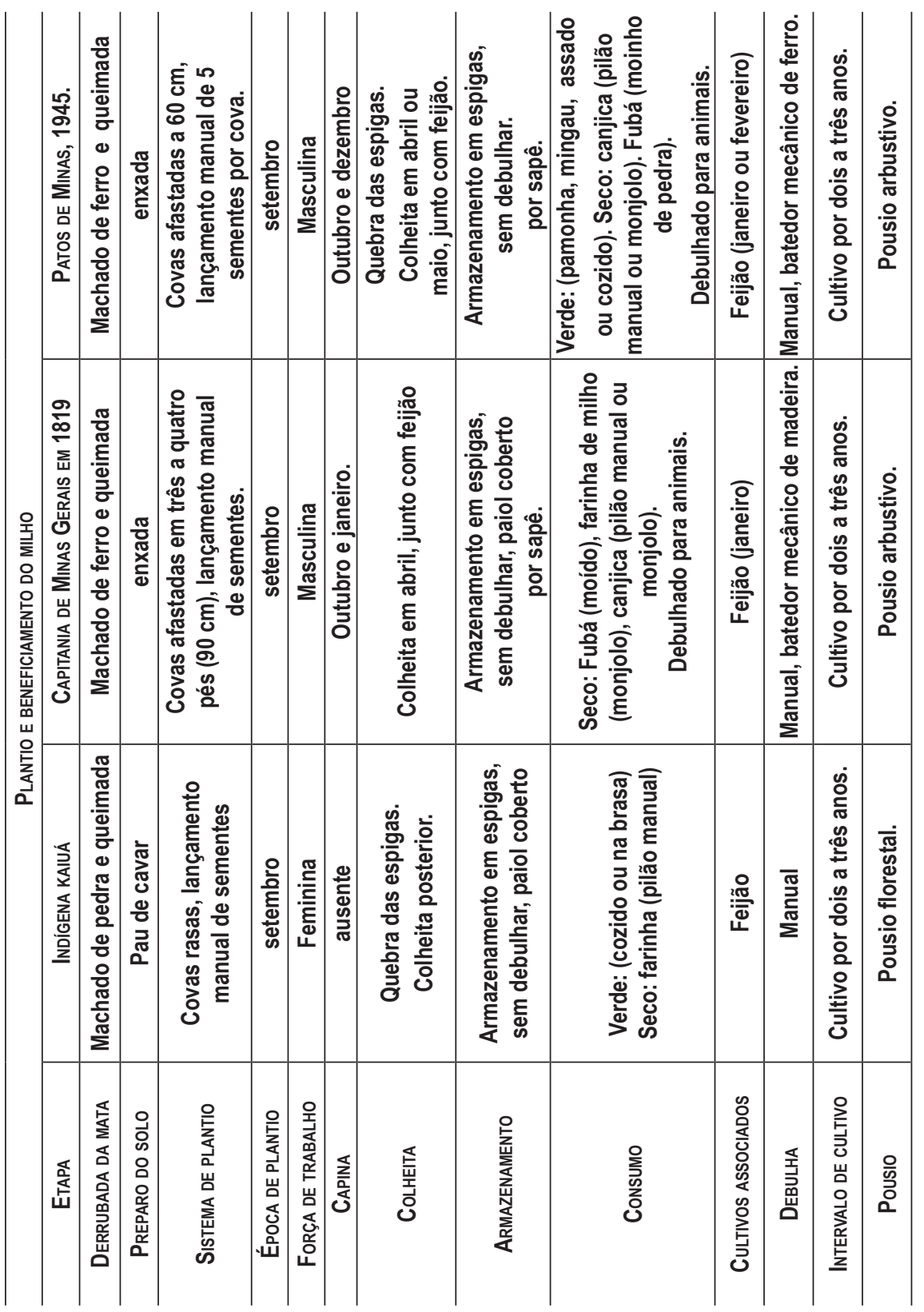

Quadro 1: sistemas de plantio e beneficiamento de milho.

Fontes: Galvão (1979), Saint Hilaire (2000), G. L. Castro, depoimento (2002). 
usado em São Paulo (Holanda, 1995). Algum tempo depois, disseminou-se pelas áreas de colonização paulista, inclusive Minas Gerais, já como monjolo de água, associado ao beneficiamento do milho.

O moinho de pedra, usado para produzir fubá, foi mais um equipamento incorporado ao complexo do milho pelo colonizador europeu. Segundo Holanda, o moinho de fubá incorpora-se ao conjunto das técnicas do milho, no momento em que se torna necessário aumentar a escala do beneficiamento do grão, para "forjar um tipo de alimentação abundante, boa para escravos e criações domésticas" (1995, p. 188). Outros equipamentos que os colonos adotaram para otimizar técnicas indígenas foram o tacho de cobre e o forno, usados para fazer farinha (HoLANDA, 1995).

Nos inventários do termo de Uberaba, os equipamentos que compunham o complexo do milho eram quase onipresentes. De um total de 167 inventários, encontramos monjolos arrolados em 48 deles, fornos em 28 (18 de cobre e 10 de ferro) e moinhos de pedra estavam presentes em 19 documentos.

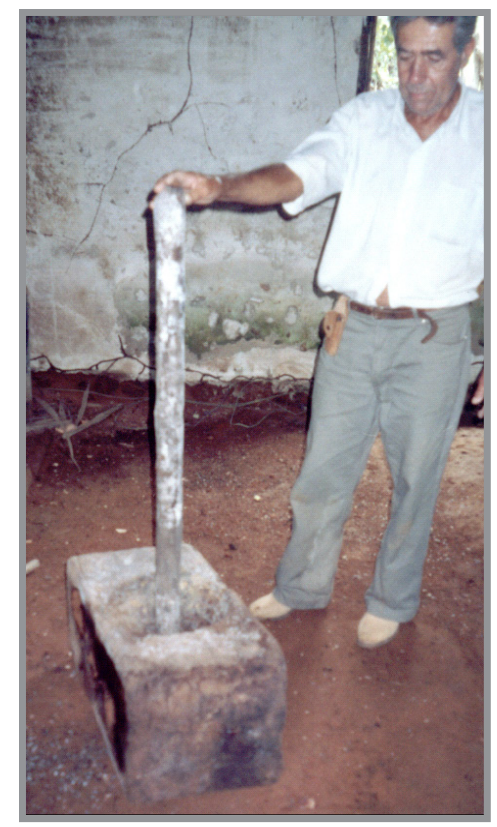

Figura 5: pilão (Nova Ponte - MG).

Fonte: foto de Lourenço, L. A. B. (2002) 
Dentre os inventariados, praticamente todos os que possuíam sítios - isto é, unidades rurais de moradia e produção — tinham monjolos, demonstrando que se tratava de um equipamento básico no beneficiamento de alimentos para os roceiros. Os "fornos de torrar farinha", por seu turno, eram menos corriqueiros, mas em praticamente todos os inventários constavam tachos de cobre, usados para a mesma finalidade, na falta do forno.

Os moinhos de pedra existiam apenas em algumas unidades. Associamos a presença dos moinhos ao número de escravos de cada inventário, e produzimos o gráfico 2. Nota-se que entre os pequenos proprietários de escravos - plantel com menos de 5 cativos — não era comum possuir moinhos, ao passo que encontramos um grande número deles nas mãos de médios proprietários de escravos - entre 6 e 10 cativos - e dos grandes proprietários - mais de 10 cativos. Essa estrutura de distribuição permitenos deduzir que a moagem do milho, apesar de se inserir no rol das atividades
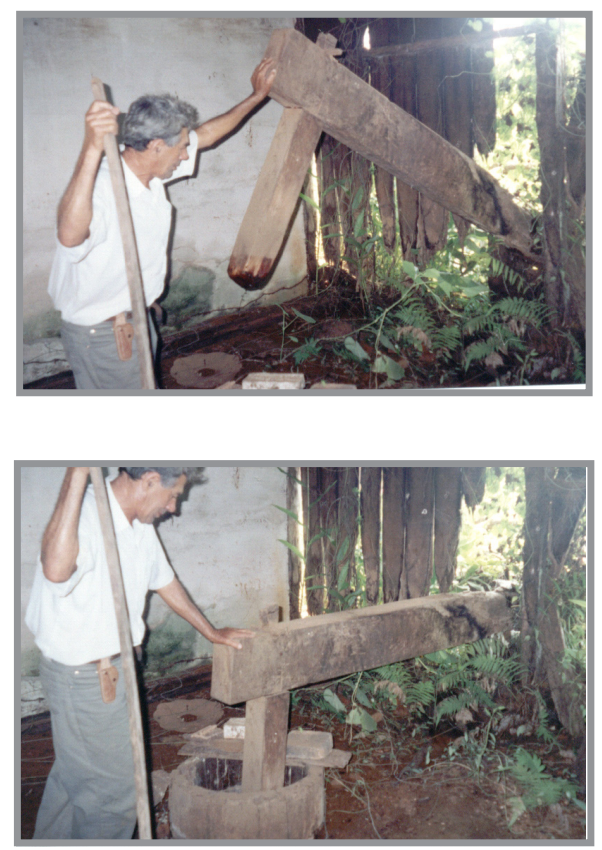

Figuras 6 e 7: monjolo (Nova Ponte, MG).

Fonte: fotos de Lourenço, L. A. B. (2002) 
domésticas, estava presente apenas em fazendas com pelo menos um razoável número de escravos, corroborando a informação de Holanda de que o fubá se destinava principalmente à alimentação dos cativos.

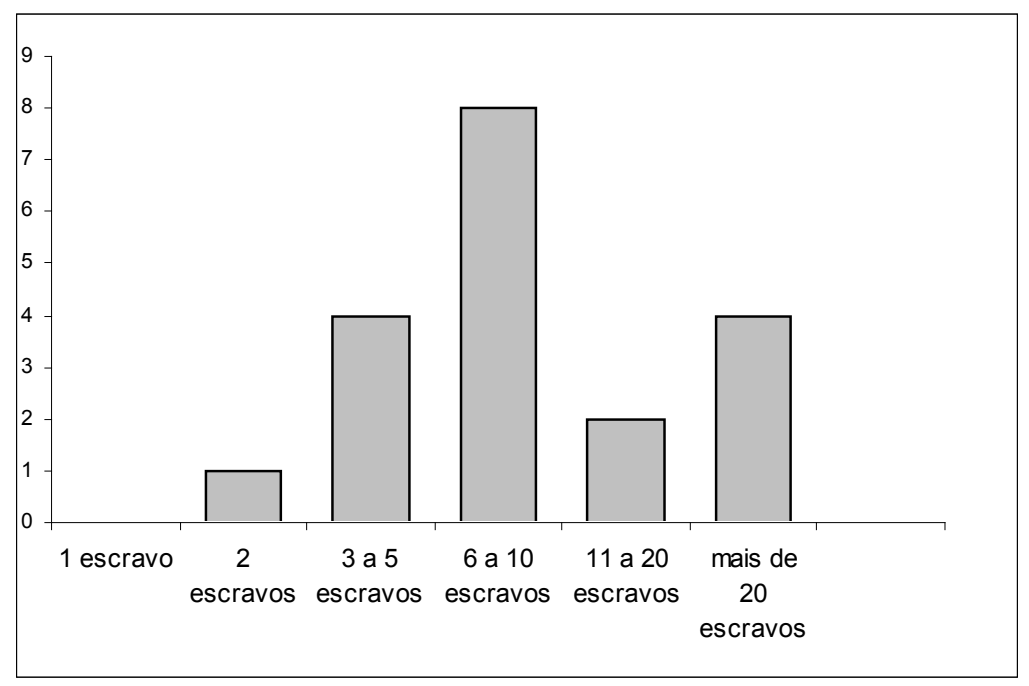

Gráfico 2: distribuição dos moinhos de fubá por fazendas, classificadas por número de escravos. Fonte: APU, inventários post mortem (1822-1861).

Contudo, é possível que os moinhos, nessas unidades escravistas, destinassem-se não só às necessidades domésticas de fubá, mas também a moer o milho produzido nas unidades menores, que pagavam pelo uso deles em espécie. Não temos provas diretas dessa relação de produção nos documentos pesquisados, mas ela era comum, por exemplo, entre os caipiras estudados por Antônio Cândido (2001), ou entre os engenhos do litoral (FerLInI, 1988), lembrando a poia e a maquia, tradicional entre moleiros de Portugal (Holanda, 1995).

Neste item, analisamos dois dos mais importantes complexos técnicos, responsáveis pela obtenção dos principais alimentos energéticos dos sertanejos do interior do Brasil, no período colonial e imperial: o milho e a mandioca. Concluímos pela presença do complexo do milho no Triângulo Mineiro na primeira metade do século XIX, mas não existem indicadores da presença de uma tradição mandioqueira na mesma região. 
A seguir, veremos como se organizava a produção têxtil na região em estudo, no mesmo período.

\section{Fios e panos}

Se os complexos do milho e da mandioca foram, em grande parte, absorvidos das práticas indígenas praticamente sem grandes mudanças, o mesmo não se deu com as técnicas de fiação e tecelagem. Embora o algodão indígena ou "algodão da terra", arbóreo, tenha sido mais utilizado que o algodão asiático ou "algodão da Pérsia", herbáceo, todas as técnicas de beneficiamento (descaroçamento), fiação e tecelagem foram trazidas pelos colonos, com base nas experiências acumuladas não só em Portugal, mas também no Império Português.

Holanda (1995) assinala que a introdução do algodão herbáceo no Brasil ocorreu somente na década de 1790, por influência dos técnicos agrícolas ilustrados, vindos no período mariano-joanino. Segundo esse autor, apesar da maior produtividade deste — 5 a 6 vezes maior que a do algodão indígena —, as primeiras tentativas de popularizá-lo não foram bem sucedidas, por causa das dificuldades de aclimatação, e talvez por não se adaptar bem às técnicas locais, principalmente ao descaroçador a manivela.

Dessa forma, é provável que, em toda a primeira metade do século XIX, o algodoeiro "da terra" tenha sido a única espécie cultivada em Minas Gerais. Saint Hilaire referiu-se somente a algodoeiros arbóreos em Peçanha, uma das principais regiões produtoras da província: "uma plantação de algodoeiros dura em média de 5 a 6 anos [...] e não produzem senão ao cabo de 2 anos" (2000, p. 172). Em nossa região de estudo, o algodão arbóreo aparece referido em alguns documentos, como na carta de padre Leandro, de 1827, onde se lê: "vi pé de algodão que um homem subiu por ele acima até a altura de 14 palmos, e me disseram que esperavam colher meia arroba na primeira panha e da segunda mais de oito libras" (PONTES, 1978, p. 91).

Uma vez colhidos os capulhos, o artefato usado na primeira etapa do beneficiamento de algodão era o descaroçador, máquina rústica derivada da churka indiana, e que se difundiu até Portugal pelas mãos dos árabes. A mais antiga referência a seu uso no Brasil é do Autor Anônimo, em 1618, no Nordeste. Em São Paulo, seu uso generalizou-se em 1680, e de lá provavelmente se 
difundiu para Minas Gerais (HoLANDA, 1995). Saint Hilaire assim descreveu o instrumento, em Peçanha:

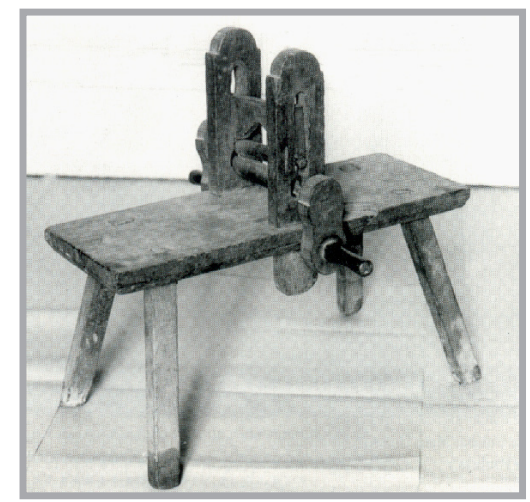

Figura 8: descaroçador de algodão de Cuiabá (século XVIII). Fonte: Holanda (1995).

Para separar o algodão das sementes se emprega uma pequena máquina portátil que se compõe de duas colunas, nas quais se apóiam outros tantos cilindros do comprimento de cerca de um pé [33 cm], da grossura de um dedo e muito aproximados um do outro. Colocam-se os flocos de algodão a um lado dos cilindros e faz-se girar estes em sentido contrário com o auxílio de manivelas colocadas do lado de fora dos montantes. Os cilindros pegam o algodão, puxam-no com a sua rotação, fazem-no passar para o outro lado da máquina, e as sementes ficam do lado em que foram colocados os flocos (2000, p. 172).

$\mathrm{O}$ instrumento não sofreu nenhuma mudança, em seus sucessivos deslocamentos, da São Paulo seiscentista até o Triângulo Mineiro de apenas algumas décadas atrás. A descrição de Saint Hilaire, feita no Norte Mineiro em 1819, corresponde precisamente ao instrumento usado pelos paulistas do século XVIII (figura 8). A descrição que obtivemos de um antigo morador da região rural de Patos de Minas, que manipulava o aparelho em sua infância, na década de 1940, coincide pontualmente com a do botânico francês:

O descaroçador é feito de madeira dura e bem seca, uma vez que necessita de ajustes milimétricos. Compõe-se de longo e pesado banco, tendo ao centro 
duas moendas presas por duas colunas laterais, na altura de mais ou menos vinte centímetros. Essas moendas, uma para cada lado, prendem-se a eixos fixos nas colunas laterais. Os eixos ficam sobrepostos e bem ajustados entre si e às colunas. Para descaroçar o algodão utiliza-se da mão de obra de dois trabalhadores, que ficam assentados, de frente um para o outro, de cada lado do grande banco. Cada um, com a mão direita, aciona a moenda de forma que os eixos giram em sentido opostos. O trabalhador que fica do lado esquerdo do banco é o alimentador, isto é, aquele que coloca o capucho no descaroçador. ${ }^{29}$

Segundo Holanda (1995), o descaroçador rústico resistiu às inovações tecnológicas, inclusive ao saw-gin, inventado no sul dos Estados Unidos no final do século XVIII, que multiplicava exponencialmente a produtividade do descaroçamento. A razão era que o descaroçador primitivo adaptava-se melhor do que qualquer outro à fibra indígena. $\mathrm{O}$ modelo americano destruía as fibras longas, produzidas pelo algodão arbóreo, sendo mais bem adaptado ao algodão herbáceo, de fibra curta. Assim, a permanência de uma técnica rústica se explicaria não por um suposto apego ao "atraso", mas a uma melhor adaptabilidade às características do produto nativo.

Nos inventários do termo da vila de Uberaba, os descaroçadores aparecem referidos em sete inventários, desde 1827. É possível que fossem mais comuns do que deixa transparecer a leitura dos documentos, como se pode deduzir pela presença das rodas de fiar, descritas na maioria dos inventários: é improvável que as famílias dispusessem de rocas e não de descaroçadores. A razão da sua ausência, em moradias que dispunham dos demais elementos do complexo da fiação, é que se tratava de artefatos de fácil feitura, e por isso muito baratos, sendo, na maioria das vezes, ignorados pelos inventariantes. Em 1828, um descaroçador era avaliado em 640 réis, algo como metade do preço de uma enxada velha. ${ }^{30}$

A carda e a fiação eram outras duas etapas que contavam com técnicas exclusivamente ibéricas. O primeiro dos dois processos era realizado por dois tipos de instrumentos: a carda de arco, instrumento simples consistido de uma vara arqueada unida nas extremidades por uma corda; e a carda de espículas, um par de escovas que eram presas uma a cada mão. O segundo processo

29 Geraldo Lourenço Castro, depoimento escrito (02/05/2002).

30 APU, inventário de Miguel Martins Morgado (07/07/1828), maço N35, caixa 459. 
consistia no uso da roda de fiar, uma roda unida a um pedal e a um fuso, no qual eram enoveladas as linhas de algodão, também este um instrumento trazido de Portugal (HoLANDA, 1995).

Holanda (1995) menciona que a carda de arco era a mais usada em São Paulo, até o século XVIII. Saint Hilaire descreve somente o uso da carda de arco, em Peçanha, Minas Gerais: "para cardar o algodão, existe um pequeno arco cuja corda pode ter comprimento de pé e meio” (2000, p. 172). É provável que esse fosse o instrumento de carda usado no Triângulo Mineiro, na primeira metade do século XIX. Nos inventários de Uberaba, é notável a ausência de qualquer referência a cardas, antes de 1850. Isto se dava provavelmente pelos mesmos motivos da quase ausência de descaroçadores: um instrumento tão simples não teria merecido a atenção dos inventariantes.

Contudo, a referência às cardas torna-se muito freqüente após essa data, e por uma razão: tratava-se, a partir de então, das escovas de cardar, um instrumento mais sofisticado e, por isso, mais valorizado. De fato, todas as referências a ele aparecem como "um par de cardas", ${ }^{31}$ o que, segundo Holanda, "a simples circunstância de serem elas avaliadas aos pares serve para mostrar que não se tratava de arcos, ou batedeiras para capulhos" (1995, p. 226).

Nos depoimentos que recolhemos de antigos moradores da região dos anos 1910 e 1920 (Tupaciguara ${ }^{32}$ e Santa Maria ${ }^{33}$ ), a única carda que conheciam era a de espículas. Assim, podemos situar provavelmente em meados do século XIX o início da substituição da carda de arco pela carda em escova, no Triângulo Mineiro.

A tecelagem, em toda a província de Minas, era feita nos teares horizontais que, segundo Holanda (1995), são de origem ibérica (figura 9). Tanto a fiação quanto a tecelagem tiveram grande desenvolvimento na capitania - depois província - de Minas Gerais no final do século XVIII e início do XIX. Saint Hilaire (2000) encontrou nessas atividades a razão da prosperidade do termo de Minas Novas, no Vale do Jequitinhonha, comarca do Serro do Frio.

Nessa região, de solos e clima adequados ao cultivo do algodão, a fiação e a tecelagem faziam dos tecidos e rendas seu principal produto, vendido tanto para a Bahia quanto para o Rio de Janeiro, de onde inclusive era exportado: "o termo de

\footnotetext{
31 APU, inventário de Antônio Francisco de Assis (04/05/1850), maço N14, caixa 470.

32 Guiomar Maria da Silva, depoimento gravado (02/05/2002).

33 Hélio Rodrigues da Cunha, depoimento gravado, (15/01/2002).
} 
Minas Novas é bem conhecido pelos comerciantes da Europa pela excelência de seu algodão" (p. 194). Em Vila do Fanado, ${ }^{34}$ capital do termo, "fazem-se cobertores de algodão [...], de que uma parte se expede para o Rio de Janeiro" (p. 223). Nos arredores daquela vila, em Chapada, ${ }^{35}$ os moradores não produziam o algodão, mas compravam-no das redondezas, para fabricar cobertores (p. 225).

A produção de algodão e tecidos também era uma atividade importante na comarca do Rio das Mortes, que o cronista visitou em 1819 — embora não tanto quanto no Serro do Frio. A área do algodão, que se iniciava nos arredores de São João Del Rei, estendia-se por todo o Oeste da comarca, ao longo da Picada Nova de Goiás, chegando a Araxá. Em São João, Saint Hilaire assinalou que "a cultura do algodoeiro é em geral feita em vários pontos da comarca, [...] tais como Queluz [...], São João Del Rei, Vila da Campanha” (1974, p. 102). Em Pium-i, já no Oeste de Minas, nos arredores da Picada de Goiás, reparou que "seus habitantes [...] derrubam as matas dos arredores [...] e nelas plantam principalmente algodoeiros, que se dão muito bem na região" (1975 b, p. 95).

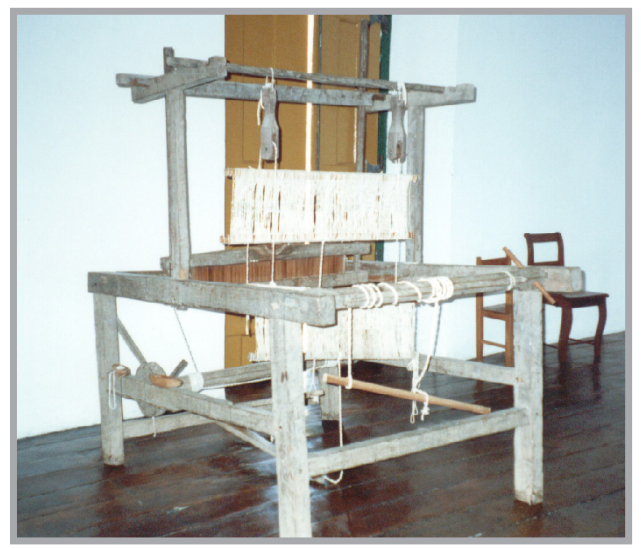

Figura 9: tear horizontal (Goiás Velho, GO).

Fonte: foto de Lourenço, L. A. B. (2002)

O algodão também era plantado e vendido ao Rio de Janeiro pela região de Araxá e Patrocínio. Saint Hilaire relatou que o algodão dessa região "era

\footnotetext{
34 Hoje Minas Novas.

35 Hoje Chapada do Norte.
} 
despachado para o Rio de Janeiro. Até Barbacena esse produto é geralmente transportado em carros de boi, que levam 80 arrobas, e a partir dessa cidade a carga é passada para o lombo de burros" (1975 b, p. 136).

Essa tradição algodoeira chegou também ao então recém-colonizado Sertão da Farinha Podre, pois Uberaba já exportava a fibra em 1819. O naturalista francês, naquela data, escreveu que "as terras da Farinha Podre são igualmente favoráveis à cultura do milho, da cana de açúcar, do feijão e do algodão, mas unicamente este último é exportado" (1975 a, p. 151).

Se uma parte do algodão do Extremo Oeste de Minas era exportado in natura, a maior parte, contudo, era usada nas manufaturas domésticas. Nisso, a região igualava-se às demais da província, onde a produção têxtil, apesar de artesanal, alcançara a auto-suficiência.

Em todo o território mineiro, no final do século XVIII e início do XIX, desenvolveu-se uma próspera manufatura têxtil que, em algumas regiões como o Serro do Frio ou Rio das Mortes, passou até mesmo a exportar tecidos para as demais regiões do Brasil. Mesmo a proibição feita à atividade têxtil, pelo alvará de 5 de janeiro de 1785, não afetou Minas, pois a produção da capitania, que consistia quase que só de tecidos de algodão, era a única exceção feita por essa lei. Com a chegada da Corte, em 1808, o Rio de Janeiro tornou-se um importante mercado, o que aqueceu a produção mineira e permitiu que ela ultrapassasse o âmbito doméstico, gerando excedentes comercializáveis (LiBBY, 1988).

A chegada dos Bragança, todavia, se, por um lado, acabou com as restrições à indústria local, por outro, abriu o mercado brasileiro às importações estrangeiras, que passaram a concorrer com o artesanato doméstico. Isso condenou ao desaparecimento a manufatura têxtil doméstica de São Paulo (HOLANDA, 1995), mas o mesmo não ocorreu com Minas. Segundo Libby, a extraordinária prosperidade das manufaturas têxteis mineiras, mesmo frente à concorrência dos produtos importados, deveu-se a um fator de ordem geográfica, representado pela barreira montanhosa:

[...] os custos de transporte oneravam o preço dos tecidos importados em Minas. Assim, a indústria doméstica contava com a proteção de uma barreira natural. [...] nas primeiras décadas do século, graças a essa proteção relativa, a indústria têxtil doméstica mineira pôde se expandir de maneira muito mais expressiva do que qualquer outra região do Brasil (1988, p. 189-190). 
Esse autor analisou as características dessa peculiar indústria oitocentista mineira usando os mapas da população, levantamentos censitários feitos pelo governo da província no início do século XIX, nos quais constam as ocupações das populações de cada localidade. As séries de 1831 a 1840 revelaram um grande número de fiandeiras e tecedeiras, sendo que "em vários distritos as fiandeiras superavam numericamente qualquer outra categoria ocupacional, mesmo a categoria [...] de 'trabalhadores na agricultura"' (1988, p. 197). Verificou que a maiorparte da população feminina de Minas era formada por pessoas que se definiam por esses ofícios: a força de trabalho feminina era a base da maior atividade manufatureira da província do século XIX.

Libby (1988) notou que praticamente em todos os fogos ${ }^{36}$ da província havia pelo menos uma fiandeira ou tecedeira, sem distinção de classe, verificando-se uma tendência ao predomínio da força de trabalho livre na atividade. Desse modo, o caráter doméstico da manufatura têxtil era claro: as rocas e teares funcionavam como uma parte do trabalho dos núcleos familiares, no qual também se incluía a agricultura e o beneficiamento de alimentos. Holanda já chamava a atenção para essa característica da atividade têxtil, falando de São Paulo dos séculos XVII e XVIII:

Mais do que outras atividades manufatureiras, a fabricação de fios e tecidos destinados a uso doméstico andava estreitamente associada, aqui, à vida do lar. Nos sítios da roça, onde quer que existisse mão de obra para o mister, o excesso da produção servira para permutas e pagamentos [...] (1995, p. 218-219).

A força de trabalho escrava (nesse caso, das escravas) funcionava mais como extensão da força de trabalho familiar do que propriamente como base de uma produção escravista. Veremos, no capítulo 5, que assim se dava com toda a produção das unidades familiares que contavam com poucos escravos.

Libby observou que, em toda a província de Minas Gerais, o número de fiandeiras era sempre superior ao de tecedeiras. O fio era o produto final de quase todas as unidades domésticas e, muitas vezes, era vendido para outras regiões. Porém, a principal razão da existência de poucas tecedeiras para muitas

36 Usaremos a terminologia fogo ao referirmo-nos à unidade familiar (que também funcionava como unidade produtiva) reunida geralmente em torno de uma família nuclear. Essa é a terminologia usada nos documentos de época. 
fiandeiras é que estas produziam fios para aquelas, num sistema integrado em que várias rocas supriam um único tear.

Esse sistema, de várias fiandeiras para algumas tecedeiras, é o mesmo que imperava na capitania de São Paulo, desde o século XVII. Estudando inventários seiscentistas, Holanda também encontrou muito mais rocas que teares, e concluiu: "nem todos dispõem de teares, de modo que alguns proprietários devem auferir bons lucros fazendo tecer o algodão próprio e alheio" (1995, p. 215). Em São Paulo, o tecelão recebia uma vara de tecido a cada sete que fabricasse.

Nos mutirões seguidos de festa — que, no Triângulo Mineiro, recebiam o nome de treição - , era comum as mulheres fiarem, enquanto os homens trabalhavam as roças. D'Alincourt descreveu um mutirão em Jundiaí:

[...] em uma casa, em que, nessa ocasião, havia um grande número de pessoas, de ambos os sexos; por ser costume juntarem-se muitos para o trabalho a que chamam muchiron na linguagem indiana; e assim passam a umas a outras casas, à medida que vão findando as tarefas: o trabalho consiste em prepararem $\mathrm{e}$ fiarem algodão, e fazerem roçados nas plantações (1975, p. 49).

Coletamos um relato de uma moradora do meio rural de Tupaciguara nos anos 1920, que descreve o mesmo sistema de organização do trabalho, com as mulheres assumindo a fiação como tarefa coletiva, na treição:

A treição dos fazendeiros [...] era a coisa mais fácil que tinha. Eles cismavam de fazer a treição lá com um fazendeiro, então juntavam um ou dois, e ali combinavam tudo como iam fazer. Se ele tinha pasto para roçar, eles viam lá que tinha muito serviço de pasto para roçar, eles iam lá roçar pasto, se era para plantar [...]. Se fosse tempo de capina era na enxada, se fosse para roçar era na foice. As mulheres iam fiar, iam cardar, descaroçar, tudo de uma vez. Aí eles combinavam tudo e o fazendeiro não sabia de nada, não. Levantava de madrugada, ali eles arranjavam sanfona, arranjavam viola, juntavam aquele monte de gente. Eu cheguei a levar a Íris, pequenina, numa treição que deram no Odilonzinho. ${ }^{37}$

37 Guiomar Maria da Silva, depoimento gravado (15/04/2002). 
Algumas fiandeiras também trabalhavam por encomenda, fiando algodão alheio e sendo pagas com parte da produção. Em 1819, Saint Hilaire, de passagem por Corumbá de Goiás, notou que "as mulheres fiam o algodão e recebem o seu salário na forma de mercadorias" (1975 a, p. 33).

O Oeste Mineiro e o Alto Paranaíba eram as regiões que mais se dedicavam à fiação e tecelagem domésticas. No Triângulo Mineiro, Libby encontrou situação semelhante. Nessa região, "mais de três quartos das mulheres chefes de domicílio eram fiandeiras ou tecedeiras" (1988, p. 203). Assim, as mesmas bases em que se estruturava a fiação e tecelagem em outras regiões da província de Minas Gerais — força de trabalho feminina, caráter doméstico da produção, uso do trabalho escravo como extensão do trabalho livre - provavelmente também existiam na região em estudo. Seria interessante tentar abordar o estudo da manufatura têxtil oitocentista no Triângulo Mineiro usando outras fontes, diferentes das de Libby, a ver se se confirma o quadro traçado pelo autor.

A leitura dos inventários da vila de Uberaba, entre 1822 e $1861,{ }^{38}$ mostra de maneira inequívoca o caráter doméstico e pulverizado da fiação e tecelagem na região. De um total de 167 inventários, 62 deles (37\%) arrolavam rodas de fiar, e $42(25 \%)$ contavam com teares. Assim, aproximadamente um terço das unidades familiares envolvia-se com a atividade de fiação, e uma quarta parte com a tecelagem. A proporção entre unidades domésticas com rodas de fiar e unidades com teares era de aproximadamente três fogos com rodas para cada dois com teares.

Esses números mostram que, embora por certo houvesse algumas unidades domésticas especializadas em tecelagem e outras em fiação, havia um baixo nível de especialização, com grande parte das famílias se ocupando tanto da fiação quanto da tecelagem. Dessa forma, do total de unidades domésticas envolvidas em atividades têxteis, $42 \%$ delas se ocupavam só da fiação, 15\% só da tecelagem, e $42 \%$ da fiação e tecelagem.

No gráfico 3, correlacionamos a presença dos artefatos do complexo têxtil com o plantel de escravas em cada unidade doméstica, pressupondo que a força de trabalho feminina estava associada a esse tipo de atividade. Como se pode verificar, não existia nenhuma correlação entre presença ou número de teares e plantel de

38 APU, inventários post mortem (1822-1861). 
escravas: tanto entre sitiantes modestos, como entre grandes fazendeiros, o número de teares por unidade nunca era superior a um. Constata-se, com isso, o caráter doméstico, e não fabril, da produção têxtil no termo de Uberaba. A correlação entre número de rodas de fiar e número de escravas também era muito fraca, exceto nas fazendas com grandes plantéis, o que sugere que, como já havia adiantado Libby, o trabalho escravo era pouco empregado na atividade têxtil.

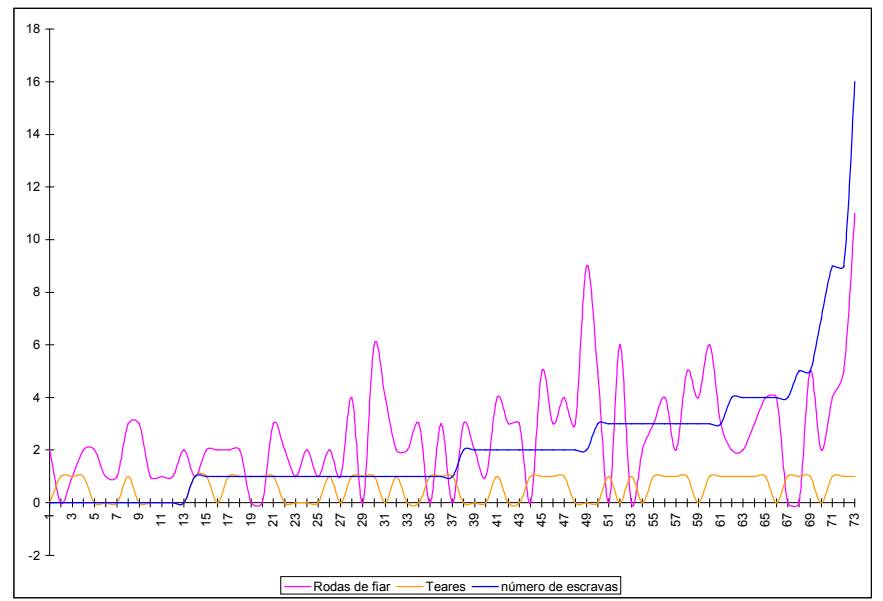

Gráfico 3: correlação entre número de escravas, rodas de fiar e teares em 73 inventários post mortem do termo de Uberaba (1822-1861), distribuída em ordem crescente do número de escravas. Fonte: APU, inventários post mortem (1822-1861).

Esse quadro sugere que, na região, o mundo da fiação e tecelagem muito se assemelhava àquele descrito por Saint Hilaire, em outras regiões de Minas. Na fazenda do alferes Machado, nas proximidades de Peçanha, Vale do Jequitinhonha, observou que "nessa casa todos estavam em atividade, espetáculo que raramente goza o viajante que percorre o Brasil. A senhora Machado cosia; algumas de suas filhas fiavam o algodão, outras faziam renda" (2000, p. 171).

A difusão dos equipamentos técnicos do complexo da fiação e tecelagem entre a população mostra que a mercantilização da produção no nível local era pequena, o que de resto ocorria com grande parte dos gêneros de subsistência, 
dada a baixa divisão social do trabalho. Analisando o inventário do capitão Manuel da Silva Cardoso, comerciante de tecidos de Uberaba, morto em 1841, foi possível conhecer as mercadorias têxteis, ou "fazendas secas", que constavam de seu estoque. ${ }^{39}$ Ali estavam arrolados chitas, riscados sortidos, lenços estampados amarelos, americanos, fustões, paninhos cor-de-rosa, mas nenhum pano de algodão. O comércio local de têxteis, ao que parece, só se ocupava de vender artigos importados, já que grande parte da população produzia ou obtinha por troca direta — os tecidos de algodão usados na vestimenta do dia-a-dia.

Deste modo, o quadro que se revela, relativo à manufatura têxtil no Triângulo oitocentista, é o de uma atividade presente em grande número de moradias, onde mulheres livres - mães, filhas e parentes - e escravas se envolviam nas várias etapas do complexo têxtil — descaroçamento, carda, fiação e tecelagem - como parte das atividades da rotina doméstica. Eventualmente, produziam excedentes — fios e panos — que eram comercializados. Havia pouca especialização nas diversas atividades, embora alguns fogos fizessem só fios, e algumas tecelãs que não fiassem, recebendo encomendas de fiandeiras, talvez fossem pagas com parte do tecido produzido.

A seguir, veremos como a sociedade de pioneiros geralistas tratava a questão da moradia no Triângulo Mineiro da primeira metade do século XIX.

\section{Casas de morada, cozinha e quintal}

A paisagem rural oitocentista do Triângulo Mineiro, que os relatos dos viajantes do início daquele século deixam entrever, resultava de um padrão de ocupação que tendia a manter praticamente desertas as chapadas, enquanto os cultivos, a moradia e o instrumental técnico de beneficiamento se situavam nos vales fluviais. Nas proximidades de Oliveira, Saint Hilaire comentou, ao chegar numa fazenda, que "como todas as outras, fica situada numa baixada" (1975 b, p. 83). No Ribeirão das Furnas, nas proximidades do Rio das Velhas, "o engenho de Furnas fica num vale profundo" (1975 a, p. 139).

39 APU, inventário do capitão Manuel da Silva Cardoso (08/11/1841), maço N9. 
Esse é o tipo de sítio no qual encontramos as fazendas mais antigas, que sobreviveram daquela época aos dias de hoje, como se vê na figura 10. A razão da escolha desse sítio é, essencialmente, a necessidade da água: esta era obtida pelos regos d'água, desviados dos córregos adjacentes. Além disso, a presença mais comum das terras de cultura nas matas galerias favorecia o cultivo de hortas e pomares. Dessa forma, o sítio deveria estar sempre a jusante de algum pequeno curso d'água, que pudesse ser facilmente transposto por estivas ou pinguelas. Raramente, contudo, o sítio escolhido ficava na margem de rios caudalosos, de difícil transposição e sujeito a febres malsãs.

O rego d’água (figura 11) era o que tornava possível não só o beber e o alimentar-se das pessoas e animais, mas também o próprio funcionamento de todo o maquinário rústico necessário aos processos de beneficiamento. Fonte de energia dos monjolos, moinhos, rodas d'água, engenhocas e alambiques, a força mecânica hidráulica só era sobrepujada pela força muscular — humana e animal — na ecologia dos estabelecimentos rurais antigos.

O rego d'água era elemento onipresente nos sítios — nome dado ao conjunto formado por moradia e benfeitorias, tanto de pequenos quanto de grandes proprietários —, nos inventários do termo de Uberaba, entre 1822 e 1861. A dependência em relação ao rego d'água impunha que se localizassem todas as benfeitorias bem próximas umas das outras.

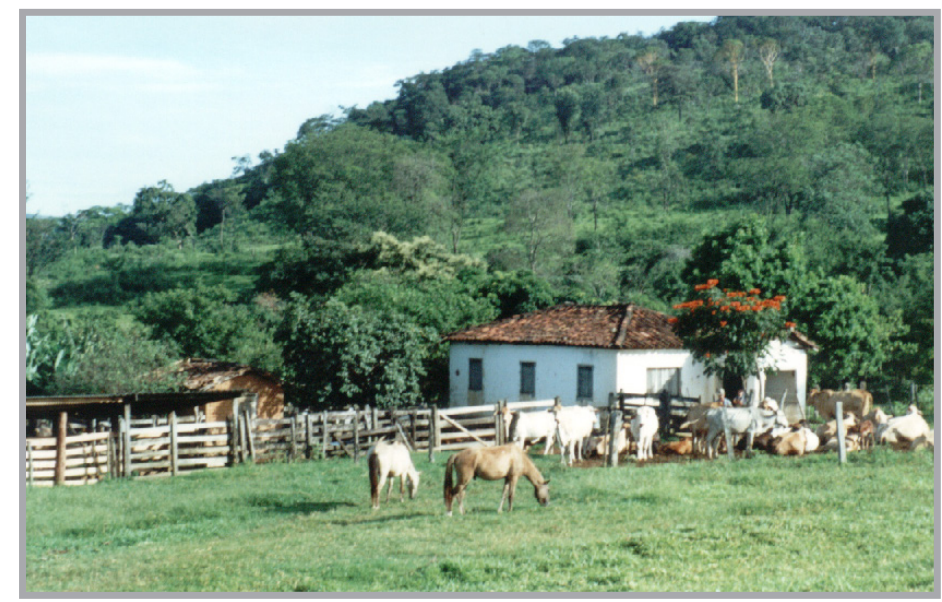

Figura 10: fazenda de gado (Pirenópolis, GO).

Fonte: foto de Lourenço, L. A. B. (2002) (2001). 
Os inventários mostram que os sítios obedeciam a um desenho básico, onde se construíam, contíguos à casa de vivenda, o curral — geralmente feito em madeira aroeira, mas podendo-se usar pedras no lugar dela —; o paiol; o monjolo; e o quintal onde, invariavelmente, constavam "arvoredos de espinhos" (laranjeiras), freqüentemente cafeeiros e bananeiras e, às vezes, jabuticabeiras. Também nesse espaço se encontravam os moinhos de fubá e as engenhocas,

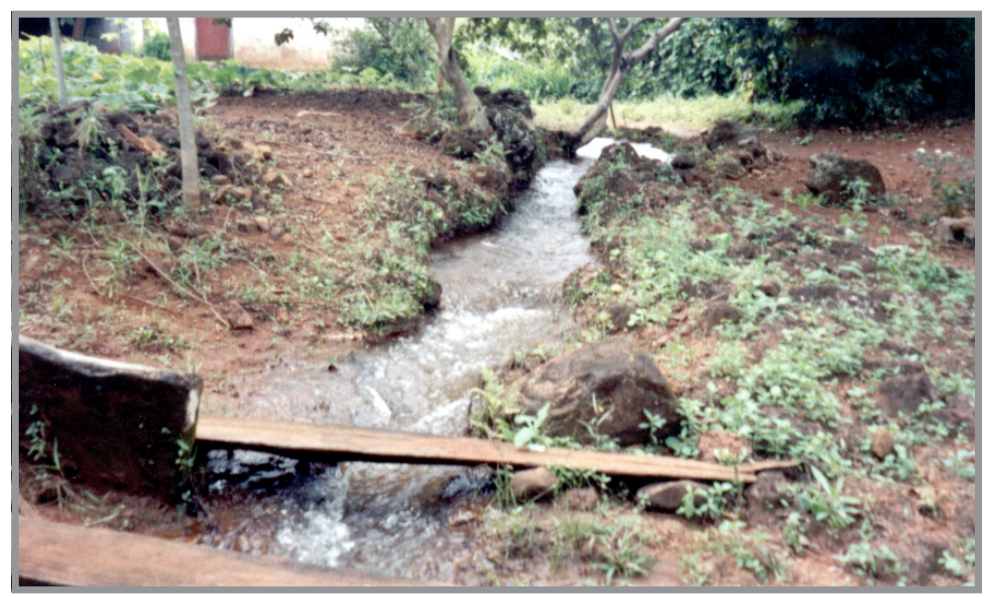

Figura 11: rego d'água e pinguela (Nova Ponte, $\mathrm{MG}$ ).

Fonte: foto de Lourenço, L. A. B. (2002).

quando o sitiante dispunha dessas benfeitorias.

Esse complexo de moradia e trabalho era cercado por aroeira ou valos, de forma a impedir a invasão do gado. Assim, o sítio de João Caetano Barbosa compunha-se, em 1832, de "pequenas casas cobertas de capim, paiol, rego d'água, monjolo, quintal, parte dele cercado de aroeira e cafés e alguns arvoredos de espinhos, um pastinho cercado de valos unido ao mesmo quintal". ${ }^{40}$

A cozinha era uma dependência apartada da casa, normalmente descrita em separado. Por exemplo, no inventário de Maria Joaquina da Silveira lê-se "morada de casas cobertas de telhas com cozinha coberta de telhas". ${ }^{41}$ A cozinha,

\footnotetext{
40 APU, inventário de João Caetano Barbosa (24/04/1832), maço N11, caixa 470.

41 APU, inventário de Maria Joaquina da Silveira (02/11/1827), maço N5.
} 
às vezes, era construída com apreço maior do que a própria casa de morada: é o que se percebe no inventário de Agma Agostinha Souza Benício, de 1843, que possuía "casas de vivenda cobertas de capim, cozinha coberta de telhas, paiol metade coberto de telhas". ${ }^{4}$

Ausências notáveis, nos inventários pesquisados, foram as habitações de escravos. Do total de 167 documentos lidos, senzalas foram referidas em apenas três deles, todos proprietários de grandes plantéis de cativos. Essas habitações coletivas de escravos foram citadas somente nos inventários do capitão Antônio José de Araújo, ${ }^{43}$ senhor de 21 escravos em Dores do Campo Formoso, em 1838; no do tenente Joaquim Silva Oliveira, ${ }^{44}$ poderoso fazendeiro de Uberaba, dono de um plantel com 42 cativos; e no de um senhor de engenho de Carmo dos Morrinhos, capitão José de Miranda Ramalho, ${ }^{45}$ dono de 33 cativos. Assim, os inventários não noticiam, por exemplo, onde viviam os nove escravos de José Gonçalves Lima, ${ }^{46}$ em 1835, pois seu sítio foi descrito como "casas de vivenda, paiol coberto de capim com seu quintal cercado de madeira, com plantações de café, arvoredos de espinhos, curral e engenhos de pilões já velhos", e só.

Essa ausência também foi percebida por Sheila Castro Faria, em seu estudo feito em inventários post mortem da região de Campos dos Goitacases entre os séculos XVIII e XIX. A autora aventou três hipóteses para o fato:

A primeira, e mais evidente, é que as senzalas eram tão destituídas de valor que não mereciam avaliações precisas [...]. A segunda hipótese é a de que a casa dos escravos era construída por eles próprios, e de sua propriedade. [...] Mais provável, e é a terceira hipótese, é que o local onde dormiam os escravos se localizasse dentro das casas de morada do proprietário, sendo, mais uma vez, a designação plural "casas de morada" que definia não só o complexo de moradia e beneficiamento como também um lugar onde dormiam pessoas diferenciadas (1998, p. 368).

Diversamente da autora, tendemo-nos mais para a segunda hipótese por ela aventada. Os relatos dos viajantes joaninos não deixam dúvidas

\footnotetext{
APU, inventário de Agma Agostinha Souza Benício (04/09/1843), maço N44.

APU, inventário de Antônio José de Araújo (20/03/1838), caixa 459.

APU, inventário de Joaquim Silva Oliveira (06/03/1839), maço N7, caixa 461.

APU, inventário de José de Miranda Ramalho (03/08/1844), maço 2.

APU, inventário de José Gonçalves Lima (05/11/1835), maço N122.
} 
quanto à exigüidade e precariedade das habitações sertanejas, mesmo quando pertencentes a senhores abastados. Eschwege descreveu, em Patrocínio, a Fazenda do Salitre, "que pertence a um dos mais nobres e ricos fazendeiros, que é também juiz e dedica-se à criação de gado", o qual, não obstante, vivia numa casa onde "as paredes da moradia, pequena e baixa, feitas de barro, estavam inteiramente esburacadas. A porta estava semi-obstruída por varas, que impediam a entrada dos porcos" (1996. p. 110). Pelo menos no contexto do Extremo Oeste Mineiro, as rústicas habitações sertanejas não poderiam abrigar a família do proprietário — geralmente numerosa — e mais as famílias escravas.

Os relatos dos viajantes permitem supor que os escravos viviam em habitações unifamiliares, vizinhas à casa do proprietário, e compondo o que os documentos da época denominavam sítio. Sempre que se referiram às moradias de escravos, os cronistas falaram de choupanas ou taperas construídas nas proximidades da casa dos senhores, muitas vezes, dela pouco se diferenciando, mas sempre dela apartadas. Nas vizinhanças de Madre de Deus, ${ }^{47}$ no Alto Rio Grande, em 1819, Saint Hilaire assinalou que:

Descrever uma das fazendas da comarca de São João significa descrever todas, pois em geral são construídas segundo o mesmo modelo. Um muro de pedras rústicas mais ou menos da altura de um homem cerca um pasto bastante vasto, no fundo do qual se enfileiram as choças dos escravos, os galpões para beneficiamento ou depósito dos produtos agrícolas e a casa grande. Esta, de pau-a-pique e coberta por telhas, é construída ao rés do chão [grifos nossos] (1975 b, p. 56).

Indo em direção ao Oeste Mineiro, pela Picada de Goiás, nas proximidades da Serra da Canastra, o naturalista relatou:

Já nos limites do sertão, as casa da sede das fazendas se compõem de várias edificações isoladas, mal construídas e dispostas sem ordem, no meio das quais dificilmente se distingue a residência do proprietário. Citarei a de Dona Tomásia, localizada entre o povoado de Pium-i e a Serra da Canastra. A propriedade era de extensão considerável e vi vários escravos e gado, e numerosos porcos. Entretanto,

47 Hoje Madre de Deus de Minas. 
em meio a várias casinhas que serviam de celeiros e senzalas, a dona da fazenda ocupava uma miserável cabana [...] [grifos nossos] (p. 75).

Nas proximidades de Araxá, observou sobre os fazendeiros que "as casas em que vivem são pequenas e escuras, e, mesmo nas fazendas um pouco mais prósperas, a que pertence ao dono da propriedade não se diferencia do alojamento dos escravos" (1975 b, p. 119). Em Goiás, numa fazenda próxima a Santa Luzia, “a casa do proprietário, coberta de palha, difere pouco da dos escravos” (1975 a, p. 23).

Essa hipótese de que, em muitos casos, os escravos viviam em ranchos unifamiliares vizinhos às moradas de seus senhores, já havia sido aventada por Robert Slenes (1999). Esse historiador, estudando as habitações de escravos de Campinas do século XIX, concluiu que as grandes habitações coletivas - senzalas no sentido estrito, ou senzalas-pavilhão, no dizer do autor - eram freqüentes em fazendas com grandes plantéis de cativos. Já nas fazendas com plantéis menores, mais comuns eram as habitações individuais ou unifamiliares, construídas pelos próprios escravos, sem janelas e cobertas de palha ou folha de buriti, num estilo que remonta a tradições construtivas da África Central. Rugendas retratou uma dessas habitações em um de seus desenhos, que pode ser visto na figura 12. Saint Hilaire deixou uma descrição dessas moradias:

[...] se compunha de uma pequena varanda em que se cozinhava, dum casebre que não passava de um alpendre coberto de esteiras e [...] de uma pequena choça em que a luz penetrava por todos os lados pelos buracos que a terra, caindo, deixara nas paredes. [...] Seu interior era dividido em quartos por um septo formado unicamente por estacas justapostas. Uma mesa, um tamborete e vários giraus ou leitos rústicos aplicados contra as paredes, formavam todo o mobiliário dessa mesquinha morada (2000, p. 169).

Dessa forma, as senzalas arroladas nos inventários post mortem de Uberaba do século XIX provavelmente se referiam às senzalas-pavilhão, isto é, habitações coletivas de cativos, já que estavam incluídas no patrimônio de senhores de grandes escravarias. Saint Hilaire, nas proximidades de Meia 


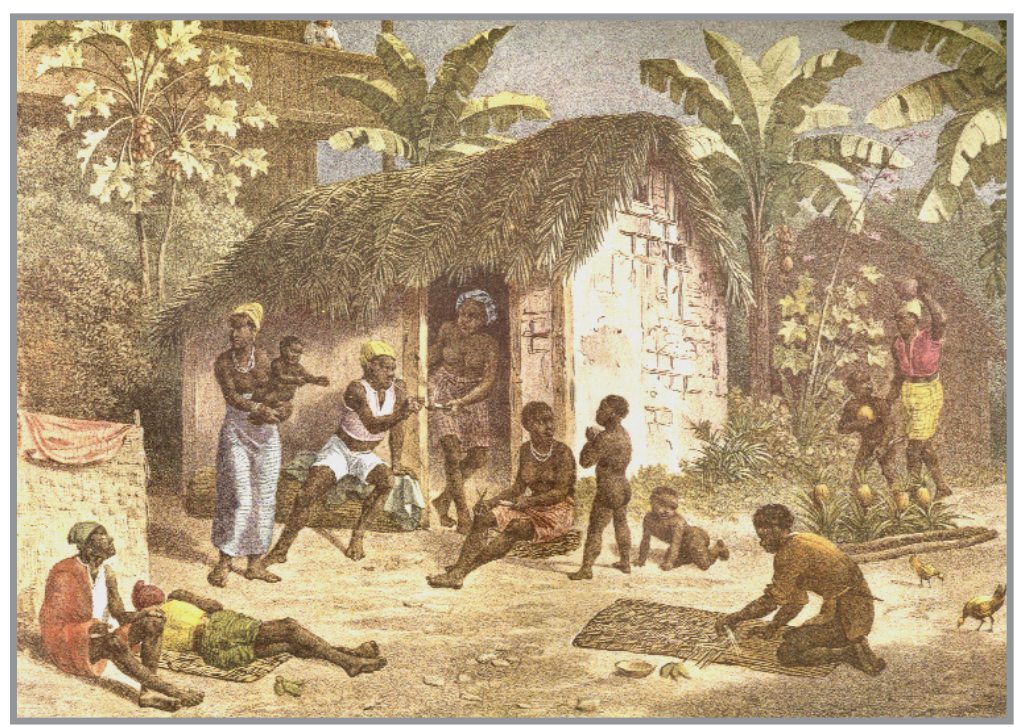

Figura 12: habitação de negros.

Fonte: Rugendas (1998).

Ponte, ${ }^{48}$ em Goiás, descreveu uma dessas senzalas, numa fazenda onde o outro lado da casa do proprietário "era constituído pelos alojamentos dos escravos casados. Esses alojamentos eram cobertos de telhas e divididos em cubículos por paredes até certa altura” (1975 a, p. 98).

Outra ausência intrigante nos inventários é a das moradias de um grupo de inventariados que, a despeito disso, eram proprietários de modestos a razoáveis patrimônios rurais e mancípios. Fortunato Nogueira da Cruz, ${ }^{49}$ por exemplo, era dono de vinte e duas cabeças de gado, trinta e sete porcos e quatro cavalos, além da escrava Claudiana e de seu filhinho Francisco, de dois anos. Com esse rebanho, um machado e três enxadas, sustentava seus cinco filhos menores, até ser assassinado pela esposa Maria Felizarda, em 1847. A questão é: onde Fortunato trabalhava para prover sua família, já que não constam terras em seu patrimônio? E - mais importante — onde vivia até seu infeliz desfecho, já que sequer um imóvel aparece arrolado em seu inventário?

\footnotetext{
48 Hoje Pirenópolis.

49 APU, inventário de Fortunato Nogueira da Cruz (27/09/1847), maço N14.
} 
Fortunato, e como ele muitos outros roceiros do Triângulo Mineiro nos primeiros anos do século XIX, era possivelmente um agregado - termo que designava aqueles que se instalavam em terra alheia, sem ônus. Os agregados eram com freqüência referidos pelos cronistas. Saint Hilaire registrou que "os fazendeiros que possuem grandes extensões de terras dão permissão aos pobres para cultivarem o que quiserem" (1975 b, p. 97).

Esses camponeses sem terra viviam geralmente nos arredores da morada do proprietário, e seus ranchos rústicos misturavam-se às choças dos escravos e às edificações das benfeitorias. Nas proximidades de Santa Luzia, o botânico francês encontrou um "sítio, que abrigava duas ou três famílias, compunha-se de algumas casinhas feitas de barro cinzento, umas cobertas de palha, outras de folhas de buriti" (1975 a, p. 22). Em Caldas Novas, no sítio de Francisco Alves, encontrou "uma dúzia de casinhas esparsas. Uma delas pertencia ao proprietário e as outras eram habitadas por escravos e agregados. Todas, porém, tinham uma aparência igualmente miserável, sendo impossível distinguir a do dono" (p. 110). Em Catalão, "paramos no Sítio do Riacho, composto de três a quatro casebres pertencentes a diferentes pessoas" (p. 123).

Existem algumas indicações nos inventários que sugerem essa disposição das habitações de agregados e escravos, dispersas nos arredores da casa do proprietário. Em alguns casos, essa referência é explícita. Por exemplo, no inventário de Maria Rodrigues da Silva, ${ }^{50}$ havia "um sítio com vários ranchos de capim, rego d'água e um monjolo, com seu quintal e arvoredos de espinho" em sua Fazenda Bagagem, em 1833. No inventário de Policarpo José de Lima, ${ }^{51}$ constavam "uma casa de madeira coberta de telha [...] e outros ranchos todos cobertos de capim, já usados".

Quanto às técnicas de edificação das moradias, os sertanejos contavam com as opções trazidas da região central da província de Minas Gerais. Em todo o Brasil, os colonos utilizaram um conjunto de técnicas de edificação (taipa de pilão, taipa de mão, adobe, alvenaria de tijolo, pedra e cal) originadas de diferentes regiões de Portugal, e trazidas por construtores ou pelos próprios imigrantes da Península Ibérica. A seleção entre uma ou outra técnica dependeu de determinantes históricos e ambientais locais, em cada região do Brasil

\footnotetext{
50 APU, inventário de Maria Rodrigues da Silva (5/11/1833), maço N7.

51 APU, inventário de Policarpo José de Lima (8/02/1837), maço N8, caixa 461.
} 
(Mello, 1985). Nesse caso, parece que a influência das técnicas de edificação indígenas, inadequadas para o tipo de família nuclear luso-brasileira, restringiuse apenas à cobertura de sapé dos ranchos (Lemos, 1999).

Não só em Minas, mas em todo o Brasil, a primeira solução para a moradia surgiu sob a forma dos ranchos, que consistiam de um plano básico com

quatro esteios de pau roliço, quatro frechais e uma cumeeira ao alto; roliços também os caibros que receberão as fibras vegetais de cobertura: sapé, folhas de palmeira etc. [...] fechando-se na periferia com tramas ainda de paus roliços e varas, esqueleto que serviria para a sustentação do barro com que se acaba (Mello, 1985, p. 96).

À medida, contudo, que a ocupação se tornava mais antiga, melhoramentos iam sendo agregados à moradia: telhas de barro no estilo "de canal”, paredes de adobe, reboco e caiação (Mello, 1985). O caráter recente da ocupação foi o fator responsável pelos comentários dos viajantes sobre a precariedade das habitações triangulinas, dos primeiros anos do século XIX. Saint Hilaire descreveu um desses ranchos, na Serra da Canastra:

São construídas rusticamente com paus cruzados e barro, que se desprende facilmente. Um capim miúdo, arrancado com raízes e a terra que as envolve, serve-lhe de cobertura. Seu interior é dividido por tabiques em minúsculos cômodos escuros, cujo único mobiliário consiste num par de tamboretes e alguns catres miseráveis (1975 b, p. 105).

Os inventários post mortem das primeiras décadas do século XIX mostram essa rusticidade das habitações dos primitivos ocupantes do Triângulo Mineiro, mesmo entre os fazendeiros de maiores posses. O fazendeiro Antônio Francisco dos Santos, ${ }^{52}$ por exemplo, possuía grande cabedal em 1829, constituído por vinte e dois escravos, 117 cabeças de gado e a Fazenda Piracanjuba, de 11:600\$000. No entanto, residia em uma casa coberta da capim.

Em regiões mais remotas do interior do Brasil, ainda hoje, podem ser vistos exemplares dessa arquitetura rural rústica (figura 13). Consistem do uso de uma estrutura de madeira (baldrames, frechais e esteios), preenchida pela

52 APU, inventário de Antônio Francisco dos Santos (15/06/1829), maço N3, caixa 459. 
taipa de mão ou pau-a-pique (figura 14), ou em alguns casos, por tijolos de adobe (figura 15), e coberta pelas folhas do sapé ou buriti.

Verificamos, contudo, mudanças diacrônicas nessa arquitetura rural, ao longo da primeira metade do século XIX, no termo de Uberaba. Se, na década de 1820, os telhados de capim cobriam $80 \%$ das moradias, pelas descrições dos inventários, nas décadas seguintes, foram dando lugar, gradualmente, às coberturas de telhas de cerâmica, até praticamente

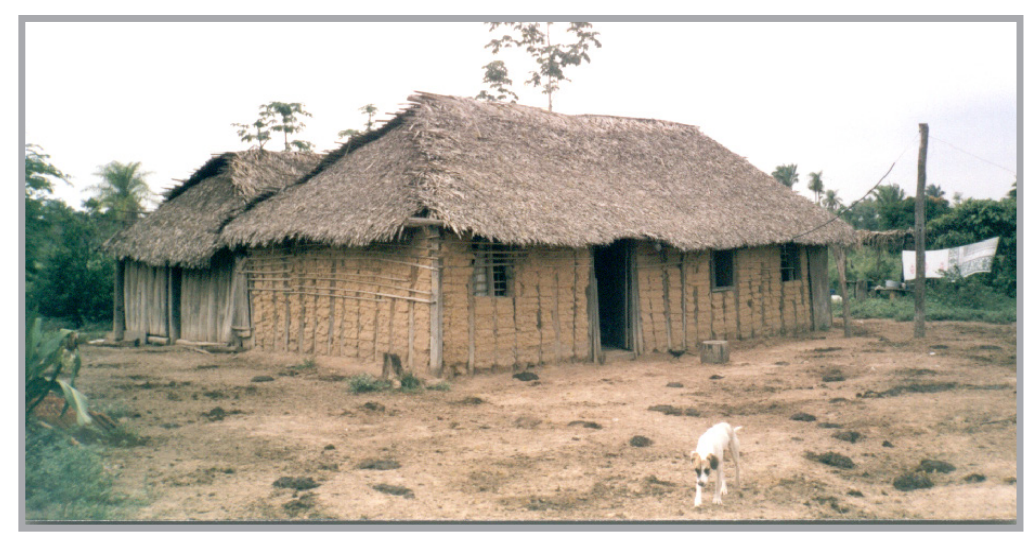

Figura 13: moradia rural coberta de sapé (Piraquê, TO).

Fonte: foto Nataniel Magela de Lima (2001).

desaparecerem nos anos 1850, como mostra o gráfico 4. A partir de 1854, as casas deixaram de ter os telhados descritos nos inventários, o que leva a supor que as coberturas de telhas passaram a predominar amplamente, já não sendo necessário especificar a natureza do material usado em sua confecção.

Vimos, neste capítulo, algumas das técnicas que compunham o sistema técnico dos imigrantes geralistas, quando da sua chegada ao Triângulo Mineiro, nas primeiras décadas do século XIX. O que se pode perceber é que sua rusticidade, se, de um lado, determinava uma baixa produtividade e obrigava a práticas extensivas, de outro, permitia reduzir a um mínimo o custo de reprodução da força de trabalho. 


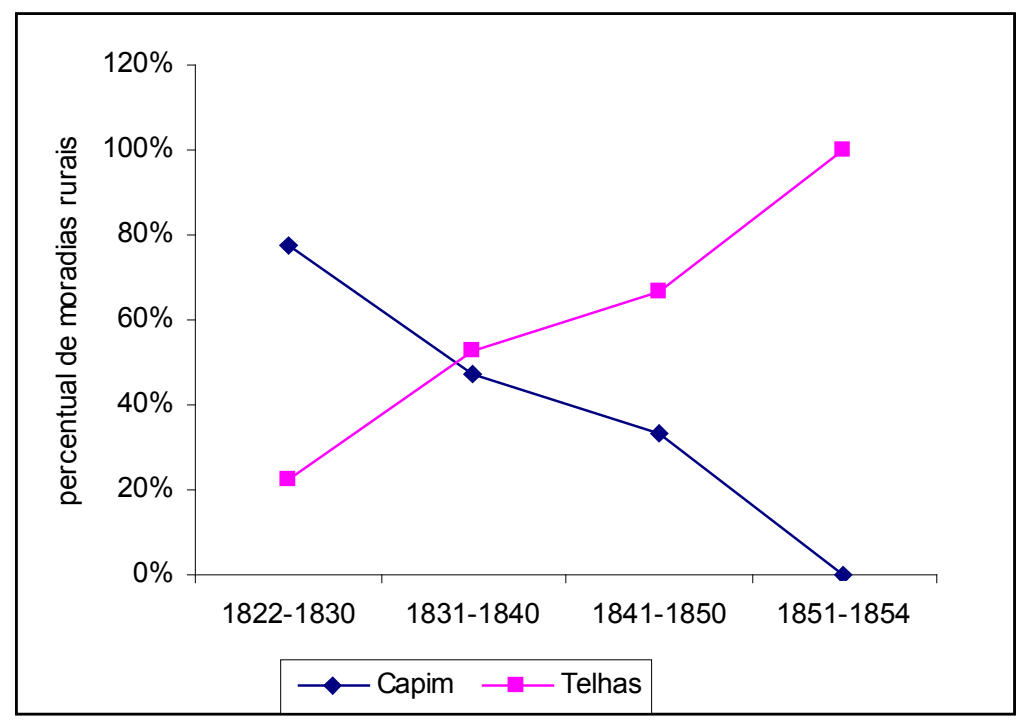

Gráfico 4: técnicas de atelhamento das moradias rurais no termo de Uberaba (1822-1854). Fonte: APU, inventários post mortem (1822-1854).

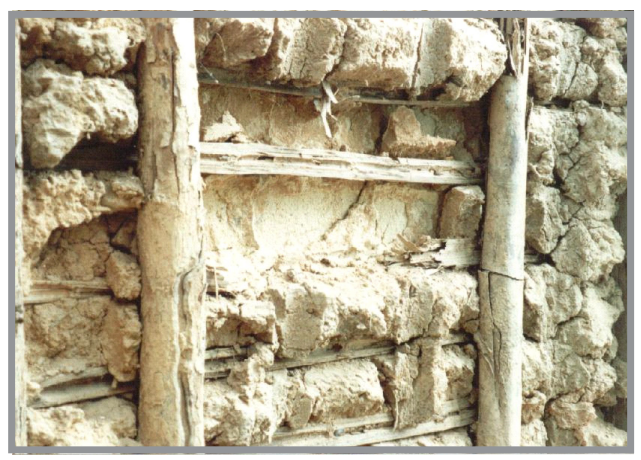

Figura 14: pau-a-pique (Cidade de Goiás, GO). Fonte: foto de Lourenço, L. A. B. (2001). 


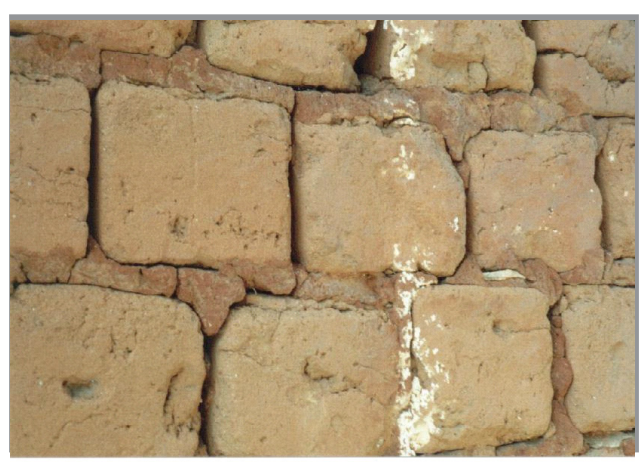

Figura 15: adobe (Pirenópolis, GO). Fonte: foto de Lourenço, L. A. B. (2001).

Esse aspecto permitia, por seu turno, que a economia regional mantivesse certa autonomia frente às crises nacionais ou mundiais, pois podia reduzir a exportação de excedentes sem que sua dinâmica interna fosse muito alterada. Mas, ao mesmo tempo, isso impunha um baixo grau de mercantilização e de liquidez na economia, o que perpetuava a concentração de riquezas. Faremos, no próximo capítulo, uma análise das formas de riqueza e das relações de trabalho no Triângulo Mineiro do século XIX. 


\section{5 | Riqueza, pobreza e escravidão}

\section{A produção historiográfica sobre a Colônia e o Império}

Nos últimos 20 anos, uma nova geração de historiadores vem revisando conceitos antes estabelecidos sobre a História Colonial. Essa nova historiografia revê categorias como sistema colonial e sentido da colonização, questionando idéias como a de uma rígida polarização entre senhores e escravos, e flexibilizando o uso de conceitos marxianos como modo de produção, aplicados à sociedade colonial. Em parte, essa revisão decorre da proliferação de teses e dissertações produzidas por cursos de pós-graduação em todo o Brasil, com acesso a novas e inusitadas fontes.

Tais autores, como João Luís Fragoso, Manolo Garcia Florentino e José Roberto Góes, da UFRJ; ${ }^{1}$ Douglas Cole Libby, Júnia Ferreira Furtado, Eduardo França Paiva e Marco Antônio Silveira, da UFMG, ${ }^{2}$ vêm demonstrando, mediante o estudo de fontes como registros portuários e de tropas, testamentos e inventários post mortem, registros paroquiais e dados censitários, que a vida colonial era bem mais complexa do que se pode supor pela leitura de Gilberto Freyre, Caio Prado Júnior, Celso Furtado e Fernando Antônio Novais.

Uma das categorias que vem sendo revista é a de sistema colonial. Termo consagrado por Caio Prado Jr. (1986), e um dos conceitos centrais no importante livro de Fernando Novais (1986), deriva da concepção de que a sociedade colonial foi o resultado de uma grande empreitada do capital comercial, representado pelos comerciantes transatlânticos associados ao Estado Absolutista português. A economia da Colônia teria uma orientação exógena, voltada para a exportação de gêneros primários, cuja organização seria instada pelos interesses de uma burguesia comercial estabelecida no Reino, a única capaz de acumular no processo.

1 Ver, por exemplo, Florentino e Góes (1997); Fragoso (1998); e Fragoso e Florentino (2001).

2 Ver, por exemplo, Furtado (1999 e 2001); Paiva (2001); e Silveira (1997). 
Segundo essa vertente, a Colônia não contava com um mercado interno consistente. Sua pequena demanda seria suprida pela economia natural de subsistência das plantations, por áreas periféricas voltadas para o abastecimento interno, e pelas manufaturas trazidas pelos comerciantes da Metrópole. Não teria acesso, portanto, a nenhuma parte do excedente gerado nas atividades agroexportadoras ou na exploração aurífera. Disso resultaria uma polarização entre Colônia e Metrópole, uma contradição cujo esgarçamento se revelaria na crise do Antigo Sistema Colonial, do período pombalino (1750-1777) à chegada da Corte (1808), culminando na Independência em 1822.

$\mathrm{O}$ acesso a novas fontes primárias, nos últimos anos, vem revelando um quadro diferente daquele sugerido por esses estudos clássicos. Fragoso (1998) demonstrou que o mercado interno - na Colônia e nos primeiros tempos do Império - sustentou um processo de acumulação endógena realizado principalmente pelos comerciantes de grosso trato. Esses mercadores, estabelecidos no Rio de Janeiro, controlavam uma rede de abastecimento que, irradiando da capital da Colônia (e depois do Império), tentacularizava-se pelo Rio Grande do Sul, Paraná, São Paulo, Mato Grosso, Goiás e Minas Gerais. Estudando registros portuários, de tropas e inventários post mortem da capitania (depois província) do Rio de Janeiro entre 1808 e 1830, concluiu que a maior parte dos comerciantes de alimentos, dos negreiros e até mesmo dos exportadores do açúcar fluminense, estava estabelecida na praça do Rio de Janeiro. Furtado (1999), usando fontes semelhantes, relativas ao século XVIII, demonstrou a importância dos comerciantes portugueses radicados em Minas, ligados a redes de influência e favorecimentos que se irradiavam desde a Corte portuguesa.

Esses autores, em resumo, vêm recuperando a dimensão complexa da sociedade colonial. Não um mero reflexo de uma empresa mercantilista (embora também o fosse), mas dotada de um alto grau de autonomia, capaz de acumulações endógenas e de gerar um grande número de diferentes formas de produção. Uma economia que, além da dimensão agroexportadora, era marcada por uma profusa rede de fluxos internos, alimentados por setores mercantis de abastecimento, com um dinamismo próprio, e não exclusivamente subordinado às flutuações do mercado internacional.

Esses autores mostram que a Colônia - e o Império sob a Casa de Bragança - era parte integrante do mundo de seu tempo e, como tal, reproduzia muitas das características do império ibérico do Antigo Regime que a 
gerou. Silveira (1997) e Fragoso e Florentino (2001) mostraram que a ideologia que informava as elites coloniais estava muito longe do ethos capitalista. A vontade da distinção, a busca do prestígio por meio dos sinais exteriores de fidalguia, a repulsa aos ofícios mecânicos, a escravidão como valor, as formas de religiosidade, as hierarquias da sociedade de ordens, tudo isso distanciava o homem colonial da racionalidade do homo economicus capitalista.

Da mesma forma, as instituições jurídicas e políticas, com a não separação entre as estatais e as eclesiásticas, as formas jurídicas não-capitalistas de propriedade e posse fundiária, as formas políticas de poder patrimonial, com indistinção entre público e privado, tornavam o mundo colonial mais próximo de uma sociedade do Antigo Regime do que de uma sociedade capitalista.

Nesse sentido, Fragoso (1998) mostrou que sociedade colonial exibia aspectos de uma formação social pré-capitalista. O caráter monopolista do capital mercantil, a existência de mercados imperfeitos com baixa liquidez e escorados em formas de produção não-capitalistas, preços e oferta com oscilações freqüentes e imprevisíveis, forte concentração de riqueza, eram características tanto da economia colonial quanto das economias do Antigo Regime europeu.

Assim, a visão de uma Colônia funcionando como uma espécie de "negativo" da Metrópole, por ela moldada, dela dependente, mas dela diferente, porque capitalista avant la letre, vem sendo substituída por um novo paradigma que vê especificidades na experiência colonial (aliás, vê uma diversidade de experiências, formando um mosaico avesso a generalizações), mas dentro de um quadro geral, como parte do Império Português e das sociedades do Antigo Regime do ocidente.

O debate sobre as relações de produção que vigeram no período colonial e no Império também vem sendo marcado por uma mudança nos referenciais. Quanto a essa questão, duas vertentes firmaram-se na historiografia. $\mathrm{Na}$ primeira delas, Caio Prado Júnior (1986), Celso Furtado (1999) e Fernando Novais (1986) entenderam que o capitalismo comercial europeu gerou a Colônia e deu o sentido da colonização. O empreendimento colonial foi o que tornou possível a acumulação primitiva de capital pela burguesia da Europa. Desse modo, a economia e a sociedade coloniais seriam, desde sempre, marcadas pelas relações capitalistas de produção. E como o escravismo - um regime em que o trabalho não é realizado diretamente como mercadoria — pôde ser a base de uma sociedade capitalista? Novais resume a questão da forma seguinte: 
A produção colonial era, basicamente [...], produção para o mercado metropolitano, isto é, produção mercantil. Na economia de mercado, contudo, é o salariato o regime mais rentável; as formas de trabalho compulsório, por seu lado, vinculam-se a economias pré-mercantis [...]. Nesse sentido regime de trabalho prevalecente no mundo ultramarino do Antigo Regime se apresenta como um contra-senso (1986, p. 99).

E mais adiante, a partir de uma citação de Marx, tenta resolver o aparente paradoxo:

Marx, porém, implacável analista do mundo burguês, precisamente por ter levado sua análise para além de todas as mistificações da realidade, pôde constatar com nitidez que nas colônias eram desfavoráveis as condições de constituição do trabalho livre, sempre havendo a possibilidade de o produtor direto assalariado, apropriando-se de uma gleba de terra despovoada, transformar-se em produtor independente. Assim, enquanto a Europa moderna o desenvolvimento capitalista 'libertava' os produtores diretos da servidão medieval e integrava-os como assalariados na nova estrutura da produção que destarte camuflava a exploração do trabalho, as economias coloniais periféricas, montadas exatamente como alavancas do crescimento do capitalismo e integradas nas suas linhas de força, punham a nu essa mesma exploração na sua crueza mais negra [...] As colônias timbravam em revelar as entranhas da Europa (p. 101-102).

Em outras palavras, a presença de uma fronteira teria impedido a constituição de um mercado de trabalho livre; e o trabalho compulsório se teria imposto como forma possivel das relações de trabalho no contexto de uma economia colonial capitalista. Mas o escravismo, surgido nessas condições, não negaria o caráter capitalista das relações de produção.

Numa outra vertente, Ciro Flamarion Cardoso (1988), desde os anos 1980, vem criticando, de forma veemente, essa idéia de um capitalismo perene, existente desde o século XVI na sociedade brasileira. O fundamento teórico da idéia de Prado Jr. e Novais, segundo o autor, seria a definição de capitalismo a partir da esfera da circulação, quando, na verdade, é a esfera da produção o que dá a lógica e a dinâmica de um sistema. Disso derivaria outro erro, de implicações metodológicas mais graves, que é tentar ver uma racionalidade capitalista, de 
busca do lucro, entre os agentes da economia colonial.

$\mathrm{Na}$ mesma vertente, mas discordando em vários momentos de Cardoso, Gorender (1988) tenta, no seu O Escravismo Colonial, estabelecer as linhas gerais da dinâmica de reprodução do modo de produção escravista colonial. Nesse modo de produção, específico da experiência colonial das Américas, o trabalho escravo teria finalidade mercantil. Mas a circulação mercantil seria externa ao universo da produção, e sua dinâmica não determinaria as formas específicas de organização da economia escravista. Esta, em primeiro lugar, exigiria uma inversão inicial na compra do escravo pelo senhor, que Celso Furtado, Fernando Henrique Cardoso, Genovese e Fraginals identificaram ao capital fixo.

Segundo Gorender, as categorias trabalho e capital fixo seriam diferentes e inassimiláveis e, portanto, impossíveis de serem ambas imputadas à figura do escravo. O escravo poderia, no limite, funcionar como capital-dinheiro ou reserva de valor, mas não seria capital produtivo. O escravista, ao comprar do traficante o escravo, esterilizaria um fundo de riqueza em favor da compra de um poder sobre o trabalhador, poder de explorá-lo e acumular seu sobretrabalho. O escravo, nesse sentido, não venderia seu trabalho ao senhor em troca do alimento, como na relação de trabalho assalariado. A mercadoria em si não seria o trabalho, mas sim o escravo, ou o poder de coerção extra-econômica sobre o trabalhador escravizado.

Usando o conceito de Godelier de formação social, Fragoso (1998) vai mais além, definindo a sociedade colonial como um mosaico de formas de produção não capitalistas. Dentre elas, a forma de produção escrava, dominante, estaria presente na plantation do litoral. Mas esta, ao reproduzir-se, levaria ao surgimento de inúmeras outras, diferentes do escravismo de plantation, no próprio litoral ou em outras regiões, ligadas a ele por redes de abastecimento internas:

O escravismo colonial, em seu movimento de reprodução, teria criado no espaço colonial outras formas de produção não capitalistas: um escravismo ligado ao abastecimento interno, à unidade camponesa (com recurso ou não ao trabalho cativo), uma produção fundada no trabalho livre assalariado (estância). Desse modo, esses segmentos, criados e voltados para o abastecimento da agroexportação, seriam elementos subordinados em uma formação econômicosocial, cujo eixo seria aquele escravismo voltado para o abastecimento internacional (1998, p. 144). 
Outra questão que vem criando um novo consenso entre os historiadores, e que consideramos pertinente recuperar neste trabalho, é sobre o papel desempenhado pela população livre e pobre na sociedade escravista. Gilberto Freyre, em sua obra clássica Casa Grande e Senzala, não dedica nenhum de seus capítulos ao homem livre e pobre dos tempos coloniais. A justificativa aparece já no primeiro capítulo: embora reconheça a importância numérica da população livre, que Louis Couty calculava seis milhões, para uma população total de doze milhões em 1881,

Melhor alimentados eram na sociedade escravocrata os extremos: os brancos da casa grande e os negros das senzalas. Natural que dos escravos descendam os elementos mais fortes e sadios de nossa população. [...] E que da população média, livre mas miserável, provenham muito dos piores elementos, dos mais débeis e incapazes. [...] E quando toda essa quase inútil população de caboclos e brancarões, mais valiosa como material clínico do que como força econômica, se apresenta no estado de miséria física e de inércia improdutiva em que a surpreenderam Miguel Pereira e Belisário Pena, os que lamentam não sermos puros de raça nem o Brasil região de clima temperado o que logo descobrem naquela miséria e naquela inércia é o resultado de coitos para sempre danados, de brancos com pretas, de portugas com índias (1983, p. 34).

Gilberto Freyre teve o inegável mérito de livrar as ciências sociais brasileiras do racismo obsessivo que a contaminou até o início do século XX. Também inaugurou o que acabou se tornando moda nos anos 1980 e 1990, e que passou a ser chamado de "história das mentalidades". Mas a sua leitura dicotomizadora da sociedade escravista brasileira acabou influenciando toda uma geração de historiadores e sociólogos, mesmo críticos seus, que tendiam a ver na população livre uma classe de marginalizados anômicos, sem lugar na ordem escravocrata.

Prado Jr. (1986) demonstrou, antes de todos, a "escravidão como valor" nos tempos coloniais, isto é, uma instituição tida como universal e socialmente aceita, e na qual todos os grupos sociais tinham como ideal ter escravos. Mas, exatamente por isso, não haveria lugar para a população livre: 
Abre-se assim um vácuo imenso entre os extremos da escala social: os senhores e os escravos; a pequena minoria dos primeiros e a multidão dos últimos. Aqueles dois grupos são os dos bem classificados da hierarquia e na estrutura social da colônia. [...] Entre estas duas categorias nitidamente definidas e entrosadas na obra da colonização comprime-se o número, que vai se avultando com o tempo, dos desclassificados, dos inúteis e inadaptados; indivíduos de ocupações mais ou menos incertas e aleatórias ou sem ocupação alguma. Aquele contingente vultoso em que Couty mais tarde veria o "povo brasileiro", e que pela sua inutilidade daria como inexistente, resumindo a situação social do país com aquela sentença que ficara famosa: "Le Brésil n’a pas de peuple” (1986, p. 281).

Historiadores contemporâneos, como Laura de Mello e Souza, referiramse de forma semelhante à população colonial de forros, libertos e livres:

Muitos pontos comuns uniam pois os escravos [...], os forros [...], os homens livres pobres. Eram parte de um mesmo todo: a camada fluida e inconsistente que, apesar das formas esporádicas de solidariedade, nunca se enxergou como um grupo coeso. [...] [a visão de mundo da sociedade escravista colonial] foi a contrapartida da falta de consciência do homem livre pobre, a ideologia da vadiagem sendo um de seus principais pontos de apoio (1986, p. 219).

Sociólogos reproduziram a mesma concepção sobre a população livre do mundo escravocrata, aplicando-lhes o conceito durkheimiano de anomia social. Assim, o trabalho braçal, tido como inferior e associado à condição escrava, seria negado pelo livre ou forro, como uma forma de negar a própria condição escrava. Essa "ideologia da vadiagem" manteria a população liberta despreparada para o trabalho livre. Com a Abolição, teria sido selado seu destino de marginalidade, pobreza e violência. É o que lemos, por exemplo, em Florestan Fernandes:

Diante do negro e do mulato abrem-se duas escolhas irremediáveis, sem alternativas. Vedado o caminho da classificação econômica e social pela proletarização, restava-lhes aceitar a incorporação gradual à escória do operariado em crescimento ou abater-se penosamente, procurando no ócio dissimulado, na vagabundagem sistemática ou na criminalidade fortuita meios para salvar as aparências e a dignidade de 'homem livre' (1978, p. 28). 
Maria Sylvia de Carvalho Franco (1983), em estudo sobre os camponeses do Vale do Paraíba do Sul do final do século XIX, chega a conclusão semelhante, ao assinalar o "desperdício" de força de trabalho que caracterizava esses grupos, nascendo daí o "preguiçoso" caipira, cujos esforços limitavam-se a garantir a subsistência elementar, inexistindo entre eles uma regulamentação das relações de trabalho e uma moral disciplinadora do trabalho (p. 30-34). A mobilidade espacial dos caipiras, segundo a autora, impediria o surgimento de uma consciência grupal, tendo influência desagregadora; a cooperação vicinal, em formas como o mutirão, típicas do campesinato brasileiro, não se daria por condicionantes culturais, mas seria um ajustamento pessoal espontâneo, suscitado por situações imediatas, nas quais também facilmente a violência substituiria a cooperação.

Essa visão de uma população livre culturalmente amorfa e embrutecida, socialmente anômica, materialmente miserável, espacial e economicamente marginal foi criticada nos anos 80 por antropólogos como Gilberto Velho (1985). Historiadores, principalmente da UnICAMP nos anos 1980, como Sidney Chalhoub (1986), Robert Slenes (1999) e Sílvia Hunold Lara (1988), também apontaram a conotação ideológica do conceito de anomia social e os preconceitos de classe embutidos na visão dos pobres livres e libertos como "desclassificados".

Recentemente, novos trabalhos vêm dando ênfase à história social da família no período colonial, revelando a importância da população livre nesse período. Sheila Castro Faria (1998), analisando testamentos, inventários post mortem e documentos paroquiais da região de Campos dos Goitacases dos séculos XVIII e XIX, mostrou que família e parentesco são categorias centrais para compreender as populações pobres camponesas do período colonial, tanto nas relações de solidariedade quanto nas relações com a terra e nos processos migratórios.

Percebemos, em nossas fontes, a onipresença das famílias na organização social do Triângulo oitocentista, confirmando, em outra região, os estudos dessa autora. Apreendemos a importância quantitativa dos pequenos produtores livres, frente ao total da população. Assim, julgamos importante rever os conceitos de campesinato e trabalho familiar, antes de iniciarmos propriamente a exposição do resultado dos nossos estudos. 


\section{Chayanov revisitado: a economia política do campesinato}

As reflexões anteriormente expostas indicam que a historiografia parece caminhar para um consenso, no qual a sociedade colonial - e a sociedade do Império que a sucedeu - passa a ser vista como um mosaico de diferentes formas de produção, com suas respectivas lógicas produtivas e relações de trabalho. Estamos cada vez mais distantes do paradigma de uma sociedade colonial polarizada entre escravos e senhores, simplesmente.

Libby (1988), analisando os Mapas de População, concluiu que a grande propriedade escrava em Minas Gerais era a exceşão e não a regra. A maioria dos fogos não contava com um escravo sequer (66,7\% do total), ao mesmo tempo em que um terço da população livre era proprietária de escravos. O maior grupo de proprietários de cativos era o dos que possuíam entre 3 e 5 escravos (28\% do total de proprietários). O autor chamou esse padrão de distribuição da propriedade cativa de "posse democrática" de escravos. Marcílio (2000) já havia detectado, antes, uma estrutura de posse mancípia semelhante, em seus estudos de demografia histórica da capitania de São Paulo do período setecentista. Castro Faria (1998) chegou à mesma conclusão em seu trabalho sobre as estruturas de riqueza e familiares de Campos dos Goitacases no século XVIII.

Fragoso (1998) fez uma revisão de vários trabalhos relativos à economia mineira oitocentista, e concluiu que, naquela província, particularmente nas regiões Sul, Oeste, Alto Paranaíba e Triângulo Mineiro:

Os números não apenas sugerem que o senhor de escravos padrão de Minas Gerais era o pequeno proprietário, mas apontam também para o fato de que a base da economia mercantil mineira voltada para o mercado interno dificilmente poderia ser classificada apenas como escravista. Em unidades econômicas com menos de cinco escravos, mesmo considerando que todos estariam em atividades produtivas, não seria de estranhar que, ao lado do cativo, surgisse o trabalho familiar dos detentores da unidade. E, avançando um pouco mais, mesmo reconhecendo que não temos base empírica para isso [grifo do autor], aquele padrão nos insinua que estamos diante de uma situação próxima à de unidades camponesas que complementam o trabalho familiar com o de outras categorias sociais, no caso o escravo (1998, p. 131). 
Nosso levantamento, fundamentado em inventários post mortem do termo da freguesia (depois vila) de Uberaba, na primeira metade do século XIX, cujo termo abrangia praticamente duas terças partes do que hoje se conhece por Triângulo Mineiro, parece confirmar o que Fragoso intuiu. Para caracterizar um conjunto de pequenas unidades produtivas como camponesas, com ou sem escravos, recorremos à metodologia desenvolvida por Alexander Chayanov.

Esse economista russo da primeira metade do século XX vem sendo relido por economistas contemporâneos, como Ricardo Abramovay (1998), por exemplo. Esse autor destacou que a insuficiência do pensamento marxiano, relativo ao conceito de campesinato, tal como aparece n'O Capital, não é devida a limitações da construção teórica marxiana em si, mas sim porque tal conceito não se encaixa em nenhuma de suas categorias. Todas as definições de campesinato dos autores clássicos marxistas foram feitas de forma negativa: alguém que não vende sua força de trabalho e não vive do trabalho alheio. O camponês, numa sociedade capitalista, seria o que não faz parte do proletariado e nem o explora.

Chayanov, partindo de uma perspectiva diferente, afirmou que a economia camponesa pode ser objeto de um conhecimento racional: é no interior do organismo camponês que se devem procurar as razões da existência dos camponeses. As categorias usadas para a economia capitalista não valem para a economia camponesa, ou, em outras palavras, a racionalidade da economia camponesa é incompreensível dentro dos parâmetros contábeis da economia capitalista (ABRAMOvay, 1998).

O economista russo começou por caracterizar o campesinato como um sistema econômico não-capitalista, por inexistir nas unidades familiares de produção o assalariamento e, portanto, a mais-valia e o lucro. A formação de preços, nesse sentido, obedece a uma lógica diferente da capitalista, pois a produção interessa exclusivamente em seu valor de uso, mesmo quando é realizada como valor de troca no mercado (CHAYANOv, 1986).

E qual seria a lógica da produção camponesa? O que o autor chamou de equilíbrio trabalho-consumo, isto é, o volume de trabalho da economia camponesa depende da medida em que o resultado desse trabalho satisfaz as demandas de consumo familiares:

A medida da auto-exploração depende no mais alto grau do quanto o trabalhador é carregado pelas demandas dos consumidores. O volume da atividade familiar 
depende inteiramente do número de consumidores e não do número de trabalhadores (CHAYANOv, 1986, p. 78).

Os trabalhadores da unidade familiar aumentariam seu esforço de trabalho, até o ponto em que percebessem que qualquer aumento marginal deste não levaria a aumentos significativos no grau de satisfação do consumo. Nesse momento, o aumento do esforço de trabalho seria interrompido e a unidade chegaria num ponto de equilíbrio.

Veremos, a seguir, se o modelo chayanoviano de unidade familiar camponesa pode ser usado para entender a sociedade de criadores e roceiros do Triângulo Mineiro, na primeira metade do século XIX. Antes, usando como fonte os inventários post mortem da freguesia — depois vila — de Uberaba de 1822 a 1861, reconstituiremos o universo do trabalho no qual viviam as pessoas daquele tempo e região.

\section{A divisão social do trabalho no Triângulo Mineiro oitocentista}

Um aspecto que chama a atenção na leitura dos inventários post mortem da vila de Uberaba é o baixo nível de divisão social do trabalho entre as unidades rurais, de diferentes tamanhos. Em fazendas grandes ou pequenas, sítios ou chácaras, encontramos a mesma gama de equipamentos técnicos, diferindo apenas em escala um do outro. Por isso, seria forçada e extemporânea uma tentativa de classificar em setores primário, secundário e terciário, as atividades de uma economia colonial e pré-capitalista. Seriam termos mais apropriados a ordenamentos capitalistas com um alto grau de especialização do trabalho.

Assim, tanto em grandes quanto em pequenas unidades, encontramos o mesmo universo produtivo, em diferentes dimensões. O capitão Antônio José de Araújo ${ }^{3}$ possuía, em 1838, um formidável patrimônio constituído pela Fazenda São Francisco, em Dores do Campo Formoso, de 14.400 alqueires no valor de 40:040\$000. Dispunha de um plantel formado por 21 escravos, a maioria homens em idade produtiva, somando 9:700\$000 em patrimônio mancípio. Esse fazendeiro podia ser considerado um grande criador para os

3 APU, Inventário do Cap. Antônio José de Araújo (20/03/1838), caixa 459. 
padrões da época, pois contava com um rebanho de 277 vacas de criar, 114 garrotes para engorda e 30 bois carreiros, que somava 3:845\$000. Terras, escravos e gado perfaziam 76\% do patrimônio de Antônio José.

O que chamaríamos hoje de "capital fixo" desse fazendeiro era constituído por um sítio com moinho, paiol, monjolo coberto de capim, currais de aroeira, senzalas e rego d'água, que valiam um conto de réis; uma engenhoca de trezentos mil réis; e ferramentas (quatro carros de boi e um carretão, cinco machados, doze enxadas, oito foices, uma alavanca e uma cavadeira), que somavam $157 \$ 000$. O equipamento técnico do rico fazendeiro equivalia a apenas $2 \%$ do seu patrimônio total!

Numa unidade de porte médio, como a fazenda de João Alves de Resende, ${ }^{4}$ em São Pedro do Uberabinha, ${ }^{5}$ em 1850, encontramos os mesmos traços das unidades maiores: um mínimo de ferramentas e benfeitorias, e uma gama de atividades que iam do artesanato doméstico à pecuária extensiva, passando pelo cultivo e beneficiamento de alimentos. Esse sitiante possuía dois casais de escravos, pais de duas crianças. Com eles, sua esposa Lina e mais os filhos adolescentes Manuel e Antônio cultivavam umas roças às margens do Rio Uberabinha. No chapadão, que se estendia daí até o rio das Velhas, criava 34 cabeças de gado, contando com quatro cavalos e um burro. Lina e as escravas Josefa e Delfina usavam um descaroçador, três rodas de fiar e um tear para a produção doméstica de panos de algodão. João, seus filhos e os escravos Custódio e Francisco dispunham também de enxó e formões, para a carpintaria doméstica da curralama, dos carros, dos esteios das casas e demais benfeitorias de seu sítio. Seu sítio dispunha de um moinho, um paiol e um monjolo. $\mathrm{Na}$ verdade, do ponto de vista técnico, trata-se do mesmo universo produtivo da Fazenda São Francisco, do afortunado capitão Antônio, a algumas léguas dali, diferindo daquela apenas em escala.

O exame de uma pequena unidade revela traços constitutivos semelhantes. João Inácio de Sá ${ }^{6}$ e sua esposa, em 1829, criavam a filha Claudina, de dois anos, numa casa coberta de capim, com paiol e monjolo, em sua pequena propriedade (uns 50 alqueires aproximadamente ${ }^{\top}$ ) na Fazenda Areão. Com o

\footnotetext{
APU, inventário de João Alves de Resende (05/02/1850), maço N16, caixa 470.

Hoje Uberlândia.

APU, Inventário de João Inácio de Sá (02/04/1829), maço N46, caixa 451.

Em muitos inventários post mortem, como neste caso, a área das propriedades não era espe-
} 
auxílio de seu escravo Antônio, e contando com dois cavalos, João criava o seu pequeno rebanho de 15 reses, dos quais seis eram vacas de leite e seis bois de carro, mais 25 porcos. Sua esposa Maria e uma escrava homônima de 14 anos fiavam e teciam, usando duas rodas e um tear. As ferramentas que João e Antônio utilizavam, em seu trabalho diário, resumiam-se a quatro foices, cinco enxadas, quatro machados e um carro. Novamente, o que se verifica é o mesmo das grandes e médias unidades: diversidade de atividades produtivas, baixo nível de investimento em "capital constante", técnicas produtivas elementares, com alto nível de dependência da natureza.

Mesmo quando detectamos pessoas especializadas em algum ofício — alfaiates, ferreiros, carpinteiros, cirurgiões-barbeiros —, o exame de seus inventários revela que também possuíam bens rurais, e suas profissões eram apenas um complemento ao núcleo produtivo doméstico, formado basicamente por atividades agropastoris.

Por exemplo, o carpinteiro Manuel Antônio da Silveira, ${ }^{8}$ em 1838, contava apenas com os filhos moços João, Jerônimo, José e Deodoro para ajudá-lo no ofício, já que não dispunha de escravos homens. No entanto, provavelmente suas carpintarias apenas complementavam a renda da família, pois era dono de uma pequena extensão de terras na Fazenda do Buracão, em Dores do Campo Formoso, onde cultivava e criava um pequeno rebanho de dezoito cabeças de gado. Noutro exemplo, sabemos que Miguel Martins Morgado9 exercia o ofício de cirurgião barbeiro, em 1828, pois em seu inventário lemos que possuía navalhas de sangrar, ventosas, e quatro livros de medicina Buchan. No entanto, só devia oferecer seus préstimos de esculápio esporadicamente, quando solicitados por algum doente na freguesia de Uberaba, já que cultivava e criava bois em sua fazenda, auxiliado pelos filhos Miguel e João, pelo pequeno José, de 10 anos, e pelos africanos João e Vicente.

Em parte, esse baixo nível de divisão social do trabalho devia-se à própria condição de fronteira da região em estudo. A baixa densidade

cificada, mas apenas o seu valor. Porém, tomando por base a média dos preços da terra nos inventários post mortem, que especificavam a área, calculamos o valor aproximado da terra em diferentes épocas, que mostraremos numa tabela mais adiante. A partir dessa tabela, calculamos esta área baseados num preço médio do alqueire — considerando uma proporção de terras de cultura e de campos de aproximadamente 1:2 — de $3 \$ 000$.

8 APU, inventário de Lauriana Teresa dos Santos (14/08/1838), maço N4.

9 APU, inventário de Miguel Martins Morgado (07/07/1828), maço N35, caixa 459. 
demográfica e as grandes distâncias em relação aos centros mais dinâmicos faziam com que as unidades agropastoris - fossem elas pequenos sítios ou grandes fazendas - buscassem a auto-suficiência. Somente quando se aumentasse a densidade demográfica, crescessem os arraiais e vilas, e se estabelecessem fluxos mais intensos com as regiões mais povoadas, é que se abriria a possibilidade de uma maior realização mercantil dos excedentes. Só assim os produtores passariam a ver a especialização como vantajosa, pois poderiam aumentar os ganhos com a economia de escala e, assim, a divisão social do trabalho seria um pouco mais estimulada. Não é outro o diagnóstico de Saint Hilaire, referindo-se aos agricultores e criadores que conhecera na capitania de Goiás, em 1819:

Mas para que uma região seja verdadeiramente rica não basta que seja fértil. É preciso também que tenha facilidade para realizar trocas de mercadorias, a fim de obter as coisas que não produz. A enorme distância que separa Goiás das grandes cidades e dos portos do Mar não permite aos colonos exportarem produtos que, sendo muito volumosos, têm contudo pouco valor. Além do mais, o milho, a mandioca, o arroz, o feijão e o café não encontram mercado fácil na própria região, devido ao fato de serem cultivados em toda ela. Sendo de um modo geral agricultores, os goianos plantam para o próprio consumo [...] (1975 b, p. 181).

$\mathrm{Na}$ Serra da Canastra, nas proximidades do Desemboque, o cronista registrou que um roceiro "com exceção do sal suas terras produzia com abundância tudo o que ele tinha necessidade" (1975 b, p. 102).

É necessário esclarecer, contudo, que tais aspectos da economia agropastoril do Extremo Oeste de Minas, certamente intensificados pela condição de fronteira em que então se encontrava, não estavam fadados a desaparecer assim que a região se inserisse num sistema de trocas mais dinâmico. Nossa hipótese é a de que tais aspectos, detectados na região em estudo, eram estruturais à economia colonial, já que se tratava de uma formação social onde formas de produção não-capitalistas — dentre elas, as unidades agropastoris escravistas, camponesas e camponesas com escravos reproduziam-se, conectadas entre si por uma extensa rede mercantil. Veremos, nesse contexto, como essa sociedade acumulava riquezas, e que tipo de bens poderiam receber esse nome. 


\section{Formas de riqueza}

No mundo das unidades de produção agropastoris sertanejas, a acumulação de excedentes não se fazia principalmente na forma de capital, se dermos a esta palavra o sentido marxiano, isto é, algo capaz de se reproduzir seguindo a fórmula geral D - M - D'. A propriedade fundiária, por exemplo, conforme o próprio autor d'O Capital,

pressupõe que certas pessoas têm o monopólio de dispor de determinadas porções do globo terrestre como esferas exclusivas de sua vontade privada, com exclusão de todas as outras. [...] O poder jurídico dessas pessoas de usar e abusar do globo terrestre em nada contribui para a valorização da terra. A utilização dessas porções depende inteiramente de condições econômicas que são independentes da vontade desses proprietários. A própria concepção jurídica quer dizer apenas que o proprietário fundiário pode proceder com o solo assim como com as mercadorias o respectivo dono (1983, v. 3, p. 124).

Mais adiante continua:

O nível de renda fundiária (e com ele o valor da terra) desenvolve-se ao longo do desenvolvimento social como resultado do trabalho social global. Por um lado, cresce com isso o mercado e a demanda de produtos da terra; por outro, imediatamente cresce a própria demanda de terras, como condição para a produção competitiva para todos os ramos possíveis da produção, mesmo os não agrícolas (p. 139).

Dito da forma que nos interessa aqui, o preço da terra se forma com base na renda fundiária que, por sua vez, depende da competição por terra pelos agentes produtivos. É no mercado, portanto, que o valor da propriedade fundiária se forma, e não como valor-trabalho, já que a propriedade fundiária não é resultado de acúmulo de sobretrabalho, mas do estatuto jurídico que garante a propriedade ao proprietário. Portanto, terra pode se tornar mercadoria que se realiza no mercado como valor-dinheiro. É riqueza, mas não capital em si.

Do mesmo modo, a outra forma de riqueza dos proprietários da região e do período em estudo, a posse de cativos, já vimos não poder ser identificada 
ao capital. Um outro trecho de Marx contribui ainda mais para esclarecer a natureza do trabalho escravo:

A força de trabalho como mercadoria só pode aparecer no mercado à medida e porque ela é oferecida à venda ou é vendida pelo seu próprio possuidor, pela pessoa da qual ela é a força de trabalho. Para que seu possuidor venda-a como mercadoria, ele deve poder dispor dela, ser, portanto, livre proprietário de sua capacidade de trabalho, de sua pessoa. Ele e o possuidor de dinheiro se encontram no mercado e entram em relação um com o outro como possuidores de mercadorias iguais por origem, só se diferenciando por um ser comprador e o outro, vendedor, sendo portanto ambos juridicamente iguais. [...] As condições bistóricas [de existência do capital] de modo algum estão presentes na circulação mercantil e monetária. Ele só surge onde o possuidor de meios de produção e de subsistência encontra o trabalhador livre como vendedor de sua força de trabalho no mercado [grifos nossos] (1983, v. 1, p. 139-141).

A condição para que o capital se remunere é a existência de trabalhadores livres e vendedores de sua força de trabalho, juridicamente iguais, unidos por uma relação que se estabelece no interior da dinâmica econômica. Se não é trabalhador livre, sua força de trabalho não é "capital variável”, pois sua força de trabalho não é negociada livremente no mercado. Tampouco é "capital constante", pois não é uma mercadoria produzida por outrem, que, uma vez adquirida, vai agregando valor a outras mercadorias à custa de seu próprio desgaste.

$\mathrm{O}$ trabalho escravo segue uma lógica diferente desta. Fundamenta-se na existência de um estatuto jurídico que diferencia os homens em livres e escravos, estes sendo propriedade dos primeiros, que podem assim aplicar sobre eles uma coerção extra-econômica e se apropriar de todo o excedente do trabalho realizado. As relações de produção no escravismo se estabelecem antes no plano político, pela legitimação do poder de um homem sobre outro, e depois no plano econômico, pelas relações de trabalho.

O escravo é capital apenas numa situação: nas mãos do traficante, na forma de mercadoria e, deste modo, capital circulante, que ao realizá-lo na forma dinheiro, obtém lucro de monopólio. Assim, embora o escravo possa assumir a condição de capital na circulação mercantil, não pode ser identificado ao capital produtivo quando submetido à exploração. 
Dito isto, resta examinar, por meio de nossa amostragem, as principais formas de acumulação de riqueza entre fazendeiros, sitiantes e agregados no Triângulo Mineiro oitocentista. Agrupamos os inventários por níveis de riqueza, baseando-nos nos montes-mores convertidos em libras esterlinas, uma moeda mais estável, ${ }^{10} \mathrm{de}$ forma a podermos comparar montantes de épocas diferentes.

Calculamos a média dos percentuais relativos às principais formas de riqueza dos montantes de cada nível, no período de 1822 a 1850. Excluímos os inventários posteriores a 1850 de nossa amostra, por duas razões. A primeira é que, conforme mostra o gráfico 1 , o preço do escravo no termo da vila de Uberaba aumentou muito em valores reais, de $1851 \mathrm{em}$ diante, por causa da extinção do tráfico transatlântico, fazendo com que, dessa época em diante, maior percentual de riqueza fosse imobilizado na forma escravo, impossibilitando comparações com a época anterior. De forma semelhante, conforme foi visto no gráfico 1 do capítulo 3, com a Lei de Terras de 1850, e com o crescente aumento da densidade de ocupação, o preço da terra, dessa data em diante, aumentou em valores reais no Triângulo Mineiro, principalmente da terra de cultura.

Feitas essas ressalvas, podemos apreciar as formas de riqueza no Triângulo Mineiro de 1822 a 1850, distribuídas por nível de riqueza, no gráfico 2. Pode-se perceber, em primeiro lugar, que escravos e terra constituíam a principal forma de riqueza para todas as faixas, inclusive pequenos sitiantes, respondendo em todas elas por pelo menos $70 \%$ do total dos cabedais. Portanto, o excedente era acumulado sob formas não-capitalistas de riqueza, independente da posição na hierarquia social.

Em segundo lugar, percebe-se que, entre as grandes fortunas (maiores que 5.000 libras), a propriedade de terras ultrapassava os escravos como principal forma de riqueza. Isto não se dava porque a terra subia de valor nas mãos dos grandes. O preço unitário do alqueire era muito baixo, na verdade. No inventário de Maria Rodrigues de Jesus, ${ }^{11}$ por exemplo, um alqueire de terra de cultura no Veríssimo foi avaliado em $4 \$ 000$, algo como o preço de uma foice de ferro... O que ocorria era uma formidável concentração fundiária, que fazia dos grandes fazendeiros verdadeiros landlords. O tenente Joaquim Silva Oliveira, morto em

\footnotetext{
10 Usamos a tabela de conversão que se encontra em Mattoso (1990).

11 APU, Inventário de Maria Rodrigues de Jesus (04/04/1829), maço N48, caixa 459.
} 


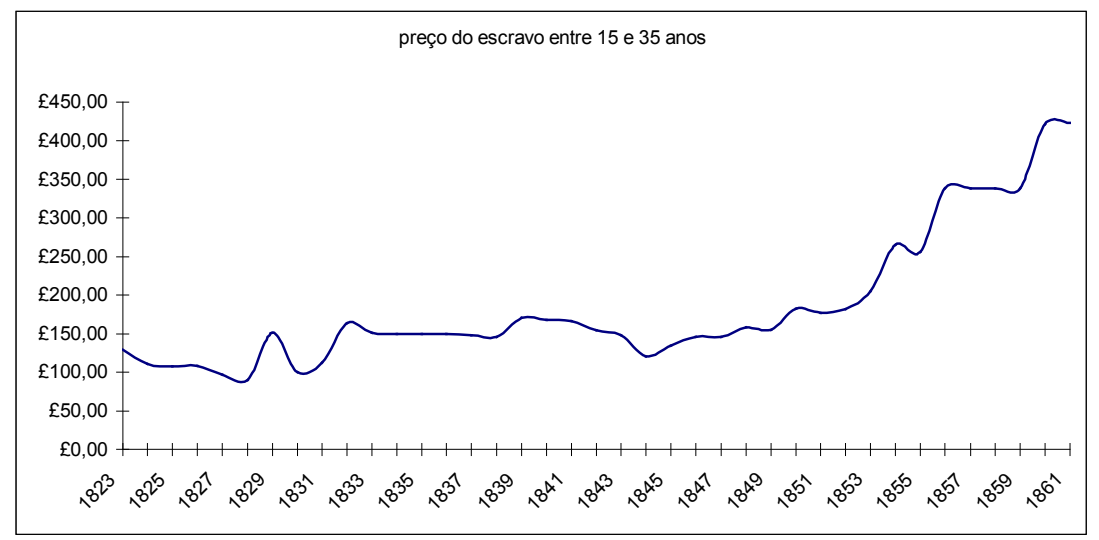

Gráfico 1: preço do escravo entre 15 e 36 anos, do sexo masculino, no termo de Uberaba, entre 1822 e 1861 (em libras esterlinas).

Fonte: APU, inventários post mortem (1822-1861).

1839, membro da parentela fundadora de Uberaba e dono de um plantel com 42 escravos, era dono de nada menos que 12.336 alqueires em três fazendas, somando 67 contos de réis em patrimônio fundiário! ${ }^{12}$

Apesar de as formas de riqueza serem semelhantes em qualquer nível de riqueza, esta era uma sociedade com uma hierarquia econômico-social profundamente diferenciada. Podemos estimar quantitativamente a distribuição da riqueza pelo cálculo do coeficiente de Gini, usando como fonte os cabedais inventariados, convertidos em libras esterlinas (gráfico 3 ).

Ressalvamos que a amostra de patrimônios inventariados não é representativa de toda a sociedade, ficando de fora os muito pobres, que não tinham nenhum bem a legar em herança, e os escravos, a quem era negado o direito à propriedade de si mesmo. Assim, a real concentração de riqueza era certamente muito maior do que a que calculamos. Mas podemos comparar nossos números com os obtidos por outros autores, relativos a outras regiões do Brasil da mesma época.

O valor de 0,67 é próximo do encontrado por Alice P. Canabrava para localidades da capitania de São Paulo do século XVIII, como Mogi-Guaçu em 1765 (0,66) ou Juqueri em 1767 (0,67) (LunA \& CostA, 1982), o que seria

12 APU, Inventário de Joaquim da Silva Oliveira, 06/03/1839, maço N\&, caixa 461. 


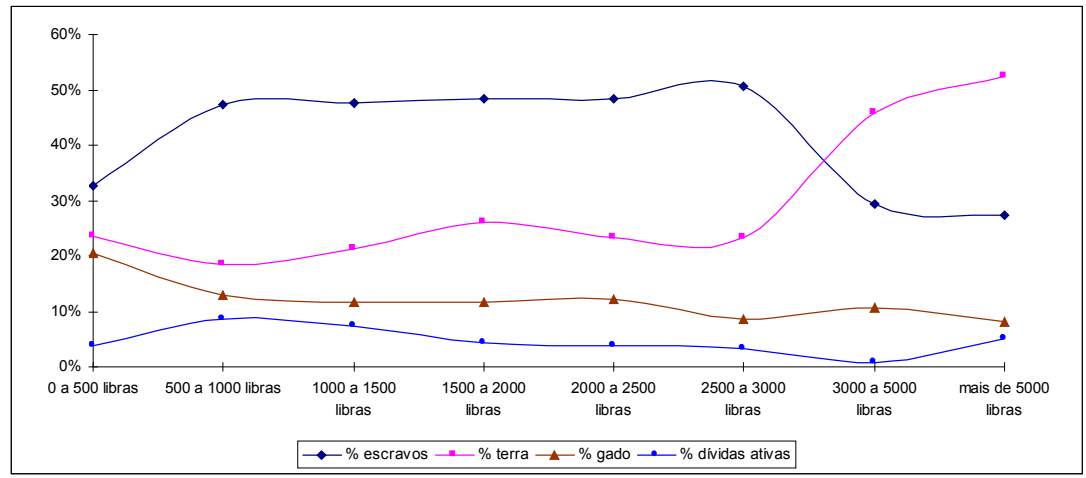

Gráfico 2: principais formas de riqueza no termo de Uberaba, entre 1822 e 1850, por faixa de riqueza (em libras esterlinas).

Fonte: APU, inventários post mortem (1822-1861).

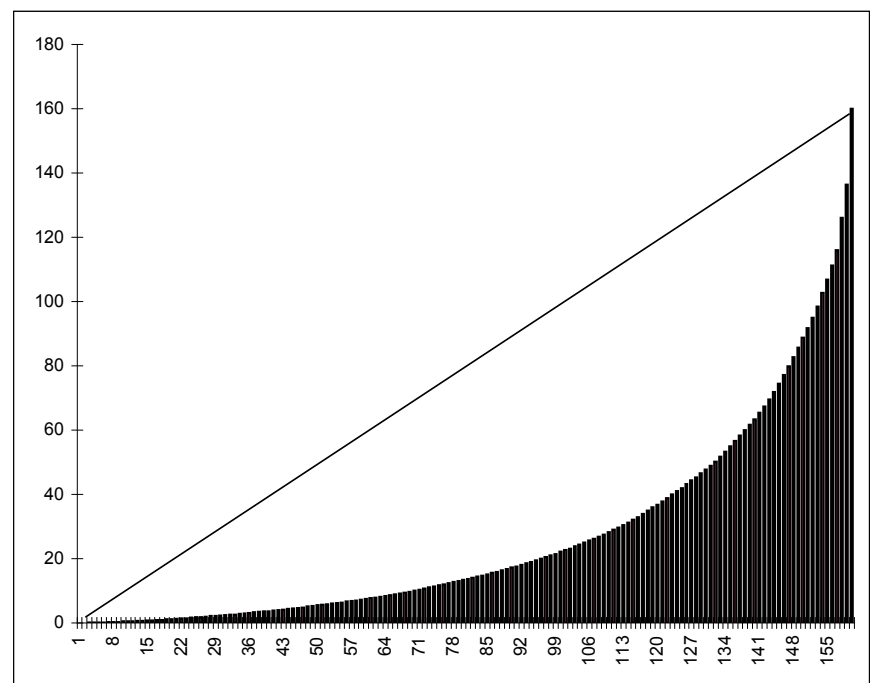

Gráfico 3: distribuição da riqueza nos inventários post mortem do termo de Uberaba de 1822 a 1861 (curva de Lorenz para cálculo do coeficiente de Gini).

Fonte: APU, inventários post mortem (1822-1861). 


\begin{tabular}{ll}
\hline SOMA & 4207,51782 \\
\hline ÁREA DO TRIÂNGULO & 12800 \\
\hline ÁREA DE LORENTZ & 8592,48218 \\
\hline GINI & 0,6713 \\
\hline
\end{tabular}

Gráfico 3: distribuição da riqueza nos inventários post mortem do termo de Uberaba de 1822 a 1861 (curva de Lorenz para cálculo do coeficiente de Gini) Fonte: APU, inventários post mortem (1822-1861).

de se esperar, pois apresentavam estruturas sócio-econômicas semelhantes às da região em estudo.

Luna e Costa (1982) compararam os dados que obtiveram a partir da distribuição da posse de escravos na região metalúrgica de Minas, entre 1718 e 1822, com os resultados de Canabrava. O coeficiente de Gini, calculado pelos autores, variou de 0,403 (Pitangui) a 0,573 (Serro do Frio), o que serviu para que concluíssem que, em Minas, ao tempo da extração do ouro, havia uma distribuição de riqueza mais homogênea do que em São Paulo. Trata-se, contudo, de dados de natureza diferente: não se pode comparar distribuição de posse de cativos com distribuição de riqueza total, pois havia um grande contingente de não-proprietários de escravos inventariados. Calculamos o coeficiente de Gini relativo à posse mancípia em nossa amostra e chegamos ao número de 0,57 , próximo ao obtido por aqueles autores. Talvez, se fossem feitos estudos relativos à distribuição da riqueza total na região aurífera-metalúrgica dos séculos XVIII e XIX, também ali se chegaria a uma estrutura próxima à de São Paulo ou do Triângulo Mineiro.

Escravos e terra não eram a única forma de riqueza, contudo. O gráfico 2 mostra que gado e dívidas ativas representavam aproximadamente um quinto do total da riqueza em todas as faixas. Por meio das dívidas ativas, podemos ter uma idéia do capital usurário que financiava as atividades produtivas daquela economia. O gráfico 4 mostra o valor médio do patrimônio mobilizado em dívidas, dividido por faixa de fortuna. Até a faixa de fortuna de 5.000 libras, a média de dívidas a receber flutua abaixo de $400 \$ 000$, para saltar acima de 1:800\$000 na faixa das grandes fortunas (maiores que 5.000 libras). Isso mostra, inequivocamente, que nessa faixa de fortuna os inventariados mobilizavam parte de sua riqueza como capital usurário. 
De fato, o já citado tenente Joaquim Silva Oliveira era credor de 25 pessoas, num total de 6:603\$400 mobilizados em crédito. A dívida de Antônio Mendes, por exemplo, foi citada como "um crédito de seiscentos e cinqüenta e quatro mil réis de principal mais prêmio de duzentos e vinte e cinco mil e noventa e cinco réis", o que significa juros de 34\%, provavelmente anuais. Dentre os devedores do rico uberabense, encontravam-se outros fazendeiros de porte, a deduzir pelos postos da Guarda Nacional que alguns ostentavam (o que era comum entre homens de fortuna), como o guarda-mor Antônio José Teixeira, o capitão Honório de Araújo ou o alferes Melquíades Coelho de Siqueira, e até mesmo religiosos, como o padre Lourenço Pereira da Silva e o vigário Antônio José da Silva. ${ }^{13}$

Os viajantes do período joanino forneceram alguns elementos para se entender como funcionava o sistema de crédito e endividamento na região, entre 1816 e 1819. Em Araxá, Eschwege referiu-se aos fazendeiros usurários:

Os fazendeiros [...] vendem qualquer coisa à vista. Por outro lado, são capazes de abrir crédito a prazos dilatados e juros de 100\%. Vencido o prazo da dívida, é comum a penhora dos bens do devedor [...] resultando disso inúmeros processos judiciais em que ambas as partes se comprometem. Não raramente, o caso acaba em assassinato (1996, p. 109).

Saint Hilaire, também em Araxá três anos depois, referiu-se à cadeia de endividamentos a que estavam presos os pequenos sitiantes:

O mais provável é que estes homens, cujas propriedades são tão novas, não tenham disposto de capital no princípio, comprando a crédito e talvez pagando com elevado juro seus escravos e tudo o mais que compõe os seus bens. Conseqüentemente são pobres, já que não são propriamente donos de tudo o que lhes parece pertencer (1975 b, p. 126).

Esses fazendeiros que ofereciam crédito, por sua vez, eram devedores de capitalistas e instituições de fora da região. O capitão José de Miranda

13 APU, inventário de Joaquim da Silva Oliveira (06/03/1839), maço N7, caixa 461. 


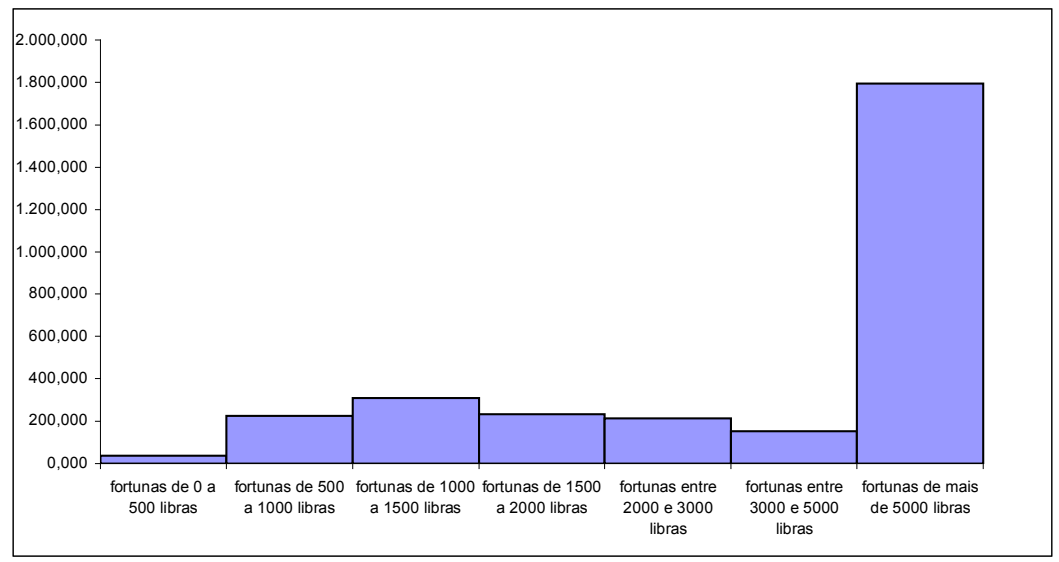

Gráfico 4: valor médio do patrimônio formado por dívidas ativas, por faixa de fortuna, no termo de Uberaba, entre 1822 e 1861 (em réis)

Fonte: APU, inventários post mortem (1822-1861).

Ramalho, ${ }^{14}$ de Carmo dos Dois Morrinhos, ${ }^{15}$ senhor do engenho de Bebedor Grande com 33 escravos, era credor de dívidas que totalizavam 1:372\$000. Ao mesmo tempo, devia 4:964\$738 a Antônio José Lopes de Araújo, da Corte do Rio de Janeiro, e mais 322\$027 à Santa Casa de Misericórdia do Rio Janeiro. Havia, na verdade, uma cadeia de endividamentos que se irradiava desde a capital do Império, e que, transitando pelas rotas comerciais para o sertão, ali chegando, disseminava-se pela hierarquia econômico-social a partir dos grandes fazendeiros.

O quadro que estamos delineando é muito próximo daquele traçado por Fragoso (1998) relativo ao Rio de Janeiro e Vale do Pará́ba da mesma época, respeitadas as proporções entre uma região central e outra periférica do Império. Também ali, estudando séries de inventários post mortem de 1797 e 1860, esse autor encontrou uma frágil divisão social do trabalho; mercados imperfeitos devidos à pouca expressão do trabalho assalariado e ao predomínio de formas não capitalistas de produção; brutal desigualdade na distribuição de riqueza; forte concentração do capital usurário no topo da hierarquia social e

\footnotetext{
14 APU, inventário de José de Miranda Ramalho (03/08/1844), maço 2.

15 Hoje Prata.
} 
uma cadeia de endividamentos se irradiando daí aos outros níveis.

Quanto à distribuição da riqueza, elaboramos a tabela 1, comparando nossos dados aos do Rio de Janeiro. Vê-se em ambos uma estrutura fortemente concentrada, contudo mais pronunciadamente na Corte do que no Triângulo Mineiro. Isso se explica pela presença, na capital do Império, dos comerciantes de grosso trato, detentores dos maiores cabedais em todo o país na época. De fato, das maiores fortunas cariocas, cinco eram fortunas mercantis ou rentistas e apenas três eram fortunas rurais. Das fortunas rurais do Rio de Janeiro, a maioria situava-se entre 5.000 e 20.000 libras (FrAgoso, 1998), faixa que no Triângulo Mineiro correspondia a $82 \%$ do total das fortunas maiores de 5.000 libras. Isto é, embora o Triângulo não contasse com os admiráveis patrimônios de mercadores do porte de um Brás Carneiro Leão, do Rio de Janeiro, de inacreditáveis um mil e quinhentos contos de réis, ultrapassando inclusive os fundos do Banco do Brasil em 1809 (Fragoso, 1998), as suas grandes fortunas rurais comparavam-se àquelas da Capital, na primeira metade do século XIX.

Por outro lado, a região em estudo não contava, nesse período, com grandes fortunas mercantis. Localizamos os inventários de três comerciantes em nossa amostra: dois ambulantes, com fortunas de $1: 983 \$ 472$ e de $2: 478 \$ 4460$, e um outro estabelecido no arraial de Uberaba, com venda aberta e botica, que possuía um patrimônio de 5:466\$336. No próximo capítulo, estaremos estudando a atuação desses mercadores na região, mas o que nos interessa neste momento é a posição que ocupavam na hierarquia econômica e social. Tratavase, na classificação estabelecida por Júnia Ferreira Furtado (1999), de negociantes a retalho, isto é, varejistas fixos ou volantes que comercializavam fazendas secas e boticas. A região não dispunha, pelo menos na primeira metade do século XIX, de comerciantes de grosso trato. Os vendeiros e mascates dos sertões mineiros recebiam gêneros de atacadistas de São João Del Rei e Barbacena, que operavam como intermediários entre os grandes fornecedores do Rio de Janeiro e o mercado sertanejo (FURTADO, 1999).

Basta analisar suas dívidas ativas para constatarmos que, diferentemente dos homens de negócio cariocas, não eram grandes fornecedores de crédito. $\mathrm{O}$ capitão Francisco José da Silva, dono de uma venda instalada no térreo de um sobrado em Uberaba, em 1837, tinha um rol de 91 devedores, que somavam 
A Oeste das Minas

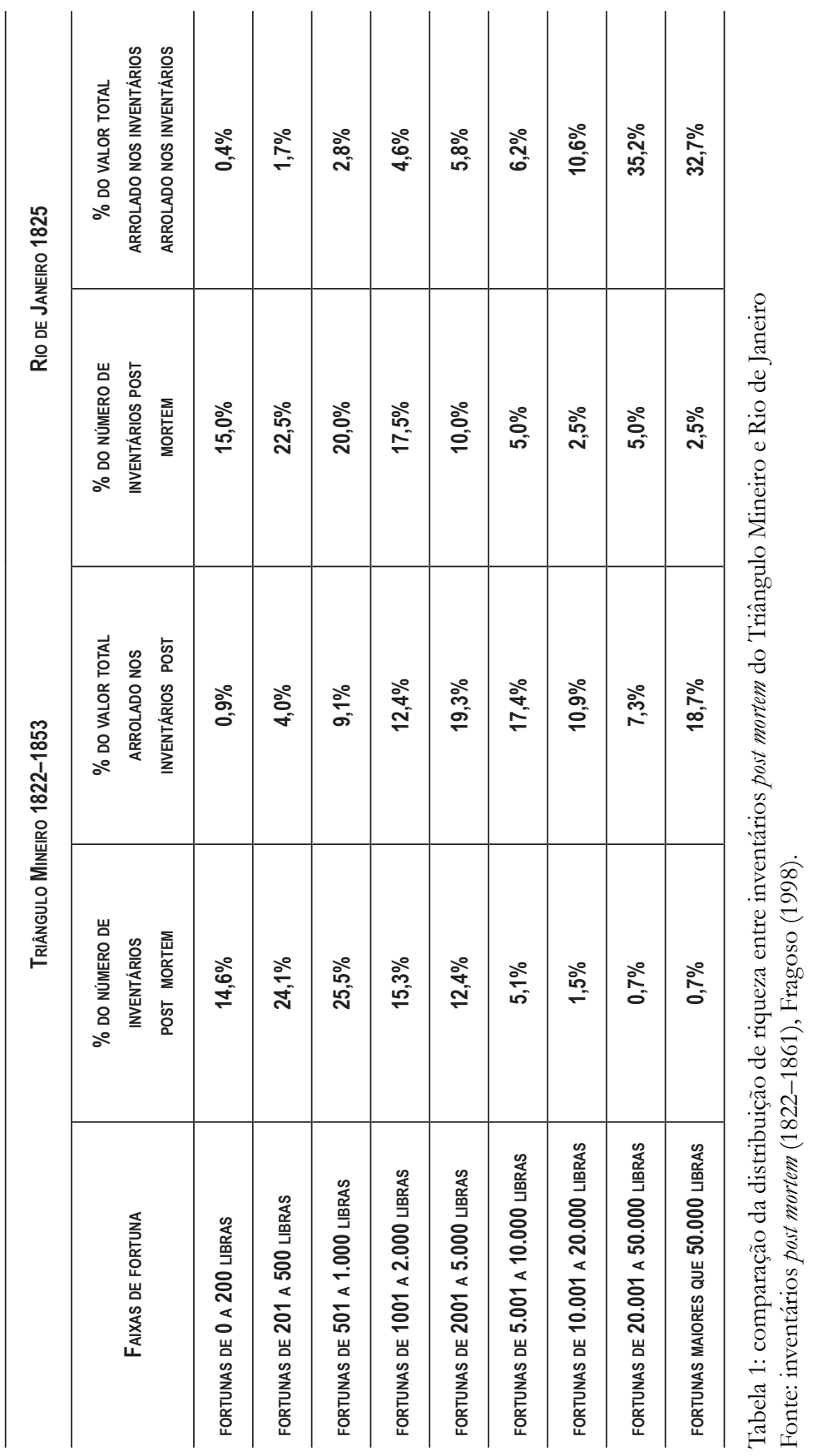


1:323\$050, ou $24 \%$ de seu patrimônio. ${ }^{16}$ Referia-se pequenos valores, variando de um a 20 mil-réis, de miudezas compradas fiadas pela sua clientela. Essa parecia ser a única forma de crédito oferecida por esses vendeiros e mascates.

Apesar dessas diferenças em relação ao que se via na Corte — fazendeiros, e não comerciantes, como agentes do capital usurário; pouca relevância da classe mercantil no processo de acumulação local; ausência de grandes capitais mercantis na região —, havia vários traços comuns entre o Triângulo Mineiro da primeira metade do século XIX e outras regiões do Brasil, inclusive o Rio de Janeiro. Se a concentração de riqueza era um desses traços, outro era o caráter restrito do mercado, isto é, um volume de trocas pequeno frente ao consumo total.

Isso ocorria porque, no Rio de Janeiro, e ainda mais no sertão do Extremo Oeste Mineiro, havia grandes limitações à mercantilização geral, típica de economias capitalistas. Não existia aqui um mercado regulado por mecanismos endógenos de feedback, impulsionadores de uma dinâmica "natural", como a descrita pelos economistas liberais clássicos. Vimos que as relações de trabalho escravistas, por exemplo, necessitavam de mecanismos de coerção extra-econômica que se formavam fora do mercado. Na ausência da força de trabalho como mercadoria, não existe um mercado consumidor formado pelos trabalhadores, mas, no lugar dele, um mercado muito mais restrito formado pelos proprietários escravistas comprando víveres.

O próprio mercado de víveres formado pelos proprietários de escravos seria ainda mais restrito, se se levar em conta a brecha camponesa, isto é, a agricultura de subsistência própria do escravo, praticada nos finais de semana com a anuência dos senhores. Segundo Cardoso (1988), ela seria estrutural ao escravismo brasileiro, hipótese que ainda carece de comprovação.

No Triângulo Mineiro, a existência de uma larga parcela de trabalho camponês - e camponês com escravos - também contribuía para tornar ainda mais restrito o mercado local. Grande parte da demanda das famílias camponesas e de seus escravos era suprida pela produção doméstica de autoconsumo. Mesmo quando se necessitava recorrer ao mercado para obtenção de algum gênero de subsistência, ele geralmente podia ser encontrado nos mercados locais, representados pelos arraiais. Além disso, havia um baixo nível de especialização e uma divisão social do

16 APU, Inventário de Francisco José da Silva (09/02/1837), maço 6, caixa 460. 
trabalho muito restrita entre as unidades produtivas. Em outras palavras, todos produziam mais ou menos as mesmas coisas, criando muito poucas oportunidades de trocas.

Outra característica desse mercado restrito era o baixo nível de liquidez da economia. Fragoso (1998) demonstrou a pequena presença de moedas nos inventários post mortem do Rio de Janeiro, dos primeiros anos do século XIX: totalizavam menos de 5\% do valor das fortunas inventariadas. Silveira (1997) evidenciou que, mesmo na região aurífero-metalúrgica de Minas, no século XVIII, onde o ouro em pó funcionava como moeda, havia insuficiência de meios de circulação. A obtenção de crédito, numa situação de endividamento generalizado, era a única forma de expandir os negócios para a maioria dos mineiros. Em nosso estudo, verificamos que o patrimônio na forma dinheiro somava apenas $7: 518 \$ 480$, ou $0,7 \%$ do valor total inventariado.

Assim, apesar das grandes diferenças culturais, de urbanização, de organização da produção, de nível de acumulação e de especialização regional do trabalho, existiam traços comuns à sociedade carioca, à mineira da região aurífera-metalúrgica e à triangulina, e que arrolamos a seguir:

- Hierarquia econômico-social fortemente diferenciada.

- Presença do capital usurário com endividamento eneralizado.

- Baixo nível de divisão social do trabalho.

- Mercados restritos e instáveis.

Tais características, segundo Fragoso,

se identificam com aqueles descritos por W. Kula e Fernand Braudel para o mercado pré-industrial europeu, assim como se aproximam das características mais gerais, analisadas por C. Mourim, para o circuito mercantil colonial do México para o século XVIII. Desse modo, a existência de um mercado restrito, baseado numa frágil divisão social do trabalho e numa precária circulação de mercadorias, inclusive moedas, onde se verificam práticas monopolistas, especulativas e a usura, não é privilégio do circuito mercantil do Sudeste-Sul brasileiro. Tais traços são atinentes àquilo que normalmente se denomina de mercado pré-capitalista (1998, p. 185). 
Cada vez mais, parece firmar-se um consenso entre grande parte dos autores da moderna historiografia ${ }^{17}$ de que as práticas e instituições do Brasil Colônia (e do Brasil sob a Casa de Bragança) foram o resultado da economia e da cultura política do Antigo Regime português, e como tal se inscreviam no quadro geral das sociedades pré-capitalistas de então.

O Triângulo Mineiro da primeira metade dos Oitocentos parece confirmar essa idéia, a despeito de ter sido, nesse tempo, uma região de povoamento pioneiro. Acreditamos, desse modo, que, ao se entender a economia e a sociedade criadas no processo de colonização dessa região, podese revelar um pouco da dinâmica de uma área de fronteira não capitalista do Antigo Regime.

Os elementos que até aqui discutimos, se servem para esboçar o pano de fundo sobre o qual se desenvolveu a economia agropastoril do Triângulo Mineiro, em princípios do século XIX, não dão conta de algumas especificidades como, por exemplo, diferenças entre proprietários e não-proprietários de terra, chacareiros e sitiantes, criadores e invernistas de gado. Além disso, as relações de trabalho que então se reproduziam não podem ser compreendidas apenas a partir da dicotomia simplificadora senhor/escravo. Nossas fontes permitiramnos entrever um mundo muito mais complexo do que esse, no qual coexistiam camponeses proprietários, camponeses agregados, camponeses com escravos, pequenos, médios e grandes escravistas. No item que se segue, entenderemos como essa sociedade reiterava suas relações com a terra e com o trabalho.

\section{Propriedade e posse da terra}

Numa tentativa de compreender as relações sociais e econômicas do Triângulo Mineiro na primeira metade do século XIX, faremos, mediante os inventários post mortem, três classificações diferentes dos fogos. A primeira delas se fundamentará na posse e propriedade sobre bens de raiz; a segunda, na posse de escravos e na razão trabalho familiar/trabalho cativo; e a terceira, no tamanho dos rebanhos e na presença (ou ausência) de atividades produtivas especializadas em cada um dos fogos. Ensaiaremos, a partir daí, algumas

17 Ver, por exemplo, Fragoso Bicalho e Gouveia (2001). 
tipologias que possam dar conta da complexidade das relações de propriedade, de trabalho e de dependência da população da região no período.

Qualquer análise da estrutura fundiária e da dinâmica de ocupação e uso da terra, no período colonial e imperial, deve levar em conta que o acesso a ela, naquela época, estava submetido a um ordenamento jurídico diferente dos dias atuais. Mesmo após a Lei de Terras de 1850, que acabou com a posse livre de terras e a tornou acessível somente por meio da compra, era possível a um produtor estabelecer-se em propriedades alheias, mediante arrendamento ou pagamento do foro, ou mesmo sem ônus e com a permissão do proprietário, nesse caso, tornando-se, como vimos no capítulo anterior, um agregado. ${ }^{18}$

$\mathrm{O}$ aforamento parecia ser mais freqüente em regiões de maior valorização fundiária e maior densidade demográfica, como o litoral norte do Rio de Janeiro (FARIA, 1998), o mesmo se dizendo do arrendamento, como a Zona da Mata nordestina (Ferlini, 1988). Já na região do Triângulo Mineiro, a posse sem ônus, em terras de terceiros, era a forma mais comum pela qual produtores sem terra se estabeleciam. Aqui, o aforamento era mais comum em terras dos patrimônios religiosos, nos arraiais.

No período em questão, havia também um mercado de situações, isto é, a possibilidade de compra, venda e herança de sítios com suas benfeitorias erguidos em terras de terceiros. A situação era reconhecida como um bem independente da terra, podendo ser livremente negociado e sendo objeto de partilhas (Fragoso, 1998). Havia, portanto, a possibilidade de posse estável sem propriedade de terras, mesmo que estas nominalmente pertencessem a terceiros.

Outras duas formas de posse fundiária presentes no período em questão, e que nos interessam no caso específico do Triângulo Mineiro oitocentista, eram o aforamento de terras do patrimônio religioso e as chácaras. O aforamento de chãos de terra (pequenos lotes), com autorização das autoridades eclesiásticas, era a principal forma de obtenção do "solo urbano", já que os arraiais se desenvolviam em

18 Usaremos esse termo como sinônimo de posseiros vivendo em terra alheia, com permissão do proprietário e dependente deste. Esse é o sentido empregado por Saint Hilaire, em sua viagem pela região em 1819 (1975 a; 1975 b) e também por Antônio Cândido (2001), embora Marcílio (2000) afirme que, até o século XVIII, a palavra agregado só fosse empregada para moradores que vivessem sob o mesmo teto do proprietário, sem laços de parentesco com o mesmo. Porém a autora admite que o termo passou a ser empregado a partir do século XIX referindo-se a sitiantes vivendo em terra alheia, sem ônus. Por isso, usaremos a palavra agregado com esse sentido. 
torno de capelas construídas sobre terras doadas à Igreja. Discutiremos a economia e a geografia urbana dos arraiais triangulinos no próximo capítulo.

As chácaras eram situações que ocupavam um status interessante. Também resultavam do aforamento de terras do patrimônio dos arraiais (ou do rocio das vilas), mas localizavam-se à distância do centro dessas localidades, na periferia das terras foreiras. Dessa forma, todo arraial dispunha de um cinturão de chácaras, organizado em torno do núcleo formado pelo adro da capela e pelo arruamento que dele partia (Murilo Marx, 1991). Nelas se constituíam pequenas unidades produtivas, em escala menor que nos sítios e fazendas.

A partir da descrição pormenorizada que, via de regra, os inventários post mortem traziam dos bens de raiz, foi possível agrupá-los numa classificação baseada no tipo de posse ou propriedade fundiária. Com base nisso, criamos os seguintes grupos:

- Proprietários: reunimos aqui todos os inventários que declararam fazendas ou sortes de terras. Como os limites fundiários eram muito imprecisos, usamos o preço da terra como critério para a divisão dos proprietários em subgrupos, segundo o valor da propriedade. Assim, os proprietários de terras com valor até um conto de réis eram aqueles que possuíam aproximadamente até 500 alqueires (na proporção média de 2 alqueires de campos para cada alqueire de cultura), o que, no contexto do caráter extensivo das práticas de então, tratavam-se de pequenas propriedades. ${ }^{19}$ Os proprietários entre 1:000\$000 a 3:000\$000 possuíam extensões que variavam de 500 a 1.500 alqueires; entre 3:000\$000 e 5:000\$000, de 1.500 a 2.500 alqueires; e mais de 5:000\$000, maiores de 2.500 alqueires. Estes últimos formavam o grupo dos grandes proprietários.

- Sitiantes: este grupo era formado por aqueles que possuíam situações (isto é, benfeitorias como casa de morada, currais, paióis, monjolos, quintais com árvores frutíferas etc.), mas não eram proprietários das terras onde elas se encontravam.

- Agregados sem sítios: agrupamos aqui aqueles que, não obstante não possuírem bens de raiz, tinham escravos, gado, milho estocado, ferramentas de roça e

19 Levando-se em conta que o preço do alqueire de cultura era de aproximadamente $4 \$ 000$, e dos campos de $1 \$ 000$, e supondo-se uma proporção aproximada de 2 alqueires de campo para cada alqueire de cultura. 
outros equipamentos que demonstravam a existência de trabalho na terra. Supomos que se tratava do grupo, certamente numeroso, de agregados, que trabalhavam em terras de terceiros e viviam em arranchações de taipa sem valor — e que, por isso, não eram inventariadas — ou viviam em moradias cedidas ou alugadas por fazendeiros.

- Chacareiros: aqui, reunimos os que tinham chácaras como único bem de raiz rural. Embora fosse comum grandes fazendeiros manterem chácaras na periferia dos arraiais, existia um grupo de chacareiros exclusivos, bem mais pobres que esses.

- Moradores dos arraiais: aqui, agrupamos aqueles que tinham nos imóveis localizados nos arraiais seu único bem de raiz. Formavam a parcela mais pobre da população, e serão objeto do próximo capítulo.

Assim sendo, a distribuição dos inventariados segundo o tipo de propriedade pode ser vista no gráfico 5. Como se pode notar, os pequenos proprietários eram a maioria simples da população inventariada, somando 31\% do total. Os agregados sem sítio formavam o segundo grupo mais numeroso, com 19\% do total. Os grandes proprietários somavam apenas $9 \%$ do total dos inventários.

A distribuição de riqueza entre os grupos pode ser vista no gráfico 6 . Nele se pode ver que os grandes proprietários de terra, apesar de formarem apenas $9 \%$ da população inventariada, concentravam $51 \%$ da sua riqueza. Com isso se comprova não só a forte hierarquização econômica, mas também que a elite regional era formada pelos grandes proprietários fundiários. Na outra ponta da escala social, encontramos os pequenos proprietários, que somavam $31 \%$ da população, mas controlavam só $10 \%$ da riqueza inventariada, e os agregados sem sítio, $19 \%$ da população, mas com apenas $4 \%$ da riqueza bruta.

O perfil econômico dos grupos pode ser desvendado pela posse média de cativos e de rebanhos em cada um deles, conforme é visto nas tabelas 2 e 3. A distribuição da posse mancípia, na tabela 2, revela o que Libby (1988) já havia sugerido existir em toda a província de Minas Gerais: a pulverização da posse de escravos entre vários grupos sociais, inclusive pequenos proprietários e agregados. Até mesmo a parcela mais pobre da população inventariada, os moradores dos arraiais, tinham em média dois escravos. Tratava-se do que esse autor chamou de "posse democrática" de escravos: o senhor de grandes escravarias de modo algum era a figura que dominava a paisagem social. 


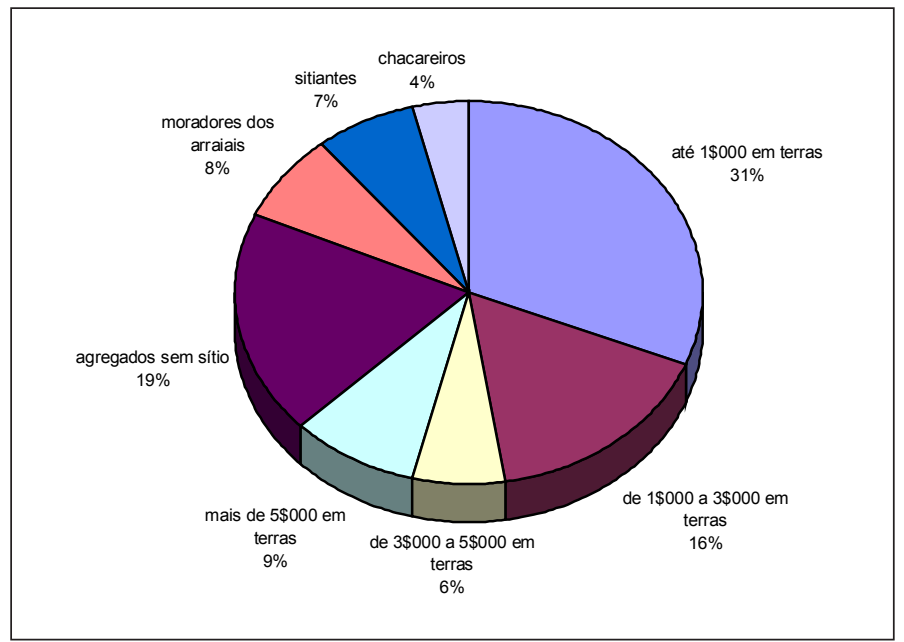

Gráfico 5: distribuição dos inventários post mortem (em \%) segundo o tipo de propriedade no termo de Uberaba (1822-1861)

Fonte: APU, inventários post mortem (1822-1861).

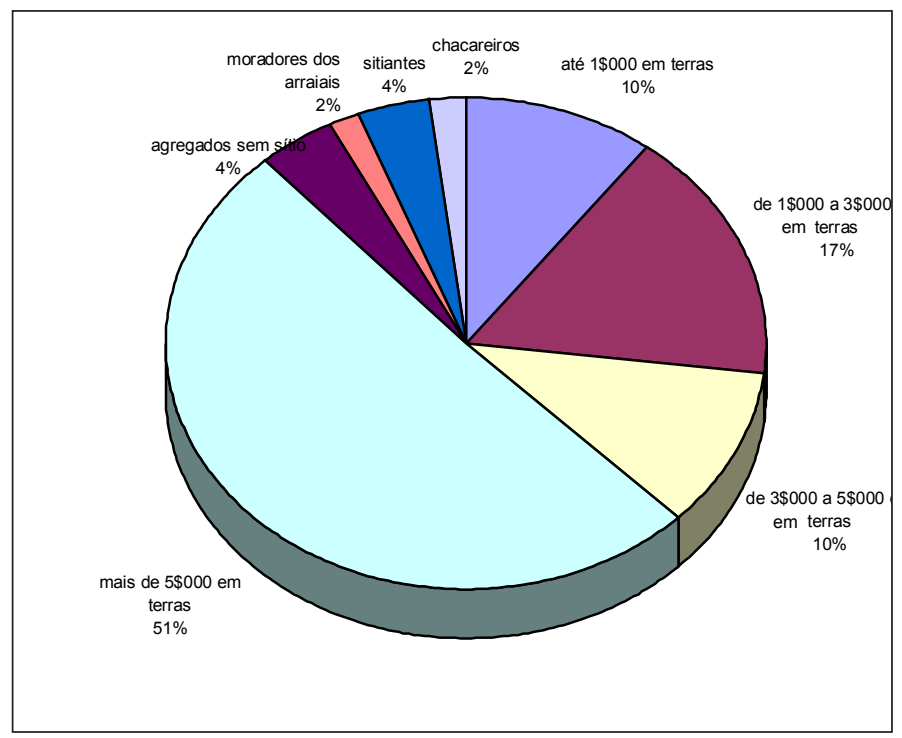

Gráfico 6: distribuição da riqueza inventariada total (em \%) segundo o tipo de propriedade fundiária, no termo de Uberaba (1822-1861).

Fonte: APU, inventários post mortem (1822-1861). 
Por outro lado, a mesma tabela revela uma forte concentração da posse mancípia, como de resto acontecia com todas as outras formas de riqueza: enquanto pequenos proprietários e agregados possuíam em média de dois a três escravos, a média dos latifundiários (mais de 5:000\$000 em terras) era de mais de 19 escravos.

A tabela revela uma correlação positiva entre tamanho da propriedade e plantel médio de escravos, o que pode ser mais bem visualizado no gráfico 7. Comprova-se, assim, como já havíamos sugerido antes, que escravos e terra eram não só as principais formas de acumulação, mas também os principais meios de reprodução de riqueza nessa sociedade, dados o baixo nível técnico das práticas vigentes (e a quase ausência de bens de capital) e a inexistência do grande capital mercantil.

A posse de rebanhos (tabela 3) também revela a concentração dos plantéis bovinos e, ao mesmo tempo, mostra que a criação de gado estava presente em

\begin{tabular}{l|c}
\hline NúMERO MÉdIO DE ESCRAVOS & \\
\hline MAIS DE 5\$000 EM TERRAS & 19,4 \\
\hline DE 3\$000 A 5\$000 EM TERRAS & 9 \\
\hline DE $1 \$ 000$ A 3\$000 EM TERRAS & 6,5 \\
\hline ATÉ $1 \$ 000$ EM TERRAS & 2,9 \\
\hline CHACAREIROS & 5,2 \\
\hline SITIANTES & 3,2 \\
\hline AGREGADOS SEM SÍTIO & 2,6 \\
\hline MORADORES DOS ARRAIAIS & 2 \\
\hline
\end{tabular}

Tabela 2: número médio de escravos por tipo de unidade, em Uberaba (1822-1861). Fonte: APU, inventários post mortem (1822-1861).

todos os extratos sociais. De fato, até mesmo os moradores dos arraiais e os agregados sem sítios dispunham de um pequeno rebanho de 10 a 14 cabeças, em média. Esses pequenos rebanhos eram formados, predominantemente, por vacas de criar e bois de carro. Por exemplo, o agregado Clemente José Ferreira, que, em 1835, também exercia o ofício de ferreiro, provavelmente alugava pastos 
ou contava com a concessão paternalista de algum grande proprietário, que lhe cedesse campos, para manter seu pequeno rebanho de quatro bois de carro, dez vacas paridas e seis novilhas solteiras. É possível que obtivesse vinte litros de leite por dia com suas vacas, com o que alimentava seus filhos e talvez fizesse queijos. Para levá-los e às suas ferrarias ao arraial de Uberaba, para vendê-los, ele, sua esposa, seus filhos e a jovem escrava Eva, de 14 anos, contavam com um carro, puxado pelas suas duas juntas de bois. ${ }^{20}$

$\mathrm{Na}$ outra ponta da escala social, encontravam-se os proprietários de fazendas de mais de cinco contos de réis, que possuíam em média mais de trezentas cabeças. Apesar de, nesse grupo, existirem grandes criadores, as atividades de recria e engorda eram as que mais interessavam aos fazendeiros ricos. Os gráficos 8 e 9, relativos a períodos diferentes, mostram a mesma tendência: quanto maior o rebanho, maior o percentual do plantel na forma de garrotes e novilhas de um a quatro anos.

\begin{tabular}{l|c}
\hline REBANHOS & \\
\hline MAIS DE $5 \$ 000$ EM TERRAS & 381,71 \\
\hline DE 3\$000 A 5\$000 EM TERRAS & 87,50 \\
\hline DE $1 \$ 000$ A 3\$000 EM TERRAS & 86,65 \\
\hline ATÉ 1\$000 EM TERRAS & 31,98 \\
\hline CHACAREIROS & 18,33 \\
\hline SITIANTES & 40,91 \\
\hline AGREGADOS SEM SÍTIO & 14,00 \\
\hline MORADORES DOS ARRAIAIS & 10,42 \\
\hline
\end{tabular}

Tabela 3: número médio de cabeças de gado por tipo de unidade no termo de Uberaba (1822-1861).

Fonte: APU, inventários post mortem (1822-1861).

Desse modo, o que parece se revelar é que a atividade de recria e engorda, que exigia relativa disponibilidade de capital circulante para a aquisição de bezerros, era realizada preferencialmente pelos mais ricos. Por

20 APU, Inventário de Clemente José Ferreira (7/12/1835), maço N37. 


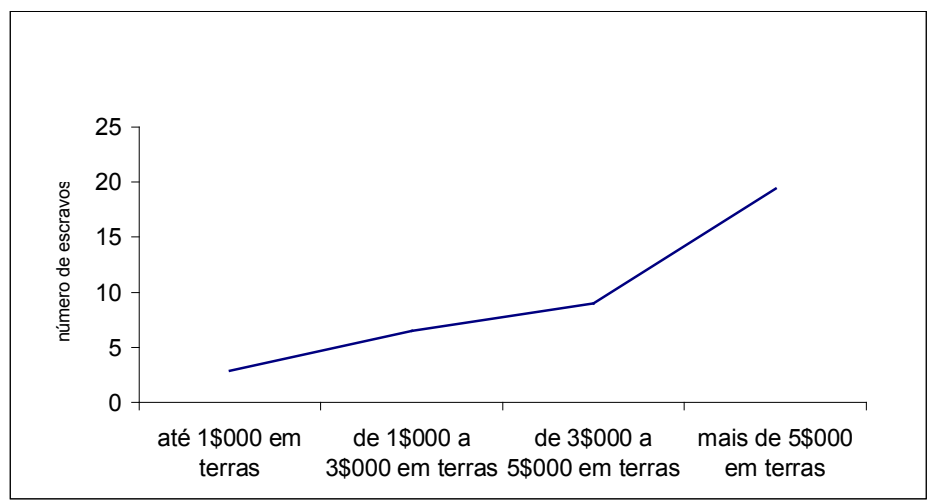

Gráfico 7: correlação entre propriedade de terras e propriedade de cativos no termo de Uberaba (1822-1861)

Fonte: APU, inventários post mortem (1822-1861).

outro lado, a atividade de criação, que não exigia inversões significativas, mas apenas a reprodução natural do gado, sob os cuidados dos membros da família e de alguns escravos, era a atividade praticada usualmente pelos pequenos.

Nos testemunhos deixados pelos cronistas joaninos, podemos confirmar a existência da atividade de engorda de gado como especialidade de alguns pecuaristas. Ao tempo de Eschwege, em Araxá, alguns fazendeiros eram criadores de bezerros, vendidos com um ano de idade para fazendas de invernada e, após a engorda, eram revendidos aos compradores de São João Del Rei:

Na Fazenda Morro Alto [...] fomos acolhidos cordialmente por dois irmãos que [...] dedicavam-se especialmente ao comércio do gado. Compram bois de um ano e vendem-no para o Rio de Janeiro, aos quatro anos (EsCHWEGE, 1996, p. 108-109).

Nos anos posteriores a 1830, também Uberaba passou, de forma crescente, a desempenhar esse papel de centro de invernada para a região.

Assim como os demais tipos de riqueza, também o gado, que era a principal forma pela qual o excedente da região era realizado no mercado extra-regional, tendia a concentrar-se nas mãos de uma elite de grandes fazendeiros. O gráfico 10 mostra a distribuição dos criadores, divididos por categorias segundo o 


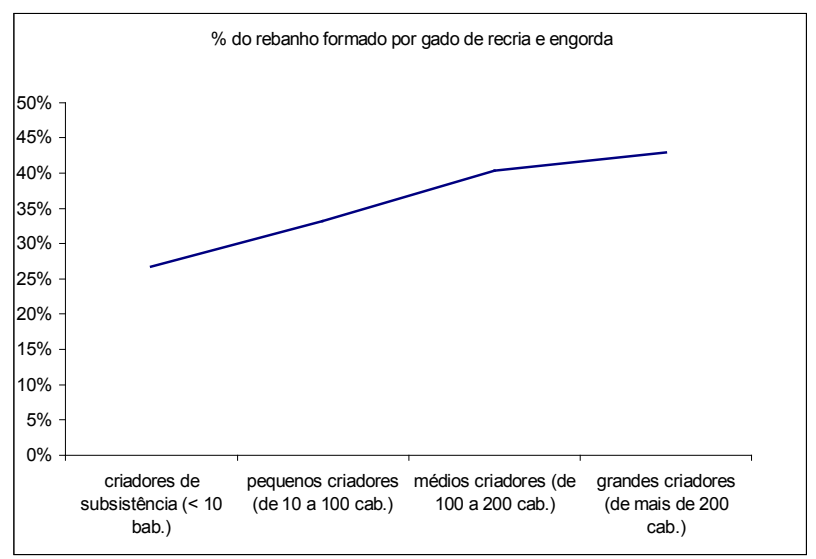

Gráfico 8: porcentagem do rebanho formado por gado de recria e engorda (garrotes maiores que 1 ano e menores que 4 anos), por categoria de criadores, no termo de Uberaba (1822-1841). Fonte: APU, inventários post mortem (1822-1861).

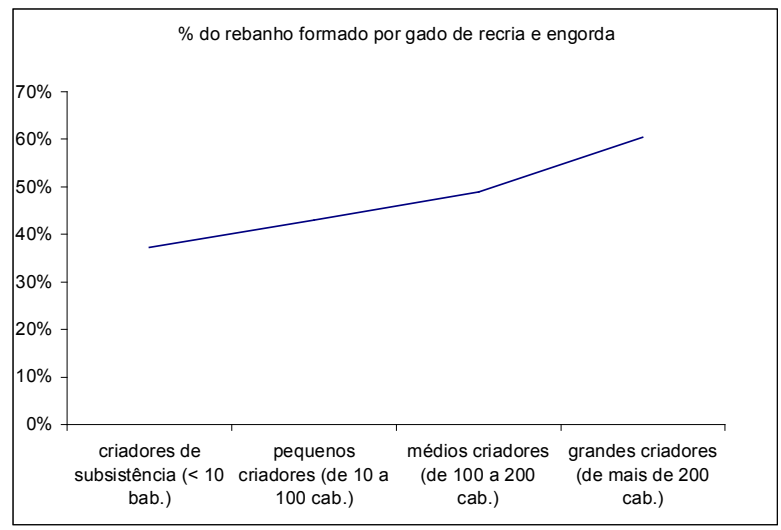

Gráfico 9: porcentagem do rebanho formado por gado de recria e engorda (garrotes maiores que 1 ano e menores que 4 anos), por categoria de criadores, no termo de Uberaba (1842-1861). Fonte: APU, inventários post mortem (1822-1861). 
tamanho dos plantéis, e o gráfico 11 mostra a distribuição do rebanho total da região em cada uma dessas categorias. Os pequenos criadores (10 a 100 cabeças de gado), apesar de constituírem $61 \%$ dos fazendeiros de gado, possuíam só $25 \%$ do rebanho da região. Já os grandes criadores (mais de 200 cabeças de gado), apesar de serem $7 \%$ dos fazendeiros, controlavam 55\% dos rebanhos da região.

As categorias que criamos, baseadas no acesso à terra, guardam uma certa correlação com outras formas de riqueza: quanto maior a propriedade fundiária, mais escravos e gado. Mas não se trata, contudo, de uma correlação absoluta. Como mostram as tabelas 2 e 3 , por exemplo, os sitiantes, que não tinham a propriedade e sim o usufruto da terra, possuíam em média mais escravos, e rebanhos mais numerosos, que os pequenos proprietários de terra. O grupo dos sitiantes era, aliás, o mais heterogêneo de todos. Nele se podem encontrar desde agricultores pobres, como Pedro José da Silva que, em 1853, vivia numa casa com curral e um paiol, sem escravos e apenas com uma vaca e um cavalo velho; ${ }^{21}$ até senhores de razoável cabedal, como Jorge de Abreu Castello Branco que, em 1860, possuía um sítio em terra alheia, na Fazenda do Veríssimo, com 14 escravos e 181 cabeças de gado, além de uma tropa com oito burros. ${ }^{22}$

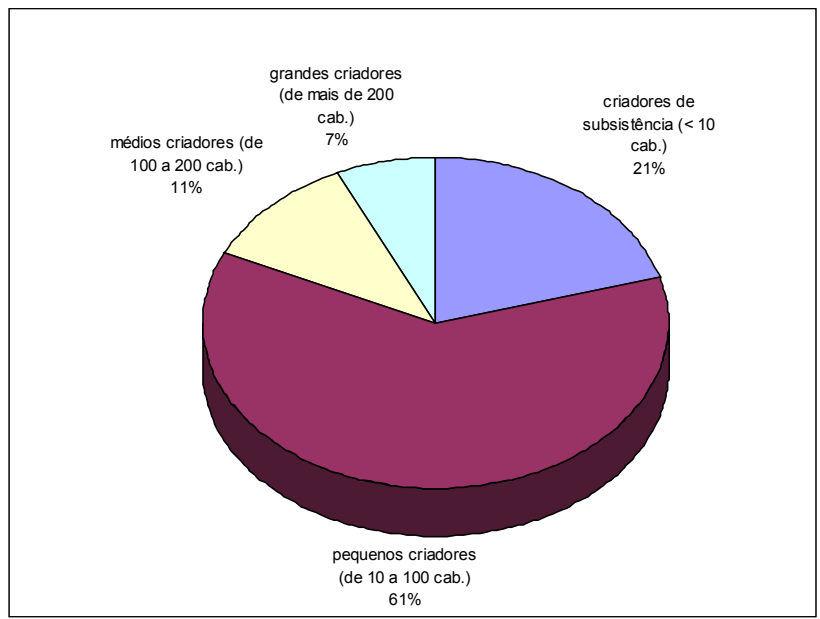

Gráfico 10: \% do número total de criadores de gado, por número de cabeças, no termo de Uberaba (1822-1861)

Fonte: APU, inventários post mortem (1822-1861).

21 APU, inventário de Pedro José da Silva (24/10/1853), maço N14.

22 APU, inventário de Jorge de Abreu Castello Branco (18/04/1860), maço N15, caixa 470. 
Os aspectos que identificamos para cada categoria baseiam-se na média de cada uma delas, mas as variações de caso a caso eram muito grandes. Não podemos a princípio, com base no critério do acesso à terra, distinguir, por exemplo, um proprietário escravista de um camponês, embora possamos afirmar que geralmente existia uma correlação entre acesso à terra e posição na hierarquia social. Isso ocorre porque o status social de um indivíduo dependia de um conjunto de fatores, dos quais a propriedade fundiária era apenas um deles. No contexto de uma economia rural, como a do Triângulo Mineiro oitocentista, a posse de escravos é uma variável muito mais importante na tentativa de apreender como se organizavam os grupos sociais coevos.

Dessa forma, se a aquisição de escravos era a principal configuração assumida pela riqueza acumulada, em qualquer grupo de proprietários, o tráfico de escravos era a principal forma pela qual o excedente, gerado na região, era drenado para outras partes do Brasil. Faremos a seguir, com base em nossas fontes, uma estimativa do tráfico negreiro no termo de Uberaba, na primeira metade do século XIX.

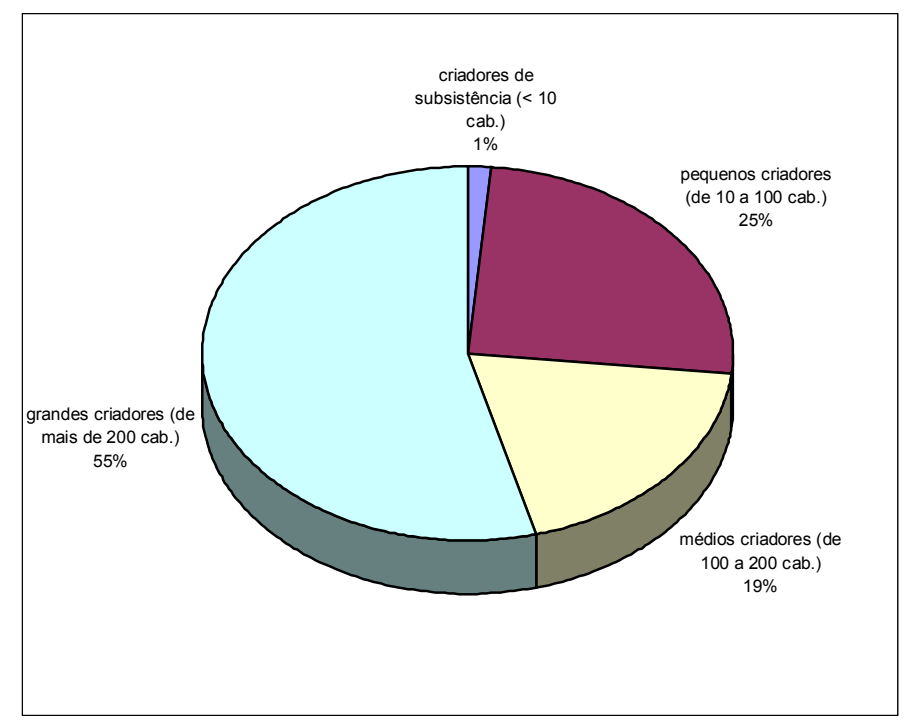

Gráfico 11: \% do rebanho da região, dividido por categoria de proprietários, no termo de Uberaba (1822-1861).

Fonte: APU, inventários post mortem (1822-1861). 


\section{O tráfico negreiro}

O estudo do tráfico negreiro é uma maneira de estimar, indiretamente, a capacidade de acumulação da economia local. Como vimos no tópico anterior, escravos eram a principal forma pela qual a riqueza era acumulada na região, tanto entre pequenos sitiantes quanto grandes fazendeiros. A maior parte do excedente realizado no mercado era usado, portanto, na aquisição de cativos.

O tráfico de escravos para Minas Gerais era feito pelas tropas vindas do Rio de Janeiro, embora o Triângulo Mineiro também recebesse, provavelmente, escravos trazidos pelas tropas paulistas. Os tropeiros especializados no tráfico terrestre eram chamados comboieiros (figura 1), mas, segundo Fragoso (1998), eram minoritários no tráfico para a província. Os estudos desse autor, que tiveram por base os Registros de Saída de Tropeiros do Rio de Janeiro, revelam que o traficante eventual - tropeiros que conduziam um a dois escravos por tropa, junto com outras mercadorias - era a regra no comércio terrestre de escravos em Minas Gerais. Na série analisada pelo autor, somente 19 traficantes $(0,3 \%$ do total) podiam ser classificados como negociantes regulares de cativos. Mesmo estes não levavam grandes cargas negreiras: em média, conduziam 5,9 cativos por tropa:

Em vista desses números, podemos dizer que o tráfico de escravos era feito através de pequenos empreendimentos. Mais do que isso, por condutores que eventualmente (talvez conjunturalmente seja o mais correto) transportavam escravos. Estaríamos, assim, diante de um negócio que, devido à eventualidade de seus agentes, não era especializado; não contava com um grupo permanente de empresários (Fragoso, 1998, p. 207).

É provável, portanto, que a tropa descrita por Saint Hilaire na Estrada do Anhanguera, a caminho do Cuiabá, levando doze cativos, tenha sido mais exceção do que regra, no tráfico de escravos para o interior do Brasil:

Conversei com o mercador a quem pertencia essa tropa e ele me disse que era composta de sessenta bestas de carga. Levava também uma dúzia de molecotes da Costa da África, e estava vindo de São Paulo com destino a Cuiabá (1975 a, p. 120). 
Usando os inventários post mortem como fontes, podemos estimar indiretamente a intensidade do tráfico para a região e, por conseguinte, a própria capacidade de acumulação da economia regional. Os inventários, agrupados em séries divididas por períodos, dão espaço a análises diacrônicas sobre o perfil dos plantéis — taxas de masculinidade, africanidade e pirâmides etárias - o que permite algumas inferências, embora aproximadas, sobre o tráfico negreiro.

Gorender (1988) demonstrou que, em regiões mais ricas, a taxa de masculinidade escrava ultrapassava, em muito, os $50 \%$ da população cativa

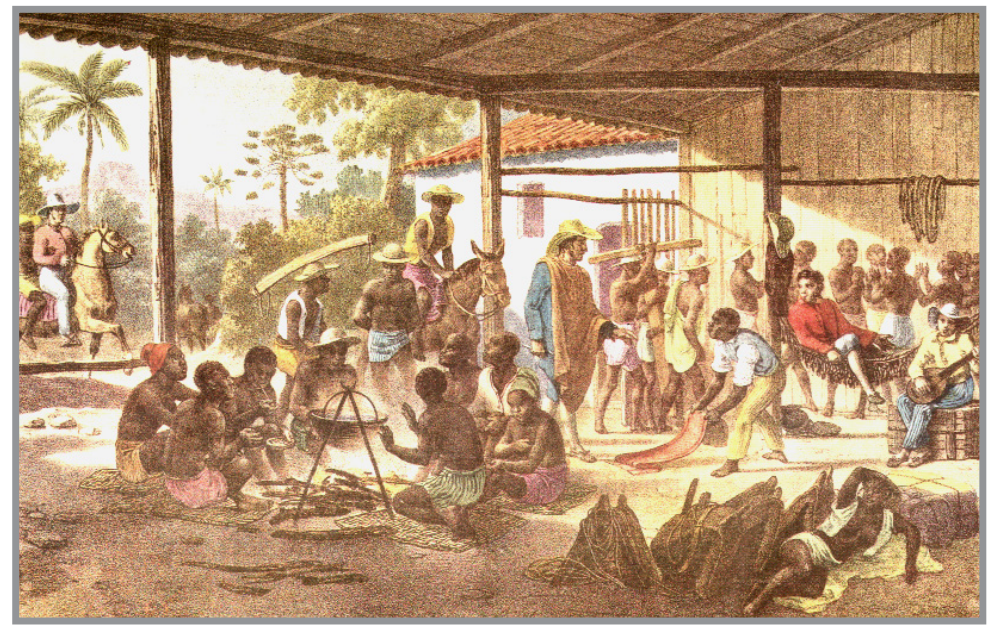

Figura 1: comboio de negros.

Fonte: Rugendas (1998).

total. Isso se devia à tendência de os senhores de escravos preferirem homens jovens para compor seus plantéis. Os desembarques negreiros no porto do Rio de Janeiro, estudados por Florentino e Góes (1997), com base nos dados relativos a africanos negociados no mercado do Valongo, entre 1822 e 1833, já traziam, desde a África, esse desequilibrio entre os sexos e as idades. Segundo os autores, os homens de idade entre 15 a 25 anos representavam algo em torno de $40 \%$ do total de escravos desembarcados na capital do Império. 
A alta taxa de masculinidade, evidentemente, tendia a desaparecer com a primeira geração de escravos crioulos, caso a população escrava não fosse renovada pelo tráfico. Dessa forma, a persistência de uma alta taxa de masculinidade, ao longo do tempo, é demonstrativa da presença do tráfico em atividade e, portanto, de capacidade de acumulação. Na região do Triângulo Mineiro, a taxa de masculinidade, calculada por meio dos plantéis constantes nos inventários post mortem, variou de 62\%, de 1822 a 1841, a 54\%, de 1842 a 1851. Esses números parecem mostrar, com a queda da taxa de masculinidade, uma redução do tráfico negreiro no período, e uma dependência maior da taxa de natalidade escrava, na renovação da força de trabalho.

Da mesma forma, a taxa de africanidade — percentual do plantel formado por africanos — também é valiosa para se estimar a intensidade do tráfico. Nos documentos estudados, foram arrolados 534 escravos, de 1822 a 1851, um ano depois da extinção do tráfico transatlântico. A taxa de africanidade em Uberaba, calculada sobre essa amostra, variou de 34,35\%, no período $1822-1841$, a 30,64\%, no período 1842-1851. Estes dados demonstram a presença de tráfico ativo na região e, deste modo, de relações mercantis intensas com as cidades portuárias. Mas mostram também uma pequena queda da taxa no período, devendo-se, provavelmente, ao inflacionamento do preço do escravo, com retração do mercado.

Uma análise ainda mais precisa dos efeitos do tráfico sobre os plantéis uberabenses pode ser obtida comparando-se as pirâmides etárias dos escravos, separados em africanos e crioulos, ao longo desse período. O gráfico 12, que mostra a pirâmide etária da população africana entre 1822 e 1841, demonstra a presença maciça de homens jovens — entre 11 e 30 anos —, o que é uma prova indireta da atividade do tráfico, a partir dos portos negreiros.

O gráfico 13, que exibe a pirâmide etária de africanos do período seguinte, de 1842 a 1851, já às vésperas da extinção do tráfico transatlântico, revela um envelhecimento daquela população, se comparada com a do período anterior. Isso evidencia que, com a proximidade da proibição do tráfico, a repressão britânica aos negreiros no Atlântico, e o conseqüente aumento do preço dos escravos importados, houve redução da importação de africanos pela região.

As pirâmides etárias da população crioula (gráficos 14 e 15) mostram perfis tipicamente pré-malthusianos, representativos não só da alta mortalidade, mas também da alta natalidade entre os escravos. Além disso, vê-se também uma simetria na distribuição entre os sexos, provando que a taxa de masculinidade 
entre eles era próxima à da população livre.

Esses dados parecem indicar, na falta de registros diretos da atividade do tráfico de escravos na região, que parte significativa do excedente gerado nas atividades econômicas era drenado para as mãos dos negociantes negreiros, fossem eles tropeiros ou mercadores do litoral.

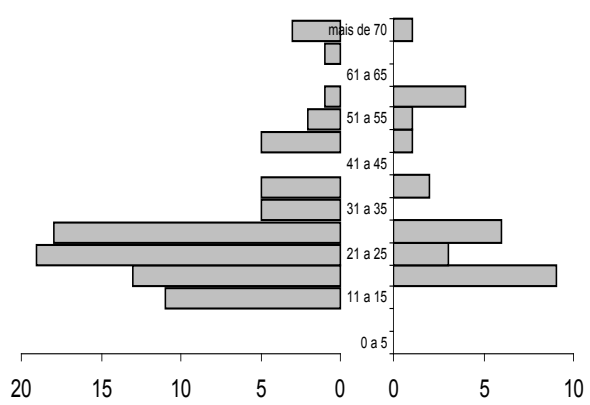

Gráfico 12: pirâmide etária da população escrava africana, no termo de Uberaba, entre 1822 e 1841.

Fonte: APU, inventários post mortem (1822-1841).

Num contexto de inexistência de um capital mercantil autóctone, de quase ausência de relações de trabalho assalariadas, e no qual quase toda riqueza era imobilizada em terra e escravos, a força de trabalho assumia predominantemente duas formas: trabalho familiar e trabalho cativo. Veremos a seguir como se estratificava a sociedade triangulina com base no recurso a essas formas de trabalho.

\section{Trabalho familiar e trabalho escravo}

Em seu trabalho sobre a economia mineira do século XIX (aliás pioneiro sobre o assunto), Libby (1988) utilizou os mapas da população, feitos pelo governo provincial entre 1831 e 1840, para estudar a distribuição da posse de cativos em toda a província. O autor percebeu que, em Minas Gerais, existiam no período dois padrões regionais distintos de distribuição da propriedade mancípia: um fortemente concentrado, e outro que exibia o que chamou de "posse democrática" de escravos. 
A concentração na posse de cativos, segundo o autor, ocorria em três regiões: Zona da Mata, Metalúrgica-Mantiqueira e Triângulo Mineiro. No primeiro caso, os grandes plantéis (mais de 30 escravos) concentravam $27 \%$ do total da população cativa, o que se explica pelo avanço, a partir dos anos 1820, da cafeicultura em sistema de plantation na região. Na zona

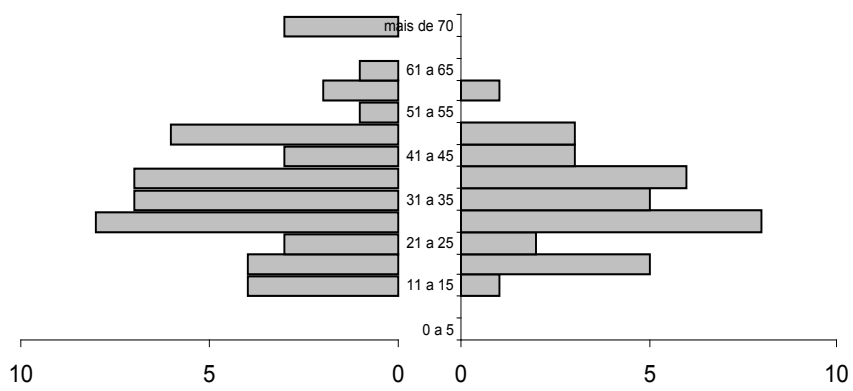

Gráfico 13: pirâmide etária da população escrava africana, no termo de Uberaba, entre 1842 e 1851.

Fonte: APU, inventários post mortem (1842-1851).

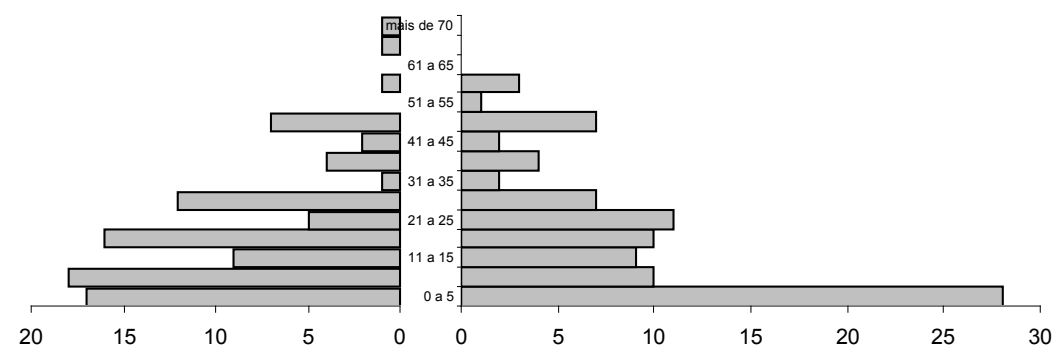

Gráfico 14: pirâmide etária da população escrava crioula, no termo de Uberaba, entre 1822 e 1841. Fonte: APU, inventários post mortem (1822-1841). 


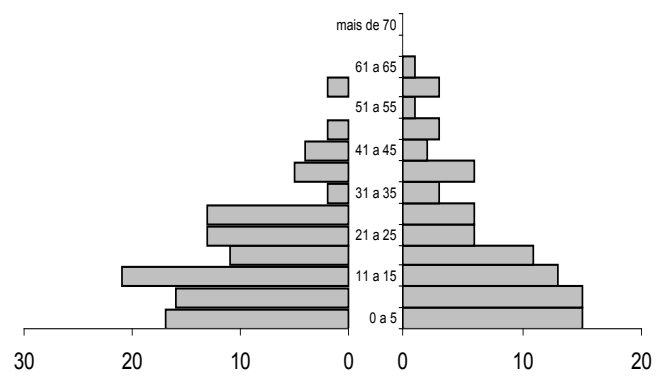

Gráfico 15: pirâmide etária da população escrava crioula, no termo de Uberaba, entre 1842 e 1851. Fonte: APU, inventários post mortem (1842-1851).

Metalúrgica-Mantiqueira, as grandes escravarias, que representavam $32 \%$ da população escrava da região, deviam-se à presença das grandes mineradoras de capital britânico, que extraíam ouro em profundidade, como a Imperial Brazilian Mining Association (Gongo Soco) e a Saint John Del Rei Mining Company (Morro Velho), e que chegavam a empregar mais de 300 escravos em suas atividades. Quanto à última região, diz o autor:

Quanto ao Triângulo Mineiro, não podemos oferecer nenhuma explicação para a desconcentração lá registrada, pois o perfil da região não destoa dos padrões provinciais em outros aspectos já discutidos (LibBY, 1988, p. 106).

O outro padrão de distribuição da posse de escravos, em que os pequenos plantéis perfaziam a maioria da população escrava e os pequenos proprietários de cativos eram majoritários, predominava no Sul de Minas, na região do Jequitinhonha e Mucuri, nas regiões de Montes Claros e Paracatu e no Oeste Mineiro e Alto Paranaíba. Aliás, na agregação dos resultados em toda a província, esse era o padrão para a distribuição da posse mancípia provincial, apesar das distorções impostas pelas Zonas Metalúrgica-Mantiqueira e Mata (e, de acordo com os resultados do autor, também pelo Triângulo Mineiro): 
Diante de tais resultados, acreditamos que seja válido concluir que na Minas Gerais do segundo quartel do século XIX predominava uma relativa desconcentração na propriedade de escravos. Quanto à base sócio-política do escravismo, podemos afirmar que a desconcentração da propriedade de escravos tenha servido de sustentação ao regime. Tal fato sugere que é importante um estudo sobre essa 'democracia relativa escravista' [...] (p. 107).

Nossos resultados corroboram essa conclusão do autor: realmente, também no Triângulo Mineiro, como de resto na maior parte da província, predominavam os pequenos proprietários de escravos. Assim, acreditamos que a excentricidade dos achados do autor relativos ao Triângulo Mineiro se deva a problemas na amostragem. Um dos problemas é que o autor utilizou, como populações-amostra do Triângulo Mineiro, os arraiais de Desemboque, São José do Tejuco ${ }^{23}$ e São Francisco das Chagas. ${ }^{24} \mathrm{O}$ Desemboque era uma localidade atípica da região, pois surgiu em 1760, por causa da descoberta de ouro na cabeceira do Rio das Velhas por migrantes vindos da região central de Minas. A existência de atividades mineradoras e de fortunas mais antigas diferia da maior parte do Triângulo Mineiro, onde predominavam agricultores e criadores que chegaram à região a partir de 1809. As outras duas localidades, São José e São Francisco, eram esparsamente povoadas no período compreendido pelo autor e devem ter contribuído pouco para os valores agregados na região.

Feita essa ressalva, comparamos os nossos resultados (gráfico 16 e tabela 4) aos do autor, relativos a outras regiões da província (gráficos 17, 18 e 19). Verifica-se que o Triângulo não destoava das outras regiões mineiras que compartilhavam das mesmas estruturas econômico-sociais. Também aqui, os pequenos proprietários de escravos (até 5 escravos) perfaziam a maioria dos proprietários $(61 \%$ do total, contra $66 \%$ no Sul, $72 \%$ no Oeste e $71 \%$ no Alto Paranaíba) e detinham $27 \%$ da população escrava (contra $24 \%$ no Sul, $32 \%$ no Oeste e 37\% no Alto Paranaíba).

É necessário, contudo, lembrarmo-nos de que não estamos diante de uma realidade em que só existissem o pequeno e o médio proprietário de escravos. As figuras mostram que, tanto aqui como em outras regiões mineiras, os senhores de plantéis superiores a 20 escravos, embora somassem apenas 3\% a 7\% dos

23 Hoje Ituiutaba.

24 Hoje Monte Alegre de Minas. 
proprietários, controlavam de 23\% (Oeste) a 35\% (Sul) da população cativa. No Triângulo, os grandes proprietários detinham $25 \%$ do total de escravos. O quadro que talvez mais se aproxime do que até agora vem sendo traçado para o Triângulo (e Minas Gerais) oitocentista seria o de alguns grandes senhores escravistas pontuando a paisagem, e gravitando em torno deles um grande número de pequenos e médios proprietários de escravos.

Para que uma unidade produtiva seja considerada camponesa, é necessário que satisfaça dois critérios: que o trabalho familiar seja a forma predominante de trabalho produtivo, e que os níveis de produção se estabeleçam a partir de um equilíbrio entre o dispêndio de força de trabalho e as demandas do consumo familiar. Nas palavras de Chayanov, "a composição da família é o que determina o volume da atividade econômica. A força de trabalho da unidade familiar é inteiramente determinada pela disponibilidade dos membros da família fisicamente aptos" (1986, p. 53).

Contudo, o uso de trabalho externo à unidade familiar não é incomum nas unidades camponesas. Chayanov (1986) assinalou que o campesinato russo, principalmente nos períodos de semeadura e colheita, lançava mão do assalariamento temporário externo à unidade, como forma de ampliar a força de trabalho familiar. No caso da sociedade colonial e imperial, o escravismo, e não o assalariamento, era a relação de trabalho que dominava a formação social

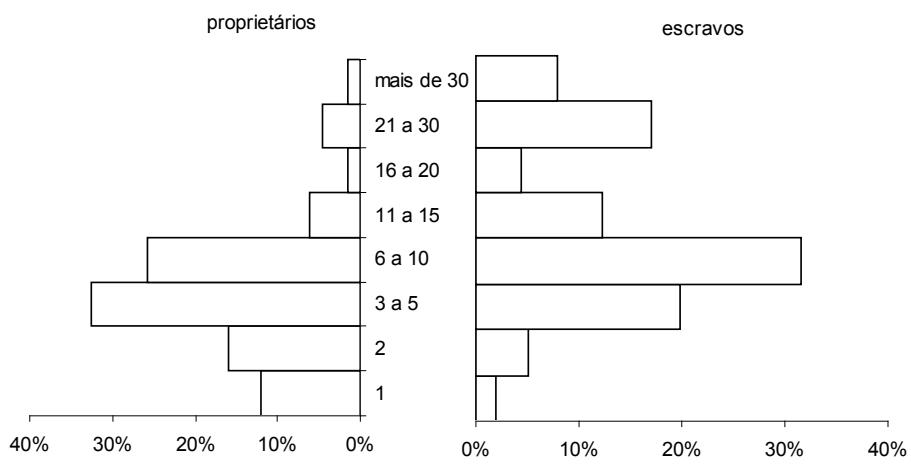

Gráfico 16: distribuição do número de proprietários e da população escrava no Triângulo Mineiro (1822-1861).

Fonte: APU, inventários post mortem (1822-1861). 


\begin{tabular}{l|c|c|c|c|c|c|c|c}
\hline & \multicolumn{7}{|c}{ CLASSIFICAÇÃO DOS PROPRIETÁRIOS SEGUNDO O NÚMERO DE ESCRAVOS } \\
& 1 & 2 & $\begin{array}{c}3 \text { a } \\
5\end{array}$ & $\begin{array}{c}6 \text { a } \\
10\end{array}$ & $\begin{array}{c}11 \text { a } \\
15\end{array}$ & $\begin{array}{c}16 \text { a } \\
20\end{array}$ & $\begin{array}{c}21 \text { a } \\
30\end{array}$ & $\begin{array}{c}\text { mais } \\
\text { de } 30\end{array}$ \\
\hline & $12 \%$ & $16 \%$ & $33 \%$ & $26 \%$ & $6 \%$ & $2 \%$ & $5 \%$ & $2 \%$ \\
\hline EROPRIETÁRIOS & $2 \%$ & $5 \%$ & $20 \%$ & $32 \%$ & $12 \%$ & $4 \%$ & $17 \%$ & $8 \%$ \\
\hline
\end{tabular}

Tabela 4: distribuição do número de proprietários e da população escrava no Triângulo Mineiro (1822-1861).

Fonte: APU, inventários post mortem (1822-1861).

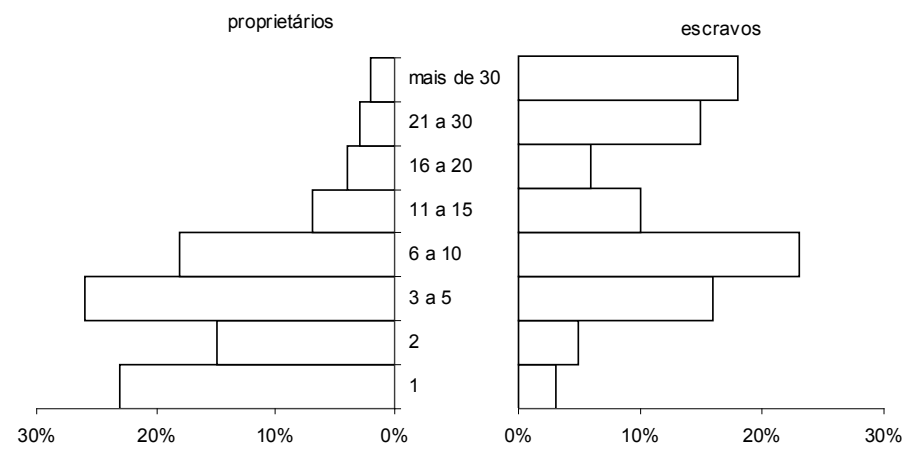

Gráfico 17: distribuição da propriedade de escravos - região Sul (1830-1840)

Fonte: Libby (1988).

e impunha sua lógica às demais. Assim, seria de se esperar que encontrássemos unidades camponesas que eventualmente lançassem mão do trabalho escravo, como forma de complementar ou estender a força de trabalho familiar.

Em nossas fontes, o fogo era a unidade produtiva básica a partir da qual o trabalho se organizava, em pequena ou grande escala. Nos fogos mais modestos, a família, com auxílio ou não de escravos, funcionava como a unidade básica de trabalho, produzindo, ao mesmo tempo, gêneros agrícolas para o autoconsumo e para a comercialização, rebanhos para a venda de garrotes ou para o fabrico 


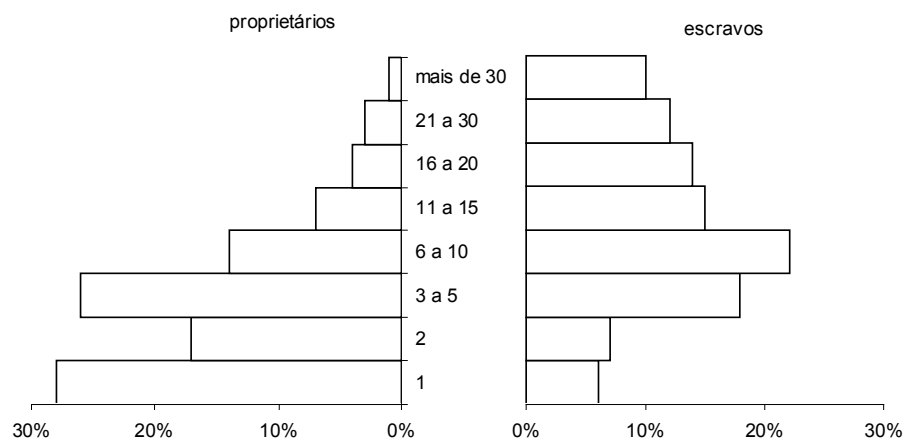

Gráfico 18: distribuição da propriedade de escravos - região Oeste (1830-1840) Fonte: Libby, op. cit., p. 100.

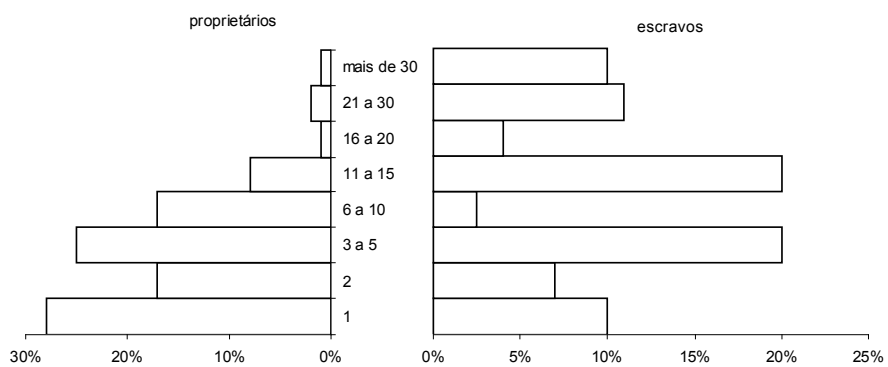

Gráfico 19: distribuição da propriedade de escravos - Alto Paranaíba (1830-1840) Fonte: Libby, op. cit., p. 101.

doméstico de queijos, carneiros para a tosa de lã, tecidos de algodão para uso próprio ou venda. Até mesmo ferramentas como carros, cangas, monjolos e pilões eram produzidos em oficinas domésticas.

No caso dos fogos com até cinco escravos (ou dez, dependendo da constituição etária do plantel), apesar da relação de exploração a que estes estavam 
submetidos, também era impossível distinguir o produto do trabalho escravo do trabalho familiar. Ao trabalho do casal proprietário do fogo e de seus filhos mais velhos se somava o trabalho de um ou dois escravos em idade produtiva. Não havia, nesse caso, uma divisão social do trabalho muito clara, e o recurso ao escravo era uma forma de ampliar o potencial produtivo de uma unidade familiar.

Chayanov demonstrou que o equilíbrio trabalho-consumo da unidade camponesa é dinâmico, isto é, varia em função das transformações demográficas ligadas ao ciclo vital familiar camponês:

Entre famílias de pequeno tamanho, temos um número de famílias jovens, freqüentemente consistindo de recém-casados - o marido e a esposa que apenas recentemente se separaram do lar paterno. Temos um número de famílias consistindo de um número de casais e crianças pequenas, e temos famílias maduras nas quais a segunda geração já trabalha. [...] Finalmente, temos várias famílias idosas que consistem em duas pessoas idosas vivendo sozinhas. [...] Em outras palavras, temos diante de nós todas as fases de desenvolvimento pelas quais a família passa (1986, p. 56).

Assim, nas fases iniciais da história de vida familiar, há uma relação consumidor/produtor igual a 1, que vai aumentando a valores maiores que 1 à medida que o lar camponês vai se enchendo de filhos pequenos. À proporção que estes crescem, a relação consumidor/produtor diminui, até que todos se tornem adultos e plenamente produtivos (gráfico 20).

A partir dessa concepção da dinâmica familiar, Chayanov (1986) procurou compreender o papel desempenhado pelo capital (e pelo processo de acumulação de capital) na unidade camponesa. A grande diferença entre o capital do empreendimento capitalista e o "capital" da unidade camponesa (sementes, equipamentos etc.) é que nesta, diferente daquele, a parte do ganho bruto auferido no processo produtivo, usado na renovação de capital, é indistinguível da parte usada na satisfação do consumo familiar.

É possível, na unidade camponesa, a reprodução ampliada do capital e, portanto, acumulação de capital, mas tal ocorrerá apenas se for visto como vantajoso pela família, isto é, se o esforço adicional de trabalho para obter excedentes para o investimento levar, com este, a um nível de satisfação maior das demandas familiares. Se aumentar a relação consumidor/produtor, deve-se 
aumentar proporcionalmente a penosidade do trabalho dos produtores para aumentar a produção e, em tal situação, o investimento em capital pode se tornar vantajoso. Assim, o investimento e a acumulação não são vistos como um fim em si mesmo, mas como parte de uma estratégia de se buscar um equilíbrio trabalho/consumo em melhores condições.

A partir dos títulos de herdeiros constantes nos inventários post mortem, foi possível reconstituir algumas das características demográficas das famílias triangulinas oitocentistas. Neles, eram informados os nomes dos filhos, suas idades, estado civil e local de moradia. Assim, pudemos construir fichas de família para a maioria dos inventários pesquisados, como já mostramos no capítulo 2. Pudemos, assim, comparar o número de membros e a idade da família com variáveis econômicas, como número de escravos, terras e gado.

Excluímos de nossa amostra os inventários de proprietários de mais de 10 escravos, de casais sem filhos e de comerciantes, mantendo os que

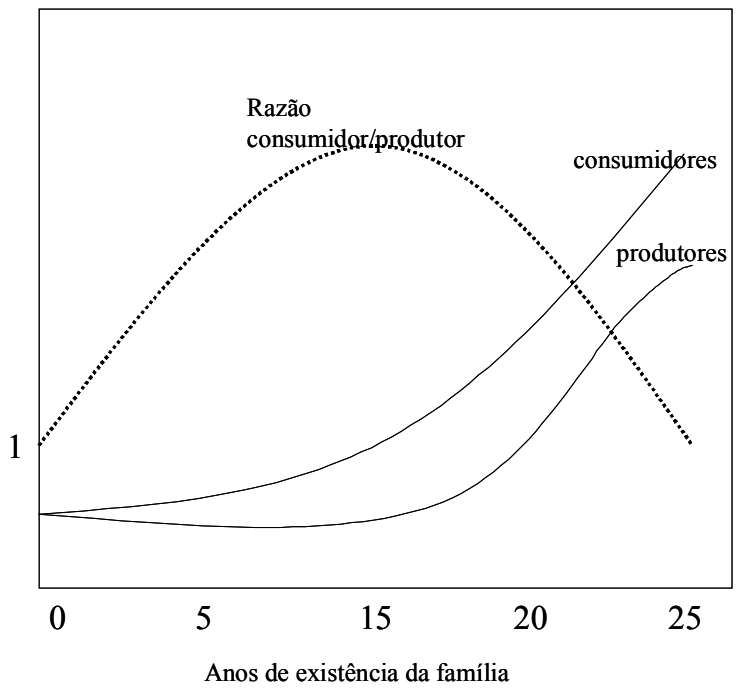

Gráfico 20: curva de Chayanov para a razão consumidor/produtor em função da idade da família. Fonte: Chayanov (1986). 
não possuíam escravos. Dividimos as famílias em famílias jovens (filho mais velho menor que 11 anos), maduras (filho mais velho menor que 20 anos) e idosas (filho mais velho maior que 30 anos ou maioria dos filhos casada), e correlacionamos esses grupos com seus respectivos plantéis médios de escravos e patrimônios fundiários. Obtivemos os gráficos 21 e 22 .

Pode-se notar que, na realidade vivida pelas famílias triangulinas, escravos e terra ocupavam o lugar do "capital" dos camponeses russos estudados por Chayanov. Em outras palavras, diante do padrão de baixo nível de desenvolvimento das forças produtivas, vigente na região, investir na aquisição de terras e cativos era a única forma de ampliar a produtividade da força de trabalho e alcançar o equilíbrio na satisfação do consumo familiar.

Porém, para avançar em nossas considerações, é necessário não só comparar a idade da família com o número de escravos, mas a força de trabalho familiar com a força de trabalho escrava, em função da idade. Usamos a tabela de Chayanov (tabela 5) para calcular a força produtiva individual de cada membro da família em função da idade e sexo, e fizemos o mesmo com os escravos. Nessa tabela, o autor considerou que a idade produtiva começaria aos 13 anos, e que um homem adulto jovem teria índice de produtividade e consumo igual a 1 , enquanto as mulheres teriam um índice de 0,8 .

A aplicação dos parâmetros de Chayanov, construídos para famílias camponesas russas do início do século XX, é passível de crítica, por se tratar o nosso objeto de estudo de uma realidade cultural e histórica diferente. Mas, por não dispormos de outras referências, usaremos os coeficientes desse autor, com essa ressalva.

Calculamos a força produtiva média, familiar e escrava, com base nos coeficientes da tabela de Chayanov, para cada faixa de idade das famílias, baseados na idade e sexo dos membros e dos cativos, conforme se vê no gráfico 23. Percebe-se que, até a família atingir de 10 a 15 anos de existência, a força de trabalho familiar superava a escrava, na média dos fogos. Dos 15 aos 20 anos, quando a família tinha sua mais alta relação consumidor/trabalhador (grande número de filhos menores), a força de trabalho escrava chegava ao seu máximo, para decair logo depois, dos 20 aos 30 anos, quando o número de dependentes diminuía, e parte dos escravos era possivelmente vendida ou dada em dote às filhas.

Com isso, podemos falar de unidades camponesas com escravos, pois a presença dos pequenos plantéis de cativos não descaracterizava o trabalho 


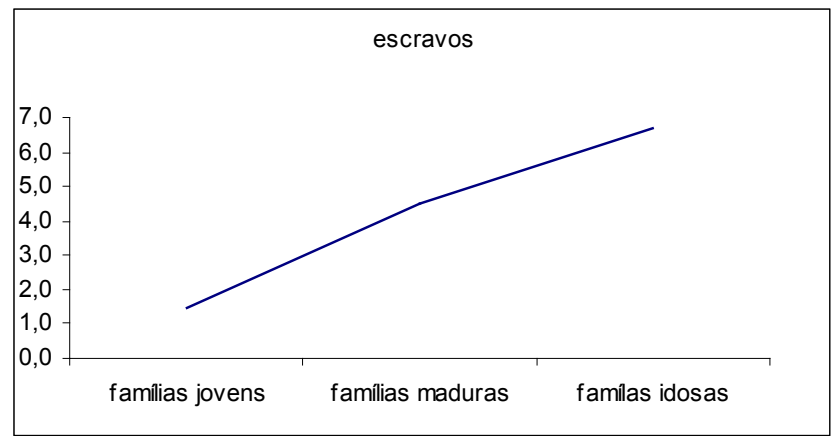

Gráfico 21: plantéis médios de escravos em função da idade da família, para famílias com menos de 10 escravos, no termo de Uberaba (1822-1861).

Fonte: APU, inventários post mortem (1822-1861).

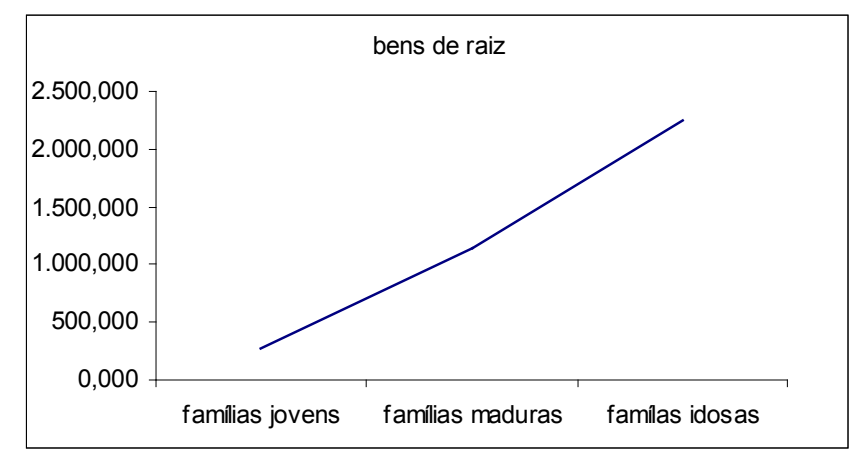

Gráfico 22: patrimônio fundiário em função da idade da família, para famílias com menos de 10 escravos, no termo de Uberaba (1822-1861).

Fonte: APU, inventários post mortem (1822-1861).

familiar, antes o ampliava. Tomamos o cuidado de não chamar tais unidades de escravistas, pois isso pressuporia uma divisão social do trabalho entre produtores diretos escravos e não-produtores livres nas unidades camponesas, o que vimos ser improvável, e o que de resto as descaracterizaria como camponesas.

É muito provável que as fazendas e sítios triangulinos fossem semelhantes, na forma de organização do trabalho, às fazendas descritas por 


\begin{tabular}{|c|c|c|c|c|c|c|c|c|c|c|c|c|c|c|}
\hline \multirow{2}{*}{\multicolumn{2}{|c|}{$\begin{array}{c}\text { Years of } \\
\text { Family's } \\
\text { Existence }\end{array}$}} & \multirow{2}{*}{$\begin{array}{c}\text { Married } \\
\text { Couple }\end{array}$} & \multicolumn{9}{|c|}{ Children } & \multicolumn{2}{|c|}{$\begin{array}{l}\text { Total in } \\
\text { Family }\end{array}$} & \multirow{2}{*}{$\begin{array}{c}\text { Consumers } \\
\div \text { Workers } \\
\end{array}$} \\
\hline & & & 1 & 2 & 3 & 4 & 5 & 6 & 7 & 8 & 9 & Consumers & Workers & \\
\hline 1 & $\ldots$ & 1.8 & - & - & - & - & - & - & - & - & - & 1.8 & 1.8 & 1.00 \\
\hline 2 & $\ldots$ & 1.8 & 0.1 & - & - & - & - & - & - & - & - & 1.9 & 1.8 & 1.06 \\
\hline 3 & $\ldots$ & 1.8 & 0.3 & - & - & - & - & - & - & - & - & 2.1 & 1.8 & 1.17 \\
\hline 4 & $\ldots$ & 1.8 & 0.3 & - & - & - & - & - & - & - & - & 2.1 & 1.8 & 1.17 \\
\hline 5 & $\because$ & 1.8 & 0.30 & 0.1 & - & - & - & - & - & - & - & 2.2 & 1.8 & 1.22 \\
\hline 6 & $\cdots$ & 1.8 & 0.30 & 0.3 & - & - & - & - & - & - & - & 2.4 & 1.8 & 1.33 \\
\hline 7 & $\ldots$ & 1.8 & 0.30 & 0.3 & - & - & - & - & - & - & - & 2.4 & 1.8 & 1.39 \\
\hline 8 & $\ldots$ & 1.8 & 0.3 & 0.3 & 0.1 & - & - & - & - & - & - & 2.5 & 1.8 & 1.39 \\
\hline 9 & $\ldots$ & 1.8 & 0.51 & 0.3 & 0.3 & - & - & - & - & - & - & 2.9 & 1.8 & 1.61 \\
\hline 10 & $\ldots$ & 1.8 & 0.5 & 0.3 & 0.3 & - & - & - & - & - & - & 2.9 & 1.8 & 1.61 \\
\hline 11 & $\ldots$ & 1.8 & 0.5 & 0.3 & 0.3 & 0.1 & - & - & - & - & - & 3.0 & 1.8 & 1.66 \\
\hline 12 & $\ldots$ & 1.8 & 0.5 & 0.5 & 0.3 & 0.3 & - & - & - & - & - & 8.4 & 1.8 & 1.88 \\
\hline 13 & $\ldots$ & 1.8 & 0.50 & 0.5 & 0.3 & 0.3 & - & - & - & - & - & 3.1 & 1.8 & 1.88 \\
\hline 14 & $\ldots$ & 1.8 & 0.5 & 0.5 & 0.3 & 0.3 & 0.1 & - & - & - & - & 3.5 & 1.8 & 1.94 \\
\hline 15 & $\ldots$ & 1.8 & 0.7 & 0.5 & 0.5 & 0.8 & 0.3 & - & - & - & - & 4.1 & 2.5 & 1.64 \\
\hline 16 & $\ldots$ & 1.8 & 0.7 & 0.5 & 0.5 & 0.3 & 0.3 & - & - & - & - & 4.1 & 2.5 & 1.64 \\
\hline 17 & $\ldots$ & 1.8 & 0.7 & 0.5 & 0.5 & 0.3 & 0.3 & 0.1 & - & - & - & 4.2 & 2.5 & 1.68 \\
\hline 18 & $\ldots$ & 1.8 & 0.7 & 0.7 & 0.5 & 0.5 & 0.8 & 0.8 & - & - & - & 1.8 & 3.2 & 1.50 \\
\hline 19 & $\ldots$ & 1.8 & 0.7 & 0.7 & 0.5 & 0.5 & 0.8 & 0.3 & - & - & - & 1.8 & 3.2 & 1.50 \\
\hline 20 & $\cdots$ & 1.8 & 0.9 & 0.7 & 0.5 & 0.5 & 0.3 & 0.8 & 0.1 & - & - & 5.1 & 3.4 & 1.50 \\
\hline 21 & $\ldots$ & 1.8 & 0.9 & 0.7 & 0.7 & 0.5 & 0.5 & 0.8 & 0.3 & - & - & 5.7 & 4.1 & 1.39 \\
\hline 22 & $\ldots$ & 1.8 & 0.9 & 0.7 & 0.7 & 0.5 & 0.5 & 0.8 & 0.8 & - & - & 5.7 & 4.1 & 1.39 \\
\hline 23 & $\ldots$ & 1.8 & 0.9 & 0.9 & 0.7 & 0.5 & 0.5 & 0.3 & 0.8 & 0.1 & - & 6.0 & 4.3 & 1.39 \\
\hline 24 & $\ldots$ & 1.8 & 0.9 & 0.9 & 0.7 & 0.7 & 0.5 & 0.5 & 0.3 & 0.8 & - & 6.6 & 5.0 & 1.32 \\
\hline 25 & $\ldots$ & 1.8 & 0.9 & 0.9 & 0.7 & 0.7 & 0.5 & 0.5 & 0.3 & 0.3 & - & 6.6 & 5.0 & 1.32 \\
\hline 26 & $\ldots$ & 1.8 & 0.9 & 0.9 & 0.9 & 0.7 & 0.5 & 0.5 & 0.3 & 0.3 & 0.1 & 6.9 & 5.2 & 1.32 \\
\hline
\end{tabular}

Tabela 5: peso de produtores e consumidores em função da idade da família (força produtiva individual em negrito).

Fonte: Chayanov (1986, p. 58).

Saint Hilaire no Alto Rio Grande, na comarca do Rio das Mortes. Essa região, que correspondia ao sul da província de Minas Gerais, tinha uma distribuição da posse de cativos semelhante à do Triângulo, conforme vimos na comparação entre os gráficos 16 e 17. Segundo o botânico francês, a presença de escravos não significava ausência do trabalho familiar, pois os fazendeiros

trabalham lado a lado com os escravos, passando a maior parte do tempo nas plantações e em contato com os animais. [...] Os filhos dos fazendeiros se dedicam todos ao trabalho. Um conduz as tropas de burros, outro cuida dos animais e um terceiro das plantações (1975 b, p. 55).

Daí a presença de uma posse pulverizada de escravos, isto é, grande número de proprietários de pequenos plantéis cativos: "os agricultores da região do Rio Grande [...] não têm sob sua responsabilidade um número excessivo de escravos" (p. 55). Como se vê, o trabalho escravo funcionava como uma extensão do trabalho familiar. 


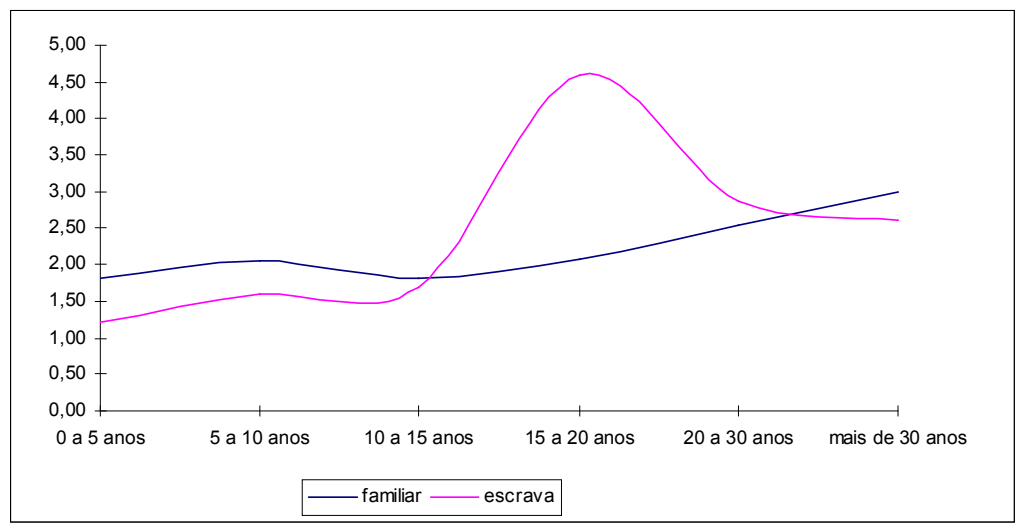

Gráfico 23: força de trabalho familiar e escrava, por grupo etário de famílias, no termo de Uberaba (1822-1861).

Fonte: APU, inventários post mortem (1822-1861).

Pela tabela 6, pode-se ver que os fogos sem escravos variaram de $16 \%$ a $24 \%$, ao longo do período em questão. Tais unidades usavam inequivocamente o trabalho familiar. Nos exemplos que se seguem, procuraremos comparálas às unidades que dispunham de alguns escravos, buscando diferenças e semelhanças qualitativas.

O velho Francisco Antônio Ribeiro dos Santos ${ }^{25}$ já morava sozinho com sua esposa Violante, quando ela morreu em 1827. Seus dois filhos mais novos, Manuel e José, já estavam casados e moravam longe dos pais, um em Tamanduá ${ }^{26}$ e outro em Santana do Rio das Velhas. Os mais velhos já haviam morrido, deixando dezoito netos. Não tinha escravos, e em seu sítio, com uma casa coberta de capim, paiol e monjolo, cuidava sozinho de suas 48 cabeças de gado, além de dispor de um machado, uma foice e uma enxada para suas lavouras.

Seu cotidiano era muito parecido com o de João Caetano Barbosa, ${ }^{27}$ que também vivia numa casa coberta de capim, com paiol, rego d'água e monjolo. Só que este, mais jovem, contava com a ajuda de sua mulher Justa

25 APU, Inventário de Violante Maria de Jesus (07/04/1827), maço N27 caixa 459.

26 Hoje Itapecerica.

27 APU, inventário de Justa Inocência da Conceição (24/04/1832), maço N11, caixa 470. 


\begin{tabular}{l|c|c|c}
\hline PARTICIPAÇÃO DE CADA GRUPO DE PROPRIETÁRIOS SOBRE O TOTAL \\
\hline & $1822-41$ & $1842-51$ & $1852-61$ \\
\hline SEM ESCRAVOS & $16 \%$ & $22 \%$ & $24 \%$ \\
1 A 5 ESCRAVOS & $55 \%$ & $40 \%$ & $49 \%$ \\
6 A 10 ESCRAVOS & $16 \%$ & $25 \%$ & $22 \%$ \\
11 A 20 ESCRAVOS & $6 \%$ & $9 \%$ & $2 \%$ \\
MAIS DE 20 ESCRAVOS. & $7 \%$ & $4 \%$ & $2 \%$ \\
\hline
\end{tabular}

Tabela 6: distribuição da posse de escravos de 1822 a 1861, no termo de Uberaba. Fonte: APU, inventários post mortem (1822-1861).

e das filhas Maria e Luísa, já moças, e com o trabalho dos escravos José Crioulo, José da Nação e Benedita, mãe da pequena Eva, de 10 anos. Esses três homens dispunham de duas foices, três machados, duas enxadas e um carro, puxado por duas parelhas de bois carreiros, para seu trabalho diário. João não possuía gado de corte ou de leite, mas tinha uma engenhoca e um alambique onde fabricava cachaça, que provavelmente vendia no arraial de Dores do Campo Formoso.

Como essas duas famílias, dezenas de outras dependiam do trabalho próprio para sobreviver, no Triângulo Mineiro nos primórdios de sua ocupação, e eram elas, predominantemente, que compunham a paisagem rural de então. A diferença entre o sítio de João e o sítio de Antônio é que, naquele, seu proprietário, sem escravos e sem filhos próximos, tinha que despender um esforço muito maior para sobreviver no dia-a-dia. Já Antônio, contando com a sua própria força de trabalho e mais a de dois moços escravos, obtinha o necessário para seu sustento com muito menos penosidade. Mas o que ambos buscavam, no entanto, era o que, só um século mais tarde, um economista russo conseguiria formular de uma maneira surpreendentemente simples: reproduzir suas existências e de suas famílias da melhor forma, e com o menor esforço possível. 


\section{A sociedade escravista do Triângulo Mineiro}

O Triângulo Mineiro teve sua ocupação pioneira iniciada nos primeiros anos do século XIX, por migrantes vindos da região central da capitania depois província — de Minas Gerais. Nesse período, surgiu uma sociedade que, ao mesmo tempo em que era semelhante à sociedade inclusa, colonial ou imperial, contava com algumas peculiaridades.

Como de resto no Brasil de então, a sociedade triangulina, desde muito cedo, exibiu os traços de uma ordem social fundamentada no tradicionalismo, na valorização da fidalguia e no desprezo pelos "defeitos mecânicos", e na escravidão como um valor profundamente arraigado em todas as consciências. Valores típicos das sociedades de ordens do Antigo Regime, eram eles que informavam aqueles homens e mulheres que criaram as primeiras fazendas e sítios nas matas e cerrados do Extremo Oeste Mineiro.

Nessa economia pioneira, a produção dependia principalmente de uma utilização extensiva e predatória dos solos, madeiras e pastagens naturais. O nível de desenvolvimento das forças produtivas era muito baixo e, por isso, mesmo os maiores potentados rurais acumulavam sua riqueza sob formas não-capitalistas, como escravos e terras. Além de conferir prestígio e distinção social numa sociedade de ordens, possuir homens e fazendas era a única forma de expandir a escala da produção num universo técnico tão limitado.

Apesar da forte diferenciação social, a divisão social do trabalho era pouco pronunciada, inclusive entre pequenas e grandes unidades produtivas, voltandose todas elas para a mesma gama de atividades, diferenciando-se uma da outra apenas na escala da produção.

O financiamento das atividades produtivas era feito pelos detentores das maiores fortunas fundiárias e escravistas, que mantinham os demais produtores numa rede de endividamento pelo capital usurário. Os grandes fazendeiros, por sua vez, contraíam dívidas com os capitalistas mercantis do Rio de Janeiro e com instituições como a Santa Casa de Misericórdia.

O mercado local era fortemente limitado pela hegemonia de relações de trabalho não capitalistas, pela produção de autoconsumo e pela pouca especialização entre os produtores, o que se refletia, por exemplo, na baixa liquidez. Esses traços (concentração de riquezas, capital usurário, mercados imperfeitos, pequena divisão social do trabalho) não eram característicos apenas 
da sociedade do Triângulo oitocentista, mas de outras regiões como o Rio de Janeiro e a área aurífero-metalúrgica de Minas, e de sociedades européias do Antigo Regime.

A despeito do grande número de pequenos proprietários, a propriedade fundiária não era essencial para garantir estabilidade no acesso à terra. A possibilidade de negociar e herdar sítios desvinculados da terra mostrava a estabilidade de um grande número de posseiros que viviam em fazendas alheias, com a permissão de seus proprietários.

Nessa sociedade, possuir escravos não era privilégio apenas dos grandes senhores. Havia uma pulverização da posse mancípia, e por isso o mais comum era encontrar proprietários de um a cinco escravos. Esses escravos, porém, não substituíam nem descaracterizavam o trabalho familiar, mas o estendiam, não havendo nessas pequenas unidades uma divisão do trabalho muito clara entre escravos e seus senhores. Tais unidades, por terem sido fundamentadas no trabalho familiar, funcionavam segundo a dinâmica do equilíbrio trabalho/ consumo, diferente da lógica de mercado do sistema capitalista.

Até agora, não abordamos ainda um curioso segmento da população do Triângulo Mineiro oitocentista: os moradores exclusivos dos arraiais, aqueles que, nos inventários, aparecem como tendo a posse de glebas urbanas, mas não eram proprietários fundiários rurais. Esse grupo, um dos mais pobres da sociedade de então, será o assunto do próximo capítulo. 


\section{6 | Os primeiros tempos do viver urbano}

\section{Os arraiais sertanejos}

A fundação dos arraiais do Extremo Oeste Mineiro resultou, em todos os casos, de iniciativas das oligarquias rurais, pela formação de patrimônios religiosos. Um fazendeiro — ou um grupo de fazendeiros vizinhos — doava um trato de terra ao patrimônio de um santo. Sobre ele, esses vizinhos, organizados numa irmandade religiosa, erigiam uma capela, e tratavam de conseguir sobre ela a bênção do vigário da freguesia. A benção da capela, como percebeu Murilo Marx (1991), significava o reconhecimento da existência do povoado pelas autoridades eclesiastico-estatais.

Um povoado, transformado pela ereção da capela em arraial, era o elemento cristalizador da identidade social e territorial do que Antônio Cândido (2001) chamou de bairro rural. Identidade que tinha o seu conteúdo manifesto na devoção a um santo, cuja imagem se abrigava na capela. Essa identidade era reforçada pelos encontros que ali ocorriam, aos domingos e dias santos. Neles, as irmandades promoviam missas, festas, procissões e organizavam novenas, das quais participava toda a comunidade de vizinhos. Ali também se realizavam os batizados, casamentos e funerais. Nos batizados, estabelecia-se o parentesco ritual ou compadrio; nos casamentos, o parentesco consanguíneo. Com esses rituais, o grupo de vizinhança ia criando uma consciência de si próprio, reforçando a identidade do bairro, o que Cândido chamou de sentimento de localidade:

Esta é a estrutura fundamental da sociabilidade caipira, consistindo no agrupamento de algumas ou muitas famílias, mais ou menos vinculadas pelo sentimento de localidade, pela convivência, pelas práticas de auxílio mútuo e pelas atividades lúdico-religiosas (2001, p. 81).

Muller (apud MARcílio, 2000) conceituou o bairro rural de uma forma muito próxima da de Cândido: 
Designa todo e qualquer conjunto de casas suficientemente próximas para que se estabeleçam contatos sociais entre seus moradores. Trata-se de uma célula de comunidade social, onde existem certos tipos de parentesco ou vizinhança reforçados freqüentemente pela existência de uma venda, capela, escola, cujo raio de ação marca os próprio limites do bairro (MARCílIo, 2000, p. 133).

O arraial cumpria, assim, uma dupla finalidade: era o elo entre a comunidade e o Estado, por meio das instituições eclesiais, e ao mesmo tempo o núcleo no qual ela reforçava seus laços e reproduzia sua identidade. A fundação de um arraial constituía a expressão da transição de um grupo disperso de sitiantes, ainda vivendo os primeiros e difíceis momentos da ocupação, geralmente isolados uns dos outros, para um grupo com laços de parentesco, cooperação e reciprocidade cada vez mais intensos. Cândido chamou o primeiro grupo de bairro centrifugo, e o segundo de bairro centrípeto:

Há, de fato, bairros de unidade frouxa, que poderíamos denominar centrífugos, propiciando um mínimo de interação; outros, ao contrário, de vida social e cultural mais rica, favorecendo a convergência dos vizinhos em atividades comuns, num ritmo que permite chamá-los centrípetos (2001, p. 81-82).

O sociólogo paulista não abordou explicitamente a importância da fundação das capelas como elemento de diferenciação entre um e outro tipo, embora deixe subentendido que o arraial, que ele chamou de núcleo territorial do bairro, ocupava uma posição social e espacialmente cêntrica nele. Chamou a atenção para o fato de que, no conceito de bairro rural, são essenciais não só a existência de grupos rurais de vizinhança, mas também uma base territorial, com ele identificada. No nosso entendimento, era na capela — e no patrimônio ao seu redor — que os grupos rurais tinham a expressão espacial de sua identidade. Era o núcleo atrator que mantinha a coesão das famílias espalhadas pela sua base territorial.

Saint Hilaire deixou a sua impressão — típica de um homem da Ilustração - sobre a importância do arraial enquanto o lugar das interações sociais no bairro rural. Referindo-se à região próxima à Serra da Canastra, observou:

Os agricultores passam a vida nas fazendas e só vão à vila nos dias em que a missa é obrigatória. A obrigação de se reunirem e comunicarem uns com 
os outros, bem como o cumprimento das obrigações religiosas, impede-os, talvez mais do que qualquer outra coisa, de reverterem a um estado de quase selvageria (1975 b, p 76).

A ereção da capela e a fundação do arraial, portanto, apesar de elementos definidores da identidade territorial de uma fração da sociedade - o bairro rural - , eram iniciativas que partiam sempre de uma elite terratenente. Um fazendeiro ou um grupo deles doava um trato de terra ao santo e à futura capela, e esta era erguida com o consórcio dos proprietários vizinhos devotos. No Sertão da Farinha Podre, por exemplo, Tristão de Castro doou, em 1812,

[...] uma posse de terras com matas e campos na paragem entre o Sítio das Toldas, estrada de São Paulo e Sítio do Lajeado que compreenderá [...] uma légua de terras em quadro [...] por este papel fazemos doação ao senhor Santo Antônio e a São Sebastião para patrimônio de Sua Igreja e ao procurador que houver dos referidos santos, ao qual cedemos e traspassamos todo o domínio que até então tínhamos (PonTES, 1978, p. 79).

No local, foi erguida, em 1816, a capela de Santo Antônio e São Sebastião, embrião do arraial de Uberaba.

Algum tempo depois, ao norte do Rio das Velhas, o major Antônio Resende Costa demarcou para si duas fazendas, a do Serrote e a da Pedra Preta. Entre ambas, assenhorou-se de um terreno de sobras que foi doado, mais tarde, ao patrimônio do Senhor Bom Jesus, local onde, em 1840, foi erguida a capela de Bom Jesus da Cana Verde, a partir da qual se desenvolveu o arraial do Brejo Alegre $^{1}$ (FERrEIRA, 1958).

Mais ou menos na mesma época, em 1842, os fazendeiros donos das terras situadas entre os rios Uberabinha (antigo Uberaba Legítima) e das Velhas nomearam Felisberto Alves Carrejo e Francisco Alves Pereira procuradores para requererem, junto à prelazia, a licença para erguer uma capela. Concedida a licença, os fazendeiros se consorciaram na compra de uma gleba de terras na margem direita do rio Uberabinha, vendida por uma prima do procurador Carrejo, e oferecida em patrimônio a Nossa Senhora do Carmo e São Sebastião.

1 Hoje Araguari. 
Iniciaram em 1846 a construção da capela dedicada aos santos, que logo se transformou no núcleo do arraial de São Pedro do Uberabinha (TeIXeIRA, 1970).

$\mathrm{Na}$ verdade, todas as capelas e respectivos arraiais no Extremo Oeste Mineiro surgiram dessa forma. Nos primeiros cinqüenta anos do século XIX, no Triângulo Mineiro, foram erguidas quase todas as capelas que originaram os arraiais da região, num verdadeiro boom, que refletia a intensificação do povoamento e a conseqüente formação de bairros rurais.

Graças às minuciosas descrições deixadas pelos viajantes do período joanino, pudemos reconstituir as primeiras fases do nascimento de um arraial na região do Alto Paranaíba, no século XIX. Em 1818, ao sair de Patrocínio e seguindo pela Picada de Goiás, Pohl (1976) deparou-se com o lugarejo de Pouso Alegre do Carabadela, ${ }^{2}$ ainda sem capela e contando só com seis casinhas. No ano seguinte, no mesmo lugar, Saint Hilaire presenciou a construção da capela, que os moradores queriam que fosse abençoada pelo vigário de Araxá:

Achava-se ali um padre que seus habitantes tinham mandado vir de Paracatu, o que fizera acorrer ao lugar um grande número de fazendeiros. Na manhã seguinte, foi celebrada a missa na capela ainda inacabada. A cobertura de telhas já fora colocada, e folhas de palmeira substituíam as paredes. Outras, espalhadas pelo chão, faziam as vezes de assoalho. Pareceu-me ter recuado ao tempo em que o cristianismo tinha lançado os seus primeiros alicerces na América (1975 b, p. 139).

Ainda segundo o naturalista, o lugarejo teve sua capela curada em 1824, ganhando o título de arraial. Contava então com 40 casas. Pode-se entrever aqui o esforço de um grupo de vizinhança em conseguir uma capela com um padre, e o fato de que sua simples presença transformara o lugar em ponto de convergência da população local.

Contudo, as hierarquias sociais também se reproduziam nos bairros rurais. Nas regiões de fronteira do Brasil no século XIX, apesar de, muitas vezes, os fazendeiros não se distinguirem da massa de camponeses na forma de moradia, vestimenta ou hábitos, como tantas vezes observaram os cronistas, constituíam obviamente uma classe social distinta da dos pequenos proprietários, agregados e escravos. Estes, por sua vez, eram dependentes do poder patriarcal

2 Hoje Coromandel. 
dos potentados locais, dos donos das terras nas quais se estabeleciam, ou de seus senhores, no caso dos cativos. O poder dessa elite sertaneja advinha da massa de dependentes sob seu controle, fossem eles escravos ou agregados estabelecidos em suas terras. A estes, favoreciam de forma paternalista, mas deles também eram cobradas manifestações de lealdade.

Essas relações de poder, fundamentadas num patriarcalismo autoritário, foram percebidas pelos cronistas do início do século XIX. Saint Hilaire, em 1819, nas proximidades do rio Paraibuna, já na província de Minas Gerais, observou:

Às vezes, [os fazendeiros] permitem a um protegido, um compadre, fixar-se à margem da estrada, e não exigem nenhuma retribuição. Se, no entanto, o agregado não presta ao proprietário todas as homenagens que este exige, corre o risco de ser expulso, e proprietários houve que mandaram atear fogo à casa de seus agregados (2000, p. 43).

O arraial e a capela, além de elementos cristalizadores da identidade de um grupo de vizinhança, funcionavam também como o elo entre ele e a sociedade inclusa. Era o lugar onde a comunidade obtinha artigos importados, não produzidos pela economia local, e vendiam seus excedentes. Ali também, por meio dos registros paroquiais, as pessoas — livres e escravas — passavam a ter existência legal. Quando, depois de algum tempo, o arraial se transformava em vila, com casa de câmara e cadeia, ali passavam a ser resolvidas as pendências judiciais e se decidiam sobre as obras públicas. Murilo Marx sintetizou bem o papel que, nesse sentido, exerciam os arraiais e vilas:

Não era somente o acesso garantido então à desejada assistência religiosa que se obtinha, mas também o reconhecimento da comunidade de fato e de direito perante a Igreja oficial, portanto perante o próprio Estado. Não era apenas o acesso ao batismo mais próximo, ao casamento mais fácil, ao amparo aos enfermos, aos sacramentos na morte, mas também a garantia do registro de nascimento, de matrimônio, de óbito, registro oficial, com todas as implicações jurídicas e sociais. Não era somente o acesso ao rito litúrgico que propiciasse no cotidiano, nos faustos e nos infaustos, o conforto espiritual; era também o usufruto da formalidade civil com todo o direito e segurança que pudessem propiciar (1991, p. 18-19). 
O papel de núcleo aglutinador do arraial era importante tanto para a oligarquia fundiária, quanto para os pequenos proprietários, agregados e escravos. Ao mesmo tempo em que o povoado era o lugar onde se produzia a identidade do grupo rural de vizinhança, era também o lugar onde se amenizavam as tensões de classe, ao se reforçarem os laços de paternalismo e dependência. Isto ocorria, por exemplo, pelo apadrinhamento, pelo entrelaçamento de parentelas pelo casamento, pelos rituais fúnebres, pela participação comum em missas, novenas e festas, pela escolha de um festeiro entre fazendeiros mais ricos. Dessa forma, o arraial ocupava um papel importante como lugar da reprodução das relações de classe no meio rural brasileiro.

\section{Viver num arraial sertanejo}

$\mathrm{O}$ arraial cumpria outro importante papel no meio rural tradicional do Brasil: era também uma váluula de escape para as tensões sociais, como já havia percebido Murilo Marx (1991). No patrimônio ao redor da capela, o capelão - e posteriormente o vigário - cedia lotes de terra à população mais pobre, formada por agricultores sem terra imigrantes ou dos arredores. O sistema de posse era o aforamento, celebrado pelo contrato de enfiteuse, pelo qual o foreiro se comprometia a pagar à capela ou à fábrica da matriz uma quantia anual fixa. $\mathrm{Na}$ data de terras cedida, o posseante erigia sua moradia e, conforme o caso, seu pequeno negócio.

O arraial passava a constituir então uma espécie de reserva de força de trabalho para os fazendeiros, principalmente para estes obterem os jornaleiros trabalhadores contratados temporariamente para tarefas que exigiam grandes turmas de trabalho, como derrubada de matas, escavação de valos — ou os camaradas, que conduziam as comitivas de gado. Saint Hilaire descreveu os jornaleiros, que viviam de forma sedentária no arraial goiano de Corumbá: “a maioria de seus habitantes ganha a vida hoje trabalhando para os agricultores da redondeza, sendo em geral pagos com os produtos da terra" (1975 a, p. 33).

Muitos foreiros também abriam pequenos ofícios no arraial, como ferreiros, alfaiates, fiandeiras, tecedeiras, pequenos estabelecimentos de comércio. A prostituição também era uma atividade que precocemente se desenvolvia nos arraiais. 
Assim, Eschwege (1996), ao passar por Patrocínio em 1816, então um arraial com 30 casinhas, almoçara numa "taverna de aguardente". Pohl, estando em Bambuí em 1818, descreveu assim o lugar:

Um miserável lugarejo de 80 casebres e uma deplorável igrejinha, onde nem sequer encontramos milho para os nossos animais [...]. para hospedar-me, consegui um quarto numa cabana arruinada. $\mathrm{O}$ rancho destinado aos viajantes havia caído. Entre os habitantes, negros em sua maioria e que não gozam de boa fama quanto aos costumes, encontrei, com espanto, um alemão [...] [que] vivia pobremente fazendo comércio a retalho neste lastimável lugar (1976, p. 93-94).

O médico austríaco passou, alguns dias depois, por São Pedro de Alcântara, ${ }^{3}$ onde seus homens se arranjaram com algumas prostitutas, e depois por Patrocínio. Neste arraial, observou que seus habitantes eram todos negros livres. Saint Hilaire, no ano seguinte, passou por Araxá, fazendo o seguinte comentário: "só permanecem na cidade, nos dias de semana, os artesãos — alguns dos quais bastante habilidosos - , as pessoas sem profissão, alguns comerciantes e as prostitutas" (1975 b, p. 130). A 15 léguas dali, em Patrocínio, observou que "os únicos habitantes permanentes de Patrocínio são alguns artesãos, dois ou três modestos comerciantes, os vagabundos e as prostitutas" (1975 b, p. 137).

Nos inventários post mortem da freguesia de Uberaba, da primeira metade do século XIX, identificamos os moradores exclusivos dos arraiais pelo arrolamento de posses urbanas (chãos ou casas no arraial) e ausência de referências a posses ou propriedades rurais. Vimos, no capítulo anterior, que esses moradores correspondiam a $8 \%$ dos inventários post mortem, mas respondiam por apenas $2 \%$ do total da riqueza inventariada. Possuíam, em média, apenas dois escravos; seu patrimônio médio - calculado pelos montesmor - era de 455 libras, e $42 \%$ deles tinham patrimônio menor do que 200 libras. Eram, portanto, o segmento mais pobre da amostragem. Resta examinar, agora, esse grupo mais de perto.

Em nossa série, encontramos doze inventários de pessoas que residiam no arraial — depois vila — de Uberaba, entre 1822 e 1861. A tabela 1 mostra a distribuição da posse mancípia entre esses moradores. Aproximadamente um

$3 \quad$ Hoje Ibiá. 
terço deles não tinha escravos, e nenhum tinha mais do que quatro escravos. Esses dados não deixam dúvidas de que esse grupo não era formado por pessoas de posses.

O alfaiate Bernardino Luís Tavares ${ }^{4}$ era um típico morador do arraial de Uberaba, no ano de 1835. Atendia sua clientela à Rua Direita, ${ }^{5}$ próxima ao Largo da Matriz. ${ }^{6}$ Homem pobre, não tinha sequer um escravo para ajudá-lo no ofício: seu patrimônio, ao morrer, resumia-se praticamente à sua casa, seis porcos, uma junta de bois com um carro, e sua tralha de alfaiate. Também pobre era a fiandeira Maria Rosa, ${ }^{7}$ provavelmente ex-escrava, pois não tinha sobrenome. Seus bens consistiam de sua casa, sua roda de fiar e do jovem escravo Manoel, de 14 anos. Dona Ana Rosa Gonçalves, moradora à Rua Direita em 1841, também fiava e tecia, mas é possível que a maior parte de sua renda viesse do pequeno comércio de fumo, rapadura e sabão, que mantinha na outra casa que possuía, de frente àquela onde morava. Não sabemos do que vivia a viúva bambuiense Luciana Maria de Jesus, ${ }^{8}$ que morava em Uberaba em 1851. Não teve filhos, e por isso deixou seus únicos bens - a casa onde vivia e mais um terreno - aos escravos Cassiano, Pedro, Ana e Maria, depois de alforriá-los. Já o capitão Francisco de Paula Santos Bueno ${ }^{9}$ devia ter sido rico um dia, a julgar pelo posto da Guarda Nacional que ostentava. Sua bela casa em Uberaba - coberta de telhas, com quatro portas e quatro janelas, para cuja construção gastou 47 dúzias de troncos de aroeira — atestava que já havia vivido dias melhores. Contudo, ao morrer, em 1855, estava endividado com a Irmandade do Santíssimo Sacramento de Pitangui e com a Irmandade do Senhor Bom Jesus de Matosinhos. Seu patrimônio incluía, além de sua casa, apenas mais os escravos João, Estulano e Maria.

Esses exemplos bastam para mostrar, pelo menos no caso específico do Triângulo Mineiro oitocentista, o início daquilo que hoje chamamos população urbana, isto é, a população que vivia sedentariamente de forma gregária num aglomerado, desempenhando atividades de serviços. Esse é o mesmo perfil que

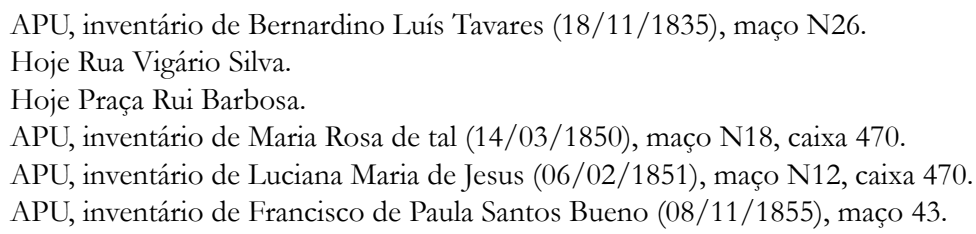


a leitura dos relatos dos viajantes do início do século XIX deixa vislumbrar: uma população pobre, formada por pessoas excluídas da posse da terra, mas muitas

\begin{tabular}{l|c|c}
\hline & NÚMEROS DE INVENTÁRIOS & PERCENTUAL \\
\hline SEM ESCRAVOS & 4 & $33 \%$ \\
\hline 1 ESCRAVO & 2 & $17 \%$ \\
\hline 2 ESCRAVOS & 1 & $8 \%$ \\
\hline 3 ESCRAVOS & 2 & $17 \%$ \\
\hline 4 ESCRAVOS & 2 & $17 \%$ \\
\hline
\end{tabular}

Tabela 1: distribuição da posse de escravos entre moradores exclusivos dos arraiais. Fonte: APU, inventários post mortem (1822-1861).

delas já especializadas em alguns ofícios e serviços, como fiandeiras e tecedeiras, comerciantes de molhados, alfaiates, carpinteiros, e muitos simples jornaleiros, isto é, homens que se empregavam temporariamente em empreitadas na roça.

A presença dessa população sedentária, com esse perfil tendendo à especialização em serviços, é o que nos permite chamar os arraiais de aglomerados proto-urbanos. Não que todo arraial fosse transformar-se um dia em cidade: houve os que desaparecem, e os que até hoje permanecem como arraiais. Mas todas as cidades da região em estudo surgiram de arraiais.

Se cabe uma classificação tipológica, os arraiais se aproximariam muito mais de burgos do que de aldeias, e nisso discordamos de Murilo Max (1991). A aldeia, na acepção ibérica, como vimos páginas atrás, era um habitat rural concentrado, formado por uma população residente camponesa cuja principal atividade era a agricultura praticada nas glebas vizinhas. Na colônia, o que mais se aproximava disso era o aldeamento. $\mathrm{O}$ arraial, de maneira distinta, contava com uma diminuta população sedentária, mas tinha sua principal forma de sustento nos ofícios e nos contratos esporádicos de trabalho remunerado, como os jornais.

É certo, contudo, que muitos — senão a maioria — tinham pequenos cultivos e criações, que praticavam nas datas aforadas ou nos limites do 
patrimônio. Pohl (1976) contou que os negros residentes no Patrocínio viviam do cultivo de subsistência de milho e feijão. Saint Hilaire presenciou os primeiros dias do arraial da Capelinha, no Vale do Jequitinhonha, e comentou sobre essa pequena agricultura:

Uma igreja começa a se construir, e coberta de telhas ergue-se sobre uma elevação [...] As casas são esparsas aqui e acolá. Só umas quatro ou cinco são cobertas de telhas; as outras o são de folhas de palmeira ou da gramínea [...]. Os habitantes da Capelinha, quase todos homens de cor, entregam-se à agricultura, e têm suas plantações em matas a alguma distância da povoação. Plantam feijão, arroz e milho (2000, p. 206).

Assim também ocorria em Uberaba, embora tenhamos encontrado apenas um inventário, dentre os moradores exclusivos do arraial, que possuísse bens rurais significativos. Francisco José Correa, ${ }^{10}$ morador naquela vila em 1849, tinha como escrava apenas a jovem Rita, de 18 anos. Devia então alugar pastos no patrimônio religioso ou nas chácaras de particulares — para criar suas 29 cabeças de gado.

\section{Os moradores temporários dos arraiais}

Todos os viajantes que estiveram pelo Triângulo Mineiro, no período joanino, espantaram-se ao encontrar a maioria das moradias dos arraiais vazia durante a semana. Aos domingos e dias santos, no entanto, os arraiais enchiamse, com um grande afluxo de fazendeiros e seus respectivos dependentes chegados da vizinhança. Eschwege (1996), visitando São Pedro de Alcântara em 1816, disse que, das doze casinhas do arraial, somente a do pároco era ocupada de forma permanente. As demais só recebiam gente nos domingos e feriados. Ao chegar a Patrocínio, num domingo, entrou no arraial acompanhado por um cortejo de 30 cavaleiros que vinham para a missa.

Dois anos depois, Pohl notou que, em Patrocínio, as casas dos fazendeiros vizinhos tinham melhor aspecto que as do arraial, pois "pertencem a pessoas

10 APU, inventário de Francisco José Correa (10/01/1849), maço N04. 
abastadas que preferem a vida no campo a morar em pequenas cidades e que, no máximo nos dias festivos, visitam a sede da paróquia" (1976, p. 96). Na mesma localidade, observou que, "sendo domingo, eu não poderia evitar as importunações dos habitantes e dos forasteiros que em tais dias vêm à cidade" (p. 97). Saint Hilaire notou algo semelhante em Araxá, onde "durante a semana a maioria das casas fica fechada. Seus donos só ali aparecem aos domingos, para assistirem missa, passando o resto do tempo em suas fazendas" (1975 b, p. 130). Em Patrocínio, "como sempre, as casas do arraial pertencem a fazendeiros que só aparecem ali aos domingos" (p. 137). Em Uberaba, o naturalista encontrou-se com o potentado Antônio Eustáquio num domingo, quando "sua casa encheu-se de abastados fazendeiros das redondezas” (1975 a, p. 151-152).

O deslocamento dominical para os arraiais era feito preferencialmente pelos homens. Nas grandes festas, contudo, tinha caráter familiar. As festas eram ocasiões em que as famílias, junto com escravos e agregados, permaneciam por mais tempo no arraial. Saint Hilaire flagrou um grupo familiar se deslocando para Pium-i, para a festa de Páscoa:

Encontrei várias carroças atreladas a três ou quatro pares de bois, que levavam as famílias ao arraial para a festa de Páscoa. No sertão, onde as fazendas ficam geralmente muito afastadas da paróquia, somente os homens vão ao povoado regularmente durante o ano, mas por ocasião das duas grandes festas, Natal e Páscoa, a família inteira empreende essa viagem. Mulheres e crianças são metidas dentro dos carros de bois, e eles passam alguns dias na casa que possuem no arraial para em seguida retornarem à fazenda (1975 b, p. 98).

Rugendas, na mesma época do naturalista, deixou a imagem de uma família de roceiros se deslocando para a igreja de um arraial (figura 1). Vêem-se as mulheres sendo conduzidas dentro do carro de bois, enquanto três homens se deslocam a pé, controlando a junta de bois. Por último, vem o chefe da família a cavalo.

$\mathrm{Na}$ região em estudo, esse padrão de ocupação periódica dos arraiais se manteve até as primeiras décadas do século XX, nas áreas de menor densidade demográfica. Em nosso trabalho de campo, recolhemos do Sr. Hélio Rodrigues da Cunha, morador no arraial de Santa Maria desde os anos 1910, uma descrição das festas religiosas de sua infância: 


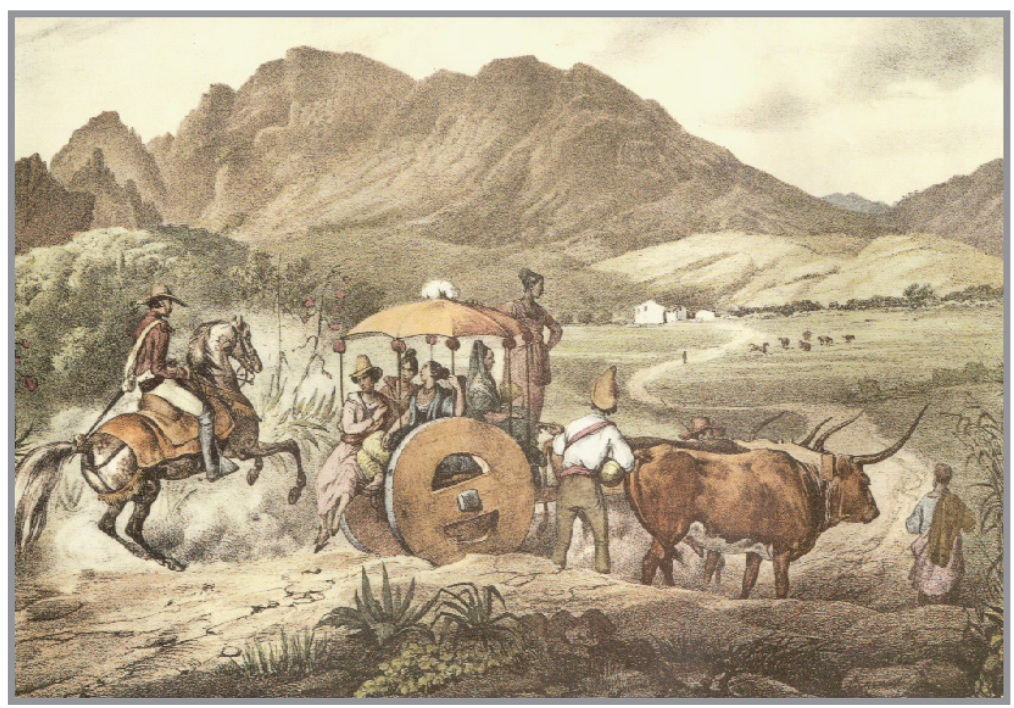

Figura 1: família de roceiros indo à igreja.

Fonte: Rugendas (1998).

A igreja era aqui em cima, onde tem o cruzeiro até hoje. Tinha uma praça grande, hoje estão fazendo até casa lá, uma praça muito grande. Armava muita barraquinha, ficava igual a Água Suja. Muita barraquinha e os carros. [...] O povo vinha tudo assim em carros de boi. Os carros ficavam na porta das barracas trazendo as coisas de comer e de dormir. Arrumavam as barracas bem arrumadinhas, e o Sr. Horácio, que tinha uma fazendinha ali encostado, alugava o pasto para as boiadas e dava de comer para o povo que vinha. Dormiam lá na barraca. [...] Vinham para a festa. Festava tudo, e na hora que queriam dormir, [tinham] a barraca bem arrumadinha, [...] tinha algumas que tinham separação. Tinham um quartinho separado dentro da barraca mesmo, por uma lona, e os carros de bois ficava ali na porta. [...] Eram umas três festas. Nossa Senhora do Rosário, sempre tinha festa. Nossa Senhora de Fátima $[. . .]^{11}$

Além dos deveres religiosos, os domingos serviam para a prática do

11 Hélio Rodrigues da Cunha, depoimento gravado (15/01/2002). 
comércio. As festas religiosas eram ocasiões privilegiadas para a mercancia. Dezenas de pessoas acorriam aos arraiais e geralmente, na praça da capela ou matriz, montavam-se as feiras (figura 2). O calendário religioso misturava-se ao comercial, e os fazendeiros e sitiantes tinham, assim, a ocasião para vender seu excedente e fazer negócios. Compravam dos comerciantes estabelecidos nas vendas os gêneros destinados às fazendas e sítios que não eram produzidos pela economia local, como tecidos finos, ferragens e principalmente o sal. Entre si, trocavam — geralmente por escambo — os gêneros de subsistência, como milho, feijão, algodão e tecidos, toucinho, açúcar e cachaça. Rugendas descreveu essa imbricação entre mercancia e religião nos arraiais:

A monotonia dessa existência só é interrompida, de quando em quando, pelas festividades religiosas; a importância delas aumenta ainda pelo fato de se tornarem uma oportunidade para a reunião de todos os colonos da região; eles surgem a fim de terminar seus negócios ou iniciar outros. Não há nada mais animado do que um domingo numa aldeia ou vila que possua uma imagem venerada de um santo. As famílias dos colonos chegam de todos os lados (Rugendas, 1998, p. 119).

Usando os inventários post mortem, ${ }^{12}$ procuramos distinguir aqueles que se deslocavam periodicamente aos arraiais pela dupla moradia, isto é, separando os documentos nos quais o inventariado declarava possuir casas de morada no arraial (ou vila) e, ao mesmo tempo, no meio rural. Encontramos 31 inventários — ou 19\% do total — que mostravam essa situação: 17 tinham residência na vila de Uberaba, oito no arraial de Dores do Campo Formoso, dois em São Pedro do Uberabinha, um em Carmo dos Morrinhos, um em São José do Tejuco, ${ }^{13}$ um em Sacramento e um no Desemboque. Tratava-se de um grupo muito heterogêneo quanto à posse de riqueza: havia desde pequenos sitiantes sem escravos até grandes fazendeiros. Esse perfil diversificado diferenciava esse grupo dos moradores exclusivos dos arraiais — isto é, os que declararam somente a moradia "urbana" — , que, como vimos no tópico anterior, era homogeneamente formado por famílias de posses modestas.

\footnotetext{
12 APU, inventários post mortem (1822-1861).

13 Hoje Ituiutaba.
} 


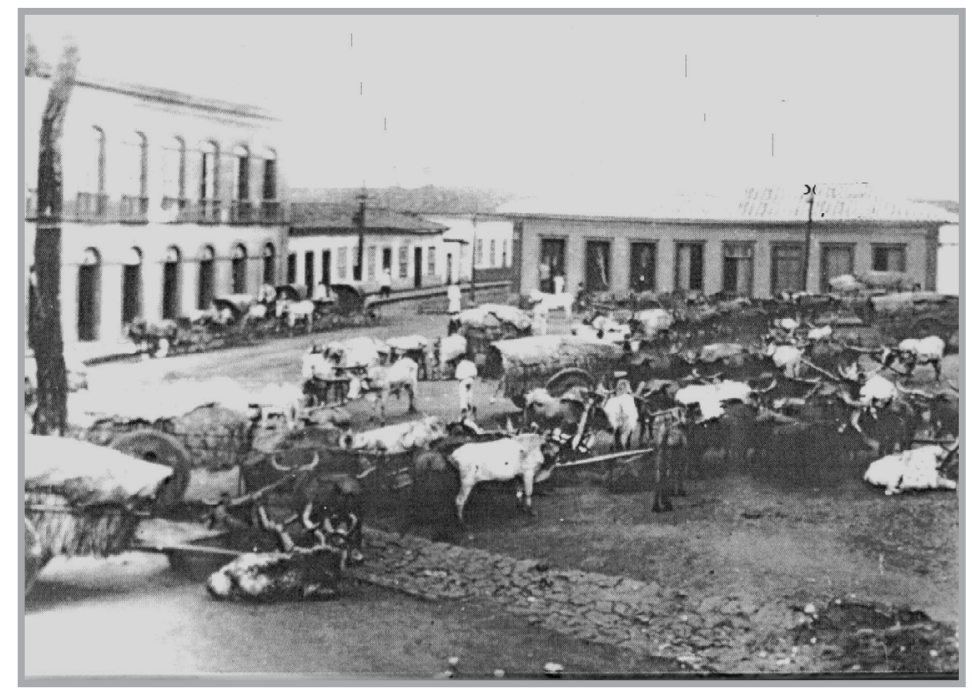

Figura 2: praça matriz de Uberaba com comércio realizado no adro da igreja no início do século XX.

Fonte: foto APU (1908).

Essa diferença entre os moradores intermitentes, comparados aos sedentários, pode ser visualizada no gráfico 1, onde os patrimônios totais foram distribuídos em ordem crescente, separando-se os possuidores de dupla residência dos que só tinham residência "urbana". Excluímos da amostra as fortunas do tenente Joaquim Silva e Oliveira, de Uberaba, e do capitão Antônio José de Araújo, de Dores do Campo Formoso, que, por terem cabedais muito grandes — respectivamente 161:986\$050 e 70:100\$370 —, tornariam difícil, caso incluídos, a visualização das pequenas e médias fortunas no conjunto. Verifica-se, dessa forma, que, dentre todos os grupos, desde os sitiantes pobres até os ricos landlords, havia os que possuíam residência no arraial. Isso mostra que a casa no povoado não era um privilégio só dos ricos, mas uma necessidade para todos.

Num levantamento usando como fontes apenas inventários post mortem, não podemos, evidentemente, visualizar todos os grupos sociais. Como já ressalvamos mais de uma vez, ficaram de fora os muito pobres, com nenhum bem a inventariar e deixar a herdeiros; e, no caso específico das residências 


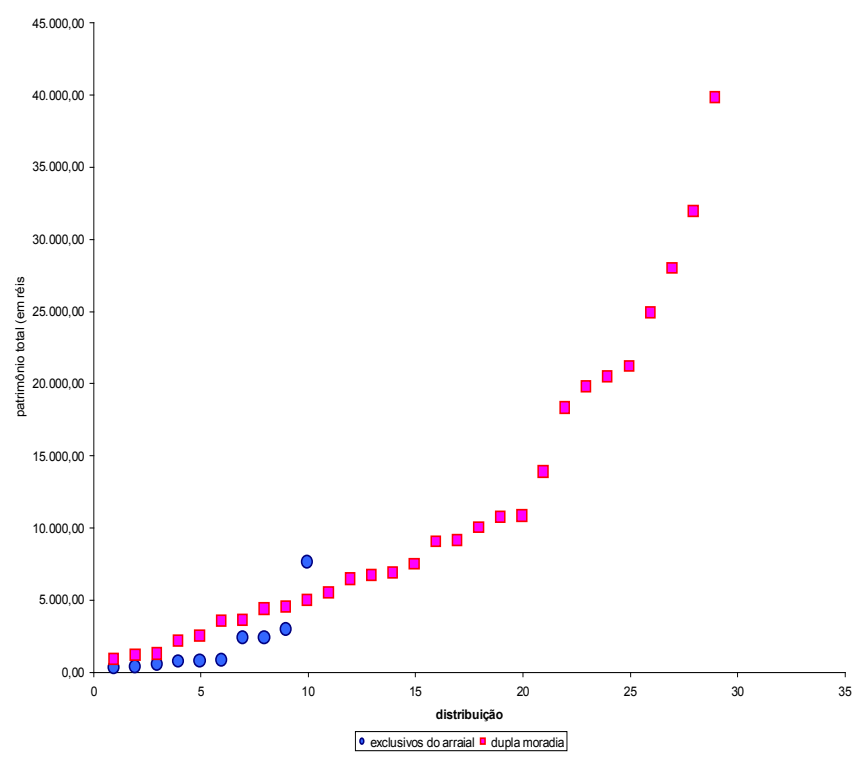

Gráfico 1: distribuição dos patrimônios dos moradores dos arraiais e dos moradores com residência rural e urbana (em réis).

Fonte: APU, inventários post mortem (1822-1861).

urbanas, os que se deslocavam para os povoados e permaneciam em casas de terceiros, não declarando por isso a posse de imóveis nos arraiais.

Fazia parte desse grupo, por certo, uma grande parcela dos agregados, que nos arraiais deviam permanecer em casas cedidas pelos senhores dos quais dependiam. Nos inventários dos fazendeiros mais poderosos, consta um número significativo de outras casas, além da de residência, que provavelmente eram usadas para esse fim. Por exemplo, o potentado Joaquim Silva e Oliveira, ${ }^{14}$ senhor de 44 escravos, possuía mais outras três casas.

Marcílio informa que esse atributo de núcleo religioso, societário e mercantil, presente nos arraiais mineiros, fazendo deles centros de afluxo periódico da população das redondezas, também estava presente nos arraiais e vilas paulistas do século XVIII:

14 APU, inventário de Joaquim Silva e Oliveira (06/06/1839), maço N7, caixa 461. 
Ecologicamente, a comunidade dispersa mantém um núcleo político-religioso em que abriga os imóveis públicos (cadeia, câmara, igreja, escola, mercado etc.), mas normalmente esse núcleo permanece sem população porque a maior parte dela vive dispersa em suas roças e fazendas, nos bairros rurais da redondeza. O núcleo recebe uma população flutuante nos dias de festas, de missas, de feiras (2000, p. 129).

Geógrafos vêm estudando esse papel de centro mercantil elementar exercido pelos pequenos povoados, entre populações rurais tradicionais. Corrêa (1997) usou os conceitos christallerianos de alcance espacial máximo e mínimo para entender a dinâmica dos mercados periódicos das pequenas povoações do interior do Brasil. O alcance espacial mínimo é o território onde se encontram consumidores em número e com demandas minimamente suficientes para justificar a existência de um estabelecimento comercial em tempo integral. O alcance espacial máximo é o território cujo mercado é realmente alcançado pelos estabelecimentos comerciais presentes naquele núcleo.

A pouca presença de comerciantes em tempo integral e a mercancia como uma atividade esporádica e periódica dos próprios produtores caracterizam a situação em que o alcance espacial mínimo é maior que o alcance espacial máximo (CORRÊA, 1997). Dizendo de outra forma, a população que se serve habitualmente dos estabelecimentos comerciais é pequena demais para fazer com que estes existam em grande número: não há escala de mercado suficiente que justifique seu funcionamento em tempo integral. A população que potencialmente poderia se utilizar das unidades de comércio fixas está dispersa num território muito grande, o que impede, pela distância, que as pessoas recorram habitualmente a elas.

No caso da região em estudo, nos primeiros anos do processo de povoamento, quando da visita dos cronistas europeus, não existiam grandes comerciantes fixos nos arraiais. O fato de grande parte da produção ainda se fazer para o autoconsumo, gerando um volume ainda pequeno de excedentes; as grandes distâncias entre as unidades rurais e os arraiais, aliadas às dificuldades de transporte; uma população ainda pequena; tudo isso ainda impedia, pelo menos até os anos 1820, que estabelecimentos comerciais fixos predominassem. Para tanto, seria necessário que o alcance 
espacial mínimo fosse igual ou menor que o alcance espacial máximo, isto é, que o território do mercado necessário fosse menor que o território do mercado real, o que só viria acontecer — e apenas na vila de Uberaba - a partir dos anos 1830.

Dessa forma, nos arraiais do Oeste de Minas surgidos nas duas primeiras décadas do século XIX, não havia escala de mercado que justificasse a sedentarização de muitos mercadores. Os únicos comerciantes fixos eram como se pode ler nos relatos dos viajantes joaninos — pequenos vendeiros e as negras de tabuleiro. O comércio predominava como uma atividade esporádica, em datas pré-estabelecidas.

Em sua revisão, Corrêa (1997) destacou que, numa situação de alcance espacial mínimo maior que o máximo, sempre existe uma classe de comerciantes exclusivos que se dispõe a deslocar de localidade em localidade, dentro de um calendário regional de feiras. Esses comerciantes periódicos — chamados em Minas Gerais de caixeiros (FurTADO, 1999) — deslocavam-se também até as fazendas e sítios para vender suas mercadorias. Corrêa, citando Bromley, Simansky e Good, destacou que os comerciantes, nos pequenos povoados, estão:

[...] associados a conceitos sócio-culturais do tempo, à duração da semana ou mês e à existência de dias dedicados ao descanso, cerimônias religiosas, reuniões públicas e festividades [...]. Muitas instituições econômicas e sociais já existiam quando as instituições regulares de comércio começaram a se desenvolver. Em muitas partes do mundo, as instituições iniciais de comércio tinham que estar coordenadas com o calendário definido pela rotina da produção, religião, administração, repouso e recreação (CORRÊA, 1997, p. 62).

Em conclusão, nessa primeira fase da formação dos núcleos territoriais dos grupos de vizinhança, as relações entre a sociedade sertaneja e o espaço dos arraiais eram marcadas por uma nítida diferenciação entre os habitantes sedentários e os temporários. Os primeiros eram a porção mais pobre dessa sociedade, geralmente trabalhadores sob contratos esporádicos e pequenos prestadores de serviços. Além deles, somente o capelão ou o vigário e os funcionários da igreja. Os últimos eram os fazendeiros e camponeses da vizinhança rural, que acorriam ao povoado nos domingos e dias santos, não 
só para as obrigações religiosas, mas também para mercadejar e selar alianças entre parentelas, por meio dos casamentos e batizados. Apesar de não viverem a maior parte do tempo no arraial, este era essencial a eles como respiradouro econômico, possibilitando trocas com a vizinhança e com a economia maior, e enquanto lugar do poder político e da reprodução ideológica.

\section{Espaço de vender, casar, batizar, rezar e morrer}

Murilo Marx afirma que, ao contrário do que comumente se pensa, os arraiais, vilas e cidades brasileiros muito pouco tiveram das "cidades informais" medievais, cujo traçado de ruas e praças se fazia sem uma lógica aparente. No que nos diz respeito — os arraiais sertanejos do século XIX —, vimos que era essencial, para a comunidade de vizinhança rural, o seu reconhecimento pelas autoridades eclesiásticas, o que significava na prática um reconhecimento oficial. Por isso, a irmandade responsável pela ereção da capela deveria seguir, na disposição do templo e no traçado do arraial, o que prescreviam as autoridades religiosas. Estas prescrições estavam codificadas nas Constituições Primeiras do Arcebispado da Babia, publicadas em 1719 e baseadas nos ritos definidos pelo Concílio de Trento (Murilo Marx, 1991).

As capelas deveriam ser erigidas em sítios altos, "em lugares decentes", desviado de lugares sujos, livres dos lados de outras edificações, afastadas das demais construções e cercadas por um adro espaçoso. Deveria se destacar na paisagem, como "candeia posta sobre o castiçal, que alumeia a todos" (Murilo MARx, 1991, p. 22-23). O autor percebeu também uma certa tendência à ortogonalidade em algumas vilas, embora diferente daquela imposta pelas Leyes das Índias espanhola. Não era tão rígida quanto aquela, tendendo a um padrão no qual se percebem avenidas principais, cortadas por vielas secundárias transversalmente.

Os arraiais criados no Sertão da Farinha Podre desde o final do século XVIII seguiram todas as especificações prescritas nas Constituições. Numa região de chapadas, os sítios que poderiam dar destaque à fachada dos templos, colocando-os em posição dominante na paisagem, seriam os topos das encostas que vertem para os córregos ou rios. Ao mesmo tempo, o sítio escolhido deveria estar no médio curso deles, de forma a se aproveitarem as aguadas. 
Foi exatamente essa a localização escolhida para a ereção de todas as capelas que deram origem às cidades no Triângulo Mineiro, sem nenhuma exceção. As figuras 3 e 4 mostram a frente das igrejas e capelas, com fachadas a montante da declividade, voltadas para um largo que envolve toda a edificação. Em todos os casos, a fachada do templo voltava-se para o vale fluvial, de forma que a torre e a frente da igreja eram as primeiras coisas que um viajante via ao se aproximar dos povoados (figura 5). Além disso, havia a necessidade prática da obtenção de água. A figura 6 mostra uma planta de São Pedro do Uberabinha do final do século XIX, onde se vêem em destaque os cursos d'água naturais e os regos d'água abertos pela população. Nota-se ali a necessidade de o sítio estar a médio curso dos córregos, para obtenção de queda para os regos d'água.

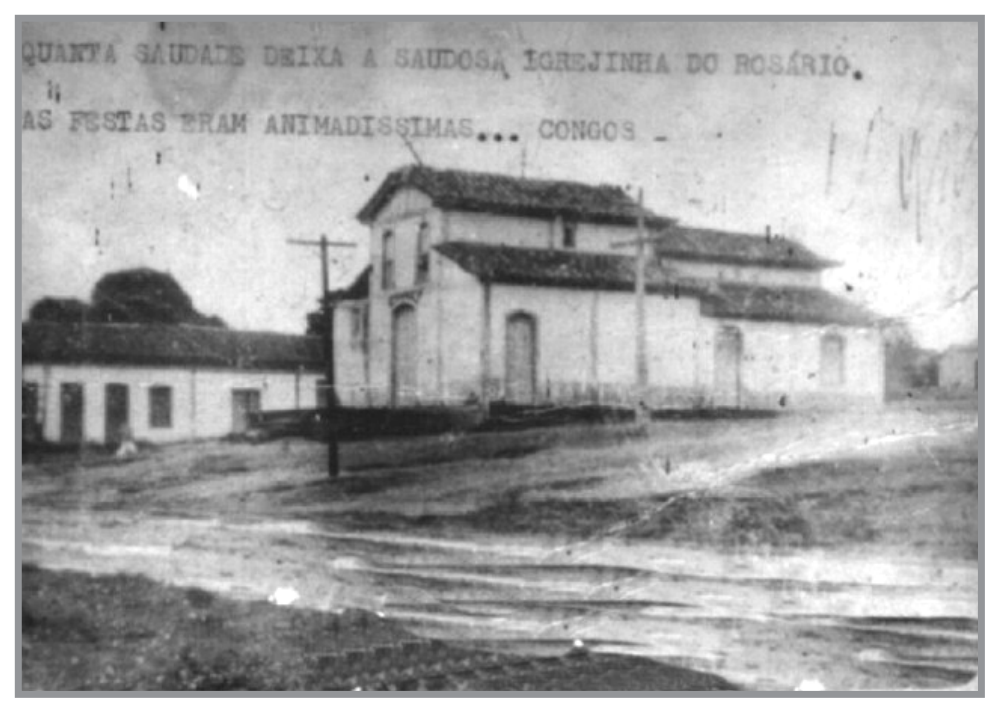

Figura 3: igreja Nossa Senhora do Rosário (Araguari 1909).

fonte: http://www.araguari.mg.gov.br

O entorno da igreja era formado pelo adro, que a cercava e isolava visualmente, aumentando o seu destaque. $\mathrm{O}$ adro sempre era mais extenso à frente do templo e menor atrás, de modo que este estava disposto de forma excêntrica dentro dele. Saint Hilaire assim descreveu Araxá: 


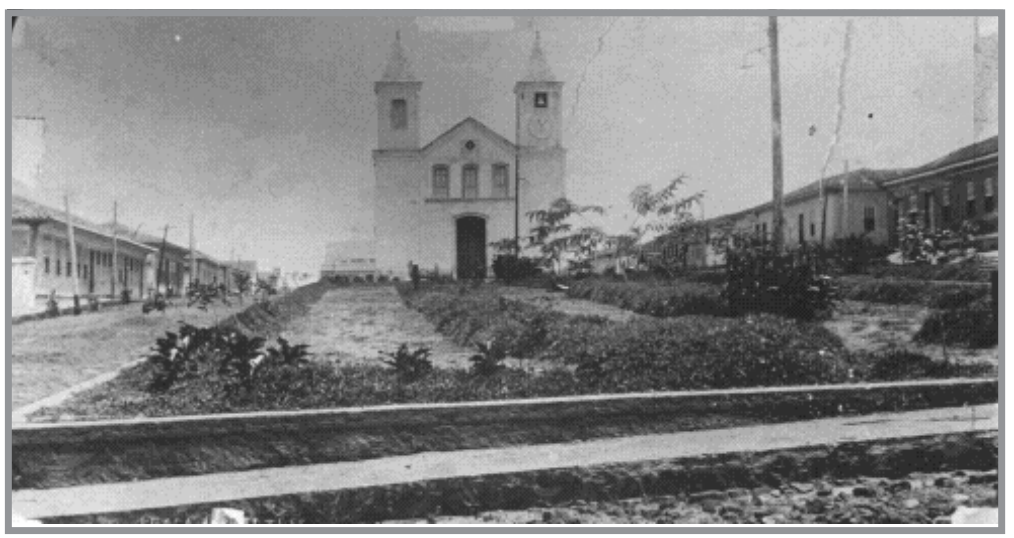

Figura 4: adro e matriz de Nossa Senhora do Carmo no início do século XX (Uberlândia). Fonte: site http://www.uberlandia.mg.gov.br

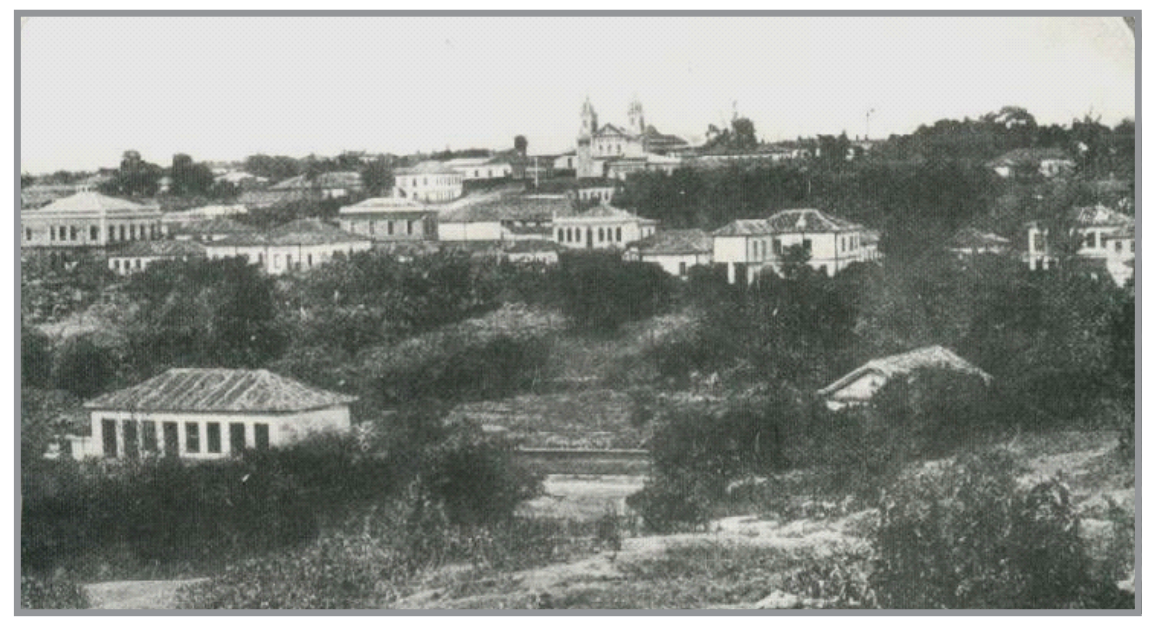

Figura 5: matriz de Santo Antônio vista do vale do Ribeirão da Laje - Uberaba 1890. Fonte: APU (1890). 
Há em Araxá uma praça muito ampla e de traçado regular, mas as casas que não dão para esta praça ficam espalhadas aqui e ali, um pouco desordenadamente. A igreja foi erguida na extremidade mais elevada da praça e, conforme o costume, fica a igual distância das duas fileiras de casas (1975 b, p. 129).

E em Patrocínio,

[...] havia ali cerca de quarenta casas muito pequenas, feitas de barro e madeiras, cobertas de telhas e sem rebocar. Essas casas, dispostas em duas fileiras, formam uma praça comprida, no centro da qual foi erguida uma pequena capela, igualmente feita de barro e madeira (p. 137).

De fato, todos os terreiros das capelas construídas nessa época tinham dois lados paralelos bem maiores do que os outros dois, formando um retângulo alongado. Provavelmente isso ocorria porque, em frente ou atrás da igreja, localizava-se o cemitério, reforçando ainda mais o caráter de "campo santo" do adro.

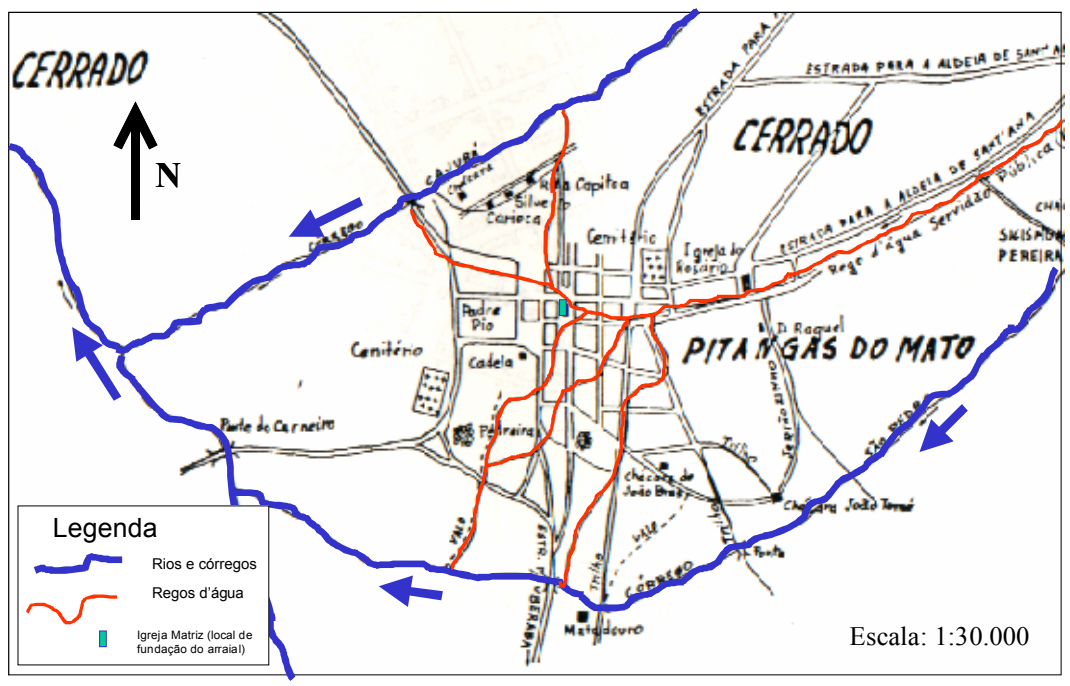

Figura 6: planta de São Pedro do Uberabinha (final do século XIX), com destaque para córregos e rego d'água.

Fonte: Lopes e cols. (1993). 
Essa disposição pode ser vista ainda hoje no cemitério do arraial do Desemboque, em frente à matriz de Nossa Senhora do Desterro (figura 7).

Os funerais ocorriam sempre nos arraiais, sendo esse mais um ritual da população sertaneja cujo lugar era a capela/arraial. Saint Hilaire relatou como eram levados os defuntos para serem sepultados nas capelas:

Como os brasileiros fazem muita questão de ser enterrados junto às igrejas [...] os homens levavam os mortos nos ombros desde a Serra da Canastra até o arraial. [...] os carregadores chegavam ao seu destino em estado quase idêntico ao do defunto que transportavam (1975 b, p. 106).

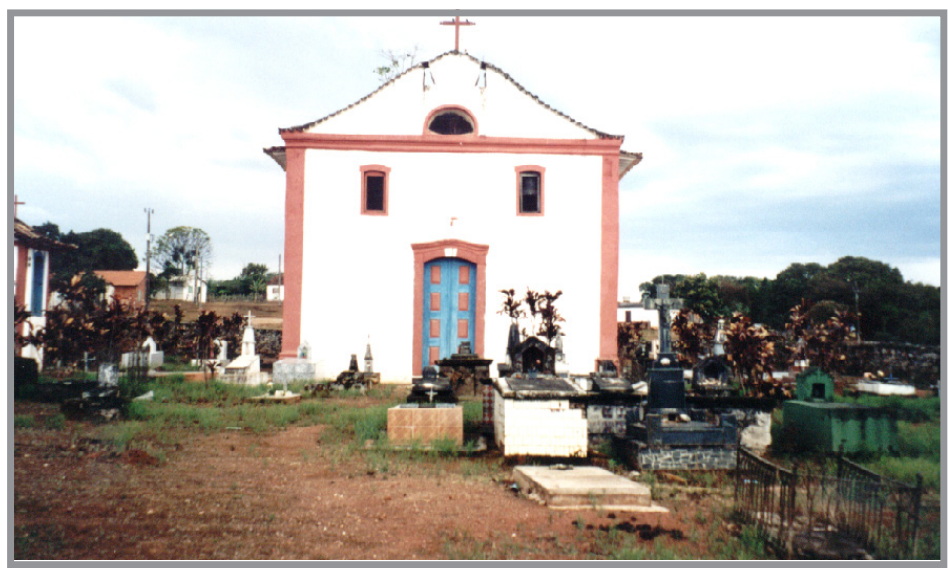

Figura 7: cemitério e matriz do Desemboque.

Fonte: foto Lourenço, L. A. B. (2002).

Como estas eram sociedades sem nenhum controle sobre a mortalidade ou a natalidade, funerais e batizados eram eventos extremamente comuns, e ambos tinham lugar na igreja ou em seu terreiro. Saint Hilaire, referindo-se à capela de São João Batista, na Serra da Canastra, relatou que "um padre vem de vez em quando celebrar a missa numa pequena capela localizada a cerca de duas léguas da fazenda de João Dias, e os moradores da região aproveitam a ocasião para se confessar e batizar os filhos" (1975 b, p. 106). Além disso, as procissões também eram realizadas no mesmo lugar, conforme pode ser visto na figura 8 , que mostra 
uma procissão em frente ao adro da matriz de Bom Jesus da Cana Verde, em Araguari, no início do século XX.

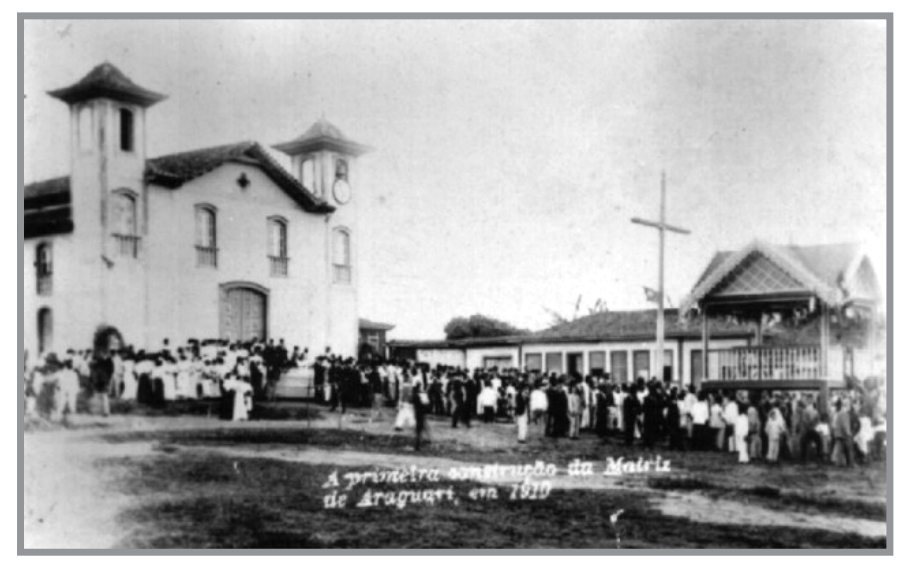

Figura 8: procissão em frente ao adro da Matriz de Bom Jesus da Cana Verde (Araguari) em 1909. Fonte: http://www.araguari.mg.gov.br.

\section{Espaço de morar}

À medida que o arraial crescia, o terreiro da capela transformava-se na praça da matrižz centro geométrico, econômico e político do povoado. Nos primeiros tempos dos arraiais e vilas oitocentistas, as casas de morada das famílias de maior distinção eram, quase sempre, erguidas no largo da matriz, voltadas para a igreja. Nessa sociedade de ordens, rigidamente hierarquizada, morar em frente ao templo conferia prestígio ao morador. Não só nesse caso, o lugar ocupado pelos grupos, em relação ao sagrado, era uma forma de reiterar as hierarquias sociais.

Os sinais de distinção começavam pelas roupas, quando das missas, casamentos e batizados. Mesmo se, no cotidiano, a vestimenta dos homens de prestígio pouco diferisse da dos roceiros, naquelas ocasiões os notáveis usavam seus melhores trajes, com seus galões, espadas, divisas e esporas de prata. Saint Hilaire descreveu um fazendeiro goiano chegando a Bonfim para uma festa religiosa: 
Segundo o costume adotado pelas pessoas ricas, eles vieram acompanhados por um moleque também a cavalo, o qual trazia ao pescoço um grande copo de prata preso a uma corrente do mesmo metal. As esporas dos homens eram de prata e o canhão de suas botas orlado com aros desse metal. Placas de prata enfeitavam as rédeas dos cavalos, e, finalmente, vê-se um facão com cabo de prata metido no cano de suas botas. Essa exibição de riqueza é comum e, na maioria das vezes, as pessoas que ostentam todo esse luxo, quando viajam a cavalo ou vão fazer visitas, não têm em casa um único móvel (1975 a, p. 102).

Em Araxá, o naturalista observou, numa missa:

Ali, como em toda parte, as mulheres se agrupam na nave, ao passo que os homens ficam mais perto do altar. Tal é a força dos costumes que, apesar do calor reinante, tanto os homens quanto as mulheres estavam metidos em grossos capotes de lã (1975 b, p. 132).

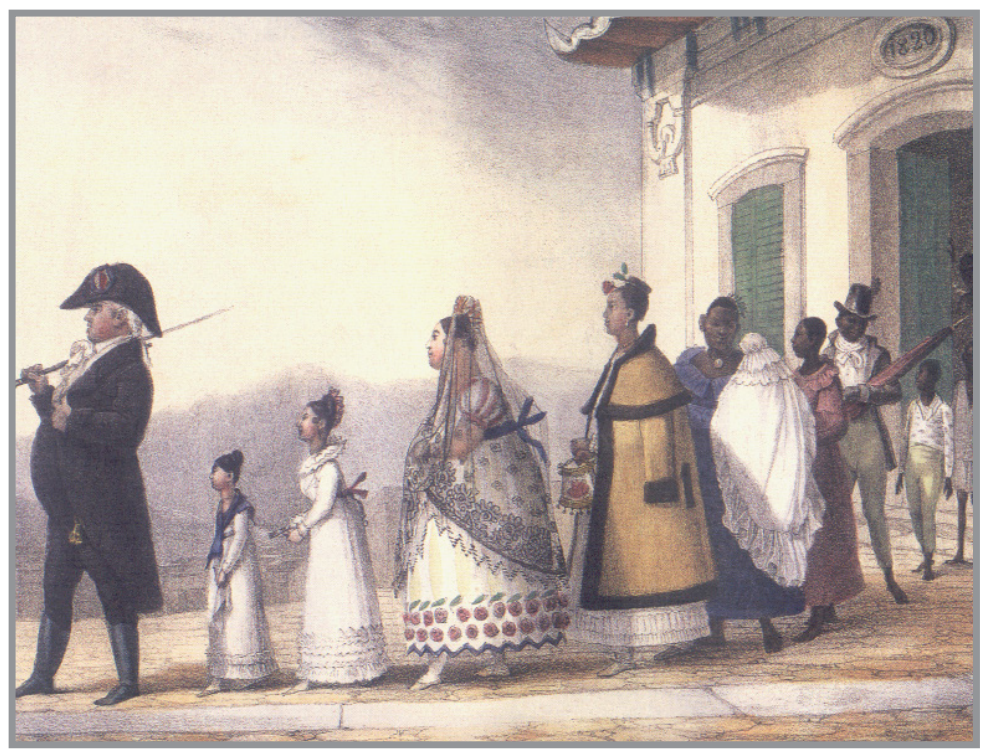

Figura 9: funcionário do governo a passeio com a família.

Fonte: Debret (2001). 
A análise dos inventários post mortem dos potentados do Triângulo Mineiro da primeira metade do século XIX confirma a impressão dos viajantes. Do inventário do fazendeiro Joaquim Silva e Oliveira, ${ }^{15}$ por exemplo, constam valiosos adereços para ostentação, como fivelas de prata, um selim com seus arreios lavrados em prata e um par de esporas de prata. Mas o mobiliário de sua morada, na Fazenda Ponte Alta, consistia apenas de cinco catres, duas mesas, uma caixa e dois bancos.

O fazer-se acompanhar pela escravaria também era uma forma de exibir poder pessoal. O espetáculo de um senhor indo à missa, ricamente trajado, acompanhado por um séquito de familiares e escravos, foi retratado num desenho de Debret, que pode ser visto na figura 9. Tal vontade de distinção, na feliz expressão de Marco Antônio Silveira (1997), era parte essencial do ethos da sociedade colonial: "para a elite, os símbolos de distinção representavam papel fundamental no reconhecimento de seu prestígio; ademais, uma vez que os padrões fossem quebrados, ficava ameaçada a ordem aparente que legitimava seu poder e privilégio" (Silveira, 1997, p. 174-175).

Tal vontade de distinção também tinha sua expressão no espaço protourbano dos arraiais, e ali, do mesmo modo, a afirmação do prestígio fazia-se em relação ao sagrado. Os cronistas do século XIX informam que o largo da igreja matriz era o lugar preferido pelas elites mineiras para erguer suas residências. No arraial de Ouro Branco, Saint Hilaire havia reparado que "essa povoação termina por uma praça em cuja extremidade foi construída a igreja [...]. De um lado da praça estão as casa mais consideráveis da povoação, do outro não há construções” (2000, p. 67). Em Salgado,

oitenta casas, afastadas umas das outras compõem-na na sua totalidade. As mais bonitas, que pertencem a lavradores abastados dos arredores, são construídas em torno de uma pequena praça mais ou menos quadrangular. [...] Num dos lados da praça, construiu-se a igreja, que é bonita e grande (p. 346).

Pohl, em Santa Luzia, notara que "só a casa do vigário tem mais de um pavimento e possui janelas de mica. Fica numa praça grande, mas desigual, cujo centro é tomado pela igreja paroquial de Santa Luzia” (1976, p. 112).

15 APU, inventário de Joaquim Silva e Oliveira (06/03/1839), maço N7, caixa 461. 
Usando como fontes os inventários post mortem e os historiadores regionais, verificamos que assim também faziam as elites nos arraiais do Triângulo Mineiro, na primeira metade do século XIX. Em Uberaba, o sargento-mor Antônio Eustáquio Silva e Oliveira, fundador daquele arraial, senhor de 21 escravos e da Fazenda Rio das Pedras, edificou sua morada urbana na praça da matriz de Santo Antônio, do lado oposto à fachada da igreja ${ }^{16}$ (SAMPAIO, 2001). Seu irmão Joaquim Silva e Oliveira, ${ }^{17}$ senhor de 44 escravos e das fazendas Ponte Alta e Bebedouro, residia em uma "morada de casas nesta Vila, na frente da matriz nova, com seu quintal cercado de pedras com arvoredos de espinhos, café e jabuticabas". O capitão Antônio José de Araújo, ${ }^{18}$ dono de 21 escravos e da Fazenda São Francisco, na freguesia de Dores do Campo Formoso, residia "no arraial das Dores, no largo da matriz". O padre e potentado Hermógenes Casimiro de Araújo, ${ }^{19}$ senhor de 16 escravos, deputado provincial e dono da fazenda Nova Suécia, possuía casa "no largo da matriz". Em São Pedro do Uberabinha, o coronel Severiano Rodrigues da Cunha, agente executivo do município, ergueu seu chalé no lado oposto ao da fachada da matriz (TeIXeIRA, 1970).

Se as elites residiam em torno do adro, onde também se instalava, com a elevação do arraial a vila, a casa de câmara e cadeia (Murilo MArx, 1991), a população mais pobre vivia nas ruas e becos que confluíam para ele. A partir do largo da matriz, irradiavam-se, quase sempre — mas não obrigatoriamente — em disposição ortogonal, as ruas principais. Estas eram cortadas por ruelas e becos transversais, mais estreitos que elas.

Usando as informações contidas nos inventários post mortem, cotejadas com a toponímia primitiva de Uberaba (SAMPAIO, 2001; TоTI, 1987), procuramos mapear o perfil dos moradores de algumas ruas desse arraial - depois vila —, na primeira metade do século XIX. Em 13 documentos, foi especificada a

16 APU, inventário de Antônio Eustáquio Silva e Oliveira (18/09/1839), maço N10. No inventário, a sua única casa na vila de Uberaba foi referida como estando à Rua do Cotovelo. Esse nome não consta do levantamento da primitiva toponímia das ruas de Uberaba, feita pelo coronel Borges Sampaio em 1880. É provável que se trate de um dos nomes pelos quais era conhecida a Rua do Comércio (hoje Rua Artur Machado), pois sua casa, ocupada pelo próprio Borges Sampaio alguns anos depois, situava-se à esquina dessa rua com a Praça da Matriz, próxima à casa de câmara.

17 APU, inventário de Joaquim Silva e Oliveira (06/03/1839), maço N7, caixa 461.

18 APU, inventário de Antônio José Araújo (20/03/1838), caixa 459.

19 Inventário de Hermógenes Casimiro de Araújo (09/11/1861), in Nabut (1986). 
localização da casa no arraial. Em quatro - todos inventários de fazendeiros ricos - as casas se localizavam, como vimos, no largo da matriz. Em um deles, o endereço foi descrito como "rua que vai para a casa do...", isto é, localizavase numa rua sem denominação. Nos outros oito documentos, todas as casas se localizavam na Rua Direita.

Esse surpreendente achado mostra que, até meados do século XIX, se as mais prestigiosas famílias de Uberaba viviam no largo da matriz, a maior parte da população pobre, remediada ou de posses medianas vivia numa única rua da vila. Essa rua, que hoje corresponde ao traçado das ruas Manoel Borges e Vigário Silva, atravessava o Largo da Matriz em seu lado norte, limitando o adro no lado oposto ao da fachada da igreja. Uma planta do centro de Uberaba de 1880, que localiza os lotes até então construídos (figura 10), mostra que, de fato, a Rua Direita era a mais densamente edificada: contam-se 51 casas, contra 19 no Largo da Matriz, por exemplo.

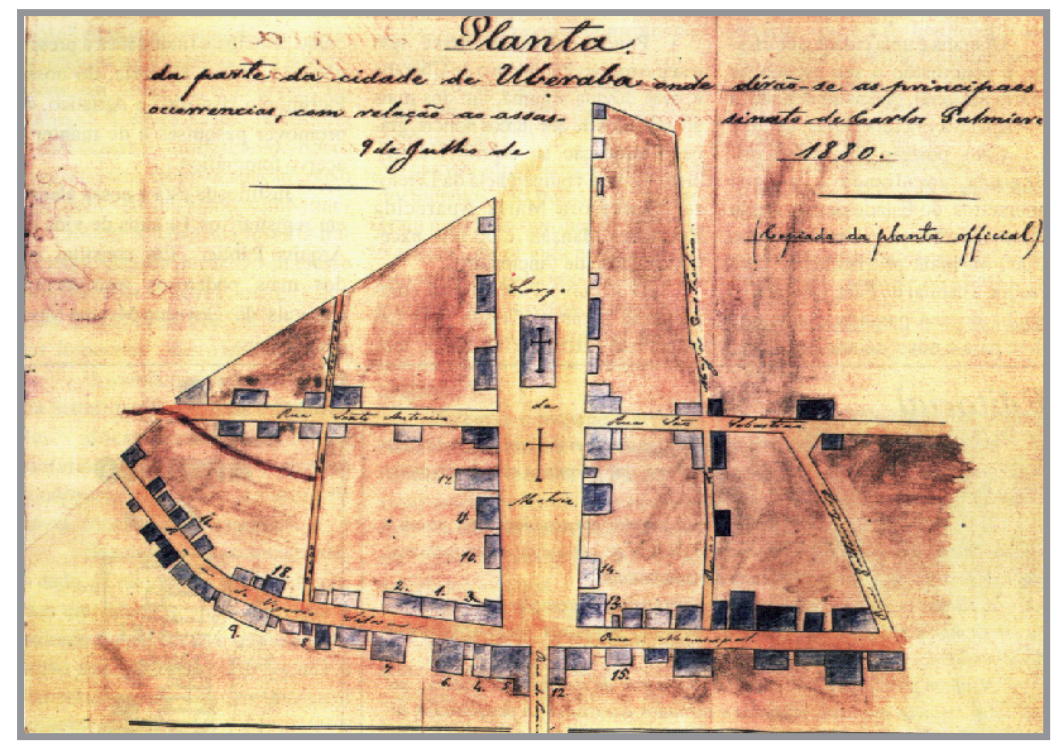

Figura 10: planta do centro de Uberaba em 1880. A Rua Direita aparece cruzando o largo da matriz perpendicularmente, na parte inferior da planta.

Fonte: APU (1880). 
O quadro 1 mostra o perfil do morador da Rua Direita, na primeira metade do século XIX. Vê-se que havia ali desde moradores pobres, com poucos ou nenhum escravo, e tendo como praticamente único patrimônio a casa no arraial, até médios proprietários de terra, donos de 13 escravos e possuindo casas relativamente valiosas, de até 800 mil-réis, ali edificadas.

Essa rua, chamada também de Rua Grande pela tradição popular (Тотা, 1987), era o eixo longitudinal do povoado. Isso fazia com que a área urbana da vila tivesse uma disposição alongada no sentido sudeste-noroeste, como pode ser deduzido pela descrição do coronel Borges Sampaio, de 1880: “a maior extensão da cidade é a que, tomando-se dos Olhos D’Água [...] até a Rua Vigário Silva [...] continua pela Vigário Silva, Largo da Matriz, ruas Municipal, Tiradentes e Mercês [...] até a porteira da chácara de Fidélis Reis. Nessa extensão [...] há 2.880 metros" (2001, p. 55).

A razão da importância dessa via, e de sua alta densidade de ocupação, aparece numa outra planta de Uberaba, de 1855 (figura 11). Verifica-se que a Rua Direita era o prolongamento, no espaço urbano, da Estrada Real, na direção

\begin{tabular}{|c|c|c|c|c|c|}
\hline DATA DO INVENTÁRIO & ESCRAVOS & $\begin{array}{l}\text { VALOR DAS } \\
\text { TERRAS } \\
\text { (EM RÉIS) }\end{array}$ & $\begin{array}{l}\text { PATRIMÔNIO dO } \\
\text { INVENTARIADO } \\
\text { (EM RÉIS) }\end{array}$ & $\begin{array}{l}\text { VALOR } \\
\text { DA CASA } \\
\text { (EM RÉIS) } \\
\end{array}$ & $\begin{array}{l}\text { NúMERO } \\
\text { DE CASAS }\end{array}$ \\
\hline $25 / 08 / 1837$ & 3 & - & 300,00 & 80,00 & 3 \\
\hline $01 / 07 / 1841$ & 0 & - & 368,00 & 300,00 & 1 \\
\hline 18/11/1835 & 0 & - & 535,51 & 300,00 & 1 \\
\hline $04 / 11 / 1841$ & 0 & - & 803,17 & 500,00 & 2 \\
\hline $10 / 01 / 1849$ & 1 & - & $2.331,00$ & 247,00 & 1 \\
\hline $17 / 11 / 1848$ & 4 & 140,00 & $4.357,00$ & 600,00 & 1 \\
\hline 04/02/1842 & 0 & 411,00 & $6.664,34$ & 16,00 & 1 \\
\hline $11 / 08 / 1845$ & 13 & 300,00 & $8.973,00$ & 800,00 & 1 \\
\hline
\end{tabular}

Quadro 1: perfil econômico do morador da Rua Direita, em Uberaba (1835-1845). Fonte: APU, inventários post mortem (1822-1861). 
sudeste-noroeste. Essa estrada, aberta pelo sargento-mor Antônio Eustáquio em 1827, passou a ligar São Paulo a Goiás e Cuiabá por um caminho mais curto que a antiga Estrada do Anhanguera, cuja saída aparece na planta como "estrada para Goiás", no rumo norte. A estrada antiga foi sendo pouco a pouco abandonada, da década de 1820 em diante, por causa da abertura da nova via e do porto da Ponte Alta, no Rio Grande, também uma iniciativa de Antônio Eustáquio. Na planta, vê-se a presença de ranchos de tropeiros na saída de São Paulo, na Rua da Prosiganga, que desembocava na Rua Direita mais adiante. A noroeste, nota-se que a Rua do Boi, de onde chegavam as boiadas trazidas de Goiás (TOTI, 1987), também convergia para a Rua Direita.

É possível, portanto, que um grande número de comerciantes, grandes e pequenos, se estabelecesse na Rua Direita para vender e comprar das tropas que por ali passassem. Como Ana Rosa Gonçalves, ${ }^{20}$ mulher pobre, sem escravos, bois ou imóveis rurais, mas que, em 1841, tinha "uma morada de casas na Rua Direita", e mais "uma morada de casas fronteando com as anteriores", onde provavelmente vendia molhados. Quando de sua morte, suas mercadorias consistiam de duas cargas de fumo, 90 rapaduras e 57 pães de sabão.

Desse modo, apesar de a busca do prestígio e a reiteração da hierarquia social serem forças que atuassem na configuração do espaço proto-urbano dos arraiais, também operavam outros fatores, como o acesso ao mercado e às vias de fluxo intenso, estes tipicamente "modernos".

$\mathrm{Na}$ periferia, mas ainda no interior da gleba patrimonial — ou do rossio público, no caso das vilas —-, os fazendeiros tinham o costume de aforar grandes datas para a construção de chácaras, pequenas unidades agropecuárias que funcionavam como casas de campo. Algumas delas, contudo, eram aforadas também por pessoas de posses mais modestas e, nesse caso, geralmente se constituíam no seu único imóvel rural. Murilo Marx explica que "nos setecentos, era freqüente a doação de uma segunda gleba às câmaras, além do rossio propriamente dito, com o fim exatamente de permitir algum rendimento às novas vilas, por meio do aforamento de pequenos sítios e chácaras" (1991, p.76).

Num levantamento feito em 1880, o coronel Borges Sampaio localizou todas as chácaras situadas em terras patrimoniais na cidade de Uberaba. Pela descrição que deixou, nota-se que as chácaras cercavam e delimitavam a

20 APU, inventário de Ana Rosa Gonçalves (04/11/1841). 


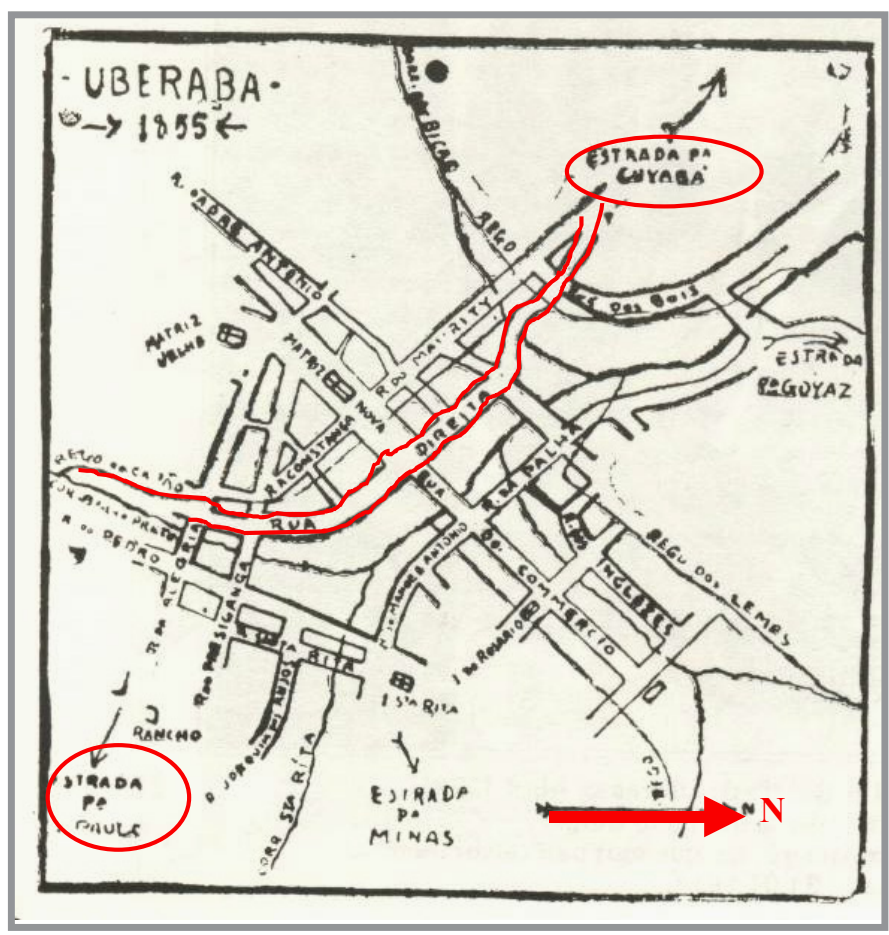

Figura 11: planta de Uberaba de 1855, com destaque para a Rua Direita e as saídas para Cuiabá e São Paulo.

Fonte: Toti (1987).

terra urbana, formando uma espécie de "transição" entre esta e o meio rural propriamente dito. Por exemplo, a chácara do Padre Zeferino situava-se "no fim da Rua do Comércio, em frente à Matriz" (2001, p. 53). A chácara do Frasquinho estava "à entrada da cidade, na estrada que vem do porto da Ponte Alta" (p. 54). A chácara dos Pinheiros "dá alinhamento, pelo lado direito, à Rua do Carmo; e pelo lado esquerdo à Rua da Ladeira” (p. 55). O historiador uberlandense Tito Teixeira (1970), com o auxílio da tradição oral e tendo vivido em época bem próxima à da fundação do arraial, relata que em São Pedro do Uberabinha, logo após a delimitação do patrimônio de Nossa Senhora do Carmo e São Sebastião, em 1858, foram concedidas 52 datas de terrenos patrimoniais, das quais seis eram chácaras ao longo da margem direita do córrego São Pedro. 
Em um trabalho anterior (LOURENÇO, 1996), fizemos uma reconstituição da planta de São Pedro do Uberabinha, no final do século XIX. Nela, percebese também a presença de chácaras cercando e delimitando toda a rede de arruamentos do arraial (figura 12).

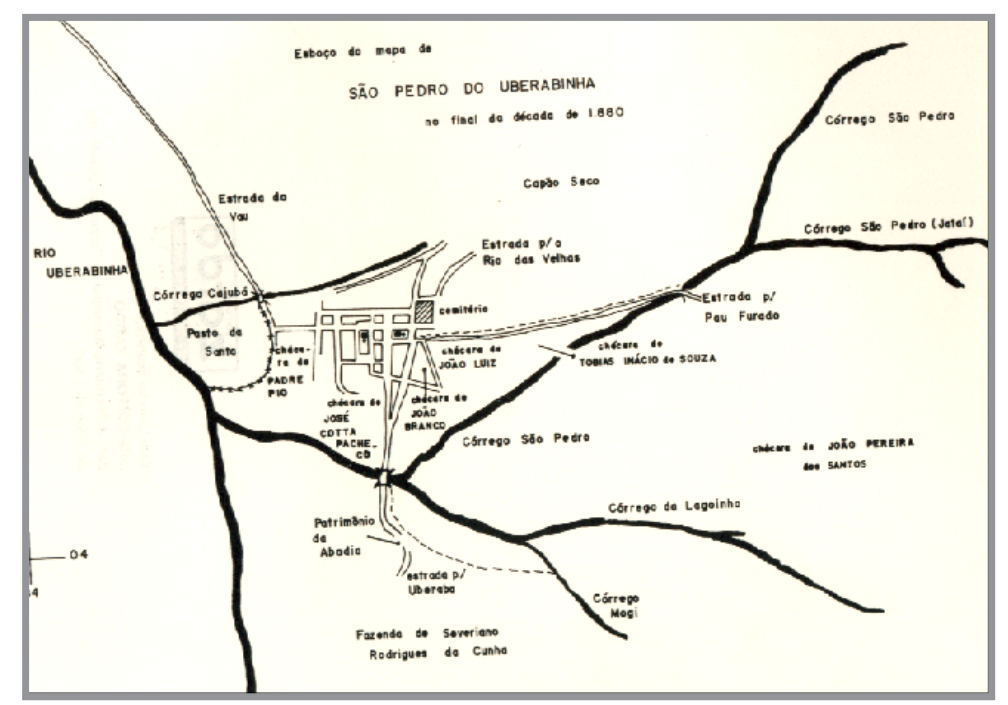

Figura 12: São Pedro do Uberabinha (1880): arruamento e chácaras. Fonte: Lourenço (1986).

Os inventários mostram que as chácaras reproduziam, em escala menor, o complexo agropastoril das fazendas, que já tivemos a oportunidade de discutir páginas atrás. José Antônio Ribeiro, ${ }^{21}$ por exemplo, homem de posses medianas, tinha como imóvel rural, em 1854, apenas uma chácara de 400 mil réis, em Dores do Campo Formoso. Nela mantinha os escravos João, Antonina e o pequeno Pedro, de dois anos. Junto com eles e seus filhos, tocava naquela chácara 47 alqueires de canavial, um engenho de cana e um alambique. Além disso, tinha ainda duas vacas solteiras e três novilhas. Sua chácara era muito mais modesta do que a do sargento-mor Antônio Eustáquio, ${ }^{22}$ situada às margens do Córrego

\footnotetext{
21 APU, inventário de José Antônio Ribeiro (11/09/1854), maço N14.

22 APU, inventário de Antônio Eustáquio Silva Oliveira (28/09/1839), maço N10.
} 
das Lages, nas cercanias da vila de Uberaba. Nela mantinha, ao morrer, "casas de morada cobertas de telha, paiol coberto de telhas, monjolo coberto de palha, curral todo murado de pedras com coxia", e ainda um engenho de cana.

Uma vez esboçado esse quadro, que dá uma idéia de como se organizava internamente o espaço - que chamamos proto-urbano — dos arraiais, resta saber como eles se relacionavam entre si e com a sociedade maior.

\section{A rede mercantil sanjoanense}

Como vimos no capítulo anterior, a produção historiográfica sobre o Brasil Colônia dos últimos anos, fundamentada no acesso a novas fontes primárias, vem caminhando para revelar uma realidade que difere da visão ortodoxa, até então vigente. Os historiadores dos anos 1960 e 1970 tendiam a ver uma sociedade colonial organizada sob uma lógica exclusivamente exógena, estruturada como um grande empreendimento agroexportador e sem uma dinâmica econômica própria. Vem-se demonstrando a importância do mercado e das redes mercantis internos à economia colonial, a ponto de, muitas vezes, ter havido crescimento do setor de abastecimento interno, mesmo quando o quadro mundial era recessivo.

É o que demonstrou Fragoso (1998), quando estudou a economia do sudeste brasileiro de 1789 a 1840, período marcado por uma fase de crescimento da economia mundial (de 1792 a 1815), e por uma fase recessiva, de 1815 a 1850. No período recessivo, o Brasil reduziu suas exportações mundiais de açúcar e algodão, mas, paradoxalmente, aumentou a produção de gêneros destinados ao abastecimento interno, e houve um aquecimento no comércio interprovincial:

Entre 1815 e 1822, as receitas do charque gaúcho que entra no porto carioca aumentam em 68,9\%. Já as saídas de reses, toucinho e carne salgada de Minas Gerais, pelo Registro do Presídio do Rio Preto, se ampliam em mais de 170\%, entre 1818 e 1828 (Fragoso, 1998, p. 20).

Isso de deve, segundo o autor, à existência de um importante mercado interno, capaz de se expandir mesmo em conjunturas internacionais desfavoráveis, e isto porque era capaz de realizar acumulações endógenas: 
A economia colonial é um pouco mais complexa que uma plantation escravista, submetida aos sabores das conjunturas internacionais. [...] Mais do que isso, a complexidade da economia colonial é verificada pela capacidade [...] de aumentar as receitas e suas produções de abastecimento, mesmo em épocas de quedas dos preços internacionais e de retração da agroexportação. Esse fenômeno nos indica, através de uma situação-limite, a possibilidade de realização de acumulações endógenas no espaço colonial. Ou melhor, nos fala sobre a existência, em uma economia colonial, de acumulações endógenas a partir do mercado interno, sendo isso factível mesmo em conjunturas internacionais adversas (p. 21).

Somente assim podemos explicar porque, no período referido pelo autor (1815 a 1840) como sendo de recessão internacional e queda no volume e nos preços das agroexportações brasileiras, houve um processo de colonização e expansão econômica no Triângulo Mineiro. Se em 1815 Uberaba sequer havia sido fundada, nos anos seguintes a 1816 os uberabenses montaram uma economia agropecuária, e vinte anos depois, em 1836, o arraial era elevado a vila.

A colonização do Triângulo Mineiro e a ascensão de Uberaba, apesar de notável, não foram fenômenos isolados em Minas Gerais. Esse foi o período em que se consolidou, na província, um sistema de produção para abastecimento interno, voltado principalmente para o Rio de Janeiro. Minas tornou-se um grande exportador de carne bovina, suína, açúcar e aguardente, panos e algodão. Com isso, alcançou a condição de maior província escravista do Império, e passou também a contar com a maior população provincial absoluta (LiBBY, 1988; FrAGOso, 1998).

Minas fazia parte de um sistema de produção para o mercado interno, que incluía várias outras províncias da região centro-sul do Império do Brasil. Tendo como grande mercado a população urbana da Corte, além da região de plantation da Baixada Fluminense e Vale do Paraíba, São Paulo também integrou esse sistema de produção de víveres para o mercado interno, além de contar com áreas de plantation da cana de açúcar no entorno de Campinas, Jundiaí e Itu. Também o Rio Grande do Sul, com a carne de charque, trazida pela rota dos tropeiros do Viamão a Sorocaba, e Santa Catarina, com a farinha de mandioca, integravam esse sistema (FraGoso, 1998).

Em Minas, como já comentado no capítulo 3, com a nova orientação econômica — decadência da mineração e ascensão das atividades agropastoris 
e das manufaturas domésticas - , houve um deslocamento geográfico dos centros econômicos. Não só Vila Rica, Sabará e Mariana, mas também Vila do Príncipe, Pitangui, Barbacena e São João Del Rei se tornariam cidades-pólo de regiões economicamente importantes.

Vila do Príncipe ${ }^{23}$ - e em certa medida também o Arraial do Tejuco ${ }^{24}$ — estavam ligadas a toda a região algodoeira do Norte Mineiro e Vale do Jequitinhonha (figura 13). Ali se desenvolveu uma próspera manufatura têxtil, produtora de panos de algodão para o mercado carioca, além de exportar também o algodão in natura (LiBBY, 1988). A maior parte do excedente dessa região era drenado para Barbacena, de onde era embarcado em tropas para o Rio de Janeiro.

Pitangui (figura 13) drenava a produção do Alto São Francisco e bacia do rio das Velhas, funcionando como centro intermediário para a produção agropecuária dessa região (VENÂNCIO, 2001). Também Barbacena, última vila antes de se empreender a descida serra abaixo até o Rio de Janeiro, pela Estrada Real, muito se beneficiou com a expansão e diversificação da economia mineira nos oitocentos (SAINT Hilaire, 2000).

Porém, talvez o núcleo mais próspero de toda a província, pelo menos no primeiro quartel do século XIX, tenha sido São João Del Rei. Como Barbacena, essa vila estava situada a jusante de uma vasta região produtora, que incluía todo o Extremo Oeste, Oeste e Sul Mineiro, e até mesmo parte da província de Goiás. Segundo Fragoso:

São João Del Rei [...] aparecia, na primeira metade do século XIX, não apenas como área produtora de alimentos, mas também como centro comercial regional, realizando feiras semanais e de ligação com o Rio de Janeiro, para onde partiam quatro tropas regulares por ano. Temos ainda que São João Del Rei, como Queluz, São José Del Rei e Barbacena, ao lado de outras atividades, se dedicavam à fabricação e panos grossos para o consumo de escravos (1988, p. 128).

As regiões de Minas mais ligadas ao mercado carioca — Sul, Oeste, Alto Paranaíba e Triângulo Mineiro — tinham São João como gargalo para as suas exportações. Esse papel de cidade primaz de uma imensa região produtora interior

\footnotetext{
23 Hoje Serro.

24 Hoje Diamantina.
} 
não escapou aos viajantes joaninos. Spix e Martius registraram, quando de sua visita àquela cidade:

Em vez da mineração do ouro, é agora o comércio do sertão que aumenta diariamente a riqueza dessa pequena cidade [...]. Quanto aqui é animado o comércio, logo se vê pelo fato de fazerem quatro tropas, cada uma de cinqüenta mulas cargueiras, contínuas viagens para lá e para cá da capital, anualmente, levando toicinho, queijos, algum tecido de algodão, chapéus de feltro, gado bovino, mulas, galinhas e barras de ouro para vender ali; pelo valor de seus produtos trazem de volta mercadorias européias, sobretudo portuguesas e inglesas, como chitas, panos, rendas, utensílios de ferro, vinho, cerveja Porter, licores etc. (1981, p. 195).

Por causa de sua condição geoeconômica, São João contava, no início do século XIX, com uma poderosa elite de comerciantes de grosso trato, atacadistas que compravam mercadorias do sertão — principalmente gado - para revender ao Rio de Janeiro, e que traziam da capital as mercadorias importadas — tecidos finos, bebidas, sal, escravos — , que eram por eles distribuídos aos núcleos do interior. Esses mercadores eram principalmente imigrantes portugueses, como assinalou Saint Hilaire (1974). O cronista também descreveu a atuação desses atacadistas:

Os comerciantes, muitos dos quais bem ricos, compram do Rio de Janeiro todos os objetos que podem ser consumidos no interior; os vendeiros da comarca do Rio das Mortes e das comarcas mais distantes têm certeza de encontrar numa mesma casa em São João quase todos os artigos que necessitam (1974, p. 111).

Um fator geográfico foi fundamental à posição alcançada por São João, no século XIX: o fato de a cidade estar na vertente ocidental da Serra da Mantiqueira, num relevo não tão acidentado quanto o das montanhas mais a leste. Esse relevo mais suave estende-se pela depressão do vale do Rio São Francisco até as serras da Canastra e da Mata da Corda. Isso favorecia a condução das boiadas e, principalmente, o transporte em carros de bois do sertão ocidental até São João. Estes, obviamente, não tinham como descer a acidentada vertente oriental da 
Serra da Mantiqueira, em direção ao Rio de Janeiro. O transbordo em São João era, então, obrigatório, onde a carga era reembarcada em tropas de burros, com destino à capital do Império.

Deste modo, Saint Hilaire observou que "os víveres que se consomem em São João vêm das fazendas vizinhas em carros de bois, que transitam pelas ruas até que toda a sua carga seja vendida. Como a comarca do Rio das Mortes é pouco montanhosa, é comum o uso de carros de bois" (1974, p. 112). Pohl (1976) viu o primeiro carro de bois em Minas Gerais apenas nas proximidades do Rio São Francisco.

Os carros de bois traziam do Oeste principalmente toucinho e algodão. Grande parte do algodão era descaroçado e fiado em São João, e embarcado para o Rio de Janeiro (SaINT Hilaire, 1974). Alguns carros de bois chegavam, contudo, até Barbacena, e dali era transbordado para as tropas. Como a condução de porcadas do Extremo Oeste era difícil, o toucinho era dali levado em carros até São João:

Ao atravessar os pastos encontrei uma série de carros puxados por três ou quatro juntas de bois, carregados de toucinho e conduzidos por homens brancos. Perguntei-lhe de onde vinham e fiquei sabendo que tinham partido de Araxá havia doze dias, e seu destino era São João Del Rei, onde deviam chegar ao fim de um mês (Saint Hilaire, 1975 b, p. 106).

Na verdade, em São João, começava uma região dominada por depressões e chapadas planas, que constituía uma verdadeira zona do carro de bois. Nos inventários post mortem do termo de Uberaba verifica-se que esse meio de transporte era onipresente: praticamente $100 \%$ dos fogos possuía pelo menos uma junta de bois carreiros, um carro e cangalhas. Ao mesmo tempo, eram raros os que possuíam jumentos, burros e bestas.

Também as boiadas eram conduzidas a São João, vindas de todo o Oeste. Normalmente, compradores sanjoanenses deslocavam-se até Araxá e compravam os animais, conduzindo-os em comitivas até aquela vila, e de lá ao Rio de Janeiro. Usavam preferencialmente o caminho do Rio Preto, que não passava por Barbacena (figura 13). O sistema que Eschwege (1996) descreveu funcionava da forma seguinte: os invernistas araxaenses compravam garrotes novos dos fazendeiros dos arredores e até do sul de Goiás, e revendiam-nos, com quatro anos de idade, aos sanjoanenses. 


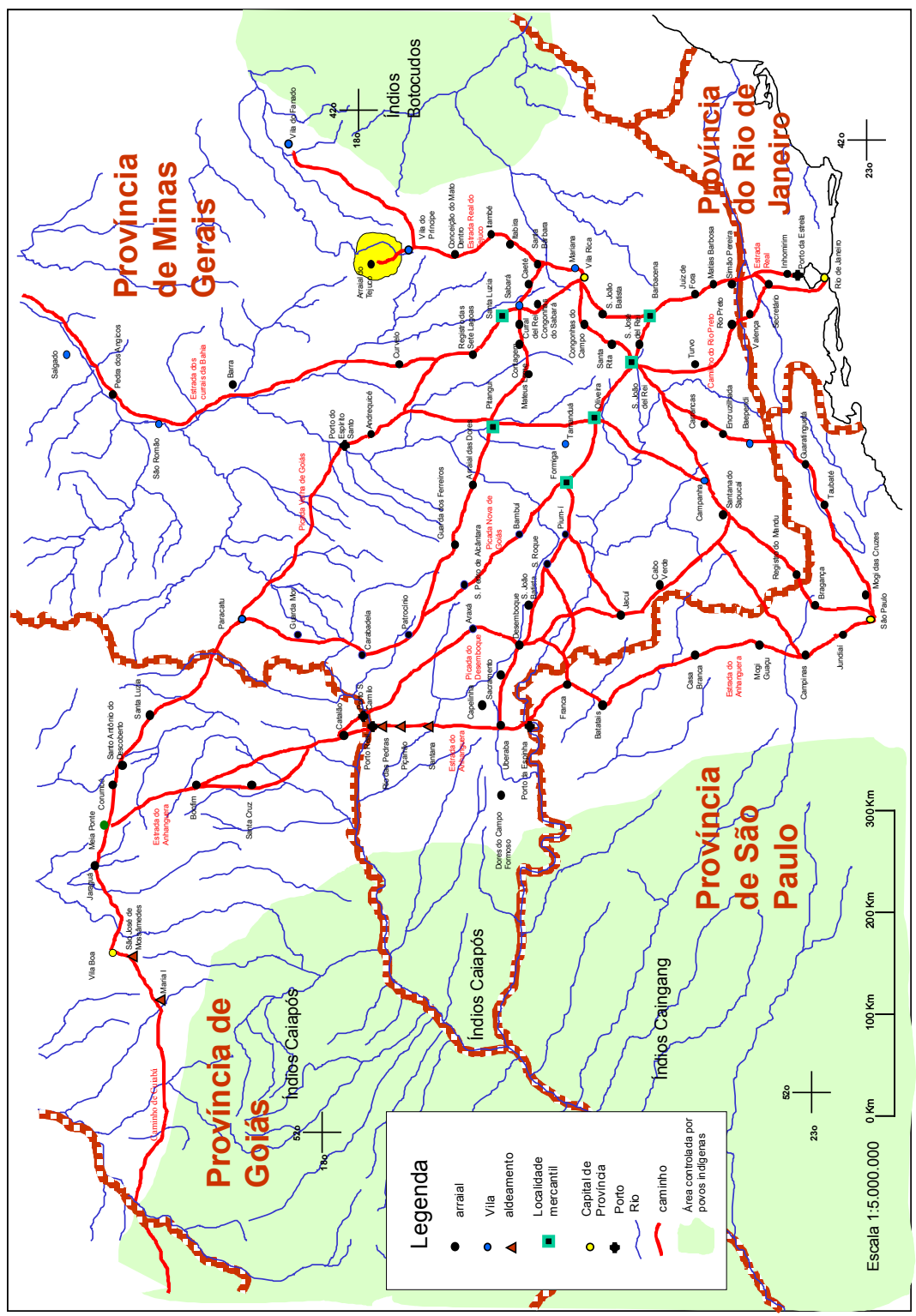

Figura 13: rede mercantil mineira (1815-1825). Fontes: Saint Hilaire (1975 a, 1975 b, 2000), Eschwege (1996), Cunha Matos (1981), Pohl (1976). 
Depois de São João, as mercadorias tomavam o destino serra abaixo, por Barbacena e pela Estrada Real (tropas), ou por Madre de Deus e Rio Preto (boiadas). Esses caminhos convergiam na altura de Inhomirim, chegando dali ao Porto da Estrela (figura 14), onde era feito o transbordo de cargas das tropas para pequenas embarcações, rumo ao Rio de Janeiro, ou, no caso das boiadas e porcadas, pelo Caminho de Terra diretamente para a cidade (SAint Hilaire, 2000).

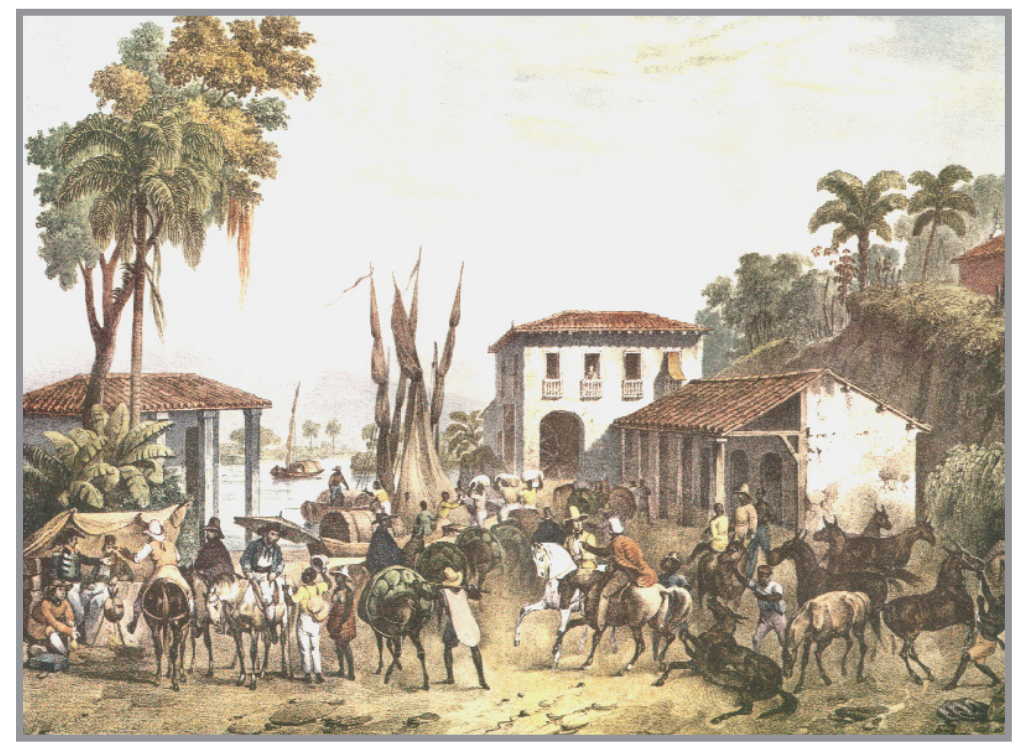

Figura 14: Porto da Estrela.

Fonte: Rugendas (1998).

A montante de São João, rumo ao sertão, já existiam, no início do século XIX, centros mercantis secundários, que também agregavam elites de mercadores. Era o caso de Formiga e Oliveira, que negociavam principalmente suínos e gado. Em Formiga, Eschwege observou:

Várias casas de comércio oferecem mercadorias européias e, segundo a informação dos comerciantes, o tráfego é intenso, tendo ele próprio, no período de seis meses, vendido mercadorias no valor de 16.000 cruzados [6:400\$000]. Segundo ele, teria podido vender mais ainda, caso dispusesse de 
estoque suficiente. A atividade comercial, aliás, baseia-se no crédito. Paga-se a compra com algodão, moeda utilizada pelos comerciantes para saldarem seus compromissos no Rio de Janeiro (1998, p. 79).

Mercadores formiguenses também compravam o gado de Araxá e de Uberaba, para revender ao Rio de Janeiro. Em Uberaba, Saint Hilaire observou: "os negociantes de Formiga, que não é demasiado distante do arraial, costumam vir até aqui para comprar bois e em seguida enviá-los à capital do Brasil" (1975 a, p. 151). Os formiguenses também compravam porcos dos arredores, engordando-os para depois descerem as porcadas ao Rio de Janeiro: “os negociantes de Formiga compram porcos nas fazendas das vizinhanças, onde são criados em grande quantidade [...]. A acreditar no que me disseram, um desses marchantes despachara, ele só, vinte mil porcos em 1818” (SAINT Hilaire, 1975 b, p. 74).

A razão da prosperidade de Formiga e Oliveira era principalmente a localização, ao longo da Estrada de Goiás e, portanto, na confluência dos caminhos dos sertões ocidentais. "São três os fatores do progresso regional: a cultura algodoeira, o progresso em geral e a Estrada de Goiás", escreveu Eschwege (1996, p. 79) a respeito de Formiga. Em Oliveira, Saint Hilaire comentou que:

sua existência se deve às vantagens de sua localização. De fato, várias estradas importantes passam pelo lugarejo: a que vai de Barbacena a Formiga, a que a região do Rio Grande a Pitangui, a que vai do Rio de Janeiro a são João Del Rei e Goiás, a Vila de Campanha, etc. (1975 b, p. 85).

Dessa forma, verifica-se que a relação com as estradas era fundamental à prosperidade de centros mercantis, pois esse era o único tipo de via que interligava a rede de arraiais. Todos os fluxos — mercadorias, migrantes, dinheiro, escravos, cartas — se faziam pelo único substrato material viário disponível: as picadas, caminhos ou estradas.

A simplicidade do sistema viário também facilita a nossa análise, e torna possível o cotejo com o modelo teórico criado por Johnson e Kelley: as redes dendríticas. Esses autores, segundo a sistematização feita por Corrêa (1997), criaram o modelo com base no estudo das redes de localidades centrais dos países subdesenvolvidos. Esse tipo de rede tomou impulso no período colonial, em regiões submetidas à conquista européia. 
Em resumo, trata-se da estrutura espacial do processo de povoamento e exploração econômica feito a partir do litoral. Constitui-se uma cidade primaz, litorânea, de localização excêntrica em face ao interior, que concentra a maior parte do comércio atacadista exportador e importador. A partir daí, em direção ao interior, a rede viária vai se ramificando, e os centros vão se tornando sucessivamente menores, até que, no extremo das ramificações, se encontram os centros que contam apenas com mercados periódicos.

Vimos que a colonização do interior do Brasil pelos geralistas, a partir da região central de Minas, deu-se segundo esse padrão. A conquista do Oeste Mineiro se fez mediante a expansão por ramificações, desde o leste, de um sistema de caminhos, em cujas pontas iam surgindo os arraiais. Se fôssemos buscar um modelo geométrico para o padrão dendrítico, diríamos que se trata de um fractal, isto é, ramificações que se repetem em sucessivas iterações (GLEICK, 1987).

As conexões entre os nós dessas ramificações eram os fluxos, não só de gado, algodão, porcos, sal e escravos, mas também migratórios, no sentido da fronteira, que ia expandindo a geometria dendrítica sempre mais para o interior. Conforme a observação de Corrêa, "à medida que se afasta da cidade primaz, os centros urbanos diminuem gradativamente de tamanho populacional, no valor das vendas do comércio atacadista e em termos de expressão política" (1997, p. 45).

Verificamos, em nosso estudo, a existência de núcleos intermediários entre o sertão, ocupado pelos arraiais e fazendas, e a cidade primaz litorânea: a esses núcleos chamamos boca de sertão. Assim, com eles, temos um terceiro nível de estratificação hierárquica da rede, entre o arraial e a cidade primaz, conforme se vê na figura 15.

A boca de sertão era o entreposto obrigatório dos fluxos mercantis vindos dos dois lados da rede. Por isso, rapidamente se tornava um núcleo urbano, graças à presença de uma classe de mercadores fixos. Usando a linguagem christalleriana, tinha um alcance espacial máximo muito maior que o alcance espacial mínimo (CORRÊA, 1997), o que justificava a sedentarização de estabelecimentos comerciais (figura 16). Estes contavam com grande escala de mercado, representada por toda a região a montante.

A boca de sertão contava com um mercado, representado por um território e respectivos consumidores das vendas em atacado, mais do que suficiente para justificar a existência de uma classe de mercadores em tempo integral. 
Veremos, em seguida, como um desses arraiais, surgido na ponta dessa rede dendrítica, acabou se tornando o segundo maior centro urbano do interior do Império.

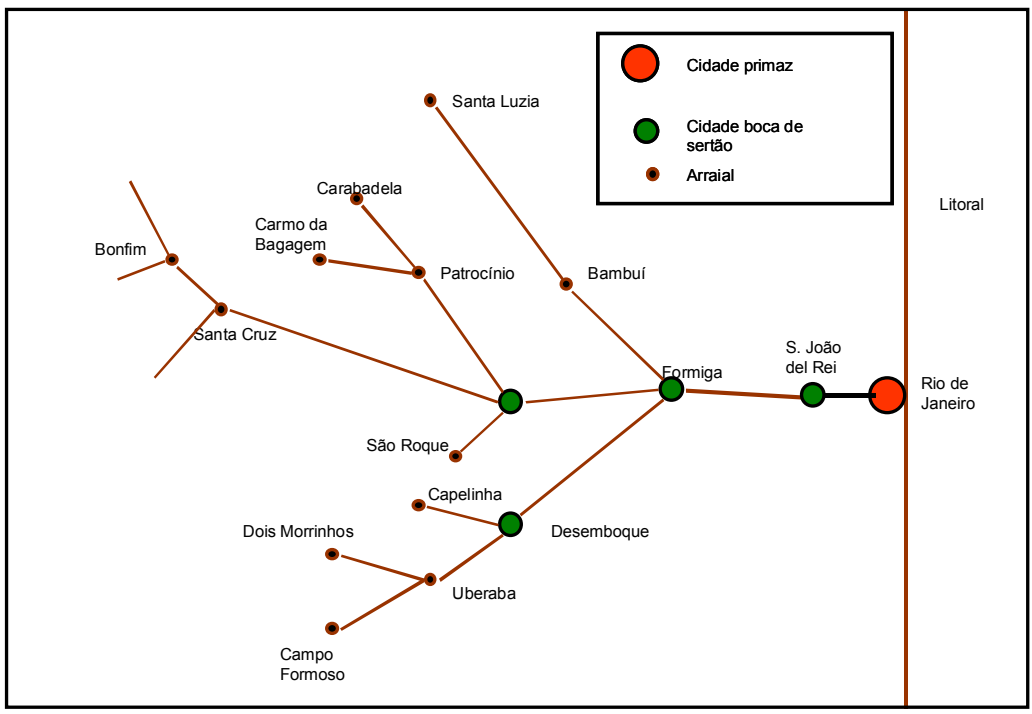

Figura 15: rede dendrítica do oeste mineiro em 1816.

Fonte: desenho Lourenço, L. A. B. (2002).

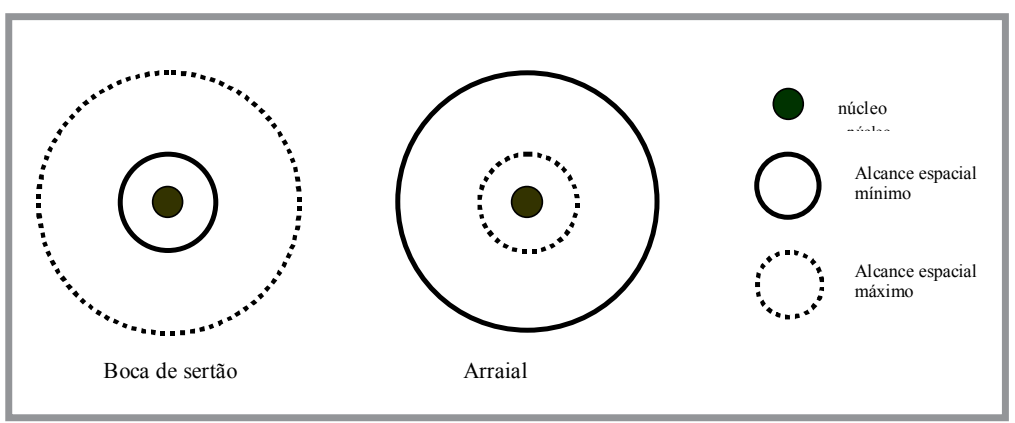

Figura 16: alcance espacial dos arraiais e bocas de sertão segundo o modelo de Christaller. 


\section{A rede mercantil uberabense}

O quadro 2 mostra a população de Uberaba, em 1868, comparada com a de outras cidades brasileiras, na mesma época. Como se vê, a cidade, nessa época, já era maior que muitas capitais de província, inclusive a capital de Goiás. A transformação de Uberaba num dos principais centros urbanos do oeste brasileiro, só comparável a Cuiabá, ao final da primeira metade do século XIX, foi o resultado de uma série de contingências: localização geográfica, entre Goiás, Mato Grosso, São Paulo e Minas; a migração geralista; os solos férteis. Porém, também dependeu das iniciativas de um homem: o sargentomor Antônio Eustáquio Silva Oliveira, fazendeiro, diretor dos índios, juiz de sesmarias, comandante e regente dos Sertões da Farinha Podre.

Não que a história tivesse resultado exclusivamente dos atos desse personagem: não era um homem "à frente de seu tempo", mas do seu tempo. Exatamente por estar sintonizado com as ambições de seu grupo social e com os mecanismos de funcionamento de sua sociedade, soube como ninguém perceber as chances que as conjunturas lhe ofereceram, e usá-las em proveito próprio e de seu grupo.

\begin{tabular}{|c|c|}
\hline Cidade & POPULAÇÃO \\
\hline CURITIBA & 3.000 \\
\hline GoIÁs & 4.500 \\
\hline VITÓRIA & 5.000 \\
\hline ARACAJU & 5.000 \\
\hline NatAL & 5.000 \\
\hline TERESINA & 6.000 \\
\hline$U_{B E R A B A}$ & 7.681 \\
\hline MACEIÓ & 8.000 \\
\hline OURo Preto & 10.000 \\
\hline DESTERRo & 12.000 \\
\hline
\end{tabular}

\begin{tabular}{|c|c|}
\hline Cidade & POPULAÇÃO \\
\hline PARAíba & 14.000 \\
\hline CUIABÁ & 15.000 \\
\hline FORTALEZA & 18.000 \\
\hline SÃo PAULO & 20.000 \\
\hline Porto Alegre & 24.000 \\
\hline SÃo LUIS & 35.000 \\
\hline BELÉM & 35.000 \\
\hline RECIFE & 100.000 \\
\hline Salvador & 180.000 \\
\hline RIO DE JANEIRO & 450.000 \\
\hline
\end{tabular}

Quadro 2: população de algumas capitais brasileiras e de Uberaba, em 1868.

Fonte: Mendes (1868), Sampaio (2001). 
Antônio Eustáquio obteve sua liderança por meio da única fonte de poder possível, numa sociedade de ordens: a influência pessoal e as ligações de parentesco. Irmão do juiz e potentado José Manuel Silva e Oliveira, obteve do Marquês de Palma, em 1809, o título de Comandante Regente dos Sertões da Farinha Podre. De posse do título, iniciou a execução de seu projeto, ao mesmo tempo pessoal e familiar, e que de resto o identificava com as demais elites coloniais: a obtenção de prestígio, o que na sociedade colonial, mais do que acúmulo de riqueza na forma de dinheiro ou capital, significava poder sobre homens e terras.

A busca do prestígio pela obtenção de sinais de fidalguia, formação de clientelas e negação do trabalho braçal era o principal anseio das elites coloniais. Fragoso (1998) demonstrou que mesmo os comerciantes de grosso trato cariocas - as maiores fortunas do Brasil da época - tinham por projeto se estabelecerem como proprietários de escravos e terras, mesmo sendo tais atividades menos lucrativas que o comércio. Mostrou inclusive que essa foi a origem de grande parte da elite cafeicultora do Vale do Paraíba, nos anos 1830. A esta busca da fidalguia, Silveira (1997) chamou de vontade de distinção, e Furtado (1999), de notabilização.

Numa região de fronteira, como o Triângulo Mineiro do século XIX, obter prestígio e alcançar a fidalguia significava não só se apossar de imensas terras devolutas e adquirir grandes escravarias. Era preciso que se estabelecessem vínculos de dependência e autoridade sobre uma coletividade de colonos livres. Só com isso se reproduziriam as várias posições hierárquicas que essa sociedade estamental necessita para se legitimar. Dessa forma, parte do excedente gerado nas atividades econômicas era usada pela elite agrária e escravista em investimentos não produtivos, destinados a legitimar, frente à coletividade de homens livres e pobres, o status quo. No dizer de Fragoso:

Nesse sentido, temos as aplicações de grandes fazendeiros e comerciantes de grosso trato na aquisição de extensos plantéis de escravos domésticos, no uso de foros de fidalguia e nas doações pias às instituições religiosas. São fenômenos da mesma categoria a permissão dada pelos grandes fazendeiros a lavradores pobres para que se instalem em suas terras, sem a contrapartida de uma renda fundiária [...] (1998, p. 32-33). 
É dessa forma que devem ser interpretadas as ações da proto-oligarquia de Uberaba, nas primeiras décadas do século XIX. O que a parentela dos irmãos Silva e Oliveira e o padre Hermógenes Casimiro de Araújo buscavam era recriar um mundo no qual pudessem distinguir-se.

O que podemos dizer é que, para tanto, criaram uma estratégia que foi muito bem sucedida. Liderando um grupo de pioneiros geralistas, transformaramse numa das mais poderosas oligarquias rurais da região central do Brasil. Expulsaram os índios que, não obstante, estavam sob tutela de Antônio Eustáquio; suas terras foram então expropriadas e distribuídas aos colonos, que criaram vários arraiais, nos limites do termo da vila de Uberaba. Antônio Eustáquio abriu uma estrada nova para Goiás, encurtando em várias léguas o caminho de São Paulo a Cuiabá, e criou um novo porto no rio Grande, para facilitar pela navegação fluvial o acesso a São Paulo.

Nos trinta anos que se estendem de 1820 a 1850, oito novos arraiais surgiram na mesopotâmia entre os rios Paranaíba e Grande, dos quais cinco no termo da vila de Uberaba, como se vê no mapa da figura 17. Esses novos núcleos (Campo Belo, São José do Tejuco, Monte Alegre, Abadia do Bom Sucesso $^{25}$ e São Pedro do Uberabinha) foram, em parte, o resultado do boom de concessões de sesmarias a geralistas, após a anexação do Triângulo por Minas em 1816, e em parte resultado da política de colonização promovida pelo sargento-mor Antônio Eustáquio Silva e Oliveira.

Constata-se, no mapa, que esse processo foi orientado por vetores espaço-temporais dispostos nos sentidos sul-norte, sudeste-noroeste e lesteoeste, isto é, formando um leque cujo vértice era Uberaba. À medida que as sesmarias iam sendo ocupadas, as comunidades locais iam formando as capelas para atender aos seus interesses religiosos, sociais e econômicos mais imediatos. Ao passo que essas localidades iam surgindo, Uberaba se consolidava como núcleo de polarização mercantil e política dessa rede de arraiais.

Contudo, a vila de Uberaba ultrapassou a condição de mero centro regional de província para se transformar, a partir dos anos 1840, no porto do sertão, para usar o termo do coronel Borges Sampaio (2001). Um olhar sobre o mapa reproduzido na figura é suficiente para perceber que esse núcleo se tornara, em 1850, o grande ponto de convergência dos principais caminhos

25 Hoje Tupaciguara. 


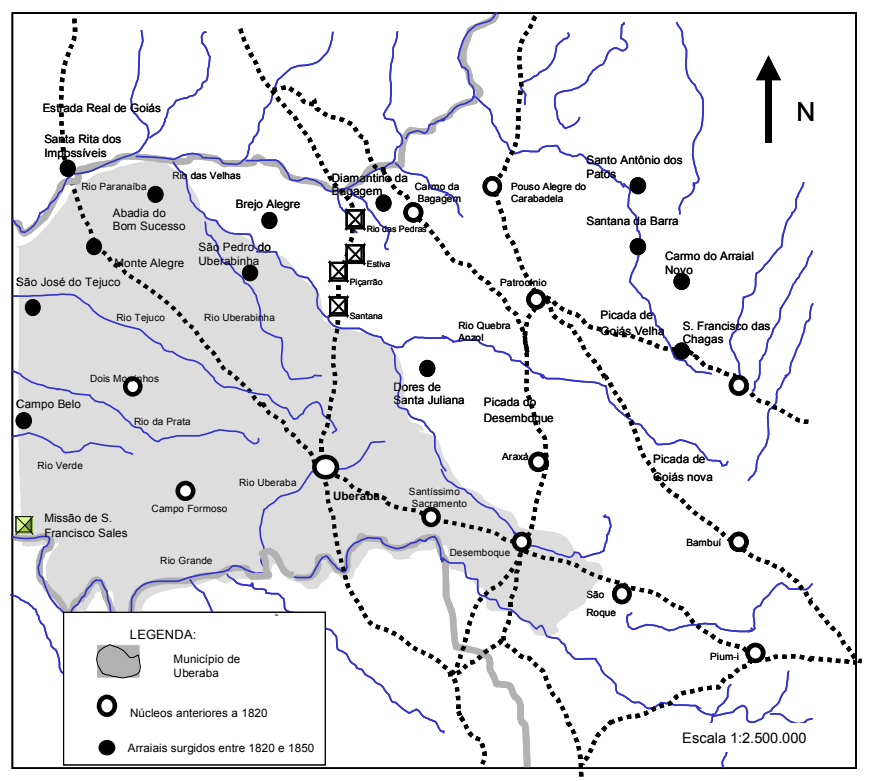

Figura 17: arraiais surgidos no Triângulo Mineiro entre 1820 e 1850.

Fonte: Barbosa (1995).

do Triângulo Mineiro, e que, portanto, há muito transcendera o papel de um simples arraial. Estava ligado a Formiga e São João Del Rei pelo Desemboque, a São Paulo e Goiás pela Estrada do Anhanguera e, a partir de 1824, também a Cuiabá pela Estrada Real ou Estrada de Cuiabá.

A forma como a oligarquia uberabense - e liderando-a, o potentado Antônio Eustáquio - lidou com a questão viária mostra que ela tinha total consciência de sua importância estratégica. Além disso, mostra que já existia então uma idéia clara das vantagens de localização que Uberaba auferia, e que era necessário tirar o máximo proveito delas.

Em 1818, dois anos após fundar o arraial, Antônio Eustáquio abriu um desvio na Estrada do Anhanguera, para que esta passasse dentro do povoado, isolando o aldeamento indígena do Vau do Caiapó (Coutinho, s.d.). O desvio começava no aldeamento de Lanhoso e chegava ao centro do arraial, por trás da capela de Santo Antônio (APU, 1987). Saint Hilaire recebeu a seguinte explicação dos moradores sobre o abandono do antigo trecho da estrada: 
Farinha Podre fica situado, segundo dizem os seus moradores, a mais de meia légua da verdadeira estrada de Goiás a São Paulo, e conseqüentemente fora dos limites do território dos índios. Mas desde sua fundação, a antiga estrada foi inteiramente abandonada pelas tropas de burros, que atualmente passam pelo próprio arraial, onde os tropeiros encontram mais facilidade para a compra de provisões (1975 a, p. 151).

Em 1823, Antônio Eustáquio abriu o porto da Ponte Alta, ${ }^{26}$ levando ao abandono o antigo Porto da Espinha, situado mais ao sul, segundo o Vigário Silva porque "por este [Porto da Espinha] raras pessoas transitam, tanto por ser tortuosa a estrada, tanto porque as maleitas dão sem distinção de tempo" (1970, p. 12). O novo porto foi construído às margens do Rio Grande, na barra (foz) do córrego Ponte Alta. Tornou possível a utilização de uma hidrovia natural que começava próxima a Mogi-Guaçu, onde as mercadorias trazidas por tropas de Santos eram embarcadas em canoas. Estas desciam o rio Mogi-Guaçu até o rio Pardo, e este até sua foz no rio Grande, de onde subiam a montante até o porto da Ponte Alta. Do porto, as mercadorias eram transbordadas para carros de boi, e levadas a Uberaba (SAMPAIO, 2001).

Em 1824, o sargento-mor construiu uma nova estrada entre o rio Grande e o rio Paranaíba (figura 18), em sociedade com o fazendeiro Pedro Gonçalves, financiado pelo governo provincial (SILVA, 1970; SAMPAIO, 2001), e sob a coordenação do engenheiro militar Cunha Matos (FERreira, 1958).

Esse caminho seguia precisamente a crista do chapadão situado entre os vales dos rios Tejuco e das Velhas, tendo, portanto, a mesma orientação de seus cursos fluviais, isto é, o sentido sudeste-noroeste, como se pode ver no mapa reproduzido na figura 19, de autoria de Alfredo E. Taunay, confeccionado ao tempo da Guerra do Paraguai (1865-1870). No local da travessia do rio Paranaíba, Cunha Matos abriu o porto de Santa Rita dos Impossíveis, ${ }^{27}$ onde foi instalado um posto de alfândega (FERrEIrA, 1958). A partir dali, o caminho bifurcava-se, seguindo uma ramificação para Morrinhos e Vila Boa, outra para Dores do Rio Verde e o Cuiabá (SAMPAIO, 2001).

A partir de então, a Estrada Real tornou-se cada vez mais a principal via de acesso das províncias de Goiás e Mato Grosso a São Paulo e ao porto

${ }_{26}$ Hoje cidade de Delta.
Hoje Itumbiara. 


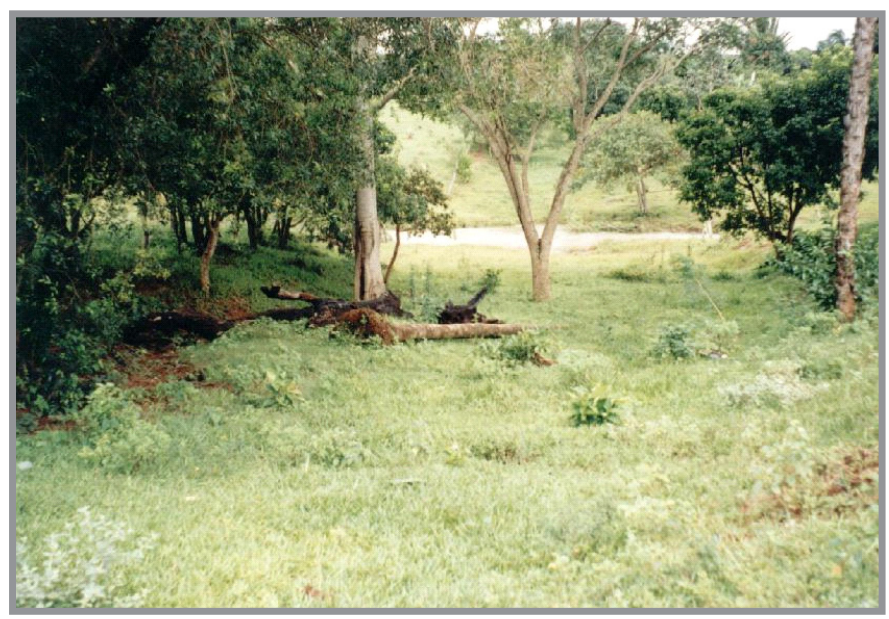

Figura 18: Miraporanga: resquícios da antiga Estrada Real, aberta por Antônio Eustáquio Silva e Oliveira em 1824 .

Fonte: foto Lourenço, L. A. B. (2002), a partir de informações de Hélio Rodrigues da Cunha.

de Santos. Encurtava em algumas léguas o trajeto de Goiás a São Paulo, e em várias léguas o de Cuiabá. Além disso, era mais plana do que a antiga estrada de Goiás, e ainda com uma vantagem adicional: por seguir a crista de um espigão interfluvial, só obrigava a uma vadeação no rio Tejuco, enquanto o antigo obrigava à travessia por balsas do rio das Velhas.

De início, o caminho foi pouco utilizado, pois não dispunha de pousos em seu trajeto, e muitas tropas ainda preferiam a velha Estrada do Anhanguera, onde os aldeamentos davam guarida a elas (SAmpaIo, 2001). Na década de 1830, porém, a colonização do Sul de Goiás por geralistas fez surgir vários arraiais naquela província, ao longo do trecho da Estrada Real. Os imigrantes mineiros fundaram Dores do Rio Verde ${ }^{28} \mathrm{em} 1835$, e, dez anos depois, uma parentela vinda de Patrocínio fundou o arraial de Morrinhos, na província de Goiás (Ferreira, 1958). Com o surgimento dos arraiais de São Francisco do Monte Alegre, em 1830, e de Santa Maria, em 1850 (figura 20), completou-se uma rede de pousos para tropas e boiadas, desde Uberaba até Goiás (TeixeirA,

28 Hoje Rio Verde. 


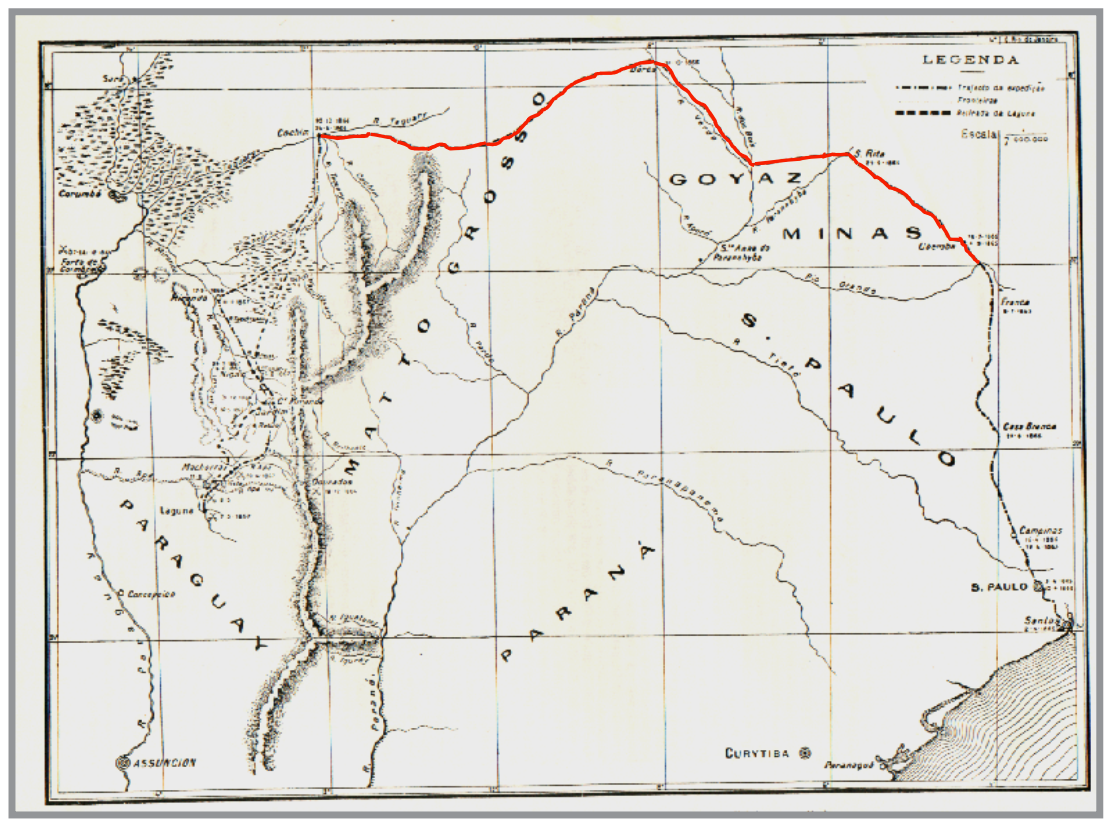

Figura 19: trajeto das forças brasileiras na Guerra do Paraguai pela Estrada Real (1865-1870). Fonte: APU (1986).

1970) e, com isso, a antiga Estrada dos Goiases foi quase abandonada.

Assim, com o porto da Ponte Alta, mais a estrada que o ligava a Uberaba e a Estrada Real, completava-se um complexo viário que abria praticamente uma linha reta, entre Franca e Santa Rita, paralela ao rumo sudeste-noroeste. Talvez essa tenha sido a obra que definitivamente transformou Uberaba em boca do sertão e num dos mais importantes núcleos urbanos do interior do Império.

A hidrovia encurtou a viagem do Cuiabá e de Goiás a Santos, tornando essa via preferencial à Picada de Goiás no acesso daquelas províncias ao mar, e aumentando a utilização daquele porto paulista como pulmão marítimo da região, em prejuízo do Rio de Janeiro. E no caminho de volta, o sal se tornou a principal mercadoria que vinha de Santos até Uberaba, e um importante fator responsável pela pujança comercial da vila até 1859 (REZENDE, 1991).

Uberaba tornou-se o principal centro distribuidor de sal para uma imensa área de pecuária extensiva que incluía o Triângulo Mineiro, Goiás 
e Mato Grosso. Surgiu, como conseqüência disso, num período de trinta e dois anos (1827-1859), uma verdadeira rede tentacular de estradas salineiras (TeIXeIra, 2001; Pontes, 1978), que vemos na figura 20. Em torno delas, desenvolveram-se os novos arraiais, consolidando de forma definitiva a ocupação fundiária e a localização dos principais núcleos urbanos futuros.

Não se pode cometer o erro de tentar encontrar, nas elites de uma vila sertaneja do século XIX, motivações ou racionalidades de tipo "capitalista"

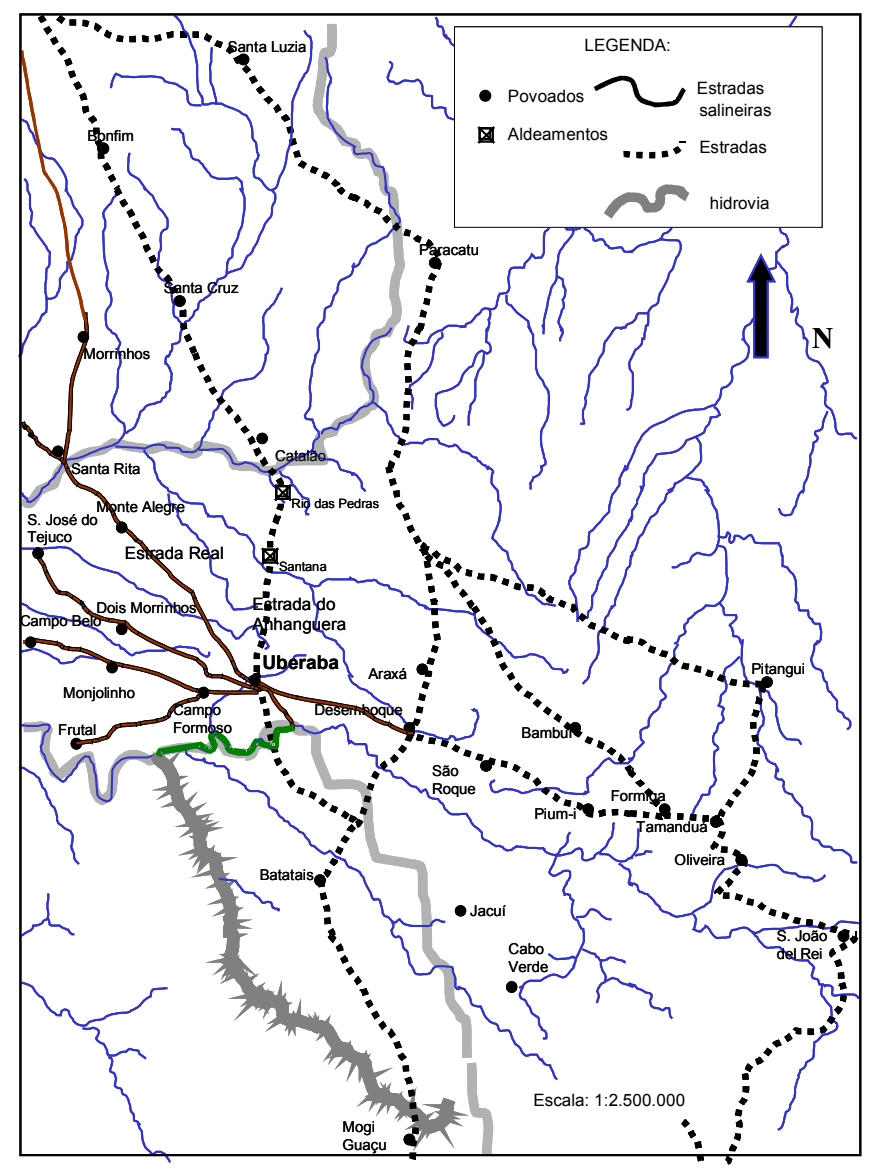

Figura 20: rotas salineiras e navegação fluvial na região de Uberaba (1827-1859). Fonte: Teixeira (2001). 
para explicar a montagem de tal sistema viário. Não era a vontade do lucro ou cálculos contábeis, típicos da racionalidade capitalista, o que levou Antônio Eustáquio e os seus a transformar Uberaba numa encruzilhada de caminhos. Como homens que tinham visões de mundo mais próximas das do Antigo Regime do que de Adam Smith, buscavam, antes de tudo, reforçar um sistema de poder pessoal, fundamentado em obrigações pessoais, posse de escravos, acúmulo de cargos públicos, títulos de nobreza e patentes militares. É nesse universo que devemos tentar explicar a rede mercantil que então se criava no Triângulo Mineiro.

Nesse contexto, o que significava, para a sociedade sertaneja de então, a localização da vila de Uberaba num entroncamento viário? Em primeiro lugar, a presença dos pousos para as tropas, carros de bois e boiadas. Vimos ter sido esse o motivo, alegado por Saint Hilaire (1975 a), para o desvio feito pelos uberabenses da Estrada do Anhanguera, em 1819. Vimos também que, com a Estrada Real, a Rua Direita constituiu-se numa via onde se instalaram vendas e pousos, depois de 1824.

Nos pousos - geralmente ranchos aberto dos lados, cobertos de palha (figura 21) — , a permanência dos tropeiros, arrieiros e camaradas era gratuita:

Encontramo-los, geralmente, no interior do Brasil, à margem das estradas chamadas Reais [...] São os habitantes, cujas terras estão próximas à estrada, que os fazem construir. Não se paga hospedagem, mas ao pé do rancho há uma venda em que o proprietário vende o milho que serve de alimento aos animais dos itinerantes (SAint Hilaire, 2000, p. 40).

A população local vendia a esses passantes os víveres de que necessitavam — farinha de milho, feijão, cachaça e fumo. Mas esse comércio pouco beneficiava os grandes fazendeiros, pois bastava, para que funcionassem, uma estrutura elementar com pequenos sitiantes e vendeiros. Por exemplo, Antônio Gonçalves Firme $^{29}$ e Luciana Maria de Jesus eram um casal sem filhos, de posses modestas, que, em 1837, tinha uma chácara em terras do rossio da vila de Uberaba. Nessa chácara, estavam suas "casas de morada, da parte de cima com ranchos de passageiros", isto é, ranchos para pouso de tropas. Antônio não criava gado,

29 APU, inventário de Antônio Gonçalves Firme (01/02/1837), maço N5. 
pois tinha apenas cinco bois carreiros, que usava para transporte. Era agricultor, ajudado pelos africanos José e Maria, já que a prole desse casal de escravos as crianças Cassiano, Ana, Maria e Pedro - era muito jovem para o trabalho no eito. Com seus cultivos, Antônio produzia um excedente que, por certo, encontrava fácil saída pelas tropas que estacionavam em seu rancho.

Ranchos e vendas eram os primeiros tipos de estabelecimentos de comércio sedentários que surgiam em regiões de fronteira, no período colonial e no Império.

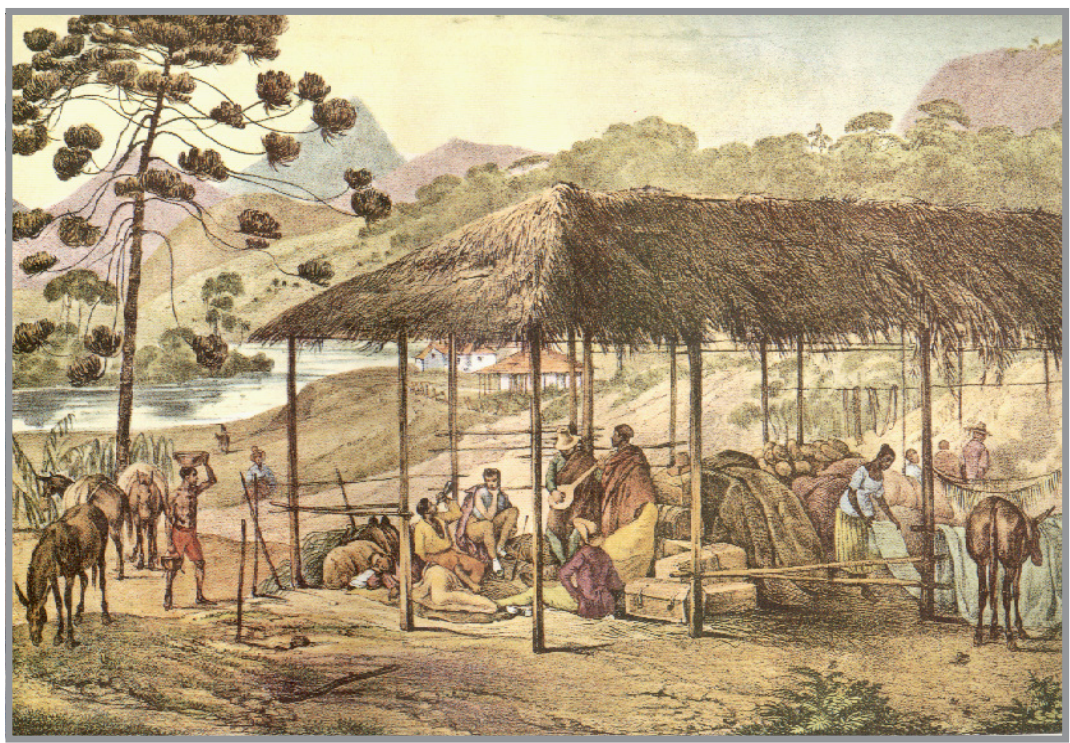

Figura 21: pouso de tropas

Fonte: Rugendas (1998).

Espalhados pelos arraiais e fazendas cortados pelos trajetos das tropas, carros de bois e boiadas, eram a forma mais elementar de comércio fixo, mantido pela população mais pobre. Neles se fazia a venda de molhados, isto é, gêneros alimentícios e similares, para os passantes e a população local (FURTADO, 1999).

Para a elite fundiária, a principal vantagem de se ter um povoado transformado em passagem obrigatória de vários caminhos, drenando regiões agropastoris a montante, era a possibilidade de diversificar suas atividades econômicas. Vimos, no capítulo anterior, que muitos grandes pecuaristas da 
região em estudo tendiam a especializar-se na atividade de invernada, no que muito ajudava a posição geográfica de Uberaba, no caminho das boiadas. Noutros casos, essa condição de ponto nodal do sistema viário estimulava alguns fazendeiros a se tornarem comerciantes, e assim aumentarem suas perspectivas de acumulação.

A presença dos fluxos de tropas e boiadas instou alguns membros da elite fundiária do Triângulo Mineiro a envolver-se diretamente no comércio, tanto de retalho como de grosso trato. O comerciante de retalho, ou lojista, era geralmente especializado em secos, e ocupava um status superior ao do vendeiro, na maioria dos casos, comerciante de molhados. Além desses, havia o comerciante itinerante ou mascate, que se deslocava de sítio em sítio, ou pelas feiras nos arraiais, para vender secos a retalho (FURTADO, 1999). Essa forma de comércio, como vimos, era comum em regiões esparsamente povoadas, onde não havia escala de mercado que justificasse ainda a presença, em tempo integral, de lojas de fazenda seca nos povoados.

Nesse contexto, nos primeiros tempos do arraial de Uberaba, alguns fazendeiros atuavam, eventualmente, como mascates. Esse era o caso, pelo menos, de Joaquim Alves, ${ }^{30}$ em 1827, inequivocamente um fazendeiro que se ocupava da mercancia. Possuía dez escravos e a fazenda Cachoeira, onde criava 48 cabeças de gado, dez carneiros e 125 porcos. Sua partida de fazenda seca, que totalizava apenas $143 \$ 000$, certamente não era seu principal ganha-pão.

Contudo, à medida que os povoados cresciam - e aumentavam a área e a população sob sua influência —, iam se estabelecendo neles os lojistas fixos de fazenda seca. Esses varejistas surgiam numa fase posterior à dos vendeiros, quando já havia uma escala de mercado suficiente para justificar a presença de comerciantes em tempo integral. Nesse sentido, o inventário do capitão Francisco José da Silva ${ }^{31}$ é um documento valioso para se entender como se organizava o comércio lojista em seus primórdios, no Triângulo Mineiro.

Esse homem vivia no pavimento superior de um sobrado na vila de Uberaba, em 1837. No andar inferior, mantinha sua loja, onde espalhava suas

\footnotetext{
30 APU, inventário de Joaquim Alves (02/11/1827), maço N3.

31 APU, inventário de Francisco José da Silva (09/02/1937), maço 6, caixa 460.
} 
mercadorias sobre três mesas, de nove, seis e quatro palmos. Ali, vendia não só panos e linhas importados, mas também mantinha uma botica, onde só a análise da lista de drogas arroladas equivale a um estudo de medicina sertaneja (quadro 3). Verifica-se, analisando-se o estoque de mercadorias de Francisco, a alta diversificação e, por conseguinte, a baixa especialização do comércio em lojas na vila, nos anos 1830.

O capitão Francisco não era tão rico quanto os potentados rurais de Uberaba, mas também não tinha do que se queixar: seu patrimônio somava mais de sete contos de réis. Porém, era um cabedal bastante diferente de uma fortuna rural típica do Triângulo Mineiro oitocentista. O que chama a atenção em seu inventário é a quase ausência de patrimônio mancípio: possuía apenas quatro escravos, as africanas Rita e Isabel, e as crianças Tertuliano e Maria. A ausência de grandes escravarias não era uma excentricidade sua: também no Rio de Janeiro da mesma época (Fragoso, 1998), e em Sabará e Vila Rica do século anterior (FurTAdo, 1999), os proprietários de estabelecimentos de comércio quase só empregavam homens livres — os caixeiros — na atividade.

Esse comerciante tinha 2:151\$000 mobilizados em mercadorias e créditos, o que equivalia a 28\% do seu patrimônio. Ao mesmo tempo, não dispunha de rebanhos ou equipamentos de beneficiamento agrícola, como monjolos ou moinhos. Isso mostra que tinha no comércio seu principal meio de vida, o que significa que, já em 1837, a vila de Uberaba comportava comerciantes de porte significativo, que tivessem na venda a retalho sua principal atividade.

O inventário do capitão Francisco permite também avaliar o alcance geográfico regional do comércio uberabense de tecidos e especiarias. Consta o documento uma extensa lista com 90 devedores do comerciante, pessoas que haviam comprado fiado em sua loja, até aquela data. Em primeiro lugar, é notável não haver distinção de classe entre os fregueses: ali estão desde o forro João Rodrigues até o Vigário Silva, e Francisco José da Silva, genro do poderoso fazendeiro Manoel Bernardes. Grande parte dos devedores tinha o local de moradia relacionado junto ao nome, como "Manuel Francisco da Silva, morador no Uberaba", ou "Manuel Pereira da Silva, morador no Caçu". Mapeamos as localidades relacionadas aos devedores (figura 22), para ter uma idéia da área abrangida pela clientela do capitão Francisco. 


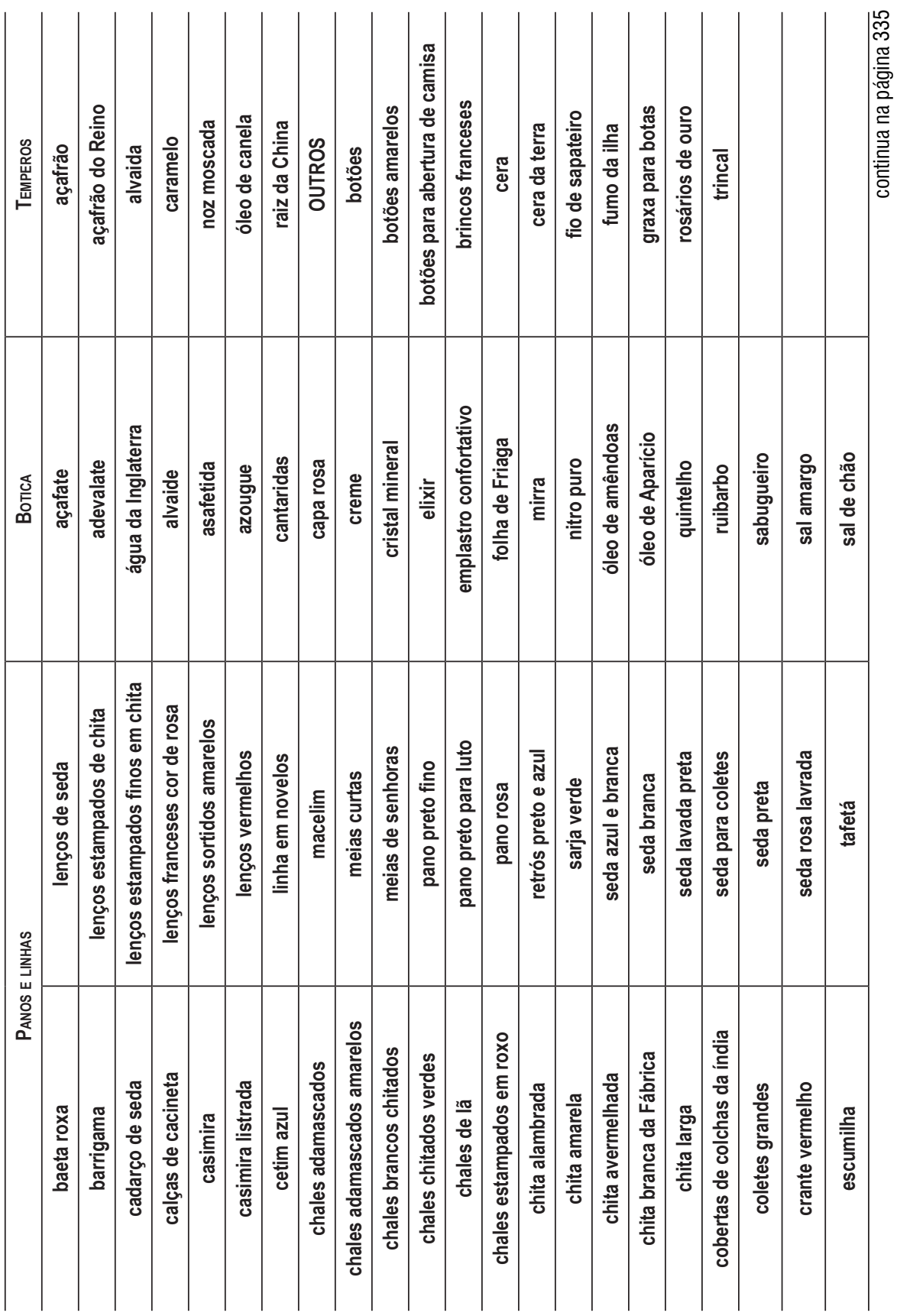




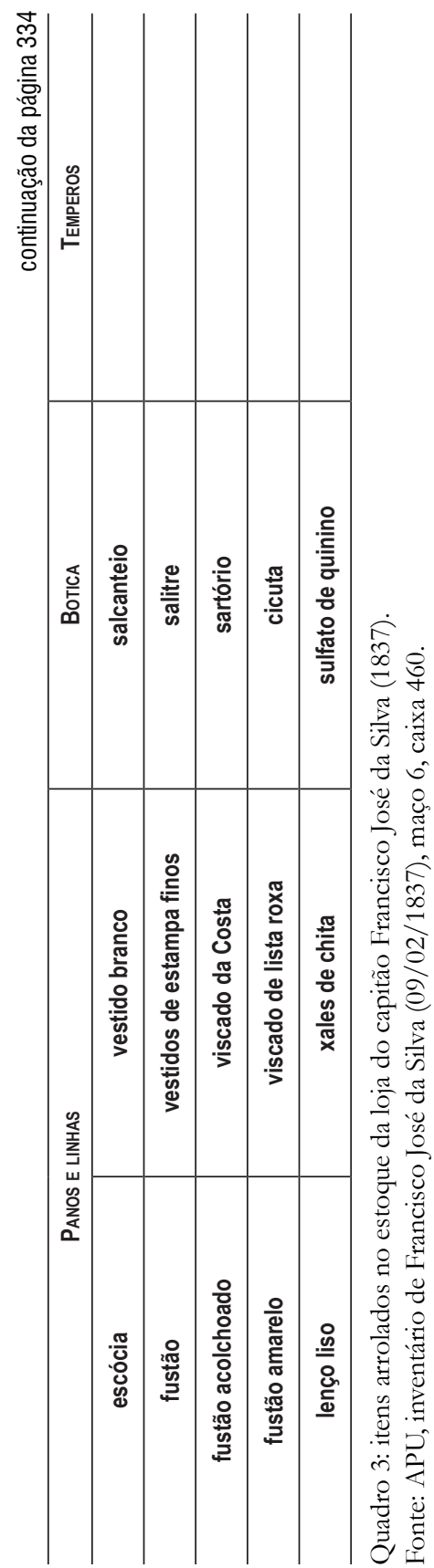


O alcance espacial do comerciante incluía toda a porção oriental do atual Triângulo Mineiro, o que demonstra não só a existência de um mercado que tornava compensadora a presença de varejistas fixos em Uberaba, na década de 1830, mas também o caráter de centro regional que a vila já assumia.

Seu patrimônio imobiliário somava 3:604\$200, ou 47\% do total. Nele se destacava a Fazenda Piedade, de mais de dois contos de réis, mas que ainda não dispunha de sítio. É provável que estivesse em seus planos estabelecer-se como fazendeiro, pois assim acontecia com os comerciantes da mesma época em todas as outras regiões do Brasil: integrar-se à elite fundiária e escravista era o ideal perseguido por todos os mercadores (FURTADO, 1999).

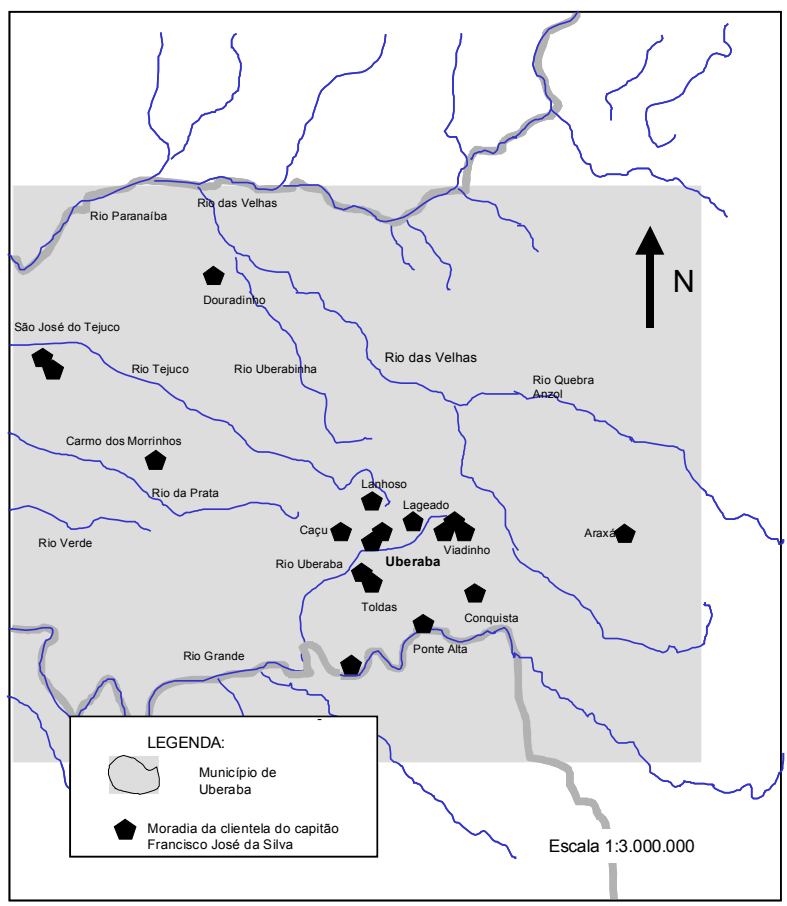

Figura 22: local de moradia da clientela do comerciante Francisco José da Silva, estabelecido em Uberaba em 1837.

Fonte: APU, Inventário de Francisco José da Silva (09/02/1837), maço 6, caixa 460. 
Em nossas fontes primárias de pesquisa, não encontramos inventários de grandes fortunas mercantis: os homens mais ricos do Triângulo, até 1861, eram todos senhores de terra e escravos, e nenhum deles possuía grandes estoques de mercadorias, de qualquer natureza. Contudo, já nas décadas de 1840 e 1850 , estabeleciam-se comerciantes de grosso trato em Uberaba, ligados ao comércio de sal.

A partir dessa época, alguns fazendeiros, com a ascensão de Uberaba à condição de entreposto em relação a uma vasta região pastoril do interior do Brasil, estabeleceram-se como atacadistas de sal grosso, trazido de Santos. Por exemplo, em 1848, o coronel Antônio Elói Casimiro de Araújo, futuro Barão da Ponte Alta, aparentado de Antônio Eustáquio, filho natural do padre Hermógenes e chefe do Partido Liberal local, abriu casa de comércio no porto da Ponte Alta, em sociedade com o imigrante português Antônio Borges Sampaio, negociante de sal grosso (SAmpaio, 2001). Alguns anos depois, seu adversário político, o comendador João Quintino Teixeira, chefe do Partido Conservador, fez o mesmo (RESENDE, 1991).

A partir dos anos 1840, portanto, Uberaba já havia se tornado algo diferente de um arraial. Muitos fazendeiros começavam a ver vantagens numa permanência mais demorada na vila, tornando-se, com o tempo, proprietários rurais absenteístas. As casas de fazenda iam sendo deixadas a administradores, e os negócios no povoado iam se tornando os mais importantes. Ao mesmo tempo, surgia uma classe de comerciantes urbanos de médio e grande porte.

A presença dessa elite gerava novas demandas e novos serviços na economia da vila, que funcionavam como fatores de atração para uma população sedentária. Por exemplo, surgiam escolas, teatros, e a política institucional, com casa de câmara e cadeia. E é justamente nesse momento que se percebe o surgimento de uma outra elite, agora com ares de urbanidade, formada pelos professores, amanuenses, juízes, padres, que começariam a publicar jornais e a fazer saraus. Pode-se dizer que nessa fase já existia o urbano.

\section{Uberaba como centro regional do Império}

O Triângulo tornou-se, já a partir do final da década de 1830, um importante foco de colonização agropecuária das terras situadas mais a ocidente 
(figura 23). Isso reforça a nossa hipótese de que não era necessária a decadência econômica de uma região para que ela se tornasse uma área de emigração. Ao contrário, sob condições de relativa prosperidade, uma região cuja economia se baseasse na agricultura de alimentos, e na pecuária praticada em pastagens naturais, poderia se tornar foco de repulsão migracional. Apenas o crescimento vegetativo é fator suficiente para fazer com que essas populações de agricultores e pecuaristas emigrem, por causa do caráter extensivo das técnicas de exploração dos recursos ambientais, como vimos nos capítulos 3 e 4 .

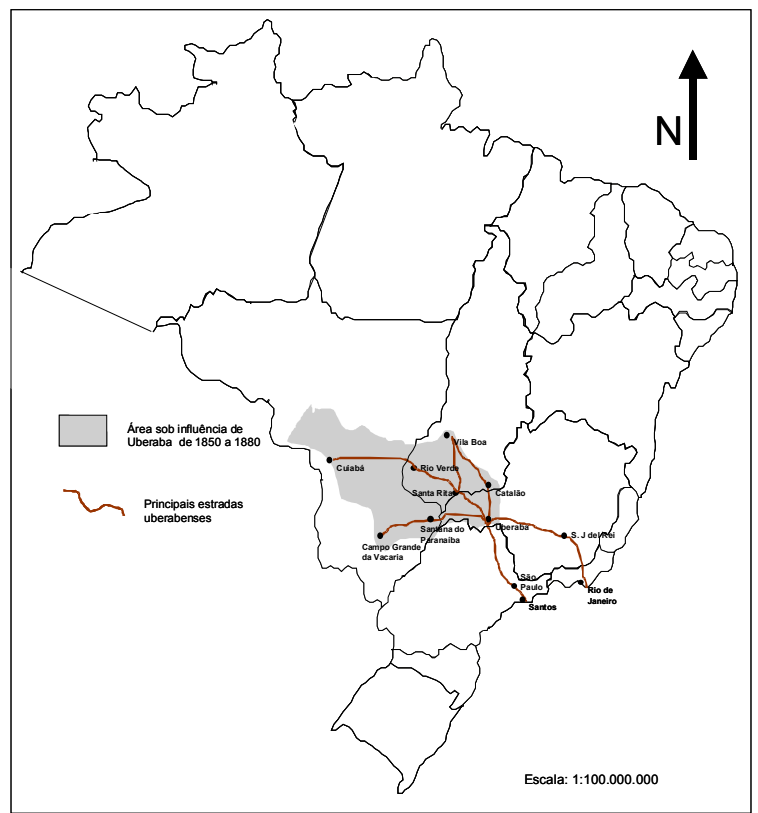

Figura 23: área de influência e principais estradas uberabenses (1832-1880)

No estudo clássico de Nelson Werneck Sodré (1941) sobre a ocupação pioneira agropastoril do Mato Grosso, vemos a expansão de famílias triangulinas — já a partir de 1830 — rumo às pastagens e terras situadas além do rio Paranaíba. Naquele ano, o geralista Joaquim Francisco Lopes reuniu as parentelas triangulino-uberabenses dos Garcia e dos Souza, estabelecidos no pontal dos rios Grande e Paranaíba, e iniciou a penetração agropastoril pioneira rumo aos 
campos mato-grossenses, fundando então o arraial de Santana do Paranaíba. ${ }^{32}$ O processo continuou nos anos seguintes: em 1872, José Antônio Pereira, de Monte Alegre, e mais 72 agregados e aparentados, fundaram o arraial de Santo Antônio do Campo Grande da Vacaria, ${ }^{33}$ nas cabeceiras do rio Anhanduí.

Uberaba foi a localidade que mais se beneficiou economicamente dessa expansão geralista pelos sertões mato-grossenses. O grande afluxo de colonos mineiros transformou em pouco tempo Campo Grande da Vacaria em importante área de pecuária, que vendia o gado a comerciantes uberabenses, os quais, no contra-frete, revendiam o sal (ArrudA, 2000). O fluxo de comitivas de gado e sal passou a se fazer pela estrada que passava por Santana do Paranaíba, Porto Alencastro, Campo Belo, Dores do Campo Formoso e Uberaba (TeiXeIra, 2001), conhecida como Estrada do Piquiri (FErreira, 1958).

Também a notável projeção alcançada por Uberaba, ao longo da primeira metade do século XIX, pode ser mais bem compreendida com base no modelo geométrico-espacial. O arraial posicionou-se, como vimos, num entroncamento entre dois sistemas dendríticos: o que partia de São Paulo e o que partia de São João Del Rei.

As ações das lideranças da elite uberabense, desde então, demonstraram uma clara compreensão das vantagens da localização do arraial: o desvio da Estrada dos Goiases para dentro da localidade, a instalação do porto da Ponte Alta, e finalmente a abertura de um caminho mais curto e regular até Goiás. Essas ações fizeram aumentar a fluidez da drenagem da região pelo arraial/ vila, rumo às cidades primazes, e destas para a região.

Mas as ações da elite uberabense não se resumiram só à abertura de vias. Houve, como vimos, um claro esforço de povoamento, com a expulsão dos índios e o boom de concessão de sesmarias entre 1816 e 1822. A elite desejava formar uma região e, a partir dela, criar entroncamentos com outras regiões. As cartas escritas pelo sargento-mor Antônio Eustáquio, que analisamos no capítulo 3, não deixam dúvidas quanto a isso.

Graças à sua situação de intersecção entre dois sistemas dendríticos (figura 24), Uberaba consolidou-se como boca de sertão, com características muito especiais: era intermediária entre duas cidades primazes — Rio de Janeiro e São Paulo —, e três

\footnotetext{
32 Hoje Paranaíba.

33 Hoje Campo Grande
} 
regiões - Triângulo, Goiás e Mato Grosso. Dai seu excepcional crescimento, a ponto de se transformar numa das principais cidades do interior do Império do Brasil.

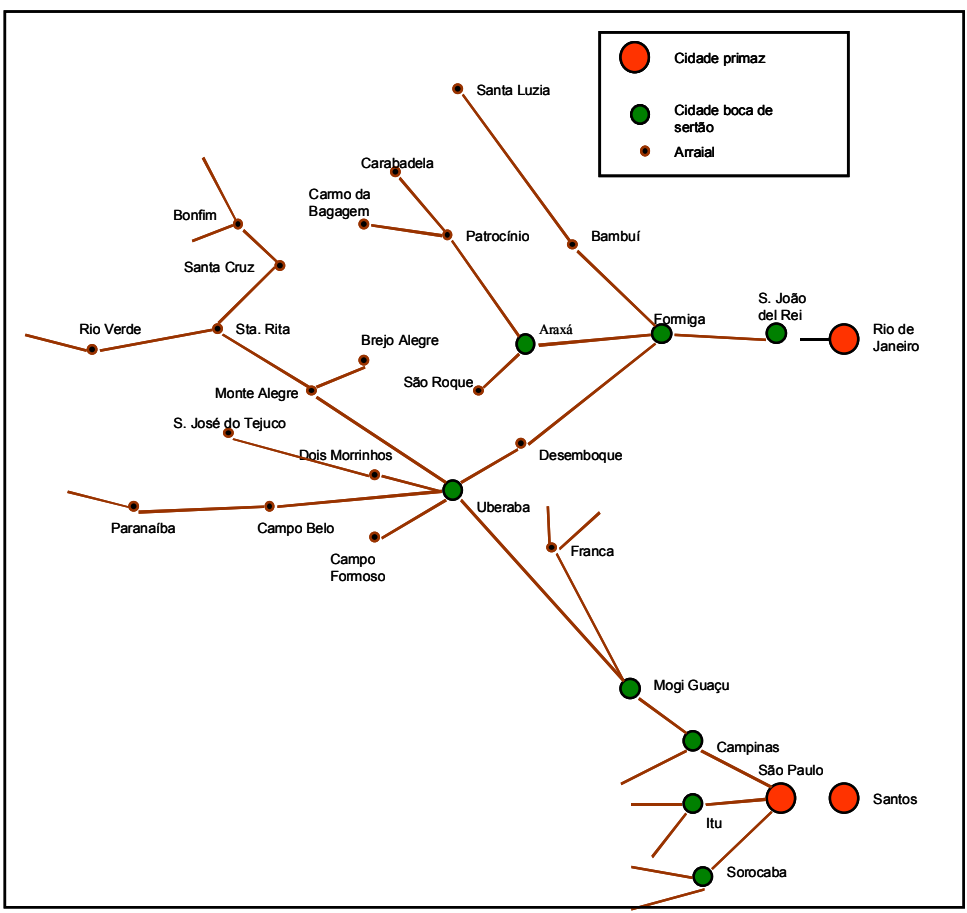

Figura 24: intercessão das redes dendríticas do noroeste paulista e do oeste mineiro nos anos 1840. 


\section{Considerações finais}

Ao longo dos seis capítulos aqui escritos, avaliamos a pertinência de se usar o instrumental teórico-metodológico da Geografia para entender o passado histórico. Delimitamos como região de estudo o Triângulo Mineiro, compreendida entre os cursos dos rios Grande e Paranaíba, e que hoje forma o Extremo Oeste de Minas Gerais. O período histórico escolhido foram os cento e dez anos que se estenderam de 1750 — data da fundação dos primeiros estabelecimentos coloniais na região — a 1861 — início da década na qual Uberaba consolidou sua posição de uma das mais importantes cidades do interior do Império do Brasil. Procuramos entender como se deu o processo de povoamento luso-brasileiro da região, no contexto da sociedade colonial brasileira.

$\mathrm{Na}$ primeira fase do processo de ocupação, o governo colonial tinha a região apenas como área de passagem e, por isso, não via como estratégico seu povoamento efetivo. O Triângulo fazia parte de um dos vários interstícios que isolavam as regiões mineradoras e, por conseguinte, sua colonização foi desestimulada, no século XVIII. No entanto, o governo da capitania de Goiás estabeleceu, ao longo da Estrada dos Goiases ou do Anhanguera, alguns aldeamentos indígenas, destinados a dar guarida e pouso às tropas que chegavam até Goiás.

Do período pombalino em diante, uma nova visão estratégica do interior levou o Estado Colonial a estimular o povoamento das "regiões vazias". O Triângulo Mineiro foi transferido de Goiás para Minas, em 1816, e, a partir daí, tornou-se alvo de uma campanha de colonização, que se estendeu por toda a primeira metade do século XIX. Nessa época, vivia-se um volumoso processo migratório, a partir da região central de Minas: a diáspora dos geralistas. Esta foi motivada por tensões demográficas, acumuladas sobre uma agricultura e pecuária praticadas com base técnica rústica.

Os migrantes que chegaram ao Triângulo Mineiro encontraram os aldeamentos indígenas criados no século anterior. Iniciou-se então a expulsão dos índios, para que suas terras pudessem ser distribuídas entre fazendeiros e sitiantes. 
Ao chegar na região, famílias vindas das comarcas de Sabará, Ouro Preto e Rio das Mortes se estabeleceram em fazendas agropecuárias, onde havia grande diversidade de produção, mas os únicos excedentes exportáveis consistiam em gado, algodão e toucinho, em função da dificuldade de acesso aos mercados consumidores. Tais famílias, como de resto a sociedade colonial, acumulavam riqueza principalmente sob formas não-capitalistas, como escravos e terras.

O escravismo não era, todavia, a única relação de trabalho. Era grande o número de camponeses pequenos proprietários e sitiantes. Uma parte deles possuía escravos, que estendia - mas não substituía — o trabalho familiar. $\mathrm{Na}$ verdade, a maior parte da população escrava da região pertencia a esses pequenos proprietários de cativos. Apesar da posse pulverizada de escravos, havia um pequeno número de grandes fazendeiros que concentravam grande parte da riqueza disponível. Esse padrão de concentração de riquezas, numa sociedade fortemente hierarquizada, era típico das sociedades do Antigo Regime, do qual Portugal e sua colônia americana eram parte.

No processo de ocupação pioneira, os colonos usaram um sistema técnico rústico, em que se fundiam elementos ameríndios e ibéricos. Esse sistema, moldado na região central de Minas, numa região de florestas e montanhas, foi adaptado para o ambiente do Triângulo Mineiro, caracterizado pelo domínio do Cerrado e pelo relevo de chapadas. A rusticidade desse sistema técnico permitia que a economia se reproduzisse com custos muito baixos, que se resumiam praticamente à aquisição de escravos.

À medida que os sitiantes e fazendeiros iam se estabelecendo, fundavam arraiais, que eram o centro social, religioso e mercantil dos bairros rurais. Estes eram grupos de vizinhança, famílias dos mais diversos estratos sociais que se identificavam a um território e à devoção a um santo, ao qual era erigida a capela que fundava o arraial. Este funcionava como o espaço da reprodução das hierarquias sociais, mediante a realização de rituais como batizados, casamentos, missas, procissões e funerais, e também era o elo entre o grupo de colonos e a sociedade maior.

As hierarquias reproduziam-se também no espaço de moradia dos arraiais, com as famílias mais abastadas ocupando o largo da matriz, enquanto as mais pobres ocupavam as ruas secundárias. $\mathrm{O}$ arraial era residência temporária para a maior parte da população, enquanto aqueles que lá tinham residência 
fixa constituíam um dos estratos mais pobres da população sertaneja, formado por artesãos, jornaleiros e pequenos comerciantes.

Dos anos 1820 em diante, a localização geográfica de Uberaba permitiu ao arraial conquistar logo uma posição de grande importância, como núcleo intermediário entre as cidades do litoral e o interior agropastoril. Por isso, tornou-se uma das mais importantes localidades do interior do Brasil, no século XIX.

Várias questões, relativas ao Triângulo Mineiro dos Setecentos e Oitocentos, contudo, permanecem por serem respondidas, tanto pela Geografia quanto pela História. Talvez a principal contribuição deste trabalho seja o de indicar alguns caminhos para estudos futuros. É necessário avaliar, por exemplo, por meio de estudos seriais, o papel do tráfico negreiro na região, no período estudado. Este comércio consistia na principal forma pela qual o excedente da economia regional era drenado e acumulado pelas elites mercantis do litoral. Estudos demográficos mais completos podem ser feitos a partir da localização de documentos paroquiais produzidos na região. Uma busca mais completa em arquivos goianos poderia revelar novos documentos acerca dos aldeamentos da Estrada do Anhanguera.

Além disso, não abordamos outras atividades econômicas que eram muito importantes, como a produção da cana de açúcar para os engenhos e engenhocas da região, como pudemos verificar pelos inventários post mortem. E, principalmente, é necessário estudar melhor a formação do capital mercantil na região, e quais eram suas relações com as elites agrárias. Tais questões permanecem propostas para futuras pesquisas. 


\section{Referências}

ABRAMOVAY, Ricardo. Paradigmas do Capitalismo Agrário em Questão.São Paulo: Hucitec, 1998.

ABREU, Maurício de Almeida. A apropriação do território no Brasil Colonial. In: Castro, Iná Elias de; Gomes, Paulo César da Costa; Correa, Roberto Lobato. Explorações Geográficas. Rio de Janeiro: Bertrand Brasil, 1997.

ABREU, Maurício de Almeida. Construindo uma geografia do passado: Rio de Janeiro, cidade portuária, século XVII. In: Geousp, N 7. São Paulo: Edusp, 2000.

AIRES de Casal, Manuel. Corografia Brasilica. Belo Horizonte: Itatiaia, 1976.

ANTONIL, André João. Cultura e opulência do Brasil. Belo Horizonte: Itatiaia, 1997.

APM. Catálogo de Sesmarias. Belo Horizonte: Arquivo Público Mineiro, 1988. 2v.

APU. Boletim informativo. N 10. Uberaba: Arquivo Público de Uberaba, 1999.

APU. Catálogo Histórico. 1 (3). Uberaba: Arquivo Público de Uberaba, 1986.

APU. Catálogo Histórico. 1 (4). Uberaba: Arquivo Público de Uberaba, 1987 a.

APU. Catálogo Histórico. 1 (5). Uberaba: Arquivo Público de Uberaba, 1987 b.

APU. Catálogo Histórico. 1 (6). Uberaba: Arquivo Público de Uberaba, 1987 c.

ARRUDA, Gilmar. Cidade e Sertões. Bauru: Edusc, 2000.

AZEVEDO, Aroldo de. Vilas e Cidades do Brasil Colonial: ensaio de geografia retrospectiva. In: Anais da Associação dos Geógrafos Brasileiros. São Paulo: Associação dos Geógrafos Brasileiros, 1957. Vol. IX, T. I.

BACELLAR, Carlos Almeida Prado; e Brioschi, Lucila Reis. Na Estrada do Anbanguera: uma visão regional da história paulista. São Paulo: Humanitas, 1999.

BACELLAR, Carlos Almeida Prado. Viver e Sobreviver em uma Vila Colonial : Sorocaba, séculos XVIII e XIX. São Paulo: Annablume / Fapesp, 2001.

BARBOSA, Avenir Alves. Cascalho Rico. Cascalho Rico: Prefeitura Municipal de Cascalho Rico, 1998.

BARBOSA, Waldemar de Almeida. Dicionário Histórico e Geográfico de Minas Gerais. Belo Horizonte: Itatiaia, 1995.

BELLUZZO, Ana Maria de Moraes. O Brasil dos Viajantes. São Paulo: Metalivros/Objetiva, 1999. 
BOSERUP, Ester. Evolução Agrária e Pressão Demográfica. São Paulo: Hucitec, 1987.

BRANDÃO, Carlos Antônio. Triângulo: Capital Comercial, Geopolítica e Agroindústria. Uberlândia: Universidade Federal de Uberlândia, 1989.

BRASILEIRO, Marília. Indianópolis: memória histórica. Indianópolis: Prefeitura Municipal de Indianópolis, s.d.

CÂNDIDO, Antônio. Os Parceiros do Rio Bonito. São Paulo: Duas Cidades, 2001.

CARDOSO, Ciro Flamarion S.; Brignoli, Héctor Pérez. História Econômica da América Latina. Rio de Janeiro: Graal, 1988.

O, Ciro Flamarion S. Escravo on Camponês? O Protocampesinato Negro nas Américas. São Paulo: Brasiliense, 1988.

CASTELNEAU, Francis. Expedição às Regiōes Centrais da América do Sul. Belo Horizonte: Itatiaia, 2000.

CASTRO, Josué de. Geografia da Fome. São Paulo: Círculo do Livro, sd.

CÉSAR, José Vicente. Índios de Minas Gerais por ocasião da Independência. In: Revista do Instituto Histórico e Geográfico de Minas Gerais. Belo Horizonte: Instituto Histórico e Geográfico de Minas Gerais, 1975, volume XVI.

CHAIM, Marivone Matos. Aldeamentos Indígenas: Goiás 1749-1811. São Paulo: Nobel, 1983.

CHALHOUB, Sidney. Trabalho, Lar e Botequim. São Paulo: Brasiliense, 1986.

CHAYANOV, Alexander V. The Theory of Peasant Economy. Madison: Wisconsin University Press, 1986.

CORRÊA, Roberto Lobato. Trajetórias Geográficas. Rio de Janeiro: Bertrand Brasil, 1997.

COUTINHO, Pedro dos Reis. Uberaba, Matriz do Brasil Central. Uberaba: Arquivo Público de Uberaba, s.d.

CROSBY, Alfred W. Imperialismo Ecológico: a expansão biológica da Europa, 900-1900. São Paulo: Companhia das Letras, 1993.

CUNHA Matos, Raimundo José da. Corografia Histórica da Provincia de Minas Gerais. Belo Horizonte: Arquivo Público Mineiro, 1981.

CUNHA, Manuela Carneiro da. Política indigenista no Século XIX. In: CUNHA, Manuela Carneiro da (org.). História dos Índios no Brasil. São Paulo: Companhia das Letras, 1998.

D’ALINCOURT, Luiz. Memórias sobre a Viagem do Porto de Santos à Cidade de Cuiabá. Belo Horizonte: Itatiaia, 1975.

DEAN, Warren. A ferro e fogo: a história e a devastação da Mata Atlântica brasileira. São Paulo: Companhia das Letras, 1996.

DEBRET, Jean-Baptiste. Rio de Janeiro: Cidade Mestiça. São Paulo: Companhia das Letras, 2001. 
DIAMOND, Jared. Armas, Germes e aço: os destinos das sociedades humanas. Rio de Janeiro: Record, 2001.

DILLEHAY, Thomas D. The Settlement of the Americas: A New Prehistory. New York : Basic Books, 2000.

ESCHWEGE, Wilhelm Ludwig von. Brasil, Novo Mundo. Belo Horizonte: Fundação João Pinheiro, 1996.

FARIA, Sheila Castro. A Colônia em Movimento: fortuna e família no cotidiano colonial. Rio de Janeiro: Nova Fronteira, 1998.

FELTRAN FILHO, Antônio. A estruturação das paisagens nas Chapadas do Oeste Mineiro. São Paulo. Departamento de Geografia. FFCL - USP. (Tese de Doutoramento), 1997.

FERLINI, Vera Lúcia do Amaral. Terra, Trabalho e Poder. São Paulo: Brasiliense, 1988.

FERNANDES, Florestan; Bastide, Roger. A estratificação racial na sociedade de castas. In: FERNANDES, Florestan (org.). Comunidade e sociedade no Brasil. São Paulo: Companhia Editora Nacional, 1975.

FERNANDES, Florestan. A integração do negro na sociedade de classes. São Paulo: Ática, 1978, V.1 . FERREIRA, Jurandyr Pires (org.). Enciclopédia dos Municípios Brasileiros. Rio de Janeiro: IBGE, 1958. FLORENTINO, Manolo; e Góes, José Roberto. A paz nas senzalas: famílias escravas e tráfico atlântico, c. 1790-c. 1850. Rio de Janeiro: Civilização Brasileira, 1997.

FRAGOSO, João Luís. Homens de Grossa Aventura: acumulação e hierarquia na praça mercantil do Rio de Janeiro (1790-1830). Rio de Janeiro: Civilização Brasileira, 1998.

FRAGOSO, João Luís; FLORENTINO, Manolo. O Arcaísmo como Projeto: mercado atlântico, sociedade agrária e elite mercantil em uma economia colonial tardia, Rio de Janeiro 1790-1840. Rio de Janeiro: Civilização Brasileira, 2001.

FRAGOSO, João Luís; BICALHO, Maria Fernanda.; Gouvêa, Maria de Fátima. O Antigo Regime nos trópicos: a dinâmica imperial portuguesa - Séculos XVI-XVIII. Rio de Janeiro: Civilização Brasileira, 2001.

FRANCO, Maria Sylvia Carvalho. Homens livres na ordem escravocrata. São Paulo: Kairós, 1983.

FREIRE, Gilberto. Casa-grande \& Senz̧ala: formação da família brasileira sob o regime da economia patriarcal. Rio de Janeiro: Livraria José Olympio Editora, 1983.

FURTADO, Celso. Formação econômica do Brasil. São Paulo: Companhia Editora Nacional, 1987.

FURTADO, Júnia Ferreira (org.). Diálogos oceânicos: Minas Gerais e as novas abordagens para uma história do Império Ultramarino português. Belo Horizonte: Editora UFMG, 2001.

FURTADO, Júnia Ferreira. Homens de negócio: a interiorização da metrópole e do comércio nas Minas setecentistas. São Paulo: Hucitec, 1999.

GALVÃO, Eduardo. Encontro de sociedades: índios e brancos no Brasil. São Paulo: Paz e Terra, 1979. 
GERBER, Henrique. Carta da Provincia de Minas Geraes. Ouro Preto: Gráfica Oficial, 1862.

GLEICK, James. Chaos: making a new science. New York: Penguin Books, 1987.

GLEISER, Ilan. Caos e complexidade: a evolução do pensamento econômico. Rio de Janeiro: Campus, 2002.

GORENDER, Jacob. O escravismo colonial. São Paulo: Ática, 1988.

Guia Rodoviário Quatro Rodas. Rio de Janeiro: Abril, 1999.

GUIMARÃES, Alberto Passos. Quatro séculos de latifúndio. Rio de Janeiro: Paz e Terra, 1977.

HOLANDA, Sérgio Buarque de (org.). A época colonial: administração, economia, sociedade. In: História Geral da Civilização Brasileira. São Paulo: Bertrand Brasil, 1985.

HOLANDA, Sérgio Buarque de (org.). A época colonial: do descobrimento à expansão territorial. In: História Geral da Civilizạạão Brasileira. São Paulo: Bertrand Brasil, 1989.

HOLANDA, Sérgio Buarque de. Caminhos e fronteiras. São Paulo: Companhia das Letras, 1995.

IBGE (1970). Carta topográfica de Campo Florido. Folha SE.22-Z-D-V. Escala 1: 100.000.

IBGE (1970). Carta topográfica de Miraporanga. Folha SE.22-Z-D-III. Escala 1: 100.000.

IBGE (1970). Carta topográfica de Sacramento. Folha SE.23-Y-C-V. Escala 1: 100.000.

IBGE (1970). Carta topográfica de Veríssimo. Folha SE.22-Z-D-VI. Escala 1: 100.000.

IBGE (1972). Carta topográfica de Nova Ponte. Folha SE.23-Y-C-I. Escala 1: 100.000.

IBGE (1972). Carta topográfica de Uberaba. Folha SE.23-Y-C-IV. Escala 1: 100.000.

IBGE (1973). Carta topográfica de Estrela do Sul. Folha SE.23-Y-A-IV. Escala 1: 100.000.

IBGE (1984). Carta topográfica de Uberlândia. Folha SE.22-Z-B-VI. Escala 1: 100.000.

KARASH, Mary. Catequese e Cativeiro: a política indigenista em Goiás, 1780-1889. in: Cunha, Manuela Carneiro da. História dos Índios no Brasil. São Paulo: Companhia das Letras, 1992.

LARA, Silvia Hunold. Campos da Violência: escravos e senhores na capitania do Rio de Janeiro 1750-1808. Rio de Janeiro: Paz e Terra, 1988.

LARA, Silvia Hunold. Do singular ao plural: Palmares, capitães-do-mato e o governo dos escravos. In: REIS, João José.; Gomes, Flávio Santos (coord.). Liberdade por um fio: história dos quilombos no Brasil. São Paulo: Companhia das Letras, 1996.

LEMOS, Carlos A. C. Casa paulista: histórias das moradias anteriores ao ecletismo trazido pelo café. São Paulo: Editora da Universidade de São Paulo, 1999.

LEWIN, Linda. Politica e parentela na Paraíba: um estudo de caso da oligarquia de base familiar. Rio de Janeiro: Record, 1993.

LIBBY, Douglas Cole. Transformação e trabalho em uma economia escravista: Minas Gerais no século XIX. São Paulo: Brasiliense, 1988. 
LOPES, Juliana Chioca, e cols. Relação Sociedade/Natureza: a produção do espaço. Uberlândia. Departamento de Geografia. UFU. (Monografia de Conclusão de Graduação),1993.

LOURENÇO, Luís Augusto Bustamante. Bairro do Patrimônio: Salgadores e Moçambiqueiros. Uberlândia: Secretaria Municipal de Cultura, 1986.

LUGON, Clóvis. A república comunista cristã dos Guaranis: 1610-1768. Rio de Janeiro: Paz e Terra, 1977.

LUNA, Francisco Vidal; COSTA, Iraci Del Nero. Minas Colonial: economia e sociedade. São Paulo: Livraria Pioneira, 1982.

Mapa do Julgado das Cabeceiras do Rio das Velhas e Parte da Capitania de Minas Geraes com a Deviza de Ambas as Capitanias. Disponível em: www.asminasgerais.com.br. Acesso em 07/04/2002.

Mapa estatístico da Comarca de Paracatu. RAPM, 10 (01). Ouro Preto: Imprensa Oficial do Estado de Minas Gerais, 1897.

MARCÍLIO, Maria Luíza. Crescimento Demográfico e Evolução Agrária Paulista: 1700-1836. São Paulo: Hucitec, 2000.

MARCÍLIO, Maria Luíza. Demografia Histórica. São Paulo: Pioneira, 1977.

MARTINS, José de Souza. A vida privada nas áreas de expansão da sociedade brasileira. In: NOVAIS, Fernando; SCHWARCZ, Lilia Moritz (org.). História da Vida Privada no Brasil. São Paulo: Companhia das Letras, 1998. Vol.4

MARTINS, José de Souza. Fronteira: a degradação do Outro nos confins do humano. São Paulo: Hucitec, 1997.

MARX, Karl. Formações econômicas pré-capitalistas. São Paulo: Paz e Terra, 1991.

MARX, Karl. O Capital. São Paulo: Abril Cultural, 1983. Vol. 1 e Vol. 3.

Marx, Murilo. Cidade no Brasil: Terra de quem? São Paulo: Edusp/Nobel, 1991.

MATTOSO, Kátia de Queiroz. Ser escravo no Brasil. São Paulo: Brasiliense, 1990.

MAXWELL, Kenneth R. A devassa da devassa: a Inconfidência Mineira, Brasil - Portugal 1750-1808. Rio de Janeiro: Paz e Terra, 1977.

MAXWELL, Kenneth R. Marquês de Pombal: paradoxo do Iluminismo. São Paulo: Paz e Terra, 1996.

MAZZAFERRI, Ernest L. Endocrinologia. Rio de Janeiro: Guanabara, sd.

MELLO E SOUZA, Laura de. Desclassificados do ouro: a pobreza mineira no século XVIII. Rio de Janeiro: Edições Graal, 1986.

MELLO, Suzy de. Barroco Mineiro. São Paulo: Brasiliense, 1985.

MENDES, Cândido. Atlas do Império do Brazil. Rio de Janeiro: Gráfica Brasileira, 2000. 
MOISÉS, Beatriz Perone. Índios livres e indios escravos: os princípios da legislação indigenista do período colonial (século XVI a XVIII). In: CUNHA, Manuela Carneiro da (org.). História dos Índios no Brasil. São Paulo: Companhia das Letras, 1998.

MONBEIG, Pierre. Pioneiros e fazendeiros de São Paulo. São Paulo: Hucitec, 1998.

MONTEIRO, John Manuel. Negros da Terra: índios e bandeirantes nas origens de São Paulo. São Paulo: Companhia das Letras, 1994.

NABUT, Jorge Alberto. Desemboque: documentário histórico e cultural. Uberaba: Arquivo Público de Uberaba, 1986.

NIMUENDAJÚ, Curt. Textos indigenistas: relatórios, monografias, cartas. São Paulo: Loyola, 1982.

NOVAIS, Fernando. Entrevista. In: MORAES, José Geraldo Vinci; REGO, José Márcio. Conversas com historiadores brasileiros. São Paulo: Editora 34, 2002.

NOVAIS, Fernando. Portugal e Brasil na crise do Antigo Sistema Colonial (1777-1808). São Paulo: Hucitec, 1986.

ODUM, Eugene P. Ecologia. Ro de Janeiro: Guanabara Koogan, 1988.

Oliveira, Nelson Soares de. As divisas de Indianópolis vão ser modificadas. In: O Repórter. Uberlândia, 30/01/1939.

PAIVA, Eduardo França. Escravidão e Universo Cultural na Colônia: Minas Gerais 1716-1789. Belo Horizonte: UFMG, 2001.

PALACIN, Luís; Garcia, Ledonias Franco; e Amado, Janaína. História de Goiás em Documentos: colônia. Goiânia: Ed. da UFG, 1995.

PALACIN, Luís; Moraes, Maria Augusta Santana de. História de Goiás. Goiânia: UCG, 1994.

PARAÍSO, Maria Hilda B. Os Botocudos e sua trajetória histórica. In: CUNHA, Manuela Carneiro da. História dos Índios no Brasil. São Paulo: Companhia das Letras, 1992.

PETRONE, Pasquale. Aldeamentos paulistas. São Paulo, Edusp, 1995.

PEZZUTI, Pedro. Município de Uberabinha. Uberlândia: Livraria Kosmos, 1922.

POHL, Johann Emanuel. Viagem no interior do Brasil. Belo Horizonte: Itatiaia, 1976.

PONTES, Hildebrando. História de Uberaba e a Civilização do Brasil Central. Uberaba: Academia de Letras do Triângulo Mineiro, 1978.

PONTING, Clive. World History: a new perspective. London: Chatto \& Windus, 2000.

PRADO JÚNIOR, Caio. Formação do Brasil contemporâneo. São Paulo: Brasiliense, 1986.

Prefeitura de Araguari. Fotos Antigas. Disponível em: www.araguari.mg.gov.br. Acesso em 04/08/2001.

Prefeitura de Uberlândia. História de Uberlândia. Disponível em: www.uberlândia.mg.gov.br. Acesso em 04/08/2001. 
PREFEITURA MUNICIPAL DE INDIANOPÓLIS. Histórico do Município de Indianópolis. Indianópolis: Prefeitura Municipal de Indianópolis, s.d.

REIS, Nestor Goulart. Imagens de vilas e cidades do Brasil Colonial. São Paulo: Edusp/Imprensa Oficial do Estado, 2001.

REZENDE, Eliane Mendonça Márquez de. Uberaba 1811-1910: uma trajetória sócio-econômica. Uberaba: Arquivo Público de Uberaba, 1991.

RUGENDAS, Johann Moritz. Viagem pitoresca através do Brasil. Belo Horizonte: Itatiaia,1998, V.8 . SAINT HILAIRE, Auguste de. Viagem à província de Goiás. Belo Horizonte: Itatiaia,1975 a.

SAINT HILAIRE, Auguste de. Viagem à Província de São Paulo. Belo Horizonte: Itatiaia, 1976.

SAINT HILAIRE, Auguste de. Viagem às Nascentes do Rio São Francisco. Belo Horizonte: Itatiaia, 1975 b.

SAINT HILAIRE, Auguste de. Viagens pelas Provincias do Rio de Janeiro e Minas Gerais. Belo Horizonte: Itatiaia, 2000.

SAINT HILAIRE, Auguste de. Viagem pelo Distrito dos Diamantes e litoral do Brasil. Belo Horizonte: Itatiaia, 1974.

SAMPAIO, Antônio Borges. Uberaba: história, fatos e homens. Uberaba: Arquivo Público de Uberaba, 2001.

SANTOS, Milton. A naturez̧a do espaço: técnica e tempo, razão e emoção. São Paulo: Hucitec, 1996.

SANTOS, Paulo. Formação das cidades no Brasil Colonial. Rio de Janeiro: UFRJ, 2001.

SAUER, Carl Ortwin. Foreword to Historical Geography. Disponível em: www.colorado/geography/ giw/sauer.co. Acesso em 12/04/2002.

SCHIMIZ, Pedro Ignácio; Barbosa, Altair Sales. Ocupação Indígena do Cerrado: esboço de uma história. In: SANO, S. M.; Almeida, S. P. Cerrado: Ambiente e Flora. Planaltina: Embrapa, 1998.

SILVA, Antônio José da. História topográfica da freguesia de Uberaba. Uberaba: Academia de Letras do Triângulo Mineiro, 1970.

SILVEIRA, Marco Antônio. O Universo do Indistinto: estado e sociedade nas Minas setecentistas (1735-1808). São Paulo: Hucitec, 1997.

SIQUEIRA, Celso Antônio de; Rosa, Roberto. Mapeamento digital dos aspectos físicos da mesorregião do Triângulo Mineiro através dos softwares Autocad 12 e Grass 4.0. In: Sociedade \& Natureza . Uberlândia. Edufu, 10 (19): 93-114, 1998.

SLENES, Robert W. Na Senそala, Uma Flor: esperanças e recordações da família escrava, Brasil Sudeste, século XIX. Rio de Janeiro: Nova Fronteira, 1999.

SODRÉ, Nelson Werneck. Oeste: ensaio sobre a grande propriedade pastoril. Rio de Janeiro: José Olympio, 1941.

SOUZA, Laura de Mello e. Norma e conflito: aspectos da história de Minas no século XVIII. Belo 
Horizonte: UFMG, 1999.

SOUZA, Marcelo Lopes de. A expulsão do paraíso: o paradigma da complexidade e o desenvolvimento sócio-espacial. In: Castro, Iná Elias de; Gomes, Paulo César da Costa; Correa, Roberto Lobato. Explorações Geográficas. Rio de Janeiro: Bertrand Brasil, 1997.

SPERA, Sílvio Túlio; CORREIA, João Robert; REATTO, Adriana. Solos do Bioma Cerrado: aspectos pedológicos. In: SANO, S. M.; Almeida, S. P. Cerrado: Ambiente e Flora. Planaltina: Embrapa, 1998.

SPIX, Johann Baptist von; Martius, Karl Friedrich Philipp von. Viagem Pelo Brasil. São Paulo: Edusp, 1981.

TEIXEIRA, Edelweiss. O Triângulo Mineiro nos Oitocentos. Uberaba: Intergraf Editora, 2001.

TEIXEIRA. Tito. Bandeirantes e Pioneiros do Brasil Central: história da criação do município de Uberlândia. Uberlândia: Uberlândia Gráfica, 1970. 2 v.

TOTI, Gabriel. Ruas de Uberaba. In: Arquivo Público de Uberaba. Catálogo Histórico no. 5. Uberaba: Arquivo Público de Uberaba, 1987.

TURNER, Frederick Jackson. The Frontier in American History. Disponível em: http://xroads. virginia.edu/. Acesso em 14/06/2002.

TURNER, Terence. Os Mebengokre Kayapó: história de mudança social. De comunidades autônomas para a coexistência interétnica. In: CUNHA, Manuela Carneiro da. História dos Índios no Brasil. São Paulo: Companhia das Letras, 1992.

VASCONCELOS, Diogo de. História Média das Minas Gerais. Belo Horizonte: Itatiaia, 1999.

VELHO, Gilberto. Desvio e divergência: uma crítica da patologia social. Rio de Janeiro: Jorge Zahar Editor, 1985.

VELHO, Otávio Guilherme. Capitalismo Autoritário e Campesinato: um estudo comparativo a partir da fronteira em movimento. São Paulo: Difel, 1989.

VENÂNCIO, Renato Pinto. Comércio e Fronteira em Minas Gerais Colonial. In: FURTADO, Júnia Ferreira (org.). Diálogos Oceânicos: Minas | Gerais e as novas abordagens para uma história do Imério Ultramarino Português. Belo Horizonte: UFMG, 2001.

WALTER, Bruno Machado Teles; RIBEIRO, José Felipe. Fitofisionomias do Bioma Cerrado. In: SANO, S. M.; Almeida, S. P. Cerrado: Ambiente e Flora. Planaltina: Embrapa, 1998. 
REFERÊNCIAS

\section{Fontes primárias}

Arquivo Público de Uberaba, inventários post mortem (1822-1861).

Geraldo Lourenço Castro. Depoimento escrito (02/05/2002).

Grande, José Pedro. Carta a Calil Porto, 1962. Originais de Calil Porto. Arquivo Público de Araguari, vol. 3, p. 08, 2 laudas.

Guiomar Maria da Silva. Depoimento gravado (02/05/2002).

Hélio Rodrigues da Cunha. Depoimento gravado (15/01/2002). 


\section{Sobre o livro}

$\begin{aligned} \text { Formato } & 16 \mathrm{~cm} \times 23 \mathrm{~cm} \\ \text { Tipologia } & \text { Berling Antiqua } \\ \text { Papel } & \text { Sulfite } 75 \mathrm{~g} \\ \text { Tiragem } & 300 \text { exemplares }\end{aligned}$

L. Imprensa Universitária/Gráfica UFU 